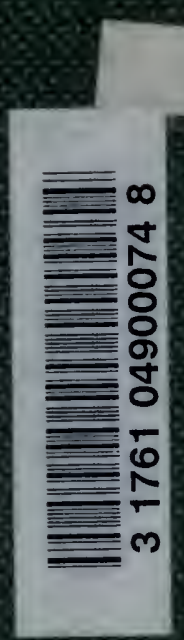




Digitized by the Internet Archive in 2008 with funding from Microsoft Corporation 



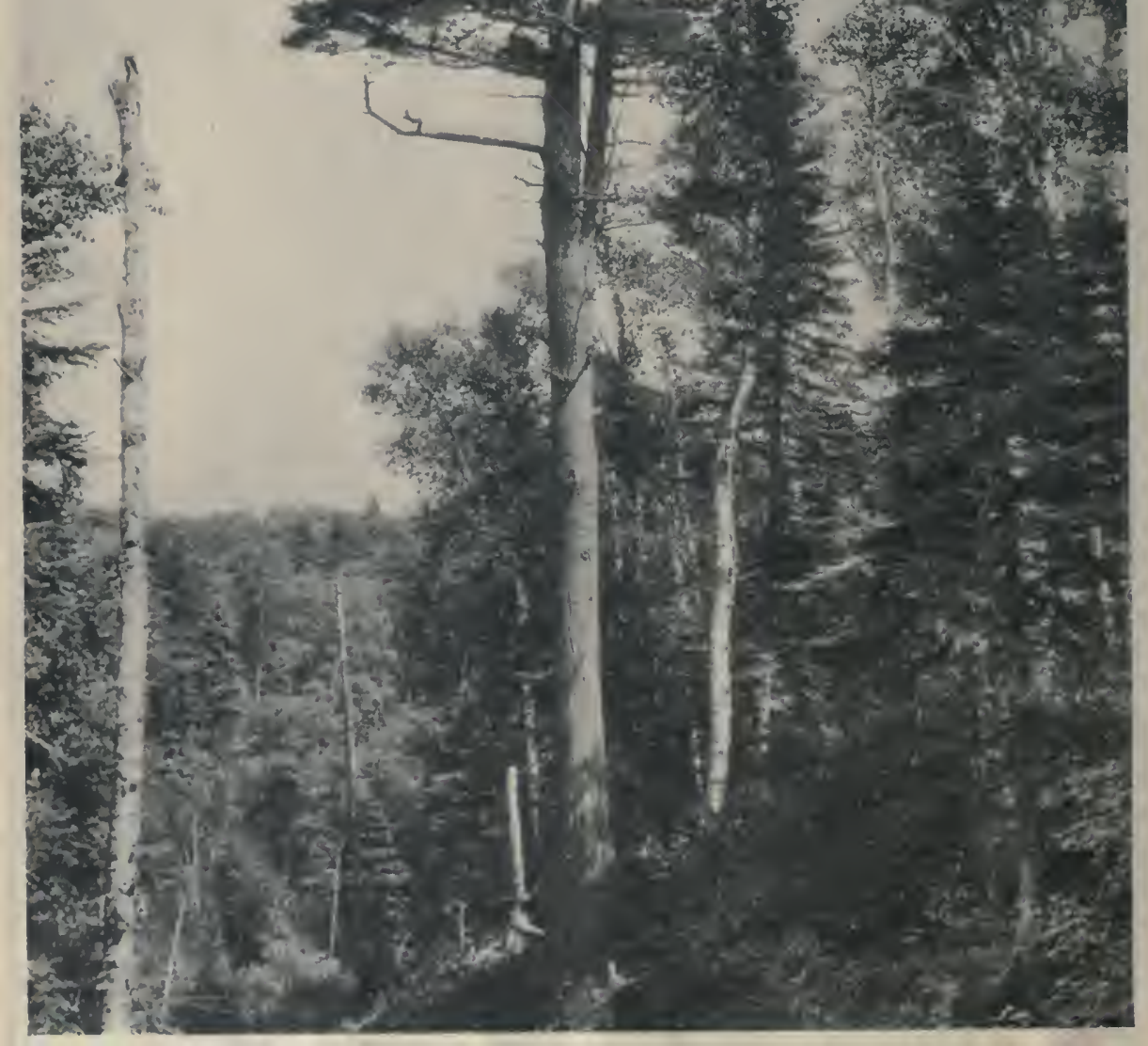




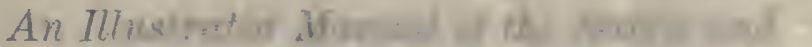

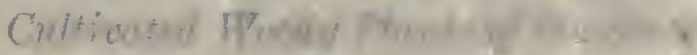

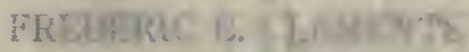

to J.9T0की

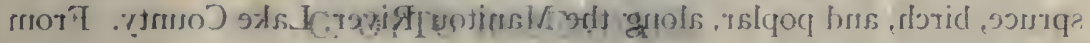

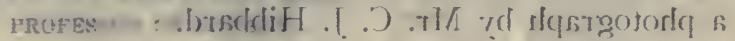

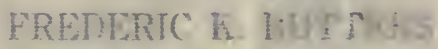
ASBISTANT F RR" + B

Report of the bownder fan in A 
White Pine (Pinus Strobus, see page .32), in a mixed forest of spruce, birch, and poplar, along the Manitou River, Lake County. From a photograph by Mr. C. J. Hibbarcl. 


\section{Minnesota TREes And Shrubs}

An Illustrated Manual of the Native and

Cultivated Woody Plants of the State

FREDERIC E. CLEMENTS

HEAD OF THE DEPARTMENT OF BOTANY AND STATE BOTANIST

C. OTTO ROSENDAHL PROFESSOR OF BOTANY

FREDERIC K. BUTTERS

ASSISTANT PROFESSOR OF BOTANY

Report of the Botanical Survey IX 


\section{PUBLISHED BY AUTHORITY OF THE \\ REGENTS OF THE UNIVERSITY \\ FOR THE \\ PEOPLE OF MINNESOTA AUGUST 15, 1912 \\ EDITION 3000

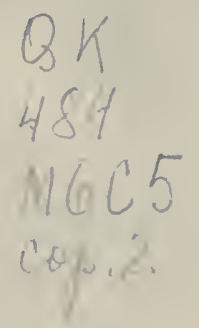




\section{Preface}

The present book is the third of a series intended to render more familiar and usable the plants of the important or interesting groups found in the State. It is less technical than "Minnesota Algae", though more technical than "Minnesota Mushrooms", but it is hoped that the abundant illustrations will made the book as useful to the layman as to teachers and students of botany, to foresters and others. All of the native woody species known with certainty to occur within the State have been included, while a few hitherto reported have been omitted owing to the lack of specimens or other authentic evidence of their occurrence. In the desire to make the book as helpful as possible, a few herbaceous species which resemble shrubs closely have also been included. It has naturally been impossible to take into account all of the rare exotic trees and shrubs grown in the State. Some effort has been made to discover which of these occur in at least three places, and all such cultivated species have been described.

The descriptions have been drawn largely, and in some groups wholly, from Minnesota material contained in the Herbarium of the University. In addition, fresh material has also been used in certain groups, particularly for the drawings. The latter have likewise been made chiefly from Minnesota specimens, though a few have necessarily been borrowed from Sargent's "Silva", Britton and Brown's "Illustrated Flora" and Bailey's "Cyclopaedia of Horticulture". The drawings have been made to scale and, except where indicated, they are natural size. A number of drawings were made by Professors Rosendahl and Butters, and a few by Miss Misz and Miss Jensen of the departmental staff. The majority of the drawings were made by advanced students in botany under the supervision of the respective authors. The half tones have been made from photographs taken by various members of the Botanical Survey from time to time. The Minnesota ranges of the species have been taken from the comprehensive unpublished catalogue of the flora of the State, prepared several years ago by the botanical staff from many sources, Upham's "Catalogue", MacMillan's "Metaspermae", etc. The continental 
ranges have been drawn chicfly from Sargent's "Silva" and "Manual" for the trees, and from Britton and Brown's "Illustrated Flora" and Gray's "Manual" for the shrubs. The information in regard to the properties and uses of the wood of the various species has been obtained almost wholly from Sargent's "Silva". The illustrations of leaf forms have been drawn from Gray's "Lessons in Botany," and the authors are under obligation to the publishers, the American Book Company, and to the holders of the copyright of the book for kind permission to use them.

Questions of nomenclature, of synonyms and of English names have been largely determined by each writer for his own portion, though it is hoped that the results are fairly consistent. In a somewhat popular manual, it has seemed chiefly important that the' reader should be able to refer readily and certainly to the standard manuals and to Sargent's "Silva". The sequence of fanilies followed in the text is that of the "Besseyan System", the Monocotyledons being placed after the other phyla, partly because of their supposedly later origin, as well as to avoid separating the Ranales from the other Dicotyledons. Of the descriptive text, Professor Rosendahl has written about half, comprising Ranales, Rosales, Celastrales, Sapindales, Unbellales, Rubiales and Asterales, with the exception of a few genera. Professor Butters has written somewhat more than a fourth, comprising the Gymmosperms, the Heaths, and the genera, Rosa, Quercus, Lonicera and Diervilla. In addition, he has written the part of the introduction dealing with the distribution of the woody vegetation, and has prepared the map showing the forest regions.

The text deals with 100 genera, represented by 274 species and about 25 varieties. All the genera are illustrated, with the exception of one not certainly known to occur in Minnesota. Of the 274 species, 15 are not represented by figures. The total number of illustrations is 118 , of which 103 are line drawings, and 15 half-tones.

The botanical publications of the Geological and Natural History Survey constitute, with the present book, nine volumes, under the general heading, "Botanical Series". Four of these volumes belong to the subseries, "Minnesota Botanical Studies", the fourth volume of which is current. Botanical publication in the Survey was suspended from 1904 to 1908 , and on resuming publication, it seemed wise to make the first number of the "Botanical Studies" part one of volume four. Volume three thus contains but three parts, the title page and index to which are found in part two of volume four. In addition, a popular series, entitled "Minnesota Plant Studies" was 
begun in 1908. A complete list of the publications of the Botanical Survey follows:

\section{REPORTS OF THE SURVEY.}

I. Minnesota Metaspermae I892: Conway MacMillan.

2. Mininesota Botanical Studies, volume I, parts I-I2, I894-98.

3. Minnesota Plant Life I899: Conway MacMillan.

4. Minnesota Botanical Studies, volume 2, parts I-6, I898-I902.

5. Minnesota Plant Diseases 1905: Edward M. Freeman.

6. Minnesota Botanical Studies, volume 3, parts I-3, I9O3-O4.

7. Minnesota Botanical Studies, volume 4, parts I, 2, I909-

8. Minnesota Algae i910: Josephine Tilden.

9. Minnesota Trees and Șhrubs I9I2:

\section{MINNESOTA PLANT STUDIES.}

I. Guide to the Spring Flowers; F. E. Clements, C. O. Rosendah1, F. K. Butters. First edition, March I908; second edition, April, I9Io.

2. Guide to the Trees and Shrubs: F. E. Clements, C. O. Rosendah1, F. K. Butters. First edition, October, 1908; second edition, September, I9Io.

3. Guide to the Ferns and Fern Allies, July, I909: C. O. Rosendah1, F. K. Butters.

4. Minnesota Mushrooms, September, I9Io: F. E. Clements. The Guide to Autumn Flowers has been printed in key form and used with classes for the past two years, but it has not been published for distribution. The above publications of the Survey are sent upon request to residents of Minnesota, and to the schools and colleges of the State. They are also sent free to working botanists and botanical departments and institutions upon the exchange list of the Survey. To all others, the publications are for sale at the following prices: Minnesota Plant Diseases (edition nearly exhausted), \$2; Minnesota Algae, \$I; Minnesota Trees and Shrubs, \$I; Guides to Spring Flowers, Trees and Shrubs, and Ferns, Ioc. each; Minrresota Mushrooms, paper 50c., cloth \$I. Minnesota Metaspermae and the first three volumes of Minnesota Botanical Studies are sent for the cost of transportation to those who can use these technical works. The edition of Minnesota Plant Life is entirely out of print, but copies can still be obtained from the New York dealers in second hand books.

Minnehaha-on-Ruxton,

Manitou, Colorado, July 3 I, I9I2.
Frederic E. Clements, Head of the Department of Botany and State Botanist. 



\section{Contents}

INTRODUCTION-

How to Use the Keys - - - _ - _ - ix

The Names of Plants -

Pronunciation - $\quad-\quad-\quad-\quad-\quad-\quad-x v$

Verification and Determination of Specimens - - - - $\mathrm{xv}$

Explanation of the Chart - - $-{ }_{-}-{ }_{-}-\mathrm{xv}$

Chart of Evolution and Relationship - _ _ _

Vegetation Regions - _ _ _ _ _ _ xviii

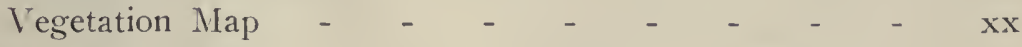

Key to the Genera - $\quad$ - $\quad$ - $\quad$ - $\quad$ - $\quad$ - II

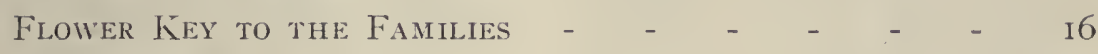

GyMnosperms $\quad-\quad-\quad-\quad-\quad-\quad-\quad-\quad-\quad-19$

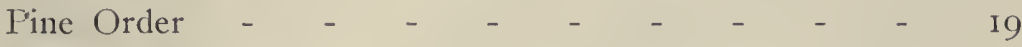

Ginkgo Order - $\quad-\quad-\quad-\quad-\quad-\quad-\quad-43$

ANGIOSPERMS - $\quad-\quad-\quad-\quad-\quad-\quad-\quad-\quad-44$

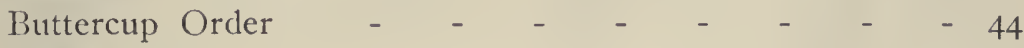

Pink Order - - - - $\quad-\quad-\quad-\quad-5^{1}$

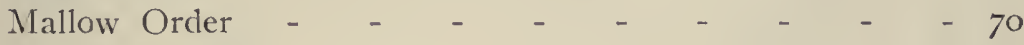

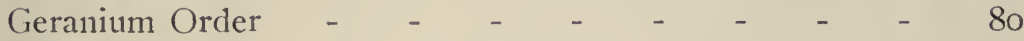

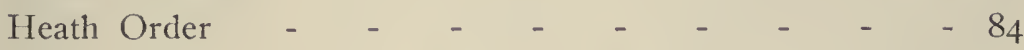

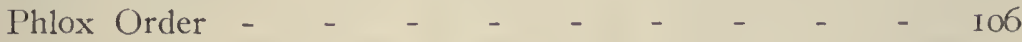

Gentian Order - $\quad-\quad-\quad-\quad-\quad-\quad-\quad-107$

Snapdragon Order - $\quad-\quad-\quad-\quad-\quad-\quad-$ II6

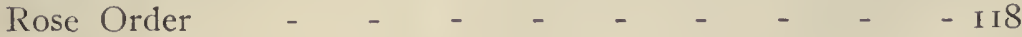

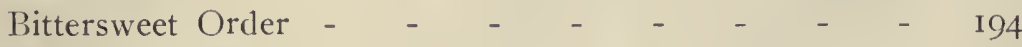

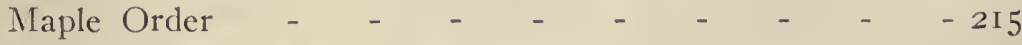

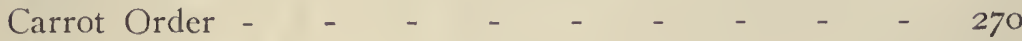

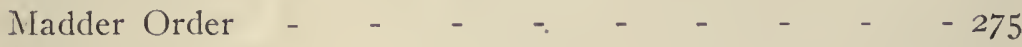

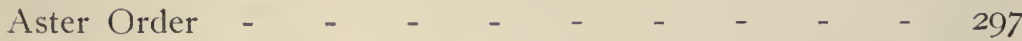

Lily Order - - - - - - - - - -298

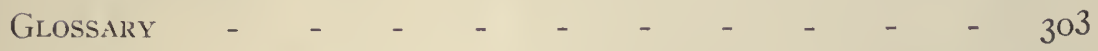

INDEX - $\quad-\quad-\quad-\quad-\quad-\quad-\quad-\quad-\quad-309$ 



\section{Introduction}

\section{HOW TO USE THE KEYS.}

Since all the genera, e. g., clm, oak, willow, pine, etc., and nearly all the species, e. g., red elm, cork elm, red oak, white oak, bur oak, etc., are illustrated, it will often be possible to find the name of a tiee or shrub by turning directly to the illustration. This is especially true when the plant is known to belong or thought to belong to a particular family or genus. For the beginner, however, this method would usually prove long and tedious, as well as uncertain in its results. Mucl the better method is to make use of the two keys found on pages II and I6. The first key is based chiefly upon the leaves and twigs, and is for use from the time the leaves unfold until they drop in the fall. The second key is based primarily upon the structure of the flower, and hence can be used only with flowering specimens. It is especially helpful in the spring for the large number of deciduous trees in which the flowers appear before the leaves, as well as for many woody plants in which the leaf characters are similar. While it is possible to determine the names of trees and shrubs in their winter condition, it is so difficult for anyone who does not already possess considerable knowledge of them, that such a key has been omitted. The best plan for the beginner to follow is to become acquainted with individual trees and shrubs during the summer, and then learn the habits and appearance of these same individuals during the winter.

Both keys are made after the same plan, namely, of making a choice for the most part between two alternatives. For example, if one wishes to find the name of the common upland oak by means of a leaf twig, he would turn to the "Key to the Genera" on page II. Here the first choice must be made between "I. Leaves needle-like or scale-like", and "II. Leaves not needle-like or scale-like." The former are the leaves of pines, spruces and tamaracks, the latter of the broadleaved woody plants, such as elms, oaks, willows, lilacs, etc. Under "II", the oak clearly belongs in "I. Trees", and not in "2. Shrubs or vines" (page I3). Again, under "I", choice must be made between 
"a. Leaves simple" (figs. I and II) and "b. Leaves compound" (fig. VI). After the former, the lobed leaf of the oak brings one to "(2). Leaves lobed" (page I5), and under this the cloice goes to

I. Outhines of Simple Leates.

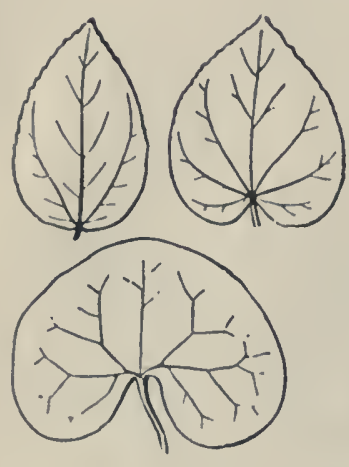

1

2

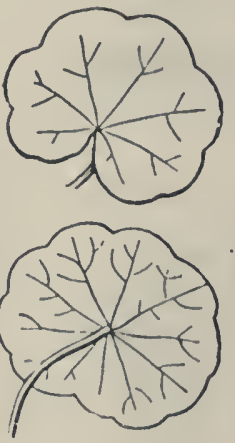

3

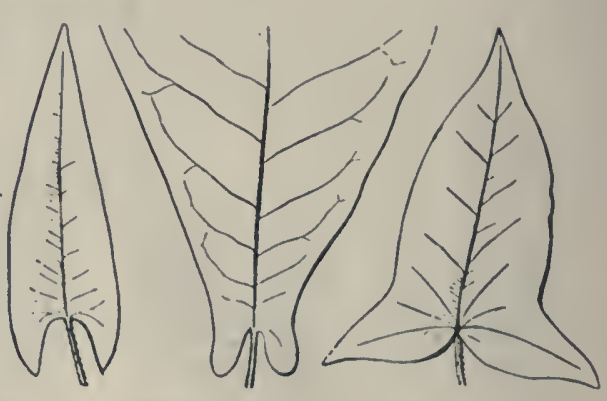

8

1. Rounded. 2. Cordate (heart-shaped). 3, 4. Reniform (klaney-shaped). 5. Peltate (shieldshaped). 6. Sagittate (arrow-shaped). 7. Auriculate (eared). S. Hastate (halberd-shaped).

"(b) Leaves alternate or fascicled". Under the latter, the oak agrees with "y. Leaves neither fan-shaped nor fascicled". and then with "(y) Leaves more than two-ranked". After the latter, the cloice falls upon "n. Leaves less lobed; bark not white", and then upon "(n) Leaf-margin entire". This brings one to the oak genus, Q u e r cus, which is described on page 257 . Here the first step is to read care-

II. Outhines and Bases of Simple Leaves.

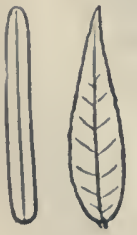

1 1. Iinear. (egg-shaped).

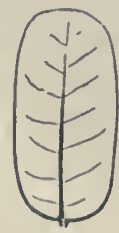

3

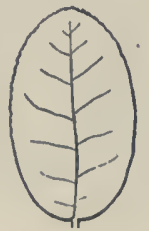

4

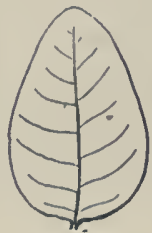

5

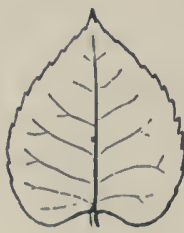

6

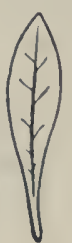

7

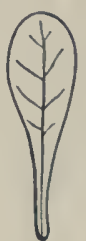

8

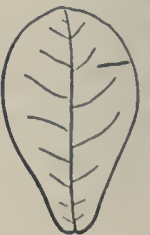

9

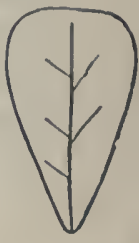

10

3. Oblong. 4. Ellptic.

5. Oval. 6. Ovate 8. Spatulate (spatula-llke). 10. Cuneate (wedge-shaped).

fully the description of the genus to make sure that one has reached the right place. The second step is to turn to the key to the species on page 258. and to find the species by making choice between "I" and "2", "a" and "b", etc. The bur oak with the deep rounded blunt lobes of the leaf falls under " 2 ", and then under "a". Here the leaves, but especially the acorn cup, guicle one to "(2) Quercus macro- 
carpa". This determination is then checked by turning to pages 264 and 265 , where the description and illustration of the species are found.

If the pine is taken for determination, the choice first falls upon "I. Leaves needle-like or scale-like". The pine with its needles in

III. IJEAF EDGES.
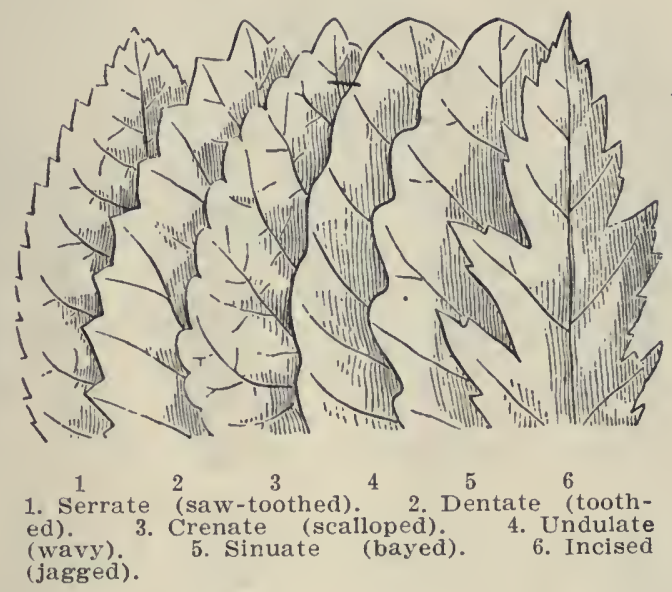

groups of 2-5 then goes in "I. Leaves alternate or fascicled", and beneath this, not in "a", but in "b. Leaves or some of them fascicled". Under this, the few evergreen leaves in a fascicle lead one to "(2) Leaves persistent, 2-5 in each fascicle" . . . Pinus: pine". On page 30 is found the description of the pine genus, and below this the key to the various pines. The five needles of the white pine at once determine this to be $\mathrm{Pinus} S \operatorname{Strobus}$, while the pines with two needles in a fascicle may be sought in the general key on page 32 , or in the key based upon leaf-sections, page $3 \mathbf{I}$.

IV. LEAF TIPS.

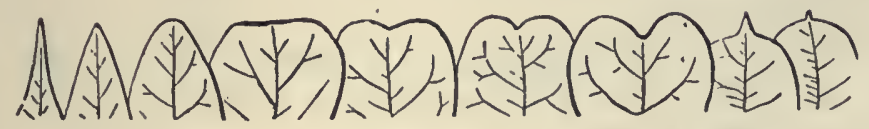
$\stackrel{1}{2} \underset{1}{2} \stackrel{3}{2} \quad{ }^{4}$
1. Acuminate.
6. Emarginate.
5. Obtuse. 7. Obcordate.
4. $^{7}$ Truncate. $^{8}$ 5. $\stackrel{9}{\text { Re- }}$ cronate.
8. Cuspidate.
9. $\mathrm{Mu}$ -

In the case of flowering twigs, the method of finding the name is essentially' similar. The lilac, for example, in the "Flower Key to the Families", falls under "I. Petals present", the alternative choice, 
"II. Petals absent", being impossible. The next clioice is "I. Flowers single or in clusters", not " 2 . Flowers in heads", as in the dandelion or the clover. The united petals lead one past "a. Petals separate" to "b. Petals united", and then one goes successively to "( I) Ovary superior", "(a) Flowers regular", and "x. Stamens 2 ". The family is consequently the olive family, Oleaceae, to be found on page

V. Lobed Simple Leaves.
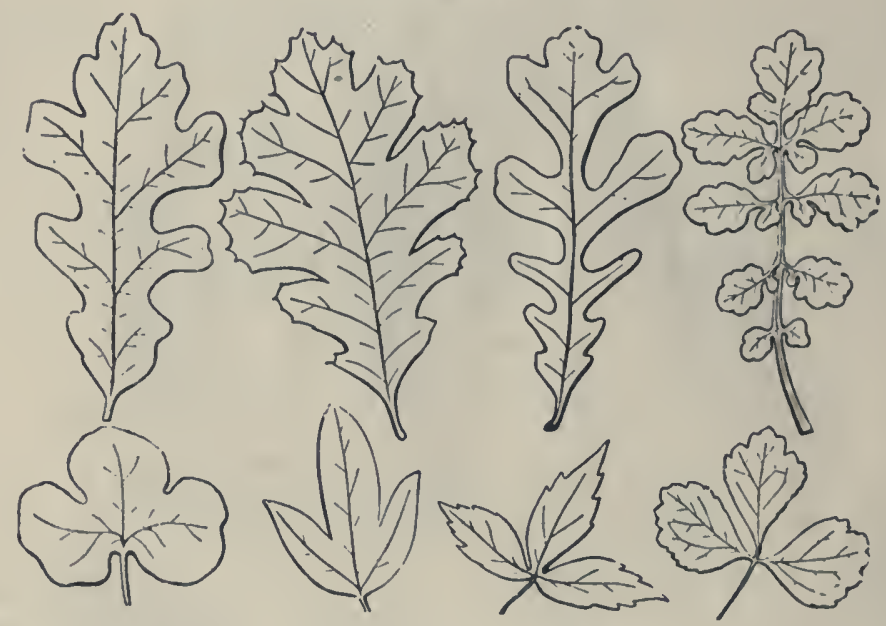

Pinnately: 1. Lobed. Paimately: 2. Lobed.

3. Cleft.

5. Parted.

7. Divided

4. Cleft. 6. Parted. 8. Divided.

107. Here the family description should first be clecked over, and then the genus of the lilac is sought in the "Key to the Genera". The choice between " $I$ " and " 2 " falls readily upon the latter and beneath " 2 ", first upon "a", and then upon "(I) Flowers purple . . . Syringa". After checking over the description of the latter upon page II the common lilac is found to be Syring a vulgaris by means of the "Key to the Species". It is described on page II 2 and figured on page II4.

In the case of the cottonwood, the small flowers of the hanging catkins, which are of two kinds, reddish brown on one tree and greenish on the cotton-bearing tree, are seen to lack both petals and sepals. Hence, under "II. Petals absent", the choice is "2. Sepals absent, or occasionally very minute". The next choice is "b. Leaves $110 t$ scale-like or needle-like, deciduous", and after this, "(I) Leaves simple". Under this, the ovate leaves lead to "(b)" and the cottony seeds to " $(x)$. . . Salicaceae", or willow family, page 53. Here 
the genus is found to be Populus, and the species, by means of the key on page 54 , to be de 1 to ides.

The many differences of leaves and flowers make it impossible to describe plants or construct keys without the aid of scientific terms

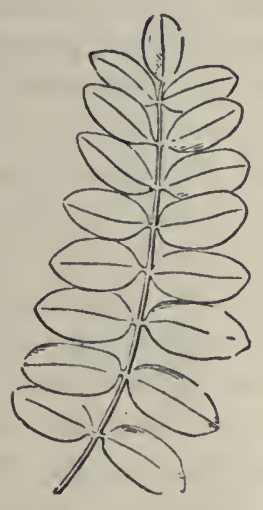

1. Odd-pinnate.

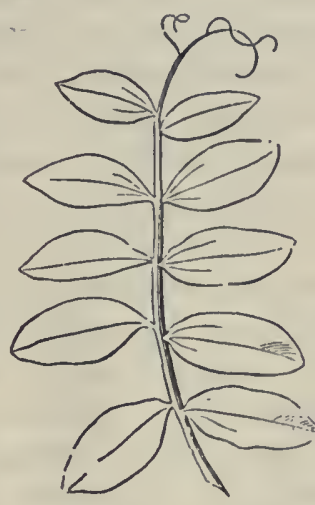

2. Tendri1-pinnate.

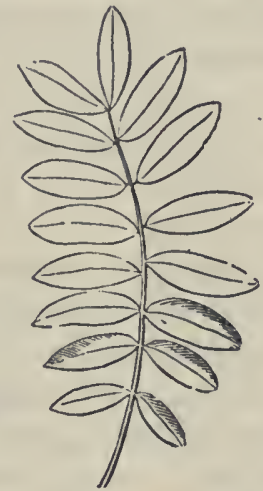

3. Even-pinnate.

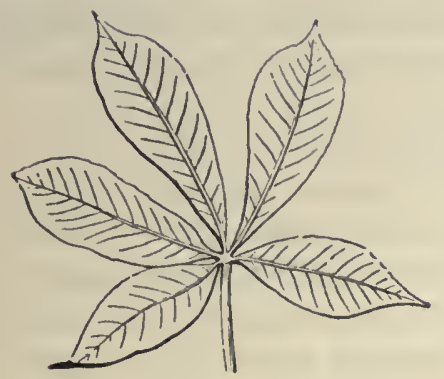

4. Palmate or digitate

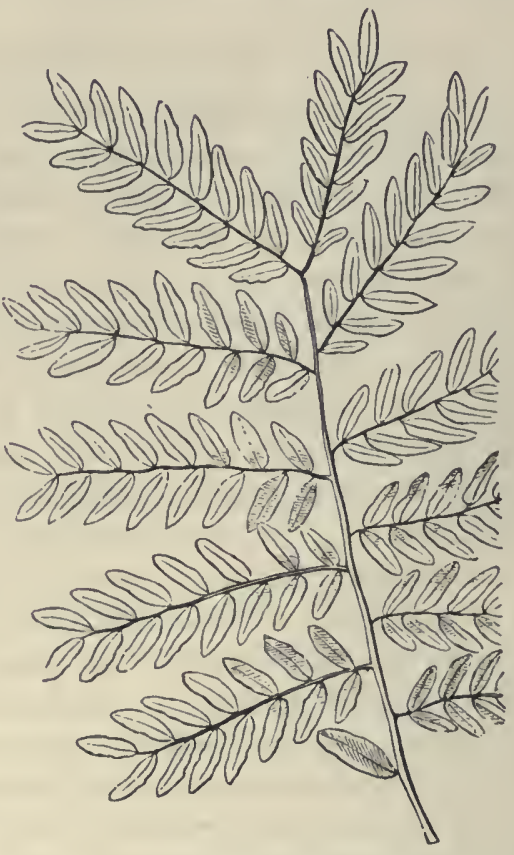

5. Twice-pinnate

Vi. Compound Leaves. 
to give definiteness and accuracy. The beginner's greatest difficulty is to decide just how mucl of a quality, such as lobing, hairiness, etc., corresponds to a particular term. It is evident that practice alone can give readiness and certainty in finding the names of plants, but the constant use of the cuts, figures I-VI, and of the glossary, page 302, will greatly reduce the practice necessary. The first plants determined will inevitably take much time and patience, but the student who makes sure of his facts before deciding upon each step of the key will be rewarded by rapidly increasing facility in using the keys. The tendency to gutess at points of structure or at the meaning of ternus must be avoicled at all times, if satisfactory results are to be secured. As a further precaution, both of the alternative choices at each step in the key must be considered, since one often throws light upon the other. Finally, much time, patience and eye-sight will be saved by the 11se of a good hand lens, magnifying IO-I5 diameters and costing from one to three dollars. Such lenses can be obtained from the H. W. Wilson Company, or the Minnesota Co-operative Store in Minneapolis, from the Spencer Lens Company, Buffalo, or the Bausch \& Lomb Company, Rochester, N. Y.

\section{THE NAMES OF PLANTS.}

The name of a plant consists as a rule of two parts or words, for example, Pinus Strobus, Ulmus americana, Acer saccharum, etc. The first word indicates the genus, and is always capitalized. The sccond word indicates the species, or kind, and is rarely capitalized. The meaning of the terms genus (plural, genera) and species (plural, species) may be clearly illustrated by the pines and maples. The white pine, jack pine and Norway pine are different kinds, or species, of the genus of pines, Pinus, cach one designated by a species name, Strobus, dizaricata and resinosa, respectively. The hard maple, soft maple, red maple and the boxelder are different species of the maple genus, Acer; they are designated by the respective species names, saccharum, saccharinum, rubrum and negundo. Genera which are rclated to each other are placed in the same family, for example, the pines, spruces, firs and larches in the pine family, Pinaceac, the roses, apples, plums, cherries, hawthorns, etc. in the rose family, Rosaccac. The ending, -aceac, which is always used to denote a family, is the feminine plural of the Latin suffix, -aceus, meaning like or related to. The family name, Rosaccae, is really an adjective agreeing with plantac, plants. and meaning "plants related to the rose." Related families are themselves grouped into orders, which also bear a distinctive ending, e.g., 
Pinales, Rosalcs. This ending is likewise in the feminine plural, and the meaning of the name is "plant families related to the pine family," etc. Orders are further arranged into larger groups, such as Monocotylcdons, flowering plants with a single seed leaf, scattered bundles in the stem, parallel-veined leaves, and a flower plan of 3 , and $D i$ cotyledons, with two seed leaves, ringed bundles, netted-veined leaves and a flower plan of 5 or 4 . These two groups form the Angiosperms, with closed pistils and usually with sepals and petals, which are contrasted with the Gymnosperms, with open pistils and no sepals or petals.

\section{PRONUNCIATION.}

The simplest and most usable pronunciation of the names of plants is probably that in which the consonants are pronounced as in English, and the vowels and diphthongs as in Latin. This makes possible a uniform and phonetic pronunciation of botanical names, such as is greatly to be desired. The sounds of the vowels may be indicated as follows: $a$ as ah; $e$ as ay; $i$ as ee; $o$ as oh; $u$ as oo; Greek $y$ much like the German $i i$. The diphthongs are as follows: $a_{\mathcal{e}}$ as aye; $a u$ as ow in how; oe as oy; $c i$ as ay; $c u$ as eoo; $u i$ as ooee.

\section{VERIFICATION AND DETERMINATION OF SPECIMENS.}

The beginner will necessarily find occasional plants which he is unable to name. Even the student of more experience will now and then find very puzzling forms. In such cases, it is necessary to refer the question to a good herbarium if one is accessible, or to the botanist. The department of botany will be glad to have fresh or dried plants sent to it for verification or determination at any time. This applies to mushrooms and other lower forms as well as to flowering plants. Fresh specimens can be sent readily through the mails by wrapping them in moist paper and placing them in a pasteboard box. The department will also be glad to verify the dried specimens in the herbaria of high schools or of individual students.

\section{EXPLANATION OF THE CHART.}

The chart on page xvii is designed to show the general lines of descent of flowering plants from the ancestral ferns, and to indicate the relationships of the various orders. It is based primarily upon the development of the flower as a special organ for pollination and seedproduction. In consequence, the trees and shrubs appear in it at various places, since the woody habit may develop in almost any order, quite irrespective of its flower structure. Some families consist wholly 
of woody plants, as in the beech, birch, elm, palm and willow families. Others, such as the rose and pea families, contain a large number of trees and shrubs, while many, such as grasses, orchids, mustards, pinks, primroses, etc., contain only an occasional woody genus or are entirely herbaceous.

Families with the simplest flowers, that is, those with the flowers least changed from the fruiting organs of the ferns, are placed at the bottom of the chart. Such families are found in the gymmosperms and in the buttercup order. The flowers of the former are windpollinated, and lack both calyx and corolla. The flowers of most buttercups, on the other hand, are pollinated by insects, and possess both calyx and corolla, or a showy calyx. These are regarded as the primitive or earliest type of flower of the angiosperms. From the specialization of these, in response to insect and wind pollination, have been derived the orders and families of the three lines of evolution shown in the chart. In detail, the primitive flower shows a large number of separate stamens and separate pistils, the petals are alike and separate, and there is no union between any of the four parts, sepals, petals, stamens and pistils. In the increasing adaptation of a flower to its work of pollination and seed production, this primitive form has given rise to the higher or more specialized forms characteristic of the various orders of the chart. The chief steps by which this has been brought about are only four, namely, reduction in number of parts, union, change in shape, and change in position of the corolla, or clevation, but these changes have not appeared in the same sequence in all three lines. Reduction in number to a flower plan of 3,4 or 5 has been almost universal in the groups just above the buttercups, though flowers occasionally occur with number plans of 6,7 , 8 and even 9. In flower structure, the arrowheads are essentially buttercups with parts in threes, while the lilies are arrowheads with the stamens and pistils reduced in number, and the latter united to form a compound pistil. In the irises, the colored periantl of sepals and petals is upon or above the ovary, and in the orchids, the corolla is strikingly irregular, one petal usually taking the form of a lip or sack.

In the roses, the buttercup type is modified by the gradual growing together of the calyx and receptacle, and finally of the ovary also, with the result that the corolla and stamens are above the calyx and ovary. In the lower roses, the number of stamens and usually of pistils also, is large, and the pistils are separate. In the higher families, the pistils are united into a componnd pistil. In the madders and 


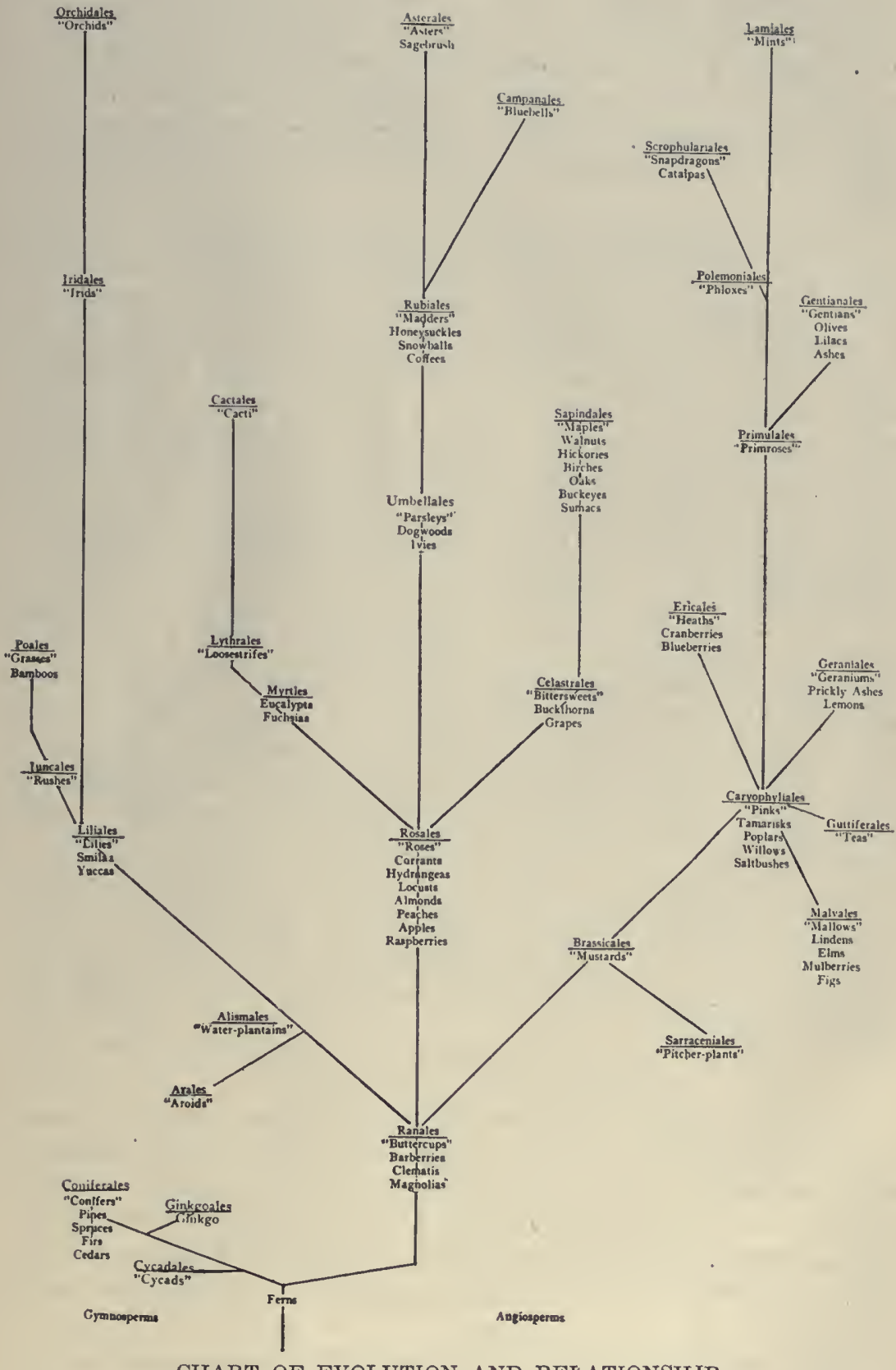

CHART OF EVOLUTION AND RELATIONSHIP 
honeysuckles, the petals have become united, and finally, in most of the asters, some or all of the flowers of the characteristic heads become irregular as to their petals. In the mustards, pinks and geraniumins, the flower parts are regularly reduced to the number plan of 4 or 5 , and the pistils are united. In the primroses, the petals become united, and in the snapdragons and mints, the corolla as a rule is highly irregular.

Many trees and shrubs have the flowers typical of the family to which they belong. The locust and redbud are readily seen to belong to the pea family, the apple, cherry and plum to the rose fanily, the bamboo to the grass family and the matrimony vine to the potato family. On the other hand, the flowers of the lilac and the ash seen wholly unlike, though they are placed in the same family. The maple and the boxelder appear to be very different, though they are usually put in the same genus, while the flowers of willows and cottonwoods seem to have nothing in common with the pinks and tamarisks from which they have descended. In a sense however, these striking differences are superficial, and are due to the excessive reduction or complete loss of calyx and corolla in consequence of lack of use in wind pollination. The absence of a corolla renders many of our tree flowers inconspicuous, especially those that bloom before the leaves appear, and has led to the popular impression that many trees do not have flowers. Trees, like all flowering plants, produce flowers every year as a rule, and it is possible to determine their real relationships even when the flowers are reduced to stamens or pistils alone. The simple appearance of the flowers of many trees and shrubs has frequently led to their being regarded as the lowest of flowering plants. A comparison of the flowers of maples, elms, oaks, ashes, etc., witli those of the pine, spruce and fir will readily prove that this is not the case, and that the majority of our tree flowers belong fairly high in the scale of evolution.

\section{VEGETATION REGIONS.}

From the standpoint of vegetation, Minnesota may be divided into three great regions, occupied originally by the evergreen forest, the deciduous forest, and the prairies, respectively. Each of these regions has its characteristic plants, while comparatively few of the trees and shrubs of the state are equally at home in all three of them. The general outline of these regions is indicated in the map on page $\mathrm{xx}$.

The evergreen forest originally covered the northeastern one-third of the state, extending south to a line about half way between Duluth 
and Minneapolis, and west nearly to the Red River valley. These evergreen forests are continuous with those of Ontario on the northeast, and with those of northern Wisconsin and upper Michigan on the east. The characteristic trees of this region are the three native pines, white spruce and balsam fir in mature upland forests, black spruce, tamarack and white cedar in the swamps. Throughout this region decidtutis trees are either minor or temporary factors in the vegetation. Thus although the hard maple, basswood, red oak and white elm occur throughout the regions they do not occupy such great areas as they hold farther south, and the abundant growth of aspen, balsam, poplars and birches which usually follows the destruction of the conifers by cutting or burning, is itself followed by evergreens, if not further disturbed.

The shrtibs as well as the trees of the evergreen forests are, many of them, characteristic. Here are found the white-flowered thimbleberry, the mountain maple, dwarf birches, alders, sweet-fern, several kinds of bush honeysuckle, high-bush cranberry, and, most characteristic of all, numerous heaths, such as trailing arbutus, wintergreen, dwarf Kalmia, the numerous blueberries and huckleberries.

The deciduous forest occupied a strip extending across the state from southeast to northwest and forming an almost complete barrier between the evergreen forests and the prairies. Throughout this region the number of species of trees diminishes steadily from southeast to northwest. The most characteristic trees on heavy rich subsoil are hard maple, basswood, elm and red oak. The finest strip of hardwood timber in the state, known to the early settlers as the "Big Woods," consists very largely of these trees. Lying about fifteen miles west of Minneapolis, it originally extended about fifty miles east and west and nearly a hundred north and south. In the southeastern corner of the state, the dominant trees are black oak, black walnut, and shellbark hickory in addition to those specics which occur farther north. Throughout the southern half of the state, somewhat sour clay subsoils are apt to be covered with a nearly pure growth of white oak. On drier and less fertile subsoils are usually open forests of bur oak, scarlet oak and northern pin oak, which pass into mere thickets where the soil is very light and porous.

Throughout this region of deciduous forest, there are almost none of the conifers which are so abundant in the northeastern part of the state. The tamarack alone occurs to any extent. It occupies many bogs and swamps as far south as the Minnesota river. These tamarack swamps are, as it were, little pieces of the northern forest 


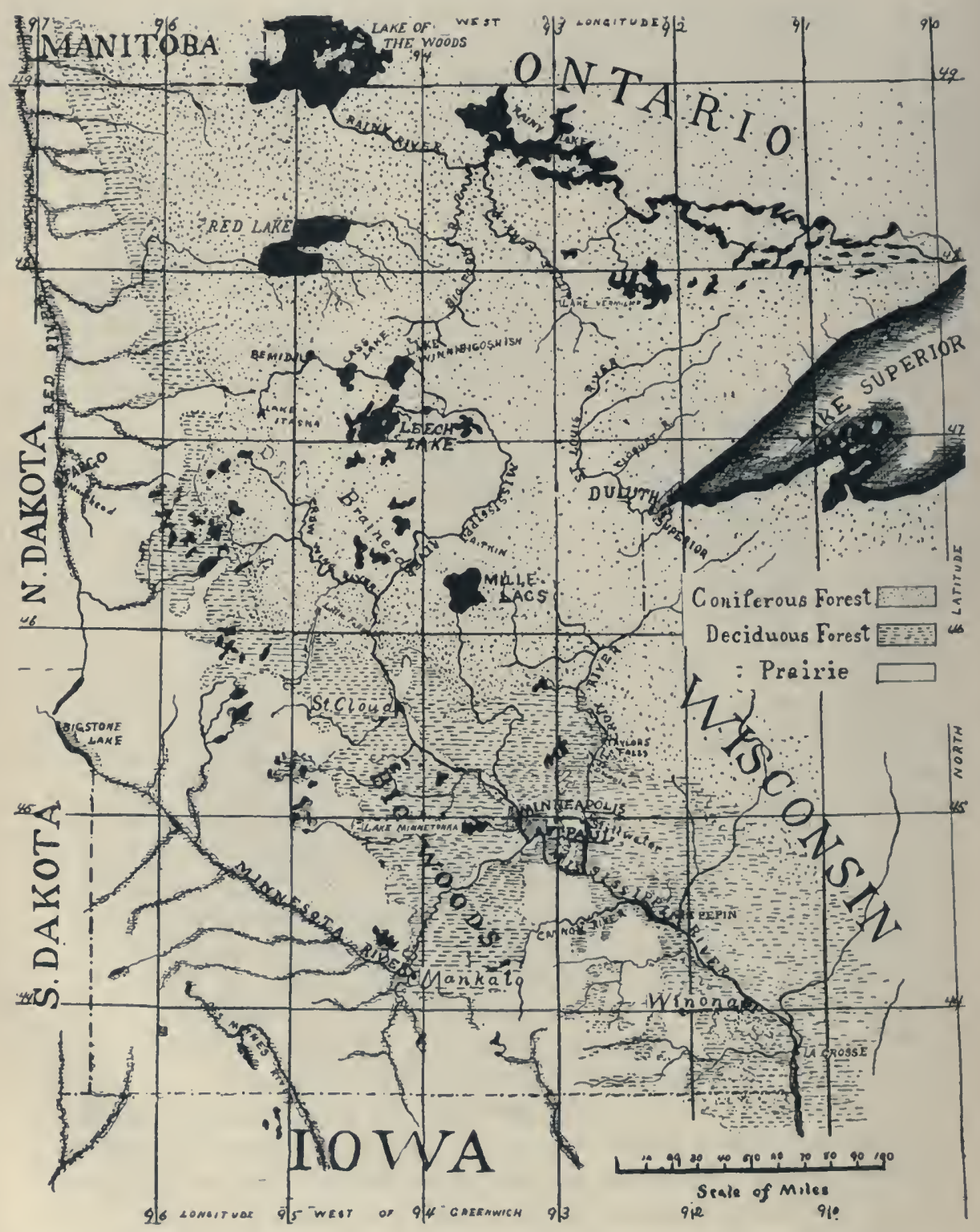

MAP OF MINNESOTA, SHOWING THE NATURAL DISTRIBUTION OF FOREST AND PRAIRIE. ADAPTED FROM UPHAM'S FLORA OF MINNESOTA. 
existing in the midst of the entirely different flora of the deciduous forest.

The most abundant shrubs of the deciduous forest are the dogwoods, especially Cornus paniculata, sumacs, thorn apples, black haw, Rosa blanda and in somewhat sterile soil, the common hazel.

The prairies occupy the southwestern quarter of the state, extending thence eastward almost to the Mississippi, and northward through the Red River valley into Manitoba. It is notable that the line between the prairies and the hardwood forests is much sharper north of the Minnesota river than south of that stream, a fact probably due to the grouping of the numerous lakes in the former region and their scarcity in the latter. Throughout the prairie region of the state, trees occurred naturally only along river valleys and in groves about lakes. The commonest trees are the cottonwood, box-elder and white elm, though numerous others occur, especially in the south. The bur oak is the only oak which extends far into the prairie parts of the state, and there it is often scarcely more than a bush.

The most characteristic shrubs of the prairie district are the Amorphas, roses, especially Rosa arkansana, hazel, and in the extreme western part of the state, the buffalo berry, Shepherdia argentea. 



\section{Key to the Genera}

I. Leaves needle-like or scale-like

1. Leaves alternate or fascicled

a. Leaves all alternate and scattered

(1) Trees with fragrant leaves

(a) Leaves square, inserted on prominent bases Picea: spruce

(b) Leaves flat

$x$. Leaves bright green, bract scales trifid, projecting
Leaves dark and glossy above, whitish be-

y. Leaves dark and glossy above, whiti
low, bract scales rounded, included

(x) Cones large $(5-10 \mathrm{~cm}$.), erect, scales deciduous

Abies: fir

(y) Cones small $(1.2-3 \mathrm{~cm}$.$) , pendent,$ scales persistent

Tsuga: hemlock

(2) Shrubs, leaves not fragrant

Tamarix: tamarisk

(b) Leaves more than $2 \mathrm{~mm}$. long, not scale-like

$x$. Leaves turned in at the edge, blunt

Empetrum: crowberry

y. Leaves flat, sharp-pointed

Taxus: yers

b. Leaves or some of them fascicled

(1) Leaves deciduous, many in each fascicle

Larix : larch

(2) Leaves persistent, 2-5 in each fascicle

Pinus: pine

2. Leaves opposite or in whorls of three

a. Leaves in whorls of three, needle-like, jointed at base

Juniperus: juniper

b. Leaves opposite, scale-like, appressed on mature branches

(1) Twigs flattened; pairs of leaves of two kinds alternating

Thuja: arbor vitae

(2) Twigs not flattened; leaves all alike on the same twigs

Sabina: red cedar

II. Leaves not needle-like or scale-like

1. Trees

a. Leaves simple

(1) Leaves not lobed

(a) Leaves ovate or round, broad

$x$. Leaves entire, mostly very large

(x) Leaves opposite, mostly cordate at base Catalpa: catalpa

(y) Leaves alternate, rounded or narrowed at base

Magnolia : magnolia

y. Leaves serrate to dentate

(x) Twigs very tough; fruit round, persistent, stalk winged

(y) Twigs brittle; fruit disappearing in spring 
(b) Leaves somewhat oblong, much longer than broad

x. Leaves opposite

y. Leaves both opposite and alternate, persistent in autumn

Viburnum: black haw

z. Leaves alternate

Rhamnus: buckthorn

(x) Leaves two-ranked, or apparently so

m. Sap milky; small trees Morus: mulberry

n. Sap not milky

(m) Leaves with one distinct midvein

r. Bark smooth, except when very old, splotched

Carpinus: hornbeam

s. Bark rough

(r) Leaves very oblique at base;

$$
\text { bark coarsely furrowed Ulmus: elm }
$$

(s) Leaf base not oblique; bark finely furrowed

(n) Leaves with three large veins at base; bark ridged

Ostrya: ironzeood

(y) Leaves not two-ranked

Celtis: hackberry

n. Bark without conspicuous lenticels

(m) Leaves doubly serrate or toothed

r. Stems and twigs more or less thorny Crataegus: hawthorn

s. Stems and twigs without thorns

(n) Leaf margin with a single row of Malus : apple teeth

r. Buds small, scales overlapping, many; fruit fleshy

s. Buds larger, covered by a single

Prunus: plum, cherry

(2) Leaves lobed

$$
\text { scale; fruit dry Salix: willow }
$$

Acer: maple

(b) Leaves alternate or fascicled

x. Leaves fan-shaped, many of them fascicled Ginkgo: maiden-hair tree

y. Leaves neither fan-shaped nor fascicled

(x) Leaves two-ranked

(y) Leaves more than two-ranked

Morus: mulberry

m. Leaves deeply cut-lobed; bark white

(m) Leaves small, bark separating into papery layers

Betula : birch

(n) Leaves silvery beneath, bark not papery

Populus: poplar

n. Leaves less lobed; bark not white

Crataegus: hawthorn

r. Stems and twigs thorny

Malus : apple

(n) Leaf margin entire

Quercus: oak

b. Leaves compound

(1) Leaves palmate

(a) Leaflets 3

(b) Leaflets many

Ptelea: hopiree

Aesculus: horse chestnut

(2) Leaves pinnate

(a) Leaves even-pinnate

$x$. Leàves twice-compound

(x) Leaves 3-9 dm. long; leaflets ovate Gymnocladus: coffee tree 172

(y) Leaves 1-21/2 dm. long; leaflets oblong Gleditsia: honey locust 173

y. Leaves once-compound

(b) Leaves odd-pinnate

$x$. Leaves opposite

(x) Leaflets entire or finely serrate

Fraxinus: ash 
(y) Leaflets lobed or doubly serrate

Acer: boxelder

y. Leaves alternate

(x) Leaflets entire

m. Leaflets elliptic, small; thorny

Robinia: locust

175

n. Leaflets ovate, large; thornless

Ailanthus: tree-of-hcaven

(y) Leaflets at least finely serrate

m. Large tree; fruit a nut

(m) Pith in plates; leaflets 11-23

(n) Pith solid; leaflets 5-11

n. Small trees; fruit fleshy, bright red

(m) Sap milky

(n) Sap not milky

Juglans: walnut, butternut

Carya: hickory

Rhus: sumac

2. Shrubs or vines

Sorbus: mountain ash

a. Leaves evergreen and leathery

(1) Creeping or prostrate shrubs

(a) Leaves narrowly linear, thick, edges folded back

(b) Leaves lanceolate to rounded, rarely linear

Empetrum : crowberry

$x$. Leaves less than $12 \mathrm{~mm}$. long

(x) Leaves much longer than wide

(y) Leaves broadly ovate

y. Leaves regularly more than $12 \mathrm{~mm}$. long

(x) Leaves serrate, fragrant

(y) Leaves entire, not fragrant

Vaccinium: cranberry

Chiogenes: snowberry

Gaultheria: wintergreen

m. Leaves narrowed at base

(m) Leaves scarcely $12 \mathrm{~mm}$. long, pale and resinous below

(n) Leaves $12-25 \mathrm{~mm}$. long, green and veined below

n. Leaf base not narrowed; leaf broadly elliptic

(2) Erect shrubs

(a) Leaves entire, with revolute margins

$x$. Leaves woolly below

y. Leaves smooth and white below

(x) Leaves opposite or in threes

(y) Leaves alternate

(b) Leaves toothed

x. Plant distinctly woody, leaves finely toothed Chamaedaphne: leatherleaf

Vaccinium: mountain cranberry 102

Arctostaphylos: bearberry

Epigaea: trailing arbutus

y. Plant semiherbaceous, leaves coarsely toothed Chimaphila: pipsissewa

Ledum: Labrador tea

Kalmia: swamp laurel

Andromeda : moorwort

b. Leaves deciduous

(1) Leaves simple

(a) Leaves not lobed on mature twigs

x. Leaves opposite or in whorls -

(x) Leaves entire

m. Leaves silvery-scurfy

Shepherdia: buffalo berry

n. Leaves green

(m) Stipules present, leaves often in

(n) Stipules absent, leaves in pairs

Cephalanthus: button-bush

$r$. Leaf-scars running together to form

a ring

(r) Stems hollow

h. Low shrub, 0.3-1 m. high

i. Tall shrubs or vines, over $1 \mathrm{~m}$. high

(s) Stems solid

h. Flowers and fruit axillary, in pairs, leaves very short petioled

Symphoricarpus: wolf-berry

Lonicera: honeysuckle

i. Flowers and fruit in terminal

Lonicera: honeysuckle 
clusters, leaves mostly longpetioled

Cornus: dogroood

s. Leaf-scars distinct

(r) Leaf-scars very small and flat, petioles short

(s) Leaf-scars round

h. Leaves smooth, flower- and fruit-clusters terminal

i. Leaves hairy or pimply beneath, flower- and fruit-clusters lateral

(y) Leaves toothed

Ligustrum : privet

Syringa: lilac

111

Chionanthus: fringe-tree

115

m. Leaves mostly in whorls of three

n. Leaves in twos, strictly opposite

$(m)$ Buds hidden by the petiole

(n) Buds not hidden

r. Leaves coarsely toothed

s. Leaves finely serrate

II'drangea: hydrangea

18.3

Philadelphus: syringa

181

Viburnum : viburnum

280

(r) Bark ridged, roots white Euonymus: burning bush

(s) Shrubs .7-1.3 m. high; bark not ridged

h. Leaf-scars running together to form a ring

i. Leaf-scars round, distinct

Diervilla: bush-honeysuckle

294

Forsythia

(t) Shrubs 2-5 m. high, petioles wide and glandular

y. Leaves alternate or fascicled

Viburnum : black haw

280

(x) Thorny shrubs with fascicled leaves Berberis: barberry

(y) Shrubs or vines with alternate leaves m. Leaves entire

(m) Leaves silvery

(n) Leaves not silvery

Elaeagnus: silverberry

r. Thorny vines

(r) Leaves oblong, pinnate veined Lycium: matrimony vine

(s) Leaves cordate, more or less parallel veined

Smilax: smilax

s. Smooth shrubs

(r) Tall shrub; leaves crowded at tips of twigs

(s) Low shrubs

h. Bark very tough

i. Bark not especially tough

(h) Leaves resinous below

(i) Leaves not resinous

Cornus : dogruood

Dirca: leatherivood

Gaylussacia: huckleberry

208

$n$. Leaves toothed or serrate

(m) Twining vine

(n) Shrubs

r. Leaves with three distinct veins

s. Leaves pinnately veined

Iaccinium: huckleberry

Celastrus : bittersweet

Ceanothus: redroot

(r) Leaves unequal at base

II amamelis: witch hazel

Leaf bases equal

h. Shrubs with spines or thorns

(h) Spiny shrubs, about $1 \mathrm{~m}$., leaves smooth and glossy above

(i) Thorny shrubs, taller, leaves not glossy

Cydonia: Japanese quince

Crataegus: hazothorn

i. Shrubs without thorns

(h) Leaves blunt to rounded at tip

p. Leaves fragrant

Myrica: stueet gale 
(1. Leaves not fragrant

(p) Leaves crowded at the tips of twigs Menziesia

(q) Leaves not crowded at the tips of twigs

e. Cultivated shrubs

f. Native shrubs

(e) Tall shrub, leaves over $5 \mathrm{~cm}$. long Alnus: alder

(f) Low shrub, leaves less than $5 \mathrm{~cm}$.

v. Swamp shrub Betula: birch

w. Shrubs of dry ground Amelanchier: juncberry

(i) Leaves acute to long-pointed at tip

p. Leaves long-pointed

(p) Leaves broadly ovate Corylus: hazel-nut

(q) Leaves lanceolate to linear Salix: zuillow

q. Leaves acute but not long-

(p) Fruit fleshy

e. Fruit with a single stone Prunus: plum, cherry

f. Fruit several-seeded

(e) Fruits solitary or 1-3 in a cluster

v. Fruit red

Ilex : winterberry

w. Fruit black, some leaves often opposite

Rhammus: buckthorn

(f) Fruits several or many in a loose cluster

v. Fruit ripening in mid-summer Amelanchier: juneberry

w. Fruit ripening in the fall

Aronia: chokeberry

Vaccinium: huckleberry

(q) Fruit dry

e. Fruits in catkins; seeds cottony Salix: zillow

f. Fruits in branched clusters

Spiraca: spiraca

(b) Leaves lobed

x. Leaves opposite

(x) Petioles usually with stipules and glands Viburnum: viburnum

(y) Petioles without stipules or glands

m. Leaves sharply and deeply lobed

n. Leaves crenately lobed

Acer: maple

Symphoricarpus: snowberry

y. Leaves alternate

(x) Leaf margin entire

m. Vines with broad palmately veined leaves

Menispermum: moonseed

n. Low aromatic shrub with linear leaves Comptonia: squeet fern

o. Low densely silky shrubs; leaves with 3-9 linear lobes

Artemisia: wormwood

(y) Leaf margin toothed

m. High-climbing vines

(m) Tendrils coiling, without disks

Vitis: grape

(n) Tendrils attached by disks

Parthenocissus: Boston ivy 
(2) Leaves compound

n. Shrubs

(m) Bark many-layered, splitting into

$$
\text { shreds Physocarpus: ninebark }
$$

(n) Bark firm

r. Tall shrub with thorns

Crataegus: hawthori

s. Bushes, sometimes prickly
(r) Leaves $1-21 / 2 \mathrm{dm}$. broad
Rubus : raspberry

(s) Leaves $1-10 \mathrm{~cm}$. broad

121

h. Leaves broad, deeply lobed

i. Leaves Ionger
slightly lobed

Ribes: currant, gooseberry

Spiraea : spiraea

(a) Leaves pinnate

$x$. Leaves opposite

(x) Vines

(y) Shrubs

Clematis: clematis

46

Sambucus : elderberry

y. Leaves alternate

(x) Leaf margin entire

m. Leaves odd-pinnate

(m) Tall spiny shrub with aromatic leaves

(n) Low bristly shrub; leaves not aro-

$$
\text { matic }
$$

(o) Neither spiny nor aromatic

r. Leaflets over $5 \mathrm{~cm}$. long

s Leaflets $5 \mathrm{~cm}$. or less
(r) Leaflets 5-7

(s) Leaflets 11-49

n. Leaves even-pinnate

(y) Leaf margin toothed

m. Leaflets 3-5

(m) Low small shrub or tall vine; leaflets obscurely toothed or sometimes lobed

(n) Spiny bushes; leaflets coarsely toothed

Rhus: poison ivy

Xanthoxylum: prickly ash 80

Robinia : rose acacia $\quad 175$

Rhus: poison sumac 227

Potentilla: potentilla 119

Amorpha: amorpha 177

Caragana: pea tree

(o) Smooth shrubs; leaves finely serrate Rubus: raspberry, blackberry 121

n. Leaflets 5-many

(m) Bushes or vines, usually prickly Rosa: rose 134

(n) Shrubs

r. Sap milky

s. Sap clear

Rhus: sumac

(r) Tall native shrub

(s) Low cultivated shrub

Sorbus: mountain ash

(b) Leaves palmate

Sorbaria: ash-leaved spiraea

$\mathrm{x}$. Vines with tendrils

Parthenocissus: woodbine

203

y. Bushes

Rubus : blackberry

\section{Flower Key to Families}

1. Petals present

1. Flowers single or in clusters

a. Petals separate

(1) Petals 3, sepals 3, stamens and pistils in differ-

ent flowers

(2) Petals 4

Smilacaceae

298

(a) Petals strap-shaped

x. Petals yellow, stamens 4, (staminodia 4) Hamamelidaceae 
y. Petals white, stamens 2

Oleaceae

(b) Petals not strap-shaped

x. Stamens 4-5

(x) Thorns present, leaves compound

Rutaceae

(y) Thorns absent, leaves simple

m. Leaves evergreen, very small

n. Leaves not evergreen, opposite

Ericaceae

(m) Ovary superior

Celastraceae

194

(n) Ovary inferior

y. Stamens 8-many

Cornaceae

270

Saxifragaceae

(3) Petals 5 or more

(a) Flowers regular

x. Pistil simple, 1-many

(x) Pistils few-many

m. Twining vines

(m) Flowers small, dioecious

Menispermaceae

50

(n) Flowers large and showy, perfect Ranunculaccae

n. Trees or shrubs

(m). Stamens inserted on the calyx, receptacle flat or hollow

Rosaceae

118

(n) Stamens free from the calyx, receptable cone-shaped

Magnoliaceae

(y) Pistil 1

m. Stamens 5-12

(m) Spiny shrubs, leaves simple or once

pinnate
(n) Trees, often thorny, leaves mostly twice pinnate

n. Stamens many

Berberidaceae

48

Leguminosae

171

Prunus in Rosaceae

y. Pistil compound

(x) Vines

m. Vines with tendrils, stamens opposite the petals

Vilaceae

n. Vines without tendrils, stamens alternate with the petals

(m) Leaves simple

(n) Leaves compound

Celastraceae

(y) Trees or shrubs

m. Leaves simple

(m) Leaves scale-like

Anacardiaceae

(n) Leaves not scale-like

r. Style 1

(r) Trees, stigma 5-lobed

Tamaricaceae

(s) Shrubs

p. Stamens 5, opposite the petals Rhamnaceae

q. Stamens 5, alternate with the petals, or more than 5

(p) Ovary superior

h. Evergreen shrubs

i. Deciduous shrubs

(h) Leaves alternate

Ericaceae

(i) Leaves opposite

Ilicaceae

Celastraceae

(q) Ovary inferior, stigmas 2

Ribes in Saxifragaceae

s. Styles $2-5$

(r) Styles 2

p. Leaves opposite, ovary superior Aceraceae

q. Leaves alternate, ovary inferior Ribes in Saxifragaceae

(s) Styles 35 , ovary inferior

p. Leaves alternate

q. Leaves opposite

Rosaceae

Saxifragaceae

.. Leaves compound

(m) Leaflets always 3

r. Flowers white 
s. Flowers greenish

(n) Leaflets usually more than 3

r. Thorny shrubs

s. Thornless shrubs or trees

(r) Flowers white

(s) Flowers greenish

(b) Flowers irregular

x. Stamens 7, separate

y. Stamens 10,9 of them united

b. Petals united

Anacardiaccae

Rutaceae

Rosaccae

118

Simarubaccae

Sapindaceae

216

I.cguminosae

(1) Ovary superior

(a) Flowers regular

x. Stamens 2

y. Stamens 4-10

(x) Ovary 2-celled

(y) Ovary 4-10-celled

(b) Flower irregular

(2) Ovary inferior

(a) Stamens 5

(b) Stamens 8-10

Oleaceae

Solanaceae

106

Ericaceae

84

Bignoniaceae

116

Caprifoliaceae

277

Ericaceae

2. Flowers in heads

a. Stamens united, style 2-cleft

b. Stamens separate, style not cleft

Compositae

297

Rubiaceac

II. Petals absent

1. Sepals present, rarely very minute

a. Climbing vines

(1) Stamens and pistils many, sepals large Clematis in Ranunculaceae

(2) Stamens 5, pistil 1, sepals minute (petals present but falling quickly)

Vitaceae

b. Shrubs or trees

(1) Flowers in catkins, at least the staminate

(a) Pistillate flowers in catkins, sap milky

(b) Pistillate flowers solitary, sap not milky

(2) No catkins present

Moraceae

Fagaccae

(a) Style 1

x. Stigma 1 or slightly 2-cleft

(x) Trees with compound leaves

(y) Low shrubs with simple leaves

m. Leaves green, glabrous

n. Leaves silvery or scurfy

y. Stigma with 6-9 radiate divisions

(b) Styles or long sessile stigmas 2

$x$. Leaves deeply cut or compound

y. Leaves simple, not deeply cut

(c) Pistils 2-5, thorny shrub

Oleaceae

Thymelacacea

207

Elaeagnaceae

Empetraceae

Aceraceae

Ulmaceae

Rutaceae

2. Sepals absent, or occasionally very minute

a. Leaves scalc-like or needle-like, usually evergreen

(1) Leaves resinous, fragrant when bruised; fruit a cone or several-seeded blue berry

(2) Leaves not resinous nor fragrant; fruit a oneseeded red berry

Pinaceae

Taxaceae

b. Leaves not scale-like or needle-like, deciduous

(1) Leaves simple

(a) Leaves fan-shaped with forking veins

(b) Leaves from ovate to linear, net veined

Ginkgoaceae

$x$. Fruit with many hairy seeds, flowers dioecious

Salicaceae

y. Fruit one-seeded, flowers usually monoecious
(x) Low shrubs with very fragrant leaves
Myricaceae

(y) Trees, rarely shrubs; leaves not fragrant Betulaceae

(2) Leaves compound

$x$. Leaves alternate, staminate flowers in catkins Juglandaceae

y. Leaves opposite, flowers in clusters

Oleaceae 


\section{Gymnospermae}

Seed-bearing plants without closed pistils, ovules and seeds exposed, or protected by the separate but overlapping scales on which they are borne; pollen grains entering the micropyle of the ovule and germinating within the developing seed; the body of the seed formed by the female gametophyte, developed previous to the fertilization of the egg and the development of the embryo.

\section{Coniferales Pine Order Pinaceae Pine Family}

Trees or rarely shrubs; leaves needle- or scale-like, usually evergreen; flowers monoecious or dioecious, cone-like, the staminate consisting of a more or less elongated axis which bears numerous usually scale-like stamens, each of which bears $2-40$ pollen sacs or sporangia, the pistillate more complex in structure, varying in the several tribes (see below), the ovules and seeds not in a closed ovary but sheltered and concealed between the scales of the pistillate cone.

Leaves, bark and wood containing much oleoresin which is often of conmercial importance.

An ancient family of trees, at one time forming the dominant vegetation of the earth, and still forming great forests in the temperate regions of both the northern and the southern hemispheres.

\section{KEY TO THE TRIBES}

1. Leaves linear, needle-like, alternate or in fascicles

Abietineae

2. Leaves often scale-like, opposite or in whorls

Cupressineae

\section{Abietineae Fir Tribe}

Leaves and cone-scales primarily alternate-the foliage leaves may be in dense clusters or fascicles which are however always arranged on the branches in an alternate spiral fashion, foliage leaves linear, needle-like or flattened, never scale-like; stamens with two pollen sacs, pistillate cones with two distinct kinds of scales, the bracts or sterile scales and the seedbearing scales, one of which is borne in the axil of each bract, each seed-bearing scale bearing two inverted seeds on its upper side. 


\section{IEY TO TIIE GENERA}

1. Foliage leaves all scattered, alternate

a. Leaves flat linear, more or less twisted into two ranks

(1) Buds small round resinous, cones upright with decidous scales

Abies

(2) Buds scaly not resinous, cones pendent with persistent scales

(a) Leaves about $2 \mathrm{~cm}$. long, their scars scarcely raised; bracts of cone long

(b) Leaves about $1 \mathrm{~cm}$. long, their scars raised on woody projections; bracts of cone short

b. Leaves four-sided in section, not at all two ranked, their scars raised on woody projections

2. Foliage leaves or some of them in fascicles

a. Leaves deciduous, some scattered, others in large fascicles

b. Leaves evergreen, in fascicles of 2-5

\section{Pseudotsuga}

\section{Tsuga}

Picea

\section{Larix \\ Pinus}

\section{Cupressineae Cypress Tribe}

Leaves and cone-scales opposite or in whorls, leaves needle-like or reduced to small flattened scales which adhere to the twigs, stamens often with more than two pollen sacs, pistillate cones without distinct "bracts," seeds erect, 1-40 upon each seed-bearing scale.

\section{KEY TO THE GENERA}

1. Cones woody, twigs and spray flat, leaves scalelike, of two alternating types

2. Mature cones fleshy, twigs and spray not flattened

a. Leaves usually opposite, scale-like on mature twigs

b. Leaves in whorls of three, all needle-like

\section{Thuja}

\section{Sabina}

Juniperus

Abies Jussie u r789 Fir

(L. and Gr. a bies, fir tree.)

Evergreen trees, sometimes shrubby at high altitudes, trunk straight, running to the top of the tree, branches irregular or whorled, horizontal; leaves needle-like but usually flat and blunt, sessile, scattered and borne 


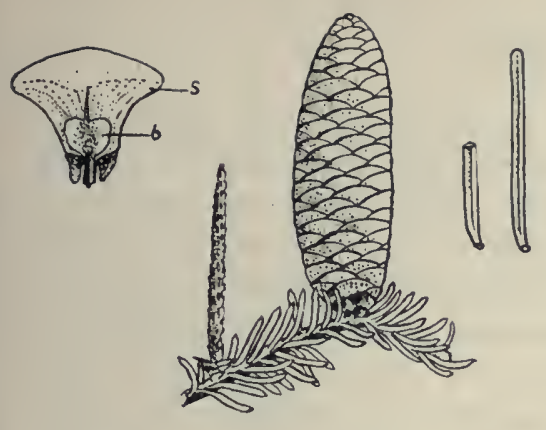

Abies

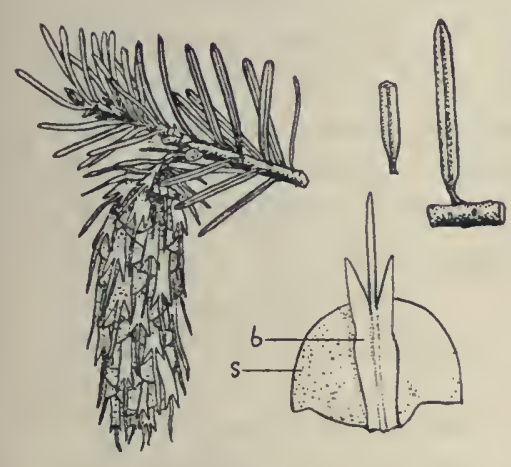

Pseudotsuoga
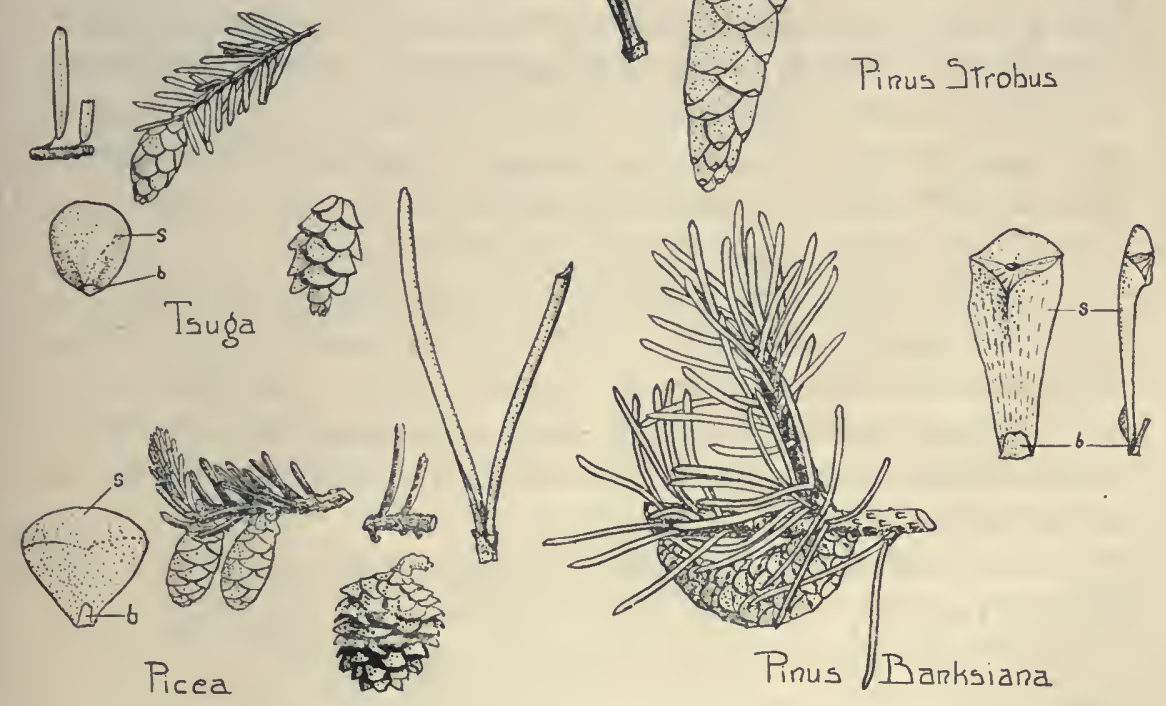

Abietineae. Species illustrated: Abies balsamea, Pseudotsuga taxifolia. Tsuga canadensis, Picea mariana, Larix laricina, Pinus Strobus and Pinu. Banksiana. Twigs with cones $x / 2$, lexves and cone-scales natural size; $\mathrm{b}$ bract, $\mathrm{s}$ seed-bearing scale.

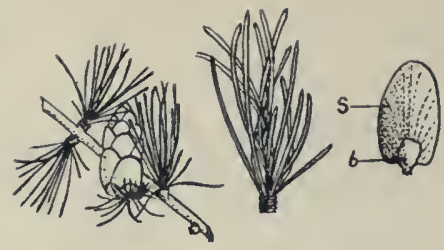

Larix
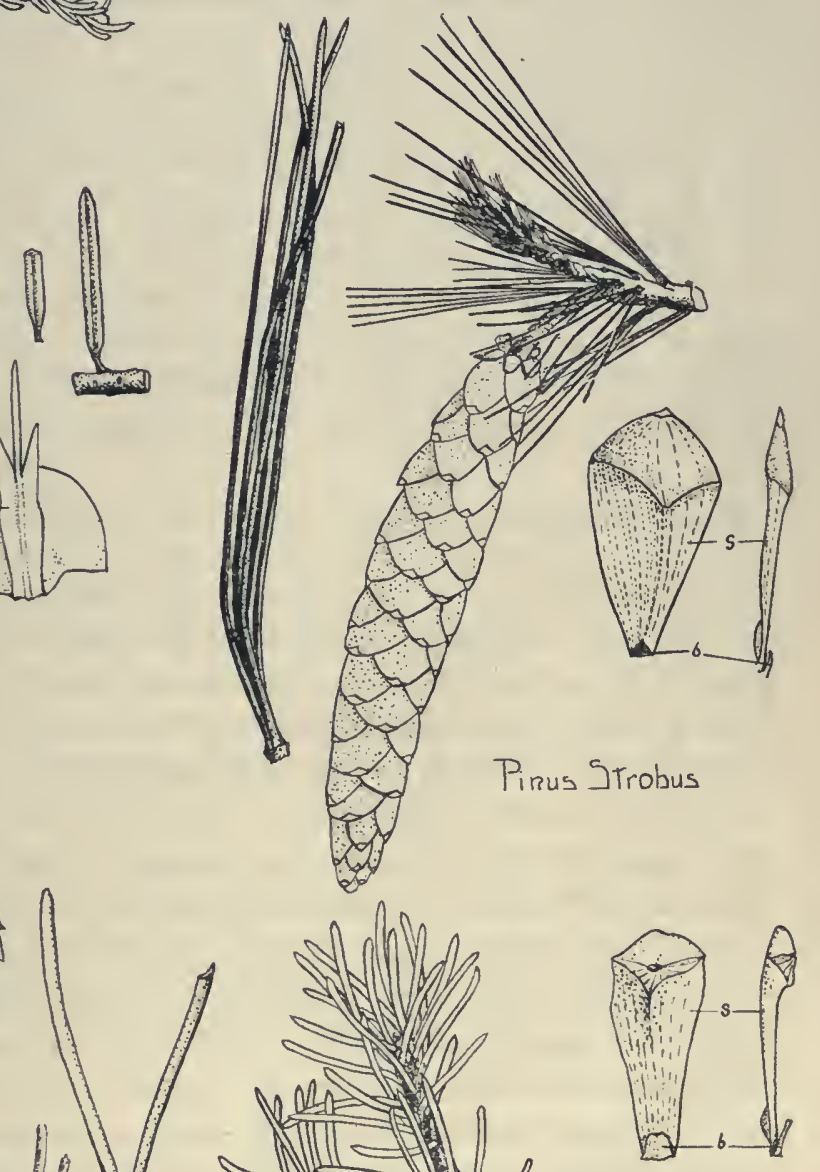
in many rows; but often twisted into an apparently two-ranked arrangement, remaining on the twigs for many years and when they fall leaving the bark nearly smooth with round scars; buds usually round and covered with resin; flowers in spring, monoecious, the staminate in the axils of last year's leaves, very small, consisting of an axis bare at the base and covered above with the numerous stamens, stamens with a spur- or knob-like tip, pollen sacs opening transversely, pollen winged as in pine; pistillate cones erect, on the sides of the uppermost branches, the young cone with long and conspicuous bracts, which may later be hidden by the developing seed-bearing scales, cones ripening in the autumn of the first year, at maturity falling to pieces leaving their bare axes standing upon the branches; seeds winged, resinous.

Trees of the cooler parts of the north temperate zone and of the adjacent mountainous parts of the tropics; about 23 species, over one half of which occur in the lands bordering the North Pacific. One other species occurs in eastern North America, eight in western North America.

\section{Abies balsamea (Linné) Mille r 1769 Balsam Fir Balsam}

Evergreen tree, 7-18 m. (23-60 ft.) high; bark smooth, grayish, covered with numerous blisters containing resin; leaves resinous, very fragrant, flat, blunt, 1-3 cm. long, except on the uppermost branches twisted into an apparently two-ranked arrangement; buds small globular covered with a varnish-like resin; young pistillate cones purple, mature cones bluish green, cylindrical, $6-10 \mathrm{~cm}$. long, the bracts concealed by the longer seed-bearing scales, ripening in autumn when the scales fall away leaving the bare axes standing upon the branches: b a ls a mea, referring to the abundance of balsam in the bark.

Evergreen forests from Labrador and Newfoundland to Minnesota, south to Virginia and northern Iowa. In Minnesota common in the northeastern and northern parts of the state, not occurring beyond the region of evergreen forests except in a few scattered localities in the southeast corner of the state. Flowers in April or May, cones ripe in the autumn of the same year.

Seldom cultivated in Minnesota. Balsam fir in cultivation is very heautiful for a few years, but soon becomes thin and straggling.

Wood light brown, soft, weak, weight $24 \mathrm{lb}$. seldom used except for paper pulp; the oleoresin from the blisters in the bark is "Canada Balsam"; the fragrant dry twigs are often used to stuff sofa-pillows and similar articles. 
Abies concolor Lind le y a n d Gordon $185^{\circ}$

A west American species with stout bluish leaves 50-75 mm. long and about $2 \mathrm{~mm}$. wide is sometimes planted in Minnesota, but at least in the vicinity of, Minneapolis it is not hardy and the upper branches are often killed back in severe winters, keeping it in the form of a low bush.

\section{Pseudotsuga Carrière I867 Douglas Fir}

(Gr. p s e u d e s, false, Japanese, t s u g a, hemlock.)

Evergreen trees, trunk straight, running to the top of the tree, branches horizontal, irregularly whorled; leaves needle-like but flat and blunt, soft, sessile or slightly stalked, scattered, borne in many rows, remaining on the tree for several years and when they fall leaving the bark almost smooth or with slightly raised oval scars; buds scaly not resinous; flowers in spring monoecious, the staminate borne in the axils of last year's leaves, consisting of an axis, bare at the base and covered above with the numerous stamens, stamens with a spur-like tip, pollen sacs opening obliquély; pistillate cones terminal or axillary, pendent at maturity, the bracts long, conspicuous, cleft at the summit into three lobes, cones ripening in the autumn of the first year, opening to discharge the seeds and finally falling entire from the tree; seed winged, not resinous.

Only 3 species, one native of southern California, one of Japan, and the following species widely distributed through western North America.

\section{Pseudotsuga taxifolia (Lambert) B ritton 1889 Douglas Fir, Douglas Spruce.}

\section{Ps. mucronata (Rafinesque) Su d w o r th 1895 \\ Ps. Douglasii (Lindley) Ca r r i èr e 1867}

In Minnesota seldom exceeding $12 \mathrm{~m}$. (40 ft.) in height (on the Pacific coast sometimes $80 \mathrm{~m}$. high), trunk straight, running to the crown of the tree, branches horizontal, bark in young trees grayish, smooth, often with a few resin blisters resembling that of the balsam fir, in older trees becoming rough and brown and in old trees in their native habitat very thick, deeply fissured and falling off in large scales; buds hrown, sharp pointed, not resinous, covered with numerous papery scales; leaves fragrant, flat, blunt and soft, arranged all about the twigs, or twisted into an apparently two-ranked arrangement; cones oval-cylindrical, pendulous, when ripe woody, $4-8 \mathrm{~cm}$. long: taxifolia, yewleaved. 
Cultivated: native to the forests of the Rocky Mountains and the Pacific Coast region from British Columbia south to Texas, Mexico, and central California. Only the trees from the Rocky Mountain region are hardy in Minnesota where the Douglas Fir is often planted as an ornamental tree. It is very hardy but has a tendency to grow thin in foliage. It has proved a successful plant for evergreen hedges, stands clipping well, and will endure dry weather better than most conifers.

In its natural habitat, particularly in the vicinity of the Pacific Coast, this is one of the finest of North American trees, reaching a height of over two hundred feet, and a trunk diameter of fifteen feet. It is the most valuable timber tree of British Columbia, Washington, and Oregon; wocd light brown, ccarse grained, very strong, weight $32 \mathrm{lb}$.

\section{Tsuga Carrière 1855 Hemlock}

( $\mathrm{T}$ s u ga-Japanese name for hemlock.)

Evergreen trees, trunk straight reaching to the top of the tree, branches irregular, spreading or often drooping, twigs slender; leaves linear, flat and blunt, short petioled, scattered and borne in many rows but usually twisted into an apparently two-ranked arrangement, remaining on the twigs for two or three years but rapidly falling if the twig is dried, when they fall leaving the twigs roughened by woody raised projections on top of which are the leaf scars; buds scaly, not resinous; flowers in spring monoecious, the staminate in the axils of last year's leaves, very small, with a bare stalk and an almost globular bunch of stamens, stamens with a spur- or knob-like tip, pollen sacs opening transversely, pollen grains not winged; pistillate cones terminal, drooping, with inconspicuous bracts, cones ripening the first autumn, opening at maturity and discharging the seeds after which the whole cone falls from the trees; seeds winged, slightly resinous.

Trees of North America and eastern Asia; 7 species; cne other occurs in eastern United States, and two in northwestern Norih America. One of the latter departs in several respects from the usual characters of the genus.

\section{Tsuga canadensis (I_inné) Carrièr e 1855 Hemlock}

A tall tree over $15 \mathrm{~m}$. (50 ft.) in height; trunk straight, upright, extending to the summit, branches spreading. nearly horizontal, the leading shoot in young trees usually more or less pendulous; twigs slender, 
leaves flat, 8-13 $\mathrm{mm}$. long, short petioled, scattered, but twisted so as to appear two-ranked, dark green above, white beneatl; pistillate cones small, ovoid, 1.5 to $2.5 \mathrm{~cm}$. long: c a n a d e $\mathrm{n} \mathrm{s}$ is, Canadian.

Coniferous forests, usually in acid soil containing considerable organic matter, from Nova Scotia to Delaware and southward along the Alleghanies, westward through northern Michigan and Wisconsin in which State it is abundant. The hemlock barely reaches Minnesota, occurring native just southwest of the head of Lake Superior.

Occasionally planted as an ormamental tree or as an evergreen hedge; neither the dry autumns nor the prevailing limestone soils of Minnesota suit the hemlock and it is apt to die out after a few years. In Upper Michigan and Wisconsin it is a valuable timber tree much used for coarse lumber, piles, etc. Wood light reddish brown, soft, coarse, brittle and splintering, weight $26 \mathrm{lb}$. The bark is extensively used in tanning leather.

\section{Picea Link 1827 Spruce}

(L. p i c e a spruce or fir tree, from $\mathrm{p}$ i $\mathrm{x}$, pitch.)

'Trees with straight trunks running to the top of the crown, and abundant, horizontal, drooping or slightly ascending branches; smaller twigs clothed with closely set evergreen needle-like leaves arranged in a close spiral; leaves usually four-sided, sharp pointed, spreading in all directions from the twig, borne upon small woody projections which render the twigs rough when the leaves fall (spruce and hemlock leaves fall quickly when a twig is dried, fir and Douglas fir leaves are apt to remain attached to the dried twig); buds scaly, not resinous; flowers monoecious, the staminate solitary, lateral, consisting of an axis bearing the numerous overlapping, scale-like stamens, each of which bears two pollen sacs which open longitudinally; pollen winged as in pine; pistillate cones usually borne laterally on the twigs with very short peduncles, drooping, ripening the same year, dry and woody or membranous when ripe; the seedbearing scales entirely concealing the small bracts; seeds winged, not resinous, discharged from the ripe cones which often remain on the tree for some time after the fall of the seeds, and finally fall off entire.

A genus of about 14 species of the far northern and the mountainous parts of the northern hemisphere. It includes the most boreal conifers in the world. Besides the following there are in North America one eastern and three western species. 


\section{Key to the Species}

1. Twigs spreading horizontally, cones less than

$8 \mathrm{~cm}$. long.

(a) Twigs smooth, cone-scales flexible

(1) Leaves very stiff and blue, $25-30 \mathrm{~mm}$. long; cultivated

(2) Leaves slender, 10-25 mm. long; native

P. pungens

P. canaderisis

(b) Twigs minutely hairy, leaves $5-15 \mathrm{~mm}$.

long, cone-scales stiff; native P. mariana

2. Twigs drooping, cones $10-20 \mathrm{~cm}$. long; cultivated

P. Abies

Picea pungens Engelmann 1879 Colorado Blue Spruce Picea Parryana Sargent I 898

Abies Menziesii var. Parryana André 1876

A tree, in its native regions sometimes $30 \mathrm{~m}$. (100 ft.) tall, here in cultivation much smaller; branches and branchlets stiffly horizontal and in layers; bark grayish brown, scaly, twigs brown, smooth; leaves 25-30 mm. long, four-sided, thick, stiff and sharp-pointed, pale bluish green, particularly in young specimens; cones cylindrical, $6-10 \mathrm{~cm}$. long, their scales pale grayish brown, longer than broad, very thin and flexible, irregular at the outer end; pungens, pricking, referring to the sharply pointed leares.

Cultivated: native to the Rocky Mountain regions of Colorado, Wyoming, and Utah. Much planted as an ornamental tree on account of its striking blue color. It is hardy, but tends with age to become somewhat straggling and to take on a darker green color. Different specimens vary much in the intensity of the blue color and the best are sometimes propagated by grafting.

Wood white to light brown, soft, weak, close-grained, weight $2.3 \mathrm{lb}$.; the wood is occasionally used locally in the mountains.

Picea canadensis (Miller) Britton, Sterns and Pogg c nberg i 888 White Spruce P. alba (Aiton) Link $18,3 \mathrm{I}$

A large tree up to about $30 \mathrm{~m}$. (100 ft.) tall ; trunk upright, straight; branches long, ascending or horizontal; bark slightly roughened, reddish or grayish brown, finally somewhat scaly, twigs light brown, smooth; leaves four-sided, 10-25 mm. long, pale bluish green, unpleasant smelling 
when bruised; cones small, cylindrical, $3.5-6 \mathrm{~cm}$. long, falling after the seeds are discharged, cone scales thin, flexible, usually entire : c a $\mathrm{n}$ a d e ns is, Canadian.

Usually in dry soil with pines, etc., reaching the northern limit of tree growth, Newfoundland and Labrador to the vicinity of Bering Sea, southward to northern New England, New York, the upper Great Lakes, the Black Hills, and the Rocky Mountains of British Columbia. In Minnesata nearly confined to the evergreen forests of the northern and northeastern parts of the state, but straggling southward along the valley of the St. Croix river, at least as far as the vicinity of Osceola, Wisconsin. Flowers in May, cones ripe in the autumn of the same year. Ornamental and doing well in cultivation in the more moist parts of the state.

Wood light yellow, soft, weak, straight-grained, weight $25 \mathrm{lb}$, used in eastern Canada for lumber, and extensively for paper pulp, for which purpose it is more employed than any other wood.

Picea mariana (Miller) Britton, Sterns and Poggen-· berg i 888 Black Spruce

\section{P. nigra (Aiton) Link I8.3 I}

A small tree with an upright, straight trunk, and short usually drooping branches; bark scaly; leaves bluish green, four-sided, 5-15 mm. long, twigs brown, under the lens appearing more or less hairy; cones small, oval, $1.5-3.5 \mathrm{~cm}$. long, borne on sharply recurved stalks, and remaining long on the tree, scales stiff, thin, usually with toothed margins.

Usually in cold swamps, often accompanied by tamarack; Labrador and Newfoundland to the valley of the Yukon, southward to northern British Columbia, Mimnesota and New Jersey. In Minnesota confined to the evergreen forests of the northeastern and northern parts of the state, and to cold bogs within a few miles of these evergreen forests. It does not extend as far south as the tamarack. Seldom cultivated as it has little beauty to commend it?

Wood pale yellow, or nearly white, soft, weak, weight 28 lbs.; seldom used for anything except paper pulp. The resinous exudation from the trunk is "spruce gum" and the leaves are boiled to produce the flavor of "spruce beer." 


\section{Picea Abies (Linné) Karste 11 188I Norway Spruce P. excelsa (Lamarck) Link I84I}

Large tree reaching in its native regions a height of $40 \mathrm{~m}$. (135 ft.), trunk straight, branches of moderate length, spreading, branchlets opposite, at first horizontal, but soon becoming drooping; bark scaly, reddish brown; twigs brown, smooth or hairy; leaves light green, four-sided, $15-25 \mathrm{~cm}$., long; cones very long $(12-15 \mathrm{~cm}$.) and cylindrical, their scales thin, firm, broad and usually with an irregular margin: a bies the Latin name of the spruce or fir.

Cultivated: a native of Europe where it grows from the extreme north to the alpine regions of the Alps and Pyrenees. Flowering in April, cones ripe the same autumn.

More commonly planted for ornament than any other spruce, it is laardy and grows rapidly, but is apt to be injured by hot dry summers, and loses its beauty after thirty or forty years, by the dying of the lower branches.

Wood reddish or yellowish, soft, fine-grained, much used in Europe for lumber for floors, boxes, cheap furniture, scaffolds, masts, spars, etc. The oleoresin from this tree, "Burgundy pitch," is used medicinally; the bark is used in tanning leather.

\section{Larix Adanson I $_{7} 6_{3}$ Larch, Tamarack}

\section{(L. 1 a rix, larch tree.)}

Trees with a straight upright trunk, extending to the top of the tree, and indistinctly whorled, spreading or ascending branches; leaves needle-

- like, bright green, turning yellow and falling in autumn, upon the new twigs borne singly in a close spiral, like the leaves of spruce, but upon the older branches and the trunk borne in tassel-like tufts, "dwarf shoots," which produce twenty to thirty leaves each year for many years; flowers monoecious, staminate cones solitary, borne without accompanying leaves on the sides of twigs and branches, globose or nearly so, the stamens twocelled, opening longitudinally, pollen wingless; pistillate cones appearing with the leaves in early spring, red or greenish, the ovule-bearing scales shorter than the bract-scales, cones small, ripening and opening the first autumn. but remaining on the tree throughout the winter, the seed bearing scales in our species concealing the short bract-scales. Our only deciduous conifers. Besides the following two there are six other species native of western North America, Siberia and Japan. 


\section{Key to the Species}

1. Native tree; mature cones $1-1.5 \mathrm{~cm}$. long

L. laricina

2. Cultivated tree; mature cones $2.5-3.5 \mathrm{~cm}$. long

L. decidua

Larix laricina (Du Roi) K o ch 1873 Tamarack, American Larch L. americana Michaux 1803

A tree about 12-18 $\mathrm{m}$. (40-60 ft.) ligh and 3-5 dnı. in diameter at the base; bark rough, scaly; leaves triangular in section, 15-30 mm. long, bright green turning golden yellow in the fall, very soft and flexible; young cones red or greenish; cones with 10-20 scales, oval, not over $2 \mathrm{~cm}$. in length: $\mathrm{l}$ a $\mathrm{r}$ i c in a, larch-like.

A tree usually inhabiting cold swampy ground, but occasionally found in drier situations and then reaching its largest size; northern North America from Labrador and Newfoundland to the Yukon valley, southward to New Jersey, Minnesota, and northeastern British Colunibia. Abundant in Minnesota in the northeastern coniferous forest, where it usually grows with black spruce, and southward in sour swamps scattered throughout the hardwood region of eastern Minnesota, as far south as Minneapolis and the region around Lake Minnetonka. It does not occur native south of the Minnesota river. Flowers in April or early May, cones ripe in the autumn of the same year.

In cultivation the tamarack grows well in soil much drier than that which it naturally inhabits. It is not however as handsome or graceful a tree as the European larch.

- Wood light brown, hard, coarse, resinous, very strong and durable, weight 39 pounds; much used for fence posts and fuel.

\section{Larix decidua Mi11er I768 Larch \\ L. europaea De Candolle 1805 \\ L. Larix (Linné) Karsten I882}

A tree about $12 \mathrm{~m}$. (40 ft.) high and $5 \mathrm{dm}$. in diameter at the base; branches spreading, young twigs somewhat drooping; bark rough and scaly; leaves 20-25 mm. long, bright green, soft and flexible, turning yellow in autumn; young cones scarlet, cones with 40 or more scales, oblong or conical, $2.5-4 \mathrm{~cm}$. long.

Cultivated: a tree from the mountainous parts of Europe, growing well in dry soil. It is planted as an ornamental tree and does well in situations too dry for any of the evergreen conifers except the red cedar. 


\section{Pinus Linn é 1753 Pine}

\section{(L. $\mathrm{p}$ i $n \mathrm{us}$, the pine tree)}

Trees or sometimes shrubs with variously branched trunks; foliage leaves evergreen, needle-like, in fascicles of two to five*, the young twigs at first without foliage leaves and clothed only with scattered spirally arranged scales, the fascicles of foliage leaves appearing in the axils of these scales, each fascicle at first surrounded by a sheath of similar scales which may later fall away, or may be permanent, the whole fascicle eventually falling away from the branch at the end of several years' time; flowers monoecious, usually on separate branches, the staminate clustered near the ends of the twigs, surrounding the base of a shoot of the current season, consisting of an axis bearing numerous overlapping scale-like stamens, each of which bears two pollen-sacs which open longitudinally; tip of stamen knob-like, or with a small scale-like appendage, pollen grains winged, the round grain bearing two air bladders which are about equal in size to the grain proper; pistillate cones solitary or in small groups, lateral or sub-terminal, the ovule-bearing scales of the young cones longer than the bracts; cones ripening in two or three years, woody, the seed-bearing scales often much thickened at the outer end; cones opening at maturity to scatter the seeds, or in some species remaining closed for many years; seeds usually winged, not resinous.

About 70 species of the north temperate zone and the mountainous parts of the northern tropics, most abundant in the warm temperate regions. Among the most valuable forest trees for timber and for their various resinous products, turpentine, rosin, pitch, tar, etc.

\section{Key to the Species}

Two sub-genera are recognized.

1. Strobus: The exposed portions of the cone scales but slightly thickened, stamens nearly crestless, leaves in fascicles of five, the scaly sheath usually quickly deciduous, wood soft.

One species in Minnesota

\section{P. Strobus}

2. Pinaster: The exposed portions of the cone scales much thickenecl, stamens bearing a crest-like scale, leaves in fascicles of 1-5 (2 in all of our species), the scaly sheath usually persistent around the base of the fascicle, wood often hard.

Key to species of Pinaster growing in Minnesota, based on leaf structure. Leaves in all of our species semi-circular or crescentic in cross section, and with two vascular bundles.

* In a peculiar species of the southwestern United States there is only one foliage leaf in each fascicle. 
1. Resin ducts numerous, close to the surface; strengthening cells epidermal.

a. Leaves over $1 \mathrm{dm}$. long, bundles close together $P$. resinosa

b. Leaves less than $1 \mathrm{dm}$. long, bundles widely separated

(1) Bundles embedded in sclerenchyma, epidermal cells nearly square $P$. silvestris

(2) Bundles not surrounded by sclerenchyma, epidermal cells radially elongated P. montana

2. Resin ducts 2, in the midst of parenchyma; strengthening cells beneath the epidermis.
a. Leaves over $1 \mathrm{dm}$. long,
P. Laricio austriaca
b. . Leaves under $5 \mathrm{~cm}$. long,
P. Banksiana
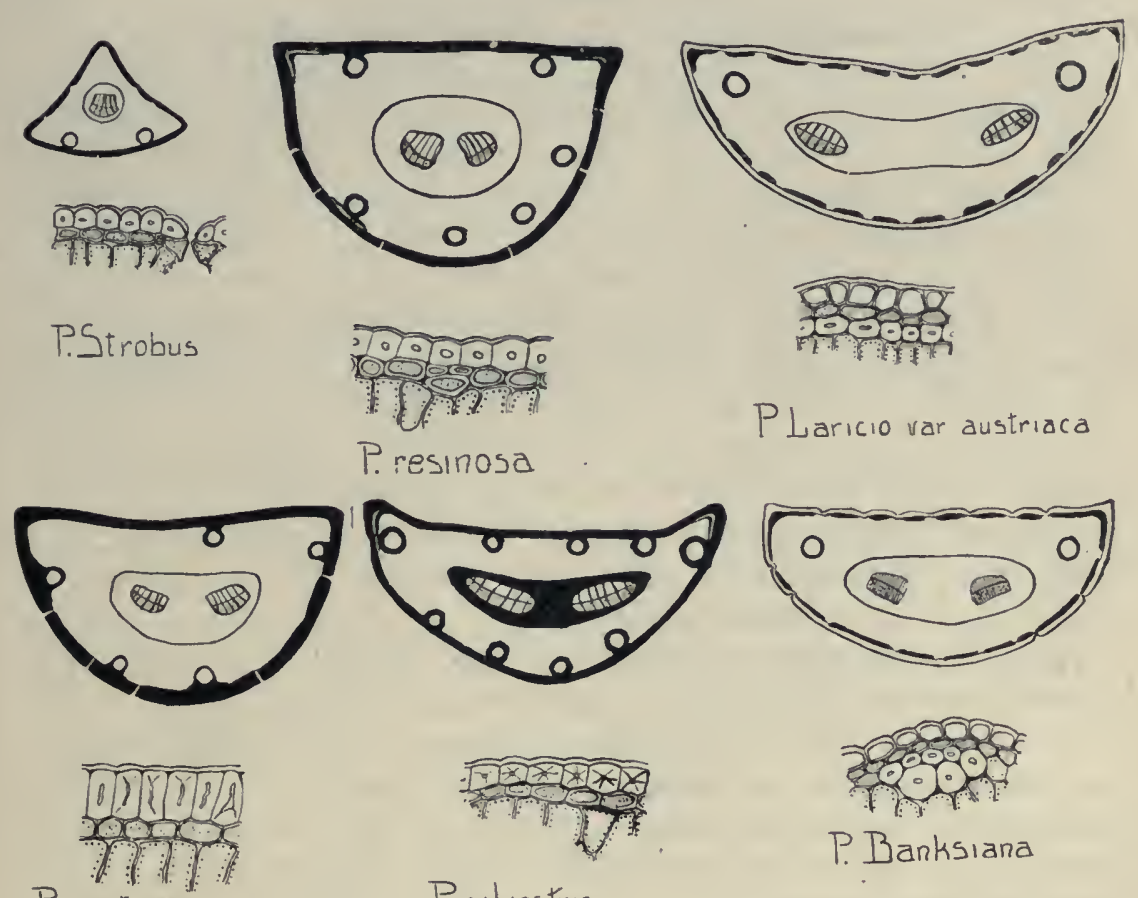

P montana
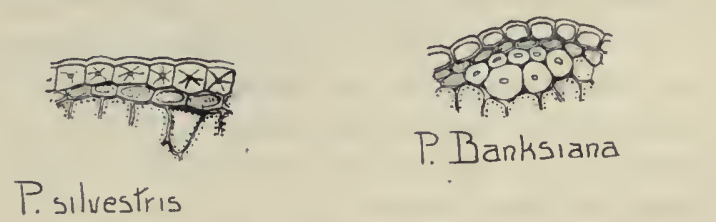

Cross-sections of leaves of species of Pinus; diagrams x20, detail of epidermis and the layers immediately beneath it $\mathrm{x} 150$. In the diagrams the sclerenchyma layer is heavily shaded. 
Key to species of Pinaster growing in Minnesota, based upon general features-

1. Leaves more than $1 \mathrm{dm}$. long

a. Leaves thin, flexible, bark reddish, native $P$. resinosa

b. I.eaves thick, stiff, bark gray, cultivated $P$. Laricio austriaca

2 Leaves less than $1 \mathrm{dm}$. long

a. Trees usually $4-20 \mathrm{~m}$. high.

(1) Leaves flexible, bluegreen, $2.5-7 \mathrm{~cm}$. long, cones reflexed, cultivated

$P$. silicstris .

(2) Leaves stiff, yellow green, 2.5 to 5.5 $\mathrm{cm}$. long, cones pointing forward, native

\section{P. Banksiana}

b. Low branching shrub, 1-t $\mathrm{m}$. high, leaves $4-7 \mathrm{~cm}$. long

P. montana

\section{Pinus Strobus Linné I753 White Pine}

Large forest tree with a straight trunk up to $40 \mathrm{~m}$. (130 ft.) high, and up to 1 meter in diameter at the base; young trees with regular whorled lorizontal branches, the older ones with strong irregular ascending branches forming an open irregular crown; bark of young tree smooth, greenish gray, very resinous, becoming very thick gray and roughly fissured; leaves in fascicles of five, the needles surrounded at first with numcrous scales which soon fall off, leaving them without a scaly sheath, fascicles usually falling at the end of the second year, leaves slender, soft, 7-10 cm. long, triangular in section, minutely serrate; cones woody, cylindrical, stalked, ripening at the end of the second season, $10-15 \mathrm{~cm}$. long, about $3 \mathrm{~cm}$. wide when open, cone scales woody, thin, dark brown when ripe, the exposed parts glossy, seeds winged escaping from the ripe cone: strobus, L. name of some tree.

In rich often calcareous soil, forming large forests or mixed with deciduous trees from Newfoundland and eastern Manitoba south to Iowa. Pennsylvania, and in the mountains to Georgia. In Minnesota throughout the northern and northeastern coniferous forests, also in scattered isolated groves in eastern Minnesota, usually on river bluffs or in sheltered ravines, along the valleys of the St. Croix and Mississippi rivers, and for some distance up some of the tributary valleys. Flowers in May, cones ripe a year from the following September.

The most valuable timber tree in the state; wood light brown or reddish, soft, fine grained, not strong, weight $24 \mathrm{lb}$; ; used for building construction, siding, doors, sash, etc. In cultivation the white pine is orna- 
mental and does well in parts of the State where the late summers and autumns are not too dry. It flourishes in the soil of our hard wood regions better than any other pine.

\section{Pinus resinosa A it on 1789 Red Pine, Norway Pine}

A forest tree $24-30 \mathrm{~m}$. (80-100 ft.) high, with a straight trunk 3-5 ft. in diameter, which extends to the crown of the tree; branches of young trees nearly horizontal, whorled, in old trees forming a rounded crown; bark reddish brown, thin, on the older branches and trunk forming broad flat scales;-leaves in pairs, each pair surrounded at the base by a persistent scaly sheath, leaves slender, soft, $8-15 \mathrm{~cm}$. long, semicircular in section, minutely serrate; cones rounded, about $5 \mathrm{~cm}$. long, and when open nearly as broad, standing straight out from the stem, cone scales woody, thickened at the tips, the exposed part diamond-shaped with a scar in the center; seeds dark, winged, escaping from the ripe cone: resin os a, resinous, not particularly appropriate to this pine.

Usually in sandy soil, avoiding rich calcareous soils, Newfoundland to western Ontario, south to Pennsylvania, Michigan and Minnesota. In Minnesota found only in the coniferous forests of the northern and northeastern parts of the state, where it originally formed almost pure forests over large areas. Flowers in May, cones ripening the second autumn.

Much used for timber though not considered as valuable as the white pine. Wood pale reddish, hard, fine grained, not strong, weight $30 \mathrm{lb}$.

\section{Finus silvestris $\mathrm{L}$ i in $n \dot{E}$ I75.3 Scotch Fine, Scotch Fir}

A tree up to $30 \mathrm{~m}$. (100 ft.) high, with a straight trunk, but in this. state seldom over $10 \mathrm{~m}$. or $15 \mathrm{~m}$. and often irregular, straggling and somewhat shrubby; branches irregular, bark reddish brown and smooth above, becoming grayish and scaly on the older trunks; leaves in clusters. of two, bluish green, 3-8 cm. long, with a basal sheath 5-8 mm. long, wrinkled transversely and rough; cones small, $5-8 \mathrm{~cm}$. long, yellow brown, usually in clusters of two or three, nearly sessile, horizontal or bent backward along the branch, cone-scales thin, woody, ending in a four-sided boss which in young cones bears a short weak spine in the middle. This may persist in the mature cone but often disappears: silvestris, relating to the forest.

Cultivated, native of Europe and of western Asia. Occasionally planted for ornament; it is entirely hardy but seldom in this region forms anything but a small straggling tree with very little beauty. 
Wood reddish brown, soft, easily split. Much used in Europe for building construction, taking the same position there that white pine does in our northeastern states.

\section{Pinus montana Mille r 1768 Mountain Pine, Mugho Pine}

\section{P. Mughus Scopoli 1772}

Shrub or small tree, seldom over 3 or $4 \mathrm{~m}$. (10-13 ft.) higl, branclies flexible, twigs short, bark brown, roughened with small conical projections; leaves in clusters of two, $4-7 \mathrm{~cm}$. long, pointed, thick, dark green with a basal sheath, 5-6 mm. long, dark brown, papery and with torn edges; cones small, $3-4 \mathrm{~cm}$. long, in groups of two or three, horizontal or oblique, subsessile, persistent, cone-scales rounded at the top, furnished with a rhomboid boss which bears at its depressed center a large sharppointed spine: mo nt a na, of the mountains.

Cultivated, native of the mountains of central and western Europe. A hardy, ornamental evergreen shrub used for covering rocky slopes, or combining with other and larger conifers. Several unimportant varieties are distinguished by the shape of the cones.

\section{Pinus Laricio var. austriaca E $n$ d 1 i c h e r 1847 Austrian Pine}

Tree up to $25 \mathrm{~m}$. ( $80 \mathrm{ft}$.) with a somewhat irregular trunk and long horizontal branches, in whorls, giving the young tree a thick conical form, and the adult a broad rounded head; bark grayish brown; leaves in clusters of two, $10-15 \mathrm{~cm}$. long, stiff, dark green, with a basal sheath $12 \mathrm{~mm}$. long, gray, wrinkled; cones small, sessile, reddish, about $5 \mathrm{~cm}$. long, projecting at right angles to the branches, solitary or in groups of 2 or 3 , falling after they open, cone-scales thickened and with a rouncled boss at the end, often with a dull spine arising from the center of the boss: la ricio, from 1 a rix, larch.

Cultivated. Pinus Laricio is a native of southern Europe and Asia Minor, oniy the northern variety, native of Austria, is hardy here. It is much planted as an ornamental tree, and is successful west and south of the natural range of our native pines.

Wood soft, resinous, durable.

Pinus Laricio with its varieties is the most valuable forest tree of southern Europe. It is used both for lumber and for the production of turpentine. 


\section{Pinus Banksiana L a m bert 1803 Jack Pine}

$P$. divaricata, of authors.

Usually a small tree $9-12 \mathrm{~m}$. (30-40 ft.) high, but occasionally taller, with a trunk about a foot in diameter, head pyramidal, bark dark brown, irregularly divided 'into small scales; leaves in pairs, each pair surrounded at the base by a short persistent scaly sheath, leaves flat, rigid, $2-5.5 \mathrm{~cm}$. long, minutely serrate; cones about $3 \mathrm{~cm}$. long, curved, conical, sessile, pointing toward the ends of the branches, often failing to open at maturity and persisting on the tree many years, cone-scales woody, thickened at the tips, spineless; seeds blackish, winged.

In very sterile sandy soil; Nova Scotia to the Mackenzie valley, southwards to northern New England, the region about the southern end of Lake Michigan and Minnesota. The most northern of our Americall pines-in Minnesota confined to the coniferous forests of the northcrin and northeastern parts of the state, where it covers large tracts of the most sterile soils.

Wood pale brown, soft, coarse grained, weak, weight 27 pounds; used for fire wood and for posts and railway ties, but the least valuable of our native pines.

\section{Cupressineae Cypress Tribe Thuja Li n 11 é 1753 White Cedar (Gr. thy i a, the arbor-vitae.)}

'Trees with fibrous bark, fragrant wood and flat fragrant spray clothed with the small overlapping scale-like leaves which adhere to the twigs by their inner faces; leaves opposite, of two kinds in alternating pairs, those on the face of the twig flat, those on the side of the twigs doubled over the edge; flowers monoecious, the staminate consisting of an axis bearing two or three pairs of peltate stamens, each with 2-4 pollen sacs, pistillate with 4-6 pairs of thin oval scales, the uppermost and lower scales usually sterile, the middle ones each bearing $2-4$ erect ovules, cone small, woody; seeds with lateral wings, borne usually two on each fertile scale.

Four species, the others occurring in northwestern North America, Japan, and China.

\section{Thuja occidentalis L inné 1753 White Cedar Arbor vitae}

Evergreen tree. with straight or forked trunk, $15-20 \mathrm{~m}$. (50-70 ft.) high, and 5-10 dm. in diameter, the short horizontal branches forming a narrow conical head; bark of branches reddish brown, on old trunks forming loose scales; spray much branched, flat, leaves except on leading 
shoots about $3 \mathrm{~mm}$. long, scale-like; flowers in spring, cones ripening the same autumn, usually with two pairs of fertile scales; seeds with winged margins, two on each fertile scale: occide nt a lis, western.

Growing usually in swampy ground where it often forms very dense pure stands, occasionally in dryer stony ground or on bare rocks; Nova Scotia to Lake Winnipeg, south to Minnesota and the south end of Lake Michigan, New England and in the mountains of Virginia. In Minnesota abundant in the northern and northeastern portions in the belt of coniferous forests. Often cultivated as an ornamental tree or shrub and much used for hedges as it bears clipping well. In the southern part of the state it often "winter kills" badly from lack of moisture following a dry fall.

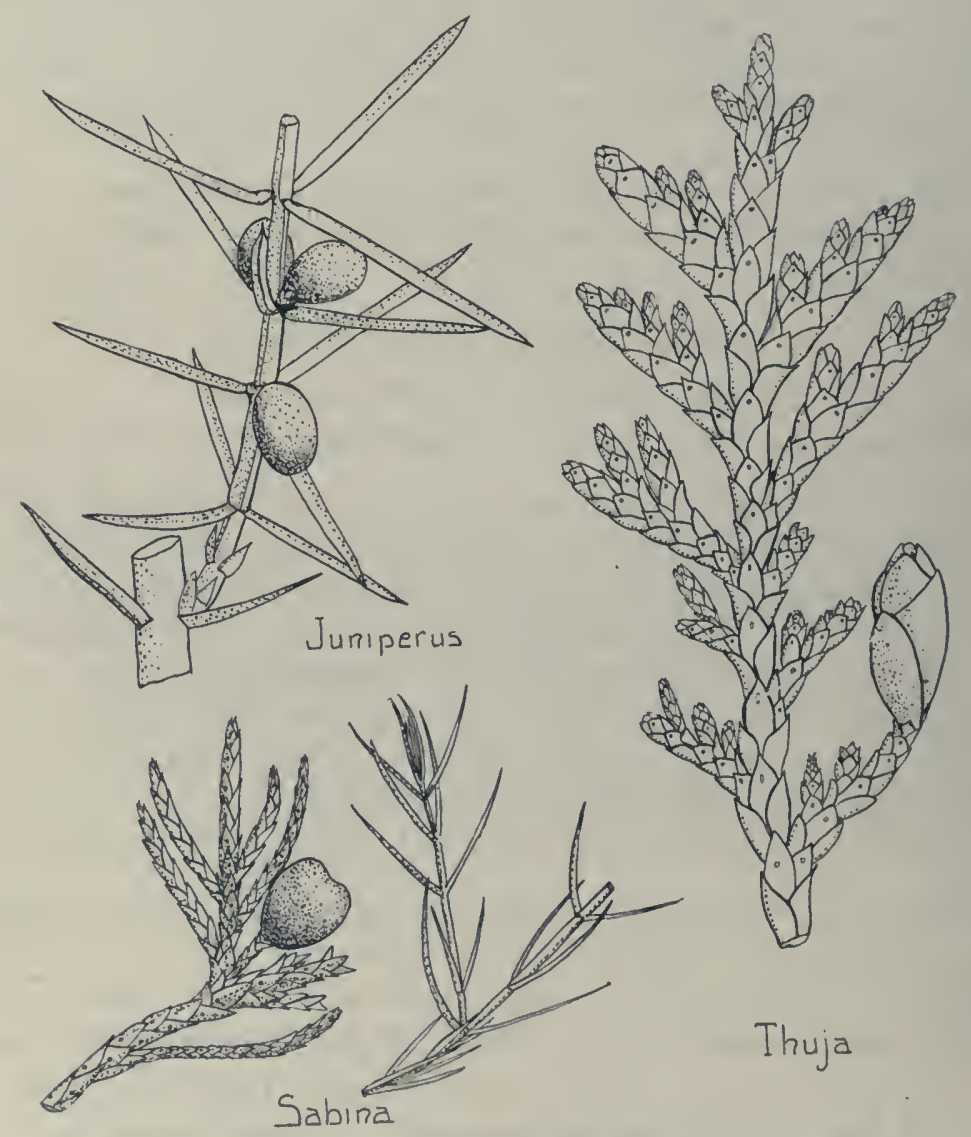

Cupressineae: Juniperus communis, Sabina virginiana, fruiting twig, and twig from young tree, Thuja occidentalis. 


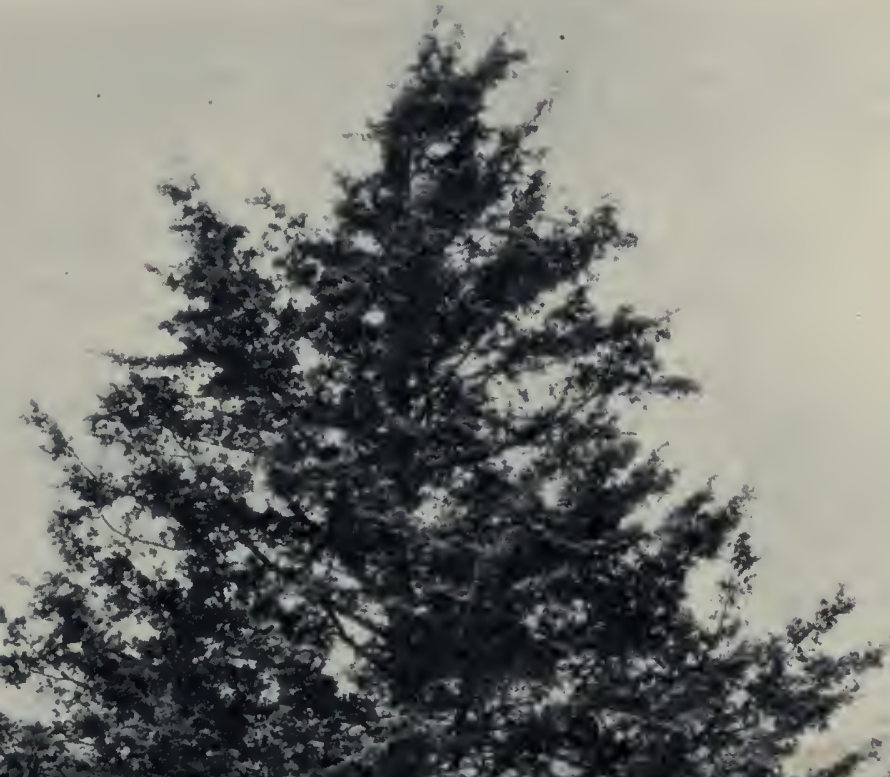

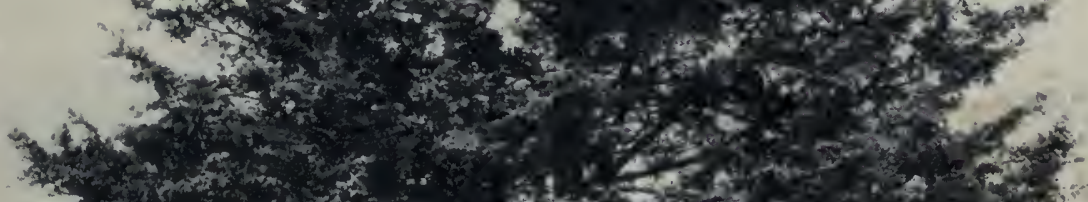

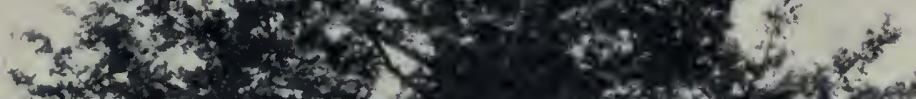

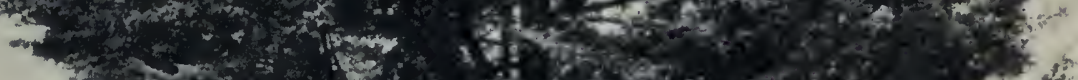
3.

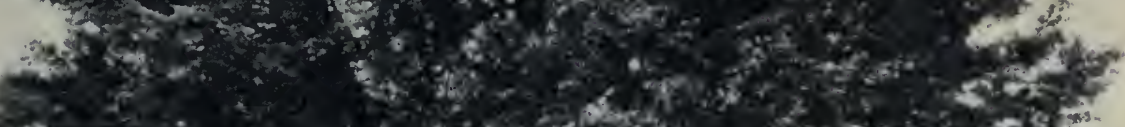

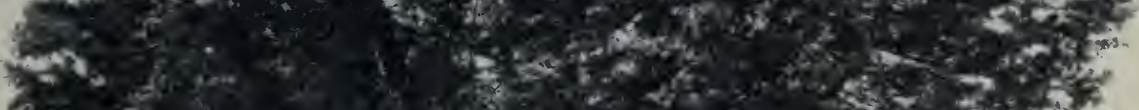

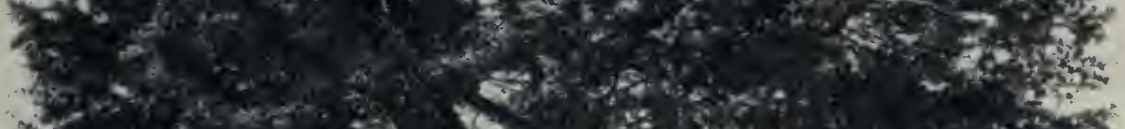

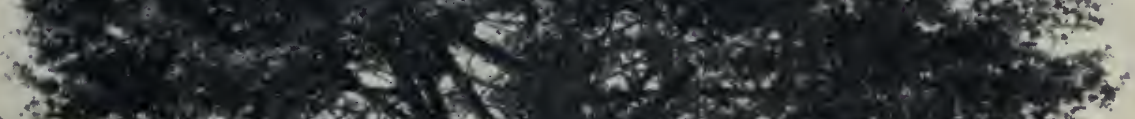

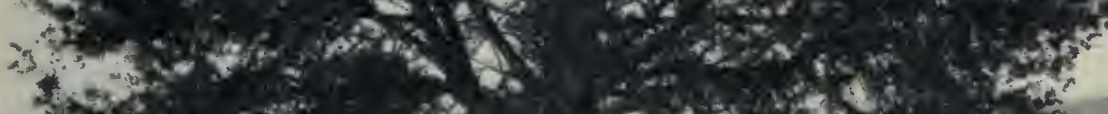

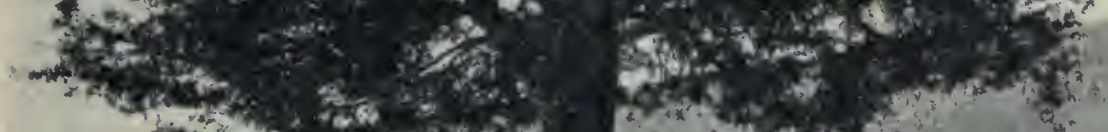

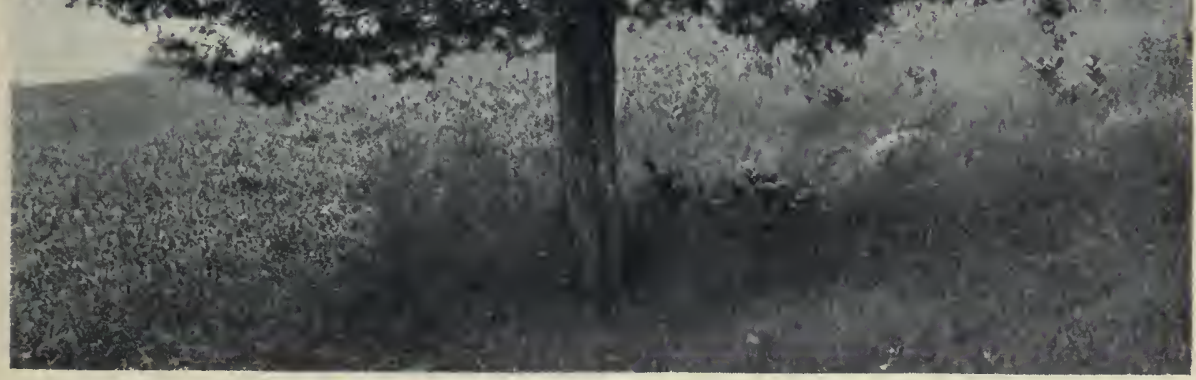


Wood light brown, coarse, brittle, weak, durable, weight 20 pounds, the lightest wood of the northeastern states; much used for posts, telegraph poles, and shingles.

\section{Sabina A n t o in e 1857 Savin, Red Cedar}

(From classic I. he r ba sa bi na, the Sabine plant.)

Trees or shrubs with fibrous bark and fragrant wood; leaves opposite or in whorls of three, scale-like and adhering to the twigs on mature branches, often needle-like on young plants or fast growing shoots; flowers dioecious, terminal on short leaf-bearing shoots, the staminate with several pairs (or whorls) of peltate stamens, each bearing 2-6 pollen sacs; pistillate flowers terminating short branches, consisting of several pairs (or whorls) of minute scales, bearing the paired orules in their axils; fruit fleshy, formed of several concrescent pairs (or whorls) of scales.

About 20 species of the northern temperate regions, about one third of which are natives of the western United States. A gemus frequently united with Juniperus with which it agrees in the berry-like character of the cone, but from which it differs both in the intimate structure of the cune and in vegetative characters.

\section{Sabina virginiana (Linné) An to in e 1857 Red Cedar, Savin}

\section{Juniperus virginiana Linné I75.3}

'Tree, in this state rarely over thirty feet high, when well grown with a straight trunk, and a broad conical head, often distorted or even a straggling irregular upright shrub; mature twigs covered with scale-like opposite triangular leares, 1-2 mm. long, but on young trees, rapidly growing shoots, or occasionally on whole trees the leaves spreading, awlshaped, $8 \mathrm{~mm}$. long, opposite or sometimes in whorls of three, decurrent and not jointed at the base; fruit subglobose, borne on a straight scaly stalk, maturing the first season, dark blue and fleshy and much eaten by birds which distribute their seeds: virg in i a na, Virginian, applied at an early date to many American plants.

Dry, gravelly, usually calcareous soil, Nova Scotia to easteru Dakuta, south to Georgia and Texas. In Minnesota throughout the state except the northeast corner, most abundant in the south and east along the river bluffs. Flowers in May, fruit ripe the autumn of the same year. 
Wood red, fine-grained, soft, weak, fragrant, and very durable, weight 31 lbs. The wood is much used for chests, pails, posts, sills of buildings, etc. It seldom reaches commercial size in Minnesota. The tree is often planted as a small ornamental tree and does well even in dry situations where other evergreens will not grow. It is sometimes planted to form windbreaks, but this use is objectionable in connection with apple orchards as it harbors various species of the fungus, Gymnosporangium, which produce leaf rust of apple.

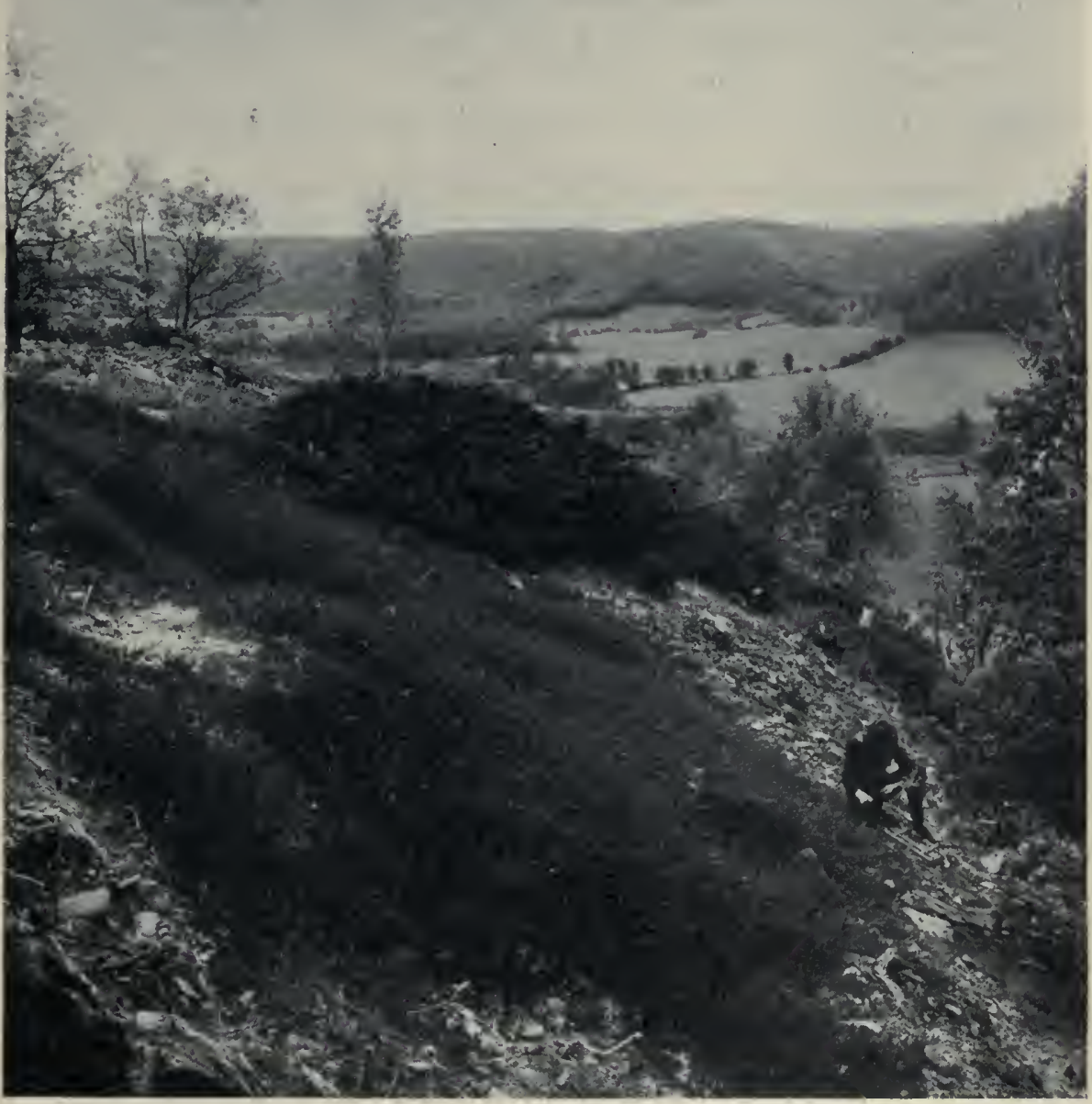

Sabina horizontalis, foreground, and Juniperus communis, middle of plate; in southeastern Minnesota. 


\section{Sabina horizontalis (Mönch) Dwarf Savin}

\section{Sabina prostrata (Persoon) Antoine 1857 \\ Juniperus Sabina var. procumbens Pursh I8I4}

Prostrate evergreen shrub often spreading over a considerable area; foliage strong smelling, leaves bluish-green, scale-like, triangular, or on young, strong growing shoots, awl-shaped; fruit on a short, recurved, scaly stalk, oval or irregular, dark blue, fleshy, ripening during the second summer: horizont a lis, horizontal.

Dry rocky slopes, Newfoundland to British Columbia, south to New England, New York, the south end of Lake Michigan, Minnesota, and in the mountains to Colorado; also in Asia. In Minnesota abundant in the extreme north, less common southward, rare and local in the southeast corner of the state. Flowers in May, fruit ripe in midsummer of the following year.

This form has been confused with the savin in Europe (Sabina officiralis Garcke, Juniperus Sabina L.), which is distinguished by its more erect habit and by blunter, more closely appressed leaves. The twigs of the European form are used medicinally on account of the irritating volatile oil they contain. The American form contains the same oil and has presumably the same medical action.

\section{Juniperus L i n n é I753 Juniper}

(J uniperus, the classical Latin name)

Evergreen trees or shrubs with fibrous bark; leaves in whorls of 3 , needle- or awl-like, spreading; flowers dioecious, the staminate with several whorls of peltate stamens each bearing three to four pollen sacs, pistillate axillary, consisting of several whorls of scales with a single whorl of terminal ovules alternating with the uppermost scales: fruit fleshy, formed of the concrescent scales of the uppermost whorl.

A genus of about 10 species, mostly of the Old World; often considered to embrace also the genus Sabina.

\section{Juniperus communis L inné 1753 Common Juniper}

A small tree, or in this state, an erect struggling slirub, or more frequently a depressed shrub with long prostrate branches turning up at the end to form a thick, dense mat; bark thin, brown, forming papery scales; leaves in threes, needle- or awl-like, 10-20 $\mathrm{mm}$. long, jointed at the base; flowers in the axils of the younger leaves, opening in the spring; fruit blue, spherical, about $10 \mathrm{~mm}$. in diameter, fleshy and sweet, ripening in 
the autumn of the third year; seeds $1-3$, with distinct resin vesicles: c o m m u is, L. common.

Throughout the cooler parts of the north temperate regions, growing as far south as Pennsylvania, Nebraska, Arizona, the Himalayas and the Mediterranean region. The most widely distributed of the conifers and the most widely distributed tree of the temperate zone. In Minnesota it occurs more or less throughout the state, most abundantly in the north and east.

Wood similar to red cedar, but not of sufficient size in this state to be of any value. The nearly ripe berries are used medicinally as a diuretic, and are employed in the manufacture of gin.

This species passes into the northern and alpine form,

Juniperus communis var. sibirica (Burgsdorf) R y d b e r g 1896 J. sibirica Burgsdorf 1787

J. nana Willdenow 1796

A prostrate shrub with broader curved leaves often less than $10 \mathrm{~mm}$. long.

\section{Taxaceae Yew Family}

'Trees or shrubs with evergreen leaves of various types; flowers monoecious or dinecious, the staminate consisting of a more or less elongated axis which bears the variously formed stamens, the pistillate various but seldom cone-like, the ovules naked, usually not concealed, the seed usually exposed at maturity, furnished with a fleshy outer coat.

\section{Taxus I, in né I753 Yew}

(L. t a x us, yew tree, probably from Gr. toxo n, a bow.)

Non-resinous trees or shrubs; leaves evergreen, flattened, linear, bitter, borne alternately in a close spiral, but twisted so as to appear tworanked; staminate flowers consisting of 4-12 peltate stamens borne at the top of a short naked axis, pistillate flower of a single naked erect orule borne at the top of a short scaly axis; seed exposed, surrounded by a fleshy, lag-like aril which becomes scarlet at maturity.

\section{Taxus canadensis Marshall i785 American Yew T. baccata var. minor Michaux 1796}

A low green shrub about $1 \mathrm{~m}$. high with the characters of the genus; leaves linear, acute and sharply mucronate, bitter and not at all resinous: c a $n$ a de $n$ s is, Canadian. 

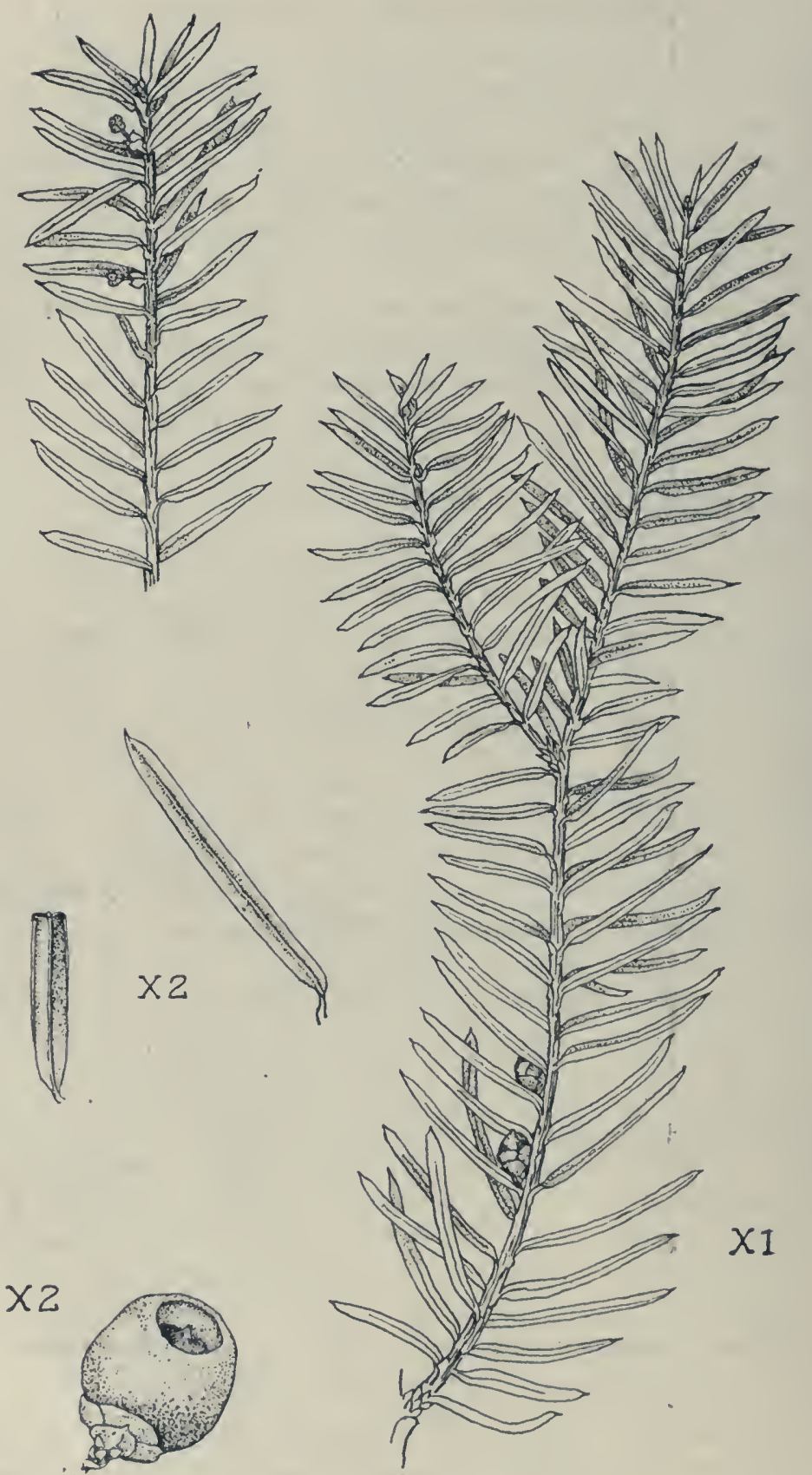

Taxus Canadensis 
In woods, Newfoundland and Manitoba, south to Virginia and Iowa. In Minnesota abundant in the northern part of the state, extending a little beyond the limits of the coniferous forests; local in several places in the southeast corner of the state.

\section{Ginkgoales Ginkgo Order \\ Ginkgoaceae Ginkgo Family}

A family consisting of only the following genus. Flowers dioecious, the staminate cone-like, consisting of an axis bearing numerous stamens; stamens stalked, furnished with two pendent pollen sacs; pistillate flowers consisting of a naked stalk bearing at its summit a pair of ovules,

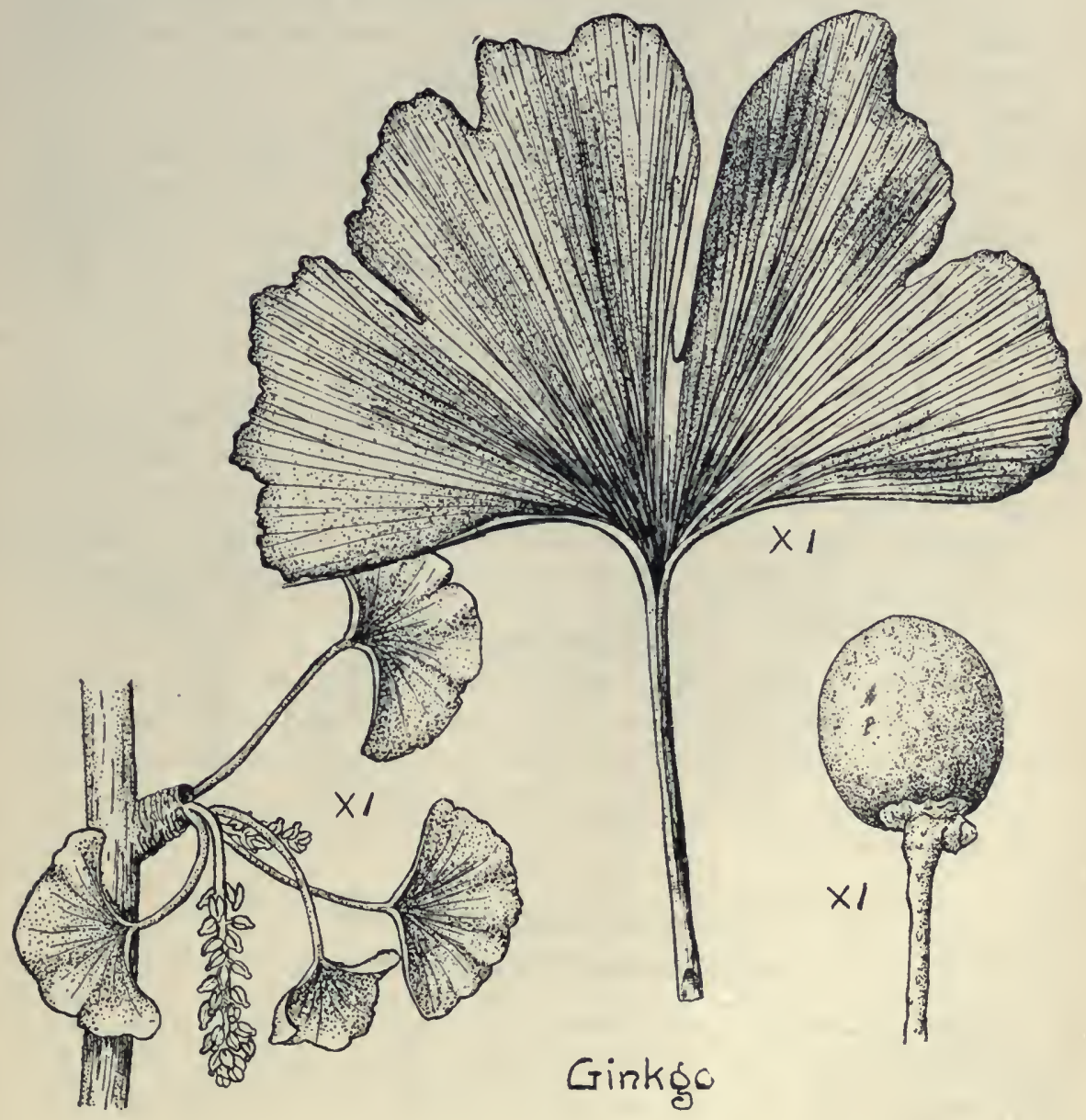


each surrounded at its base with a collar-like growth; seeds drupe-like, the integuments consisting of an outer fleshy coat, a firm stony coat, and a thin inner papery layer.

\section{Ginkgo L i nl 11 é I77I}

(Chinese name of the tree.)

The only genus of the family, containing the following species:

\section{Ginkgo biloba Li 11 né I77I Maiden-hair Tree}

\section{Salisburia adiantifolia Smith 1797}

Deciduous tree reaching in old age a height of $20 \mathrm{~m}$. (65. ft.) ; trunk straight, extending to the top of the tree; branches long, ascending, twigs not numerous, covered with many short spurs, or dwarf twigs; bark at first smooth, the epidermis separating as a shredded papery layer, later roughened and seamed longitudinally, gray; leaves borne scattered on the long twigs and in dense clusters on the spur shoots, petioled, smooth, fan-shaped, usually two-lobed, veins forking repeatedly and running free to the margin; leaves $3-5 \mathrm{~cm}$. long, $4-7 \mathrm{~cm}$. wide, petioles $3-5 \mathrm{~cm}$. long; flowers as described under the family; seeds plumlike, scarlet, ill-smelling, about $2 \mathrm{~cm}$. in diameter: bilol) a, two-lobed, referring to the leaves.

Cultivated: Native to China and Japan, widely cultivated in those countries and in Europe and North America. Planted to some extent in the vicinity of Minneapolis and St. Paul where it is entirely hardy. A handsome tree with very ornamental foliage; the staminate tree is preferable, as the seeds of the pistillate tree have a very offensive odor.

\section{Angiospermae}

Seed-bearing plants with closed pistils; the ovules and seeds developing within a closed ovary; pollen grains received by, and germinating upon a stigma; body of the seed (endosperm) not the female gametopliyte, developing after the fertilization of the egg, and during the development of the embryo.

\section{Ranales Buttercup Order Magnoliaceae Magnolia Family}

Trees or shrubs; leaves alternate, entire or lobed, marked with transparent dots; leaf buds covered with membranous stipules; bark bitter and aromatic; flowers large and solitary; sepals and petals colored alike, 
arranged in 3's, mostly imbricated in the bud, hypogynous and deciduous; stamens numerous, large, anthers adnate; pistils many, on an elongated or cone-shaped receptacle, free or cohering with each other and in the fruit, forming a sort of fieshy cone; seeds one or two in each pistil.

A family of about 10 genera of wide geographic distribution. The following is represented by one cultivated species in Minnesota.

\section{Magnolia Li 11 n é 1753 Magnolia}

(Named for the French botanist, Magnol.)

Trees or shrubs with large usually thick, entire leaves; leaf buds covered with sheathing stipules; flowers large, fragrant, borne singly at the ends of branches, appearing, before or with the leaves; sepals 3 , petal-like; petals 6-9, in whorls of 3 ; stamens imbricated, with short filaments and large anthers; carpels on a cone-shaped receptacle, cohering and forming at maturity an aggregate, cone-like fruit with dry or fleshy follicles that dehisce and let out by slender threads, one or two, usually red seeds.

A genus of about 15 species, natives of eastern North America, eastern Asia and the Himalaya mountains.

Some species with large white flowers that open before the leaves appear are handsome ornamental trees.

The following species is planted to some extent in Minnesota.

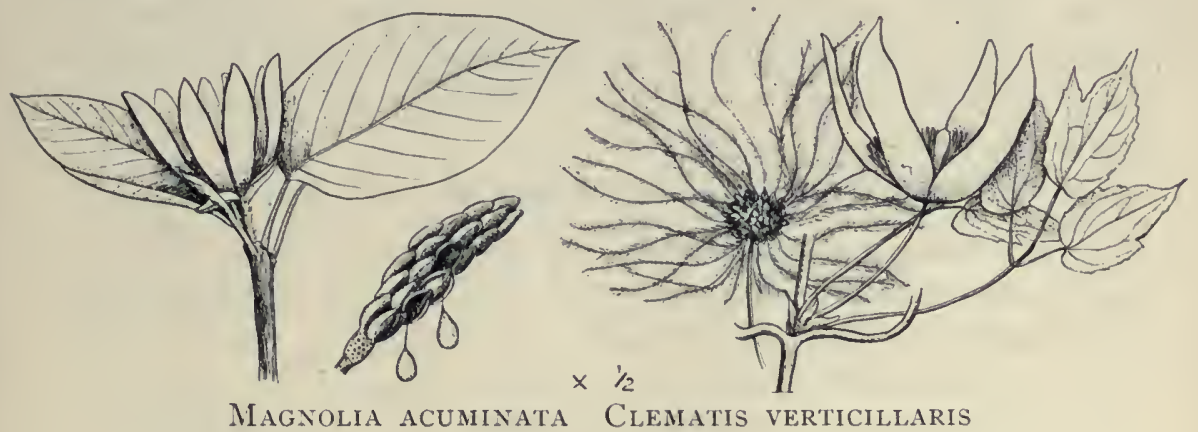

\section{Magnolia acuminata L i n n é I753 Cucumber Tree}

A tree about 15-20 meters high, attaining a maximum height farther south of 30 meters ( $90 \mathrm{ft}$.) leaf buds silvery gray and silky pubescent; leaves oblong or ovate, acuminate at apex, pinnately veined, margin entire, glabrous above, more or less pubescent beneath, 13-24 cm. long, 7-13 $\mathrm{cm}$. wide; flowers somewhat narrowly campanulate, greenish yellow', 
glaucous, orange-colored within, 4-7 cm. long; fruit-cone about $4-7 \mathrm{~cm}$. long; a cuminata, pointed, in reference to the leaf.

Cultivated. Distributed from western N. Y. to I1l, south to Kell., N. C. and Ala., west to Ark.

The wood is soft, yellowish brown, and weighs 29 lbs. per cubic foot.

\section{Ranunculaceae Buttercup Family}

Herbs or sometimes woody plants, with acrid usually colorless sap; leaves alternate (opposite in Clematis), simple or compound, petioles dilated at the base, sometimes with stipule-like appendages; flowers regular or irregular, polypetalous or apetalous, with sepals often colored like petals; stamens numerous (or rarely few); pistils many, or rarely solitary, 1-celled; ovules 1-many, anatropous; fruit achenes, follicles, or a berry.

\section{Clematis L in 11 é 1753 Virgin's Bower}

(Gr. c le mat is, a climbing plant.)

Climbing vines or erect or ascending perennial herbs, sometimes woody; climbing by bending or twining of the leaf-stalks; leaves opposite, pinnately compound, lobed or in some species entire; flowers solitary or in panicles; sepals 4 or rarely 5 , petaloid; petals 0 , or as many as the sepals; pistils many; styles long, plumose, silky or naked, persistent; fruit 1 -seeded achenes.

A genus of over 100 species of wide geographical distribution. The greatest number of species occur in the temperate regions. Besides the following, some 20 others occur in the southern and western parts of North America.

\section{Key to the Species}

1. Flowers large, solitary on the old branches; sepals purple

C. verticillaris

2. Flowers smaller, numerous, on the years growth; sepals white

a. Leaflets toothed; flowering in summer

C. virginiana

b. Ieaflets entire; flowering in autumn

C. paniculata

Clematis verticillaris D e C a 11 dolle 1818 Purple Virgin's Bower Atragene americana Sims 1806

A trailing or climbing vine with smooth angular stems and large nodes; leaves trifoliate, leaflets ovate, rounded or cordate at the base, atcute at the apex, coarsely and evenly serrate, thin, glabrous, $3-6 \mathrm{~cm}$. 
long, $1.5-3 \mathrm{~cm}$. wide, petioles $2-3 \mathrm{~cm}$. long; flowers axillary, purple, 5-7 $\mathrm{cm}$. broad when expanded; sepals $3-4.5 \mathrm{~cm}$. long, thin and prominently veined, silky hairy along the margin, petals spatulate, $1.2-1.8 \mathrm{~cm}$. long, persistent, styles persistent, becoming plumose and $5-6 \mathrm{~cm}$. long in fruit: vertic $11 \mathrm{lar}$ is, in a whirl, possibly in allusion to the climbing habit.

Infrequent in rocky woods in the eastern part of the state from the northern boundary to the southern. Distributed from eastern Quebec to Hudson's Bay and Lake Winnepeg, south to Del., W. Va., Mich., and Minn.

Flowers in May and June, fruits in July and August.

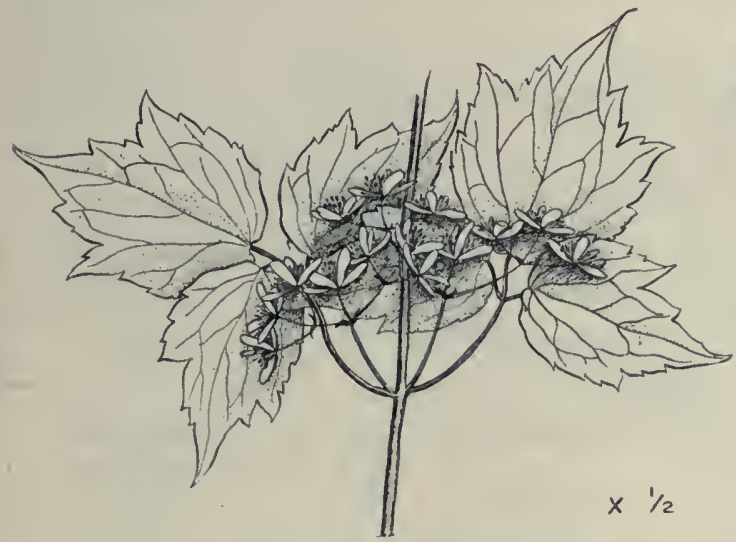

Clematis virginiana

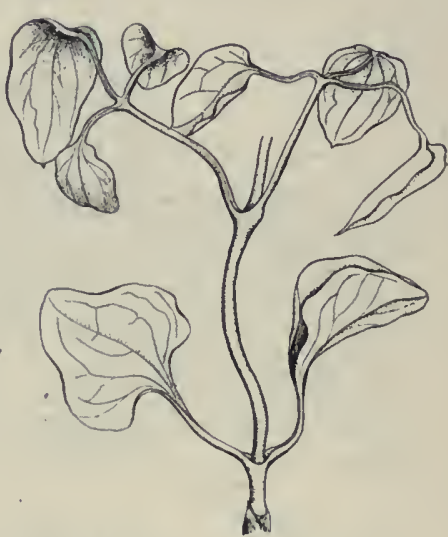

Clematis paniculata

\section{Clematis virginiana L in né 1753 Virginia Virgin's Bower}

A long vine, climbing freely over shrubs, fences, etc.; stems furrowed; leaves opposite, trifoliate, petioles straight and deflexed, or bent and acting as tendrils, leaflets ovate, rounded or cordate at the base, acute or acuminate at the apex, coarsely toothed or sometimes slightly 3 -lobed, bright green and glabrous above, paler and sometimes slightly pubescent beneath, $4-9 \mathrm{~cm}$. long, $2-6 \mathrm{~cm}$. broad; flowers in leafy panicles, white, 15-20 mm. broad; styles persistent, forming long, whitish, feathery plumes to the achenes, $4-5 \mathrm{~cm}$. long: vi $\mathrm{r}$ gin i a $\mathrm{n}$ a, Virginian.

In woods, on river banks etc, occurring throughout the state, common eastward. Distributed from Nova Scotia to Manitoba, south tc Ga. and Kan.

Flowers in June and July, fruits in Aug. and Sept. 


\section{Clematis paniculata Th u n berg r $\mathrm{r} 794$ Clematis}

$A$ vigorous climbing vine, climbing over fences, trellises, porches, etc.; leaves 3-5-foliate (the first pair of leaves of a shoot usually entire and cordate) leaflets ovate, rounded or mostly cordate at the base, acuminate at the apex, glabrous on both sides, young leaves with blotches of white along the veins, $2.5-5 \mathrm{~cm}$. long, $1.8-3 \mathrm{~cm}$. wide, the widened bases of the petioles connate; flowers in axillary and terminal panicles, white, fragrant, $2.5-3 \mathrm{~cm}$. broad; fruit with persistent, plumose styles: p a n i c ulat $\mathrm{a}$, in a panicle.

Extensively cultivated as an arbor and trellis plant. Native of Japan. Flowers anc. fruits in autumn (Sept.-Oct.)

\section{Berberidaceae Barberry Family}

Shrubs or herbs with alternate or basal simple or compound leaves, with or without stipules; flowers in racemes or solitary; sepals and petals imbricated in the hud, mostly in 2 whorls of 3 each, occasionally 2 or 4 in the whorl; stamens as many as the petals and in front of them. or more numerous; anthers usually opening by two valves; carpel 1; style short; ovules 2-many, fruit a berry or a capsule.

The following genus is represented in Minnesota by two caltivated species.

\section{Berberis Linné 1753 Barberry}

Shrubs with yellow woed and inner bark, usually spiny; leares mostly in fascicles, simple or compound; flowers yellow, in drooping racemes or singly from each fascicle; sepals 6, oblong, with 2-6 acutish, sepallike bracts on the outside; petals 6 , obovate, with two glands at the base; stamens 6 , with sensitive filaments, closing up around the style when touched; anthers opening by valves; pistil 1, stigma shield-shaped ; fruit a 1 -few seeded berry.

A genus of about 75 species, natives of North America, Europe northern Asia and South America. About 12 species occur in N. Am.

\section{Key to the Species}

1. Leaves serrate; flowers and fruits in racemes

B. vulgaris

2. Leaves entire, flowers mostly 1 to each leafcluster

B. Thunbergii 


\section{Berberis vulgaris Linné 1753 European Barberry}

\section{(Latin form of the Arabic name.)}

A spiny shrub, 2-3 meters (6-8 ft.) high, with arched branches, glabrous throughout; leaves alternate or fascicled, obovate or spatulate, obtuse at the apex, cuneate at the base, bristly serrate, glabrous on both sides, prominently reticulate-veined beneath, $2.5-7 \mathrm{~cm}$. long, $.8-2 \mathrm{~cm}$. wide, 1-3-pronged spines (modified leaves) below the fascicles; racemes pendulous, terminating the short shoots bearing the leaves, $4-8 \mathrm{~cm}$. long; many-flowered, flowers yellow, about $8 \mathrm{~mm}$. broad, ill-smelling; petals entire; fruit an oblong berry, scarlet when ripe, acid, persistent through the winter.

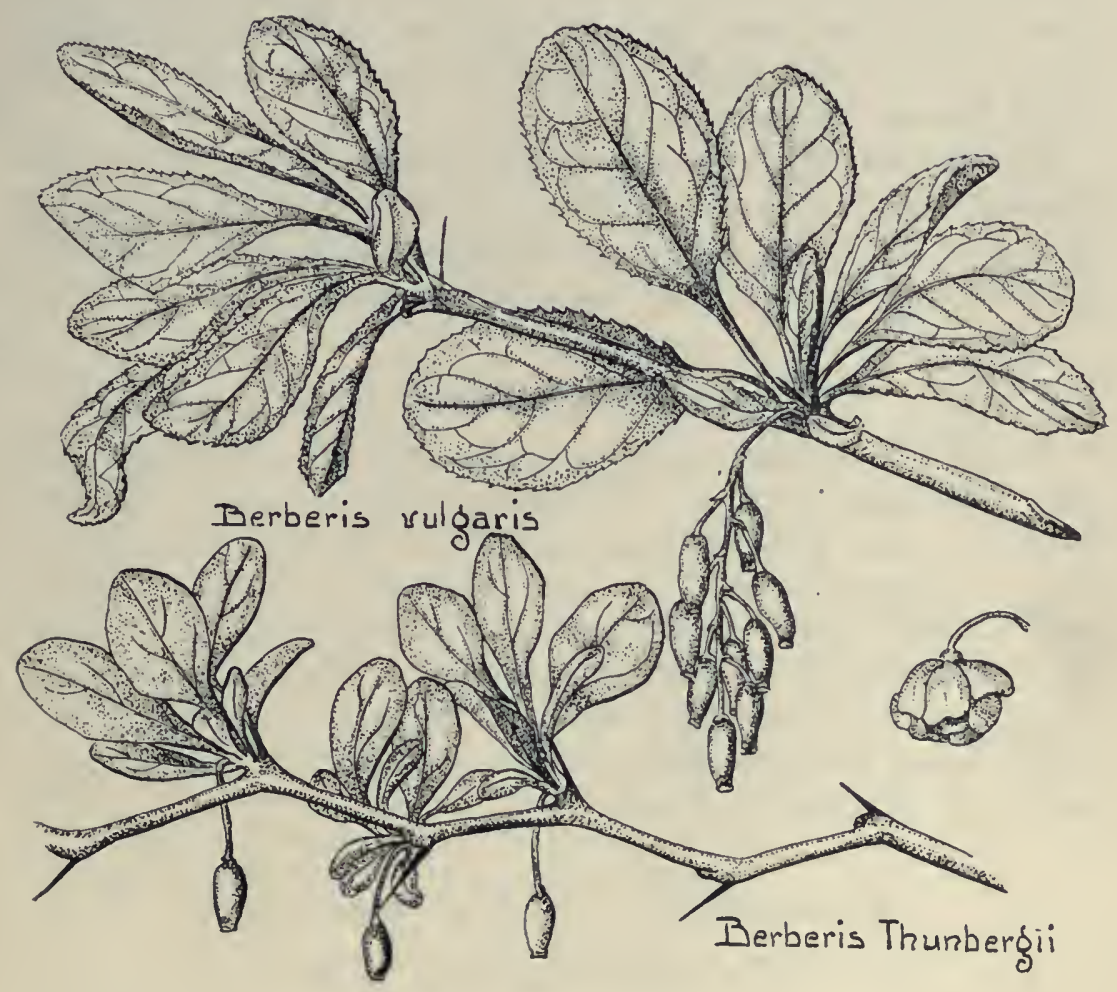

Frequently planted as a hedge and ornamental shrub. Introduced and naturalized from Europe. In the eastern and middle states, it has become wild, growing in thickets and waste ground.

Flowers in April and May, fruits in autumn. 
Numerous forms and varieties have been developed through cultivation, among which the following is the most commonly planted within the state.

Var. a tropurpure a Regel.

IVith purple-colored leaves, otherwise like the species.

\section{Berberis Thunbergii De Cand olle 18 r 8}

Low very dense shrub, .5-1 meter (1.5-3 ft.) high; branches spreading and slightly curved, twigs brown, grooved; leaves in dense fascicles, spatulate rounded or sometimes mucronate-tipped at the apex, glabrous thruout, glaucescent beneath, entire, .5-4 cm. long, .2-1 cm. wide, fascicle subtended by simple spines; flowers 1-3 (mostly 1 ) terminating the short shoots, yellow with pinkish bracts, 6-8 mm. broad, pedicels $8-10 \mathrm{~mm}$. long; fruit elliptic or ovoid, bright red when ripe, about $8 \mathrm{~mm}$. long; named for the botanist Thunberg.

Planted extensively as an ornamental shrub on account of its dense spreading growth, its dark red berries, as well as the handsome autumn coloring of the foliage. It is especially well adapted for borders of walks and drives and is perfectly hardy in our climate. Native of Japan.

\section{Menispermaceae Moonseed Family}

Climbing or twining, woody or herbaceous vines; leaves alternate, palmate or peltate, entire or lobed, stipules lacking; flowers in panicles, racemes or cymes, small, dioecious; sepals $4-12$; petals 6 , in two whorls of 3 each, sometimes fewer or none, imbricated in the bud; stamens about the same number as petals; carpels 3 to many (mostly 6), ovule one; fruit a drupe, ovary often curving in developing into a fruit, causing the seed to be bent into a crescent.

The family is chiefly tropical and is represented in the Minnesota flora by the following genus only.

\section{Menispermum L in né r753 Moonseed}

(Gr. m e n e, crescent, s p e rma, seed.)

Climbing vines with large peltate or cordate, lobed or alternate leaves; flowers in panicles, small, dioecious; sepals 4-8, in two series or whorls; petals 6-8, shorter than the sepals; stamens 12-24; pistils in the fertile Howers $2-4$, on a raised receptacle, staminodia usually present ; stigma broad and flat; fruit a flattened drupe; seed bent into a crescent, hence the name. 
A genus of about three species, one in eastern North America the others in eastern Asia.

\section{Menispermum canadense L i n 13 é I753 Moonseed}

A vine climbing over bushes or fences, $2-4$ meters $(6-12 \mathrm{ft}$.$) in$ length; stems slightly pubescent; leaves on long slender petioles, cordate and entire or variously 3-7 lobed or angled, mostly peltate near the margin, glabrate above, pubescent beneath, 6-17 cm. long, 7-29 cm. broad; flowers in loose panicles, greenish white; drupe oblong, bluish black; seed crescent-shaped: c a n a d e n s e, Canadian.

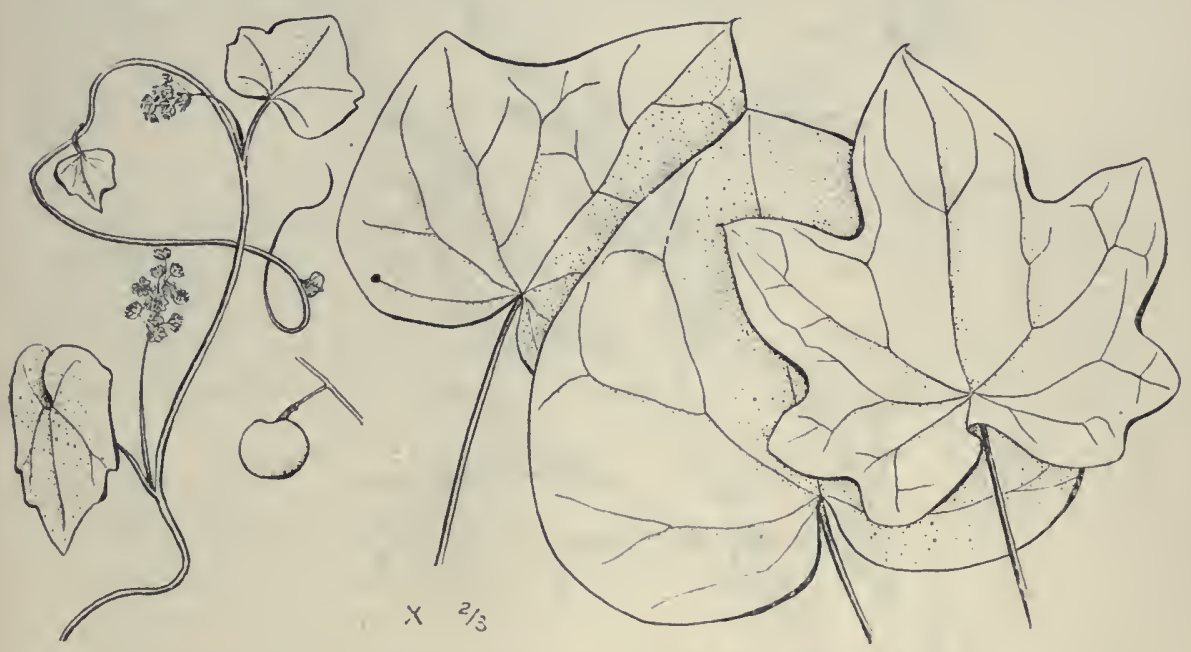

In woods and along hillsides and streams. Rather common thruout the state, especially southward. Distributed from western Quebec and western New England to Manitoba and south to Ga. and Ark.

(The long slender bitter yellow root is used by the Sioux as medicine, being called Pejuta zizi; and from this the name of Pejuta Zizi, or yellow medicine river. T. M. Young.)

Flowers in June and July, fruits in autumn.

\section{Caryophyllales Pink Order}

\section{Tamaricaceae Tamarisk Family}

Trees or shrubs with alternate scale-like leaves; flowers regular, perfect, in catkins; sepals 4-5, petals separate, 4-5, stamens 4-5, or many; fruit a capsule with many small hairy seeds. 
A family of 5 genera, natives of the northern hemisphere and of South Africa.

\section{Tamarix Linné I753 Tamarisk}

(The Latin name)

Shrubs or small trees, with tiny, scale-like, clasping leaves in four rows, buds of several rows of tiny scales, shading into. leaves; flowers perfect, regular, pink, in dense spikes or catkins, petals and sepals distinct,

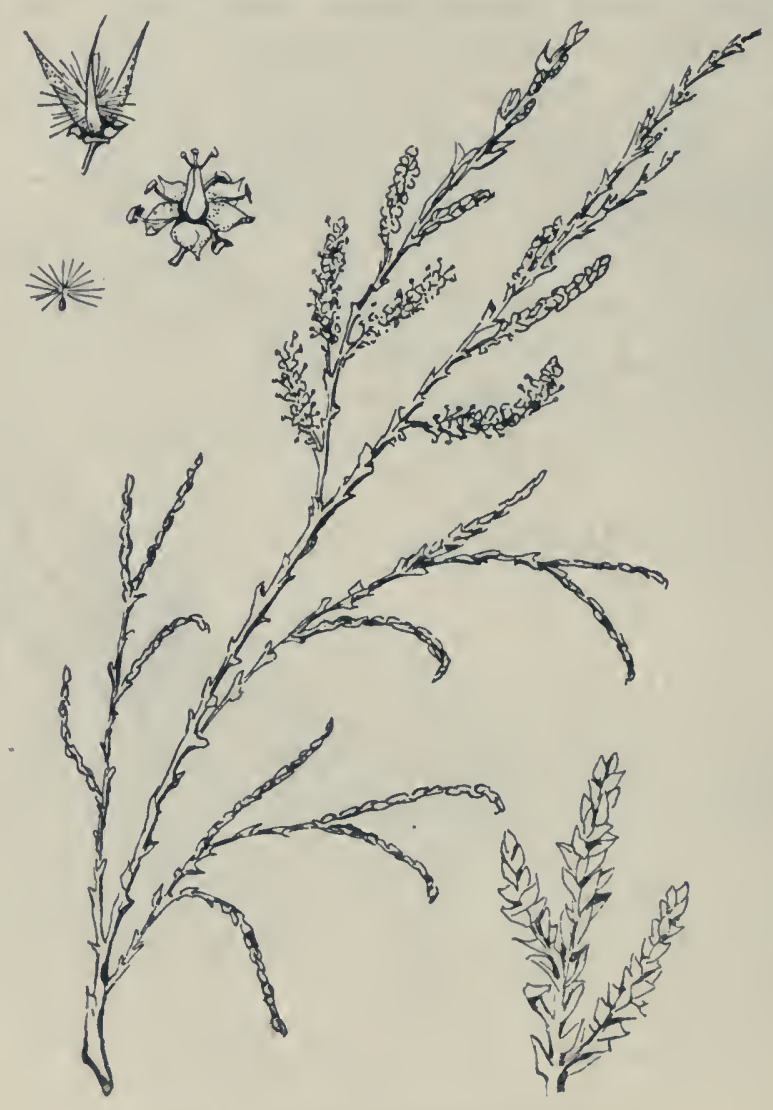

Tamarix gallica

and below the ovary, sepals persistent, stamens free or slightly united, ovary beaked, with 3-4 short styles; fruit an awl-shaped capsule with $3-4$ valves.

A genus of about 25 species, natives of tropical and subtropical regions. 


\section{Tamarix gallica L i n n é 1753 Common Tamarisk}

Buslyy shrub or small tree, 5-20 ft. high, with numerous feathery branches; leaves tiny, scale-like, ovate to lanceolate, entire, the margin papery, sharp-pointed, broadly clasping at base, smooth, 11/2-3 mm. long; flower spikes in racemes at the ends of branches, often $1 \mathrm{ft}$. long; spikes oblong, $2-5 \mathrm{~cm}$. long, $1 / 2-1 \mathrm{~cm}$. wide; flowers tiny, pink, short-pedicelled, $11 / 2-3 \mathrm{~mm}$., capsules awl-shaped, smooth, shining, splitting usually into three elongate valves, $5-6 \mathrm{~mm}$. long; g a $11 \mathrm{ic} \mathrm{a}$, of Gaul, referring to its home.

Occasionally cultivated, but not perfectly hardy. In the East and Middle West, it is highly valued for its beautiful, feathery appearance and masses of delicate flowers, and for its wide range of adaptability.

\section{Salicaceae Willow Family}

'Trees or shrubs with alternate simple leaves; flowers dioecious, both kinds in catkins; sepals 0 , petals 0 , stamens 1-60, ovary 1 -celled, stigmas 2, often 2-4-cleft; fruit a small capsule, splitting into 2-4 parts; seeds tiny, covered with long white or whitish hairs.

A family containing but the two following genera, represented by about 200 species, chiefly native to the north temperate and arctic zones.

\section{KEY TO THE GENERA}

1. Buds with several scales; bracts of the catkin fringed or cut; stamens usually many in each flower

\section{Populus}

2. Buds with one scale; bracts entire; stamens $1-10$, usually 2

\section{Salix}

\section{Populus L i n n é 1753}

(I. p o p u 1 u s, poplar, probably from the root *pal, to shake)

'Trees; leaves alternate in five rows, simple, with prominent midrib; buds resinous, covered with several scales; flowers dioecious, rarely monoecious, appearing before the leaves in hanging catkins with cutfringed scales; sepals and petals lacking, but the disk often cup-like stamens 6-60, ovary 1-celled, ovate-conical, with $2-3$ or rarely 4 rows of seeds, stigmas 2-4, entire or lobed; fruit a capsule with 2-4 valves, smooth or hairy; seeds enclosed in a tuft of hairs.

Propagated readily from seeds, cuttings and suckers.

$\Lambda$ genus of 25 species, natives of the northern hemisphere; five other species occur in western North America. 


\section{Key to the Species}

1. Leaves with much flattened petioles

a. Petiole and lower leaf surface white or woolly; leaves lobed

P. alba

b. P'etioles and mature leaves smooth

(1) Leaves coarsely wavy-toothed, densely woolly at first

(2) Leaves more finely crenate-toothed, smooth

(a) Leaves round or ovate, short-pointed

P. tremuloides

(b) Leaves truncate at base, long-pointed

$x$. Branches spreading; crown broad

P. deltoites

y. Branches erect; crown long and narrow

P. sranailicutata

P. nigra italica

2. Leaves with round or channeled petioles,

a. Leaves 1-3 cm. wide, more or less lanceolate; petioles smooth

b. I.eaves $4-10 \mathrm{~cm}$. wide, ovate; petioles hairy

(1) Leaves smooth on both sides, not heart-

shaped at the base
(2) Leaves hairy below, heart-shaped at

P. angustifoliu base

P. balsamifera

P. b. canlicans

\section{Populus alba L in né White Poplar, Silver Leaf}

Tall tree, 50-100 ft. high, 2-4 ft. diam.; bark smooth, bright, gray or yellow-green; leaves ovate or broadly wedge-shaped, tip blunt or rounded, base more or less truncate, densely white-woolly when young, the upper surface becoming smooth and green at maturity, $4-6 \mathrm{~cm}$. long, $3-4 \mathrm{~cm}$. wide, petioles densely white-woolly, $3-4 \mathrm{~cm}$. long; staminate catkins 3-5 cm. long, fruiting catkins 5-6 cm. long, capsules small, 3-4 mm. long; a $1 \mathrm{~b}$ a, white, referring to leaves and bark.

Cultivated and thence spreading spontaneously by means of root sprouts; native of Eurasia. Flowering in March or April, the cottony seeds flying in June. Our commonest variety is P. a. n i v e a, often called the "silver-leaf maple," with snowy lower leaf surface and larger lobes. Propagated by cuttings and suckers.

Wood white to yellowish, soft, weak, splitting with difficulty, weight 38 lbs. ; used for boxes, flooring, interior finishing, rollers; of little value. 


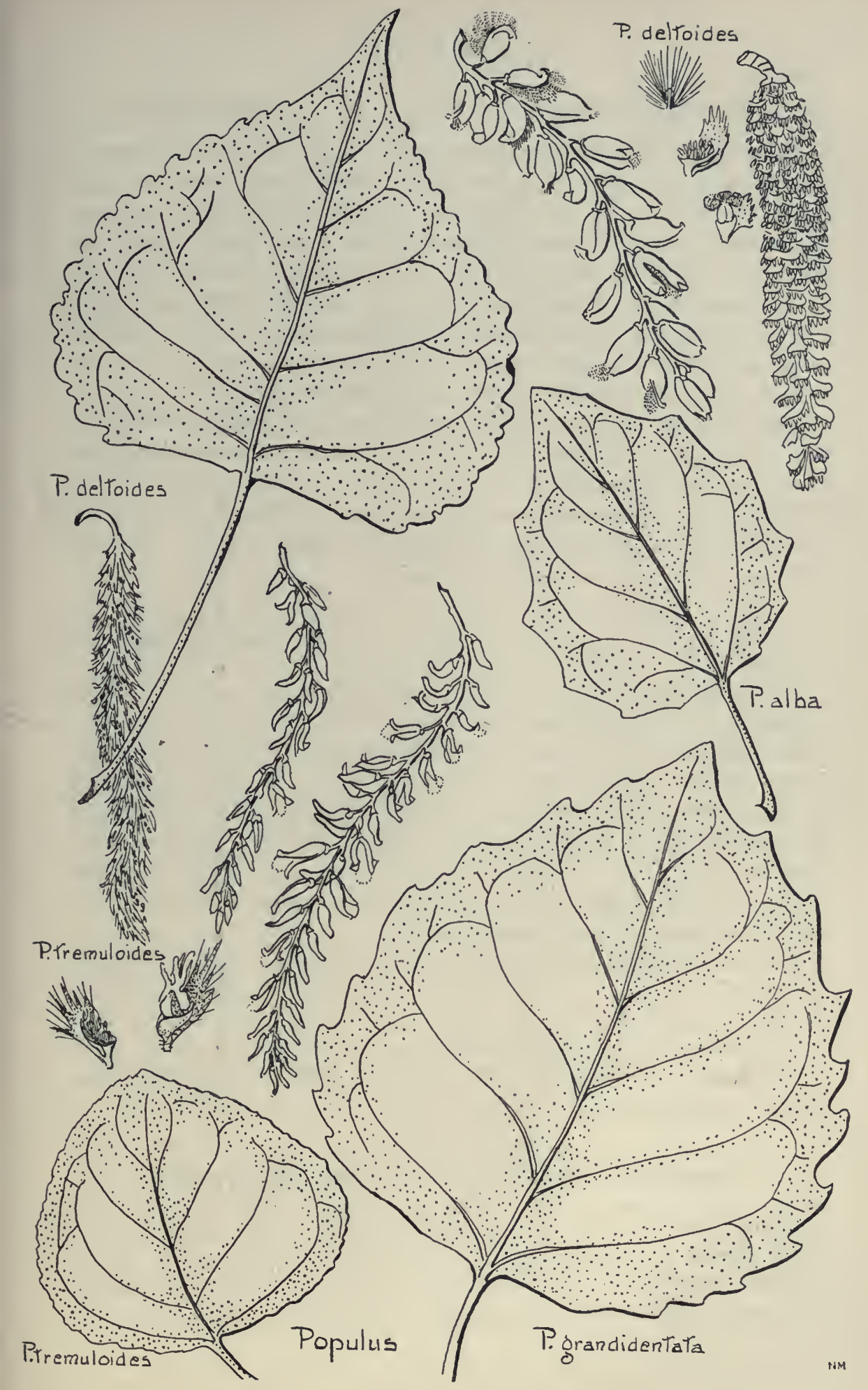




\section{Populus grandidentata $\mathrm{Mich}$ a $u \times 1803$ Toothed Aspen}

'Tree of medium size, 30-50 ft. high, 1-2 ft. diam.; bark smooth, green-gray or yellowish; leaves ovate or round in outline with 6-12 large usually blunt teeth on each side, tip also rather blunt, base tapering, truncate or somewhat rounded, densely white woolly when young, the wool persisting for a long time on the lower surface, but both surfaces finally smooth, more or less three-nerved at base, the lateral veins 6-12. 6-15 cm. long, 4-12 cm. wide, petioles flattened, long, 5-8 cm., densely white woolly, then smooth; bracts 5-6-cleft and silky, stamens 6-12 in each flower, the catkins $4-10 \mathrm{~cm}$. long, pistillate catkins $6-15 \mathrm{~cm}$., the capsules 2-valved, finely warted, 5-7. mm. long; flowering in March or April, the seeds flying in May: grandidentat a, large-toothed, referring to the leaf margin.

'Throughout the state, except the southwest; NS-NC-Tenn-Minn.

Wood brownish, soft, weak, close-grained, weight 29 lbs.; used for excelsior, paper, woodenware, and in turnery.

\section{Populus tremuloides M i cha $u x$ Aspen, Quaking Asp}

Variable, but usually a small tree, and often a shrub, 20-50 ft. high, $1 / 2-11 / 2 \mathrm{ft}$. diam.; bark smooth, bright gray-green or yellow-green; leaves broadly ovate to rounded, the margin finely toothed or wavy; and sparsely hairy, abruptly tipped, the tip sharp, $1 / 2 \mathrm{~cm}$. long, base truncate or rounded, smooth above and below, lateral veins $6-12$, petioles strongly flattened, slender, 3-5 cm. long; bracts deeply 3-5-cleft and long-hairy, stamens $6-12$ in each flower, the catkins $3-6 \mathrm{~cm}$. long; pistillate catkins 5-7 cm. long, the capsules two-valved, $6 \mathrm{~mm}$.; flowering in March and April, fruit maturing in May and June.

Common throughout the state, but especially in the north; Lab-NfdKy-Mex-Cal-Ala.

Propagated by root sprouts and cuttings, readily grown from seed.

Wood brownish, soft, weak, weight 20 lbs.; used for excelsior, paper boxes, flooring and turnery. The young inner bark is used for food by the northern Indian.

\section{Populus deltoides M a r sha 11 I785 Cottonwood}

I,arge tree $80-120 \mathrm{ft}$. high, 2-6 ft. diam.; bark smooth and gray-green for a number of years, deeply ridged when old; leaves broadly ovate or rounded, edge coarsely wavy-toothed, tip long-pointed, base truncate or shallowly cordate, smooth and shining, 5-10 cm. long and wide, petioles 
smooth, 6-12 cm. long; staminate catkins $6-10 \mathrm{~cm}$. long, $1-2 \mathrm{~cm}$. wide, stamens 30-60, bracts cut and fringed; fruiting catkins 10-20 cm. long, capsules ovate, finely warted, 10-14 mm.; de 1 to ides, delta-like, in reference to the leaves.

Common throughout the southern half of the state, often forming extensive woods on flooded lowlands, rarer northward; Quebec-Fla-N.MColo-Alberta. One of the commonest of cultivated trees in America, and widely grown in Europe; its rapid growth and massive habit make it desirable for planting in newly settled regions, but it is less satisfactory in cities. The staminate tree is especially attractive on account of its red-brown catkins, and should alone be planted in cities, in order to avoid the shower of cottony seeds produced by the pistillate tree.

Wood dark brown, light, soft, weak, close-grained, weight 24 lbs.; extensively used during the development of the Middle West, but now used only for fuel, packing boxes, and wood pulp, or locally for lumber.

\section{Populus nigra italica D u R o i I77I Lombardy Poplar}

Tall pyramidal tree, 50-100 ft. high, 2-4 ft. diam.; bark yellowish, then gray to brown, deeply furrowed; branches upright, appearing on all parts of the trunk; leaves broadly wedge-shaped, often much broader than long, margin wavy-toothed, short to very long-pointed, base triangular to truncate, smooth on both surfaces, 5-10 cm. long, 5-10 cm. wide, petioles flattened, 4-6 cm. long; staminate catkins $3-6 \mathrm{~cm}$. long, stamens 20-25, fruiting catkins 5-10 cm. long, capsules ovoid, blunt; it a 1 i c a, Italian, in reference to its home in Lombardy.

Frequently cultivated throughout the state except in the north, rarely spontaneous. A short-lived tree, especially liable to winter-killing and not desirable for planting in dry or cold northern climates.

The wood is of little value.

\section{Populus angustifolia J a mes I823 Narrowleaf Cottonwood}

Medium tree, 30-60 ft. high, 6-8 in. diam.; bark smooth and yellowish; leaves narrowly ovate-lanceolate to lanceolate, or nearly linear, edge minutely wavy-toothed, tip rounded or tapering, usually blunt, base usually tapering, rarely rounded, smooth, $5-15 \mathrm{~cm}$. long, $1-4 \mathrm{~cm}$. wide, petioles smooth, $1-4 \mathrm{~cm}$. long; staminate catkins $4-6 \mathrm{~cm}$. long, bracts deeply cut into many fine lobes; fruiting catkins 5-7 cm. long, capsules 2-valved, ovate, wrinkled; a n g u st if o 1 i a, narrow-leaved.

Rarely planted in parks: Assiniboia-Nebr-NM-Nev. 


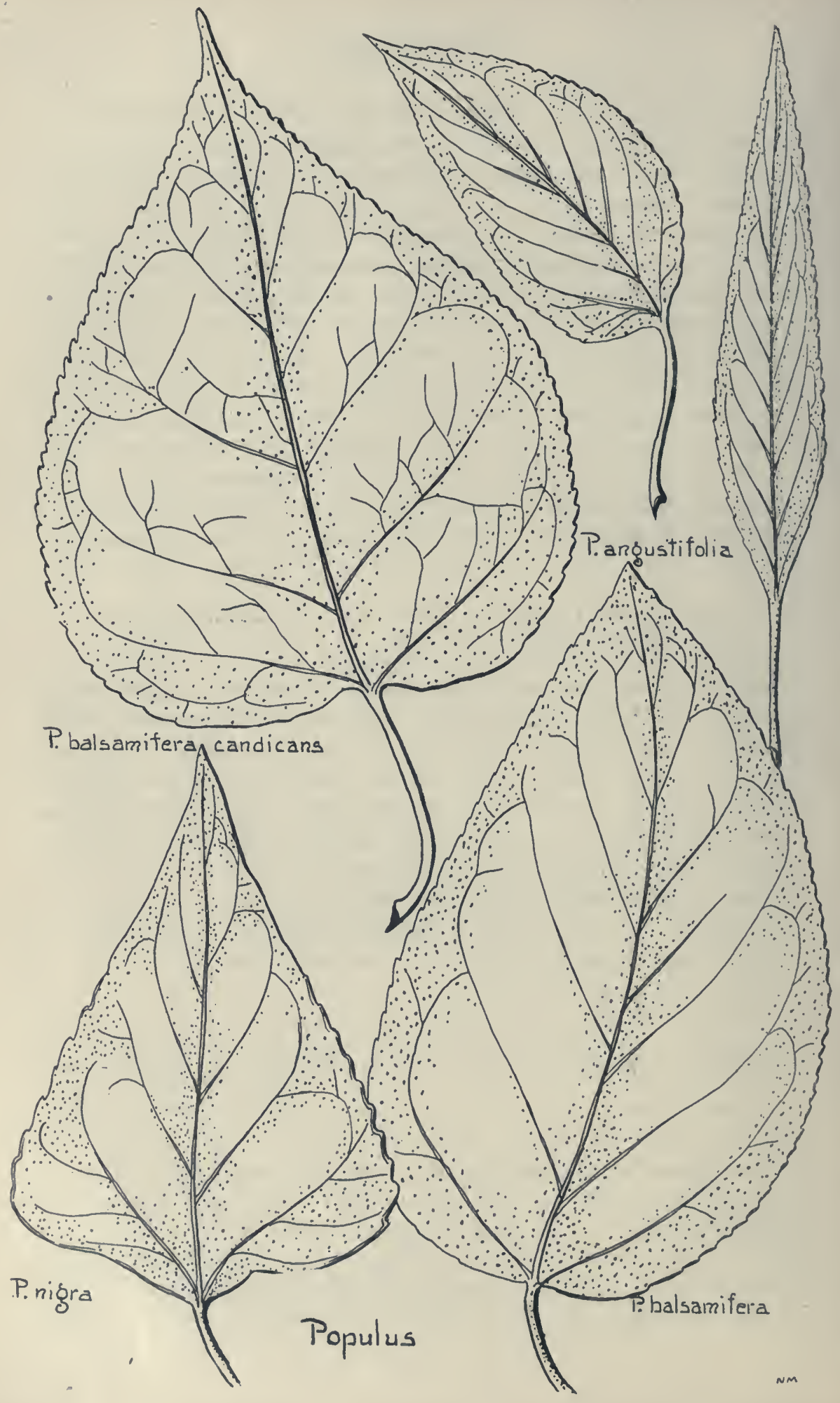


Wood light brown, soft, weak, weight 24 lbs.; used in the W'est for boxes, fencing, fuel, etc.

\section{Populus balsamifera L i n 11 é 1753 Balsam, Balsam Poplar}

Tall tree, 50-100 ft. high, 2-5 ft. diam.; bark grayish or greenish, smooth, somewhat ridged on old trunks; leaves narrowly to broadly ovate, the edge closely and finely wavy-toothed, tip rather long, acute, rounded, rarely slightly cordate at base, smooth, dark green, and shining above, the lower surface pale and resinous, often splashed with red, somewhat 3-nerved at base, $7-12 \mathrm{~cm}$. long, $4-6 \mathrm{~cm}$. wide, petioles round, hairy: 4-6 cm. long; staminate catkins $5-10 \mathrm{~cm}$. long, bracts usually coarsely fringed, sometimes lobed or divided, stamens 20-30; fruiting catkinsi 12-15 cm. long, capsules ovate, rugose, 8-10 mm. long; b a ls a $\mathrm{m}$ if e r a, balsam-bearing, referring to the resinous buds and leaves.

The variety $\mathrm{c}$ a $\mathrm{n}$ d i $\mathrm{c}$ a $\mathrm{n}$ s differs in its broadly ovate leaves with heartshaped bases, 10-12 cm. long, $8-10 \mathrm{~cm}$. wide, and in the hairy petioles and veins.

Along streams and edges of swamps, common throughout the northern half of the state but rare or lacking in the south; Nfd-NY-MichNebr-Colo-Saskatchewan-Alaska.

Wood light brown, soft, weak, close-grained, weight 22 lbs., used for boxes, pails, packing cases, wood-pulp and net floats.

\section{Salix L in né 1753}

(L. s a $1 \mathrm{ix}$, willow or sallow, the archaic name of willow in English)

Trees or shrubs; leaves alternate in 5 rows, simple, pinnately veined; buds not resinous, with a single scale; flowers dioecious, though exceptionally monoecious, appearing before the leaves or with them, in catkins, with entire usually hairy scales, each flower with a nectar-bearing disk, fragrant; stamens 1-10, usually 2, in each flower, ovary 1-celled, conical to beaked, with two rows of ovules, stigmas 2, capsule 2-valved, smooth or hairy, seeds enclosed in a tuft of hairs. Flowering in April or May.

Propagated by seeds or cuttings.

A genus of 170 species, widely distributed through the north temperate and arctic zones, about 80 species occur in North America. 


\section{Key to the Species}

1. Leaves smooth, or nearly so, on both sides when mature.

a. Leaves linear, linear-oblong, or linear-lanceolate

\section{S. flurintilis}

b. Leaves broader, lanceolate to ovate

(1) Branches drooping

(2) Branches more or less ascending, not drooping

(a) Shrubs or low trees, less than $20 \mathrm{ft}$. high

x. 'Twigs purplish, leaves oblanceolate or spatulate

y. Twigs brownish or yellowish; leaves lanceolate to ovate

(x) Petioles and stipules glandular

(y) Petioles and stipules not glandular

m. Leaves entire, elliptic; 1-3 ft. high

n. Leaves more or less toothed ( $\mathrm{m}$ ) Ieaves green on both sides, at least not glaucous below

S. purpuria

S. bublylonica

S. lucila

S. myrtilloides

S. cordatu

(n) Leaves glaucous or white below

r. Leaves elliptic to ovate, the fine teeth glandular

S. balsamifera

s. Leaves lanceolate to oblonglanceolate

(r) Young leaves densely silky

S. sericia

(s) Young leaves only slightly silky or hairy

h. I.eaves lanceolate, acuminate

i. I.eaves oblong-lanceolate acute

S. petiolaris

(b) Trees, 20-70 ft. high 
x. Leaves narrowly lanceolate, shortpetioled S. nigra

y. Leaves broadly lanceolate or lanceovate; slender-petioled.

S. amygaloides

2. I.eaves persistently hairy, at least beneath

a. Cultivated trees
(1) Leaves serrulate
S. alba
(2) Leaves entire
S. viminalis

b. Native shrubs

(1) Low shrubs, 1-6 ft. high

(a) Leares 2-5 cm. long; shrub 1-2 ft. high

(b) Leaves 5-10 cm. long; shrub 2-6 ft. high

$x$. Leaves and young twigs white-hairy beneath

y. Leaves gray-hairy beneath

S. candida

S. humilis

(2) Tall shrubs, 5-12 ft. high

(a) Leaves lanceolate, silky shining below S. sericca

(b) Leaves ovate-lanceolate or ovate, densely white-hairy below $\$$. rostrata

\section{Salix fluviatilis $N$ ut a 11 I842 Sandbar Willow, Longleaf Willow}

\section{S. longifolia Muhlenberg I803, not Lamarck 1778}

Low branching shrub, 3-10 ft. high, or rarely a low slender tree; bark smooth, gray, yellow or brown; leaves linear, rarely oblong, with 10-20 minute spiny teeth on each edge, tip very long-pointed, long tapering toward the base, white-silky on both sides when young, becoming smooth when mature, or in one form persistently silky below, inidrib prominent, lateral veins indistinct, $6-15 \mathrm{~cm}$. long, 2-12 $\mathrm{mm}$. wide, petioles very short, 1-2 mm. long; staminate catkins $2-4 \mathrm{~cm}$. long, $1 / 2-1 \mathrm{~cm}$. wide, stamens 2, wiłh distinct hairy filaments, pistillate catkins $2-5 \mathrm{~cm}$. long, $1 \mathrm{r} / 2 \mathrm{~cm}$. wide in fruit, capsule ovate, beaked, rugose or somewhat hairy: f $l$ u viat i l is, from f $l$ u vi us, stream, in reference to the habitat.

Abundant throughout the state along streams, on sandbars and sandy shores; Quebec-Va-Ky-NM-Athabasca. Flowering in May or June. Valuable for binding sandy banks and shores, and in reclaiming lowlands.

Wood soft, reddish brown, weight 31 lbs., of no value except for charcoal. 


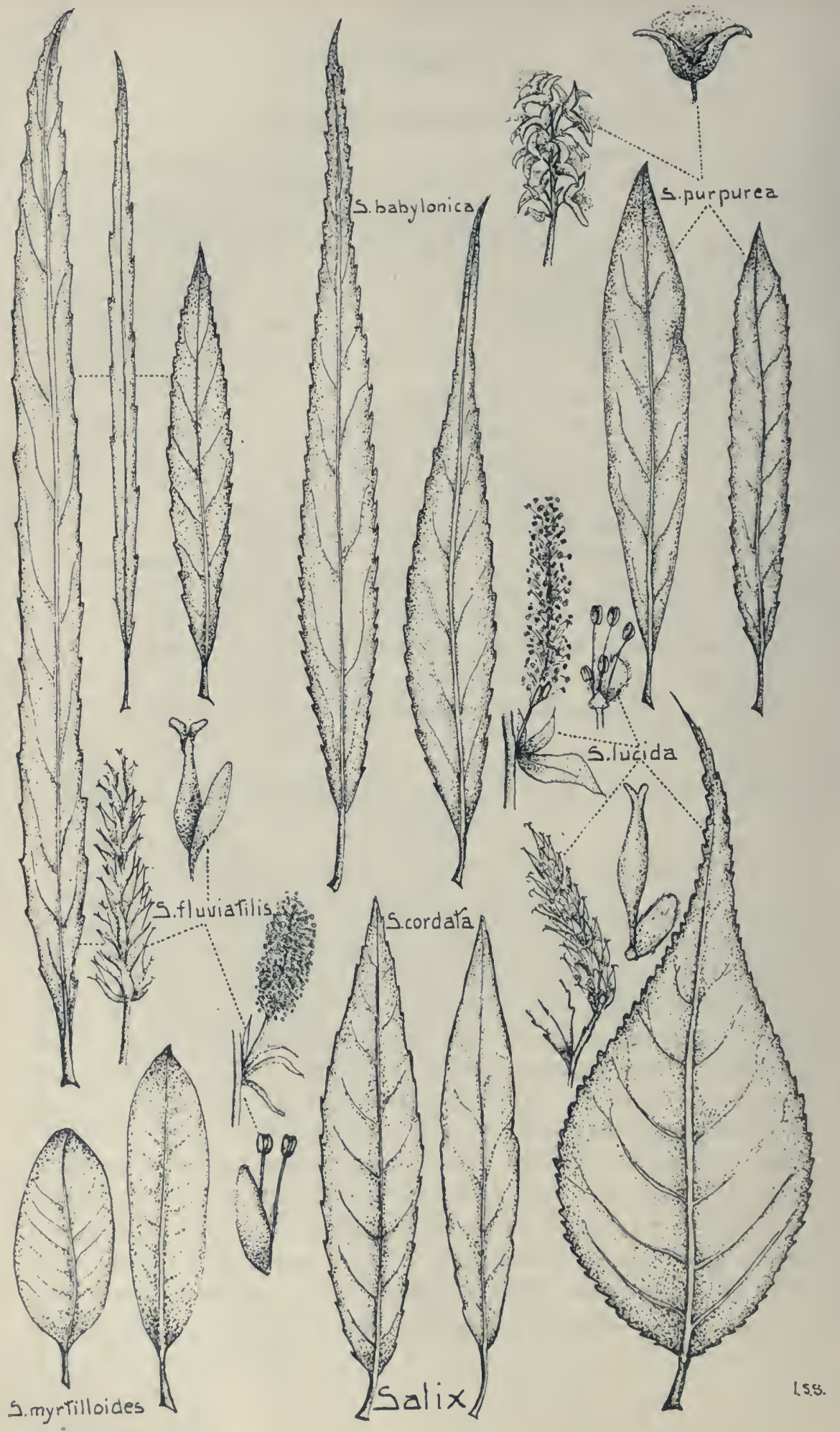




\section{Salix babylonica L in 11 é I753}

Tall tree, 50-70 ft. high, 2-6 ft. diam.; bark gray, rough; twigs very long and drooping; leaves linear-lanceolate to lanceolate, with 30-50 minute sharp teeth on each edge, very long-pointed, tapering toward the base, smooth on both sides when mature, green above, glaucous beneath, $8-12 \mathrm{~cm}$. long, $1-1 / 2 \mathrm{~cm}$. wide, petioles usually twisted, somewhat hairy, $1-1 / 2 \mathrm{~cm}$. long; stamens 2 with distinct hairy filaments, pistillate catkins 2-3 cm. long, $1 / 2 \mathrm{~cm}$. wide, capsule ovate, beaked; ba by 1 o n ica, of Babylonia, referring to its original home.

Occasionally cultivated; native of Asia.

\section{Salix purpurea L in né I753 Purple Willow}

Shrub, 6-12 ft. high, with somewhat purplish flexible twigs; leaves oblanceolate to spatulate, rarely oblong, entire or finely and sharply toothed, tip acute, tapering from above the middle to the base, smooth, paler below, veiny, 5-8 cm. long, $1-1 \mathrm{~T} / 2 \mathrm{~cm}$. wide, petioles $3-6 \mathrm{~mm}$. long; staminate catkins $3-5 \mathrm{~cm}$. long, $7-8 \mathrm{~mm}$. wide, stamens 2 , filaments hairy, united, pistillate catkins $2-3 \mathrm{~cm}$. long, $5 \mathrm{~mm}$. wide, capsule ovoid, blunt, densely hairy, scales minute, hairy; p u r p u rea, purple, perhaps in reference to the purple twigs.

Occasionally cultivated; native of Europe.

\section{Salix lucida M u h 1 e n berg I803 Glossy Willow}

Tall shrub or low tree, 6-20 ft. high, 4-8 in. diam.; bark smooth: brown, twigs yellow-brown, shining; leaves broadly lanceolate to ovatelanceolate or ovate, finely and closely toothed, tip very long, pointed, often 3-4 cm. long, base tapering or rounded, smooth, shining above, paler below, veiny, glandular at base, $7-15 \mathrm{~cm}$. long, $2-5 \mathrm{~cm}$. wide, petioles $\mathrm{T} / 2-1 \mathrm{~cm}$., staminate catkins $2-3 \mathrm{~cm}$. long, $1-1 \frac{1}{2} \mathrm{~cm}$. wide, stamens 5 , filaments hairy at base, pistillate catkins $3-4 \mathrm{~cm}$. long, $1-1 \frac{1}{2} \mathrm{~cm}$. wide in fruit, capsules ovoid, beaked, minutely rugose; l u c id us, shining, in reference to twigs and leaves.

Common throughout the whole state along banks of streams and on lake shores; Nfd-NY-Ky-Nebr-Athabasca. Flowering in April or May. Used for ornament by reason of its shining leaves and large bright yellow staminate catkins. The wood is not used and its qualities have not been determined. 


\section{Salix myrtilloides Li n n é 1753 Bog Willow}

Low shrub, 1-3 ft. high, with grayish or brownish twigs; leaves elliptic to oblanceolate or spatulate, or more rarely oblong, margin entire, revolute, tip rounded or acute, base rounded to tapering, smooth, green above, glaucous beneath, $2-4 \mathrm{~cm}$. long, $1-2 \mathrm{~cm}$. wide, or $2-5 \mathrm{~cm}$. long, $1 / 2-1$ $\mathrm{cm}$. wide in the narrow forms, petioles $2-5 \mathrm{~mm}$. long; staminate catkins $2-3 \mathrm{~cm}$. long, stamens 2, filaments smooth, pistillate catkins short, $11 / 2-3$ $\mathrm{cm}$. long, $1 \mathrm{~T} / 2 \mathrm{~cm}$. wide, capsules ovoid, beaked, smooth, red-brown; myrtilloides, myrtle-like. The variety pedicellaris differs only in the narrow oblong or oblong-linear leaves mentioned above.

Frequent in bogs and wet meadows in the north, rarer southward, and lacking in the southwest; Quebec-NY-Ia-B.C.

\section{Salix cordata M u h 1 e n b e r g I803 Cordate Willow}

Shrub, 4-12 ft. high, the twigs often minutely hairy; leaves lanceolate to oblanceolate, finely and usually closely toothed on the margin, tip acute or somewhat pointed, tapering toward the base, somewhat whitehairy when very young, smooth when mature, paler beneath, $4-8 \mathrm{~cm}$. long, 8-15 mm. wide, petioles $3-6 \mathrm{~mm}$. long; staminate catkins $3-4 \mathrm{~cm}$. long, stamens 2, filaments smooth, pistillate catkins $4-5 \mathrm{~cm}$. long, $1 \mathrm{I} / 2 \mathrm{~cm}$. wide in fruit, capsules ovoid, beaked, smooth; cord a t a, heart-shaped, referring perhaps to the large heart-shaped stipules, which are often lacking. In the variety a $\mathrm{ng} \mathrm{us} t \mathrm{t} \mathrm{a}$, the leaves are linear-lanceolate.

Frequent throughout the state along river banks and in marshes; Nebr-Ga-Mo-Colo-Cal-B.C.

\section{Salix balsamifera B a r a t $\mathrm{I} 839$ Balsam Willow}

Shrub, 3-10 ft. high, with dark shining twigs; leaves elliptic, ovatelanceolate or ovate, finely toothed or more closely wavy-toothed, the teeth glandular, tip pointed, base rounded or slightly heart-shaped, somewhat hairy when young, smooth when mature, green above, very glaucous below, veins prominent, $4-9 \mathrm{~cm}$. long, $2-3 \mathrm{~cm}$. wide, petioles $11 / 2-2 \mathrm{~cm}$. long; staminate catkins $2 \mathrm{r} / 2-3 \mathrm{~cm}$. long, $1 \mathrm{~cm}$. wide, stamens 2 , filaments smooth; pistillate catkins $3-4 \mathrm{~cm}$. long, $1-11 / 2 \mathrm{~cm}$. wide, capsules oroid, beaked, smooth: bals a mif e ra, balsam-bearing, in reference to the glandular leaves.

Rare-chiefly in the Red River Valley: Labrador-Me-Ont-Minn-Manitoba. 


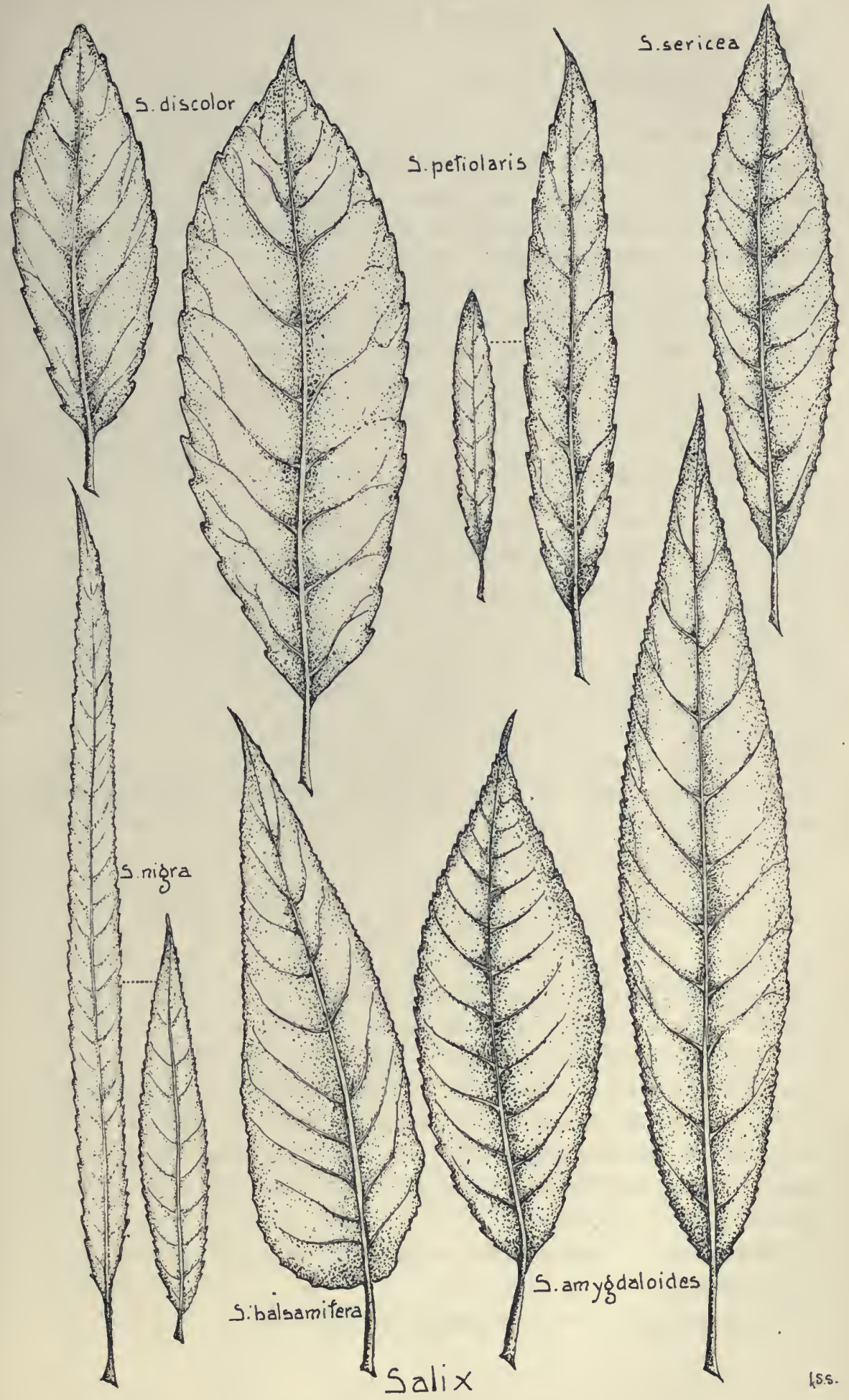




\section{Salix sericea Marsha 11 I 785 Silky Willow}

Shrub, 5-12 ft. high, often with finely hairy twigs, leaves lanceolate, pointed, tapering toward the base, the margin closely wavy-toothed, when young sparsely hairy above and densely white-woolly below, smooth and green above when mature, usually silky shining below, rarely less shiny but apparently always hairy, $6-10 \mathrm{~cm}$. long, $1-2 \mathrm{~cm}$. wide, petioles $1 \mathrm{~cm}$. long; staminate catkins $11 / 2-2 \mathrm{~cm}$. long, $7-8 \mathrm{~mm}$. wide, stamens 2 , filaments smooth, pistillate catkins $2-3 \mathrm{~cm}$. long, $1 \mathrm{~cm}$. wide in fruit, capsules ovate-conic, densely gray-hairy; sericea, silky referring to the leaves.

Not yet reported from a definite locality in Minnesota; Me-Va-Mich.

\section{Salix petiolaris J. E. S m ith 1802 Slender Willow}

Shrub, 4-12 ft. high; leaves linear-lanceolate to lanceolate, margin finely toothed, or wavy-toothed, sharp-pointed, tapering toward the base, silky-hairy when young, smooth or somewhat hairy above when mature, very glaucous below, $3-8 \mathrm{~cm}$. long, $1 / 2-11 / 2 \mathrm{~cm}$. wide, petioles usually hairy, $1 / 2-1 \mathrm{~cm}$. long; staminate catkins $2-3 \mathrm{~cm}$. long, stamens 2 , filaments smooth, pistillate catkins $2-3 \mathrm{~cm}$. long, capsules long-beaked, finely hairy; pet io $l$ aris, petioled. In the variety $\mathrm{grac} i \mathrm{l}$ is, the leaves are linearlanceolate, and the pedicel nearly as long as the capsule.

Along stream banks and wet mealows, rare northward; NB-Va-MinnMont-B.C.

\section{Salix discolor M u h l e n b e r g 1803 Pussy Willow}

Shrub or low tree, 6-20 ft. high, 4-8 in. diam.; bark brownish, scaly; leaves oblong or elliptic to oblong-lanceolate, coarsely wavy-toothed, acute or sharp-pointed at tip, more or less rounded at the base, nearly or entirely smooth when mature, green above, very glaucous below, prominently veined, $8-15 \mathrm{~cm}$. long, $2-5 \mathrm{~cm}$. wide, petioles usually hairy, 2-3 $\mathrm{cm}$. long; staminate catkins $3-4 \mathrm{~cm}$. long, $11 / 2 \mathrm{~cm}$. wide, stamens 2, filaments smooth, pistillate catkins densely hairy, $5-6 \mathrm{~cm}$. long, $11 / 2 \mathrm{~cm}$. wide, capsules large, long-beaked, hairy: dis color, referring to the contrast between the two leaf surfaces.

Common along streams and in wet places throughout the state: NSNC-Mo-Minn.

Wood brownish, soft, close-grained, weight 26 lbs. 


\section{Salix nigra M a r sh a 11 r 785 Black Willow}

Tree, 40-80 ft. high, 1-3 ft. diam.; bark dark brown, more or less deeply ridged, and separating in plates; leaves narrowly lanceolate, usually tapering gradually to a very long point, tapering or slightly rounded toward the base, margin closely set with fine sharp teeth, usually smooth, slightly paler below, $6-12 \mathrm{~cm}$. long, $8-12 \mathrm{~mm}$. wide, petioles often hairy, 5-10 mm. long; staminate catkins 5-10 cm. long, 7-10 mm. wide, stamens $3-7$, filaments hairy, pistillate catkins $4-6 \mathrm{~cm}$. long, $1 \mathrm{~cm}$. wide, capsules ovate, abruptly pointed, rugose; $\mathrm{ni} \mathrm{g} \mathrm{r}$ a, black, referring perhaps to the bark.

Frequent throughout the state, common in the south; NB-Fla-TexCal-Manitoba.

Wood light reddish brown, soft, weak, weight $28 \mathrm{lbs}$.

\section{Salix amygdaloides Anderson 1858 Almond Willow}

Tree, 40-60 ft. high, 1-2 ft. diam.; bark brown, ridged and more or less scaly; leaves lanceolate to ovate-lanceolate, margin finely and sharply toothed, tip long-pointed, base tapering, rounded or rarely slightly cordate, smooth when mature, more or less glaucous beneath, $6-12 \mathrm{~cm}$. long; $11 / 2-21 / 2 \mathrm{~cm}$. wide, petioles smooth or hairy, $1-2 \mathrm{~cm}$. long; staminate catkins 3-6 cm. long, 6-8 mm. wide, stamens 5-9, filaments somewhat hairy below, pistillate catkins $4-6 \mathrm{~cm}$. long, $11 / 2 \mathrm{~cm}$. wide in fruit, capsules ovate, smooth: a mygda $10 \mathrm{ides}$, almond-like, referring to the leaves.

Frequent along streams and in wet soils throughout the state; QuebecNY-Mo-NM-BC-Saskaţchewan.

Wood light brown, soft, weak, weight 28 lbs.

\section{Salix alba Lin né I753 White Willow, Huntingdon Willow}

Large tree, 50-80 ft. high, 3-6 ft. diam.; bark gray, ridged; leaves lanceolate or somewhat oblanceolate, margin finely and closely toothed, teeth glandular, tip usually long-pointed, tapering toward the base, sparsely silky above, white and shining silky below, 5-10 cm. long, $1-2 \mathrm{~cm}$. wide, petioles hairy, 2-5 mm. long; staminate catkins $3-5 \mathrm{~cm}$. long, 7-8 $\mathrm{mm}$. wide, stamens 2, filaments hairy, pistillate catkins $5-7 \mathrm{~cm}$. long, $6-8 \mathrm{~mm}$. wide, in fruit, capsule ovoid, rugose, smooth; al b a, white, referring to the leaves.

Occasionally cultivated, especially the golden osier, the variety vit e I- 
$1 \mathrm{i}$ s a, with leaves smooth above and yellowish twigs; hardy and hence valuable for wind-breaks and for live fences.

Wood soft, light, tough and flexible.

\section{Salix viminalis $\mathrm{L}$ i n 11 é 1753 Osier Willow}

Shrub or low tree, 10-25 ft. high; leaves very long, linear-lanceolate or lanceolate, or sometimes oblanceolate, margin usually entire and revolute, tip long-pointed, base tapering, dark green and nearly smooth above, densely white silky below, $5-15 \mathrm{~cm}$. long, 1-2 cm. wide, petioles more or less hairy, 2-5 mm. long; staminate catkins $3-4 \mathrm{~cm}$. long, $1 \mathrm{~cm}$. wide, stamens 2, filaments smooth, pistillate catkins $4-6 \mathrm{~cm}$. long, $1 \mathrm{~cm}$. wide in fruit, capsules ovate-conic, densely white silky: vim in a 1 is, vimen, a pliant twig, referring to its use in wicker work.

Occasionally cultivated, native of Eurasia; used for wicker ware.

\section{Salix tristis A it o n 1789 Dwarf Willow}

Low branched shrub, 1-3 ft. ligh, with dark hairy twigs; leaves spatulate or oblanceolate, sometimes oblong, margin entire or very slightly wavy, revolute, tip pointed or obtuse, base tapering, green and more or less hairy above when mature, densely gray-woolly below, 2-6 cm. long, $1 / 2-11 / 2 \mathrm{~cm}$. wide, petioles densely hairy, $1-3 \mathrm{~mm}$. long; staminate catkins $1-11 / 2 \mathrm{~cm}$. long, $1 / 2 \mathrm{~cm}$. wide, stamens 2 , filaments smooth; pistillate catkins $2-3 \mathrm{~cm}$. long, $1 \mathrm{I} / 2 \mathrm{~cm}$. wide in fruit, capsules very long, beaked, gray lairy: $\mathrm{t} r$ is $\mathrm{t} i \mathrm{~s}$, sad, referring to the gray color.

Infrequent; occasional in the southern part of the state; Me-NV-GaMo-Nebr-Minn.

\section{Salix candida Fl u e g g e 1806 Hoary Willow}

I.ow shrub, 2-6 ft. high, the young twigs densely white woolly; leaves linear, oblong-lanceolate or oblanceolate, margin entire and revolute: tip pointed or blunt, base long-tapering, more or less sparsely longwoolly above, densely white-woolly below, veiny above, $4-8 \mathrm{~cm}$. long $1 / 2-11 / 2 \mathrm{~cm}$. wide, petioles densely woolly, 1-5 mm. long; staminate catkins 1-2 cm. long, 6-8 mm. wide, stamens 2, flaments smooth, pistillate catkins $3-4 \mathrm{~cm}$. long, $1-1 \mathrm{I} / 2 \mathrm{~cm}$. wide in fruit, capsules ovoid-conic, densely woolly: c a nd ida, shining, in reference to the white leaves.

In wet places throughout the state except in the south; Labrador- $\mathrm{NV}$ Colo-Saskatchewan. 


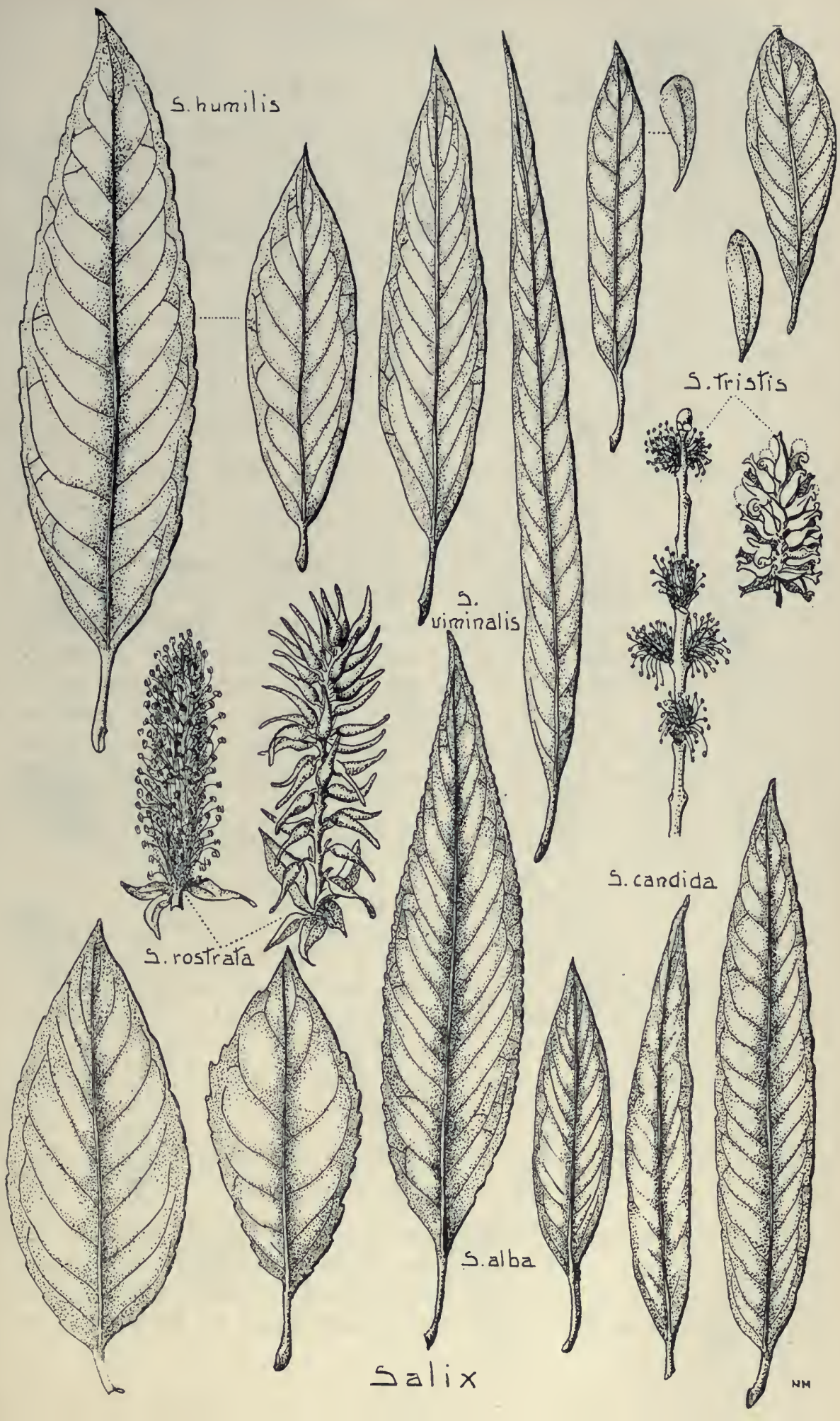




\section{Salix humilis Ma rsha $11 \quad \mathrm{r} 785$ Prairie Willow}

Low shrub, 2-6 ft. tall, with densely hairy twigs; leaves oblong-lanceolate to oblanceolate or spatulate, margin entire or slightly wavy toward the tip, revolute, tip rounded or acute, base tapering or rounded,' smooth or slightly hairy above when mature, densely or rarely sparsely whitewoolly below, $2-8 \mathrm{~cm}$. long, $1-21 / 2 \mathrm{~cm}$. wide, petioles densely woolly, $3-15$ mm. long; staminate catkins $1-2 \mathrm{~cm}$. long, $7-8 \mathrm{~mm}$. wide, stamens 2 , filaments smooth, pistillate catkins $2-4 \mathrm{~cm}$. long, $1-1 \frac{1}{2} \mathrm{~cm}$. wide, capsules ovoid, long-beaked, white-silky; humilis, on the ground, alluding to the low habit.

Probably throughout the state; NS-NC-Nebr-.Minn.

\section{Salix rostrata $\mathrm{R}$ ichardson $\mathrm{I} 823$ Beak Willow}

Salix bebbiana Sargent 1895

Shrub, 6-15 ft. high; bark gray, slightly ridged and somewhat scaly; leaves ovate-lanceolate or ovate, margin entire or slightly wavy, tip acute or blunt, base more or less wedge-shaped, somewhat hairy above, more or less densely long white-hairy below, or sometimes nearly smooth in old age, 3-6 cm. long, $11 / 2-21 / 2 \mathrm{~cm}$. wide, petioles densely hairy, 8-10 mm. long; staminate catkins $3-4 \mathrm{~cm}$. long, $1 \mathrm{~cm}$. wide, stamens 2 , filaments smooth, pistillate catkins $5-7 \mathrm{~cm}$. long, $11 / 2 \mathrm{~cm}$. wide in fruit, capsules long-beaked, hairy: rostrat a, beaked, in allusion to the long-beaked capsules.

Throughout the state; Quebec-N Y-Nebr-Ariz-Athabasca.

\section{Malvales Mallow Order \\ Tiliaceae Linden Family}

Trees with alternate simple leaves; flowers perfect in open clusters; sepals 5, petals 5, stamens many, in several groups; ovary 2-10-celled; fruit 1-10-celled, drupe-like or berry-like.

$\Lambda$ family of about 25 genera, found chiefly in tropical and subtropical regions, a few occurring in temperate climates.

\section{Tilia L in né r753 Basswood, Linden (L. tili a, linden or lime tree)}

Trees with rounded heart-shaped oblique leaves, and cream-colored or yellowish flowers in axillary or terminal clusters, the stalk grown togetther with a leaf-like bract; sepals 5, petals 5, narrow and spatulate, often with small basal scales, stamens many, united by the filaments or 


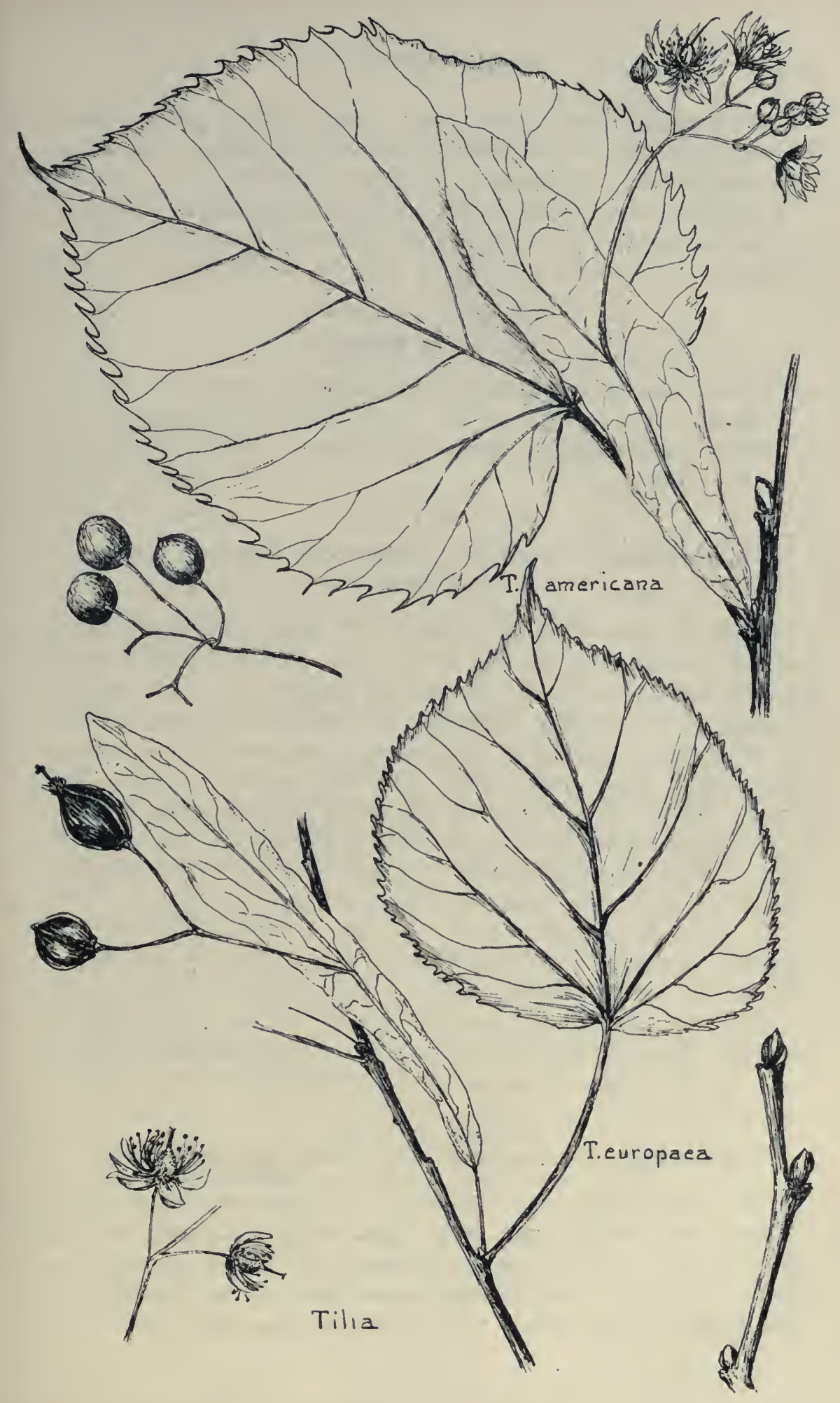


with the petal scales in 5 groups; ovary 5-celled, with 2 ovules in each cell, style simple, stigma 5-toothed; fruit dry, indehiscent, 1-2-seeded, drupe-like, more or less globose.

Propagated from stratified seed, though these often fail to germinate until the second year; also from cuttings grown in a solar pit.

A genus of 12 species, all native to the north temperate zone.

\section{Key to the Species}

1. Petioles smooth; leaves $8-10 \mathrm{~cm}$. and more long

T. americana

2. Petioles hairy, especially at the blade; leaves 5-8 cm. long

T. curopaca

\section{Tilia americana Li n n é 1753 Basswood, American Linden, Bee Tree}

Medium or tall tree, 30-75 ft. high, 1-3 ft. diam.; bark smooth for a long time, reddish grey, and with shallow ridges; leaves broadly ovate, or rounded, deeply and sharply toothed, tip abruptly sharp-pointed, base irregular, one side $2-5 \mathrm{~cm}$. longer than the other, smooth above and below, prominently veined, $8-25 \mathrm{~cm}$. long, $6-15 \mathrm{~cm}$. wide, petioles smonth, 4-8 cm. long: flower bract oblong, veiny, $6-15 \mathrm{~cm}$. long, $1-3 \mathrm{~cm}$. wide clusters 8-20-flowered, flowers $1 \mathrm{~cm}$. wide, fragrant, nectar-bearing; petals creamy or yellowish, oblong, narrow, longer than the lanceolate hairy sepals; fruit globose, hairy, $6-8 \mathrm{~mm}$. diam., often persisting all winter; a mericana, American, referring to its native lome.

In rich soil, common through the central and southern portions, especially dominant in the "Big Woods," rare northward; New Brunswick-( ia-Tex-Nebr-Manitoba.

Wood light brown, soft, weight 28 pounds per cubic foot; used for carriages, furniture, panels, inner soles of shoes, paper pulp, wooden ware, and the tough bark for mat fiber, cordage, etc.

\section{Tilia europaea L in né I753 Lime Tree, European Linden}

'Tall tree, 40.80 ft. high, 1-3 ft. diam.; hark dark, riclged, leaves oblicpuely and broadly ovate or rounded, finely and sharply tootherl, abruptly pointed, very oblique and irregular at the hase, smooth above, more or less hairy below, especially on the veins and at the angles, and usually with a characteristic weft of hairs at the base, $5-8 \mathrm{~cm}$. long, 
5-7 cm. wide, petioles hairy, 3-5 cm. long; flower bracts oblong, 6-8 cm. long, 1-2 cm. wide; clusters 6-12-flowered, flowers $7-8 \mathrm{~mm}$. wide, without a scale at base; fruit ovoid, hairy, with 5 prominent angles; e urop a e a, European.

Rarely cultivated, native of Europe.

\section{Ulmaceae Elm Family}

Trees with alternate, simple, serrate leaves; flowers monoecious, rarely perfect, clustered or rarely single; sepals 3-9, petals 0, stamens 3-9, ovary 1-celled, stigmas 2 ; fruit a winged achene (samara), nut, or drupe.

A family of about 13 genera found throughout temperate and tropical regions.

\section{KEY TO TII GENERA}

1. Fruits winged, in clusters; bark with flattened ridges

\section{Clmllis}

2. Fruits berry-like, single, persistent; bark with deep corky ridges

Ciltis:

\section{Ulmus L i nn é I753 Elm}

(L. $₫ 1 \mathrm{mus}$, elm, the two words cognate)

Trees; leaves alternate in two rows, simple, serrate, the mid-rib giving rise to many regular veins; flowers monoecious or perfect, in clusters, on last year's twigs, appearing before the leaves; sepals 4-9, united, petals lacking, ovary 1-celled, styles 2 ; fruit a round or oval samara, broadly winged.

Propagation: species grown from seed which should be sown as they fall; varieties by budding and grafting; seeds of the red elm are kept stratified until the following spring.

A genus of 16 species, natives of the northern hemisphere; 5 native species are found in the United States.

\section{Key to the Species}

1. Bud scales densely brown-hairy; leaves very rough above; samaras smootl, U. fulva

2. Bud-scales smooth; leaves nearly smooth above; samaras ciliate at edge

a. Some twigs with corky lines; sides of fruit hairy; flowers in racemes 
b. No twigs with corky lines; sides of fruit smooth; flowers in dense clusters

1. Edges of fruit densely hairy; leaves rough above, hairy below

U. americana

2. Edges of fruit smooth; leaves soft above, hairy below

U. campestris

\section{Ulmus fulva M i c h a u x I8o3 Slippery Elm, Red Elm}

Tree of medium size, 30-50 ft. high, $1 \frac{1}{2}-2 \mathrm{ft}$. diam.; bark gray, rough, the inner layers very mucilaginous; leaves more or less ovate, doubly toothed, tip 1-2 cm. long, saw-toothed, base oblique on one side, rounded on the other, midrib prominent with 20-30 nearly parallel lateral veins, very rough above, hairy balow, or sometimes nearly smooth, 8-15 $\mathrm{cm}$. long, $4-\tau \mathrm{cm}$. wide, petioles densely hairy, short, $1 / 2-1 \mathrm{~cm}$. long, stipules papery, deciduous, $1 \mathrm{~cm}$. long; flowers 10-25 in dense umbel-like clusters, mostly perfect, pedicels $3-5 \mathrm{~mm}$. long, sepals brown-hairy; fruits rounded, wing smooth, but densely brown-hairy over seed, veiny, edge not ciliate, 15-20 mm. long; flowering in March or April, fruit falling a few weeks later: $f \mathrm{ulv}$ a, red brown, referring to wood and buds.

In woods especially along streams, frequent throughout the state, except in the north; Quebec-Fla-Tex-N. D.

Wocd dark brown or reddish, hard, compact, coarse-grained, splitting easily, durable, weight $43 \mathrm{lbs}$. per cubic foot; much used for agricultural implements, boat-ribs, heelstocks, ox-yokes, posts, runners, sills, sleighs and tires. The mucilaginous inner bark is used in medicine as a demulcent; it has also some nutritive value.

\section{Ulmus racemosa Tho m a 183 I Cork Elm, Rock Elm}

Tree of medium size, 40-75 ft. high, 1-2 ft. diam.; bark moderately rough, ridges flat on the trunk, prominent and corky on the twigs; leaves elliptic to ovate, doubly toothed, tip $1 / 2-1 \mathrm{~cm}$. long, base oblique and rounded, midrib prominent, lateral veins $30-40$, smooth above or nearly so, slightly velvety beneath, 7-12 cm. long, $4-6 \mathrm{~cm}$. wide, petioles hairy or finally smooth, short, $4-10 \mathrm{~mm}$. long, stipules papery, deciduous; flowers 6-12 in a raceme, $2-4 \mathrm{~cm}$. long, pedicels prominently jointed, $2-6 \mathrm{~mm}$. long; fruit unequally oval or rounded, hairy on the faces, the edges densely hairy: $\mathrm{r}$ a c e m os a, referring to the flower cluster.

Somewhat common on lowlands in the southwest, but becoming infrequent westward and lacking northward; Quebec-N. J.-Tenn-Mo-NebrMinn. 


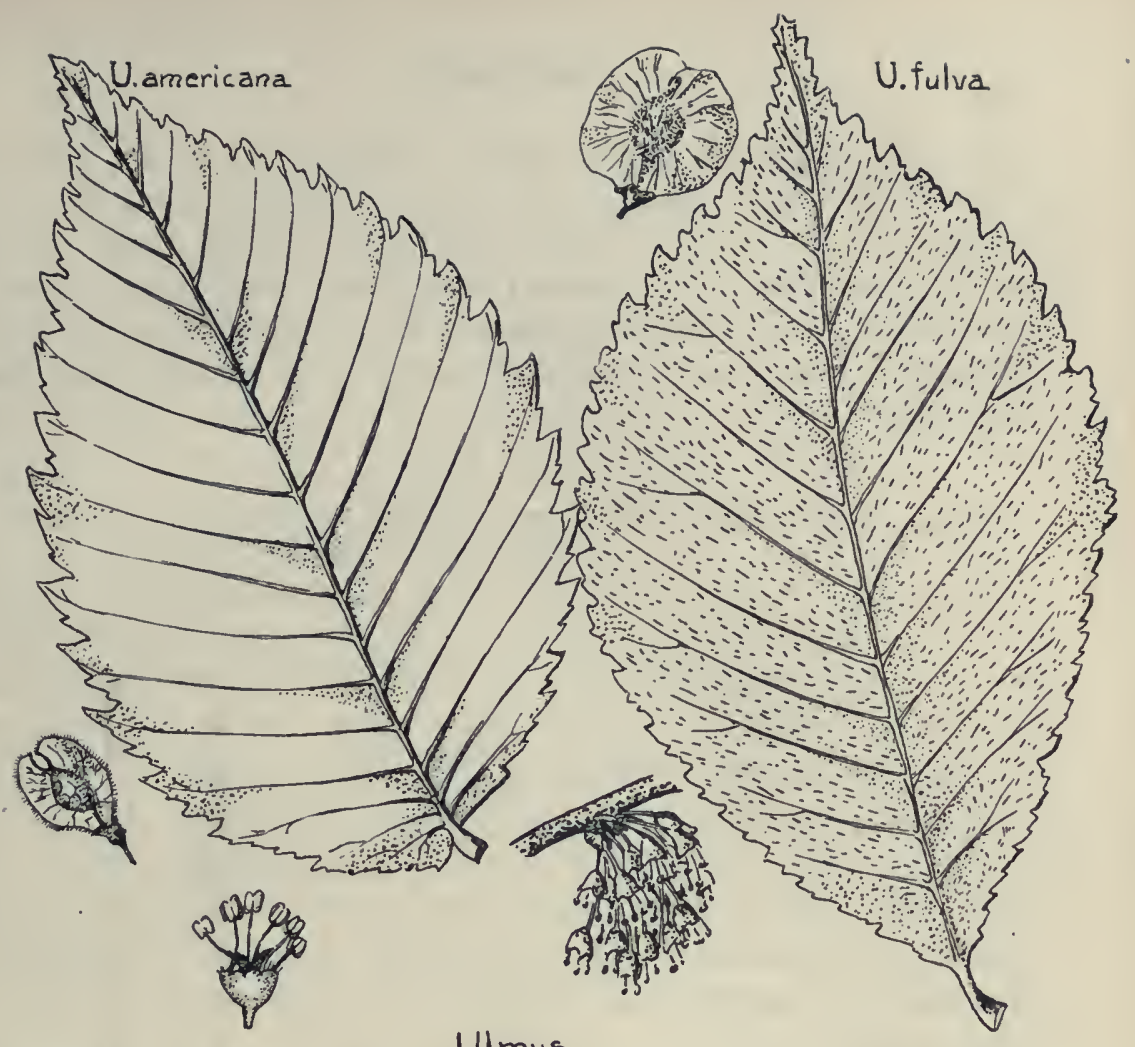

\section{U. racemosa}

Ulmus

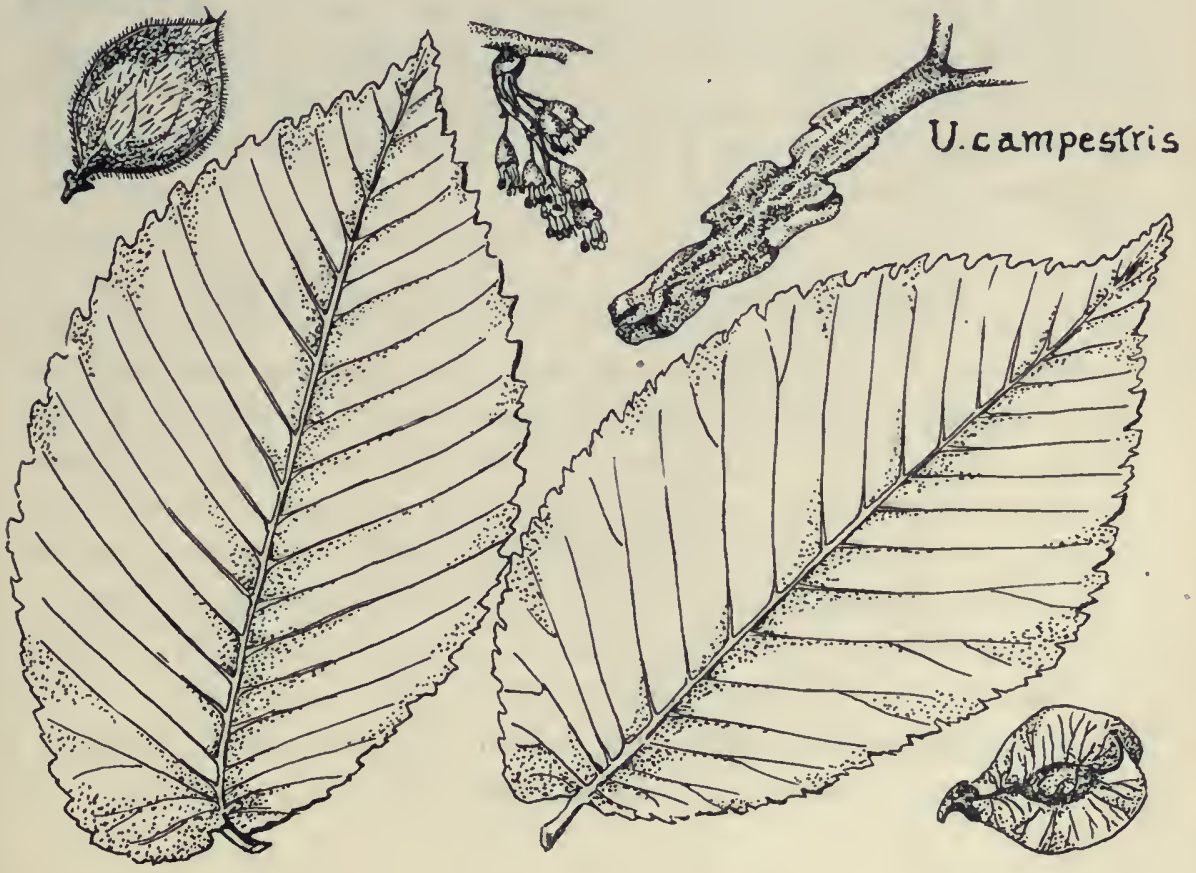


Wood close-grained, compact, hard, durable, splitting with difficulty, weight $45 \mathrm{ll}$ s. to the cubic $\mathrm{ft}$.; drier and more valuable than that of the white elm; used for agricultural implements, mowers, plows, reapers. threshers, for beams, bicycle rims, boat-building, bridge timbers, chairs, coach-building, hubs, piles, sills, ties and wheels; superior to hickory for ax handles; used wherever toughness, solidity; flexibility, and durabliity are required.

\section{Ulmus americana Linné 1753 American Elm, White Elm}

Large tree, 40-75 ft. high, 1-4 ft. diam.; bark moderately rough, with broad flattened ridges on the trunk, often separating in scales; leares elliptic to ovate, doubly toothed, tip $1-2 \mathrm{~cm}$. long, hase very oblique on one side, rounded on the other, rough above, more or less short-hairy beneath, veins prominent, laterals $25-35,7-12 \mathrm{~cm}$. long, $4-6 \mathrm{~cm}$. wide; petioles hairy to smooth, $1 \mathrm{~cm}$. long; flowers in clusters of 10-12; fruit elliptical to oval or almost round, tips curved together, smooth and reiny on the surfaces, densely hairy at the edge, $1-11 / 2 \mathrm{~cm}$. long.

Common on lowlands and along banks of streams, throughout the state, especially abundant in the "Big Woods"; Newfoundland-Fla-TexDak-Saskatchewan.

Wood rather cuarse-grained, compact, hard, tough, strong, splitting with difficulty, weight 40.5 lbs.; used for agricultural implements, boat and ship-building, cooperage, flooring, flumes, hubs, saddle trees and tool handles; bark used by the Indians for canoes and houses; inner bark formerly used for ropes.

\section{Ulmus campestris L in né 1753 English Elm}

Tall tree, 40-75 ft. high, 1-3 ft. diam.; bark dark and ridged, divided into irregular squares; leaves oblong-ovate to ovate, the margin doubly toothed, tip, $1-2 \mathrm{~cm}$. long, coarsely saw-toothed, hase oblique, soft and somewhat hairy above, smooth beneath, $6-12 \mathrm{~cm}$. long, $4-6 \mathrm{~cm}$. wide, petioles hairy, short, $1 / 2-1 \mathrm{~cm}$. long; fruit elliptic to rounded, smooth throughout, somewhat veiny, $1 \frac{1 / 2}{2}$ to $2 \mathrm{~cm}$. long; campestris, of a field, in allusion to the habitat.

Rarely cultivated; native of Europe.

Wood fine-grained, hard, heavy, durable under water; used for hubs, piles, pumps, ship-blocks, and water pipes. 


\section{Celtis $L$ in 11 é 1753 \\ (L. c e $1 \mathrm{t}$ is, lotus tree)}

Trees; leaves alternate in 2 rows, serrate or entire, the lateral veins few and sharply ollicpue; flowers mostly monoecious, on the new shoots, staminate in clusters, pistillate usually solitary, appearing soon after the leaves on slender drooping pedicels; sepals 4- 6 , more or less united, petals 0 , stamens 4-6, ovary 1-celled, styles 2 ; fruit a round drupe.

A genus of 60 species, natives of temperate and tropical regions: 5 native species occur in the United States.

\section{Celtis occidentalis L in $n \dot{e} 1753$ Hackberry}

Large tree, 40-80 ft. high, 1-t ft. diam.; bark rough, the ridges prominent and projecting, characteristically corky and curly or sinuous; leaves ovate-lanceolate to ovate, edge singly toothed, tapering gradually to an acute tip, base more or less unequal, but usually rounded on both sides and frequently cordate, midrib fairly prominent, the lateral veins 5-15, basal two prominent, often giving the leaf a 3-nerved appearance, more or less rough-hairy above, nearly smooth beneath, except on the veins, 8-15 cm. long, $4-7 \mathrm{~cm}$. wide, petioles short, hairy, 1-2 cm. long; flowers small, greenish, clustered or solitary; fruit a globose drupe: pointed at tip, purple or orange, $1 \mathrm{~cm}$. diam. on a slender pedicel, 2-3 cm. long, often persisting through the winter: occidentalis, western.

Frequent in woodlands and along streams in the southern part of the state, rarer northward; Quebec-Ga-La-NM-Wash. One of the most important shade trees in the Middle West. Flowering in May and fruit ripening in September and October. Readily grown from seed, sown when ripe, or stratified; easily transplanted, and a rapid grower.

Wood soft, weak, coarse-grained, heavy, wéight $45 \mathrm{lbs}$; sometimes used as a substitute for elm, in fencing, furniture or wheel-making.

\section{Moraceae Mulberry Family}

Trees, shrubs or herbs with single alternate leaves and often with milky juice; flowers monoecious or dioecious, often in spikes; sepals 4-5, petals 0 , stamens 4-5, ovary 1-celled; fruit often multiple and fleshy.

A family of 55 genera, natives of temperate and tropical regions; more than 600 species are known for the genus Ficus, the fig. 


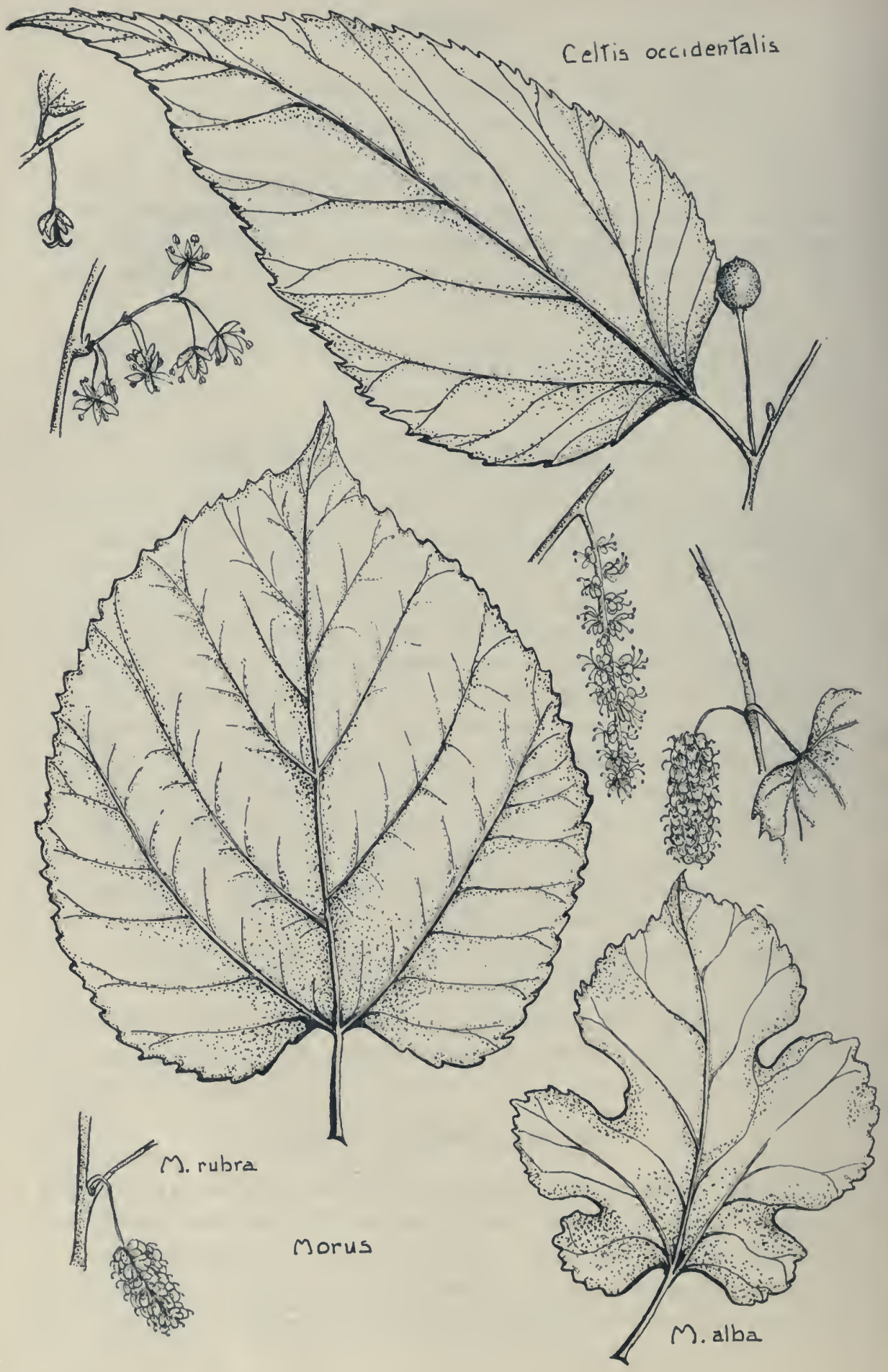




\section{Morus L in né I753 Mulberry}

(L. morus, Gr. moron, mulberry, probably from Gr. moros. insipid, referring to the taste; mulberry was originally mur-

berry, from the same root; cfr. Ger. $m$ a $u 1$ b e e r e.)

'Trees or shrubs with milky juice; leaves alternate in 2 rows, simple, often lobed, 3-nerved; flowers monoecious, in catkins; sepals 4 , petals 0 , stamens 4, ovary 1-celled, stigmas 2 ; fruit a mass of tiny drupes.

Propagation by seeds or cuttings.

$A$ genus of 10 species, natives of the northern hemisphere; a third species occurs in the southwestern United States.

\section{Key to the Species}

(1) Leaves rough above, hairy below; fruit long, red to black

1\%. rubra.

(2) Leaves smooth or slightly hairy below; fruit elliptic, white or pink

M. alba

\section{Morus rubra L i n n é I753 Red Mulberry}

Tree of medium height, 20-60 ft. high, 1-3 ft. diam.; bark yellowishbrown, moderately rough; leaves ovate or rounded, usually deeply 3-lobed, often with 2-3 smaller lobes at the base, sometimes entire, margin dentate, tip pointed, $1-2 \mathrm{~cm}$. long, base truncate or heart-shaped, strongly 3-nerved, slightly rough above with scattered hairs, hairy beneath, $10-25 \mathrm{~cm}$. long, $8-20 \mathrm{~cm}$. wide, petioles short, rather stout, $2-4 \mathrm{~cm}$. long; staminate spikes many-flowered, cylindric, drooping, $4-5 \mathrm{~cm}$. long, $1 \mathrm{~cm}$. wide, pistillate spikes spreading, usually hanging when ripe, on a slender stalk, $2-3 \mathrm{~cm}$. long, 1-1.5 cm. wide, deep red, then red-black, edible; flowering in May, fruit ripening in June or July: $\mathrm{r}$ u b r a, red, in reference to the fruit.

In deciduons woods in southeastern Minnesota and along the Mississippi; Ont-Fla-Tex-S.D.

Wood yellow or orange, coarse-grained, compact, soft, weak, tough; durable, weight 37 lbs.; used in boat-building, cooperage and fencing. The fibers of the inner bark were used by the Indians in making a coarse cloth. An ornamental tree but scarcely hardy, except in southern Minnesota. 


\section{Morus alba Lin 11 é I753 White or Russian Mulberry}

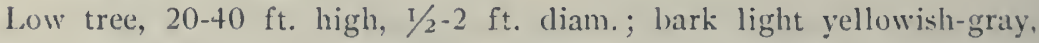
more or less deeply furrowed; leaves orate to nearly round, often 3-5lobed, edge coarsely serrate, tip rounded or pointed, base usually heartshaped, smooth and somewhat shining on both faces, 8-12 cm. long, 7-10 $\mathrm{cm}$. wide, petioles sparsely hairy, $2-4 \mathrm{~cm}$. long; staminate catkins $1-2 \mathrm{~cm}$. long, pistillate catkins elliptic to glohose, $1 \mathrm{~cm}$. long; fruit oblong to elliptic, white to pink, $1 \mathrm{~J} / 2-2 \mathrm{~cm}$. long: a $1 \mathrm{~b}$ a, white, in reference to the fruit.

Cultivated; introduced from Europe for feeding silkworms. The fruit is much more insipid than in the red mulberry, and the tree is hardly desirable because of the litter of fallen berries. It is of some value in cherry orchards in drawing birds from the cherries, but it is scarcely hardy.

\section{Geraniales Geranium Order}

\section{Rutaceae Rue Family}

Trees or shruls, with alternate or opposite compound leaves, glandular-dotted, and odorous; flowers usually diclinic, rarely perfect, in clusters; sepals $0-5$, petals $4-5$, stamens $4-5$, pistils 1-5, 1-2-celled; fruit a pod or samara.

$\Lambda$ family of about 110 genera found mostly in Soutl America and Australia.

\section{Xanthoxylum L in n é i 753}

(Gr. $x$ a n thos, yellow, $x y 10 n$, wood)

Small trees or shruls, with alternate odd-pinnate leaves, prickly on twigs and leaves; flowers in axillary or terminal cymes, dioecious or polygamous, greenish, small, petals and sepals $4-5$, distinct, or the latter lacking; staminate flowers with 4-5 stamens, pistillate flowers with 2-5 separate pistils, occasionally with a few stamens; pods somewhat fleshy, pungent and aromatic, 2-valved, 1-2-seeded.

Propagated from seed and perhaps from cuttings also.

A genus of 110 species, natives of temperate and tropical regions; in addition to the following, 3 others occur in the southern United States. 


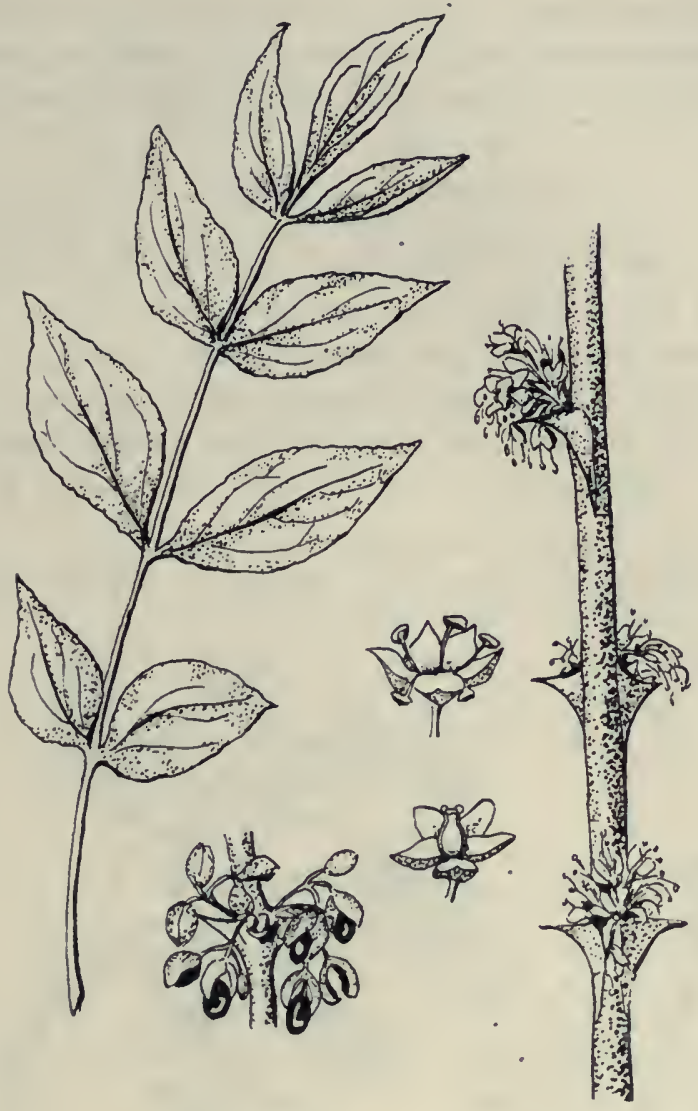

Xanthoxylum americanum Mille r i768 Prickly Ash Toothache Tree

Small tree or shrub, 10-25 ft. high, 2-6 in. diam.; leaves odd-pinnate, of 7-11 leaflets, $10-20 \mathrm{~cm}$. long, the axis with scattered sharp prickles on the lower side, leaflets elliptic, ovate, or obovate, margin minutely glandular-indented, tip blunt, base rounded, sparsely hairy on both faces, 3-6 $\mathrm{cm}$. long, 2-4 cm. wide, petioles usually brown-hairy, prickly with two large stipule-like prickles at base, $2-5 \mathrm{~cm}$. long; flowers appearing before the leaves, small, greenish in axillary clusters, usually dioecious, calyx lacking, capsules dark brown or blackish when mature, ellipsoid or ovoid, rugose, 5-6 mm. long, $3 \mathrm{~mm}$. wide; seeds black; a m e r i c a n u $\mathrm{m}$, referring to its home.

Frequent along streams and the edges of woodlands; Quebec-Va-MoNebr-Minn-Ont. 
Wood light brown, soft, weight 35 lbs., of little value; the bark yields a yellow dye and a bitter resin. The latter is a stimulant and tonic, and is used for toothache and sometimes in the treatment of rheumatism.

\section{Ptelea Lin né 1753}

(Gr. p t e le a, elm, probably in allusion to the winged fruit)

Small trees or shrubs with alternate 3-5-foliolate leaves, and without prickles; flowers in panicles, polygamous, whitish, sepals and petals 4-5, distinct, stamens $4-5$, the anthers often tiny or wanting in the pistillate flowers, ovary 2-celled, flattened; fruit a broadly winged, round samara.

A genus of 6 species, natives of the United States and Mexico.

\section{Ftelea trifoliata Li in n é I753 Hop-tree, Shrubby Trefoil}

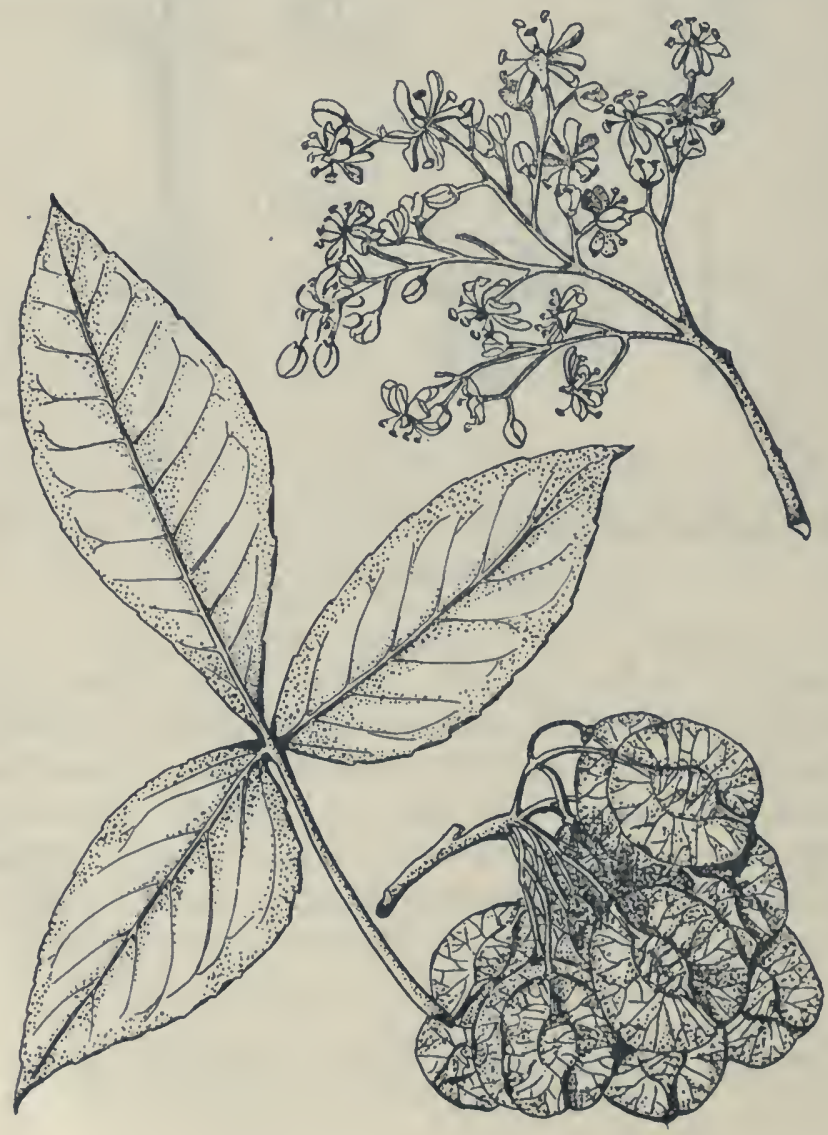


Small tree or shrub, 10-25 ft. high, 2-6 in. diam.; leaves of 3 leaflets, $6-15 \mathrm{~cm}$. long and wide, leaflets ovoid to obovate, margin finely wavy, pointed, with more or less wedge-shaped base, smooth above when mature, sparsely hairy below, petioles $3-10 \mathrm{~cm}$. long; flowers appearing after the leaves, whitish, 8-10 $\mathrm{mm}$. wide; fruit a round yellowish samara with a broad veiny wing, $2-21 / 2 \mathrm{~cm}$. diam.; $\mathrm{t}$ r if o 1 i a $\mathrm{t}$ a, three-leaved.

Occasionally cultivated; not known to occur in the state as a native: LI-Fla-Tex-Colo-Ont.

Wood yellow-brown, hard, close-grained, weight 52 lbs.; the bitter bark is used to yield a tonic. Readily grown from seed if the latter are planted as soon as they are ripe.

\section{Simarubaceae Ailanthus Family}

Trees or shrubs with alternate pinnate leaves, not glandular-dotted, and bitter bark; flowers dioecious or polygamous, in axillary panicles or racemes, sepals $3-5$, more or less united, petals $3-5$, stamens $2-10$, ovaries 2-5, separate, or more or less united, styles 1-5; seeds usually solitary.

A family of about 27 genera, ${ }^{-f o u n d}$ in tropical and subtropical regions.

\section{Ailanthus Desfontaines I786 Tree-of-Heaven, Ailanthus}

\section{(The Chinese name in classical form)}

Trees, or shrubs in northern climates, with alternate odd-pinnate leaves; flowers in terminal panicles, polygamous, greenish; sepals 5, united, petals 5, stamens 10 in staminate, 2-3 in pistillate flowers, pistils 2-5, partly united; fruit elongate, winged, 1-seeded, 1-5 in each flower.

A genus of 3 species, native to China and the East Indes.

\section{Ailanthus glandulosa D e s f o n t a in es 1786}

Tree, 20-50 ft. high, 6-18 in. diam., or a shrub with long clubshaped twigs, 5-12 ft. high; leaves odd-pimnate, of 11-41 leaflets, 3-10 $\mathrm{dcm}$. long, leaflets ovoid to lanceolate, margin entire or slightly wavy and often with one or more blunt teeth at the base, long-pointed, rounded or somewhat heart-shaped and oblique at the base, smooth or slightly hairy above, 8-15 cm. long, 3-7 cm. wide, petioles sparsely hairy, $7-15 \mathrm{~cm}$. long; panicles appearing soon after the leaves, $15-20 \mathrm{~cm}$. long; flowers greenish, ill-scented, 3-5 cm. wide; samara oblong, fusoid, or spatulate, yellowbrown, with netted veins over the central seed, 4-6 cm. long, $1-1 \mathrm{I} / 2 \mathrm{~cm}$. wide: gla ndu 1 os a, glandular, possibly in reference to the odor. 


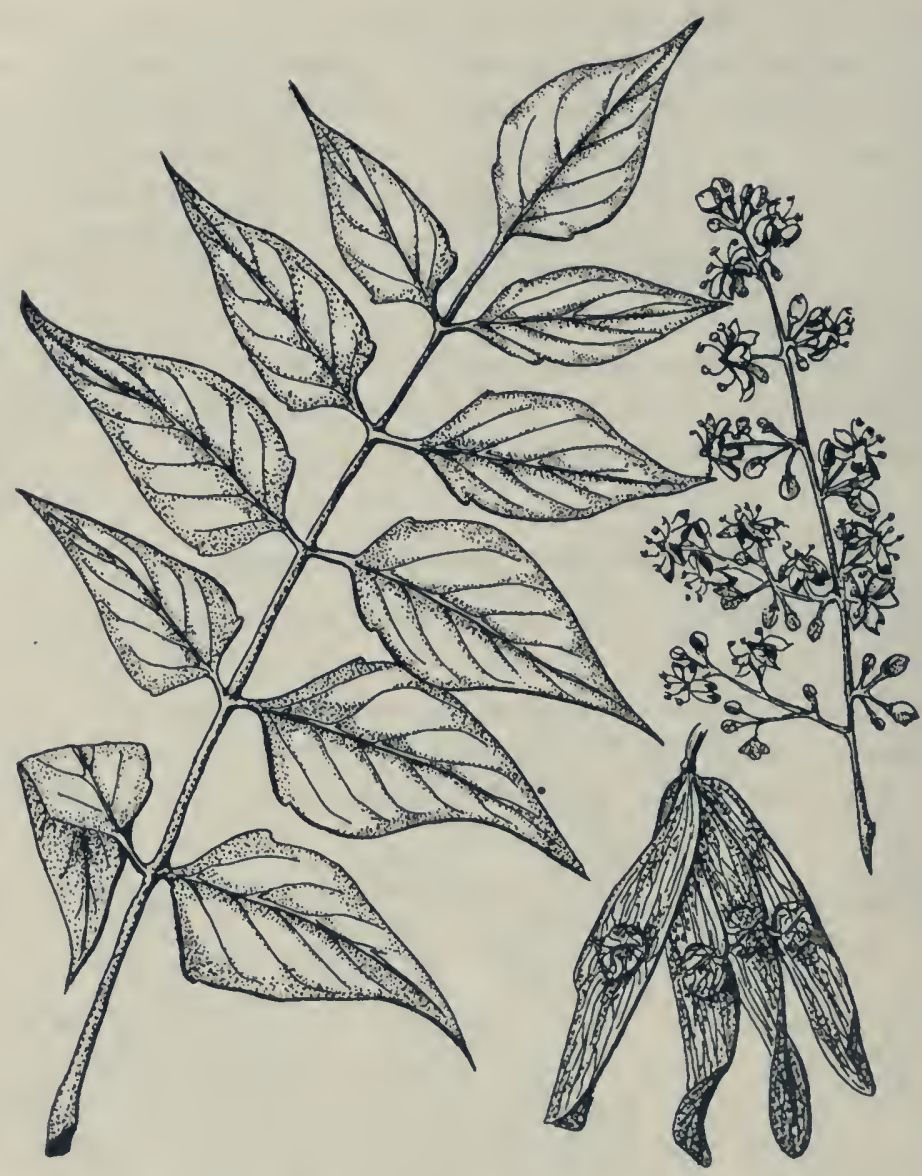

Rarely cultivated in Minnesota owing to the readiness with which it is killed back by winter; native of China; grown from suckers or from seed.

\section{Ericales Heath Order \\ Ericaceae Heath Family}

Shrubs or rarely herbs or trees, often evergreen; sepals 4-5, free or more or less united, petals $4-5$ rarely free, usually united more or less completely, stamens usually 8 or 10 , lut sometimes the same in number as the petals, inserted with the petals, and free from them; anthers often appendaged, usually opening by pores, disk often present between the stamens and the pistil; ovary superior or inferior, 3-10 celled, style 1, 
stigma 1 ; fruit a capsule, either septicidal or loculicidal, a berry, or a drupe with a compound stone; seeds small.

A large family of about 90 genera and 1400 species, several of the tribes of which are often segregated as families, notably those with inferior ovary as "Vacciniaceae", and the herbaceous forms with separate petals as "Pyrolaceae."

\section{KEY TO THE GENERA}

1. Ovary superior

a. Corolla composed of separate petals

(1) Evergreen undershrub, scarcely woody, leaves smooth, flowers pink

(2) Low bushy evergreen, leaves very woolly beneath, flowers white

Chimaphila

Ledum

b. Corolla composed of plainly united petals

(1) Leaves deciduous, corolla bell-shaped

(2) Leaves evergreen

(a) Corolla with a flat or spreading limb: stamens awnless

x. Corolla wheel-shaped, stamens opening by pores

Kalmia

y. Corolla salver-shaped, very fragrant, stamen opening by slits

Menziesia

(b) Corolla bell-shaped or jug-shaped

$x$. Anthers awnless

y. Anthers awned

(x) Leaves not aromatic, fruit a capsule

Andromeda

(y) Fruit fleshy

m. Leaves aromatic, sepals plainly united at base, calyx tube becoming fleshy in fruit

Gaultheria

Epigaea

Chamaedaphne

eaves not aromatic, sepals imbricated and little connected, fruit a drupe

2. Ovary more or less inferior, fruit fleshy

a. Ovary half inferior, foliage aromatic, evergreen

x. Berry red-here might be sought fruiting specimens of

Gaultheria 
y. Berry white, anthers awnless, opening by slits

b. Ovary wholly inferior, foliage not aromatic

$x$. Ovary with ten ovules, fruit drupe-like

y. Ovary with 'many ovules, fruit a manyseeded berry

\section{Chiogenes}

\section{Gaylussacia}

Vaccinium

\section{Chimaphila P ursh I8I4}

(Gr. chim a winter, phil a loving, referring to its evergreen habit)

Low semi-herbaceous under-shrubs; stems upright from a woody creeping root-stock; leaves evergreen, leathery, flowers small in a terminal cluster, sepals 5, persistent in fruit, petals 5, separate, stamens 10 , the anthers opening by pores which are basal in the bud but become inverted in the flower, pistil 5-parted, ovary globular, 5-celled, superior, style very short, stigma disk-shaped; fruit a loculicidal capsule splitting from the top downward; seeds dust-like, very minute.

Six species of the northern hemisphere. Two others occur in the United States, one eastern, the other far western.

\section{Chimaphila umbellata (Linné) $\mathrm{N}$ ut ta 11 I8I8 Pipsissewa}

Low semi-herbaceous shrub, stems 1-3 dm. high; leaves alternate but crowded toward the top of each year's growth, leathery, evergreen, narrowly wedge-shaped, sharply serrate, dark green and glossy above, paler beneath, 2-6 cm. long, $8 \mathrm{~mm} .-2 \mathrm{~cm}$. wide, petioles $3-6 \mathrm{~mm}$. long, tip broadly wedge-shaped or rounded, base narrowly wedge-shaped; flowers in a 2-8 flowered corymb; peduncles bare, $6-10 \mathrm{~cm}$. high, bracts very small, soon deciduous, pedicels about $1 \mathrm{~cm}$. long, flowers bell-shaped, sepals very: small, united, petals round, pink, 6-8 mm. long, stamens purplish:

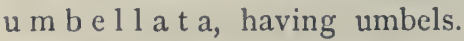

Dry woods, widely distributed throughout the cooler parts of the northern hemisphere; in North America occurring across the continent from Nova Scotia to British Columbia, southwards to Georgia, Iowa, and the mountains of Mexico. In Minnesota throughout the forest districts of the northern and eastern parts, most abundant in the evergreen forests of the north; rare southward, usually in white oak forest. Flowers in July, fruit ripe in late autumn or winter.

The leaves are used medicinally. 
The eastern Chimaphila maculat a (Linné) Pursh, with lanceolate spotted leaves is reported from eastern and central Minnesota. There are no specimens in the University herbarium and it probably does not reach this state.

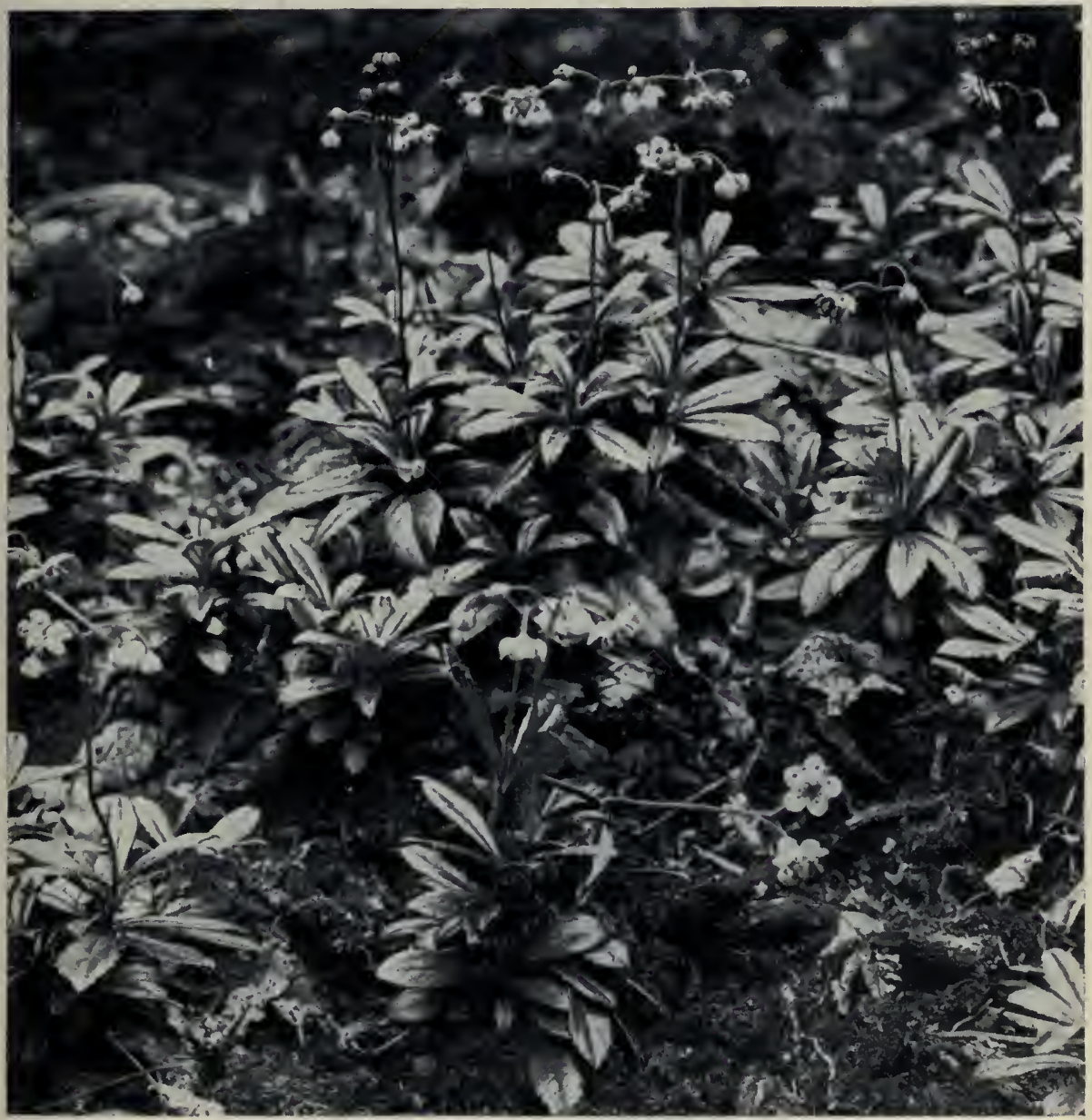

Chimaphila umbellata

\section{Ledum L i n n é I753}

(Gr. name of an oriental shrub)

Erect evergreen shrubs; leaves alternate, resinous, entire; buds scaly; flowers in dense terminal clusters; sepals 5, very small, united, petals 5 , free, stamens 5-10, exserted, anthers opening by terminal pores, pistil 5- 
parted, ovary superior, style thread-like, stigma small, capitate; fruit a septicidal 5-celled capsule, splitting up from the base.

A genus of three species. All occur in northern North America, one occurs also in northern Europe and Asia.

\section{Ledum groenlandicum $\mathrm{O}$ e d e r I77 I Labrador Tea}

Shrub, 3 dm.-1 m. high, stems slender, brittle; bark gray, young twigs brown woolly; leaves evergreen, lanceolate, entire, the edges rolled backwards, green and finely rugose above, the midrib depressed and finely hairy, other veins scarcely evident, completely covered with long tawny wool beneath, $2-8 \mathrm{~cm}$. long, 5-16 $\mathrm{mm}$. wide, petiole about $2 \mathrm{~mm}$. long, tip rounded, base rounded wedge-shaped; flowers white, borne in a terminal umbel-like corymb, enclosed during the previous winter in a large scaly terminal bud; axis of the cluster and pedicels hairy and glandular, pedicels thread-like, $1.5-2 \mathrm{~cm}$. long, sepals $.3 \mathrm{~mm}$. long, petals narrowly ovate, about $5 \mathrm{~mm}$. long, stamens 5-7; capsule slender, pointed, about $5 \mathrm{~mm}$. long, the style persistent; seeds thread-like: g r o e n l a n d i c u m. of Greenland.

Greenland to Alaska, south to New Jersey, the region of the Great

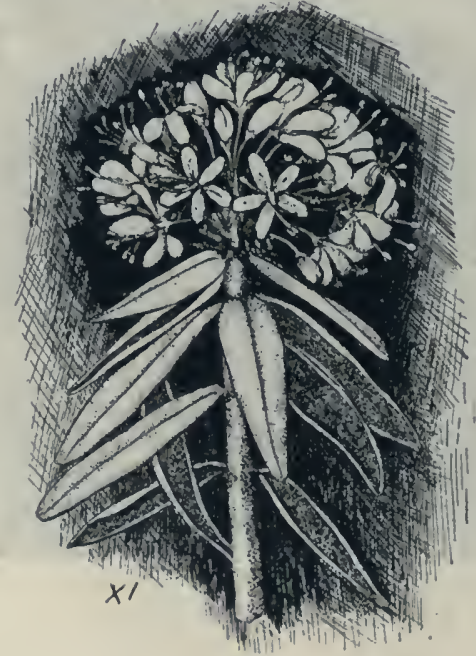

Ledum

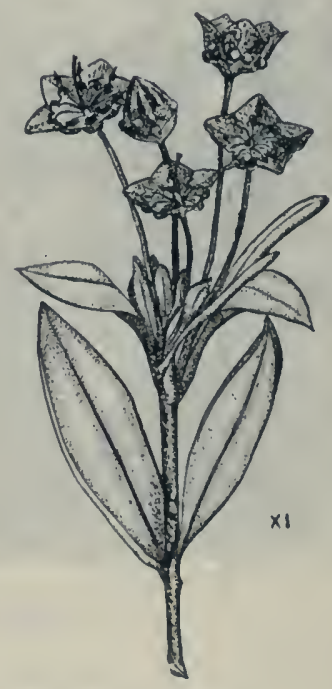

Kalmia

Lakes, and the State of Washington. In Minnesota common in bogs in the northern and northeastern parts of the state, extending very little 
beyond the limits of the coniferous forests. Flowers usually in June, fruit ripe in August.

The leaves are said to have been used as tea by the Indians.

\section{Menziesia J. E. S m it h I791 \\ (Named for Archibald Menzies)}

Shrubs, leaves thin, entire, deciduous;. buds very scaly; flowers small, in terminal clusters opening with the leaves, calyx small, of four united sepals, corolla bell-shaped of four united petals, stamens 8 included, anthers appendaged opening by terminal pores, pistil compound, 4-parted, style thread-like, stigma 4-lobed; fruit a 4-celled capsule, septicidal, many seeded.

A small genus of about seven species of North America and Japan.

\section{Menziesia glabella A. Gr a y 1878}

Bark grayish brown, shreddy; leaves obovate, petioled, entire, light green above, pale and glaucous below, finely and sparsely rough hairy, tips obtuse wedge-shaped, very slightly bristle tipped, base narrowly wedge-shaped, 3-7 cm. long, 1-3 cm. wide, flowers in a terminal sessile umbel, pedicels thread-like, about $3 \mathrm{~cm}$. long, flowers about $7 \mathrm{~mm}$. long, calyx barely lobed, ciliate, corolla brownish; seeds thread-like; foliage with a skunk-like odor: g l a b e 11 a, somewhat smooth.

British Columbia to Oregon and Montana. Reported from Minnesota Point, Duluth. It possibly occurs in the northeastern corner of Minnesota but there are no specimens in the herbarium of the University. Flowers in May.

\section{Kalmia Lin né 1753 American Laurel (Named for Peter Kalm)}

Erect shrubs, sometimes very dwarf, leaves entire, leathery, evergreen ; buds naked; sepals 5, united at base, corolla flat, wheel-shaped, of five united petals furnished with ten small pouches in which the anthers are situated in the bud and in the newly-opened flower, stamens 10 , anthers without appendages opening by terminal pores, pistil 5-parted, ovary superior, style thread-like, stigma slightly enlarged; fruit a five-celled capsule, septicidal, many-seeded: seeds small, round.

A genus of six species of North America and Cuba. None of the other species reach as far west as Minnesota. 
Kalmia polifolia IV a $n \mathrm{~g}$ e $\mathrm{n}$ h e im 1788 Swamp Laurel Kalmia glauca Aiton 1789

Low shrub 1-6 dm. high; twigs with ridges running down from the bases of the leaves; leaves opposite, sessile, ovate, lanceolate or linear; evergreen, leathery, dark green and glossy above, white beneath, margins entire and rolled backwards, midrib prominent beneath, tip blunt pointed, base tapering, $1-3 \mathrm{~cm}$. long, 2-10 $\mathrm{mm}$. wide; flowers in terminal umbel-like clusters, pedicels thread-like, erect, about $15 \mathrm{~cm}$. long, sepals ovate, persistent, corolla pink-purple about $1.5 \mathrm{~cm}$. across; capsule globose, about $5 \mathrm{~mm}$. in diameter.

Newfoundland and Labrador to Alaska, southward to New Jersey; Michigan, Colorado, and California. In Minnesota in bogs, most abundant in the northeastern part of the state, apparently not reaching beyond the region of coniferous forests. Flowers in June, fruit ripe about August .1.

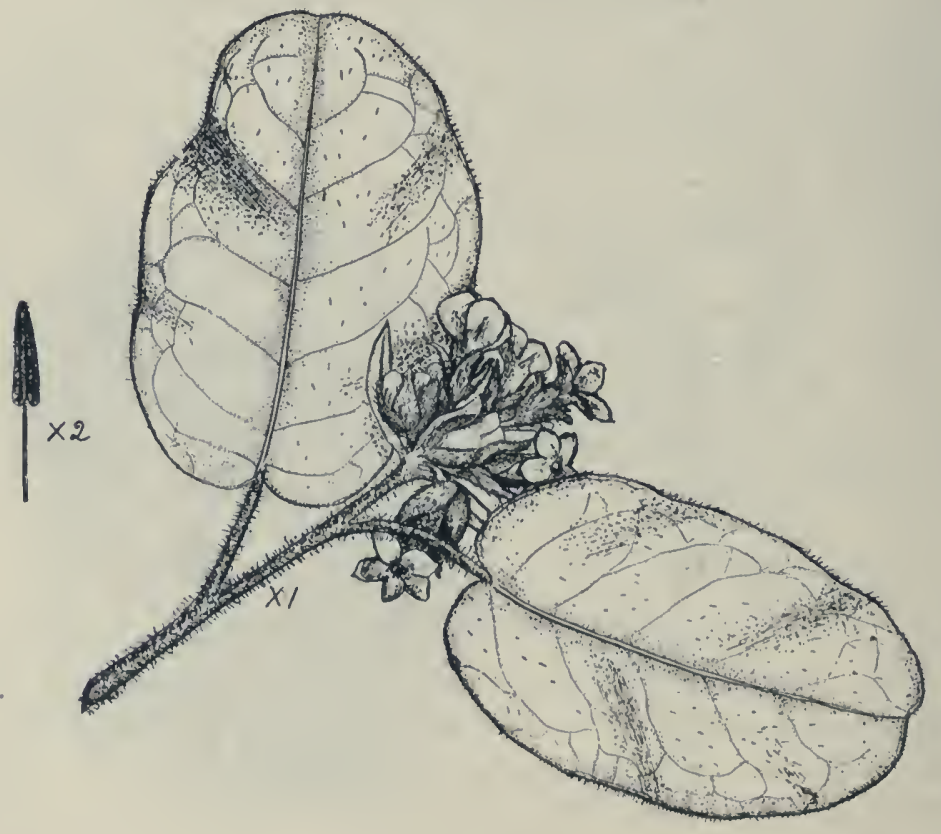

Epigaea L i n n é I753

(Gr. e p i upon, ga e a the ground)

Prostrate semi-herbaceous undershrubs; leaves evergreen, alternate, 
or crowded and nearly opposite; flowers in terminal clusters from scaly buds, sepals 5, large, persistent, petals 5, united to form a salver-shaped corolla, stamens 10, not exserted, ovary 5-lobed, 5-celled, style columnar, stigma 5-lobed; fruit a fleshy capsule, finally loculicidal; seeds oval.

Two species, the other Japanese.

\section{Epigaea repens Li in né I753 Trailing Arbutus}

Leaves petioled, elliptical, rough hairy, tip round, base round or heartshaped, 3-6 cm. long, $2-4 \mathrm{~cm}$. wide; flowers pink, very fragrant, sepals lanceolate, about $7 \mathrm{~mm}$. long, corolla $1 \mathrm{~cm}$. across, corolla-tube about 1 $\mathrm{cm}$. long; r e p e $\mathrm{n} \mathrm{s}$, creeping.

Newfoundland to Saskatchewan, south to Florida, Kentucky, the region of the Great Lakes, and Minnesota. In Minnesota common in the northeastern and northern parts in sandy evergreen forest, extending as far southwest as the head waters of the Mississippi. Flowers opening in earliest spring.

\section{Chamaedaphne M o e n c h I794}

(Gr. c h a ma e upon the ground, d a p hn e a kind of shrub)

An erect shrub, branches slender, stiff; buds scaly; leaves alternate; petioled, leathery, scurfy, evergreen, flowers in leafy racemes; flowers with two small bractlets just below the calyx, sepals 5, separate, corolla cylindric of 5 united petals, stamens 10, included in the corolla, anthers not

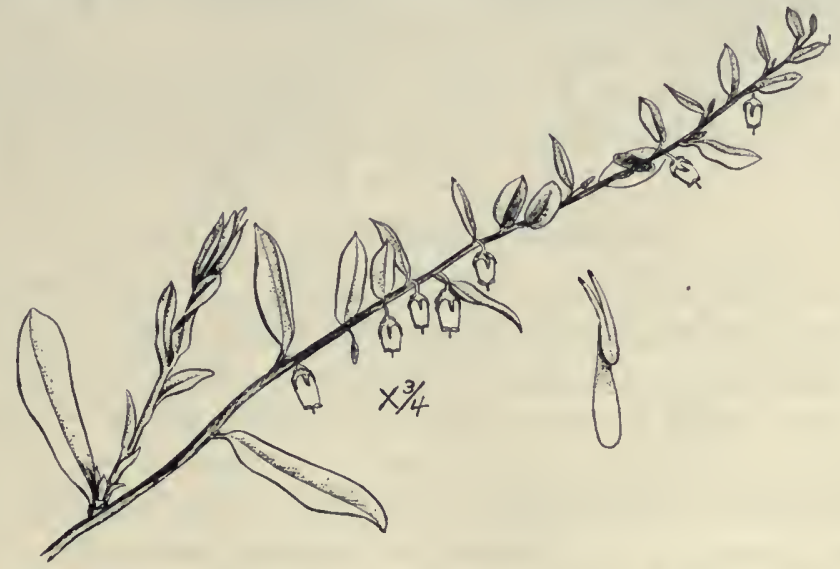

awned, the sacs elongated above into long tubes with terminal pores: pistil of five united carpels, ovary superior, 5-celled, style straight, stigma 
unlobed; fruit a globose capsule surrounded by the persistent calyx, loculicidal, the inner layer of the pericarp separating from the outer layer and splitting into 10 valves; seeds small, numerous.

One species,

Chamaedaphne calyculata (Limné) M o e n c h I794

$3 \mathrm{dm} .-1 \mathrm{~m}$. high ; leaves with scurfy scale-like hairs, apex pointed, base rounded, $5 \mathrm{~mm} .-4 \mathrm{~cm}$. long, $2-15 \mathrm{~mm}$. wide, those of the inflorescence smallest ; flowers white, about $5 \mathrm{~mm}$. long: $\mathrm{c}$ a 1 y c u 1 a t a, cup-like.

Bogs; Newfoundland to Alaska, Siberia and Scandinavia, south to Georgia, Illinois, Minnesota, and British Columbia. In Minnesota most abundant in the northern part of the state, occuring southward in the edge of tamarack swamps to the region about Minneapolis and more rarely in open peaty swamps further south. Flowers in May.

\section{Andromeda L i n ñ é I753}

(Named for the mythological character Andromeda)

Small upright shrubs (some of the sub-genus $\mathrm{P}$ i e r is, tree-like) ; buds very small, scaly; leaves evergreen, alternate, flowers in terminal clusters, sepals 5, pointed, united at the base, petals 5, almost completely united to form a jug-shaped corolla, stamens 10, included, anthers awned, opening by terminal pores, ovary 5-celled, superior, style short, straight, columnar, stigma terminal, unlobed ; fruit a sub-globose capsule, loculicidal, many seeded, seeds small, flat, oval.

A genus of two closely related species, one Arctic the other of northeastern North America, with which are often included the twelve species of P i e r is of eastern Asia and eastern North America.

\section{Andromeda glaucophylla L in k I82I}

Shrubs $5 \mathrm{~cm} .-4 \mathrm{dm}$. high, from a creeping base; bark of young shoots brown, of older shoots gray; leaves linear, leathery, nearly sessile, margins rolled back, dark green above, white and finely hairy beneath, tip acute, base wedge-shaped, midrib prominent, $2-5 \mathrm{~cm}$. long, $2-5 \mathrm{~mm}$. wide; flowers in small terminal umbel-like clusters, pedicels $3-5 \mathrm{~mm}$. long, curved, glaucous; flowers white, about $4 \mathrm{~mm}$. long; capsule depressed, globular, indented on top; g l a u coph y lla, Gr. glaucous leaved.

Labrador to Manitoba, south to New Jersey and Minnesota. In Minnesota common in bogs in the northern and eastern parts of the state, 
most abundant in the region of coniferous forests, but extending south as far as Minneapolis. This species has been much confused with the more northern A. polif olia L inné. Flowers in June, fruit ripe about August 1.

\section{Gaultheria L in né 1753 \\ (Named for Dr. Gaultier)}

Shrubs, stems creeping or erect; leaves leathery, evergreen, usually alternate; flowers solitary or clustered, sepals 5, more or less united, the calyx surrounded by a few small scale-like bracts, corolla narrowly bellshaped, composed of five united petals, stamens 10 included in the corolla, filaments somewhat thickened, anthers opening by terminal pores, awned, pistil 5-parted, ovary superior, 5-celled, style somewhat thick, straight, stigma entire; fruit a more or less fleshy capsule, surrounded by the thick and fleshy calyx; seeds minute.

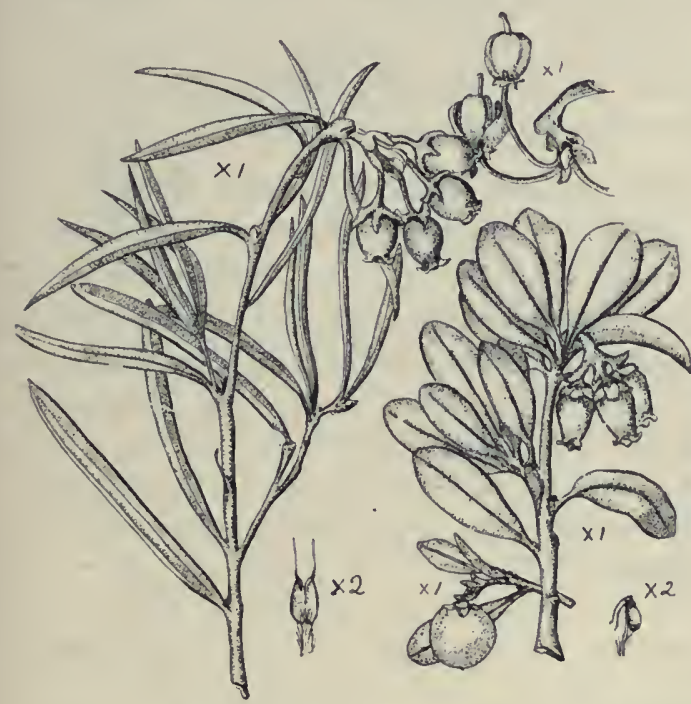

Andromeda

Arctostaphylos

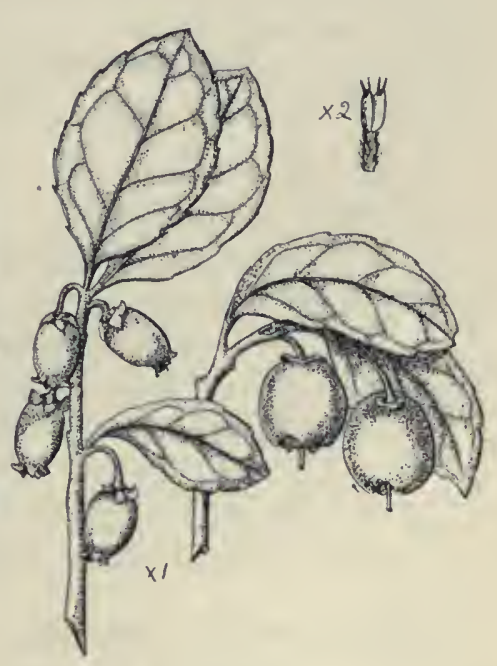

Gaultheria

About 100 species of wide geographical distribution, most abundant in the cooler parts of the southern hemisphere, especially in the Andes, three species in western North America, one in Japan, ten in southeastern Asia.

\section{Gaultheria procumbens Li n n é 1753 Wintergreen, Checkerberry}

Low, creeping, almost herbaceous aromatic shrub, about $1 \mathrm{dm}$. high; leaves petioled, evergreen, alternate, crowded near the tops of the branches, smooth, upper sides dark glossy green, lower sides paler, margins obscurely 
serrate with bristle tipped teeth, tip rounded or obtusely wedge-shaped, base wedge-shaped, leaves $2-5 \mathrm{~cm}$. long, 1-2.5 cm. wide; flowers white or pale pink, axillary, solitary; peduncles about $5 \mathrm{~mm}$. long, bracteoles 2 or 3 , close under the calyx, calyx wheel-shaped, 5-pointed, corolla jug-shaped, 5-8 mm. long, the tips of the petals triangular, anthers with four terminal awns; fruit scarlet, round, 5-10 $\mathrm{mm}$. in diameter, composed chiefly of the fleshy calyx, surrounding a nearly dry capsule, style persistent; pro$\mathrm{cu} \mathrm{m}$ b e $\mathrm{ns}$, creeping.

Newfoundland to Manitoba, south to Georgia, Michigan and Minnesota. In Minnesota very abundant as an undershrub in dry evergreen woods of the northern and northeastern parts of the state. Flowers in August, fruit ripening the next summer.

All parts of the plant, but especially the leaves and fruit contain the fragrant oil of wintergreen; commercially, however, this oil is most frequently obtained from the twigs of the black birch.

\section{Arctostaphylos A da n s o n 1763 Bearberry}

(Gr. arctos a bear, staphyle a grape)

Shrubs or small trees; leaves alternate, petioled, leathery, evergreen; flowers in terminal clusters, sepals 4-5, corolla bell-shaped or jug-shaped of 4-5 united petals, stamens 8 or 10 included in the corolla, anthers awned on the back, opening by terminal pores, pistil 4-5-parted, ovary superior, 4-5 or 8- or 10-celled with one ovule in each cavity, style slender: stigma terminal; fruit a drupe, with 4-10 coherent stones, the calyx persisting unchanged in the fruit.

About twenty species. The following occurs in all the northern parts of the northern hemisphere, the others in western Nortl America, where they are commonly called "Manzanita."

\section{Arctostaphylos Uva-ursi (Linné) S prenge 1 I825 Bearberry}

Trailing shrub, the branches often a meter or more long, but rising scarcely $1 \mathrm{dm}$. from the ground; bark gray and scaly, becoming finally smooth and red-brown; leaves alternate, petioled, leathery, evergreen, dark green, glossy, and finely reticulate above, rough and for a time hairy beneath, tip round, base narrowly wedge-shaped, leaves $1-1.5 \mathrm{~cm}$. long: 5-7 mm. wide, petioles about $2 \mathrm{~mm}$. long; flowers in small terminal clusters, peduncles about $2 \mathrm{~mm}$. long, recurved, flowers pale pink, corolla narrowly jug-shaped, about 4-7 $\mathrm{mm}$. long; drupe globose, 5-10 $\mathrm{mm}$. in diameter, scarlet, rather dry and scarcely edible, the stone composed usually of 5 coherent nutlets: u v a u r si, bear-berry. 
Greenland to Norway, south to New Jersey, the region of the Great Lakes, Nebraska, California, central Asia, and central Europe, usually in dry sandy or rocky soil, often calcareous. In Minnesota abundant in the northern and northeastern parts of the state extending considerably beyond the region of the coniferous forests, rare in the southeastern parts of the state. Flowers in May, fruit ripe in August.

The dried leaves are used in medicine.

\section{Chiogenes $\mathrm{S}$ a 1 is b ury 1815}

(Gr. ch ion snow, ge nes born, in allusion to the white berries)

Creeping evergreen semi-herbaceous aromatic shrubs; leaves small, thin, leathery, alternate; flowers solitary, axillary, furnished with two bractlets close under the calyx, sepals 4 , united, and fused with the lower part of the ovary, corolla bell-shaped, composed of four united petals, stamens 8 , included in the corolla, anthers not awned, opening by short slits, pistil of four united carpels, ovary partly inferior, 4-celled, style straight, short, stigma terminal; fruit a fleshy berry, the ovary becoming entirely inferior; seeds numerous, small.

One or two species of North America and Japan.

Chiogenies hispidula (Linné) T o r r e y \& G r a y 1843 Creeping Snowberry.

Stems and lower sides and margins of leaves brown, strigose; leaves elliptical, finely rugose above, leaf margin revolute, tip obtuse with a short projecting point, base wedge-shaped, leaves 5-9 $\mathrm{mm}$. long, 4-7 $\mathrm{mm}$. wide, petioles $1 \mathrm{~mm}$. long; flowers about $4 \mathrm{~mm}$. long; berry white, about $8 \mathrm{~mm}$. in diameter: his pid ula, somewhat bristly.

In cold wet woods, bogs, tamarack swamps, etc. Labrador to British Columbia, south to North Carolina, Michigan and Minnesota. In Minnesota common in wet coniferous forests of the northern and northeastern parts of the state, extending south in tamarack swamps as far as Minneapolis.

Gaylussacia $\mathrm{H}$ u $\mathrm{m}$ b o ld t, B on p land a n d K un th I8r8 (Named for the chemist Gay-Lussac)

Shrubs; leaves alternate; flowers in racemes; sepals 5 , united at the base and fused with the ovary, corolla urn-shaped or bell-shaped, composed of five fused petals, stamens 10 usually included in the corolla; 
anthers without awns, prolonged upward into 2 tubes and opening by apical pores; pistil of 5 united parts, ovary inferior, 10-celled through the development of false partitions, each cell with one ovule, style straight, thread-like, stigma terminal, scarcely lobed; fruit a berry-like drupe with ten stones which are more or less solidly grown together.

About 40 species, all American and for the most part South American, about 5 occur in eastern North America.
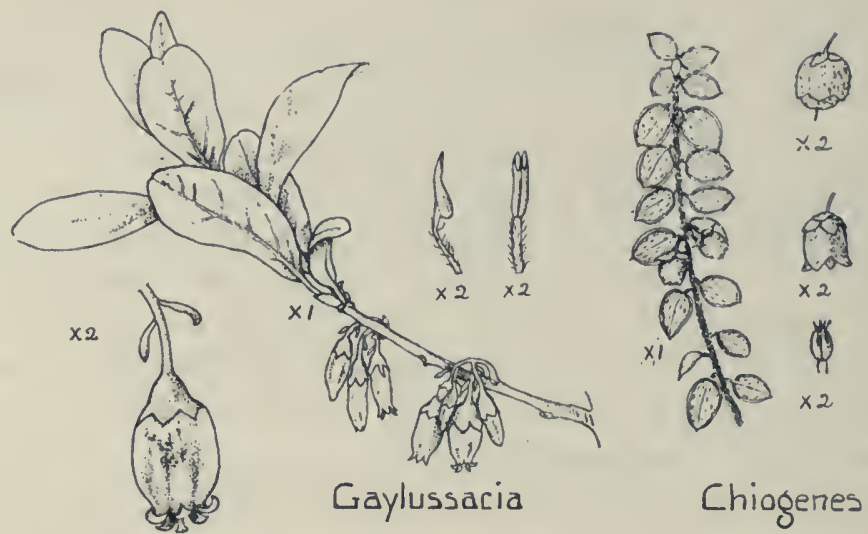

Gaylussacia baccata (Wangenheim) L. Koch 1872 Huckleberry Gaylussacia resinosa (Aiton) Torrey and Gray 18.43

Branching shrub, 3 dm.-1 m. high; stems stiff, gray, young twigs hairy; leaves alternate, ovate or ovate lanceolate, tough and somewhat leathery, resinous dotted, smooth except for slight hairiness on the margin and along the larger veins, green on both sides, somewhat pale below; margin entire, tip acute or rounded, base wedge-shaped, leaves $2-4 \mathrm{~cm}$, long, 1-1.7 cm. wide, petioles about $1 \mathrm{~mm}$. long; flowers in small lateral racemes from scaly winter buds; peduncles and pedicels resinous dotted, pedicels about $6 \mathrm{~mm}$. long, calyx tube hemispherical, free tips of sepals broadly triangular, corolla tubular bell-shaped, 5-sided, reddish, 3-4 mm, long, about $2 \mathrm{~mm}$. wide, stamens included, filaments short, hairy; fruit black, about $6 \mathrm{~mm}$. in diameter, edible: b a c c a t a, having berries.

Dry sandy soil, Newfoundland to Manitoba, south to Georgia and Kentucky. In Minnesota apparently very rare, barely entering the eastern border of the state; there are specimens in the herbarium of the University of Minnesota from near WVinona, and from Washington County, east of 
St. Paul, it is also reported near Duluth. Flowers in May and June, fruit ripe in late summer.

\section{Vaccinium L i n n é I753 \\ (V a c c in i u $\mathrm{m}$, L. name for blueberry)}

Shrubs, sometimes semi-herbaceous; leaves alternate, deciduous or evergreen, in the latter case leathery; flowers solitary in the axils of the leaves or in the terminal or lateral racemes, sepals 5 (or 4 ) united at the base and fused with the ovary, corolla of 5 (or 4 ) united petals variously shaped, stamens 10 (or 8), anthers with or without awns, prolonged upward into two tubes and opening by apical pores, pistil of 5 (or 4) united parts, ovary inferior 5- (or 4-) celled, or by false partitions 10- (or 8-) celled, each cell with several ovules, style straight, stigma small; fruit a many-seeded berry.

A genus of over a hundred species distributed throughout the boreal regions and thence southward into the warm temperate regions and the mountainous parts of the tropics. Several of the subgenera are often regarded as genera.

\section{Key to Sections of genus Vaccinium}

1. Leaves deciduous, corolla cylindrical, bellshaped, jug-shaped, or globular
a. Anthers awned, berry 4- or 5-celled
Eu-vaccinium
b. Anthers not awned, berry 8- or 10-celled
Cyanococcus

2. Leaves leathery and evergreen

a. Corolla bell-shaped, petals plainly united

b. Corolla consisting of reflexed, nearly separate petals

Vitis-Idaea

Oxycoccus

\section{Key to the Species}

\section{Eu-vaccinium Billberries}

Free limb of calyx collar-like, often with scarcely any lobes, corolla bell-shaped, or globular, stamens included, anthers awned, berry 4- or 5-celled, blue, black, or red, leaves deciduous.

(1) Parts of the flower mostly in fours, leaves entire, thick

V. uliginosum

(2) Parts of the flower in fives, leaves serrate, thin

$V$. caespitosum 


\section{Cyanococcus Blueberries}

Free limb of calyx deeply lobed, corolla bell-shaped to cylindrical, stamens included, anthers not awned, berry more or less completely 10 celled (rarely 8-celled), blue, black, or sometimes whitish; leaves deciduous.

(1) Leaves finely serrate, nearly smooth, twigs warty, nearly glabrous

(2) Leaves entire, twigs and leaves densely hairy

\section{V. pennsylvanicum}

V. canadense

\section{Vitis-Idaea Mountain Cranberry}

Free limb of calyx deeply lobed, corolla bell-shaped, stamens included, anthers not awned, berry 4 -celled, red; leaves evergreen.

\section{Vitis-Idaea.}

\section{Oxycoccus Cranberries}

Free limb of calyx deeply lobed, corolla reflexed, deeply cleft or of almost or quite separate petals, stamens exserted, not awned, berry 4 celled, red; our species, prostrate evergreen shrubs with very small leaves.

(1) Leaves ovate, acute, fruit less than $1 \mathrm{~cm}$.
in diameter
V. oxycoccus

(2) Leaves elliptical, obtuse, fruit more than 1 $\mathrm{cm}$. in diameter

\section{V. macrocarpum}

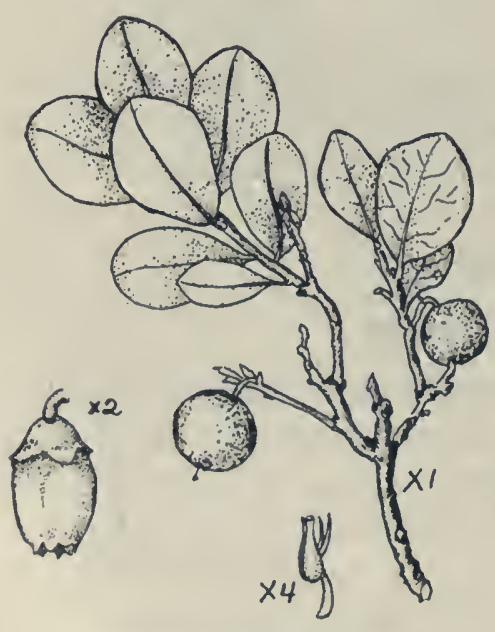

Vaccinium uliginosum

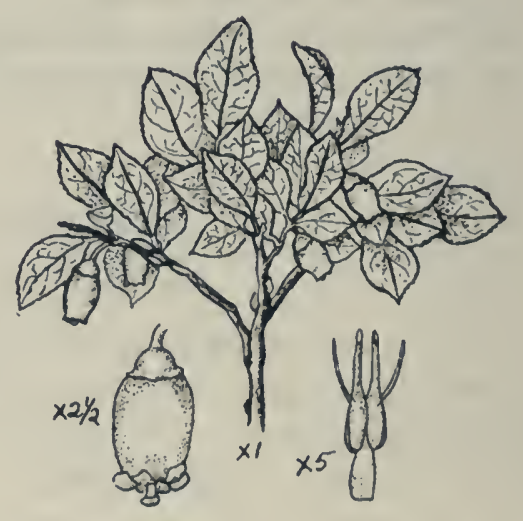

Vaccinium cacspitosum 


\section{Vaccinium uliginosum L in né I753 Billberry}

Low much branched bush, stems upright, $2-60 \mathrm{~cm}$. high, $1-3 \mathrm{~mm}$. in diameter, stiff, smooth, round, dark purplish-gray after the shedding of tha thin whitish epidermis; leaves deciduous, somewhat thick and firm, obovate or nearly round, veiny, upper side dull green, smooth, lower side paler, slightly hairy, margin slightly revolute, entire, tip rounded, indented, or broadly wedge-shaped, base wedge-shaped, 9-15 mm. long, 2.5-10 $\mathrm{mm}$. wide, sometimes nearly double this size in the far north; petioles $1 \mathrm{~mm}$. long or wanting, flowers solitary or in groups of 2-4 from special scaly winter-buds, sepals 4 (rarely 5) their free tips broadly triangular and very obtuse, corolla globular, bell-shaped, pink, composed of 4 (rarely 5) petals which are fused about two thirds of their length, stamens 8 (rarely 10 ) included, filaments smooth, anthers each bearing two long awns on the back, the sacs tapering upward into short tubes with terminal pores, style shorter than the corolla, berry 4-celled (rarely 5-celled), bluish black with a bloom, sweet and edible: ul $1 \mathrm{ig}$ in os u m, full of moisture, i. e., growing in moist places.

Moorland, heaths and rocks, Arctic regions of the old and new world, south to northern New England, Lake Superior, Washington, the Alps and England. In Minnesota it occurs only in the extreme northeast corner along the shore of Lake Superior. Flowers about July 1.

\section{Vaccinium caespitosum $\mathrm{M}$ i ch a $\mathrm{t} \mathrm{x} \mathrm{I} 8 \mathrm{o} 3$ Dwarf Billberry.}

Dwarf tufted shrubs, stems upright, branched, 5-30 cm. high, .5-3 $\mathrm{mm}$. in diameter; stiff, round, finely pubescent, grayish brown; leaves deciduous, thin, obovate, or spatulate, veiny, smooth and green on both sides, margin finely serrate, tip rounded or abruptly wedge-shaped, base narrowly wedge-shaped, $10-20 \mathrm{~mm}$. long, 3-10 mm. wide, rarely considerably larger, petioles $1 \mathrm{~mm}$. long or wanting; flowers solitary from the axils of the lower leaves of the new growth, peduncles $2-3 \mathrm{~mm}$. long, drooping; sepals 5, almost completely united, their upper portion forming a free collar-like projection which is very slightly and obtusely 5lobed, corolla bright pink or red, jug-shaped, about $5 \mathrm{~mm}$. long, composed of 5 petals which are united almost to the tip, stamens 5 , included in the corolla, filaments smooth, anthers each bearing two long ạvns on the back, their sacs tapering upward into rather long tubes with terminal pores, style straight, about as long as the corolla; berry 5-celled, blueblack, with a bloom, sweet and edible: c a e s p i t o s us, sod-like. 
Gravelly woods, shores, mountain slopes, etc. Labrador to Alaska, south to northern New England, Wisconsin, Minnesota, Colorado and California. In Minnesota apparently uncommon, occurring only in the northern part of the state, reaching as far west as the head waters of the Mississippi.

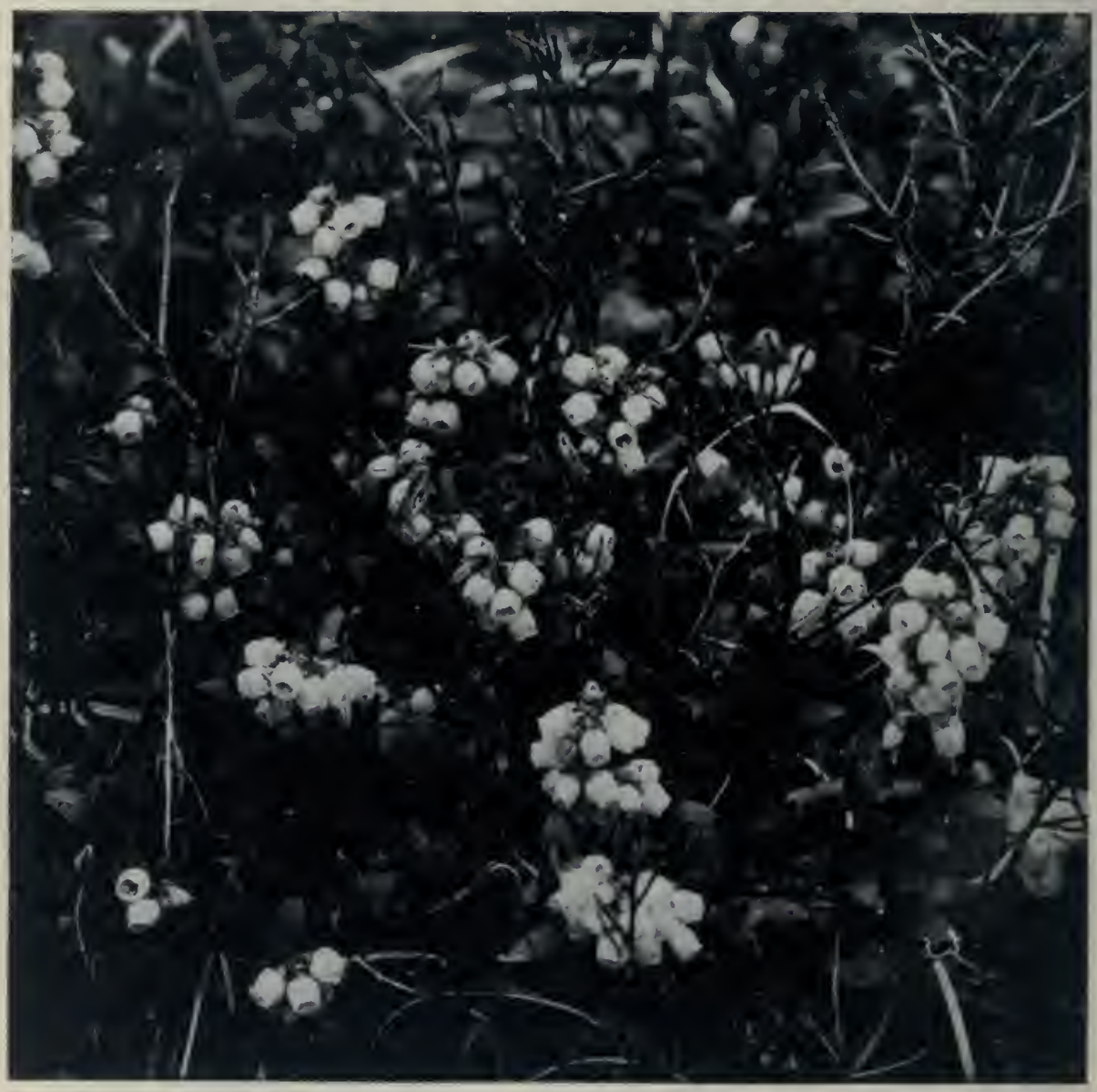

Vaccinium pennsylvanicum $\mathrm{L}$ a in a $\mathrm{r} \mathrm{c} \dot{\mathrm{k}} \mathrm{I} 783$ Blueberry

Low upright shrub; stems 2-6 dm. high, green, finely warty, smooth except for 2 narrow lines of fine hairs running down from each node; leaves deciduous, thin, lanceolate, bright green, smooth above, smooth 
below, or hairy along the midrib, margin finely serrulate the teeth bristle tipped (rarely nearly entire), tip acute, base wedge-shaped, leaves 13-35 $\mathrm{mm}$. long, $5-15 \mathrm{~mm}$. wide, petioles about $1 \mathrm{~mm}$. long; flowers in terminal or lateral racemes or panicles from scaly winter buds, appearing with the leaves, bracts broadly oval, reddish, pedicels about $1 \mathrm{~mm}$. long, sepals 5 their free tips triangular, somewhat acute, about $1 \mathrm{~mm}$. long, corolla of 5 petals united nearly to their tips, white or pale pink, narrowly bellshaped or almost spherical, tube 4-5 mm. long, free tips of the petals about $1 \mathrm{~mm}$. long, scarcely spreading, stamens 10 , included in the corolla, filaments slightly hairy, usually a little shorter than the anthers, anthers without awns, the sacs prolonged upwards into tubes with terminal pores, style straight, slightly exserted; berry 10-celled, blue with a bloom, sweet and edible: pennsylvan icum, Pennsylvanian.

Dry sandy soil, Newfoundland to Saskatchewan, southwards to Virginia, Illinois, and Minnesota. In Minnesota abundant in the northern part of the state and in the eastern part as far south as Minneapolis,

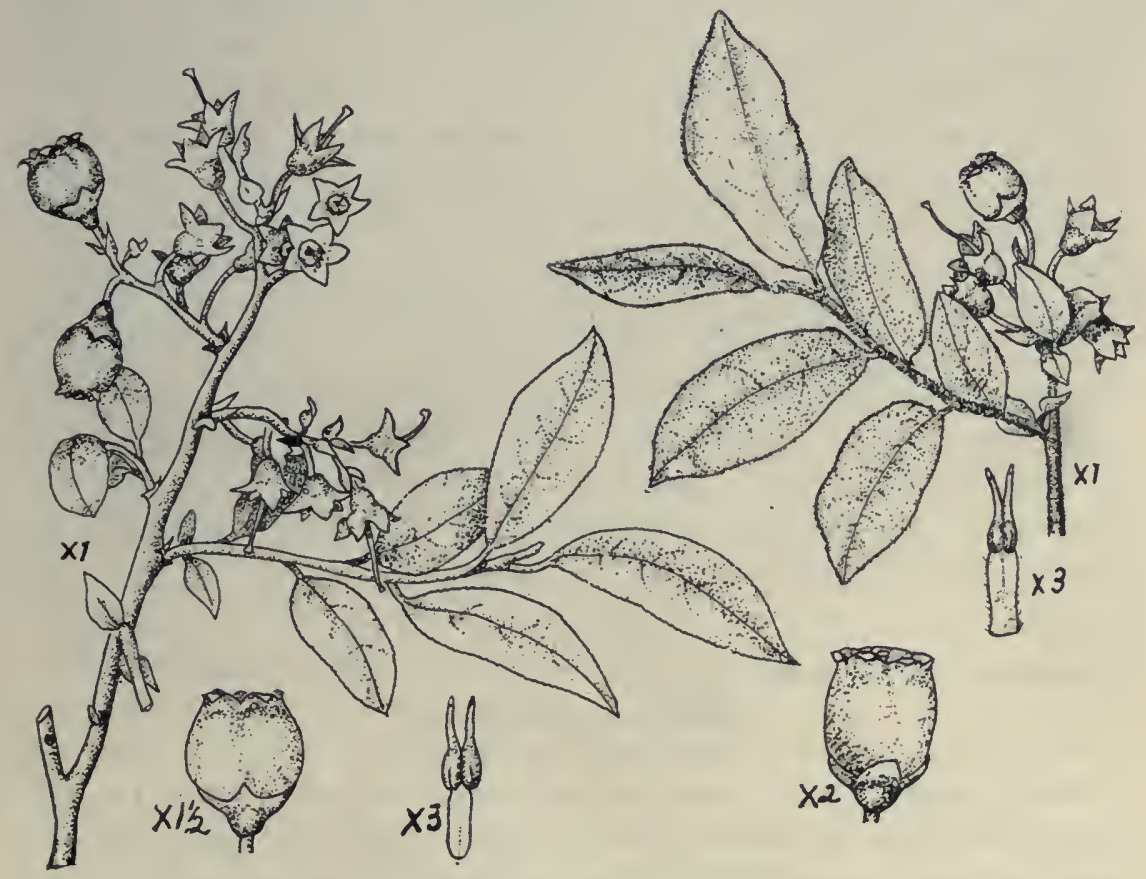

Vaccinium pennsylvanicum. Vaccinum canadense.

reported from the vicinity of Lake Pepin. Flowers in May or June, fruit ripe in July.

The most abundant blueberry in Minnesota and the earliest to ripen. 


\section{Vaccinium pennsylvanicum var. nigrum W o o d 1873}

Differs from the species in having thicker leaves, glaucous below, and black berries.

The same general range as the species, but not extending so far north and west. In Minnesota less abundant than the typical form of the species, more abundant northwards.

\section{Vaccinium canadense $\mathrm{K}$ a $1 \mathrm{~m}$ I823 Blueberry}

Low upright shrub; stems 2-6 dm. high, greenish brown, finely warty and densely woolly pubescent ; leaves deciduous, thin, lanceolate or ovate, bright green, hairy below and along the veins above, margin entire, tip acute to rounded, base broadly wedge-shaped or rounded, leaves 15-35 $\mathrm{mm}$. long, 7-15 mm. wide, petioles about $1 \mathrm{~mm}$. long; flowers in terminal or lateral few-flowered racemes from scaly winter buds, opening with the leaves; bracts lanceolate, early deciduous, pedicels $2-5 \mathrm{~mm}$. long: sepals 5 , their free tips triangular, acute, about $1.5 \mathrm{~mm}$. long, corolla of 5 petals, united nearly to the tips, white streaked with pink, narrow bellshaped, or somewhat constricted at the throat, about $4 \mathrm{~mm}$. long, free tips of the petals about $1 \mathrm{~mm}$. long, not spreading, stamens 10 , included in the corolla, filaments hairy, about as long as the anthers, anthers without awns, the sacs prolonged upwards into tubes with terminal pores, style not exserted; berry 10-celled, blue with a bloom, sweet and edible: c a $n$ a d e $11 \mathrm{~s} \mathrm{e,} \mathrm{Canadian.}$

Dry sandy soil or more moist soil, often in oak woods; Labrador to Manitoba, south to Pennsylvania, Illinois and Minnesota. In Minnesota in the northern part of the state and in the eastern part as far south as Minneapolis, less abundant than V. pennsylvan icum. Flowers in 'May and June, fruit ripe in August.

Vaccinium Vitis-idaea Li n né I753 var. minus Loddiges, Mountain Cranberry

Dwarf matted shrub, stems creeping, upright branches stiff, $2-15 \mathrm{~cm}$. high, about $1 \mathrm{~mm}$. in diameter; leaves evergreen, leathery, broad elliptical, upper side dark green, glossy, lower pale and with more or less black bristly dots, margin entire or finely crenate, revolute, tip rounded or indented, base wedge-shaped, leaves 5-18 $\mathrm{mm}$. long, 3-9 $\mathrm{mm}$. wide, petioles about $2 \mathrm{~mm}$. long; flowers in terminal racemes from scaly winter buds, bracts thin, ovate, about $3 \mathrm{~mm}$. long, green or reddish, pedicels about 
$2 \mathrm{~mm}$. long, furnished with two bractlets resembling the bracts, sepals 4 , their free tips triangular, acute, glandular along the margin, about $1 \mathrm{~mm}$. long, corolla pink, bell-shaped, about $5 \mathrm{~mm}$. long, composed of 4 petals united about half their length, stamens 8, included, filaments hairy, short, anthers without awns, their sacs elongated upward into tubes with terminal pores, style curved, slightly exserted; berry dark red, 4-celled, acid and scarcely" edible unless cooked: vit is - id a e a, probably "vine of the wood," in reference to its habitat.

Dry granitic rocks and sphagnum swamps. Arctic regions of America and Asia, south to Massachusetts, Lake Superior and British Columbia. The large typical form occurs in northern Europe. In Minnesota locally abundant in the northeastern part of the state. Flowers in late June, berries ripe in the autumn.

The berries "Preiselbeeren," "Tyttebaer," are much used for cooking in parts of northern Europe. There seems to be no reason why they should not be similarly employed here.

\section{Vaccinium Oxycoccus Lin 11 é I753 Small Cranberry \\ Oxycoccus palustris Persoon 1805 Oxycoccus Oxycoccus MacMillan I892}

Creeping prostrate shrub, stems very slender, about $.5 \mathrm{~mm}$. in diameter; leaves leathery, evergreen, ovate lanceolate, upper side dark green, glossy, under side nearly white, margin with a few small teeth, strongly revolute, tip wedge-shaped, acute, base truncate or slightly heart-shaped, 4-12 mm. long, 2.5-3.5 mm. wide, petioles slender, about $1.5 \mathrm{~mm}$. long; flowers in small terminal racemes of $1-5$, the axis of the raceme usually very short (2-5 $\mathrm{mm}$.), but occasionally prolonged upwards into a leafy shoot and then the flower-bearing part often $1 \mathrm{~cm}$. long, bracts about $1.5 \mathrm{~mm}$. long, broadly elliptical, obtuse, pedicels thread-like, red, $2-4 \mathrm{~cm}$. long, bearing 2 minute reddish bractlets; sepals 4 , their free tips broadly triangular, obtuse, petals 4 , lanceolate, $5-8 \mathrm{~mm}$. long, separate almost to the base, spreading or reflexed, pink, stamens 8 , exserted, filaments hairy, anthers without awns, the anther-sacs prolonged upward into long tubes with terminal pores, style straight, slightly longer than the stamens; fruit red, less than $1 \mathrm{~cm}$. in diameter, sour and nearly inedible when raw, pleasant when cooked: o x y c o c c u s, Gr. sour berry.

Sphagum bogs, tundra and wet sour soil, generally; Arctic regions, southward to North Carolina, Michigan, Minnesota, British Columbia: Japan and central Europe. In Minnesota it occurs in sphagnum bogs of 
the northern part of the state, extending in tamarack swamps slightly beyond the region of evergreen forests. Flowers in June, fruit ripe in late fall.
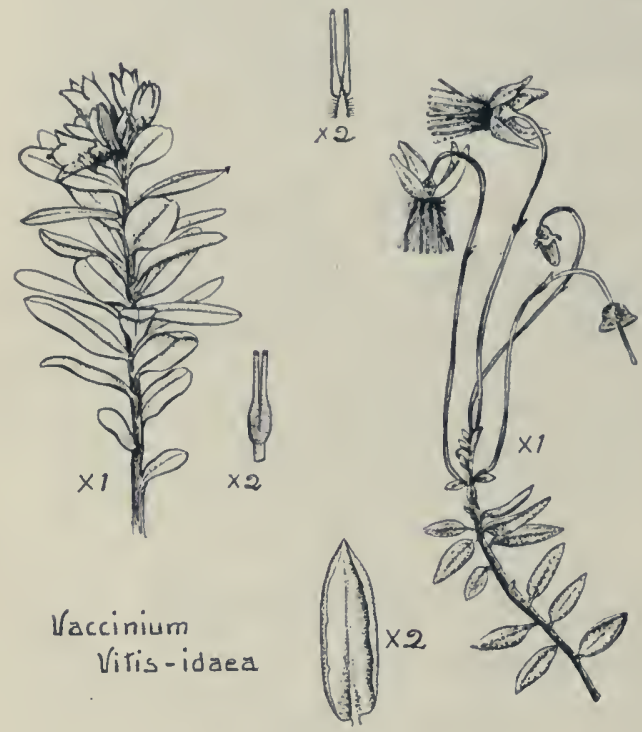

Vaccinium

Oxycoccus

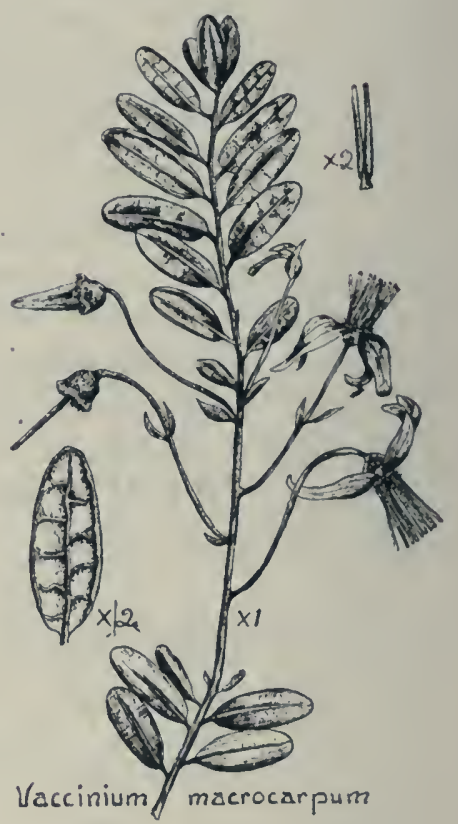

\section{Vaccinium macrocarpum A it o n I789 Large Cranberry \\ Oxycoccus macrocarpus Persoon I8I5}

Creeping prostrate shrub, stems slender, often a meter long, about 1$1.5 \mathrm{~mm}$. in diameter, flowering branches more or less erect; leaves leathery; evergreen, elliptical, upper side dark green, glossy, under side paler, glaucous, margin entire, slightly revolute, tip rounded, base rounded, 6-15 mm. long, 2.5-5 mm. wide, petioles slender about $1.5 \mathrm{~mm}$. long; flowers in raceme-like clusters of $1-10$, the axis of the raceme $1-3 \mathrm{~cm}$. long, and prolonged upward into a leafy shoot, bracts $2-4 \mathrm{~mm}$. long, ovate, pedicels thread-like, red, $2-4 \mathrm{~cm}$. long, bearing two small green leaflike bractlets above the middle; sepals 4 , their free tips broadly triangular: obtuse, petals 4, lanceolate, $6-10 \mathrm{~mm}$. long, separate almost to the base, spreading or reflexed, pink, stamens 8 , exserted, filaments hairy, very short, anthers without awns, the anther sacs prolonged upward into long tubes with terminal pores, style straight, slightly longer than the stamens; fruit red, $1-2 \mathrm{~cm}$. in diameter, sour and nearly inedible when raw, pleasant when cooked: $\mathrm{m}$ a cr o c a r p u m, Gr. large-fruiterl. 
Bogs, wet sandy soil and other situations which combine a sour soil with an abundance of moisture; Newfoundland to Minnesota, south to North Carolina, central Ohio and Indiana. In Minnesota common in the edges of tamarack swamps and sour bogs in the eastern part of the state, extending south across the Minnesota river and northwest as far as Lake Itasca, less common northward than V. oxycoccus. Flowers in June, fruit ripe in the fall.

The common cranberry of commerce, much cultivated in Wisconsin, less frequently in Minnesota. It should do well in bogs in the region north of Minneapolis and east of the Mississippi river.

\section{Empetraceae Crowberry Family}

Low, evergreen, heath-like shrubs; leaves small, narrow, sessile, channeled on the lower side; flowers small, dioecious, or rarely polygamous, axillary or in terminal heads, sepals 3 , petals 2,3 , or 0 , staminate flowers with 2-4 stamens, filaments slender, sometimes with a rudimentary pistil; pistillate flowers with 2-several-celled ovary, styles 2-several; fruit a berry-like drupe containing 2 -several 1 -seeded nutlets.

A family of three genera and five species, of Europe and America.

\section{Empetrum Ldi n é 1753 Crowberry}

Low spreading freely branching shrub with the aspect of a heath; flowers polygamous, purplish, scattered and solitary in the axils of the leaves, scaly bracted, inconspicuous, calyx of 3 somewhat petal-like spreading sepals, stamens 3 exserted, styles short, stigma 6-9-lobed; fruit a berry-like drupe, black or red, with 6-9 seed-like nutlets.

A genus of two species, the following and one in southern South America.

\section{Empetrum nigrum $L$ in n é 1753 Crowberry}

Much branched, branches diffusely spreading, gla-

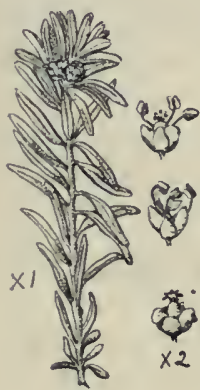
brous or puberulous, $6-25 \mathrm{~cm}$. long; leaves crowded, linear oblong, thick, glabrous or slightly puberulent, margin revolute, tip obtuse, 4-7 mm. long, 1-1.5 mm. wide; fruit black, 4-6 mm. in diameter: $\mathrm{n}$ i g rum, black.

In rocky places, Greenland to Alaska, south to coast of Maine, the mountains of northern New England and New York, Isle Royale, and the coast of Oregon, Asia and Europe. There are no Minnesota specimens in the herbarium of the University of Minnesota but it has been 
collected on Isle Royale and is almost sure to occur on the north shore of Lake Superior.

\section{Polemoniales Phlox Order \\ Solanaceae Potato Family}

Herbs, shrubs, or vines, with typically alternate simple often lobed leaves; flowers perfect and regular, solitary, or in clusters; sepals 5, united. petals 5, united, stamens 5, on the corolla tube and alternate with its lobes; ovary 2-celled, superior, fruit a berry or capsule with many seeds.

$\Lambda$ family of about 70 genera, of world-wide distribution, but most abundant in the tropics.

Lycium Li in $n$ é I 753

(Named from the country Lycia)

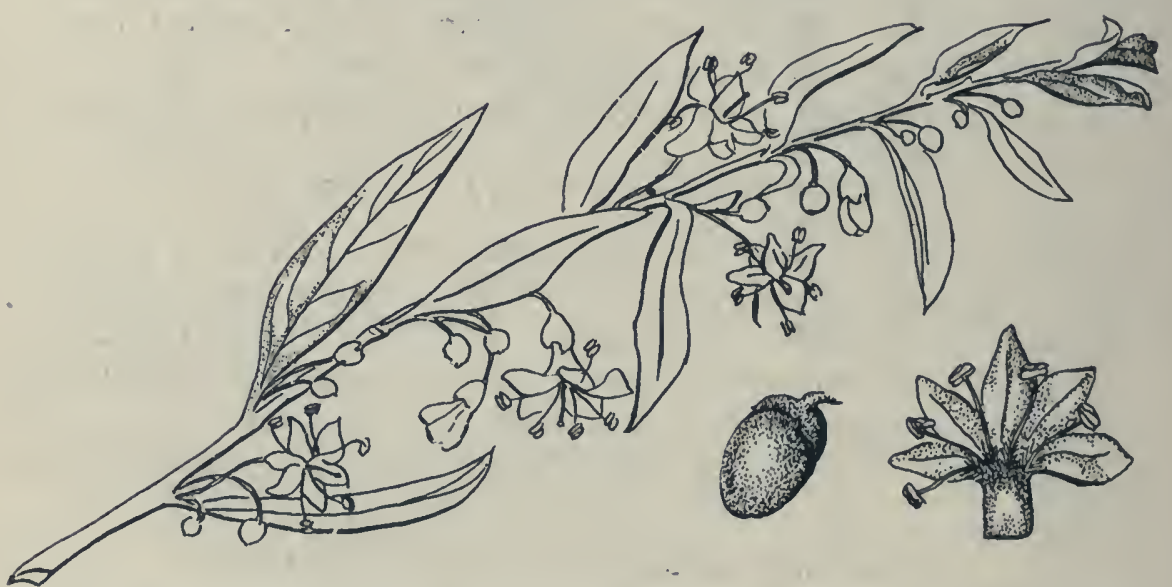

Vines or shrubs, often with thorns, with alternate entire leaves; flowers solitary or clustered, axillary or terminal, greenish to purple, calyx 3-5 lobed, persistent, corolla 5-lobed, more or less funnelform, stamens 5, ovary 2 -celled, becoming a globose to oblong berry.

A genus of about 75 species, widely distributed in temperate and tropical regions; 17 native species occur in western North America.

\section{Lycium vulgare D una 1852 Matrimony. Vine}

Bushy vine with slender trailing or hanging stems, 5-20 ft. long, the lateral branches often reduced to thorns; leaves lanceolate to spatulate or ovoid, margin entire, tip blunt or acute, base tapering into the petiole, 
smooth on both sides, $3-5 \mathrm{~cm}$. long, $1 / 2-11 / 2 \mathrm{~cm}$. wide, petioles $1 / 2-1 \mathrm{~cm}$. long; flowers solitary or $2-5$ in the axils, on slender peduncles, $1 / 2-1 \frac{1}{2}$ $\mathrm{cm}$. long, funnelform, purple to greenish-purple, $10-15 \mathrm{~mm}$. wide, corolla lobes oblong to ovate, 5-6 mm. long; berry oblong to ovoid, red or orangered: v u $1 \mathrm{~g}$ a r e, common.

Frequent in waste places, originally an escape from gardens: Ont-VaKan-Colo-Minn; native of Europe. Of great value in covering eroding slopes and banks, and waste places; especially ornamental as a trailer on stone walls. Grown readily from cuttings, suckers, or seeds.

\section{Gentianales Gentian Order Oleaceae Olive Family}

'Trees or shrubs, with typically opposite simple or compound leaves; flowers perfect, polygamous or dioecious, sepals united, 2-4, or lacking, petals united, $2-4$, or lacking, stamens on the corolla tube, $2-4$, ovary 2-celled, superior; fruit a capsule, berry, drupe or samara, 1-few-seeded.

A family of about 21 genera, widely distributed in temperate and tropical regions.

\section{KEY TO THE GENERA}

1. Trees with pinnate leaves, dioecious flowers and winged fruit

Fraxinus

2. Shrubs with entire leaves and perfect flowers

a. Flowers purple or yellow, rarely white; fruit

a capsule

(1) Flowers purple

Syringa

(2) Flowers yellow

Forsythia

b. Flowers white; fruit a drupe or berry

(1) Petals thread-like, separate; fruit a drupe

(2) Petals united; fruit a berry

Chionanthus

Ligustrum

\section{Fraxinus Lin né 1753}

(L. fraxinus, the ash-tree)

Trees with opposite odd-pinnate leaves; flowers in clusters, usually appearing before the leaves, polygamous or dioecious; sepals $0-4$, united, petals $0-4$, more or less united, stamens typically 2 , ovary 2 -celled; fruit a 1-seeded samara.

Propagated by seed sown in autumn or stratified for spring sowing. 
$\Lambda$ genus of about forty species, 12 of which are matives of the United States.

\section{Key to the Species}

1. Lateral leaflets stalked

a. Twigs round

(1) 'Twigs and leaves velvety-hairy

F. pennsilvanica

(2) Twigs and leaves smooth, at least above

(a) Leaves pale below; wing of fruit terminal

(b) Leaves green below; wing extending along the sides

F. americana

F. lanccolata

b. Twigs square or 4-angled

F. quadrangulatu

2. Lateral leaflets not stalked

F. nigra

\section{Fraxinus pennsilvanica M a r sha 11 r 785 Red Ash}

Tree, 30-60 ft. high, 1-2 ft. diam.; bark brown with shallow furrows, the ridges somewhat scaly, twigs hairy; leaves velvety-hairy or woolly: of 5-9 leaflets, 2-5 dcm. long, leaflets ovate-lanceolate to ovate, somewhat coarsely and sharply toothed, tip pointed, base more or less rounded, sparsely hairy or smooth above, coarsely hairy, woolly or velvety beneath, 6-12 cm. long, 2-5 cm. wide, petioles coarsely hairy, $3-6 \mathrm{~cm}$. long; flowers dioecious, the small calyx of the pistillate flower persisting at the base of the fruit; fruit oblong-spatulate, paddle-shaped, the wing running down the sides, $21 / 2-31 / 2 \mathrm{~cm}$. long, 5-7 mm. wide; the specific name refers to the original locality.

Frequent throughout the wooded portions of the state; NB-Fla-MoNebr-Minn-Saskatchewan.

IVood brown, coarse-grained, strong, brittle, hard, weight 39 lbs.; used chiefly as a substitute for white ash in agricultural implements, carriage-building, furniture, interior finishing, oars and tool handles. An excellent tree for general planting in the northwest, though less used than the closely related green ash.

\section{Fraxinus americana Li n né I753 White Ash}

Large tree, 40-100 ft. high, 1-5 ft. diam.; bark brown or gray-brown, moderately ridged, twigs smooth; leaves smooth, of 5-9, usually 7 , leaflets, 2-4 dcm. long, leaflets oblong, ovate-lanceolate or ovate, margin sharply toothed, tip pointed, base rounded, smooth and green above, pale green 


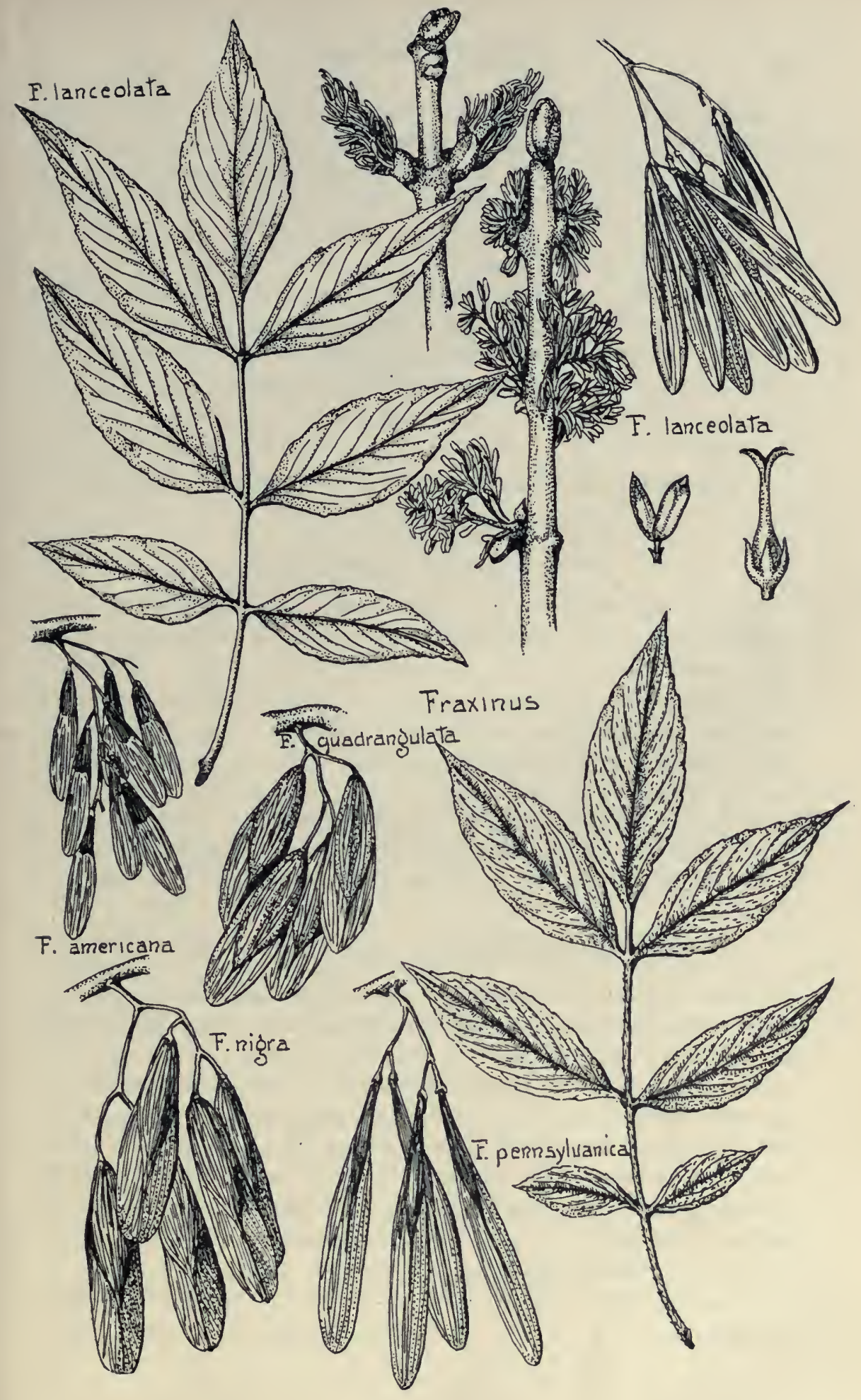


or slightly hairy below, 6-12 cm. long, $2-5 \mathrm{~cm}$. wide, petioles slightly hairy, 5-7 cm. long; flowers dioecious, calyx persistent in the pistillate flower; fruit paddle-shaped, the wing almost wholly terminal, $3-4 \mathrm{~cm}$. long, 6-7 mm. wide; a meric a n a, American, native to this continent.

Somewhat common throughout the state, except westward and far northward; NS-Fla-Tex-Minn.

Wood brown, coarse-grained, strong, tough, hard, weight 41 lbs.; used in large quantities in agricultural implements, carriage-building, furniture, interiors, oars, and tool handles. The inner bark has some use in medicine. An excellent ornamental but less valuable than green ash for the Northwest.

\section{Fraxinus lanceolata B or ck ha u s c 11 I800 Green Ash}

\section{F. viridis Michaıx I 8 I 3}

\section{F. pennsilvanica lanceolata Sargent I894}

Medium tree, 30-50 ft. high, I/2-2 ft. diam.; bark gray or yellow-brown with shallow furrows; leaves smooth or nearly so, of 5-9 leaflets, $2-3 \mathrm{dcm}$. long, leaflets ovate-lanceolate to ovoid or obovoid, margin with coarse, usually shallow teeth, tip long-pointed, base more or less rounded, smooth and green on both sides, slightly paler below, $6-12 \mathrm{~cm}$. long, $2-5 \mathrm{~cm}$. wide, petioles slightly hairy, $4-6 \mathrm{~cm}$. long; flowers dioecious, calyx persistent; fruit winged down the sides, 4-5 cm. long, 6-7 mm. wide; 1 a n ce o lat a, lance-shaped, probably in reference to the leaves.

Common throughout the state; Vt-Fla-Tex-Ariz-Saskatchewan.

Wood essentially as in the red ash, Fraxin us pennsilvanica.

\section{Fraxinus quadrangulata $\mathrm{Mich}$ a $\mathrm{ux} \mathrm{I}_{803}$ Blue Ash}

Large tree, 30-80 ft. high, 1-3 ft. diam.; bark gray, scaly; twigs four-sided, winged, and more or less velvety when young; leaves smooth, or with white tufts of hairs on the veins below, of 7-11, usually 9, leaflets, 2-3 dcm. long, leaflets lanceolate or ovate-lanceolate, more or less wavy-toothed, tip very long-pointed, base rounded, smooth on both sides or slightly hairy or hairy tufted below, $6-12 \mathrm{~cm}$. long, $21 / 2-5 \mathrm{~cm}$. wide, petioles smooth, $5-8 \mathrm{~cm}$. long; flowers dioecious, calyx usually disappearing in fruiting; fruit oblong or oblong-wedge-shaped, the wing extending completely around, $21 / 2-3 \mathrm{~cm}$. long, $1 \mathrm{~cm}$. wide; $q u$ a d r a n$\mathrm{gu} l$ a t a, four-angled, referring to the twigs.

Rarely cultivated; not known to occur native in the state; Mich-AlaMo-Ia. 
Wood brownish-yellow, coarse-grained, hard, brittle, weight 45 lbs.; used for carriage building and flooring, and probably not distinguished in use from white ash. A blue dye is made from the inner bark.

\section{Fraxinus nigra Marshall I785 Water Ash, Black Ash}

Large tree, 40-80 ft. high, 1-3 ft. diam.; bark gray, with irregular plates separating into thin scales; leaves smooth, of 7-11 leaflets, 2-4 $\mathrm{dcm}$. long, leaflets lanceolate to ovate-lanceolate, margin wavy-toothed, tip very long-pointed, base tapering or rounded, smooth above, slightly hairy below, especially along the midrib, $7-15 \mathrm{~cm}$. long, $3-5 \mathrm{~cm}$. wide, petioles smooth, 4-6 cm. long; flowers dioecious, calyx lacking; fruit oblong or oblong-spatulate, wing extending around, $21 / 2-3 \mathrm{~cm}$. long, 7-8 $\mathrm{mm}$. wide; $\mathrm{nig} \mathrm{r} \mathrm{a,} \mathrm{black,} \mathrm{probably} \mathrm{in} \mathrm{reference} \mathrm{to} \mathrm{the} \mathrm{color} \mathrm{of} \mathrm{the} \mathrm{wood.}$

Frequent or even plentiful throughout the state, except to the southwest; Newfoundland-Del-Va-Ark-Minn-Manitoba.

Wood dark brown, coarse-grained, soft, weak, tough, durable in the soil, weight 39 lbs.; used for baskets, cabinet-making, fences, hoops and interiors.

\section{Syringa L i n né I753 Lilac}

(Gr. s y ri nx, tube, of doubtful application)

Shrubs, with opposite simple entire leaves; flowers in terminal panicles or thyrses, appearing after the leaves, perfect ; sepals 4, united, persistent, petals 4 , united into a cylindric salverform tube, stamens 4 , on the throat of the corolla; ovary 2-celled, stigma 2-cleft; fruit a 2-valved capsule.

Propagation by seed sown in the spring, by suckers and division, grafting and hardwood cuttings, and in the rarer sorts by greenwood cuttings. Pruning should be done shortly after blooming is over.

A genus of about 12 species, natives of Asia and eastern Europe.

\section{Key to the Species}

1. Corolla much longer than calyx

a. Flower clusters from lateral buds; terminal bud abortive

(1) Leaves cordate or truncate at base

S. vulgaris

(2) Leaves narrowed toward the base

S. persica

b. Flower clusters usually on terminal leafy branches

S. villosa

2. Corolla little longer than calyx

S. amurensis 


\section{Syringa vulgaris L i n né I753 Common Lilac}

Shrub, 6-20 ft. high; leaves ovate, margin entire, tip acute or pointed, base truncate, rounded or cordate, often oblique, smooth and green on both sides, $5-8 \mathrm{~cm}$. long, $3-5 \mathrm{~cm}$. wide, petioles $1 \mathrm{I} / 2-2 \mathrm{I} / 2 \mathrm{~cm}$. long; flowers in large apparently terminal thyrses $8-20 \mathrm{~cm}$. long, lilac to white, 10-12 mm. long, on short glandular pedicels; capsule oblong, $15-25 \mathrm{~mm}$. long, $4 \mathrm{~mm}$. wide; $\mathrm{v} u \mathrm{lg}$ a ris, common.

Cultivated throughout the state, and sometimes an escape; native of Europe. The best and most reliable of the several cultivated species, especially desirable for ornamental hedges.

\section{Syringa persica L i n n é 1753 Persian Lilac}

Shrub, 6-12 ft. high; leaves lanceolate or ovate-lanceolate, margin entire, tip pointed, base tapering, smooth and green on both sides, 3-7 $\mathrm{cm}$. long, $2-3 \mathrm{~cm}$. wide; flowers in loose, apparently terminal panicles; 7-12 cm. long, pale lilac to white; capsule oblong, 15-20 mm. long; persicus, Persian, from its home.

The species rarely cultivated in Minnesota, and rather inferior in most respects to the common lilac; native of Asia, Caucasus to Afghanistan. The hybrid between the common lilac and the Persian lilac, $\mathrm{S}$. chinensis, is common.

\section{Syringa villosa V a h 11805 Hairy Lilac}

Shrub, 5-8 ft. high; leaves broadly elliptic to oblong, margin ciliate, acute at tip and base, bright green and smooth above, somewhat hairy below on the midrib, $6-15 \mathrm{~cm}$. long, $3-7 \mathrm{~cm}$. wide; flowers in terminal leafy panicles, 7-16 cm. long, lilac, pinkish or white; vill os a, hairy; in reference to the hairy leaves.

Occasionally cultivated; native of Asia.

\section{Syringa amurensis $\mathrm{Ruprecht} 1857$ Siberian Lilac}

Shrub, 8-12 ft. high; leaves ovate or round-ovate, margin entire, tip acute, base rounded, smooth on both sides, bright green above, pale beneath, 5-15 cm. long, 3-6 cm. wide; flowers in large loose panicles 8-20 $\mathrm{cm}$. long, yellowish white, the stamens projecting from the corolla tulse: a $\mathrm{mur}$ u $n \mathrm{~s}$ is, of the river Amur, in reference to the original locality.

Rare in cultivation; native of Manchuria and Siberia. 


\section{Forsythia V a h 1 I805}

(Named for William Forsyth, an English horticulturist)

Shrubs, with opposite-simple or ternate serrate leaves; flowers single or in groups of 2-3 along the branches, appearing before the leaves, perfect; sepals 4, united, petals 4, united toward the base, stamens 2, included; fruit a 2-celled capsule with winged seeds.

Propagated by seeds; and readily grown from both hardwood and greenwood cuttings.

A genus of 3 species, 2 native of China, and 1 of southeastern Europe.

\section{Key to the Species}

1. Corolla golden yellow, with orange yellow stripes within; leaves more or less ovate

F. suspiensa.

2. Corolla rather greenish yellow, not striped within; leaves lanceolate

F. viridissima

\section{Forsythia suspensa V a h 1 I805}

Shrub, $2-8 \mathrm{ft}$. high, the slender branches often bent to the ground and rooting; leaves oblong-ovate to broadly ovate, margin toothed, tip acute, base tapering, smooth, 6-12 cm. long, 3-6 cm. wide, petioles $2 \mathrm{~cm}$. long; flowers 1-3, golden yellow, with orange yellow stripes in the corolla tube, $2-3 \mathrm{~cm}$. long, calyx about the length of the corolla tube; capsule ovate, $2-3 \mathrm{~cm}$. long: $\mathrm{suspens}$ a, suspended, probably in reference to the rooting branches.

Occasionally cultivated, though not entirely hardy; in protected situations it is one of the most attractive of the early flowering shrubs; native of China. The variety fort une i is more upright with leaves often of three leaflets.

Forsythia viridissima $\mathrm{L}$ in $\mathrm{d} 1$ e y 1846

Shrub, 3-10 ft. high; leaves lanceolate or oblong-lanceolate, or somewhat spatulate, margin toothed above the middle, tip acute or rounded, base tapering, smooth and dark green, 6-15 cm. long, petioles 2-3 cm long; flowers 1-3, bright yellow or greenish yellow, $2-3 \mathrm{~cm}$. long, calyx about half as long as corolla tube; capsule $2-3 \mathrm{~cm}$. long: vi $\mathrm{r}$ i d is s $\bar{i} \mathrm{~m}$ a, very green, in reference to the leaves.

Rarely cultivated; less desirable than the preceding; native of China. 


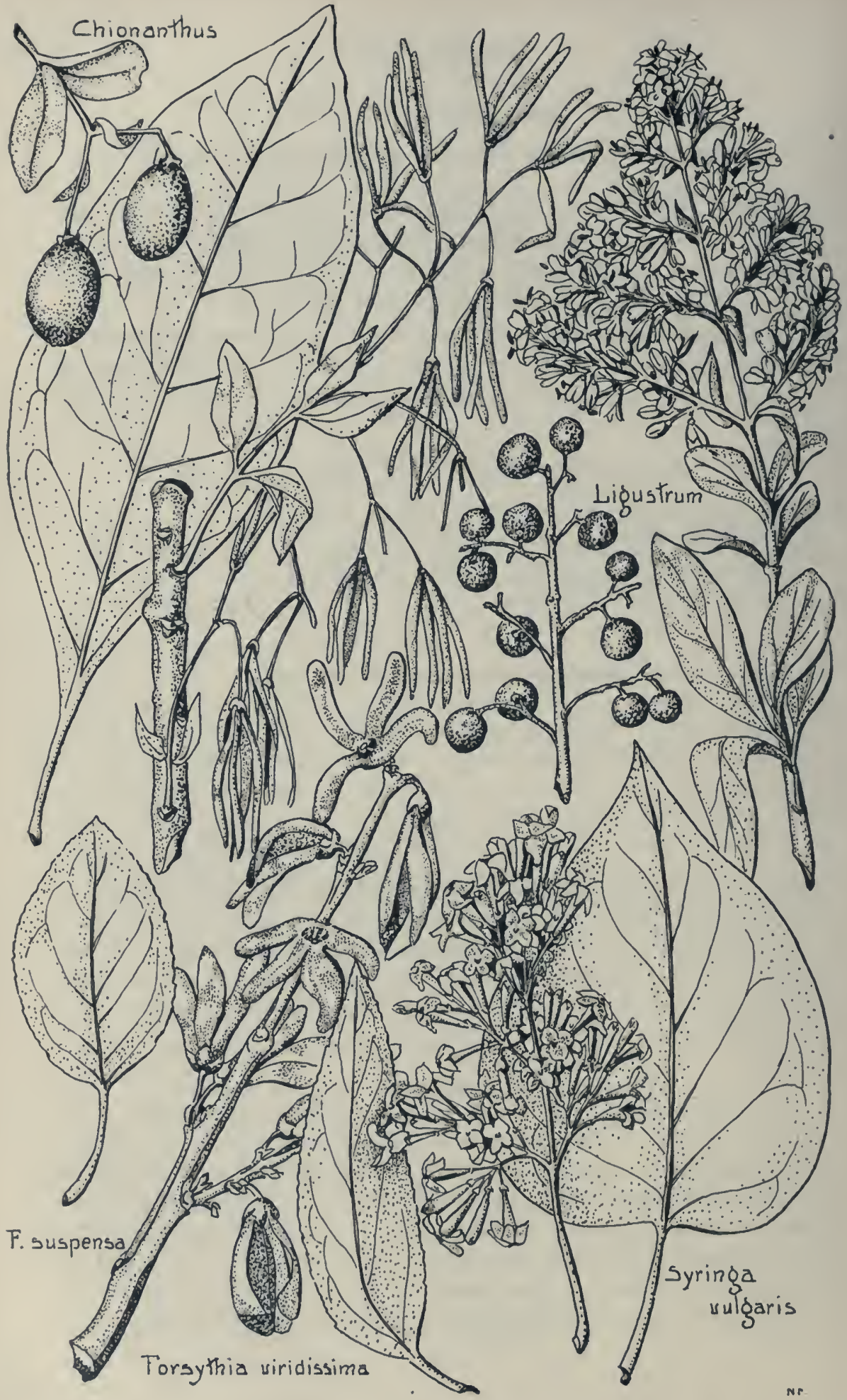




\section{Chionanthus Li n n é 1753}

(Gr.ch io n, snow, a $\mathrm{th}$ h s, flower, in reference to the inflorescence)

Snall trees or shrubs, with opposite simple entire leaves; flowers in panicles, appearing soon after the leaves, perfect; sepals 4, united, petals 4 , slightly united at the base, stamens 2 on the base of the corolla, ovary 2-celled; fruit a 1-seeded drupe.

Propagation by seeds planted in the fall, by layering, or by greenwood cuttings under glass.

A genus of 3 species, two of them natives of China.

\section{Chionanthus virginica $L$ i nn é 1753 Fringe Tree}

Shrub or small tree, 8-20 ft. high, with more or less finely hairy twigs; leaves ellipsoid to obovoid, thickish, tip acute or blunt, base tapering, smooth, long white-hairy below, 6-15 cm. long, $3-5 \mathrm{~cm}$. wide, petioles more or less white-hairy, 1-2 cm. long; flowers in open drooping panicles 1-2 dcm. long, on slender pedicels, petals strap-shaped, white, $2-3 \mathrm{~cm}$. long, 1-2 mm. wide; fruit a more or less oblong black drupe, 10-14 mm long: virginic a, Virginian, referring to the original locality.

Occasionally cultivated; Pa-Fla-Ark-Tex.

Wood light brown, close-grained, hard, weight $40 \mathrm{lbs}$; the bark is tonic and sometimes used in medicine.

\section{Ligustrum L i n n é I753}

(The ancient Latin name)

Slirubs or small trees, with opposite simple entire leaves; flowers in terminal panicles or thyrses, perfect; sepals 4, united, petals 4, united, stamens 2 on the corolla tube, ovary 2-cclled; fruit a 1-3 seeded berry.

Propagation by seeds sown in the fall, or stratified, the germination often delayed, and by hardwood cuttings.

A genus of about 35 species, natives of Eurasia.

\section{Ligustrum vulgare Lin né I753 Privet, Prim}

Slirub, 4-10 ft. ligh, with slender branches; leaves firm and somewhat persistent, elliptic, oblong, lanceolate or spatulate, entire, tip acute or rounded, base tapering, smooth, $2-3 \mathrm{~cm}$. long, $1 / 2-11 / 2 \mathrm{~cm}$. wide, petioles 2-5 mm. long; flowers in erect dense panicles $3-8 \mathrm{~cm}$. long, white, 5-6 $\mathrm{mm}$. wide ; fruit a round black berry, 5-6 mm. diam.; v u l g a ris, common. 
Occasionally cultivated, especially as a hedge plant; native of Eurasia, but escaped from cultivation; Ont-N ${ }^{\top}$-NC-I1l.

\section{Scrophulariales Snapdragon Order}

\section{Bignoniaceae Catalpa Family}

Trees, shrubs, or woody vines, with opposite simple or compound leaves; flowers perfect, sepals 5, united, petals 5, united, and more or less irregular, stamens 2-5 on the corolla tube, ovary 2-celled, stigma 2-lobed; fruit a 2-valved capsule, seeds flat, winged.

A family of about 60 genera, widely distributed in the tropics.

\section{Catalpa Scopoli I77I}

(The name given by the Indians)

Trees, with large opposite simple entire leaves; flowers in terminal panicles or corymbs, appearing after the leaves, perfect, large, white, mottled; sepals 5, united, usually 2-lipped, petals 5, united into a 2-lipped bell-shaped corolla; anther-bearing stamens 2, antherless stamens 3, ovary 2 -celled, ovules in 2-several rows; fruit a long linear capsulc, with flat winged seeds.

Propagation by seeds.

\section{Key to the Species}

1. Corolla $4-5 \mathrm{~cm}$. long; capsule $10 \mathrm{~mm}$. wide

C. catalpa

2. Corolla 6-7 cm. long; capsule 12-20 mm. wide

C. speciosa

\section{Catalpa catalpa (Linné) K a r s te n 1880 Catalpa, Indian Bean} Bignonia catalpa Linné 1753

Catalpa bignonioides Walter 1788

Tree, 25-60 ft. high, I/2-3 ft. diam.; with a thin smooth bark, separating in flakes; leaves very large, broadly ovate, entire or somewhat 3-lobed, tip long-pointed, base truncate to heart-shaped, smooth above, hairy below, 12-25 cm. long, 10-25 cm. wide, petioles $10-15 \mathrm{~cm}$. long; flowers many in large panicles $20-30 \mathrm{~cm}$. long, bell-shaped, 2-lipped, white, spotted with yellow and purple, $4-5 \mathrm{~cm}$. long; capsules $15-40 \mathrm{~cm}$. long, $1 \mathrm{~cm}$. wide, the winged seeds $4-5 \mathrm{~cm}$. long, 5-6 $\mathrm{mm}$. wide.

Rarely cultivated in Minnesota as it is less hardy than the following; Ga-Fla-Miss. 


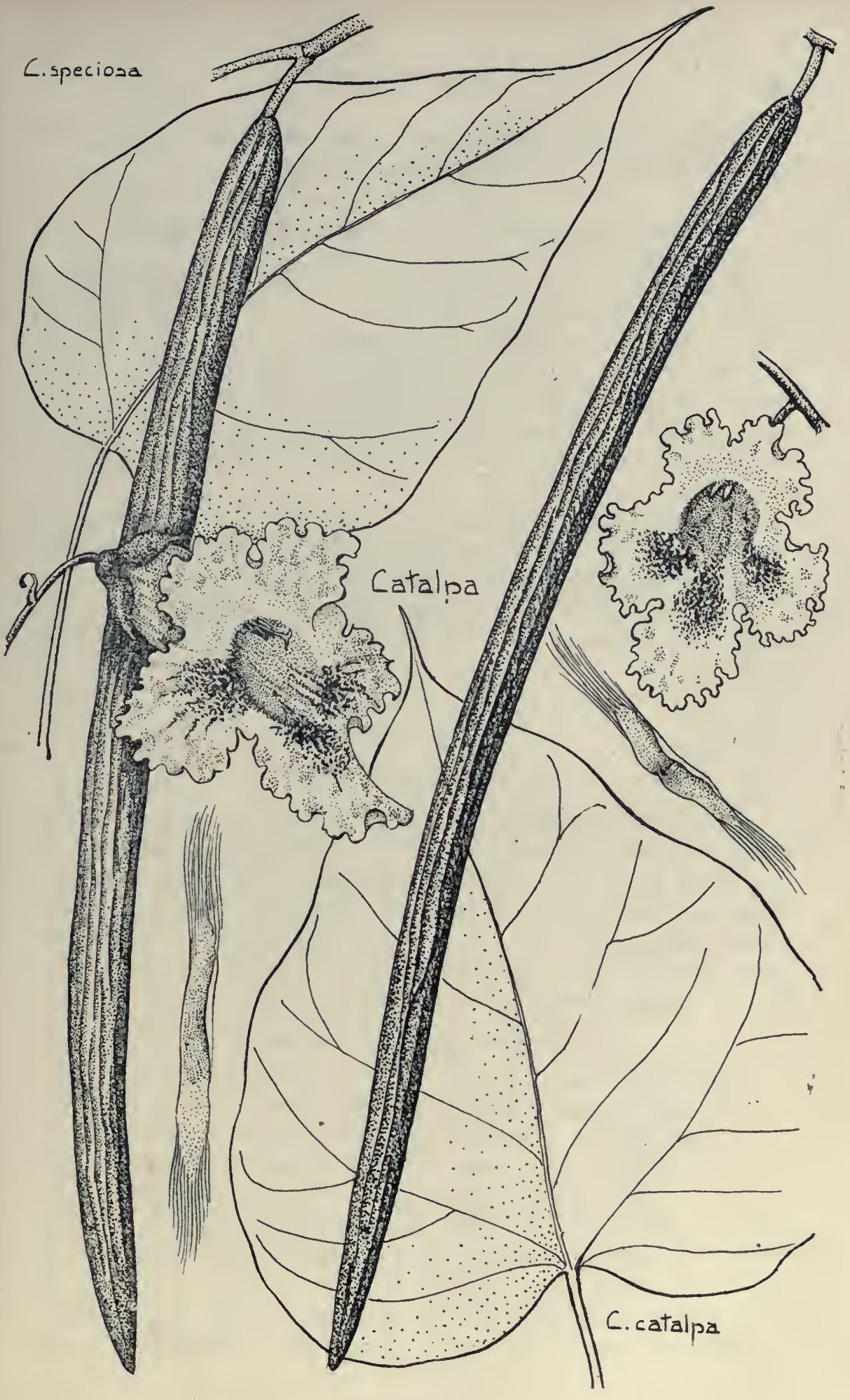


Wood brown, coarse-grained, light, soft, weak, durable in the ground, weight 28 lbs.; much used for fence posts and rails.

\section{Catalpa speciosa IV a r d e r 1880 Hardy Catalpa}

Tree, 30-80 ft. high, I/2-3 ft. diam.; bark gray-brown, with shallow furrows; leaves very large, broadly ovate, entire, rarely 3 -lobed, tip longpointed, base truncate to heart-shaped, smooth above, hairy below, 15-25 $\mathrm{cm}$. long, 10-25 cm. wide, petioles $10-20 \mathrm{~cm}$. long; flowers few in large panicles $12-20 \mathrm{~cm}$. long, white, spotted with yellow and purple, $6-7 \mathrm{~cm}$. long; capsules $15-40 \mathrm{~cm}$. long, 12-20 $\mathrm{mm}$. wide, the winged seeds 4-5 $\mathrm{cm}$. long, 5-6 mm. wide: s p e c i o s a, beautiful, in reference to the habit and flowers.

Frequently cultivated but scarcely hardy north of Minneapolis; IndTenn-Ark-Mo-111.; a rapidly growing tree, much planted for railway ties: and also of much charm as an ornamental, owing to its flowers.

Wood light brown, coarse-grained, light, soft, weight 26 lbs.; much used for fence posts, rails, railway ties, and occasionally for furniture and interiors.

\section{Rosales Rose Order \\ Rosaceae Rose Family}

Herbs, shrubs or trees, with alternate, simple or compound leaves, stipules commonly present; flowers perfect or sometimes polygamo-dioecious; sepals 5 , often with 5 bractlets alternating with them; petals 5 , or rarely none; stamens mostly numerous, inserted on the edge of a disk; pistils 1-many, simple and free or united below into a 2-10 celled, compound ovary; styles terminal or lateral; ovules 1-2 or several; fruit various, achenes, follicles, pomes or drupes.

\section{KEY TO TIYE GENERA}

\section{Leaves compound}

a. Pistils numerous, more than 5, fruit achenes, drupelets, or nutlets

(1) Flowers yellow, fruit ripening into dry, hairy achenes; smooth slirub

Potentilla

(2) Flowers white or pink, fruit drupelets or nutlets; spiny or prickly shrubs

(a) Pistils on a raised or conical receptacle, fruit an aggregate of drupelets

Rubus 
(b) Pistils in a fleshy urn-shaped receptacle, which encloses the nutlets

Rosa

b. Pistils few, (5 or less), free or united with the receptacle, fruit follicles or a pome

(1) Flowers in flat corymbs, fruit a pome

(2) Flowers in ample panicles, fruit follicles

Sorbus

Sorbaria

2. Leaves simple

a. Pistils more than one, 3-5 or many

(1) Pistils on a conical receptacle, fruit an aggregation of drupelets

Rubus

(2) Pistils in a concave or hollow receptacle, free or united with it

(a) Flowers perigynous, fruit dry, 2-5 follicles

x. Follicles inflated, splitting on both sides, seeds shiny

y. Follicles not inflated, splitting on one side, seeds dull

(b) Flowers epigynous, fruit a fleshy pome

x. Carpels cartilaginous or leathery when mature, imbedded in the axis

(x) Cavities of the compound ovary as many as styles

m. Ovules and seeds 1-2 in each cavity

o. Trees; flowers in cymes

p. Low shrubs; flowers in compound cymes

n. Ovules and seeds numerous in each cavity

(y) Cavities of the ovary becoming. twice as many as the styles

y. Carpels hard and bony when ripe, distinct or cohering in fruit

b. Pistil one, fruit a drupe

\section{Physocarpus}

Spiraea

Malus

Aronia

\section{Cydonia}

Amelanchier

Crataegus

Prunus

\section{Potentilla Li n n é I753 Cinquefoil Fivefinger}

(L. p o te ns, powerful, with a diminutive suffix, referring tọ the medical properties)

Herbs, or rarely shrubs; leaves alternate, compound and stipulate; flowers mostly yellow, cymose or solitary; calyx tube flat or hemispheric, 
sepals 5 , persistent, with 5 bracts alternating with them; petals 5 , obovate or orbicular; stamens mostly numerous; carpels many, on a dry usually hairy receptacle; fruit a collection of achenes.

A genus of about 150 species, nearly all of them natives of the north temperate zone. Some 24 species occur in eastern North America and about 30 others in the western and northwestern parts of the continent. The great majority of the species are herbaceous; the following one is strictly shrubby.
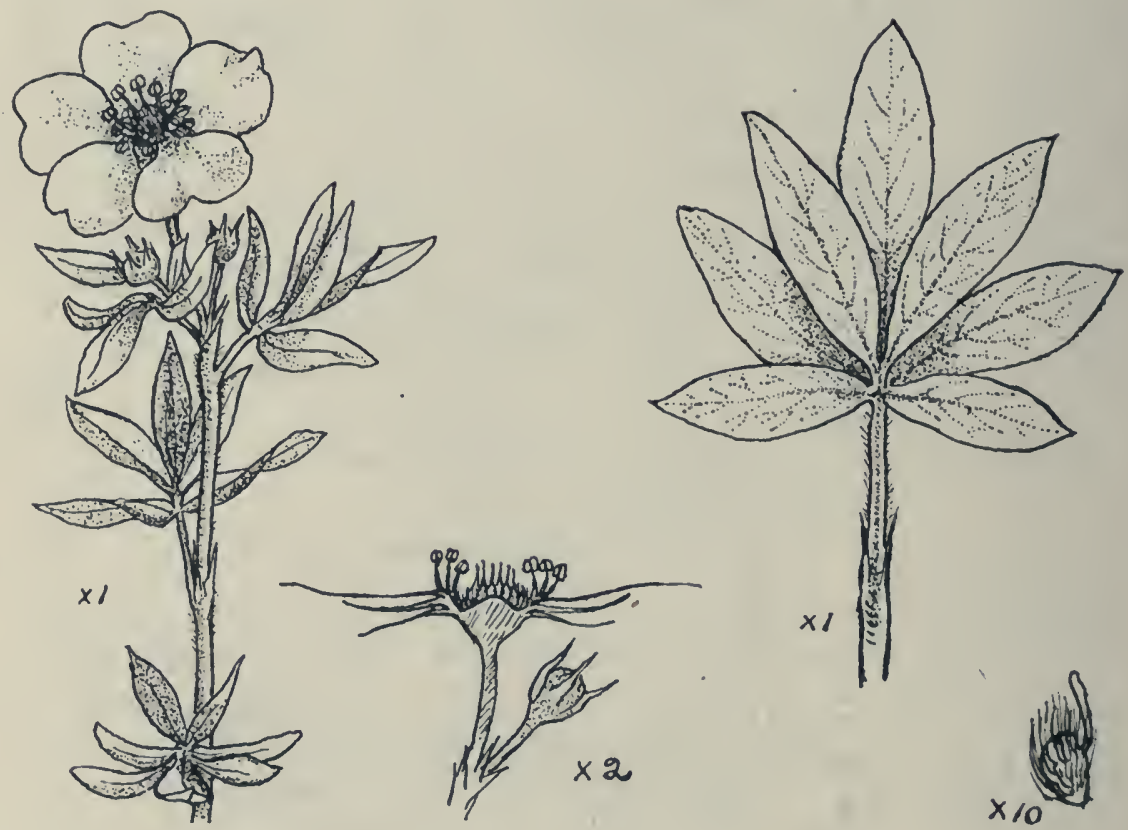

Potentilla fruticosa L in n é r753 Shrubby Cinquefoil.

Dasiphora fiuticosa (Linné) Rydberg 1898

Stem more or less erect, shrubby, 2-8 dm. (8-32 inches) high, much branched, bark shreddy; leaves pinnate, $1-3 \mathrm{~cm}$. long, leaflets oblonglanceolate, entire, silky pubescent, margins revolute, 10-15 mm. long, 2-4 mm. wide; petals bright yellow, orbicular, achenes long-hairy: $\mathrm{f} \mathrm{rut} \mathrm{i-}$ cos a, shrubby.

Frequent in dry and rocky situations, along the north shore of Lake Superior and in the northern part of the state; occurs scattered southward and westward. Distributed from Labrador to Alaska, south to 
N. J., Pa., the Great Lake region, northern Iowa, Ariz, Cal. and Eurasia. Flowers and fruits from June to Sept.

\section{Rubus L i n né I753 Bramble, Blackberry, Raspberry}

(L. $\mathrm{rubus}$, bramble, akin to $\mathrm{ruber}$, red)

Erect or procumbent shrubs or trailing vines, frequently prickly, with alternate simple, lobed, or 3-7-foliate leaves; flowers white (sometimes pink or purple); calyx flat, 5-parted, persistent; petals 5, deciduous; stamens numerous; carpels usually many, borne on a spongy or succulent receptacle, ripening into drupelets and forming an aggregate fruit, edible.

A genus of about 250 species, of wide geographical distribution, but most abundant in the north temperate zone. About 20 species in addition *? to the following occur in North America.

\section{Key to the Species.}

1. Leaves simple, palmately lobed; stems unarmed

2. Leaves compound, 3-7-foliate; stems prickly or bristly

a. Fruit falling off whole from the dryish receptacle when ripe

(1) Stems upright, beset with straight, stiff bristles; fruit red

(a) Calyx bristly-hispid, with słender prickles; native

(b) Calyx not bristly-hispid, woollypubescent ; cultivated

(2) Stems recurved, rooting at the tips, armed with hooked prickles; fruit purple-black

b.' Fruit nòt separating from the juicy receptacle when ripe

R. parviflorus

Raspberrics

R. strigosus

R. idaeus

R. occidentalis

Blackberries

(1) Stems trailing or at least prostrate towards the ends; fruiting branches upright

$R$. villosus

(2) Stems erect or arched ascending

(a) Old stems unarmed or nearly so ; leaflets glabrous on both sides

(b) Old stems purplish and armed with stout prickles

R. canadensis

$R$. allegheniensis 
Rubus parviflorus $N$ ut a 11 I 818 Salmonberry Thimbleberry R. Nutkanus Mocino I 825

A more or less erect-growing, branched shrub, 1-2 meters (3-6 ft.) high; young branches glandular but hardly bristly, old stems with gray. shreddy bark; leaves large, simple, 3-5-lobed, cordate at the base, coarsely

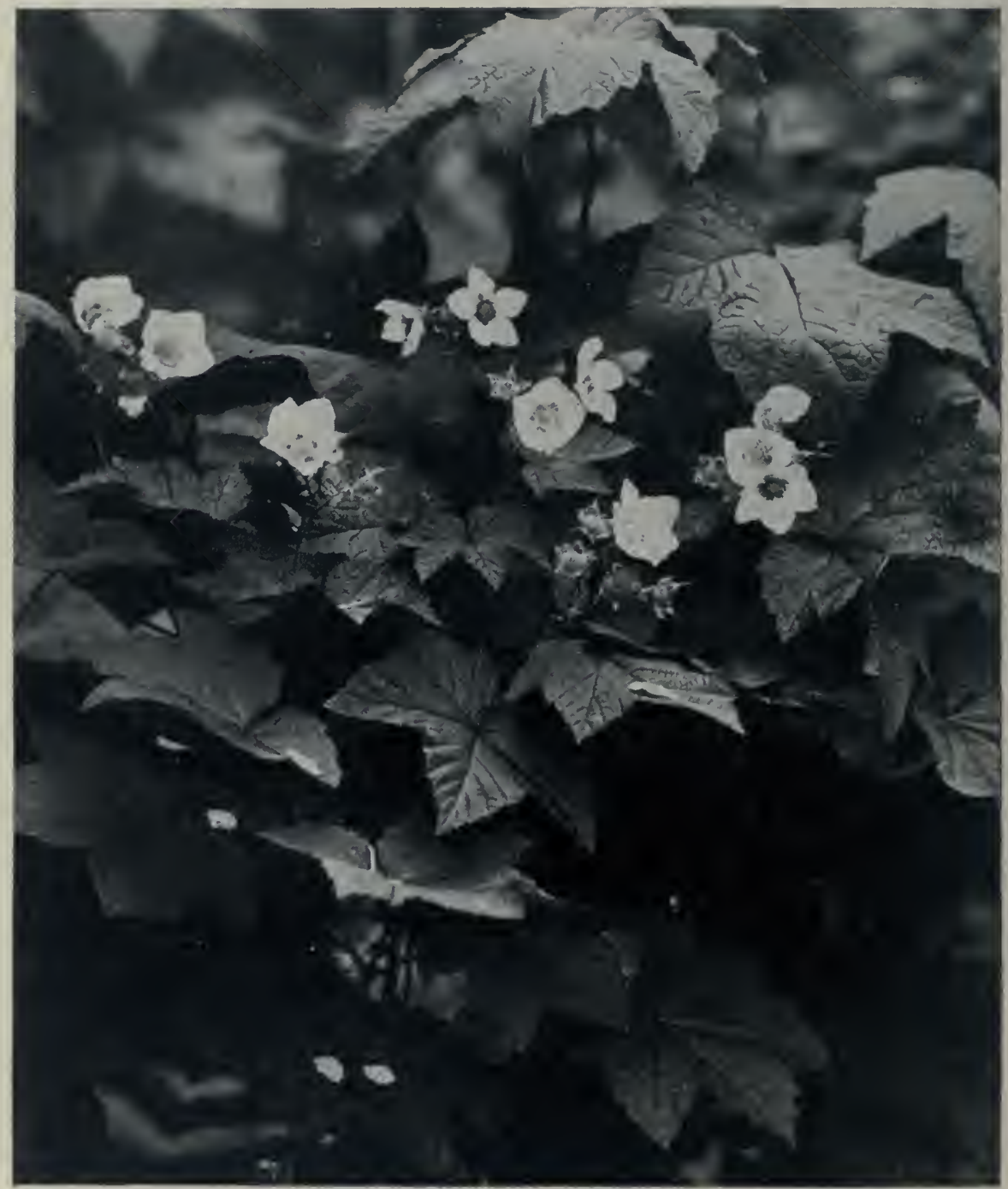

Rubus parviflorus. 
toothed, 10-25 cm. broad; inflorescences cymose, terminal, few-flowered, flowers $2.5-6 \mathrm{~cm}$. broad, white, calyx lobes tipped with a long slender appendage, petals oval, $1-2.5 \mathrm{~cm}$. long; receptacle large; fruit flattenedhemispheric, edible but rather dry and tasteless: p a r vif 1 o r u s, smallflowered.

In rocky woods, banks of streams etc. in the northern and northeastern part of the state. Distributed from Michigan, Minn., western Ontario to Alaska and south to California, and in the Rocky mountains to Utah and Colorado.

\section{Rubus strigosus M ich a $\mathrm{u}$ x 1803 Wild Red Raspberry} R. idaeus var. aculeatissimus (C. A. Meyer) Regel \& Tiling 1877

A branching shrub, 1-2 meters (3-6 ft.) high, biennial, usually densély covered with weak bristles (glandular when young), or the older stems with weak hooked prickles, often glaucous; leaves petioled, 3-5-foliate, pinnate, leaflets ovate or ovate-oblong, pointed or acuminate, sharply serrate or sometimes sharply lobed, whitish pubescent beneath, $2.5-7.5 \mathrm{~cm}$. long; petioles glandular-hairy and prickly, $2-8 \mathrm{~cm}$. long; inflorescence terminal and axillary, racemose, few-flowered, pedicels slender, curving in fruit; flowers $8-12 \mathrm{~mm}$. broad, petals white, ascending, 5-6 mm. long, sepals bristly hispid 10-12 mm. long; fruit elongated-hemispheric, bright red: strigos us, hairy, in reference to the bristly stem.

Very common in thickets, on hillsides etc. throughout the state. Distributed from Labrador to British Columbia south to N. J., Pa., and the Great Lake region and along the Alleghanies to N. C., in the Rocky mountains to N. Mex. Flowers from May to July. Fruit ripe July-Sept.

\section{Rubus idaeus Li n né I753 Red Raspberry}

$\Lambda$ shrub, resembling the preceding very closely, differs mainly in the less bristly stem, and in having the calyx only woolly-pubescent instead of bristly-hispid: i d a e u s Gr. of the woods.

Very extensively cultivated and probably escaping from cultivation. Introduced from Europe.

\section{Rubus occidentalis Lin né I753 Black Raspberry}

A shrub with recurved stems, sometimes 3-4 meters (9-12 ft.) long, rooting at the tips, glaucous all over and armed with hooked prickles, 
not bristly; leaves mostly 3 -foliate, ovate, rounded at the base, pointed at the apex, coarsely and doubly serrate, white pubescent beneath, $3-8 \mathrm{~cm}$. long, $2-5 \mathrm{~cm}$. wide; inflorescence corymbose, several-flowered, usually only terminal, flower 8-10 $\mathrm{mm}$. broad; sepals longer than petals, 5-7 $\mathrm{mm}$. long; pedicels short, ascending or erect in fruit; fruit hemispheric, blackpurple: occident a lis, western.

Common in copses, fence-corners, along roadsides, etc., throughout the southern and eastern part of the state. Distributed from New Brunswick to Quebec south to Ga. and westward to Oregon and British Columbia.

Several cultivated forms have been derived from it, such as the Gregg, Hilborn, etc. Flowers in June, fruit ripe in July.

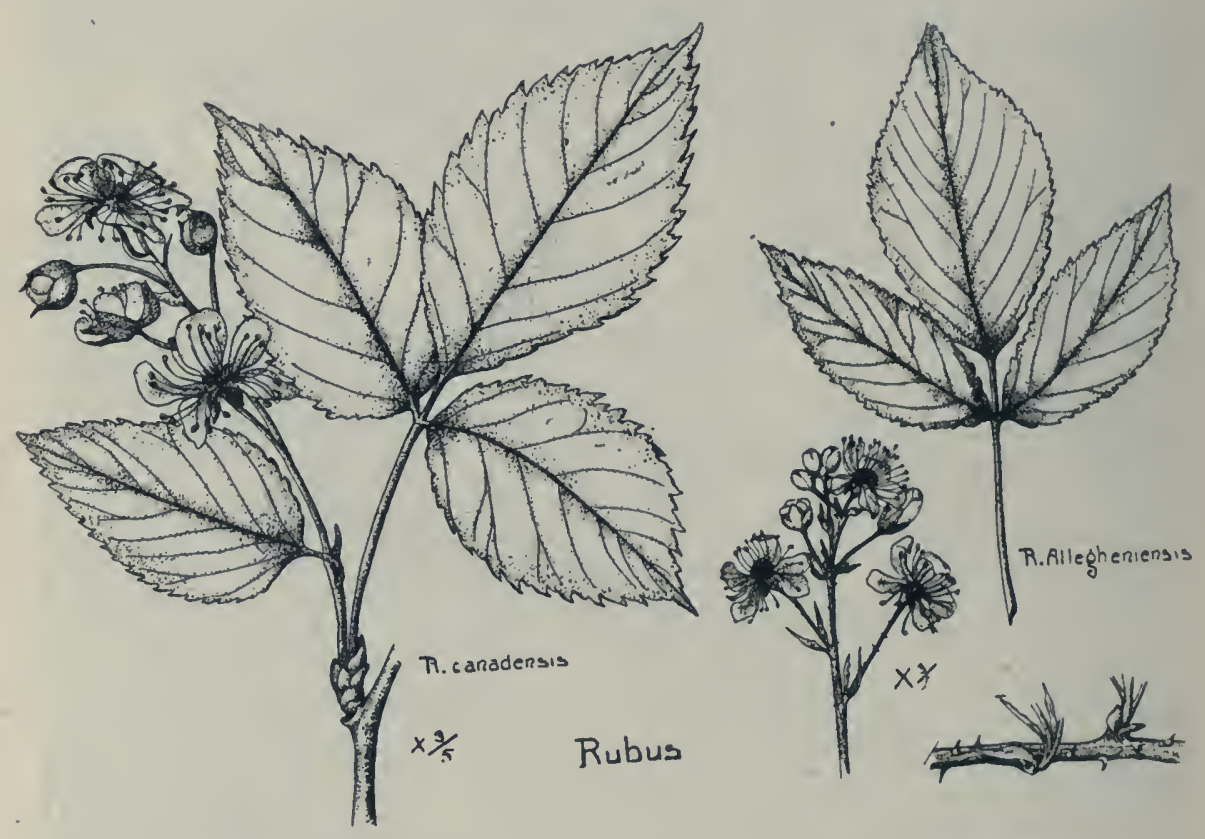

Rubus villosus A it o 11 I789 Dewberry

R. procumbens Muhlenberg 1813

R. canadensis of Authors

A prostrate or trailing shrub, sometimes 2 meters ( $6 \mathrm{ft}$.) long, stems subterete, rather woody, sometimes armed with retrorse prickles, fruiting branches upright, $10-30 \mathrm{~cm}$. high; leaves petioled, with $3-7$ leaflets, 


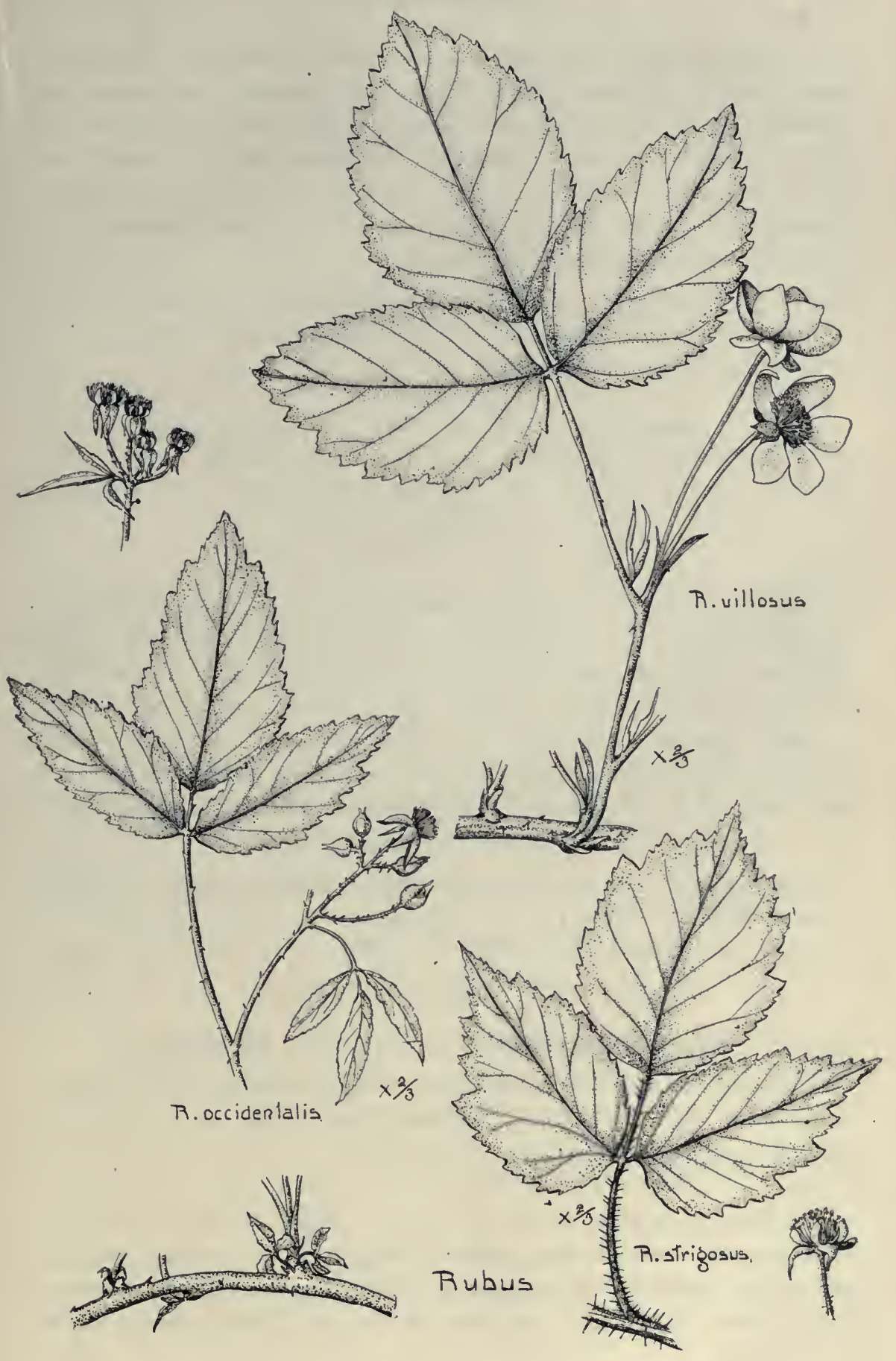


leaflets ovate, oval or ovate-lanceolate, rounded or narrowed towards the base, acute at the apex, doubly serrate, thin, smooth or slightly villous beneath, $3-7 \mathrm{~cm}$. long, $1.5-5 \mathrm{~cm}$. wide, terminal leaflet petioled; flowers 1-15, in shortened, leafy racemes, 2-3 cm. broad; sepals 4-6 mm. long, not foliaceous; petals obovate, $12-15 \mathrm{~mm}$. long; fruit black, subglobose short-cylindric, with few to many large, juicy delicious drupelets: vil $10 \mathrm{~s}$ us, shaggy, referring to the leaves.

In dry open places, common in the eastern part of the state. Distributed from Newfoundland to Lake Superior, south to Va., La., and Oklahoma. Flowers in May, fruit ripe June-July.

\section{Rubus canadensis Li n né I753 Blackberry}

Not R. canadensis of Authors.

Rubus amabilis Blanchard 1906

Shrub with erect or recurving canes, of ten stout, old canes glabrous, unarmed or with occasional prickles; leaves 3-5-foliate, terminal leaflet petioled, long-acuminate, $6-10 \mathrm{~cm}$. long, lateral leaflets $4-7 \mathrm{~cm}$. long, sessile, all glabrous on both sides, finely, evenly and sharply serrate; racemes cylindric, $10-15 \mathrm{~cm}$. long, leafy bracted at the base, pedicels tomentose, not glandular; flowers $2.5-4 \mathrm{~cm}$. broad, petals obovate, 12-15 $\mathrm{mm}$. long; fruit subglobose to short cylindric, drupelets large and juicy: c a n a d e $\mathrm{n}$ sis, Canadian, from the original locality.

In rocky soil and thickets, and along roadsides, common (?) in the southeastern part of the state. Distributed from Newfoundland to Lake Superior, southward to N. C. Flowers in June, fruit ripe in July-August.

\section{Rubus allegheniensis P orter 1896 Blackberry}

R. villosus of Gray's Manual Ed. 6. in large part, not R. villosus of Aiton.

R. nigrobaccus Bailey i 898 .

A branched shrub, 1-2 meters (3-6 ft.) high, old stems purplish or reddish, with stout, straight prickles; branchlets and pedicels glandularpubescent; leaves 3-5 foliate, leaflets ovate to ovate-lanceolate, rounded or narrowed at the base, acuminate at the apex, mostly doubly serrate, 
villous above, velvety beneath, $3-10 \mathrm{~cm}$. long, $1.5-4 \mathrm{~cm}$. wide; flowers in racemes, lowermost ones leafy-bracted, $2.5-3.5 \mathrm{~cm}$. broad, petals narrowly obovate, 4-12 $\mathrm{mm}$. long; fruit mostly subcylindric, $1-2 \mathrm{~cm}$. long, drupelets numerous, rather small: allegheniensis, referring to the Allegheny mountains.

In dry open thickets, roadsides etc., common throughout the state except southwest and extreme northeast. Distributed from New England to Fla., west to Minn. and Ark. Flowers in June, fruit ripe in July-Aug.

Various garden blackberries have been derived from this species.

\section{Physocarpus M a i m ow ic z 1879 Ninebark}

(Gr. physa, bladder, car pos, fruit, referring to the swollen carpels)

Shrubs with shreddy bark and alternate, simple, palmately lobed leaves; flowers white, numerous, in umbel-like corymbs; calyx bellshaped, 5-lobed, 5-6 mm. long; petals 5, rounded, inserted on the throat of the calyx, 4-5 mm. long; stamens numerous; carpels 1-5, shortstalked; fruit 1-5 inflated follicles.

A genus of about 5 species; one occurs in eastern North America, 3 in the Rocky mountains, one on the Pacific Coast, and one in Manchuria.

Physocarpus opulifolius (Linné) M a x i m o w i c z 1879 Ninebark Spiraea opulifolia Linné I753

Opulaster opulifolius Kuntze 1893

A shrub, 1-2 meters (3-6 ft.) high, with long, more or less recurved branches; old bark peeling off in numerous layers or strips; leaves rounded, somewhat 3-lobed, cordate or truncate at the base, $2.5-5 \mathrm{~cm}$. long, or larger on young shoots; follicles glabrate, purplish, membranous, showy: o p u lif olius, leaves as in Viburnum Opulus, the snowball or guelder rose.

Banks of streams and edges of woods, apparently rare; collected from the north shore of Lake Superior. Distributed from Quebec to Fla. west to Ill. and Manitoba. 


\section{Var. in termedius (Rydberg) Robinson 1908}

Follicles permanently pubescent, otherwise like the species. Growing in similar situations; the common form throughout the state, and sometimes planted as an ornamental shrub. Distributed from Mich. to S. Dak., Ark. and Ala.

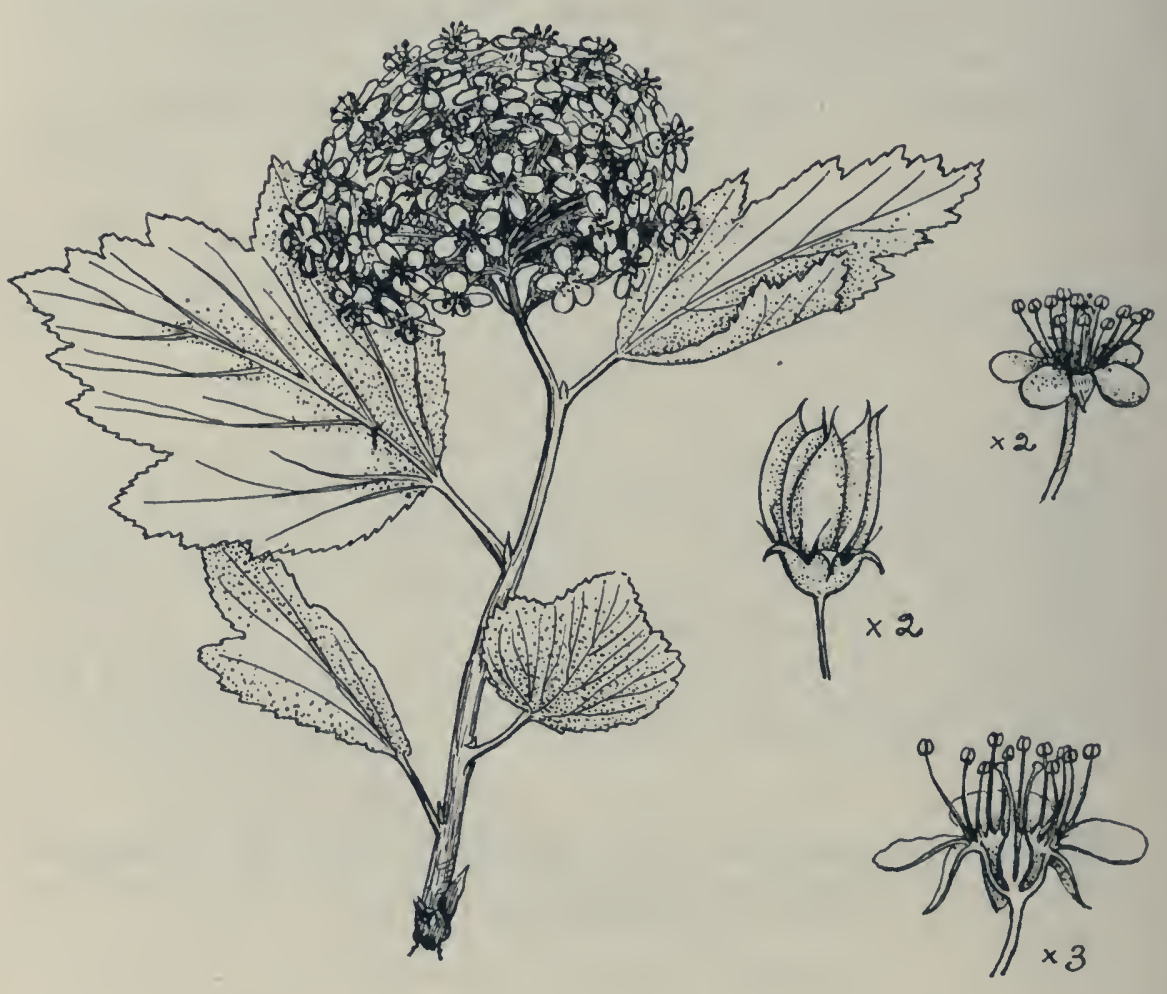

\section{Spiraea L in n é 1753 Spiraea}

(Gr. sp i r a e a, meadowsweet, perhaps originally from the twisted pods)

Shrubs with alternate, simple, toothed or lobed leaves; flowers small, white to rose or pink, in corymbs or panicles; calyx 5-cleft, persistent, bell-shaped; petals 5 , borne on the calyx-tube; stamens $20-50$, also inserted on the calyx-tube; carpels $5-8$, in fruit forming follicles, with few to several seeds. 
A genus of about 60 species, natives of the north temperate zone; four occur in the eastern and two in the western part of North America; two are native to Minnesota. Many of the cultivated Spiraeas are introduced species, while many others are of garden origin.

\section{Key to the Species}

1. Flowers white, in numerous, small umbels or corymbs, on the upper side of arched branches; cultivated shrubs

a. Corymbs terminating short, leafy shoots; leaves lobed

S. Van Houttci

b. Umbels sessile, subtended by a few small leaves; leaves not lobed

S. arguta

2. Flowers white or pink, in panicles or terminal corymbs, branches not arched; cultivated and native shrubs

a. Flowers pink to rose-color, in compound corymbs, cultivated

S. Bumalda

b. Flowers in dense terminal panicles, white or rose-color; native

(1) I,eaves smooth, scarcely paler beueath

S. salicifolia

(2) Leaves green above, densely tomentose and white or tawny beneath

S. tomentosa

\section{Spiraea Van Houttei Z a be 11884 Bridal Wreath}

A shrub 1-2 meters (3-6 ft.) high with arching branches, bark on young branches smooth, yellowish brown, on older parts gray, and somewhat shreddy; leaves rhombic ovate, cut-serrate or obscurely lobed, narrowed at the base, dark green above, pale bluish green beneath, $1.5-4 \mathrm{~cm}$. long; flowers in numerous many-flowered umbels, white, 5-7 mm. broad, sepals upright or spreading in fruit, petals twice as long as the stamens.

Very extensively cultivated as an ornamental shrub. A very handsome early flowering spiraea, of garden origin, a hybrid between $\mathrm{S}$. c antoniensis and S. triloba.

Flowers in May and June; quite hardy and endures the Minnesota winter climate without injury. 


\section{Spiraea arguta $Z$ a be 1 I $88_{+}$Spiraea}

A shrub 1-1.5 meters (3-5 ft.) high, with arched branches, ends of branches very slender, beset with prominent buds which remain unopened on account of the twigs dying back $5-15 \mathrm{~cm}$. each year; leaves oblanceolate, narrowed towards the base, acutish at the apex, serrate above, the middle, glabrous on both sides, $1.5-3 \mathrm{~cm}$. long, .5-1 cm. wide; umbels very numerous, each with a few scale-like leaves at its base, flowers $2-5$ in each umbel, white, flat, $8-11 \mathrm{~mm}$. broad, pedicels smootl, $1.2-1.5 \mathrm{~cm}$. long; follicles smooth: a r g ut a, bright.

Of garden origin, being a lyybrid between $\mathrm{S}$. Th $\mathrm{u} n \mathrm{n}$ e r g i i and $\mathrm{S}$. $\mathrm{m} u \mathrm{lt}$ if $\mathrm{l}$ or a. It blossoms a few days earlier than S. V an H o u t te i, and before the foliage is much developed. The umbels are. very closely crowded so that in full bloom the branches are one mass of flowers.

\section{Spiraea Bumalda B u rven i c h I868?}

A more or less erect shrub, about .5 meter (1-2 ft.) high; bark brown, striped; young shoots with. small ridges running from the base of the petiole; leaves ovate-lanceolate, sharply and mostly doubly serrate, narrowed towards the base, acute at the apex, dark green above, paler beneath, glabrous on both sides, $2-8 \mathrm{~cm}$. long, $1.2-2 \mathrm{~cm}$. wide; flowers numerous, in corymbs, whitish to pink; follicles diverging when ripe.

Of garden origin, a hybrid between S. j a p o n i c a and S. a l b if 1 or a: Numerous forms or varieties are cultivated, among which the following is probably the most commonly planted within the state.

\section{Spiraea Bumalda var. Anthony Waterer}

Low compact shrub, flowers pink-purple, very numerous in compound cymes. Most of the branches kill back almost to the ground in the winter. but it renews itself very rapidly from the basal parts and bears the flowers on the season's growth. Flowers in July and Aug.

\section{Spiraea salicifolia L in né 1753 Meadow Sweet}

Erect shrub .3-1.2 meters (1-4 ft.) high, bark of branches smootl, yellowish brown or grayish, peeling slightly on main stems; leares oblanceolate to obovate, rounded or sharp-pointed at the apex, tapering towards the base, finely serrate, glabrous on both sides, sometimes a few scattered hairs on the veins beneath, 4-7 cm. long, 7-20 mu. wide. (on young shoots much larger) petioles $3-5 \mathrm{~mm}$. long; inflorescence a terminal 


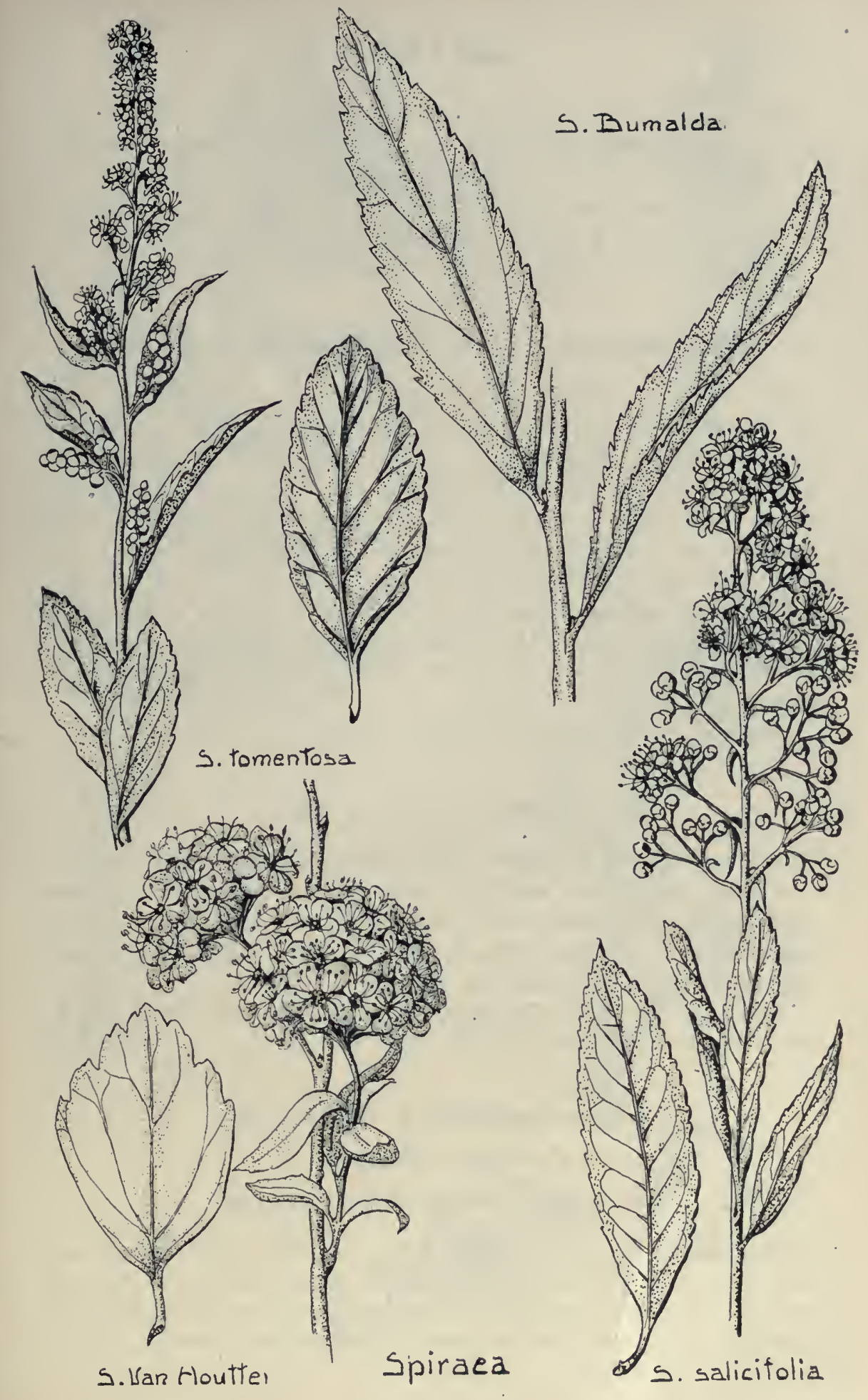


panicle 10-20 cm. long, $5-9 \mathrm{~cm}$. in diameter, flowers numerous, white, 6-7 mm. wide, petals orbicular $2.5 \mathrm{~mm}$. in diameter, stamens numerous: salicifolia, leaves as in Salix, the willow.

Mostly in low moist ground throughout the state. Distributed from N. Y. to N. C., Mo. and northwestward; also in Asia.

Flowers in July, fruits in Sept.

\section{Spiraea tomentosa L i n n é I753 Hardhack, Steeple Bush}

Erect shrub, .5-1.2 meters (1.5-4 ft.) high, twigs covered with woolly pubescence; leaves obovate to oblong, tapering towards the base, coarsely serrate or toothed, glabrous above, densely white-woolly beneath, or sometimes rusty along the veins, $3-6 \mathrm{~cm}$. long, $1-2 \mathrm{~cm}$. wide, short petioled or almost sessile; flowers in racemes, crowded into a dense panicle, pink or rose color, rarely white; follicles 5 , woolly, $2-2.5 \mathrm{~mm}$. long: to m e n to s a, hairy, referring to the twigs and leaves.

In moist meadows, swamps and low grounds; frequent in the eastern part of the state from the Twin Cities northward towards Duluth.

Distributed from New Brunswick and Nova Scotia to the mountains of Ga., west to Minn. and Kan.

Blossoms in July and August, fruits in Sept.

\section{Sorbaria A. B r a 1111864}

(From Sorbus, the monntain ash, in allusion to the similar leaves)

Shrubs, more or less branched; leaves alternate, compound, odd-pinnate, leaflets oblong-lanceolate, sessile, sharply serrate; flowers white, small, in large panicles, calyx 5-lobed, petals 5, spreading; stamens numerous; carpels 5, opposite the calyx lobes.

Shrubs of the aspect of Spiraea. A genus of 5 species, four in Asia and one in North America.

Sorbaria sorbifolia A. B r a $11 n 1864$

Spiraea sorbifolia Linné 1753

Basilima sorbifolia Rafinesque 1836

Erect shrub, 1-2 meters (3-6 ft.) high, (sometimes almost herbaceous), with gray bark, leaves $10-40 \mathrm{~cm}$. long, leaflets $13-21$, lanceolate, with many straight veins running from the mid-vein, narrowed at the base, acuminate at the apex, stellate pubescent beneath when young, $7-10 \mathrm{~cm}$. 


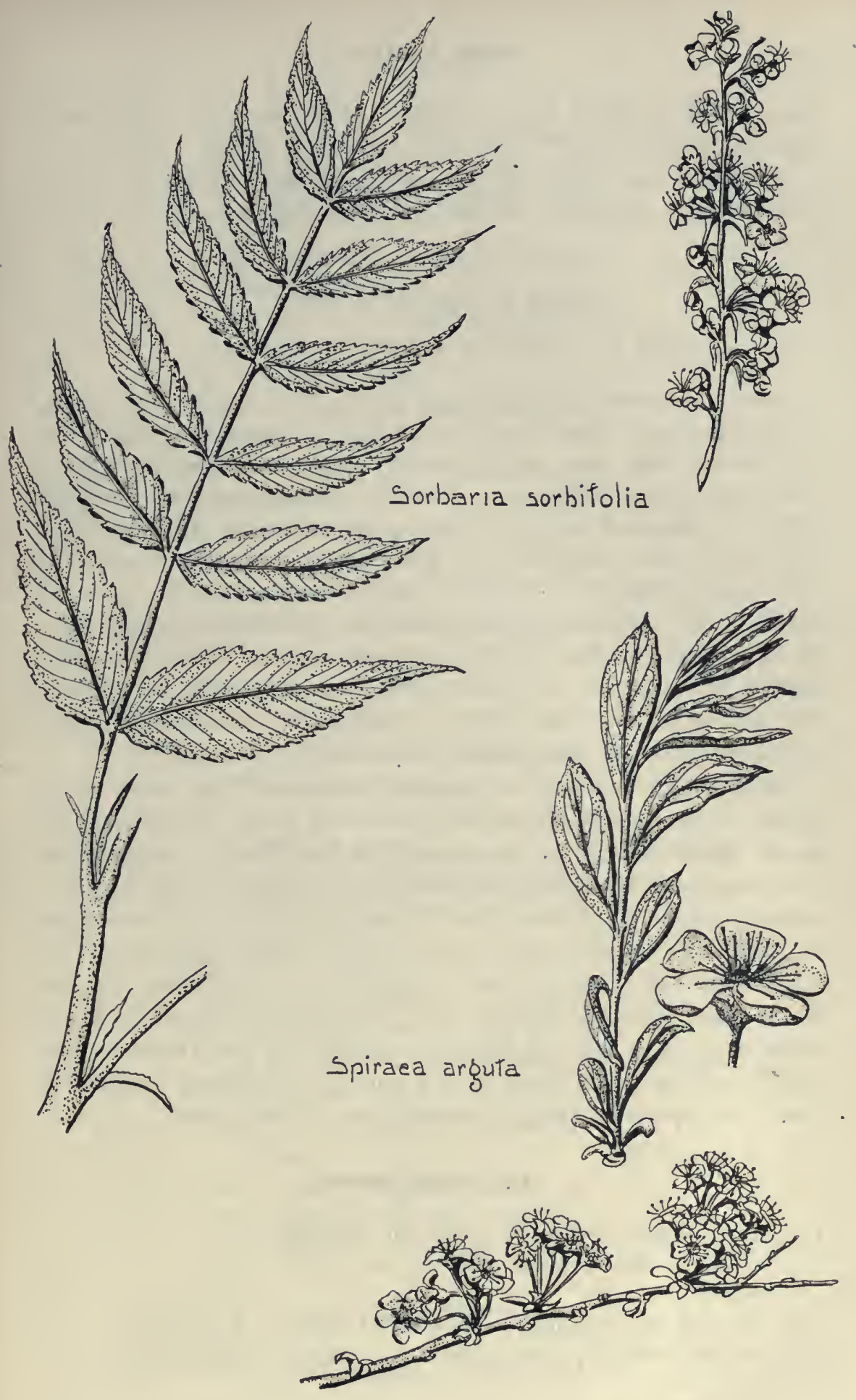


long; panicles terminal, large, pyramidal, $15-30 \mathrm{~cm}$. long; flowers white, 7-8 mm. broad: s o r bif olia, with leaves like sorbus.

Frequently cultivated and occasionally growing wild. Native of northern Asia, extending from the Ural mountains to Japan.

\section{Rosa L in 11 é I753 Rose \\ (R os a, classical L. name for the rose)}

Bushes sometimes with very long canes which take a semi-climbing or vine-like habit; stems usually armed with prickles, often with a pair of unusually large ones just below each node (infrastipular prickles); buds scaly; leaves deciduous or in warm climates sometimes evergreen, pinnately compound with 3-11 leaflets (simple in one Asiatic species), stipules persistent, large, adherent to the petiole with short free auricles at the top ; flowers perfect, receptacle deeply cup-shaped, sepals 5, petals 5, stamens many, pistils many, the ovaries free, becoming achenes in fruit, the styles sometimes united, sepals, petals and stamens borne on the upper edge of the receptacle cup, ovaries borne on its inner surface completely concealed by the cup, fruit a "hip" formed by the fleshy receptacle containing the numerous bony achenes; seed solitary, with endospern.

A very large genus of the northern hemisphere. 'The limits of the species are exceedingly difficult to define owing to the variability of the species themselves, and the hybridizing of different species whenever they occur together. These two characteristics of rose species have served as a foundation for the great and ever increasing number of cultivated forms of roses. Our native roses need much further study especially in the living state. In collecting roses for study it is well to have all parts of the plant, flowering branches, fruit, and young non-flowering shoots. Roses which have been cut down at or before the usual flowering time often flower late in the season on new rapidly grown shoots, which differ greatly in appearance from the normal type of the species.

\section{Key to the Species}

1. Vines; styles united to form an exserted column; flowers white, pink, or red; cultivated

a. Stipules nearly entire; leaves with 3-5 leaflets

R. setigera

b. Stipules fringed; leaves with about 9 leaflets

R. multiflora 
2. Upright shrubs; styles free, not protruding

a. Native species and introduced species which have become establislıed; flowers pink; "wild roses"

(1) Definite infrastipular prickles wanting, prickles needle-like

(a) Flowering branches nearly unarmed; leaflets usually seven

R. blanda

(b) Stems densely prickly

x. Semi-herbaceous; leaflets usually 9 ; flowers in clusters

R. arkansana

y. Bushy; leaflets 3-7; flowers usually solitary

(2) Infrastipular prickles well developed, prickles enlarged at the base; leaflets $7-11$, small

b. Cultivated species, occasionally persisting in the vicinity of old gardens

(1) Leaflets 1-2 cm. long

(a) Foliage glandular

x. Stems green, stout infrastipular prickles; flowers pink

y. Stems brown, no infrastipular prickles; flowers yellow

(b) Foliage glabrous, stems brown, prickles bristle-like; flowers white, yellowish or pinkish

(2) Leaflets $2-5 \mathrm{~cm}$. long

(a) Leaflets downy beneath, not glandular, or very slightly so

$x$. Twigs red, leaflets thin, flowers pink

y. Twigs grayish brown, leaflets thick, leathery and wrinkled; flowers red or white

(b) Leaflets nearly or quite smooth beneath, more or less glandular, thick, and leathery; flowers pink, white or red

x. Prickles slender; leaflets obtuse, rugose

y. Prickles stout, hooked; leaflets usually acute

R. rubiginosa

R. foetida

R. spinosissina

R. cinnamomea

R. rugosa

R. gallica

R. centifolia 


\section{Rosa setigera, Mich a $\mathrm{x}$ I803 Prairie Rose}

Vines with canes 2-6 m. long, armed with stout, hooked, infra-stipular prickles, 6-8 $\mathrm{mm}$. long, about the same width at the base; leaves with three large leaflets, often with an additional much smaller basal pair, leafiets ovate, sharply double serrate to the base, smooth, glossy, dark green above, paler and smooth or soft pubescent beneath, tip acute, base rounded, upper leaflets $4-7 \mathrm{~cm}$. long, $2.5-4 \mathrm{~cm}$. wide, petiole and rachis prickly, glandular, stipules narrow with sharply acute auricles the pair only about $3 \mathrm{~mm}$. wide, entire except for a row of small glands along the margin; flowers borne in many-flowered corymbs with narrow lanceolate bracts, pedicels, receptacles and calyx glandular, sepals $1-1.7 \mathrm{~cm}$. long, the outer ones usually with narrow linear lateral lobes, petals deep pink, changing to nearly white, styles long, cohering in a projecting column, flowers $3-5 \mathrm{~cm}$. across, nearly scentless, calyx deciduous after flowering, fruit globular, about $1 \mathrm{~cm}$. in diameter, achenes pale, angular about $4 \mathrm{~mm}$. long: se tig e r a, prickle bearing.

Native of the eastern United States, from the gulf states north to Nebraska, Wisconsin, and southern Ontario. Not native of Minnesota. Cultivated occasionally in its typical form and in the double flowered form "Prairie Queen." The canes winter kill in the vicinity of Minneapolis unless laid on the ground and given a light protection of straw. Flowers in July.

\section{Rosa multiflora Th u n b e r g 1784 Rambler Rose}

Vine with canes up to $3 \mathrm{~m}$. in length, armed with stout curved, infrastipular prickles about $5 \mathrm{~mm}$. long; leaves with 7-9 leaflets, leaflets lanceolate, simple and sharply serrate, bright green and smooth above, paler and soft pubescent beneath, tip acute, wedge-shaped, base wedge-shaped, upper leaflets $2.5-3 \mathrm{~cm}$. long, about 1.5 wide, rachis and petiole prickly and soft pubescent, stipules narrow, glandular, conspicuously and strongly fringed; flowers in many-flowered corymbs with lanceolate fringed bracts, the pedicels glandular, receptacle nearly or quite smooth, sepals $5-7 \mathrm{~mm}$. long, glandular, the outer with narrow lateral lobes, petals white or pale pink, styles long and cohering in a column, flowers about $2 \mathrm{~cm}$. across, nearly scentless; sepals deciduous in fruit, fruit globose about $5 \mathrm{~mm}$. in diameter, achenes pale, angular, about $3.5 \mathrm{~mm}$. long: multiflora, many flowered.

Native of China and Japan. Several double-flowered hybrids of this species are commonly cultivated, the commonest being the "Crimson 


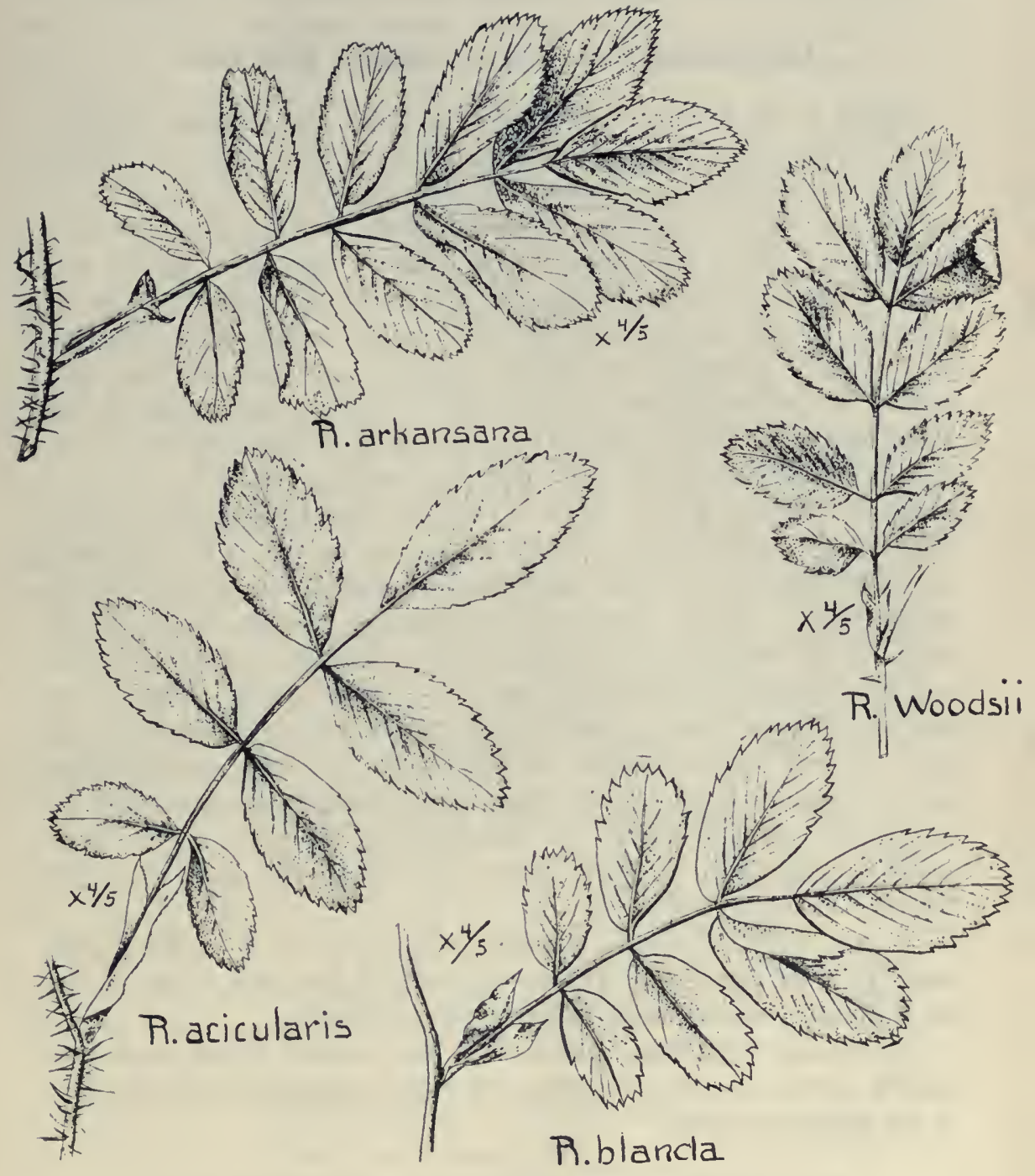

Native Species of Rosa 
Rambler," a Japanese hybrid of unknown origin. The canes are not entirely hardy in Minnesota unless taken down and covered with straw.

\section{Rosa blanda A it on 1789 Smooth Wild Rose}

Shrub $2 \mathrm{dm} .-12 \mathrm{dm}$. high, spreading widely by creeping rhizomes; woody twigs usually dark purplish red, first year shoots from the rhizome usually covered with many weak bristle-like prickles, shoots on old wood with a few scattered prickles, or often entirely smooth; leaves with $5-7$ leaflets, very rarely with more, leaflets ovate to lanceolate, usually with stalks about $1 \mathrm{~mm}$. long, sharply and usually simply serrate down to the middle or a little lower, upper side dull, nearly smooth, lower side pale, finely woolly pubescent, the midrib prominent, ridged, principal veins distinct but not ridged, tip rounded, obtuse or acute, base wedge-shaped. upper leaflets 2.1-4 cm. long, 1-2 cm. wide, lower leaflets one-half or twothirds as large; petiole and rachis with fine woolly pubescence, very rarely: glandular; stipules simple, entire or with the free auricles finely serrate. thin, veiny, usually smooth except along the margin, wide expanded, especially those of the upper leaves, the pair often $1 \mathrm{~cm}$. wide; flowering shoots borne on the old wood, flowers solitary or in loose clusters of 2-8, bracts of the inflorescence leaf-like, or with the blade reduced or lacking and the stipules forming broad round-ovate bracts, pedicel of flower outside of receptacle smooth, sepals usually simple, slightly broadened at the tip, $1.5-2 \mathrm{~cm}$. long, glandular on the outside, or rarely smooth, finely woolly pubescent within, petals bright pink or sometimes pale, flower 3.5 $\mathrm{cm}$. across; calyx persistent, in fruit more or less erect, fruit scarlet, round or somewhat elongated; achenes slender about $4 \mathrm{~mm}$. long, light brown: b l and a, smooth.

Copses, edge of woods, prairies, Newfoundland to Saskatchewan, south to New Jersey and Illinois-throughout the state except in the far northeast, most common in the woodland portion.

A form with glandular pubescent foliage, doubly serrate leaves and usually solitary flowers occurs about the Twin Cities, and in several places in the Minnesota valley.

\section{Rosa arkansana P orte r 1874 Prairie Wild Rose}

R. pratincola Greene

Low shrub about 3-5 dm. high, or almost herbaceous from the widespreading woody rhizome, and sometimes scarcely $1 \mathrm{dm}$. high, woody twigs purplish red or reddish green, twigs usually covered with fine bristle-like 
prickles about $3 \mathrm{~mm}$. long, the prickles sometimes larger in the vicinity of the nodes but not forming distinct pairs of infrastipular prickles; leaves with 7-11, mostly 9, leaflets, leaflets broadly obovate or oblanceolate with stalks about $1 \mathrm{~mm}$. long or sessile, thick, sharply and usually simply serrate down to the middle or a little below, upper side dull, nearly smooth, lower side scarcely paler, finely woolly pubescent, the midrib and principal veins prominently ridged, tip occasionally rounded but usually broadly or acutely wedge-shaped, base rounded or wedge-shaped, upper leafiets 2-4 cm. long, 1.2-2.5 cm. wide, lower leaflets smaller; petiole and rachis with fine woolly pubescence, sometimes intermixed with a few glandular hairs; stipules simple, entire or serrate, rather narrow, the pair of stipules rarely exceeding $\delta \mathrm{mm}$. in width, thick, usually covered beneath with fine woolly pubescence, showing one prominent vein close to the upper side of the auricle, other veins small; flowering shoots borne on the old wood or often arising directly from the underground parts of the stem, flowers solitary or more frequently in dense clusters of $2-10$, bracts of the inflorescence lanceolate, acute; pedicel of flower and outside of receptacle smooth, sepals usually simple, more or less broadened at the tip, 2-2.5 $\mathrm{cm}$. long, smooth or glandular pubescent on the outside, densely fine woolly pubescent within, petals bright pink, often of a salmon tone, flower 4-6 cm. across ; calyx persistent in fruit, somewhat spreading; fruit round or somewhat elongated; achenes stout, light brown, about $5 \mathrm{~mm}$. long: a $r$ a n sana, Arkansan, the species being originally described from the valley of the Arkansas river in Colorado.

Prairies, Wisconsin to Manitoba, Montana and Colorado. Throughout the prairie regions of Minnesota. It intergrades with Rosa blanda. Intermediate forms are especially common in the region about Minneapolis where prairie and woodland forms are often much intermixed.

A rose probably of this species occurs in southeastern Minnesota with few spines, fruit narrow and top-shaped, stipules with prominent auricles, very long sepals (sometimes over $3 \mathrm{~cm}$. long).

Rosa acicularis $\mathrm{L}$ in $\mathrm{d} l$ e y 1820

R. Sayi Schweinitz 1824

R. Engelmanni S. Watson 1889

Shrub 3 dm.-1 m. high, stems reddish or greenish, thickly beset with slender straight prickles, 3-6 mm. long, those by the nodes often longer and stouter than the others, but scarcely forming definite infrastipular spines; leaves with 5-7 leaflets, leaflets elliptical or ovate, short-stalked (about $1 \mathrm{~mm}$.) or often entirely sessile, thin, rather coarsely serrate, the 
teeth minutely serrulate, upper side dull, smooth, lower side paler, somewhat silky and resinous, glandular, usually wedge-shaped, broadly acute, base wedge-shaped or more often rounded, or cordate, upper leaflets 2-5 $\mathrm{cm}$. long, $1.5-2.5 \mathrm{~cm}$. broad, lower leaflets one-third to two-thirds as large; petiole and rachis glandular, with or without long silky hairs; stipules simple, usually widely dilated, a pair of stipules often $1.5 \mathrm{~cm}$. broad, occasionally narrow, thin, veiny, glandular, and sometimes also woolly pubescent, the margin roughened by glands but usually otherwise entire; flowering shoots borne on the old wood, flowers solitary or rarely in clusters of 2-3, pedicel of the flower and outside of receptacle smooth or rarely glandular, sepals usually simple, somewhat broadened at the tip, $2-3 \mathrm{~cm}$. long, glandular on the outside and sometimes finely pubescent within, petals bright pink, flower 5-7 cm. across; calyx persistent in fruit, sepals erect, fruit elongated, tapering at the base, about $1.5 \mathrm{~cm}$. in diameter; achenes thick, very light colored, about $4 \mathrm{~mm}$. long: a c ic u 1 a ris, furnished with needles.

In the variety $R$. acicularis Bourgeauiana Crepin the fruit is round and the leaves are usually soft pubescent as well as glandular.

Thickets and woods, Anticosti to Alaska, south to Vermont, the region about the Great Lakes and Colorado; in Siberia growing within 300 miles of the Arctic Ocean. In Minnesota occurring in the northern and northeastern parts of the state, chiefly in the region of evergreen forests.

Forms apparently intermediate between this rose and $\mathrm{R}$. a $\mathrm{rk}$ a n s a $\mathrm{n}$ a occur in the northern Red River Valley.

\section{Rosa Woodsii L in d 1 e y 1820}

\section{R. Fendleri Crepin 1876}

Stems 2-9 dm. high, young woody twigs reddish brown or purple red, older twigs becoming grayish with the peeling of the epidermis, prickles straight or slightly bent at the base, 2-12 mm. long, infrastipular prickles well developed, often the only ones present on flowering branches, young shoots from the rhizome often with numerous other prickles, some of them as large as the infrastipular ones; leaves with 5-9 leaflets, leaflets elliptical, with stalks 1-2.5 mm. long, thin, sharply and simply serrate except at the base, upper side dull, lower side whitish, downy pubescent, the midrib and principal veins somewhat prominent beneath, tip rounded, base rounded or somewhat wedge-shaped, upper leaflets $1-3 \mathrm{~cm}$. long, 6-18 $\mathrm{mm}$. wide, lower leaflets somewhat smaller, petiole and rachis finely woolly pubescent and often bearing a few slender prickles, stipules entire or 
slightly glandular serrate, the pair about 4-7 mm. wide, veiny, slightly woolly pubescent beneath; flowering shoots borne on old wood, flowers solitary or in clusters of $2-8$, lower bracts leafy, upper much reduced, lanceolate, pedicels and outside of receptacle smooth, sepals slightly broadened at the tip, simple, or the outer ones slightly lobed, about $1.5 \mathrm{~cm}$. long, slightly pubescent and often a little glandular on the outside, finely cobwebby within, petals pink, flowers about $3 \mathrm{~cm}$. across; calyx persistent in fruit erect or somewhat spreading, fruit globose or nearly so, about $8 \mathrm{~mm}$. in diameter, wall thin; achenes dark-colored, hairy along one angle, not exceeding $4 \mathrm{~mm}$. in length: named for the botanist, Joseph Woods.

Mostly prairies or exposed dry slopes, Minnesota to Alberta, south to Nebraska and New Mexico. In Minnesota native Ros a Woodsi i is rare, occurring in typical form along the western border of the state in the vicinity of Bigstone Lake. An excessively prickly form of this rose, apparently the "Ros a M a c unii" of Greene has become established along railroad tracks in the vicinity of Minneapolis, probably introduced from Montana or the Canadian plains. In the northern and northwestern parts of the state occur forms more or less intermediate between this rose and $\mathrm{R}$ os a blanda. Their proper disposition is still in doubt.

\section{Rosa cinnamomea Li in n é I753 Cinnamon Rose}

Tall bush, $2 \mathrm{~m}$. in height, stems reddish, armed with somewhat hooked broad-based infrastipular prickles about $5 \mathrm{~mm}$. in length, often with other smaller scattering prickles; leaves with 5-7 leaflets, leaflets narrowly elliptical, finely, sharply and simply serrate almost to the base, dull green, puberulent above, paler and soft pubescent below, upper leaflets $2-3.5 \mathrm{~cm}$. long, $1.2-1.8 \mathrm{~cm}$. wide, rachis and petiole soft pubescent and sometimes slightly glandular, stipules narrow or more or less widely dilated on flowering twigs, the pair sometimes $12 \mathrm{~mm}$. wide, veiny, more or less pubescent and glandular; flowering shoots borne on the old wood, flowers usually solitary, fragrant, pedicels and receptacles nearly smooth, sepals up to $3 \mathrm{~cm}$. long, woolly pubescent, enlarged at the tips, the outer usually with prominent lateral lobes, petals dull pink, flower about $4 \mathrm{~cm}$. in diameter; sepals persistent and erect in fruit; hips elongated, tapering upwards, 12-15 mm. long, red: c in $\mathrm{n}$ a $\mathrm{m}$ o $\mathrm{me}$ a, cinnamon-like, probably from the fragrance of the flowers.

Native of northern Europe and northwestern Asia. The double flowered form, Rosa cinnamomea var. foecundissisma, with flat very double pink flowers is often planted in old-fashioned gardens. It 
is perfectly hardy and sometimes persists for some time without cultivation and spreads by suckers.

\section{Rosa rugosa $\mathrm{T}$ h u n b e r g 1784}

Shrubs $6 \mathrm{dm}$. to $2 \mathrm{~m}$. high; stens stout, grayish brown or black, pubescent, armed with many crowded bristles and strong pubescent needlelike prickles; infrastipular prickles not obvious; leaves with 5-9 leaflets, leaflets elliptical or ovate-lanceolate, finely blunt-serrate or crenate to the base, thick and firm, rugose, glossy and dark green above, paler and soft pubescent beneath, tip rounded or pointed, base cordate or rounded, upper leaflets 2.5-4 cm. long, $1.5-2.75 \mathrm{~cm}$. wide, lower ones somewhat smaller, petioles soft pubescent and prickly, stipules dilated, finely crenate, the pair often $15 \mathrm{~mm}$. wide; flowers in small clusters borne on all the shoots throughout the season, pedicels pubescent or prickly, receptacle smooth, sepals pubescent, pointed, usually simple, $1.5-2 \mathrm{~cm}$. long, petals deep rose or white, flower $6-8 \mathrm{~cm}$. across; sepals persistent in fruit, hip globular, scarlet, $2 \mathrm{~cm}$. or more in diameter: $\mathrm{rug}$ o s a, rugose, referring to the leaves.

A very variable rose, native of Japan, Siberia and eastern Europe. The forms from Russia and Siberia are perfectly hardy in Minnesota without protection in winter. It is much planted in shrubberies and hedges and is valuable on account of its fine foliage, large flowers borne throughout the summer, and handsome scarlet fruit. Double flowered forms are in cultivation and also several hybrids of this species with various garden roses. They are not all as hardy as the original species.

\section{Rosa rubiginosa $L$ i n n é i77 I Sweetbrier}

Shrub $6 \mathrm{dm}$. to $2 \mathrm{~m}$. high, stems greenish or brown, armed with stout hooked infrastipular prickles, 6-12 mm. long, often also with similar scattering prickles; leaves with 5-7 leaflets, fragrant; leaflets broadly elliptical or obovate, sharply doubly serrate almost to the base, bright green, finely pubescent on the upper side, slightly pale and densely glandular pubescent below, tip broadly wedge-shaped or rounded, base usually rounded, upper leaflets $1-2 \mathrm{~cm}$. long, $8 \mathrm{~mm} .-1.8 \mathrm{~cm}$. wide, lower about one-half as large, rachis and petiole soft pubescent, glandular and prickly, stipules widely dilated, veiny, glandular along the margin and on the under side; flowering shoots borne on the old wood, flowers solitary or in few-flowered clusters mostly with leafy bracts, pedicels and often receptacles prickly and glandular, sepals $1.5-2 \mathrm{~cm}$. long, very glan- 


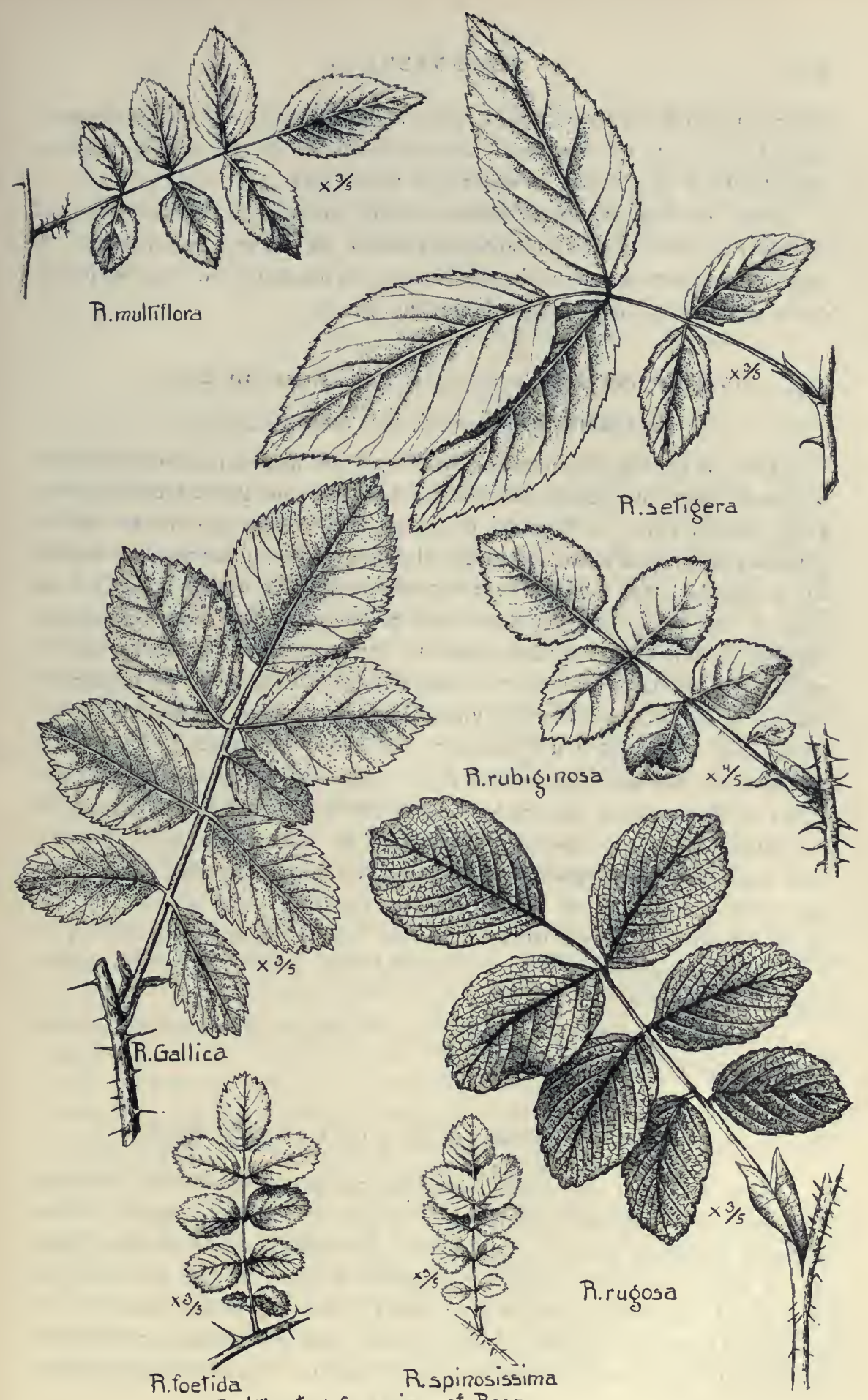

Cultivated Species of Rosa 
dular, the outer ones with well developed lateral lobes, petals pink, flower about 2-3.5 cm. in diameter; sepals deciduous in fruit, hip obovate, scarlet, about $12-15 \mathrm{~mm}$. in diameter: r u big in os a, rusty.

Native of Europe, widely naturalized in the eastern United States and on the Pacific Coast. Occasionally planted for its fragrant foliage. It is hardy without protection in the vicinity of Minneapolis, but the longer canes are apt to kill back and it seldom flowers.

\section{Rosa foetida Herrm a n 1762 Austrian Brier \\ R. eglanteria of Authors (? Linné 1753)}

Shrub 6-12 dm. high, stems dark reddish brown, armed with very numerous straight, strong, needle-like prickles, the longest about $1 . \mathrm{cm}$. long; leaves with 5-7 leaflets, fragrant, leaflets oblong, doubly serrate, glabrous above, hairy and somewhat glandular beneath, tip usually broadly wedge-shaped, base rounded or wedge-shaped, upper leaflets about $1.5 \mathrm{~cm}$. long, $1 \mathrm{~cm}$. wide, petioles hairy and prickly, stipules glandular, small, narrow, with acute triangular auricles; flowering shoots borne on the old wood, flowers usually solitary, pedicels smooth or prickly; receptacle smooth or hispid, sepals entire, glandular pubescent, petals golden yellow, flower 4-5 cm. across, fruit globose: f o e t i d a, bad smelling.

Eastern Europe and western Asia. The only form commonly cultivated in Minnesota is the semi-double "Harrison's Yellow" rose, a variety of American origin, possibly a hybrid with $\mathrm{R}$ os a spinos is $\mathrm{sim}$ a, and the only yellow garden rose commonly grown in this state. It is perfectly hardy without protection and ripens a large amount of seed so that it would not be surprising to find it growing spontaneously in the vicinity of old gardens. Flowers in early June, fruit dark reddish purple, ripe in September.

Other forms of Austrian briers would probably prove hardy here and would be useful gardew shrubs.

\section{Rosa spinosissima L i n 11 é I753 Scotch Rose}

Shrub 6 dm.-1 m. high, branches grayish, armed with numerous bristles and strong needle-like prickles; leaves with 7-11 leaflets, leaflets broadly elliptical, doubly or simply sharply serrate, glabrous, and bright green above, similar or slightly glandular beneath, $8 \mathrm{~mm} .-1.8 \mathrm{~cm}$. long, i mm. $-1.5 \mathrm{~cm}$. wide, stipules very small; flowering shoots borne on the old wood; flowers solitary, very fragrant, pedicels smooth or somewhat glandular, sepals entire, smooth, petals white, or in some forms yellowish 
or pinkish, flower 3-4 $\mathrm{cm}$. across ; sepals persistent and erect in fruit, hip globular, black: sp in os is s im a, most spiny.

Native of northern Eurasia, from Iceland to China. The typical form is cultivated as a flowering shrub and a semidouble white-flowered form is much grown in Minnesota. It is perfectly hardy, blooming in late May and June.

\section{Rosa gallica L i n n é I753 Rose}

Low bush with stems $1 \mathrm{~m}$. or less high, prickles unequal, scattered, slender, straight; leaves with 3-7 leaflets, leaflets thick, somewhat rugose, simply serrate, dull green and smooth above, paler, smooth or somewhat pubescent beneath, tip usually rounded, base rounded, the upper leaflets $1.5-4 \mathrm{~cm}$. long, $1-3 \mathrm{~cm}$. wide, petioles hairy and somewhat glandular, stipules somewhat dilated, thin; flowers solitary or in small clusters, pedicels glandular, receptacles somewhat prickly, sepals $2-3 \mathrm{~cm}$. long, glandular, the outer ones with lateral lobes, petals red or pinkish, flower $5 \mathrm{~cm}$. or more across; sepals inflexed and finally deciduous in fruit, hip dark red, almost globose: g a $11 \mathrm{ica}$, French, from its native country.

Native of southwestern Europe, established in the eastern United States. This rose is the parent of many garden varieties, some of which like the pale pink "blush rose" are the only large-flowered garden roses which are truly hardy in Minnesota.

\section{Rosa centifolia Lin n é 1753 Cabbage Rose}

Bush, $5 \mathrm{dm} .-1.5 \mathrm{~cm}$. high, stems green, prickles unequal, stout, hooked; leaves with 5-7 leaflets, leaflets thick and sharply serrate, nearly smooth on both faces, tip usually pointed, base rounded, upper leaflets $4-5 \mathrm{~cm}$. long, 2.5-3 cm. wide; petioles glandular; stipules somewhat dilated, glandular; flowers solitary or in small clusters, fragrant, pedicels glandular, receptacles smooth or somewhat prickly, sepals $2.5 \mathrm{~cm}$. long, glandular, the tips expanded and leafy with many lateral lobes, petals very numerous, pink, flower $8 \mathrm{~cm}$. across; fruit seldom formed, subglobose, orange red: centif olia, hundred-leaved.

Rosa centifolia L. var muscosa Seringe 1818, Moss Rose, whole plant more prickly and glandular. The glandular pubescence is particularly noticeable on the pedicels, receptacles, and large sepals.

The cabbage rose is a double pink rose of ancient and unknown origin, sometimes regarded as a variety of $\mathrm{R}$ os a gallica L., sometimes as a distinct species. The type and the moss varieties of various colors are 
often grown as garden roses in Minnesota but are not quite hardy without protection. During severe winters the canes often kill back to the level of the snow unless covered with straw.

\section{Garden Roses}

The large flowered garden roses are mainly rarietics of $\mathrm{R}$ os a $\mathrm{g}$ a $\mathrm{l}$ lica L. and Rosa centifolia L. and hybrids of these and other species. These species have been crossed with $\mathrm{R}$ os a $\mathrm{dam}$ a s cen a Mill, the Damask rose of southwestern Asia and especially with R os a $\mathrm{c}$ h i n e n s is Jacq. of eastern Asia. Many of the garden roses have most complicated pedigrees, the above mentioned species being crossed and recrossed with one another, sometimes with the introduction of yet other species.

The hardiest garden roses are the varietięs of $\mathrm{R} \mathrm{os} \mathrm{a} \mathrm{gallic} \mathrm{a} \mathrm{and}$ Rosa centifolia, but they flower but once each year. Rosa chinensis, the parent of most of our hothouse roses blooms contilluously but is tender. The hybrids of this species with $\mathrm{R}$ os a $\mathrm{g}$ a $11 \mathrm{ic} \mathrm{a}$ and $\mathrm{R}$ os a centifolia show varying degrees of hardiness, but all need good protection in Minnesota in winter. In general the freedom of bloom after the first blossoming season in June is inversely proportional to the hardiness of the rose.

\section{Cydonia (Tournefort) Miller I752 Quince}

\section{(L. c y d o n i a, quince, from Cydonia, a town of Crete)}

Shrubs or small trees, sometimes spiny, with alternate, stipulate, serrate or entire leaves; flowers large, scarlet or white, short-stalked, appearing before or with the leaves; calyx tubular-campanulate, sepals 5, petals 5, stamens 20 or more, carpels 5 with numerous ovules, styles united at the base; fruit a large 5-celled pome, firm when ripe, and fragrant.

A genus of three or four species and several subspecies, natives of warm temperate Asia and southern Europe. The cultivated quince belongs to this genus.

\section{Cydonia japonica Persoon 1807 Scarlet Quince}

Small, more or less spiny shrub, 1-2 meters (3-6 ft.) high; leaves ovate, serrate, glossy above, $3.5-7.5 \mathrm{~cm}$. long; flowers on the old twigs in 2-6 flowered clusters, appearing before or with the leaves, typically scarletred, $3.5-5 \mathrm{~cm}$. wide, sometimes only staminate; fruit globular or ovoid, 


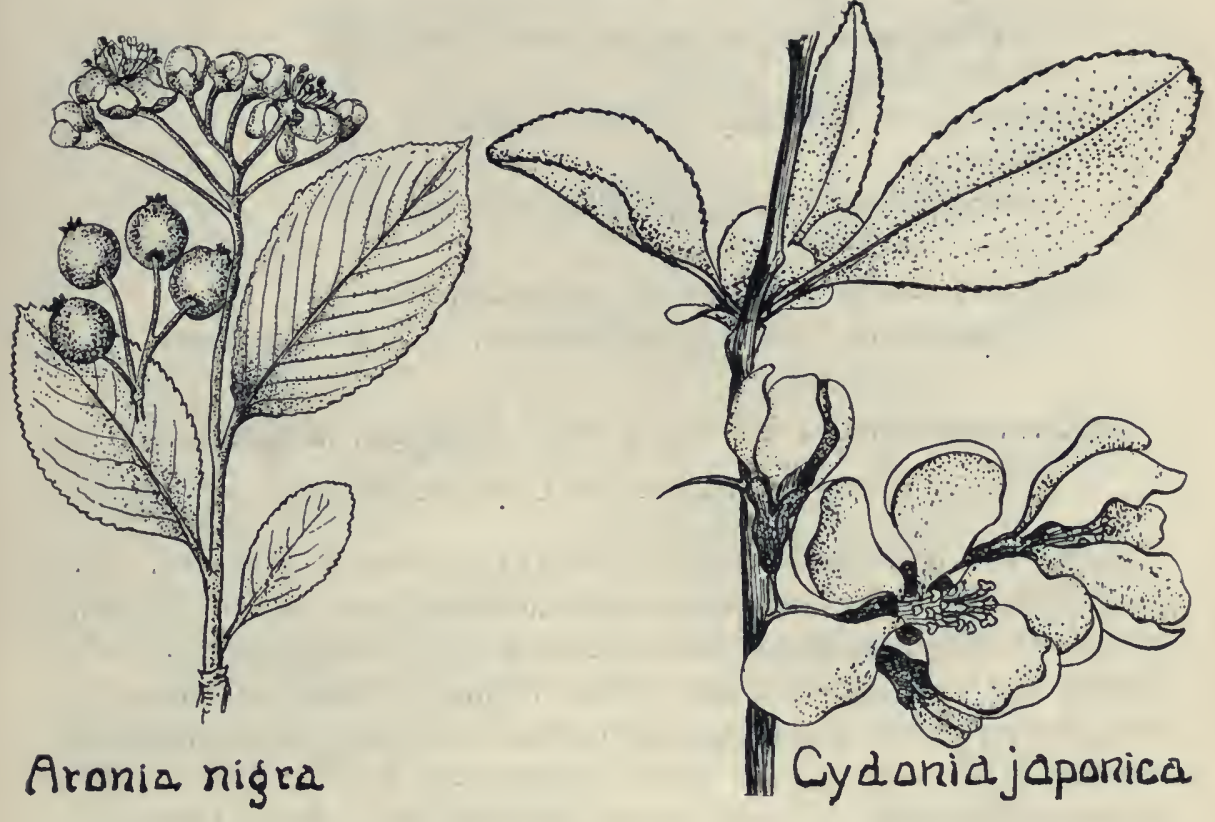

3.5-5 cm. in diameter, yellowish green, fragrant: $\mathrm{j}$ a p o $\mathrm{n} \mathrm{i} \mathrm{c} \mathrm{a,} \mathrm{Japanese.}$

Native of Japan. Used as an ornamental shrub in parks and gardens. Adapted for borders or shrubberies, and low ornamental hedges. Flowers in April and May.

\section{Sorbus Linné I753 Mountain Ash}

\section{(L. sorbus, the service-tree)}

Shrubs or trees with alternate, simple or compound leaves, stipules deciduous; flowers white, in terminal compound cymes; calyx 5-lobed, tube urn-shaped; petals 5, spreading, short-clawed; stamens numerous; ovary inferior; styles usually 3 , distinct; ovules 2 in each cell; fruit a small berry-like pome, red.

A genus of about 7 species, natives of the north temperate zone. Three species occur in North America. The genus is hardly separable from Pyrus and should probably only be regarded as a section of the latter. 


\section{Key to the Species.}

1. Leaflets acuminate, smooth on both sides; fruit 4-6 $\mathrm{mm}$. long

S. americana

2. Leaflets more or less obtuse, thicker; fruit 6-12 $\mathrm{mm}$. long

a. Leaflets pubescent below, especially along the veins; native

b. Leaflets always more or less pubescent or tomentose on both sides; cultivated

S. sambucifolict

S. aucuparia

\section{Sorbus americana M a r h h 11 I785 American Mountain Ash} Pyrus americana De Candolle 1825

Small tree, 6-7 meters (18-21 ft.) high; bark smooth, light gray, with small plate-like scales; winter buds acute, $8-18 \cdot \mathrm{mm}$. long, scales dark red, pilose with gummy secretion; leaves $15-20 \mathrm{~cm}$. long, petiole green or red, leaflets 13-17, oblong-lanceolate, sessile, rounded at base, acuminate at apex, sharply serrate, glabrous on both sides, bright green above, paler beneath, 5-8 cm. long, $1-2 \mathrm{~cm}$. wide; inflorescence flat, $10-15 \mathrm{~cm}$. broad, flowers cream-white, 4-6 mm. broad, calyx obconic; petals contracted below into a short claw; fruit sub-globose, $4-6 \mathrm{~mm}$. in diameter, bright red, flesh thin, sour: a me r i c a n a, American.

In woods of the northern part of the state. Distributed from Labrador to Manitoba, south into northern N. E., N. Y., and the Great Lakes region, extending south in the mountains to $\mathrm{N}$. C.

Flowers in May and June, fruits in Sept. and Oct. Sometimes planted as an ornamental tree. The wood close grained, light, soft and weak, pale brown, weight 34 lbs.

Sorbus sambucifolia (C. \& S.) R o e m e r 1847 Western Mountain Ash

Pyrus sitchensis (Roemer) Piper I906

Pyrus sambucifolia C. \& S. 1827

Small tree, 6-10 meters (18-30 ft.) high; bark gray and smooth with small scales; winter buds $18-20 \mathrm{~mm}$. long, acute, scales dark red and slightly hairy; leaves $10-15 \mathrm{~cm}$. long, petioles usually briglt red or green; leaflets $7-15$, oblong to lance-ovate, base rounded and unequal, apex obtuse or abruptly pointed, sharply and sometimes doubly serrate, with spreading teeth, dark green and glabrous above at maturity, paler beneath and 


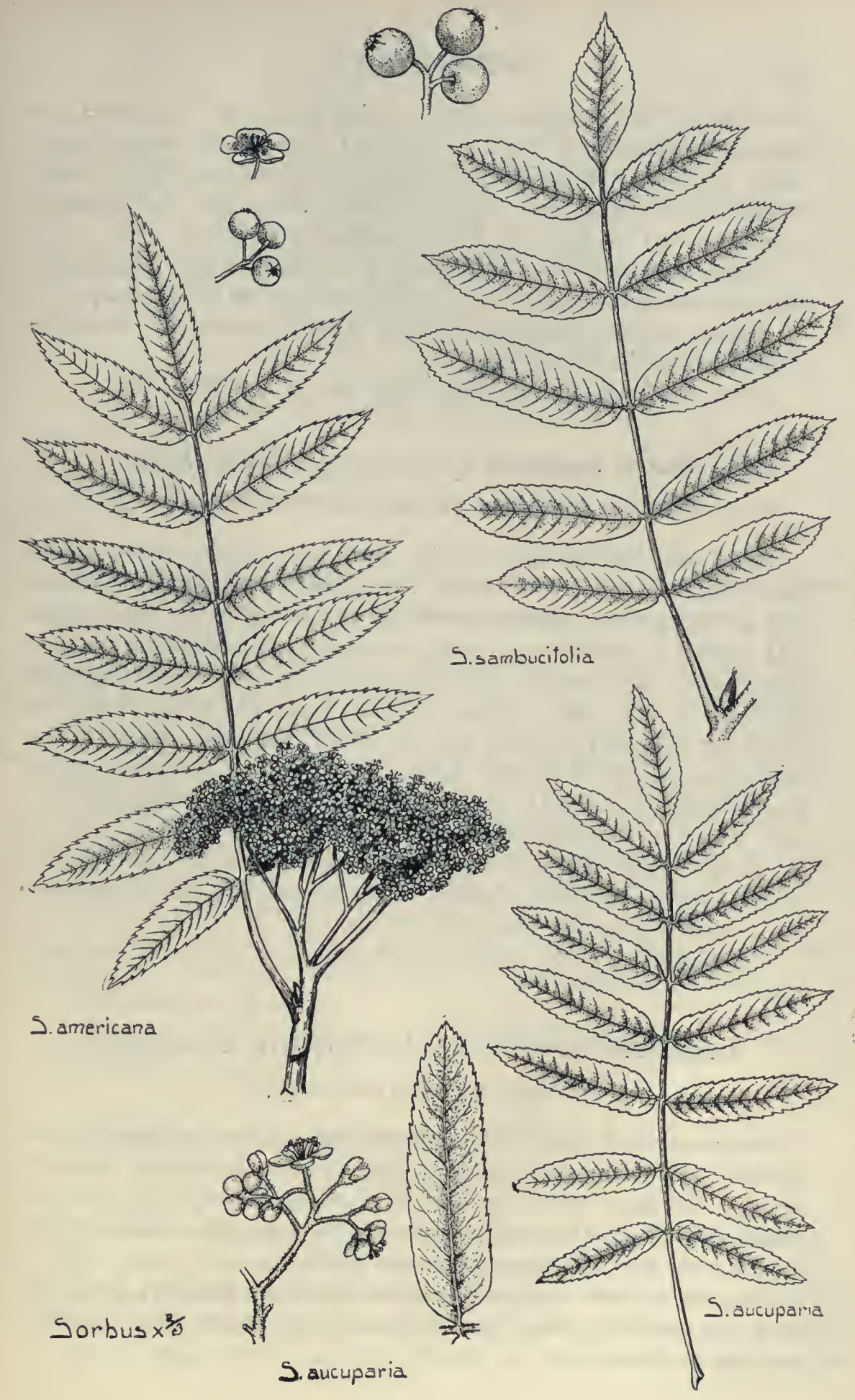


pubescent, at least along the veins, 5-7 cm. long, 1.8-2.5 cm. wide; inflorescence composed of several flat cymes, 5-7 cm. broad; flowers creamwhite, 8-12 mm. broad; calyx glabrous or puberulous; petals ovate, clawed; fruit subglobose, bright scarlet, 8-10 $\mathrm{mm}$. in diameter: $\mathrm{s}$ a m b u cifolia, leaves as in the elderberry, Sambucus.

Common on river banks and woods of the northern part of the state; rare southeastward, where it occurs along the bluffs of the Mississippi.

Distributed from Labrador to central Maine, westward and northward to Alaska, Kamchatka and Japan.

Wood close grained, soft, weak, light brown, weight 37 lbs.

\section{Sorbus aucuparia Li 11 né 1753 Rowan Tree}

Pyrus aucuparia (Linné) : Ehrhart 1787-92

Small tree, 7-80 meters (20-30 ft.) high; bark grayish, smooth; winter buds acute, 10-12 mm. long, vinous red, slightly white tomentose; leaves with reddish petioles, grooved on the upper side, $10-20 \mathrm{~cm}$. long, leaflets 9-15, oblong to lance-oblong, sharply serrate, usually rounded at the base, pointed at the apex, midrib furrowed, permanently more or less tomentose, especially on the lower surface, $3-7 \mathrm{~cm}$. long, 10-18 mm. wide; inflorescence somewhat flattened, $8-12 \mathrm{~cm}$. broad, tomentose, flowers numerous, cream-colored, $8-10 \mathrm{~mm}$. broad, calyx obconic, tomentose; petals nearly orbicular, clawed; fruit subglobose, $5-8 \mathrm{~mm}$. in diameter, red, sour; a u c u p a ria, bird catching.

Extensively planted as a shade and ornamental tree and now and then escaping from cultivation, especially in the southeastern part of the state.

Flowers in June and July, fruits in August.

The characters of the wood are about the same as that of the native species.

\section{Amelanchier Me dicus I789 Juneberry Service-berry}

\section{(Name of uncertain origin)}

Small trees and shrubs with alternate, simple, serrate or dentate leaves; flowers white, in raccmes; calyx 5-cleft, the tube bell-shaped, petals 5, ovate to oblong or rarely linear, stamens numerous, carpels 5, ovary becoming 10-celled in fruit, styles united at the base and becoming hairy; fruit a small berry-like pome, sweet and edible.

A genus of about 12 species, natives of the north temperate zone. Besides the following, some three others occur in western North America and one in Mexico. 


\section{Key to the Species.}

1. Petals narrowly oblong, $14-25 \mathrm{~mm}$. in length;

leaves finely and sharply serrate

A. canadensis

2. Petals oblong to obovate, $4-12 \mathrm{~mm}$. in length

a. Flowers in racemes, 5-many flowered; leaves obtuse or cordate at base

(1) Leaves oblong, finely serrate; blossoming April 10-May 15, fruits June-July

(2) Leaves oval or sub-orbicular, coarsely

dentate; blossoming May 15-25, fruit ripe Aug.-Sept.

A. oblongifolia ers 1-4 in terminal clusters; leaves acute

b. Flowers 1-4 in terminal clusters; leav
or somewhat wedge-shaped at base

A. spicata

A. oligocarpa

Amelanchier canadensis (L.) Me dic us I793 Shadbush Juneberry Service-berry

A tall shrub or sometimes a small tree 3-12 meters (10-40 ft.) high; bark smooth or nearly so; buds 6-8 $\mathrm{mm}$. long, scales chestnut-brown, imbricated, slightly pubescent; leaves ovate or oval, acute or acuminate at the apex, somewhat cordate at the base, finely and sharply serrate, when young folded lengthwise and brownish purple, somewhat pubescent at first but soon glabrate, bracts and stipules long-silky hairy, flowers in drooping racemes, white, large, petals narrowly oblong, 14-25 mm. long, 3-4 times as long as the calyx; fruit a globose pome, red or purple, about $6 \mathrm{~mm}$. in diameter: $\mathrm{c}$ a $\mathrm{n}$ a d e $\mathrm{ns}$ is, Canadian.

Along banks of streams, river bluffs, shores of lakes, etc., common throughout the state. Distributed from Newfoundland to Minnesota, south to Florida and Louisiana.

Flowers in April and May, fruit ripe in June and July. Wood very hard, brown, weight 49 lbs.

\section{Amelanchier oblongifolia ('Torrey \& Gray) R o e m e r 1847}

\section{A. spicata of Authors.}

A shrub or small tree, 2-6 meters (6-20 ft.) high, bark as in preceding species; leaves oblong, usually rounded at each end, sometimes mucronate at the tip, finely and sharply serrate, densely white tomentose when young, becoming glabrate, usually pale green, especially beneath, 4-6 cm. long, $1.5-2.5 \mathrm{~cm}$. wide; flowers in rather dense white tomentose 

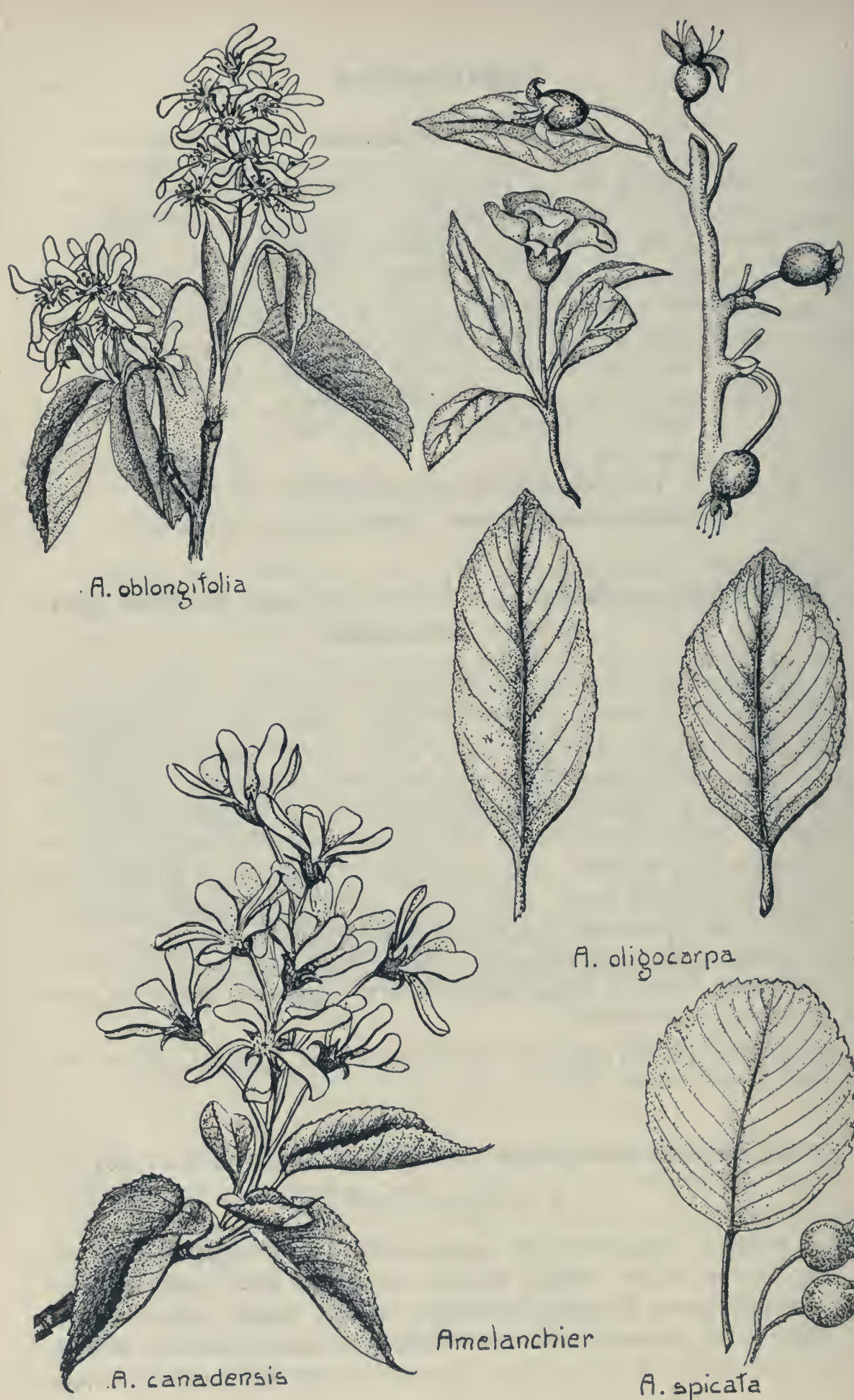

A. digocarpa

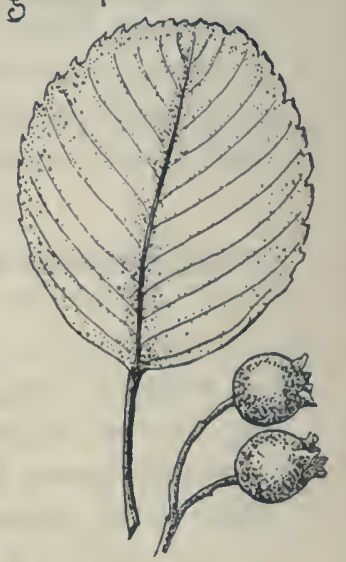

A. spicata 
racemes, small, petals obovate or slort-oblong 7-10 $\mathrm{mm}$. long; fruit about $5-6 \mathrm{~mm}$. in diameter, red or purple, juicy: o b l o $11 \mathrm{~g}$ i f o $1 \mathrm{i}$ a, with oblong leaves.

Common on edges of river bluffs, rocky uplands etc. throughout the state. Distributed from New Brunswick to Virginia, Missouri and Minn. Flowers early, from April 15 to May 15, fruit ripe in June and July.

\section{Amelanchier spicata (Linné) C. K o c ll} Amelanchier rotundifolia Roemer I847 Amelanchier alnifolia of some Authors

A shrub 1-3 meters (3-10 ft.) high; bark smooth; buds 6-7 mm. long, scales brown, imbricated, pilose or smooth; leaves oval or orbicular, coarsely dentate towards the end or sometimes nearly to the base, veins numerous and straight, while young the lower surface at least covered with a dense yellowish white tomentum, becoming glabrous with age, $3-8 \mathrm{~cm}$. long, 2.3-5.5 cm. wide; flowers in short racemes, rather dense, white, petals 6-12 mm. long; fruit dark purple, 6-8 $\mathrm{mm}$. in diameter: $\mathrm{sp}$ ic a t a, in a spike, referring to the short dense racemes.

Woods, thickets, and banks of streams, infrequent throughout the state. Distributed from eastern Quebec to central Manitoba, south to central Mass., westward as far as Minn. Flowers from May 20 to June 25, fruit ripe in August and September.

\section{Amelanchier oligocarpa (Michaux) R o e m e r $\mathrm{I} 847$}

A shrub 1-3 meters (3-19 ft.) high, with smooth bark; leaves narrowly oblong or oval, usually acute at the base, finely serrate, early glabrate or nearly so, 3-5 cm. long; flowers solitary and terminal or in terminal 2-4flowered racemes, petals obovate or oblanceolate, $6-8 \mathrm{~mm}$. long; fruit pear-shaped or sub-globose, $6-8 \mathrm{~mm}$. long, dark purple with dense bloom: o 1 i g o c a r pa, of few fruits.

In cold swamps and wet rocky places, northern and northeastern part of the state. Distributed from Labrador to New England, westward to Minn. Blossoms in May, fruits in Autumn.

\section{Aronia P e r s o o n 1807 Chokeberry}

(L. a r on ia, formed from aria, the beam-tree)

Low shrubs, with alternate simple finely serrate leaves; flowers small, white or pink, in terminal, compound cymes; calyx 5-lobed, urn-shaped; 
petals 5, spreading; styles $3-5$, united at the base; ovary woolly, pome small, berry-like.

A North American genus of two species, probably not to be separated from the genus Pyrus. Besides the following species, another occurs in the eastern part of the United States.

\section{Aronia nigra (Willdenow) B ritt o n 1894 Black Chokeberry Pyrus nigra Sargent I89o}

A branching shrub 1-1.5 meters (3-5 ft.) high, bark smooth grayish; leaves from broadly oblong and acuminate to spatulate-oblanceolate, finely glandular serrate, narrowed at the base, acute or mucronate at the apex, glabrous or nearly so on both surfaces, $2-7 \mathrm{~cm}$. long, $1-2.5 \mathrm{~cm}$. wide, petiole 5-6 mm. long; corymbs 3-5 cm. long, several-flowered, flowers white, $10-12 \mathrm{~mm}$. broad; calyx and pedicels slightly tomentose or soon becoming glabrous; petals ovate, 4-5 mm. long; fruit a globose pome, 6-8 mm. in diameter, black or purplish: $\mathrm{n}$ i $\mathrm{g} \mathrm{r}$ a, black, from the color of the fruit. (See Fig. page 147.)

In swamps and moist ground, occurring in the eastern part of the state from Olmsted county northward. Distributed from Nova Scotia to western Ontario, south to Florida and Minnesota. Flowers in May and June, fruits in August.

\section{Crataegus Li in né I753}

(Gr. krataigos, the hawthorn tree, from $\mathrm{kratos}$, strength, referring to the wood)

Thorny shrubs or small trees, with alternate, simple, usually lobed leaves; buds small obtuse, 3-4 mm. long, scales imbricated; flowers in corymbs; calyx tube cup-shaped or campanulate, adnate to the carpels, 5-cleft or divided; petals 5, rounded, white or rose color; stamens 5-25, in 1-3 rows, anthers oblong, yellow or red; ovary inferior, consisting of 1-5 carpels, styles distinct; fruit a small pome, yellow or red, flesh dry or mealy, nutlets $1-5$, each usually 1 -seeded.

A large genus, widely distributed throughout the temperate regions of the northern hemisphere. The genus offers great taxonomic difficulties and it is impossible at present to say how many species the genus includes. Of late years numerous species have been segregated and described, but it is very likely that when the group is thoroughly monographed a large proportion of these will have to be withdrawn. 
No critical work has as yet been done on Minnesota Crataegi and for that reason it has been thouglit advisable to adhere only to the broader concept of species in this work. It is therefore to be expected that after more extensive collection and careful systematic work several more species will be credited to the state.

\section{Key to the Species.}

1. Leaves ovate, elliptic-ovate or nearly orbicular in outline, mostly lobed, more than $4 \mathrm{~cm}$. wide

a. Leaves cordate to truncate at the base, densely tomentose below, fruit pubescent

C. mollis

b. Leaves cuneate at the base, glabrous or pubescent, fruit glabrous

(1) Leaves ovate-orbicular, coarsely serrate, glabrous on both sides

C. rotundifolia

(2) Leaves rhombic-elliptic, pubescent, at least on the veins beneath coarsely serrate

(a) Leaves coriaceous, dark green and shining above

C. macracantha

(b) Leaves thin, dull green, pubescent and with impressed veins above

C. tomentosa

2. Leaves obovate, oblanceolate, or spatulate, slightly or not at all lobed, mostly $2-4 \mathrm{~cm}$. wide

a. Leaves dull, gray-green, pubescent

C. punctata

b. Leaves bright green, glabrous and shining

C. crus-galli

Crataegus mollis (Torrey and Gray) Sche ele I845 Red-fruited Thorn

A shrub or small tree 2-7 meters (6-21 ft.) high; branches armed with thorns 3-6 cm. long, lustrous, or at last grayish; bark of trunk ashy gray; leaves broadly ovate, cordate to truncate at the base, acutish at the apex, jobed, sharply and rather coarsely serrate, rough above, densely tomentose below, 4-13 cm. long, 4-10 cm. wide; corymbs several- to many-flowered; flowers white, about $2 \mathrm{~cm}$. broad, pedicels and calyx densely tomentose, stamens about 20 ; fruit sub-globose, scarlet, $1.5-2 \mathrm{~cm}$. in diameter, pubescent when young, flesh yellow, nutlets usually 5, 7-8 mm. long, dropping off as soon as ripe: $\mathrm{mol} 1 \mathrm{is}$, soft, referring to the leaves. 


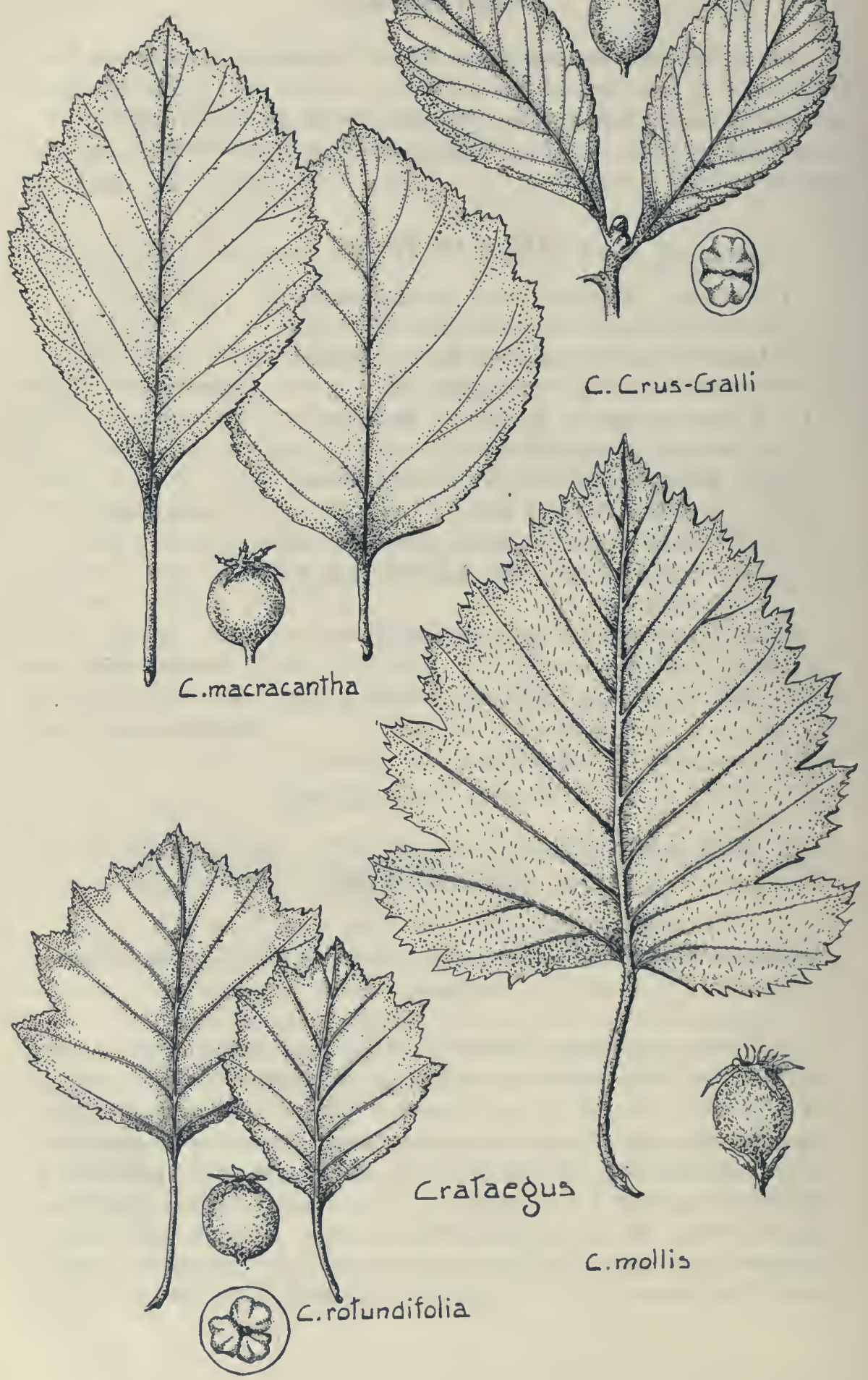


Perhaps common from the region of Minneapolis southward and westward. Distributed from southern Ontario to eastern S. Dak., eastern Kan., and south to Mo. and $\mathrm{Ky}$. This species is said to be the largest and handsomest of the scarlet hawthorns of North America. The wood is light brown or red, close grained and hard and weighs 49 lbs. Blossoms in May, fruits in September.

\section{Crataegus rotundifolia M o en ch $\mathrm{I} 794$ Glandular Thorn}

A shrub or small tree, 3-5 meters (9-15 ft.) high; bark smooth, greenish gray; branches spiny, spines $3-5 \mathrm{~cm}$. long; leaves ovate, orbicular or obovate, broadly cuneate at the base, acute at the apex, 3-4 pairs of lobes, doubly serrate, entirely glabrous, $3-6 \mathrm{~cm}$. long, 3-6 cm. wide; corymbs glabrous or slightly pubescent; flowers white, about $1.5 \mathrm{~cm}$. broad, calyx lobes lanceolate, glandular serrate, slightly villous inside, about $5 \mathrm{~mm}$. long; stamens 5-10, styles $2-4$; fruit $1 \mathrm{~cm}$. long, red, flesh yellow, sweet: rot undif o li a, round leaved.

Common throughout the state. Occurs from Nova Scotia to southern Minn. and northern Ill., in the Alleghenies, south to Va. Flowers in May, fruit ripe in September.

\section{Crataegus macracantha Loddiges 1854 Long-spined Thorn}

A bushy tree, 3-6 meters (10-20 ft.) high; bark ashy gray or light brown; thorns on the straggling branches $5-10 \mathrm{~cm}$. long, bent, chestnut brown, on the main stem $7-20 \mathrm{~cm}$. long and branched; leaves rhombicovate to obovate, wedge-shaped and contracted below into the wide petiole, acute at the apex, sharply lobed, doubly and sharply serrate, coriaceous and shiny above, slightly hairy on the veins beneath, $2-8 \mathrm{~cm}$. long, 2.5-6 $\mathrm{cm}$. wide; corymbs slightly villous; flowers $1.5-2 \mathrm{~cm}$. broad; sepals glandular, about $4 \mathrm{~mm}$. long; stamens 10 ; styles $3-4$; fruit sub-globose, 8-10 $\mathrm{mm}$. in diameter; nutlets $3-4,5-7 \mathrm{~mm}$. long: $\mathrm{m} \mathrm{acrac} \mathrm{anth} \mathrm{a,} \mathrm{with}$ long thorns.

Common throughout the eastern and southeastern parts of the state. Distributed from Novia Scotia to Manitoba, southward in the mountains to Virginia.

The wood is brown and tinged with red, hard and close grained. Flowers in May, fruit ripe in Sept.

\section{Var. succule nt a (Schrader) Eggleston igo8}

A variety with.somewhat larger fruit and about 20 stamens. Occurs with the species. 


\section{Crataegus tomentosa L in n é 1753 Pear-thorn, Pear Haw}

C. Chapmani (Beadle) Ashe Var. Plukenetii Eggleston Gray's New Manual 1908

A small tree or shrub, 2-5 meters (6-15 ft.) high; bark of main stem gray or fissured; branches spiny, spines $3-5 \mathrm{~cm}$. long, clothed with tomentum when young; leaves rhombic-ovate, narrowed below into broad petioles, acute or acuminate at the apex, mostly incisely lobed, sharply serrate, pubescent on both sides, becoming scabrate, dull green, 4-11 cm. long, 3-8 cm. wide, petioles pubescent; corymbs white tomentose; flowers $1-1.5 \mathrm{~cm}$. broad; stamens $10-20$; styles $2-4$; fruit upright, pyriform to ellipsoid, $1-1.5 \mathrm{~cm}$. long, orange red, flesh yellow, nutlets $2-3$, about 5-7 $\mathrm{mm}$. long, strongly ridged on the back: $\mathrm{t}$ o me n t o s a, woolly.

Probably throughout the state. Distributed from southern Ontario to N. J., westward to Minn. and eastern Kan., and in the mountains to Ga.

Flowers in May, fruit ripe in Sept.

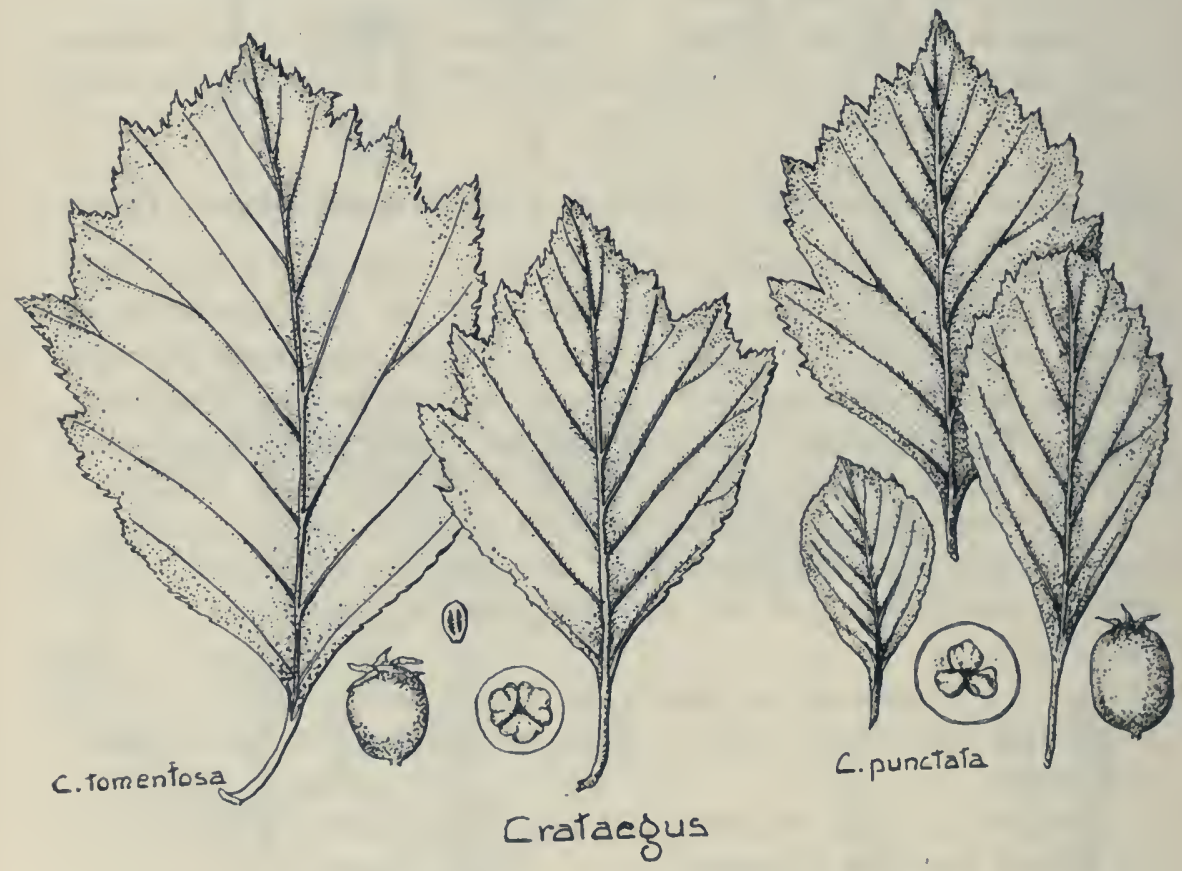

Crataegus punctata J a c q $u$ i n 1770 Large-fruited Thorn

A flat or round-topped tree, 3-9 meters (9-28 ft.) high; branches spreading at right angles with the spiny stem, $9-16 \mathrm{~cm}$. in diameter; bark 
rough, dark gray or brown; ieaves wedge-obovate or spatulate, wedgeshaped at the base, rounded or acute at the apex, doubly serrate, sometimes lobed, dull gray-green, becoming orange or scarlet in autumn, scattered pubescent and impressed-veined above, strongly pubescent on the veins below, 2-8 cm. long, $1-4 \mathrm{~cm}$. wide; corymbs flat, tomentose; flowers $1-2$ $\mathrm{cm}$. broad, calyx tube obconic, pubescent, stamens about 20 , anthers white to pink, styles $2-5$; fruit pyriform or subglobose, $1.2-1.5 \mathrm{~cm}$. in diameter, yellow or red, flesh thin, dry, nutlets $3-4,8 \mathrm{~mm}$. long: p u n c t a t a, dotted.

Common throughout the southeastern part of the state and in the Big Woods country. This is the largest and commonest of our native species of Crataegus. Distributed from Quebec to Minn., through western New England to Pa., Ill., and Iowa, along the mountains to Ga.

The wood is bright red in color, close grained, hard and heavy, weigh. ing about 49 lbs. Flowers in May and June, fruits in Aug. and Sept. Fruit drops off when ripe.

\section{Crataegus crus-galli Linné 1753 Newcastle Thorn, Cockspur Thorn}

A shrub or a small tree, 2-6 meters (6-20 ft.) high, with spreading branches and gray bark, thorns numerous, slender and nearly straight, 4-8 cm. long; leaves obovate or oblanceolate, sometimes nearly spatulate. very much narrowed at the base, obtuse or abruptly acuminate at the apex, sharply serrate except at the base, leathery and shining above, duller beneath, glabrous on both sides, $3-6 \mathrm{~cm}$. long, $1-4 \mathrm{~cm}$. wide, petioles short, passing gradually into the blade; corymbs many-flowered, glabrous, $4-6 \mathrm{~cm}$. broad; flowers $1.2-1.5 \mathrm{~cm}$. broad, calyx lobes narrowly lanceolate, glabrous or slightly pubescent, about $3 \mathrm{~mm}$. long, stamens 10, styles 1-3; fruit ovoid or sub-globose, about $1 \mathrm{~cm}$. long, greenish to dull red, firm; cr u sg a 11 , cock's spur.

Occasionally planted but not native to the state. Occurring in thickets from western Quebec and Ontario to southern Michigan, southeastern Kansas and south to Georgia.

\section{Malus J u s s i e u 1789}

(M a lus, classical L. name of the apple-tree)

Trees or shrubs with alternate, toothed or lobed, simple leaves; flowers in corymbs or umbel-like cymes, white or pink, showy and fragrant ; calyx tube bell-shaped or urn-shaped; sepals 5; petals 5, rounded or obovate; 
stamcns numerous; carpels 2-5, papery or leathery; styles united at the base; fruit usually a large fleshy pome, sometimes small and berry-like.

A genus of about 15 species, natives of the north temperate zone. Besides the following, one occurs in eastern and one in western North America.

\section{Key to the Species.}

1. Leaves and outer surface of sepals glabrate, cultivated trees or shrubs

a. Leaves thick, flowers very numerous, fruit $1-1.2 \mathrm{~cm}$. or less, red

M. Aloribunda

b. Leaves thin, flowers less numerous, fruit 1.5-

$2.5 \mathrm{~cm}$., yellow

M. baccata

2. Leaves and outer surface of sepals persistently tomentose, native or cultivated

a. Leaves rounded or cordate at the base, pome

$5-10 \mathrm{~cm}$. in diameter, cultivated

M. silvestris

b. Leaves mostly narrow at the base, pome 2.5-

$3.5 \mathrm{~cm}$. in diameter, native

M. ioensis

\section{Malus floribunda Sie b o I d $1835-44$ Flowering Crab Pyrus floribunda Nicholson.}

A shrub or sometimes a small tree, often spiny, young branches smooth or soon becoming so; leaves ovate, acuminate at the apex, finely and sharply serrate, smooth and shining above, glabrous below, at least in age. thickish, 4-7 cm. long; petioles thick and reddish, about $2.5 \mathrm{~cm}$. long; flowers in umbels, appearing with the leaves and very numerous, white and showy, carmine in bud; fruit $1-1.2 \mathrm{~cm}$. in diameter, red: $\mathrm{f} l$ or i b u $\mathrm{n} d \mathrm{a}$, many flowers.

Planted in gardens and parks as an ormamental tree of shrub. Native of Japan.

\section{Malus baccata (Linné) M o e n ch 1794 Siberian Crab Pyrus baccata Linné 1753}

A small tree with spreading branches; leaves ovate-oblong, finely and evenly serrate but not lobed, acuminate at the apex, thin and glabrous on both sides, at length becoming subcoriaceous, $4-8 \mathrm{~cm}$. long; petioles slender $2-3 \mathrm{~cm}$. long; flowers appearing with the leaves, fascicled, petals narrowly oblong, with narrowed, elongated base, pedicels green, 5-7 cm. long; fruit on long hard stems, $1.5-2.5 \mathrm{~cm}$. in diameter, yellow with a reddish cheek, 


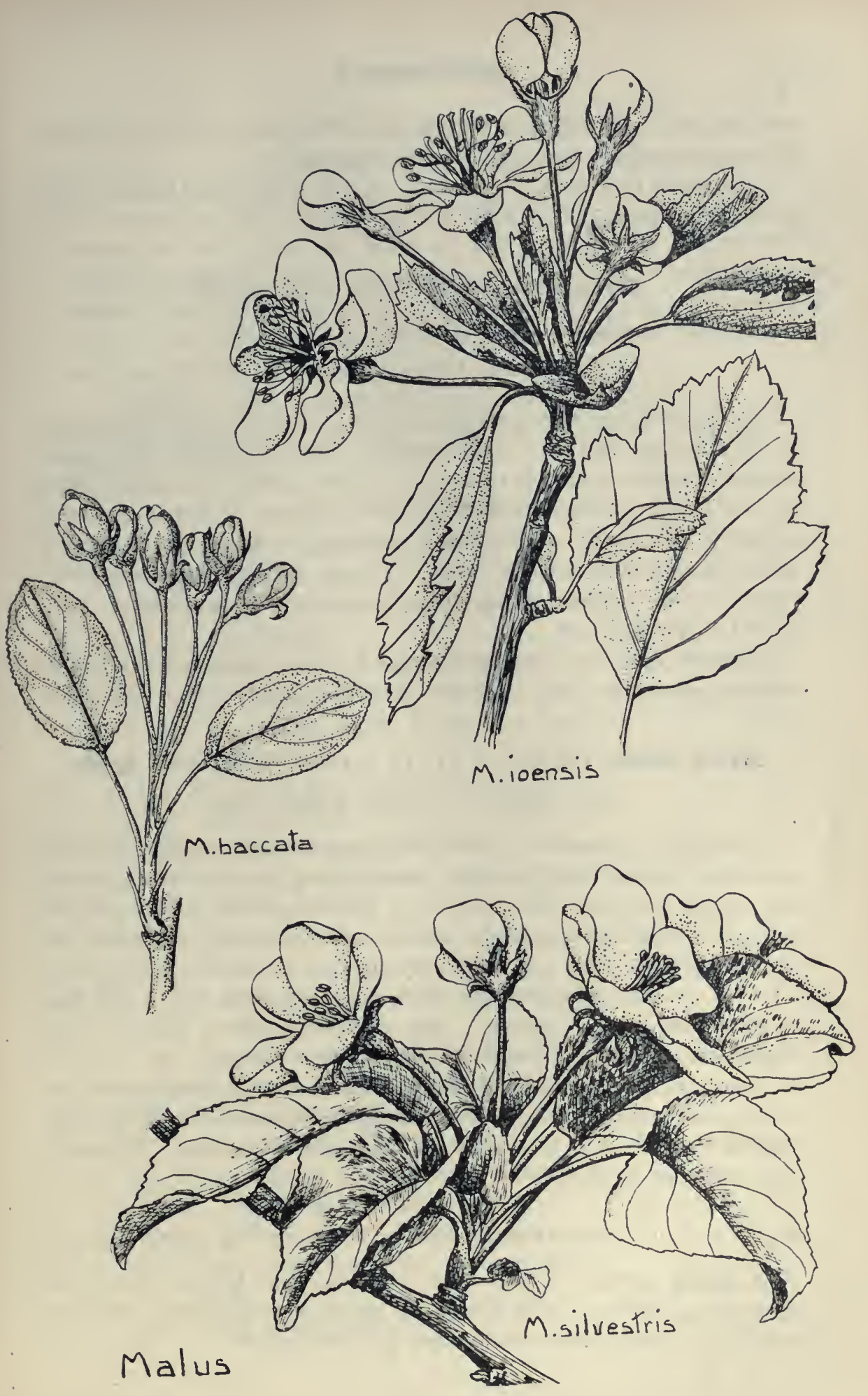


firm and often translucent in texture, never becoming mellow, calyx falls off before maturity: b a c a t a, having berries.

Introduced from Europe and Asia. Native of Siberia, Manchuria and the Himalaya region.

\section{Malus silvestris Mi11 e r I768 Apple Malus Malus (Linné) Britton 1897 Pyrus Malus Linné 1753}

A cultivated tree with spreading branches, sometimes reaching a lreight of 10-15 meters (30-45 ft.); bark on mature trunks rough and gray; leaves broadly ovate or rounded or cordate at the base, acute at the apex, dentate or nearly entire, sometimes slightly lobed, glabrous or nearly so above, pubescent and often woolly beneath, especially when young; flowers in umbel-like corymbs, white or pink, $3.5-7 \mathrm{~cm}$. broad; calyx tomentose; pedicels stout, woolly, $2-3 \mathrm{~cm}$. long; fruit $5-10 \mathrm{~cm}$. in diameter: $\mathrm{sil}$ vest ris, of the forest.

Common fruit tree, sometimes escaped from cultivation. Numerous -varities or races have been developed from this species through cultivation.

\section{Malus ioensis (Wood) B ritt o n 1897 Wild Crab Apple Pyrus joensis (Wood) Bailey I89I}

A small tree, sometimes a shrub 2-6 meters (6-12 ft.) high; branchlets sometimes hardened and thorn-like; leaves oblong or ovate-oblong, usually narrowed at the base, doubly serrate or pinnately several-lobed, glabrate, dull green and somewhat rugose above, pale and densely tomentose beneath, $2.5-5 \mathrm{~cm}$. long; petioles woolly; flowers in corymbs, rose colored, 2.5-4 cm. broad, pedicels slender, tomentose, becoming 2.5-3.5 cm. long in fruit; calyx lobes persistent; fruit green or yellowish green, $2-4 \mathrm{~cm}$. in diameter: i o e n s is, named from the original locality.

Along edges of woods and thickets, common in the southeastern part of the state, comparatively rare as far north as the Twin Cities. Distributed from Ill, and Wis. to Minn., Kan. and Oklahoma. Flowers in May, fruit ripe in October.

Malus Soulardi (Bailey) Britton Soulard's Crab Apple

A hybrid between Malus silvestris and Malus ioensis, reported to occur in a wild state from Minnesota southward. May possibly occur in the extreme southeastern part of the state. 


\section{Prunus Lin né I753}

(Classical L. name of the plum-tree)

Trees or shrubs, sometimes spiny; leaves alternate, simple and serrate; flowers variously clustered, white or pink; calyx tube campanulate or obconic, sepals 5, petals 5, spreading; stamens 15-20, distinct, filaments slender; pistil 1, in the hollow cup-shaped calyx tube, style terminal; ovule 1 ; fruit a drupe, stone smooth or a little roughened, globose or oval, or oblong and flattened.

A genus of 90 species, natives of the north temperate zone, tropical America and Asia. In addition to the following about 25 species occur in North America.

\section{Key to the Species.}

1. Flowers single Cherries and Plums

a. Large shrubs or trees

(1) Flowers in racemes, terminating the season's growth

(a) Small tree, or large shrub, leaves broadly ovate $P$. virginiana

(b) Large tree, leaves narrowly ovate or lanceolate

P. serotina

(2) Flowers in scaly umbels or corymbs, expanding with or before the leaves

(a) Branches usually thorny or armed, fruit sub-globose, borne singly Plums

x. Teeth of leaves obtuse, gland-tipped, stone of fruit flat

y. Teeth of leaves acute, bristle-tipped, stone round

(b) Branches not thorny or armed, fruit globose or sub-globose Cherries

$x$. Flowers in corymbs, small, petals 4-6 $\mathrm{mm}$. long, fruit 3-6 mm.

y. Flowers in umbels, large, petals 8-12 $\mathrm{mm}$. long, fruit 8-15 mm.

P. nigra

$P$. americana

$P$. pennsylvanica

P. cerasus

b. Dwarf shrubs, (1-4 ft.), with narrow leaves

(1) Shrub with wand-like branches, leaves thin

P. pumila

(2) Bushy shrub, leaves thick

P. Besseyi 
2. Flowers double Flowering almonds and plums
a. Leaves lanceolate, flowers $2-3 \mathrm{~cm}$. broad
P. japonica
b. Leaves ovate, mostly 3 -lobed, flowers $3-5 \mathrm{~cm}$. broad
P. triloba

\section{Prunus virginiana Lin né 1753 Choke Cherry}

A tall shrub or a small tree 1-3 meters (3-10 ft.) high, with grayishbrown bark, the inner layers of which have strong, disagreeable odor; leaves oval, oblong, or obovate, rounded at the base, abruptly acute or acuminate at the apex, sharply serrate with slender teeth, glabrous or slightly pubescent along the veins beneath, thin, $4-8 \mathrm{~cm}$. long, $2-4.5 \mathrm{~cm}$. wide; petiole $1-1.5 \mathrm{~cm}$. long, with 1 or 2 glands; racemes erect or spreading, terminating the leafy shoots of the season, 5-12 cm. long, manyflowered, flowers white, strong scented, $0.8-1 \mathrm{~cm}$. broad; pedicels 4-6 mm. long; fruit red or nearly black, $8-10 \mathrm{~mm}$. in diameter, very astringent, stone globular: vi r g i n i a n a, Virginian.

Common throughout the state. Distributed from Newfoundland to Ga. and westward to Minn. and British Columbia.

The fruit is sometimes used for making wine and preserves; it was formerly an important article of food among the North American Indians. The wood is heavy, hard and close grained, light brown in color and weighs 40 lbs. per cubic foot. Flowers in May, fruit ripe July and August.

\section{Prunus serotina Eh $\mathrm{r}$ ha $\mathrm{rt}$ I 788 Wild Black Cherry, Cabinet or Rum Cherry}

A large forest tree, 12-25 meters (36-75 ft.) high and 2-5 dm. (7-22 inches) in diameter, (in more southern localities reaching much greater dimensions); bark dark brown, very rougl and peeling off in flakes, branches reddish brown, inner bark fragrant; leaves oblong or lanceolateoblong, round or narrowed at the base, long pointed at the apex, shining. above, glabrous or pubescent along the veins beneath, serrate with appressed callous teeth, $4-12 \mathrm{~cm}$. long, $2.5-3.5 \mathrm{~cm}$. wide; petioles $2-3 \mathrm{~cm}$. long; racemes at the ends of leafy shoots, spreading or drooping, flowers numerous, white, $8-10 \mathrm{~mm}$. broad; fruit rounded, $8-10 \mathrm{~mm}$. in diameter, dark purple or black, slightly astringent, but with sweetish taste: serotina, late ripe.

Rather common throughout the hardwood region of the state. Distributed from Nova Scotia to Fla., west to Dakota, Arizona, and along. the mountains of Mexico, Central America and Peru. 


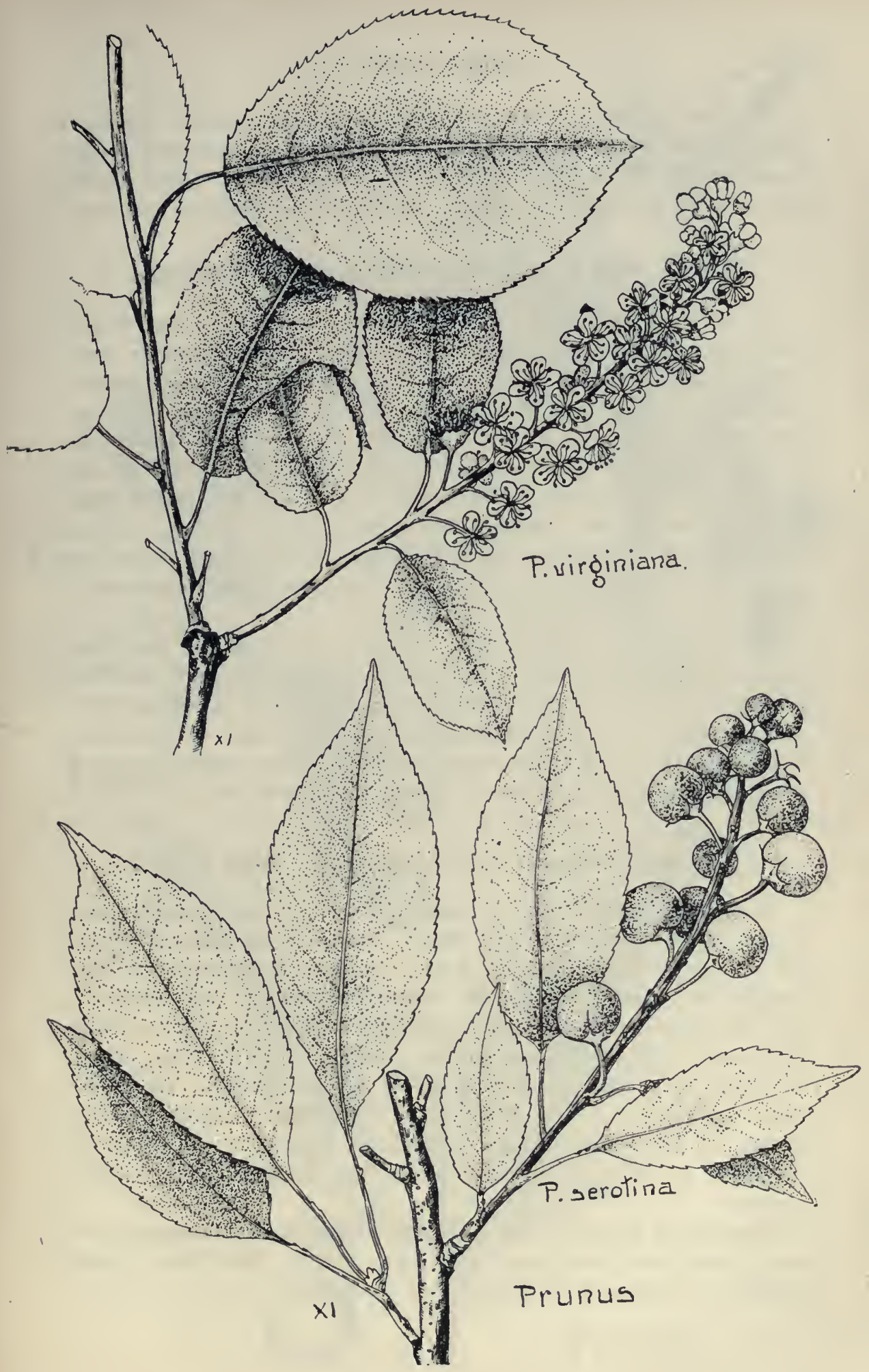


The fruit is used to flavor alcoholic liquors and sometimes fermented and made into a liquor. The wood is close grained, hard, strong, reddish brown in color, a cubic foot weighs $36 \mathrm{lbs}$. It is used in cabinet making and is capable of a very high polish. Flowers in May, fruit ripe Aug.-Sept.

\section{Prunus nigra A it on 1789 Canada Plum Wild Plum}

A shrub or small tree 2-7 meters (6-21 ft.) high, armed with thorns; bark brownish gray, exfoliating in plates; leaves oval to broadly ovate, obtuse or slightly cordate at the base, long acuminate at the apex, crenateserrate, the teeth usually gland-tipped, pubescent when young, $7-13 \mathrm{~cm}$. long, 3-7 cm. wide; petioles $1-1.5 \mathrm{~cm}$. long, with 1 or 2 red glands near the base; flowers in lateral umbels, opening before the leaves, $2.5-3 \mathrm{~cm}$. broad; calyx lobes glandular serrate, glabrous within; petals white, pinkish tinged towards the base, broadly obovate, 1.2-1.4 cm. long; stamens pinkish tinged; fruit orange, pink or yellow, sub-globose or compressed ovoid, with little or no bloom, $2.5 \mathrm{~cm}$. long, stone oval, compressed or flattened: nigra, black.

River banks and thickets. In the eastern part of the state from north to south, infrequent. Distributed from Newfoundland and New England westward to the Great Lakes, Lake Winnepeg and south to Iowa.

The fruit is very delicious, rather firm fleshed, used for jellies and preserves. The wood close grained, hard and heavy, reddish brown in color and weighs 43 lbs. Flowers in May, fruits in August.

\section{Prunus americana Marsha 11 I785 Wild Plum}

A shrub or a small tree, 3-10 meters (9-30 ft.) high; branches more or less thorny; bark thick and rough, exfoliating in irregular plates; leaves ovate or obovate rounded at the base, long acuminate at the apex, sharply and doubly serrate, the teeth bristle-tipped, not glandular, pubescent when young, glabrous or nearly so when mature, $4-10 \mathrm{~cm}$. long, $2-5 \mathrm{~cm}$. wide; petioles with or without glands, about $1 \mathrm{~cm}$. long; flowers in sessile, lateral umbels, opening before the leaves, white, $1.5-2.5 \mathrm{~cm}$. broad, pedicels $1.5-2.5 \mathrm{~cm}$. long; calyx lobes entire, hairy on the inner surface; petals narrowly obovate, about $1 \mathrm{~cm}$. long; fruit subglobose, red or yellow, $1.5-2 \mathrm{~cm}$. in diameter, bloom light or none: a mericana, American.

Common in thickets, along roadsides, riverbanks, etc., throughout the state. Distributed from Com. to Fla, west to Tex., New Mexico, northern Mexico, northward to Colorado and Montana. 


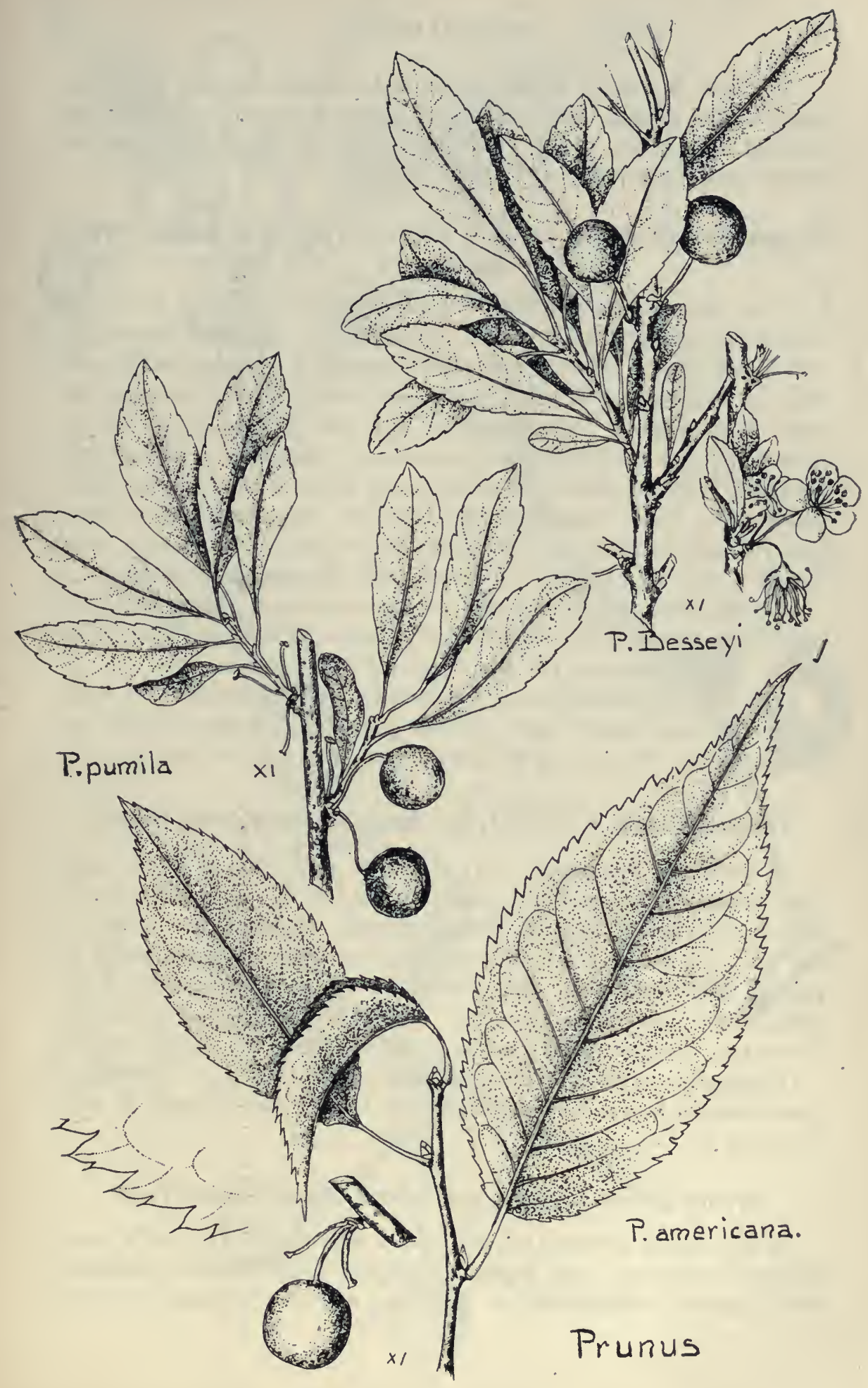


The fruit is used for making jellies and preserves or eaten raw. The wood is close grained, heavy and hard, it is dark brown in color, tinged with red, and weighs $47 \mathrm{lbs}$. Flowers in April and May, fruit ripens in August and September.

\section{Prunus pennsylvanica Linné filius I78r Pin Cherry Wild Red Cherry}

A tall shrub or a small tree, 5-10 meters (15-30 ft.) high; bark light reddish-brown, bitter and aromatic, on the trunk it separates horizontally into broad, papery plates; leaves oblong lanceolate, rounded at the base, acute or acuminate at the apex, finely and sharply serrate, serrations not equal, shining, green and glabrous on both sides, $4-8 \mathrm{~cm}$. long, 1-3 cm. wide, petiole $1-2 \mathrm{~cm}$. long; flowers numerous, in umbel-like clusters, white, appearing with the leaves, $1-1.2 \mathrm{~cm}$. broad, sepals $2 \mathrm{~mm}$. long glabrous, petals ovate, $5 \mathrm{~mm}$. long, pedicels $1.5-2.5^{\circ} \mathrm{cm}$. long; fruit globose, light red, 4-6 $\mathrm{mm}$. in diameter, without bloom, its flesh thin and sour, stone globular: pennsylvanica, named from the original locality.

Woods, thickets, and clearings, throughout the state, except southwestward. Distributed from Labrador to British Columbia and Col., south to Pa., central Iowa, and the mountains of North Carolina.

The fruit is sometimes used domestically and in preparation of medicines. The wood is soft, light and close grained, light brown in color and weighs 31 lbs. Flowers in April and May, fruit ripe in August.

\section{Prunus Cerasus L i n 11 é 1753 Sour, Pie, or Morello Cherry}

A small tree 2-4 meters (6-12 ft.) high, with a round crown; bark gray; leaves ovate to obovate, rounded at the base, abruptly short pointed at the apex, serrate, firm in texture and more or less glossy above, 4-8 $\mathrm{cm}$. long, $2-5 \mathrm{~cm}$. wide; flowers in small clusters, from lateral buds, appearing mostly before the leaves, large, $3-4 \mathrm{~cm}$. broad, petals $1.2-1.5 \mathrm{~cm}$. long; fruit depressed-globose, 8-12 mm. in diameter: Ce rasus, Gr. cherry tree, from the town Cerasus in Pontus, where the cherry is native.

Commonly cultivated in the southeastern part of the state. Introduced from southern Europe, probably native of $\Lambda$ sia Ninor. Flowers in May, fruit ripe in July.

\section{Prunus pumila Lin n é 1753 Sand Cherry, Dwarf Plum}

A low, much branched shrub, 0.2-1.5 meters (1-5 ft.) high, strict, branches wand-like; bark brown or grayish, shiny lenticels numerous; leaves mostly oblanceolate or spatulate, narrowed towards the base, 


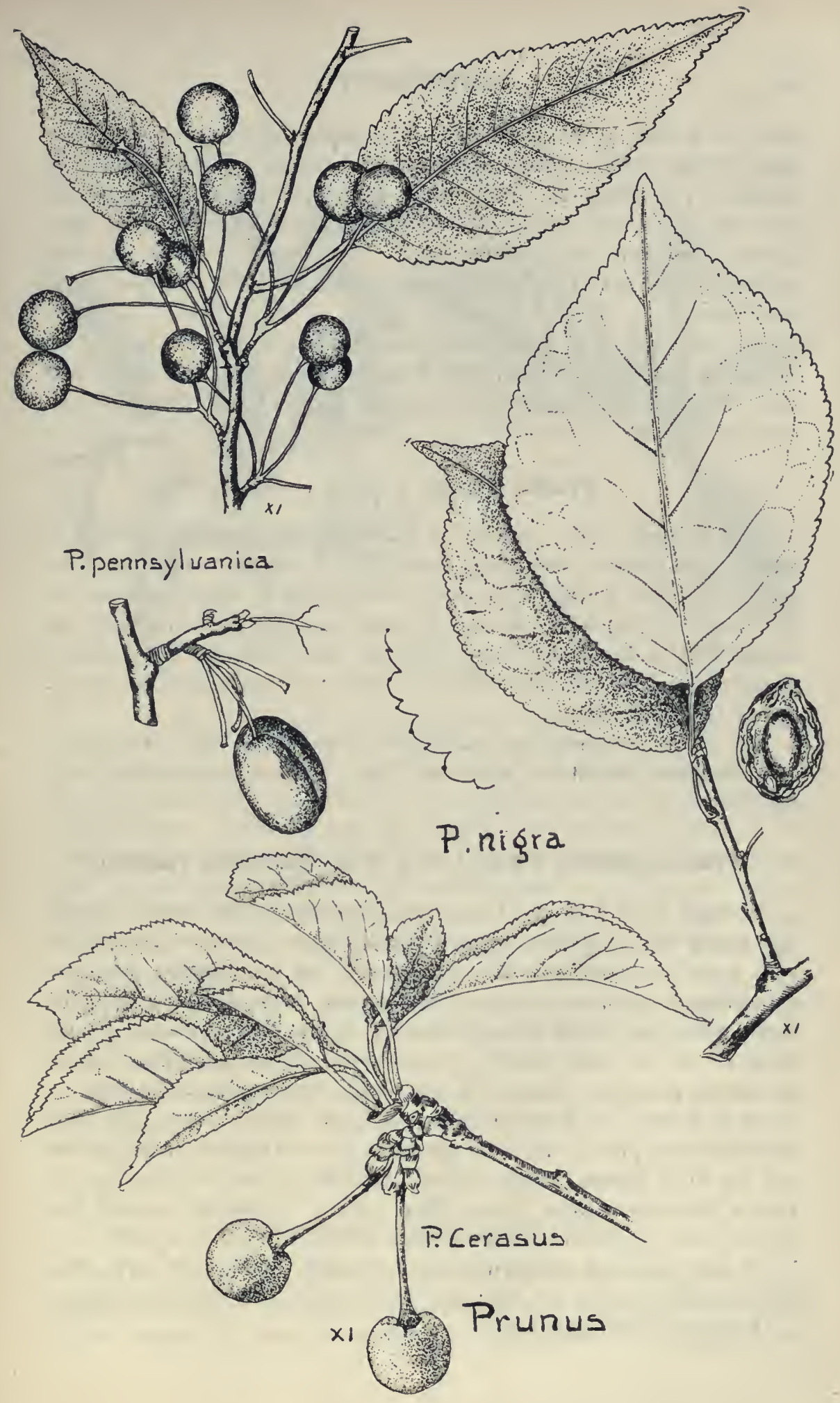


acute or acutish at the apex, toothed or serrate above the middle, deep green above, paler beneath, glabrous or nearly so on both sides when mature, 3-7 cm. long, 0.6-1.8 cm. wide; flowers 2-5, in fascicles, appearing with the leaves, white, $0.8-1 \mathrm{~cm}$. broad, pedicels $0.6-1.2 \mathrm{~cm}$. long; fruit globose, pendulous, dark red or nearly black, $0.8-1.2 \mathrm{~cm}$. in diameter, without bloom, flesh thin, acid: pumila, dwarfish, in reference to the small size.

In sandy and rocky soil, common throughout the northern part of the state, rare southward. Distributed from eastern Quebec to Pa., northern Ind., Wis., Minn. and Manitoba. Blossoms May and June, fruit ripe June and July.

\section{Prunus Besseyi B a il e y 1894}

A low shrub, 0.3-1.2 meters (1-4 ft.) high, the branches diffuse or spreading, not strict; bark gray; leaves elliptic, oblong or oval, narrowed towards the base, acutish at the apex, teeth appressed, thick, glabrous, 3-6 $\mathrm{cm}$. long, 1-2 cm. wide; flowers in sessile umbels, expanding with the leaves, $0.8-1.2 \mathrm{~cm}$. broad, fruit on short, stout pedicels, $1-1.5 \mathrm{~cm}$. in diameter, black or sometimes yellowish, bitter and astringent: B es s e y i, named for C. E. Bessey.

On prairies, southern and southwestern part of the state. Distributed from Manitoba and Minn., Kan. and Utah. Flowers in April-May, fruit ripe July.

\section{Prunus japonica T h $\mathrm{n} n \mathrm{~b}$ e $\mathrm{r} g$ I 784 Flowering Almond}

A shrub about 1 meter ( $3 \mathrm{ft}$.) high, branches slender, erect or ascending, young shoots reddish; leaves ovate-lanceolate, narrowed towards the base, acute or acuminate at the apex, doubly but finely serrate, serrations gland-tipped, glabrous above, a few scattered hairs along the veins beneath, veins and reticulations prominent on the lower surface, $4-8 \mathrm{~cm}$. long, 1.4-2.5 $\mathrm{cm}$. wide, petiole $3-4 \mathrm{~mm}$. long, stipules lance-linear, entire or remote glandular-serrate, $5-6 \mathrm{~mm}$. long; flowers appearing with the leaves in lateral, few-flowered umbels, $2-3 \mathrm{~cm}$. broad, at first light, later turning a deep pink, petals very numerous, stamens much reduced or lacking, the filled flowers usually produce no fruit, in fertile flowers the ripe fruit is globular or short oblong, about $1.2 \mathrm{~cm}$. in diameter, smooth shining and red: japonica, named from the place where it is native.

A very beautiful ornamental shrub, flowers in April or early May. It is reasonably hardy but does best with a slight protection in winter.

Native of China and Japan. 


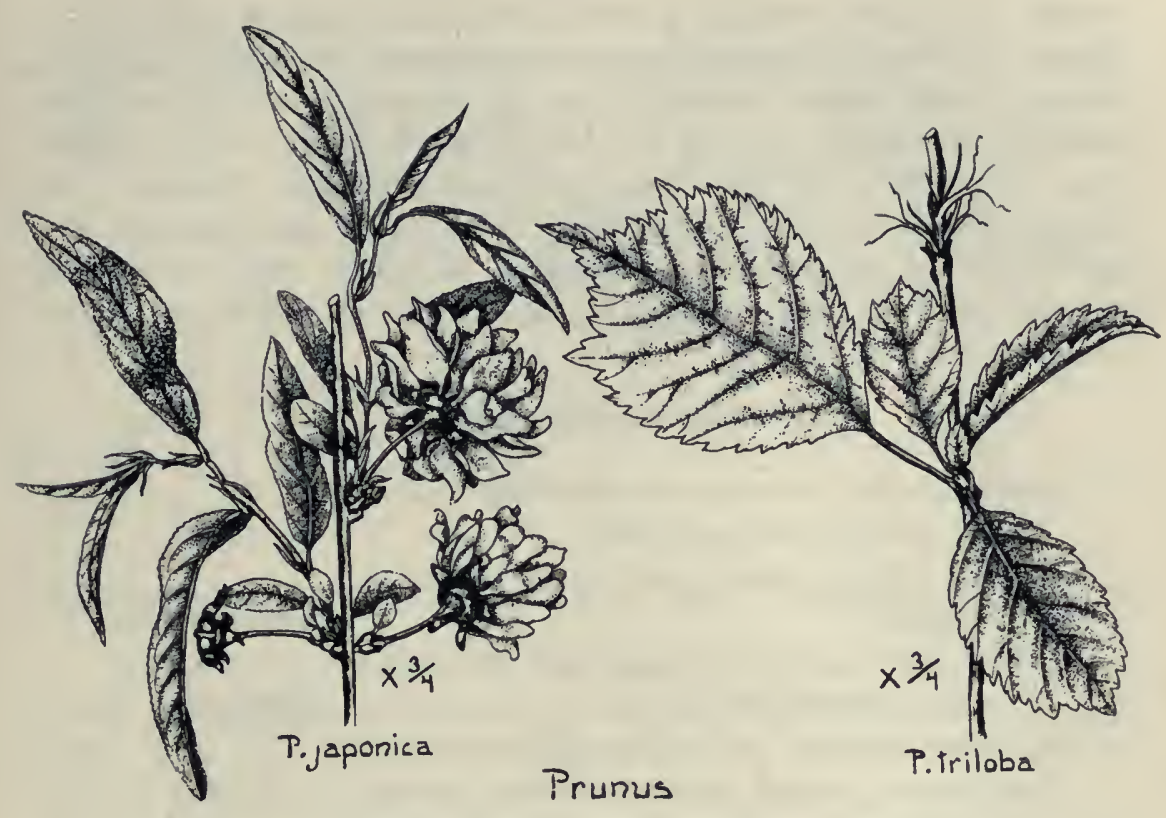

\section{Prunus triloba Lind 1 e y 1857 Flowering Plum}

An erect shrub, 1-3 meters (3-9 ft.) high, with spreading or ascending branches; bark brownish, young shoots reddish, puberulous or glabrous; leaves obovate, cuneate at the base, 3-lobed and abruptly pointed at the apex, sometimes merely obtuse or acute, coarsely and doubly serrate, rough with a few bristly hairs and impressed-veined on the upper surface, prominently veined and with scattered hairs beneath, $3-6 \mathrm{~cm}$. long, $2-4 \mathrm{~cm}$. wide, petiole $1-1.5 \mathrm{~cm}$. long, pubescent along the upper side; flowers solitary, appearing before the leaves, $3-4 \mathrm{~cm}$. broad, petals numerous, light pink; pistil hairy, the fruit usually does not set from the filled flowers, from fertile flowers the fruit is small, red and shining when ripe: $\mathrm{t} r \mathrm{i}$ $10 \mathrm{~b}$ a, three-lobed, in reference to the leaf.

A very desirable ornamental bush as it is entirely hardy in our climate. It is not quite as showy as the preceding species.

Native of China.

\section{Leguminosae Pulse or Pea Family}

Herbs, shrubs, vines, or trees ; leaves alternate, mostly compound, with stipules; flowers perfect, monoecious, dioecious, or polygamous, in spikes, heads, racemes, or panicles, apopetalous, hypogynous, or perigynous and 
regular or irregular, sepals 3-5, more or less united, petals 5, rarely fewer, stamens 10 , more or less united by their filaments or distinct; pistil 1 , simple, 1-many-seeded, becoming a pod or legume in fruit. The typical flower of this family, e. g. the pea, has the sepals united into an irregular cup; the petals are of three forms, an upper odd petal (standard), two lateral, spreading petals, (the wings), and two lower ones, the keel, more or less united and inclosing the stamens and pistil. The stamens are usually united by their filaments into a group of nine, the tenth stamen being free.

\section{KEI TO THE GENERA}

1. Flowers regular or nearly so, imperfect, monoecious or dioecious, large trees

a. Tree without thorns, leaves twice pinnate, stamens 10

b. Tree with thorns, leaves once and twice pinnate, stamens less than 10

2. Flowers. irregular, papilionaceous (sometimes with only 1 petal), perfect, trees or shrubs

a. Flowers numerous, in spikes or racemes, not yellow

(1) Flowers small, in dense spikes, 1-petalled, pods less than $2 \mathrm{~cm}$. long

(2) Flowers large, in drooping racemes, pods over $2 \mathrm{~cm}$. long

b. Flowers solitary or in few-flowered racemes, yellow

Gymnocladus

Gleditsia
Amorpha

Róbinia

\section{Caragana}

\section{Gymnocladus L a m a r c k 1783}

(Gr. gy m nos, naked, cla dos, branch, in allusion to the stout, naked branches.)

Trees with rough bark and stout branchlets; leaves large and bi-pinnate; flowers showy, in terminal racemes, monoecious or dioecious, calyx tubular, 5-lobed, lobes narrow, petals 5, oblong, equal, inserted at the top of the calyx-tube, stamens 10 , distinct, short, pistil rudimentary or lacking in the staminate flowers, sessile and many-ovuled in the pistillate and polygamous ones; fruit an oblong pod, flat, hard, pulpy inside, seeds numerous.

A monotypic genus of eastern North America. 


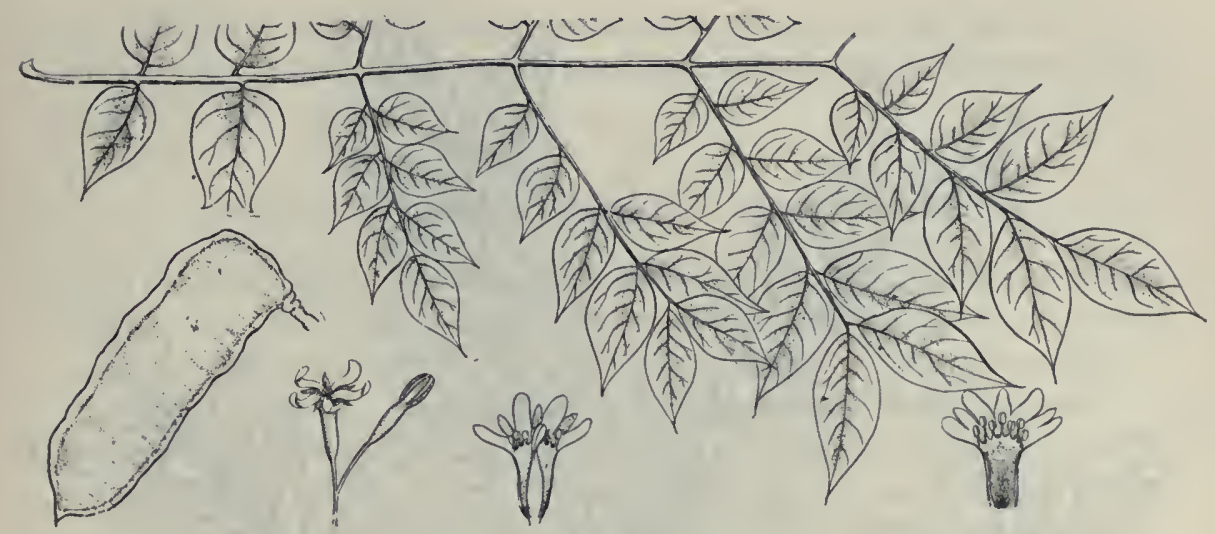

Gymnocladus dioica (Linné) K och 1869 Kentucky Coffee-tree

Tree attaining a height of $15-30$ meters $(45-90 \mathrm{ft}$.) and a trunk diameter of 1.5-8 dm; bark gray, deep-fissured and roughened by persistent scales; buds small, in hairy cavities, 2 in the axil of each leaf, one above the other, the lower sterile; leaves large, 6-9 dm. long, bi-pinnate, the pinnae with 7-15 leaflets each, leaflets stalked, ovate, rounded at the base, acute or acuminate at the apex, sometimes pubescent on the veins beneath, 2-10 cm. long, $2-6 \mathrm{~cm}$. wide; racemes many-flowered, $10-18 \mathrm{~cm}$. long, flowers 15-18 mm. long, calyx-tube campanulate, $1 \mathrm{~cm}$. long; pod 12-25 $\mathrm{cm}$. long, $4-5 \mathrm{~cm}$. wide: d i o i c a, dioecious.

In the southeastern part of the state as far north as St. Paul and westward in the Minnesota River valley to New Ulm. Common in the Mississippi River Valley and westward along some of the tributaries. Distributed from N. Y. and Pa. to Minn., Neb. and Kan., southward between the mountains to the middle of Tenn.

The wood is heavy but. not very hard, strong and coarse grained and very durable in contact with the soil. It is light brown in color and takes a good polish, weight $48 \mathrm{lbs}$. Frequently planted as a park tree but not very ornamental. Flowers in June.

\section{Gleditsia L in n é I753}

(Named for J. G. Gleditsch, a German botanist who lived at the same time as Linné.)

Thorny trees with evenly, once or twice pinnate leaves; thorns branched or simple, situated above the axils of the leaves, often very large; flowers small, greenish, in axillary spikes; calyx short, 3-5-cleft, petals equal, 


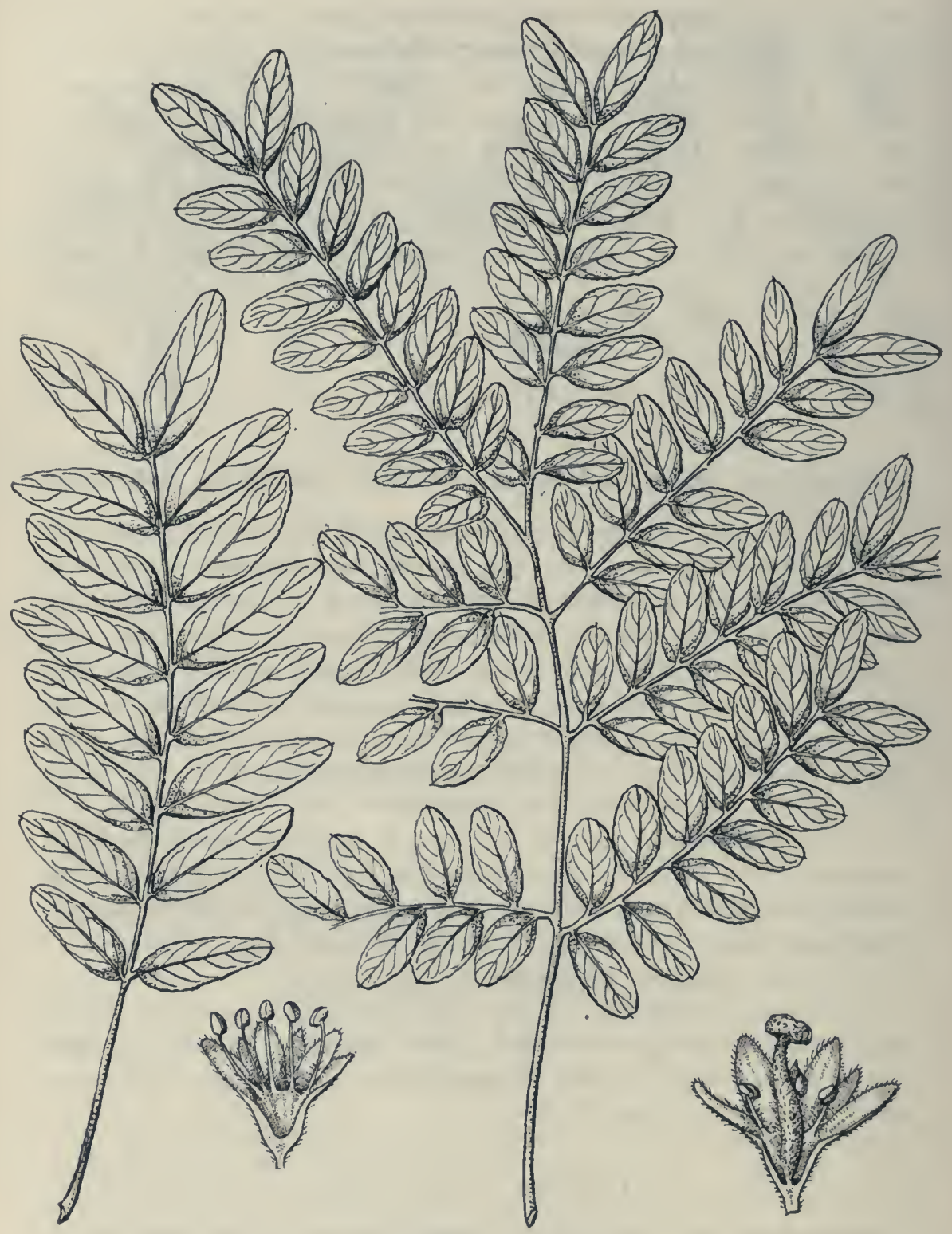

Gleditsia triacanthos

the two lower sometimes united, stamens 3-10, distinct, pistil rudimentary or none in the staminate flowers, in the pistillate ones elongated or ovoid, ovules 2-many; pods flat, nearly straight at first, twisted at maturity, pulpy between the seeds. 
A genus of 5 species, natives of eastern North America and Asia; in addition to the following one other species occurs in the southeastern part of the U. S.

\section{Gleditsia triacanthos L in n é I753 Honey Locust}

Tree attaining a height of 15-20 meters (45-60 ft.) within our range, and a trunk diameter of $15-40 \mathrm{~cm}$.; bark dark brown, fissured; thorns large and numerous, simple or branched; branches slender, spreading or somewhat pendulous, with numerous lenticels; buds minute, several together and superposed, upper ones with scurfy scales, the others hidden by the base of the petiole; leaves 1-2-pinnate, $10-20 \mathrm{~cm}$. long, leaflets shortstalked, oblong-lanceolate, somewhat crenulate, $2-3 \mathrm{~cm}$. long, $6-10 \mathrm{~mm}$. wide; inflorescence $5-10 \mathrm{~cm}$. long, the staminate ones more slender than the pistillate; calyx obconic; pods $15-45 \mathrm{~cm}$. long, bent or twisted, pulp sweetish, edible: $\mathrm{tri}$ a c a $\mathrm{nth}$ os, three-spined.

On the Mississippi River bottom lands of Houston County. Distributed from the Allegheny mountains of $\mathrm{Pa}$. through southern Ontario to Minn., Neb., Kan., south to Tex., Ala., and Miss.

The wood is red or light reddish brown in color, it is coarse grained, hard, strong and durable in contact with the soil, weight $42 \mathrm{lbs}$. It is used for fence posts, rails, for hubs of wheels, etc. Frequently planted as a park tree.

\section{Robinia L in n é 1753}

(Named for John and Vespasian Robin, the latter being the first who cultivated the Locust-tree in Europe.)

Small to medium sized trees or shrubs, with rough and furrowed bark and spiny stipules or in the shrubby forms bristly; leaves alternate, compound, odd-pinnate; leaflets oblong or ovate, short-stalked; flowers showy, white or deep rose color, in hanging axillary racemes, calyx 5-toothed, the two upper teeth slightly united, upper petal or standard rounded, reflexed, wings oblong, curved, blunt, stamens diadelphous, pistil stalked, ovules numerous; fruit a flat, linear pod, several-seeded.

A genus of 6 species natives of the southern United States and Mexicn.

\section{Key to the Species}

Tree with glabrous twigs, petioles and pods Shrub with bristly twigs, petioles and pods
R. pseud-acacia

R. hispida 


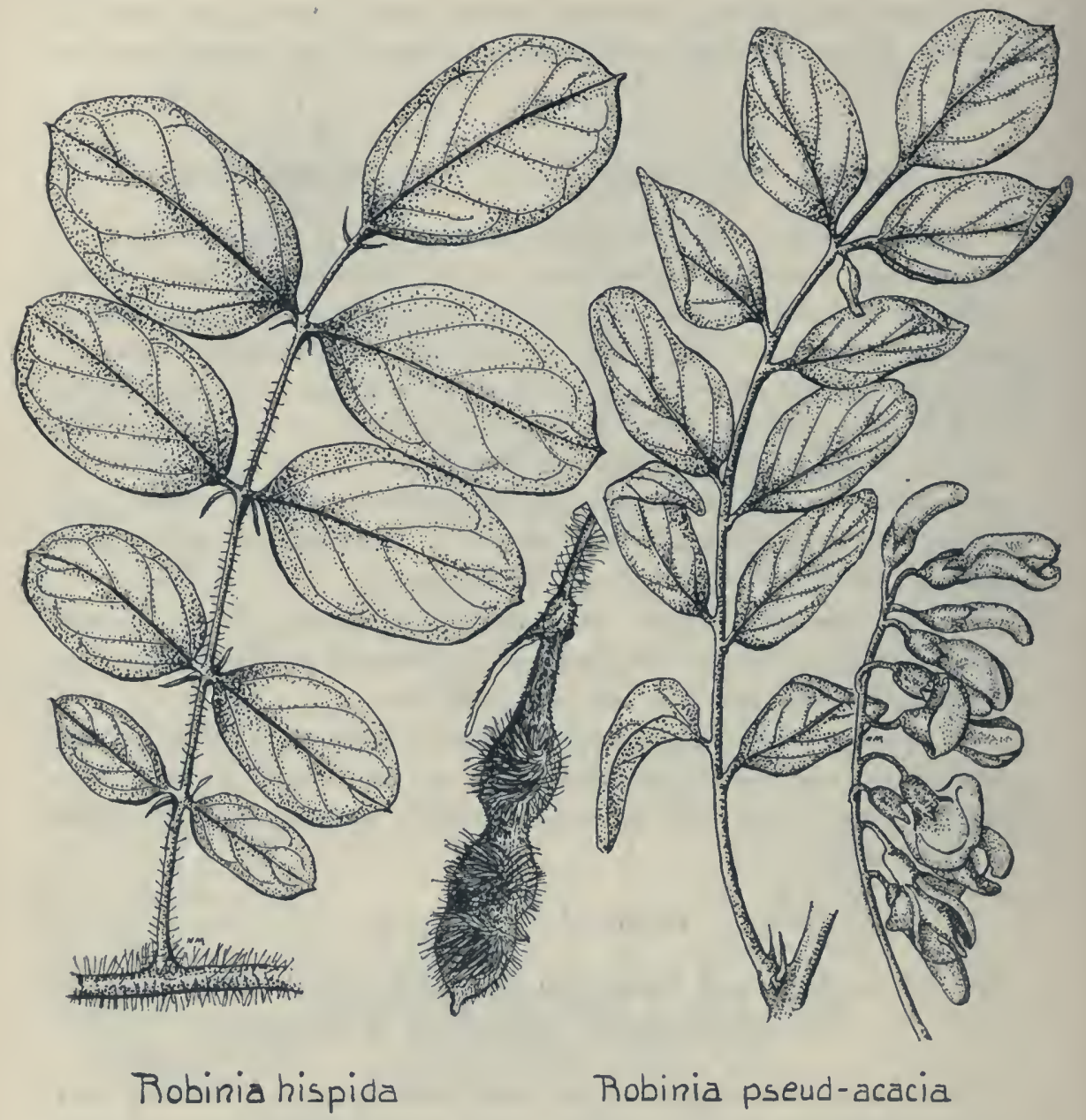

Robinia pseud-acacia L i n n é I753 Common Locust False Acacia

A tree 6-20 meters (20-60 ft.) high and a trunk diameter of 20-40 ('m.; bark nearly black, rough and deeply furrowed; twigs glabrous, with spines in pairs (stipules); leaves $12-25 \mathrm{~cm}$. long, leaflets $11-15$, ovate to oblong, 2-6 cm. long, 1-3 cm. wide, glabrous, margin entire, petioles short ; racemes slender, 9-20 cm. long, loose, flowers white, fragrant, about $2 \mathrm{~cm}$. long; pod smooth, $6-12 \mathrm{~cm}$. long, flat, brown, $1.2 \mathrm{~cm}$. wide: p seud a c a c i a, false acacia.

Along the mountains from $\mathrm{Pa}$. to Ga. and in the Ozark mountains of Mo., also in Ark. and Oklahoma. Extensively planted as an ornamental 
tree and becoming more or less naturalized. Often spreading by means of underground stems and forming thickets of small trees. Perfectly hardy in Minnesota, but suffering greatly from the attacks of borers, and as a result short-lived.

The wood is brown or light green in color, close grained, very hard and heavy and is very durable in contact with the soil, and used to some extent as fence posts, weight about $45 \mathrm{lbs}$. Flowers in late May or June.

\section{Robinia hispida L i n n é I767 Rose Acacia Bristly Locust}

A much-branched shrub, 1-3 meters (3-9 ft.) high; branches, twigs and petioles bristly; leaves $10-20 \mathrm{~cm}$. long, leaflets $9-15$, ovate or orbicular, $2-5 \mathrm{~cm}$. long, $2-3.5 \mathrm{~cm}$. wide, rounded at the base, blunt at the apex and mucronate-tipped, glabrous above, pubescent on the veins beneath; racemes drooping, 6-10 cm. long, flowers large, deep rose color or purple, not fragrant, $2-3 \mathrm{~cm}$. long; pod linear, bristly hispid, constricted between the seeds, 4-6 $\mathrm{cm}$. long brown: his p id a, prickly.

Native of the mountains of $\mathrm{Va}$. to Ga. Cultivated to some extent as an ornamental shrub in parks. Flowers in June, fruit ripe in Sept.

\section{Amorpha Li n n é 1753}

(Gr. a, without, mor $\mathrm{ph}$ e, form, referring to the four lost petals)

Branching shrubs with odd-pinnate, compound leaves, leaflets marked with minute dots or glands; flowers violet or purple, in dense terminal spikes; calyx-teeth 5, nearly equal, only one petal, the standard present, wrapped around the stamens and style; stamens 10 , united at the base, pistil 2-celled; fruit an oblong pod, exceeding the calyx, 1-2-seeded, tardily' splitting.

A genus of about 10 species, natives of North America and Mexico.

\section{Key to the Species}

1. Tall shrub, $1-3$ meters, leaflets $2-5 \mathrm{~cm}$. long

A. fruticosa

2. Low shrubs, 3-14 dm. high, leaflets $6-12 \mathrm{~mm}$. long

a. Densely silky-hairy all over, 3-14 dm. high

A. canescens

b. Smooth or nearly so throughout, $3 \mathrm{dm}$. or less

A. nana 


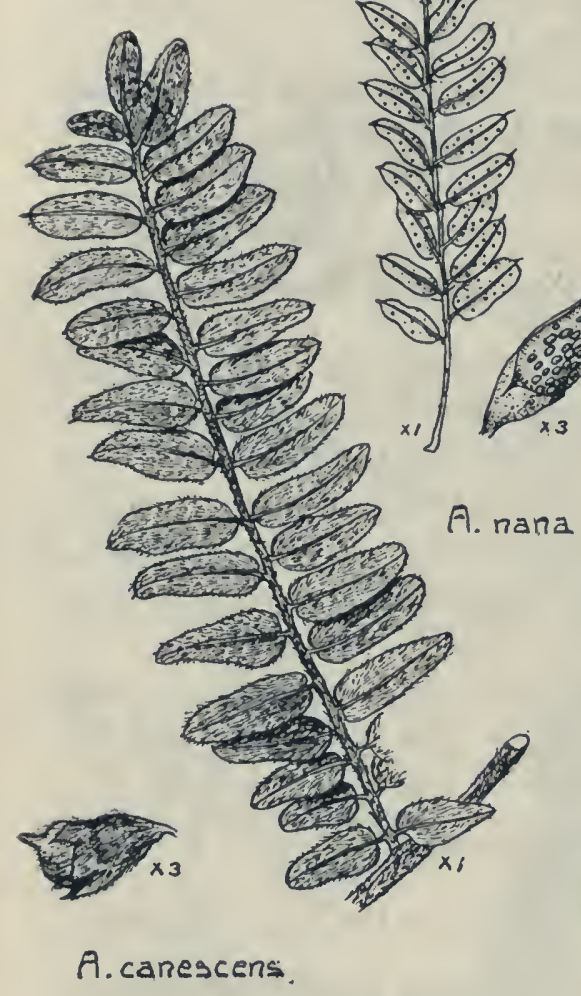

Amorpha

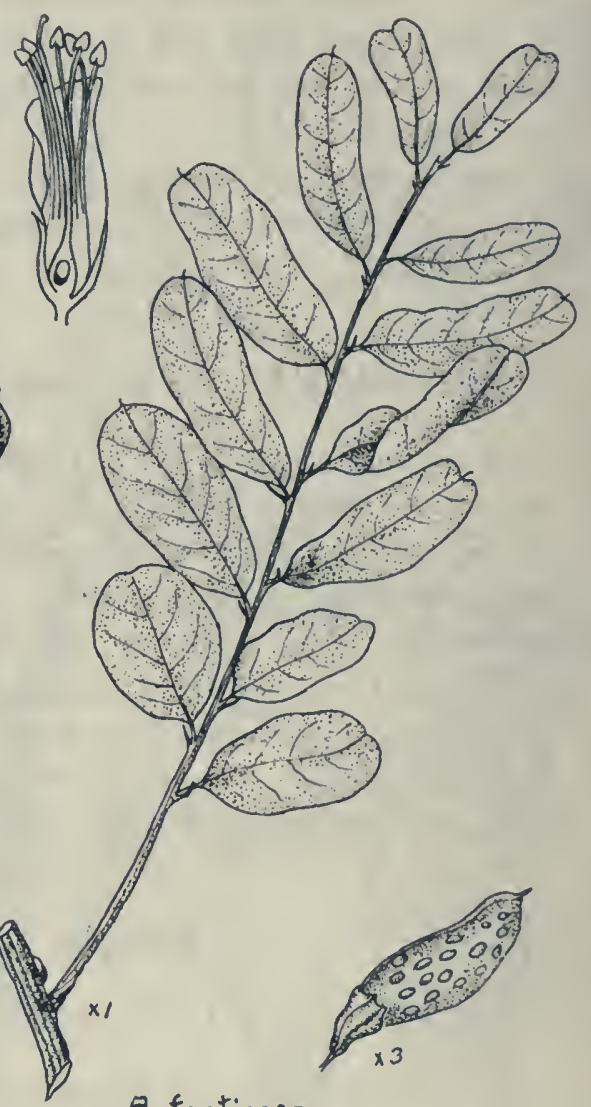

A. fruticosa

\section{Amorpha fruticosa $\mathrm{L}$ in n é I753 False Indigo}

'Tall shrub, 1-3 meters (3-9 ft.) high; leaves 15-30 cm. long, leaflets 9-25, short-stalked, oblong or broadly elliptic, rounded and mucronate at the tip, rounded or slightly narrowed at the base, $2-3.5 \mathrm{~cm}$. long, $1.2 \mathrm{~cm}$. wide; spikes clustered, $7-15 \mathrm{~cm}$. long, clustered or solitary, flowers very numerous, purple, 7-10 mm. long, stamens exserted, with bright orange anthers; pod 5-10 mm. long, with numerous dark glands, thick-stalked: f r u t i cos a, shrubby.

Common throughout the state except northeast. Along banks of rivers, streams and lakes. Distributed from Ohio to Manitoba, south to Fla., Colo, and Chihuahua. Flowers in June and July, fruit ripe in August. 


\section{Amorpha canescens $\mathrm{P} u \mathrm{rsh}$ I8I4 Lead-plant Shoe-strings}

A bushy shrub, 3-14 dm. (1-4 ft.) high, densely white-canescent all over; stems longitudinally ridged or furrowed; leaves $5-10 \mathrm{~cm}$. long, leaflets 21-49, crowded, oblong-elliptic, short-stalked, rounded at the base, obtuse or acutish and mucronate at the apex, less hairy on the upper than on the lower side, 8-14 mm. long, 4-9 mm. wide; spikes densely clustered at the summit of the stems, $5-18 \mathrm{~cm}$. long; flowers deep-purple, stamens. orange yellow; pods 1 -seeded, slightly exceeding the calyx in length: c a n e s c en s, hoary.

Common on hills and prairies throughout the state except northeast. Distributed from Ind. to Manitoba, south to La. and Tex.

Flowers in June and July, fruit ripe in August and September.

\section{Amorpha nana $\mathrm{Nutta} 11$ I8I3 Fragrant False Indigo Amorpha microphylla Pursh I8I4}

A low bushy shrub, 2-3 dm. (8-13 in.) high, branches glabrous or nearly so throughout; leaves $3-8 \mathrm{~cm}$. long, leaflets $13-19$, oval or oblong, rounded at the base, blunt and mucronate at the tip, glabrous or nearly so with glistening glands or dots, rather ridged; spikes usually only one to a branch $4-7 \mathrm{~cm}$. long, flowers fragrant, dark purple; pods 1-seeded, gland-dotted, about $3 \mathrm{~mm}$. long: $\mathrm{n}$ a $\mathrm{n}$ a, dwarf.

Common on prairies throughout the western part of the state from south to north. Distributed from Minn. to Manitoba and Kan. Flowers in May, fruit ripe in July.

\section{Caragana $\mathrm{L}$ a $\mathrm{m}$ a r ck $\mathrm{I} 783$}

(Tartar name of the original species)

Branching shrubs or small trees, with alternate, compound, even-pinnate, often fascicled leaves; stipules sometimes spiny and persistent; flowers yellow in long-stalked, few-flowered racemes, or solitary, clustered at the base of the young twigs or at the nodes of older twigs; calyx tubular, the two upper sepals smaller, standard with reflexed sides and longclawed, wings oblique, elongated, keel short, blunt, pistil nearly sessile, ovules many, style straight or slightly bent; fruit a sessile, linear, at length cylindrical pod, about 4-5 cm. long, pointed, seeds oblong or nearly spherical.

A genus of 20 species, distributed from southern Russia to China. 
Key to the Species

1. Small tree, leaflets $8-18$

C. arborescens

2. Shrub, leaflets 4 , almost palmate

C. digitata

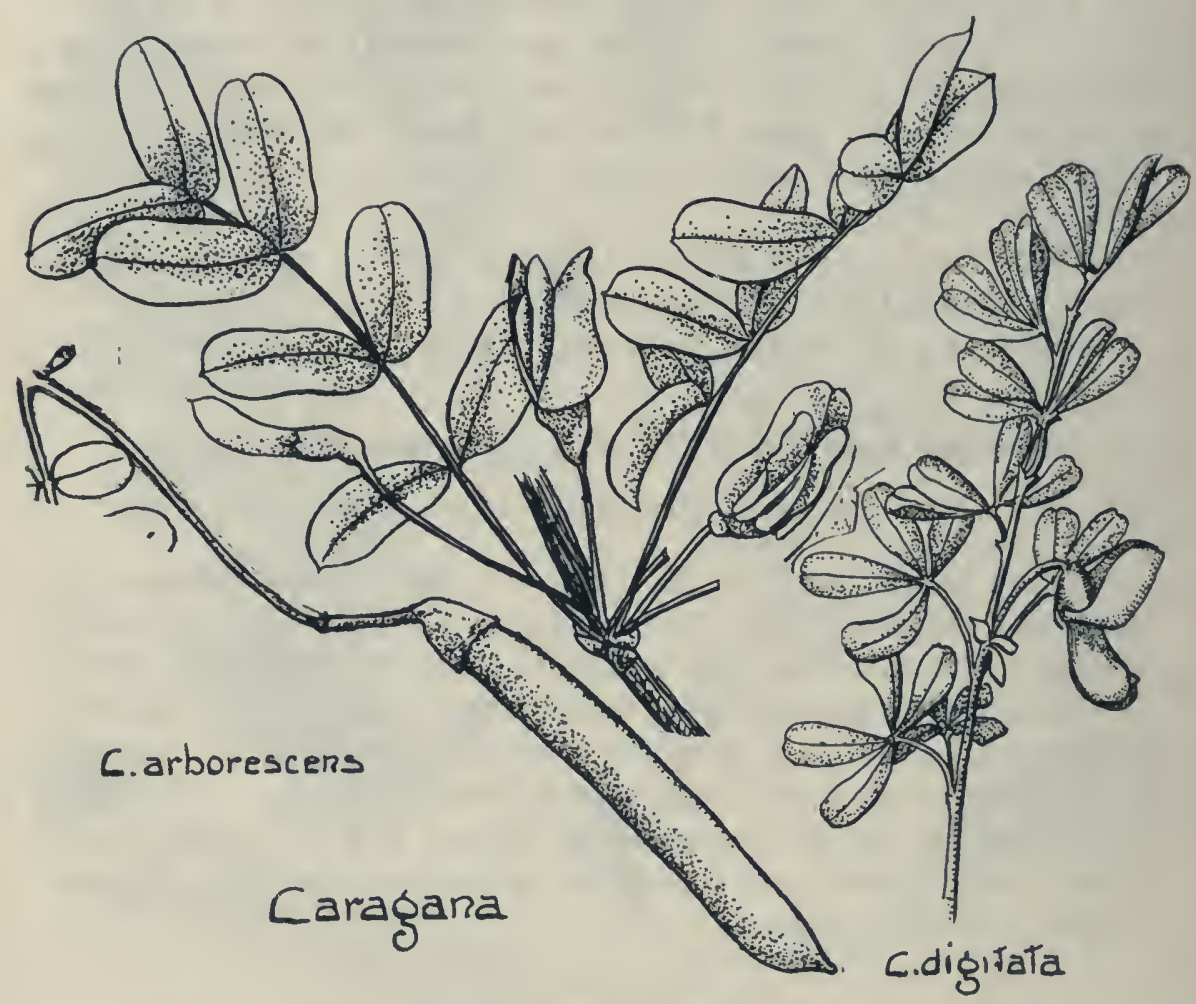

Caragana arborescens La marck $\mathrm{I}_{783}$ Siberian Pea Tree

Shrub or small tree, 2-6m. (6-18 ft.) high; bark gray; leaves 5-10 cm. long with 8-12 leaflets, obovate or oblong, rounded at the base, mucronate at the tip, sparsely pubescent beneath or at length glabrous, $1-3 \mathrm{~cm}$. long, 5-10 cm. wide; flowers $2-4$, pale or bright yellow, $1.5 \mathrm{~cm}$. long, pedicels usually longer than the flower; fruit a linear pod: a r b o r e s c e n s, treelike.

Native of Siberia and Manchuria. Frequently cultivated in Minn. and perfectly hardy. Flowers in May.

Several varieties, of which variety pen $\mathrm{d} u 1 \mathrm{a}$, with pendulous branches, is the most remarkable. 


\section{Caragana digitata $\mathrm{L}$ a $\mathrm{m}$ a r c k $\mathrm{I} 783$}

A shrub 2-3.5 mm. high; leaves with 4 leaflets which are nearly digitately arranged, cuneate, obovate or oblong, rounded or emarginate at the apex, glabrous, $1-2.5 \mathrm{~cm}$. long; flowers solitary, $1.5-2.5 \mathrm{~cm}$. long, yellow: digit at a, like the fingers of the hand.

Distributed from southern Russia to China.

Var. grand if 1 or a, with large flowers and usually large and broad leaflets.

\section{Saxifragaceae Saxifrage Family}

Herbs, shrubs, vines, or sometimes trees; leaves alternate or opposite or whorled or basal; flowers mostly perfect and regular, sometimes polygamo-dioecious, racemose, cymose, or paniculate or sometimes solitary, calyx mostly 5-lobed, sometimes 4-12 lobed, united below and adnate to the concave or cup-shaped axis, petals mostly 5 , sometimes 4 or all are lacking, perigynous or epigynous, stamens mostly 5 or 10 , or sometimes numerous, disk usually present; carpels mostly 2, or 1-several, united, (sometimes only towards the base), styles as many as carpels or united into one; fruit a capsule or a berry, seeds small and numerous.

\section{KEY TO THE GENERA}

1. Leaves opposite or whorled, not lobed, stamens more than 5

a. Stamens more than 10 , flowers white and showy, leaves opposite

b. Stamens 3-10, flowers greenish, outer ones often sterile, leaves mostly in whorls of 3

2. Leaves alternate, lobed, stamens 4-5

\section{Philadelphus}

Hydrangea Ribes

\section{Philadelphus L in né I753 Syringa Mock Orange}

(Gr. Phila delphon, a sweet flowering shrub)

Shrubs with opposite, simple, toothed or entire leaves; flowers large white or cream colored, terminal or axillary, in cymes, racemes or solitary, calyx top-shaped, sepals 4-5, persistent, petals 4-5, rounded or obovate, stamens 20-40, styles free united below, ovary 3-5-celled; fruit a 3-5-celled capsule, seeds numerous.

A genus of about 15 species, natives of North America, Asia and Central Europe. In addition to the following 6 other species occur in the southern and western parts of North America. 


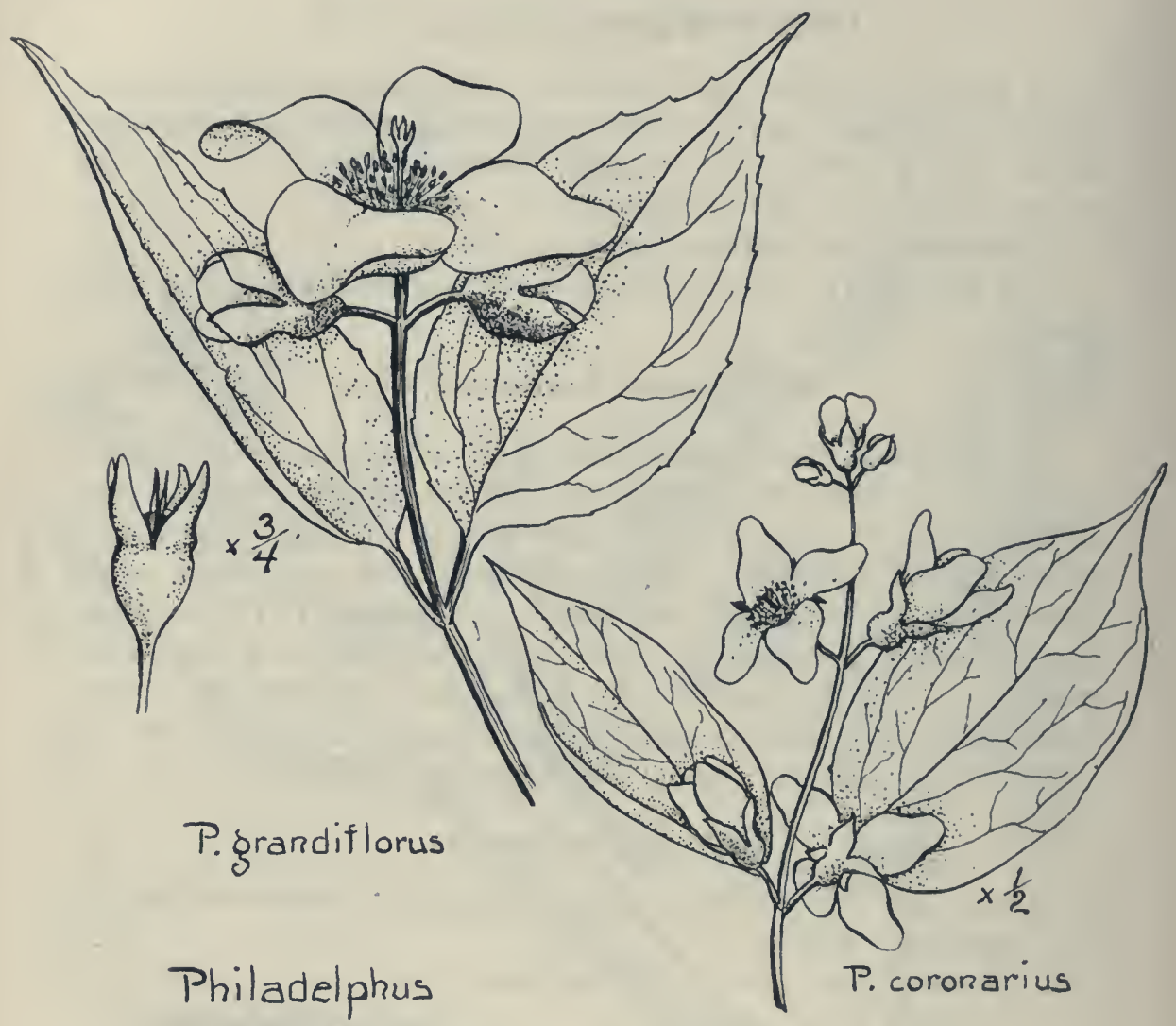

Key to the Species

1. Flowers solitary or few, not odorous, leaves 8$12 \mathrm{~cm}$. long

\section{P. grandiflorus}

2. Flowers racemose, odorous, leaves $12-20 \mathrm{~cm}$. long

$P$. coronarius

Philadelphus grandiflorus Will de now I809 Large-flowered Syringa

A shrub 2-3 m. (6-9 ft.) high, with reddish twigs, bark on the older branches grayish, buds covered by the base of the petioles; leaves ovate to ovate-lanceolate, narrowed towards the base, acuminate at the apex, 3 nerved, teeth or serrations distant, small, glabrous or nearly so, $6-10 \mathrm{~cm}$. long, 3-6 cm. broad, petiole less than $1 \mathrm{~cm}$. long; flowers $1-3$ borne at the 
ends of branches or axillary, white and scentless, $3-5 \mathrm{~cm}$. broad, calyxlobes lanceolate, about $1 \mathrm{~cm}$. long, petals ovate $1.5-2 \mathrm{~cm}$. long; fruit a top-shaped capsule, 9-12 mm. long: $\mathrm{g}$ r a n d i f 1 o r u s, large-flowered.

Distributed from Va. to Tenn. and Fla.

Grown in parks and yards as an ornamental shrub and entirely hardy. Flowers in June, fruit ripe in August.

\section{Philadelphus coronarius $\mathrm{L}$ in né I753 Mock Orange Garden Syringa}

A shrub 2-3 meters (6-9 ft.) high, with smooth grayish bark, young twigs reddish, glabrous; leaves oval or elliptic, rounded at the base, acuminate at the apex, margin with sharp and distant teeth, mostly 5veined, glabrous above, mostly pubescent below, 4-7 cm. long, $2-5 \mathrm{~cm}$. wide, short petioled; flowers in racemes at the ends of branches, cream-colored, 3-4 cm. broad, calyx-lobes lanceolate, 5-6 mm. long, petals ovate, 12-16 $\mathrm{mm}$. long; fruit a top-shaped capsule, $7-10 \mathrm{~mm}$. long; c o r o n a ri us, crown-like.

Frequently cultivated as an ornamental shrub, and quite hardy, escaped from gardens in Va. to IIl. Native of central Europe. Blossoms in June, fruit ripe in August and September.

\section{Hydrangea $L$ i n n é 1753}

(Gr. hy d r o, water, a $\mathrm{ng}$ e i o n, vessel, referring to the shape of the fruit)

Shrubs with opposite or whorled, simple leaves; flowers white or tinged with pink, in terminal, compound cymes, the marginal ones usually sterile and consisting of a large, membranous, flat, colored calyx, fertile flowers small, calyx-tube hemispherical, adnate to the ovary, 5-lobed, petals 4-5, ovate, stamens 8-10, ovary 2-4 celled, styles $2-4$, distinct; fruit a manyribbed, many-seeded capsule, opening between the styles.

A genus of about 35 species, natives of eastern North America, eastern Asia and the Himalayas, and South America. Three species occur in the southeastern states.

\section{Key to the Species}

1. Leaves ovate, mostly cordate at base, flower cluster nearly flat-topped

H. arborescens

2. Leaves ovate-lanceolate, flower cluster pyramidal, large

H. paniculata 


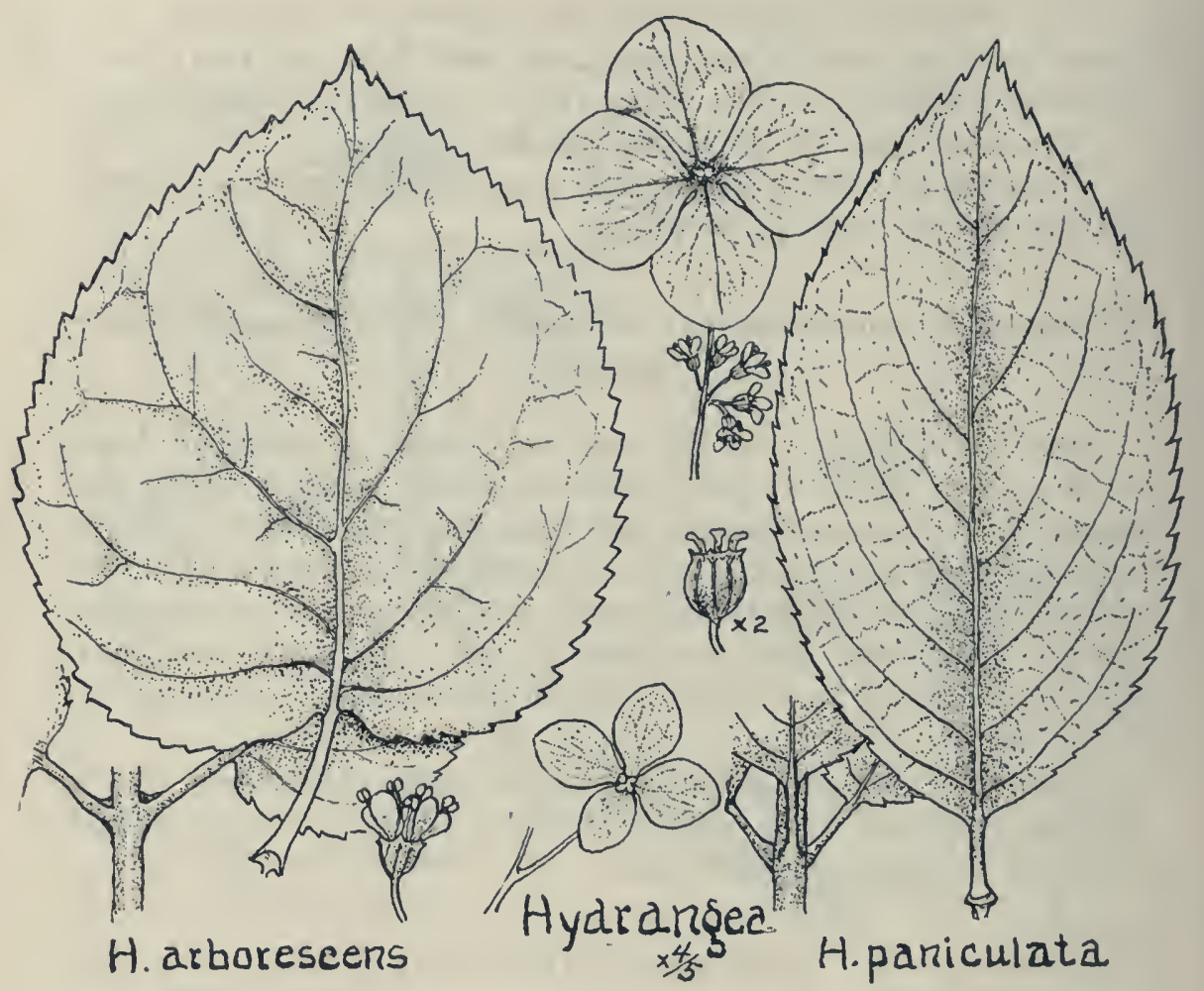

\section{Hydrangea arborescens L in né 1753 Wild Hydrangea}

A shrub 1-3 m. high (in our climate only about 5-9 dm., dying back in winter to within $2-3 \mathrm{dm}$. of the ground), young twigs pubescent; leaves ovate, cordate at the base, acute at the apex, serrate, scattered rough hairs on upper surface, pubescent along the veins beneath, thin and with prominent veins beneath, $6-9 \mathrm{~cm}$. long, $4.5 \mathrm{~cm}$. wide, petioles $1-2 \mathrm{~cm}$. long; cyme compound, flattened, $5-10 \mathrm{~cm}$. broad, sterile marginal flowers few or quite numerous (in the cultivated forms of ten constituting the entire flower cluster), white and showy; fruit a two-beaked capsule: a r b o r e s c e n s, tree-like.

Common oin rocky banks and river banks, from southern N. Y. and N. J., south to Florida and west to Iowa and Mo. Not native of Minn. The following variety is frequently cultivated within the state.

Var. steril is Torrey and Gray.

This variety has almost all the flowers sterile. It is sometimes called "Hills of Snow." 
Hydrangea paniculata Si e bold \& Z uc carin i $1835-44$ Hydrangea

A shrub or small tree 1-9 m. high; leaves opposite or mostly in whorls of 3, elliptic or ovate, narrowed at the base, acuminate at the apex, serrate, pubescent with stiff, scattered hairs above, more densely and finely pubescent on the veins beneath, 5-12 cm: long, 4-6 cm. wide, petioles less than $1 \mathrm{~cm}$. long; cymes terminal, $9-30 \mathrm{~cm}$. long, flowers whitish, the sterile ones later changing to purplish, styles 3, fruit a 3-beaked capsule, about $4 \mathrm{~mm}$. long: pan iculat a, in a panicle.

Native of Japan.

The following variety is perfectly hardy and is the one commonly grown in Minnesota.

Var. grandif $10 \mathrm{ra}$ of gardeners.

Almost all the flowers are sterile. The panicles are very large and showy. Blossoms in August and September.

\section{Ribes Lin n é 1753}

(Ribes, the Arabic name)

Low shrubs, often with spines or prickles; leaves alternate, palmatelylobed, often fascicled; flowers small, white, yellowish-green, yellow or purplish, borne with the leaves or from separate lateral buds, calyx 5lobed, the tube adherent to the ovary, petals 5 , inserted in the throat of the calyx, stamens 5, alternate with the petals, ovary 1-celled, with 2 styles; fruit a berry, crowned with the remains of the calyx, mostly edible.

A genus of about 60 species, natives of the north temperate zone and the Andes of South America. In addition to the following about 40 others occur in the western parts of North America.

\section{Key to the Species}

1. Stems with spines or prickles or both

a. Flowers 1-4, rarely 5 (Gooseberries)

(1) Cultivated shrub, sometimes escaped from gardens, spines stout, usually in 3's

R. Grossularia

(2) Native shrubs, spines mostly slender

(a) Calyx-lobes shorter than the tube, berries mostly bristly

R. Cynosbati

(b) Calyx-lobes as long or longer than the tube, berries smooth 
x. Calyx 9-12 mm. long, stamens longexserted

R. gracile

y. Calyx 5-7 mm. long, stamens not exceeding the calyx

R. o.ryacanthoides

b. Flowers in elongated racemes, mostly numer-

ous, stems densely prickly

R. lacustre

2. Stems smooth, without spines or prickles, flow-

ers in racemes (Currants)

a. Calyx flat or saucer-shaped

(1) Ovary and berries glandular bristly

R. prostratum

(2) Ovary and berries smooth

$x$. Calyx purplish, shrubs decumbent

R. triste

y. Calyx greenish-yellow, shrubs erect, cultivated

R. vulgare

b. Calyx campanulate to long-tubular

(1) Racemes erect or ascending, calyx white

R. hudsonianum

(2) Racemes drooping

$\mathrm{x}$. Calyx greenish white

R. floridum

y. Calyx bright yellow

$R$. aureum

\section{Ribes Grossularia Li n n é 1753 European Gooseberry}

Ribes uva-crispa Linné 1753

Cultivated shrub 0.5-1 m. high; spines stout, 1-1.5 cm. long, usually together in 3's; leaves cordate to truncate at the base, widening upwards, rather short petioled, 3-5 lobed, pubescent at least when young, lobes obtuse or crenate-dentate, $2-3.5 \mathrm{~cm}$. long, $2-5 \mathrm{~cm}$. wide; petiole $1-3 \mathrm{~cm}$. long; peduncles very short, 1 or rarely 2 flowered; flowers green, about $6 \mathrm{~mm}$. long, calyx hirsute, sepals oblong, 3-4 mm. long, fruit globoseovoid, smooth, 1-2 cm. long; gross u la ria, like a small unripe fig.

The ordinary garden gooseberry, sometimes escaped from cultivation, locally established in Quebec, New England and the Middle States. Introduced from Europe.

\section{Ribes cynosbati L in n é I753 Prickly Gooseberry Dogberry}

Low spiny shrub; spines slender, 5-10 mm. long; prickles of the branches few or weak or none; leaves round-ovate, 3-5 lobed, rounded or subcordate at the base, soft-pubescent, $2-5 \mathrm{~cm}$. long, $2.4 \mathrm{~cm}$. wide, petiole 1-2 cm. long, pubescent; racemes loose, $2.5-6 \mathrm{~cm}$. long, few-flowered, flowers 7-10 mm. long; stamens and united styles not longer than 


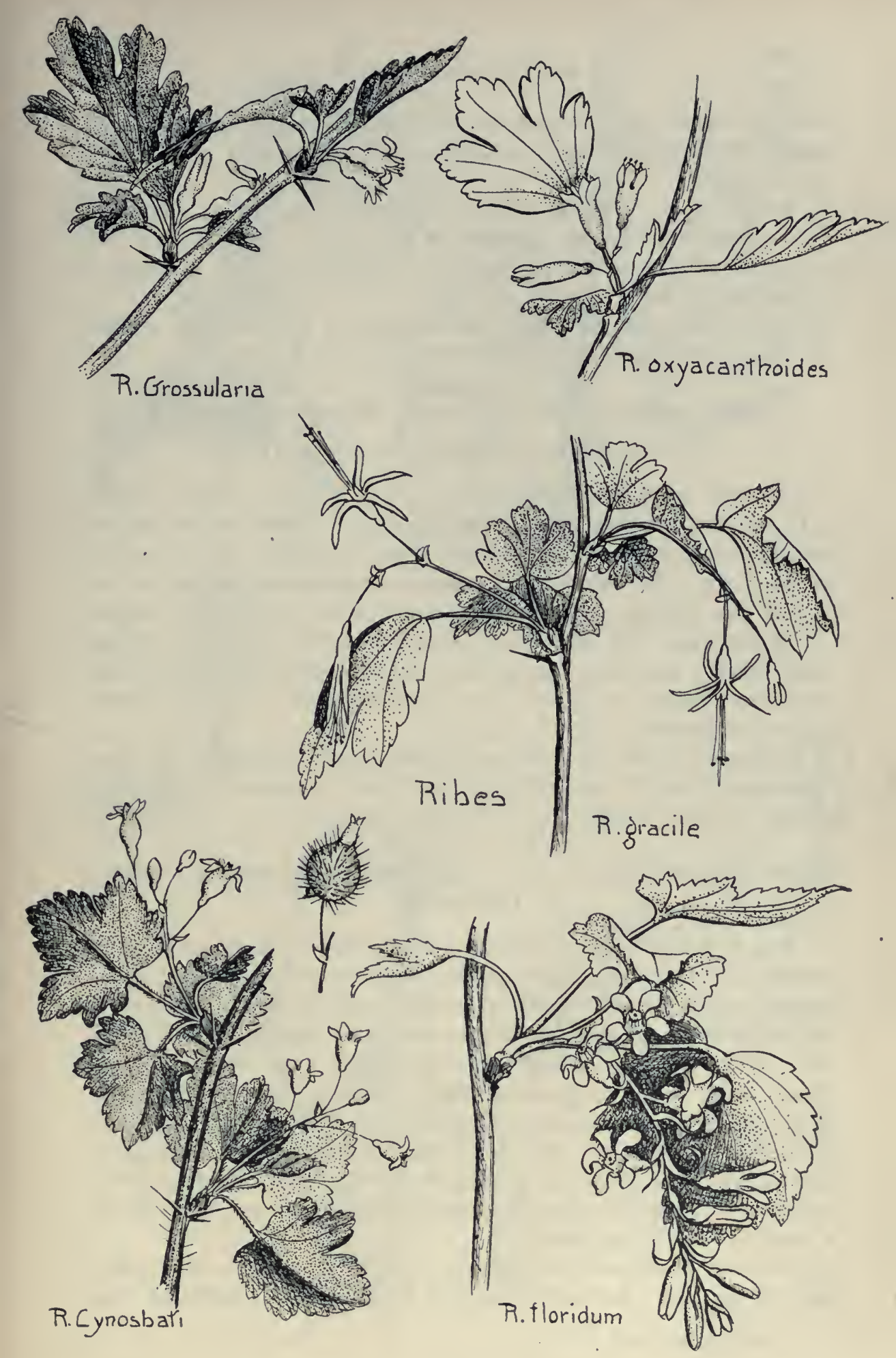


the bell-shaped calyx; sepals reflexed; petals yellowish-white; berries large, with long prickles, or sometimes smooth: c y n o s b a $\mathrm{i}$, resembling the wild-briar.

Rocky woods, throughout the wooded part of the state. Distributed -from western Maine to the mountains of N.C., west to Manitoba and Mo.

Distributed from western Me. to the mountains of $N$. C., west to Manitoba and Mo.

Fruit edible but not much used on account of the sharp prickles. Blossoms in May, fruit ripe in July.

\section{Ribes gracile Mi cha $\mathrm{ux}$ I803 Missouri Gooseberry}

\section{Ribes missouriensis Nuttall I8I4}

A bushy, much branched shrub 1-2 m. high, spines mostly solitary, 7-17 mm. long, reddish, bark grayish, peeling off; leaves slender-petioled round or broader than long, 3-5 lobed, lobes blunt and dentate, pubescent when young, 2-3.5 cm. broad; racemes several-flowered, pedicels of the flowers very slender, $8-12 \mathrm{~mm}$. long, flowers white or whitish, drooping, 12-18 mm. long, calyx tube narrow, shorter than the lobes, lobes 5-6 mm. long, petals $2 \mathrm{~mm}$. long, stamens with slender filaments $10-15 \mathrm{~mm}$. long, projecting beyond the sepals; berry reddish-purple, 10-12 mm. long: g r a c i le, slender.

Common on river bottoms and in rocky soil throughout the state. Distributed from Ct. to S. D. and southward. Blossoms in May, fruit ripe in July and August.

\section{Rikes oxyacanthoides L i n né I 753 Smooth Gooseberry Northern Gooseberry}

Branching slırub, 0.5-1.5 m. high, bark grayish to dark, spines generally solitary, 5-10 mm. long, light-colored, sometimes with scattered prickles; leaves round, 3-5 lobed, truncate to broadly cuneate at base, thin but leathery, thinly pubescent along the margins and on the veins beneath, $1.5-3 \mathrm{~cm}$. wide, 1.5-3.5 cm. long, petioles pubescent, 1-2 cm. long, of ten with naked glands among the hairs; racemes 1-3 flowered, their peduncles about $12 \mathrm{~mm}$. long, flowers short pediceled, greenish-yellow to dull purple, 6-8 $\mathrm{mm}$. long, stamens about the same length as the oblong calyx lobes, calyx lobes $3 \mathrm{~mm}$. long, about as long as the tube, erectly spreading; berry glabrous, 8-12 $\mathrm{mm}$. in diameter. reddish-purple when ripe: o x y a c a 11 th o id es, with sharp spines.

In moist woods and low grounds, common throughout the northern half of the state, rare as far south as Minneapolis. Distributed from 


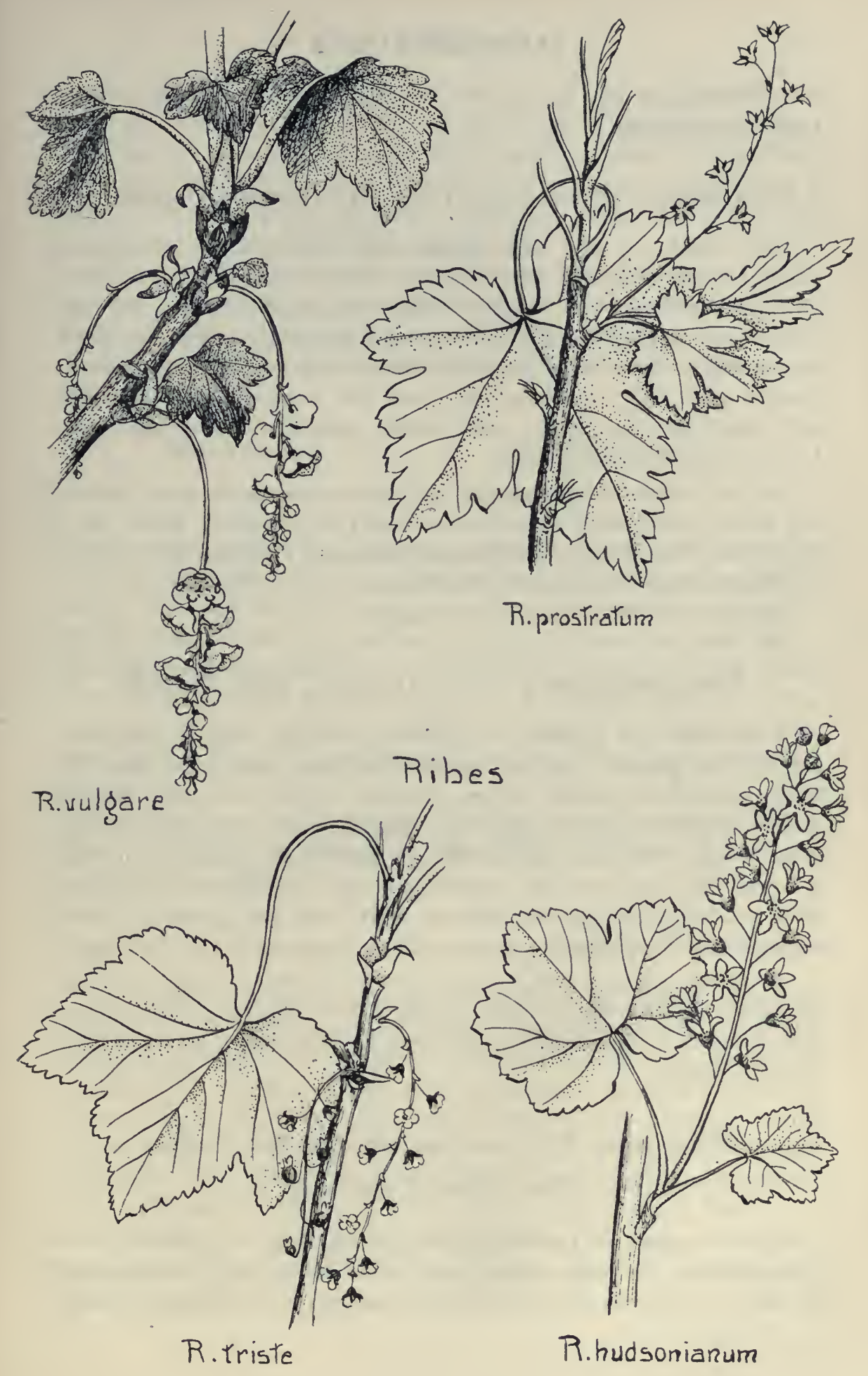


Newfoundland to Pa., west to N. D. and Manitoba. Blossoms in June, fruit ripe in August.

\section{Ribes lacustre (Persoon) Poiret i8I I Swamp Gooseberry}

Low shrub, 4-6 dm. high, young stems and branches covered with bristly prickles and weak slender spines; leaves heart-shaped, deeply 3-5 lobed or parted, $3-6 \mathrm{~cm}$. long, $2.5-5 \mathrm{~cm}$. wide, pubescent along the veins beneath and on the petioles; racemes loosely spreading or drooping glandular-bristly, 2-5 cm. long, pedicels about $4 \mathrm{~mm}$. long, flowers greenish, about $4 \mathrm{~mm}$. long, calyx-tube very short and broad, stamens and styles not longer than the petals; fruit bristly, purplish-black, $4 \mathrm{~mm}$. long: la custre, of the lake shore.

In cool woods and swamps in the northern and northeastern part of the state. Distributed from Newfoundland to Vancouver island, south to northern New England, Michigan, Minnesota, Colorado and northern California, in the mountains to Pennsylvaia.

Blossoms in June, fruit ripe in August.

\section{Ribes prostratum L'Heritier I784 Fetid Currant}

Low shrub with reclined or decumbent branches, without prickles or thorns, bark grayish or brown; leaves deeply heart-shaped, 5-7 lobed, the lobes ovate-acute, doubly serrate, smooth, $2.5-7.5 \mathrm{~cm}$. wide, petioles slender, 2.5-7.5 cm. long, glabrous; racemes erect, appearing from the same buds as the leaves, flowers about $5 \mathrm{~mm}$. broad, pedicels glandular, 4-5 mm. long, calyx broadly campanulate, sepals spreading, about $2 \mathrm{~mm}$. long, petals minute, purplish, stamens short; fruit red, glandular-bristly, about $4 \mathrm{~mm}$. in diameter: prostrat u m, prostrate.

Common in damp woods, northern part of the state. Distributed from Labrador to Athabasca south to northern New England, Mich., Minn., and along the mountains to North Carolina. Blossoms in May and June, fruits in August.

\section{Ribes triste Palla S I797 Swamp Red Currant}

\section{Ribes rubrum Linné 1753}

Low straggling or reclining shrub, $2-5 \mathrm{dm}$. high, the branches often rooting freely, the bark of last year's shoots brownish, often peeling off in strips; leaves somewhat cordate when mature, the lobes mostly broadly 
deltoid, white-tomentose on the lower surface, 5-10 cm. wide, petioles 2-5 $\mathrm{cm}$. long; racemes drooping, $3.5-9 \mathrm{~cm}$. long, borne on the old wood, mostly below fascicles of leaves, pedicels mostly glandular, flowers 5-6 $\mathrm{mm}$. broad, calyx mostly purplish, its lobes broadly triangular, about as broad as long, petals broadly wedge-shaped, disk conspicuous; fruits small and hard, 4-6 $\mathrm{mm}$. in diameter, dark red: $\mathrm{t} \mathrm{r}$ is t e, dark.

In cool woods and swamps, from Minneapolis northward and northeastward. Distributed from Newfoundland, to Alaska, south to Me., Vt., Mich. and Minn. Blossoms in May, fruit ripe in July.

This species has been confused with the common red currant of the garden.

\section{Ribes vulgare $\mathrm{L}$ a m a r ck 1786 Red Currant}

\section{Ribes rubrum Linné 1753}

Cultivated shrub, 0.5-1.5 m. high, unarmed, bark gray or brownish; leaves mostly cordate, slightly pubescent beneath, or glabrate, broadened upward, 3-5 lobed, the lobes mostly short-ovate and coarsely dentate, 3.5$6.5 \mathrm{~cm}$. wide, $3-6 \mathrm{~cm}$. long, petioles $2-5 \mathrm{~cm}$. long, pubescent; racemes $3-7$ $\mathrm{cm}$. long, mostly drooping, borne among the leafy shoots, pedicels mostly glandular, flowers flat, 6-9 mm. broad, calyx yellowish-green, the lobes oval and narrowed below the middle, 1-2 mm. long, petals narrowly wedge-shaped, style cleft partly down; fruit a red juicy berry: $\mathrm{v} u \mathrm{lg}$ a r e, common.

The common cultivated currant, sometimes escaping from cultivation. Native of Europe and naturalised from thence. Blossoms in May and June, fruit ripe in July.

\section{Ribes hudsonianum $\mathrm{R}$ i c h a rds o 1823 Northern Black Currant}

Shrub with erect, unarmed branches, bark grayish, peeling off in thin layers; leaves broader than long, 3-5 lobed, the lobes obtuse or acute, more or less pubescent and resinous dotted beneath, $2.5-10 \mathrm{~cm}$. wide, petioles $1-7$ $\mathrm{cm}$. long; racemes short, upright or spreading, from the same buds as the leaves, 3-10 cm. long, about $2 \mathrm{~cm}$. in diameter, flowers numerous, white, 5-6 mm. long, calyx broadly campanulate, its lobes $2 \mathrm{~mm}$. long, tube less than $2 \mathrm{~mm}$. long, stamens short, not exserted ; fruit smooth and black, 4-6 $\mathrm{mm}$. in diameter: hu ds on i a $\mathrm{n} \mathrm{m}$, found about Hudson's Bay.

In swamps, northern and northeastern part of the state. Distributed from Hudson's Bay westward and northward. Blossoms in June, fruit ripe in August. 


\section{Ribes floridum L'H eritier I 784 Wild Black Currant}

Shrub with erect, unarmed branches, bark gray or grayish ; leaves somewhat heart-shaped, 3-5 lobed, the lobes acutish, doubly serrate, glabrous above, somewhat pubescent below, $2.5-7 \mathrm{~cm}$. wide, petioles $2-4 \mathrm{~cm}$. long; racemes appearing from the same buds as the leaves, pubescent, $3-8 \mathrm{~cm}$. long, the elongated bracts persistent, flowers yellow and whitish, calyx tubular-campanulate, $8-10 \mathrm{~mm}$. long, smooth, sepals spreading, longer than the petals; fruit black, smooth, $6 \mathrm{~mm}$. in diameter: $\mathrm{f} 1$ o r i d u m, flowery.
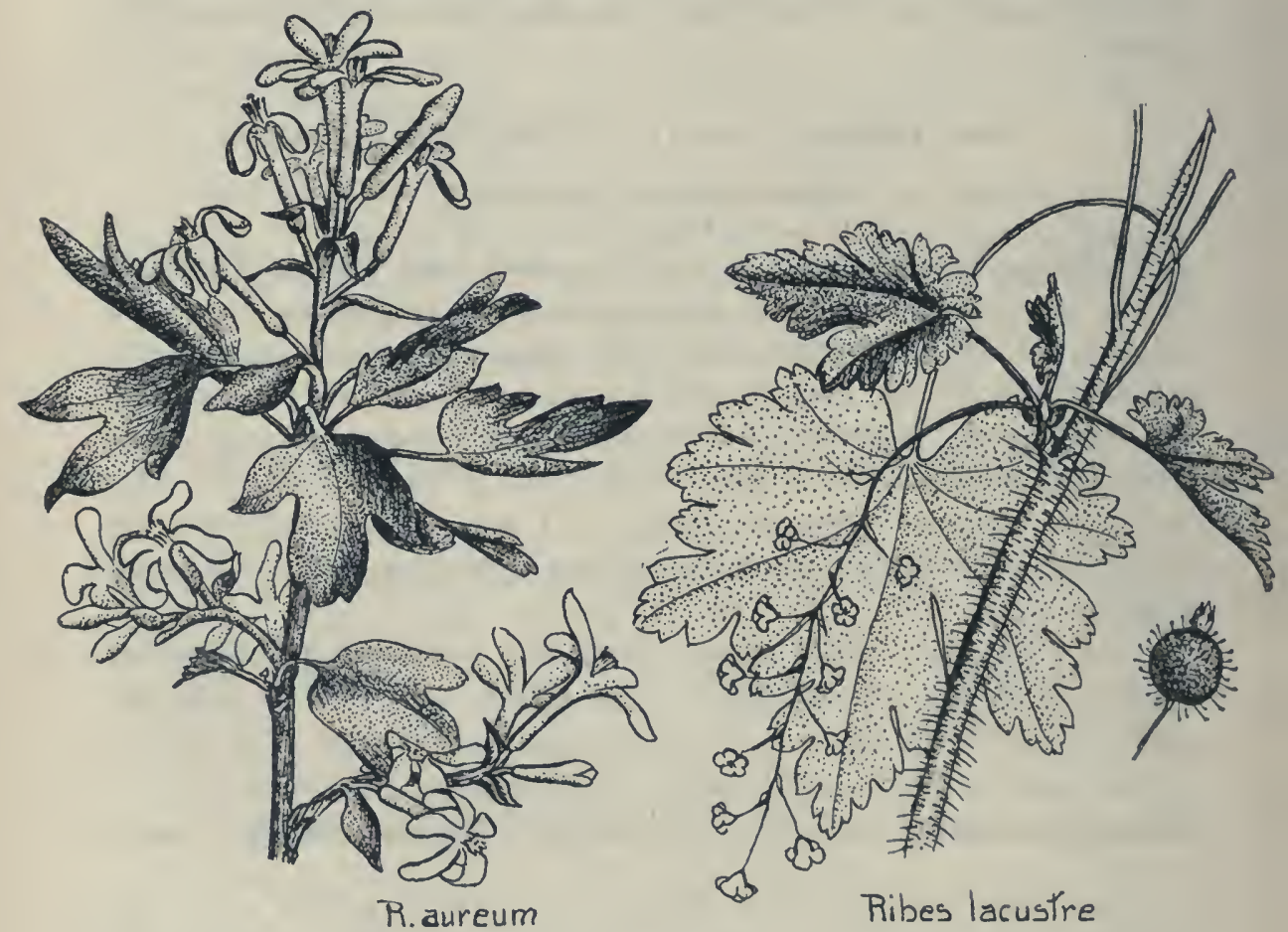

In rich woods, thickets and banks, throughout the wooded part of the state. Distributed from New Brunswick to Saskatchewan, south to Va., Ky., Ia. and Neb. Blossoms in May, fruit ripe in August.

\section{Ribes aureum Pursh I8I4 Golden Currant Buffalo Currant}

Tall unarmed shrub, 1-2 m. high; bark gray or brown, peeling off on the old branches; leaves broadly wedge-shaped or truncate at the base, 3-5 lobed, pubescent and ciliate or at length glabrous, thick, convolute 
in buds, 2-5 cm. long, petioles $1-3 \mathrm{~cm}$. long, puberulent; racemes $3-5 \mathrm{~cm}$. long, leafy-bracted, few-flowered, flowers golden yellow, spicy scented, 12$24 \mathrm{~mm}$. long, calyx-tube cylindric, 3-4 times as long as the spreading or reflexed lobes, petals pink, erect, 2-2.5 mm. long, stamens short, slightly exserted; berries black or yellow : a u r e u m, golden.

Along banks of streams, probably native in the southwestern part of the state. Extensively cultivated as an ornamental shrub and occasionally escaped. Distributed from Minn. (?) through Mo. and Ark. westward to Saskatchewan, eastern Washington and Oregon. Blossoms in May, fruit ripe in July and August.

\section{Hamamelidaceae Witch-Hazel Family}

Shrubs or trees with alternate simple leaves and deciduous stipules, flowers in heads or spikes, often polygamous or monoecious, calyx adhering to the base of the pistil, 4-5 parted or lobed, petals 4-many or none, long and narrow, stamens 4-many, distinct, pistil compound, carpels 2, united at base; fruit a two-beaked, two-celled, woody capsule, opening at the summit, with 1 -several bony seeds in each cell.

\section{Hamamelis Lin n é $r 753$ Witch-Hazel}

(Greek name for some tree)

Tall shrubs or small trees, with alternate, toothed, straight-veined leaves; flowers in small axillary clusters, bright yellow, surrounded by a scale-like 3-leaved involucre, appearing in late summer or autumn, calyx 4-parted, persistent, adnate to the base of the ovary, petals 4, narrow, strap shaped, stamens 8 , short, the 4 opposite the petals imperfect and scale like, pistil 2-celled, styles 2, short; fruit a woody capsule, opening by two valves at the top.

A genus of 3 species, one native of eastern North America, the others of Japan.

\section{Hamamelis virginiana L in né 1753 Witch-Hazel}

A branching shrub 2-4 meters (6-12 feet) high, twigs with slightly scurfy or smooth bark; leaves short petioled, obovate or oval, wavy toothed and stellate pubescent at least when young, $6-15 \mathrm{~cm}$. long, 4-10 cm. wide; flowers appear in autumn when the leaves are falling and while previous fruit remains; seeds mature the summer after the flowering: virg in i a n a, Virginian. 


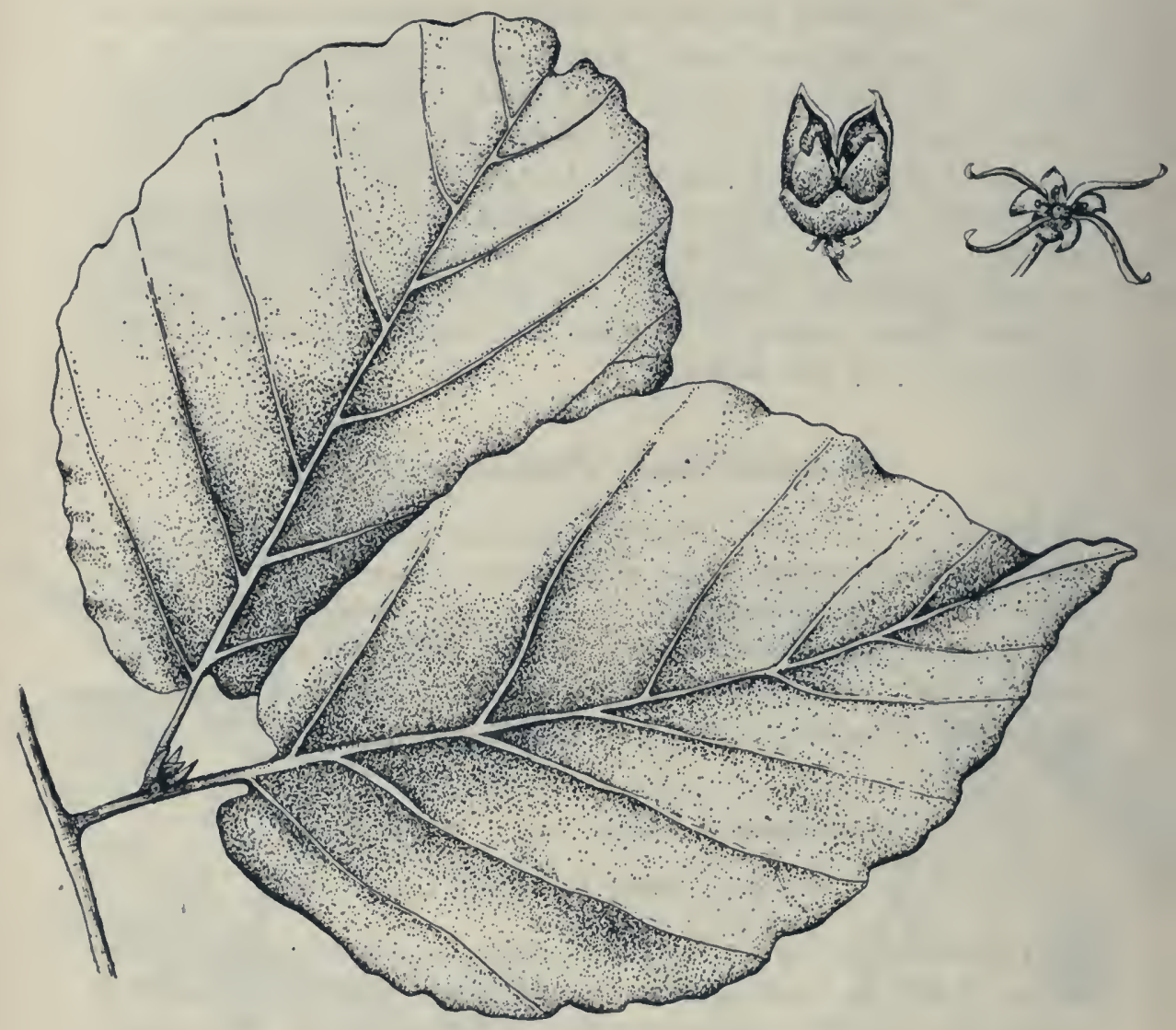

In damp woods in the extreme southeastern corner of the state. Distributed from Nova Scotia to Florida, west to eastern Minn. and Texas. Blossoms in September and October, fruits the following summer.

Wood is hard, light brown and streaked with red, weighs 43 lbs. The bark is astringent and is used in the form of fluid extracts and decoctions, but is not known to have any essential properties.

\section{Celastrales Bittersweet Order \\ Celastraceae Bittersweet Family}

Shrubs or twining woody vines with simple alternate or opposite leaves; flowers small, regular, in cymes or racemes, sepals 4-5, more or 
less united, petals 4-5, stamens 4-5 alternate with the petals, borne on a fleshy disk which fills the bottom of the calyx, ovary 3-5 celled; fruit fleshy, dehiscent, seeds arilled, remaining on till late in the winter.

\section{IFY TO THE GENERA}

1. Shrub with opposite leaves, flowers in cymes, fruit lobed

2. Twining vine, leaves alternate, flowers in racemes

\section{Euonymus}

\section{Celastrus}

\section{Euonymus L i 11 né I753}

(Gr. e u, good, o nom a, name, of doubtful application)

Shrubs with opposite, simple, petioled, serrate leaves; branchlets foursided ; cymes axillary, several-flowered, 4-6 cm. long, borne on the season's growth, flowers flat, 7-10 mm. wide, sepals 4-5, united at the base, petals $4-5$, rounded, spreading, about $3 \mathrm{~mm}$. long, stamens 4-5, usually borne on the top of a flat disk which adheres to the calyx, ovary 3-5 celled; fruit 3-5 lobed, loculicidal, seeds 1-3 in each cell.

A genus of 65 species, of the north temperate zone, besides the following, two occur in Eastern North America and tẉo in California.

\section{Euonymus atropurpureus $\mathrm{J}$ a $\mathrm{c} q u$ in 1772 Burning Bush, Wahoo}

A shrub, sometimes tree-like, 3-4 m. high, bark greenish-gray; leaves oval, oblong, tapering at the base, long acuminate at the apex, finely serrate, glabrous above, puberulent beneath, $5-14 \mathrm{~cm}$. long, $2.5-5.5 \mathrm{~cm}$. wide, petioles 1-1.5 cm. long; flowers in cymes, purplish, inconspicuous; fruit 3-5 lobed, pinkish, dehiscent, seeds with crimson aril: a tro p u r p u r e u s, deep purple.

Common throughout the southern part of the state and reported as far north as Clay county in the Red River Valley. Distributed from New York to Minnesota, Nebraska, southward and westward. Frequently planted as an ornamental shrub on account of the brilliant scarlet fruits which remain on the tree for several months during the fall and winter.

\section{Celastrus Li n n é I753 \\ (Greek name of some evergreen)}

Shrubs, mostly climbing; leaves alternate, thin, deciduous; flowers in terminal or axillary racemes, or paniculate, inconspicuous, dioecious or polygamo-dioecious, calyx 5 -lobed, petals 5 , inserted below or along the 


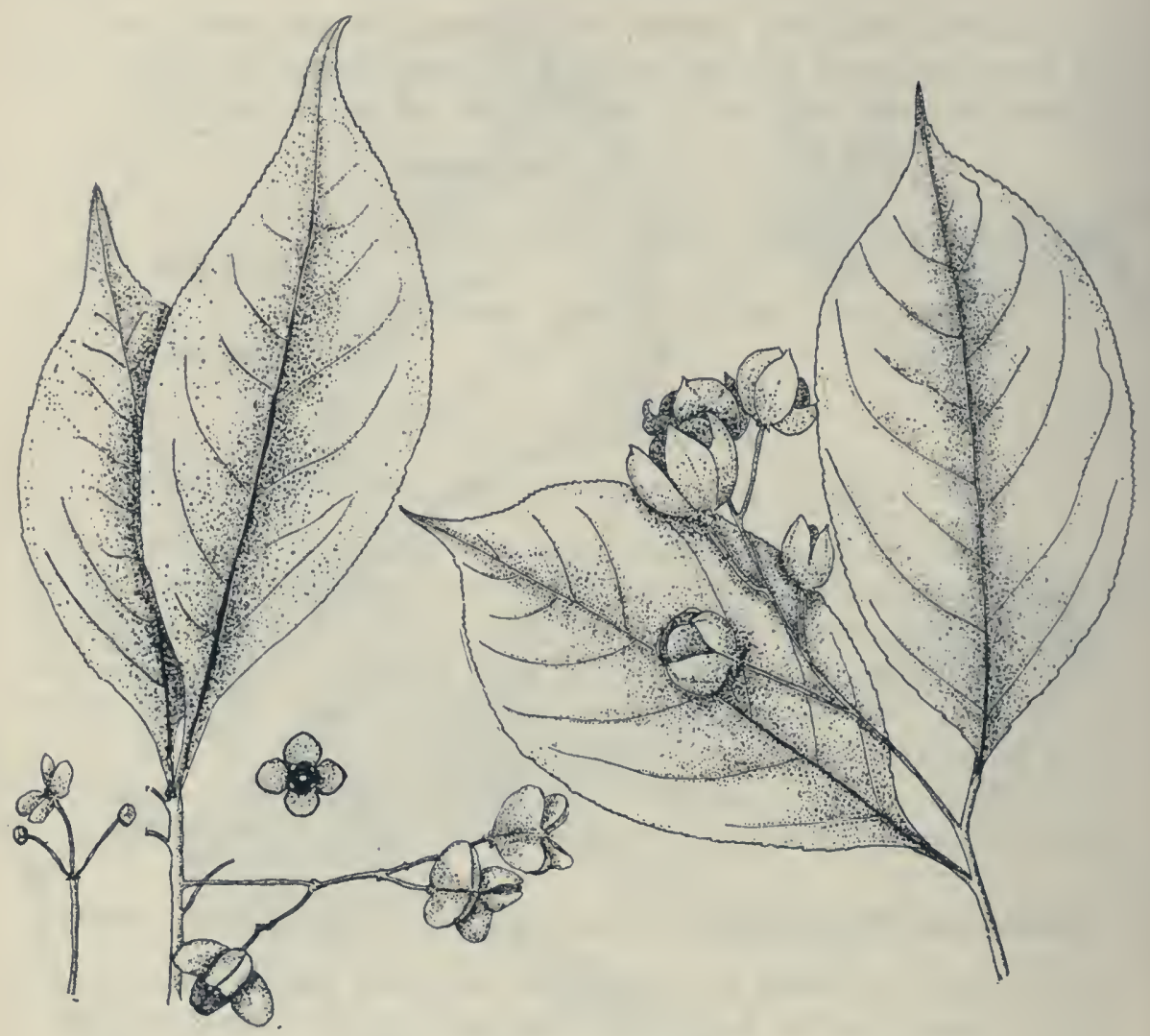

\section{Evonymus atropurpureus Celastrus scandens}

margin of the disk, stamens in the staminate flowers 5 , in the sinuses of the disk, ovary 2-4 lobed and 2-4 celled, two ovules in each cell; capsule 2-4 celled, dehiscent into as many valves, 1-2 seeds in each cell, each with a scarlet aril.

A genus of about 30 species, one of which occurs in North America, the others are found in Asia, Australia and Madagascar.

\section{Celastrus scandens L i n né I753 Shrubby or Climbing Bittersweet}

A twining woody vine climbing up trees to a height of 8-10 m., sometimes trailing on the ground, bark gray or brownish, smooth; leaves alternate, appearing 2-ranked by the twisting of the stem, ovate to obovate, or ovate-lanceolate, narrowed or rounded at the base, acuminate at the apex, crenulate-serrate, thin, glabrous on both sides, 5-10 cm. long, $3-5 \mathrm{~cm}$. 
wide, petioles $1-2 \mathrm{~cm}$. long; flowers in terminal racemes or panicles, yellowish-green, 8-9 mm. broad, sepals short, triangular, petals 3-4 $\mathrm{mm}$. long, crenulate; fruit a yellow, globular capsule, about $1 \mathrm{~cm}$. in diameter, seeds with scarlet aril : sc a n d e n s, climbing.

In woods, common throughout the southern half of the state, less frequent northward. Distributed from Quebec to North Carolina, especially along the mountains, west to Manitoba, Kan., Okla. and New Mexico. Often planted as a climber on trellises, porches, etc. Sometimes it is troublesome among young trees as it encircles and strangles them. Blossoms in June, fruit ripe in September and persisting through the winter.

\section{Rhamnaceae Buckthorn Family}

Erect or climbing shrubs or small trees, often thorny; leaves mostly alternate, simple, stipulate, often prominently 3-5 nerved; flowers in axillary or terminal cymes or racemes, small and regular, perfect or polygamous, calyx-tube obconic or cylindric, sepals 4 or 5, small, petals 4-5, inserted on the calyx-tube or lacking, stamens 4-5, in front of the petals, disk fleshy; ovary free from or immersed in the disk, 3-5 (mostly. 3) celled, one ovule in each cell; fruit a drupe or capsule, mostly 3celled, seeds solitary in each cell.

KEY TO THE GENERA

1. Calyx and disk free from the ovary, fruit a drupe

Rhamnus

2. Calyx and disk adherent to base of ovary, fruit a dry capsule

\section{Ceanothus}

\section{Rhamnus L in né I753 Buckthorn}

(Gr. rh a m nos, buckthorn)

Shrubs or small trees with alternate or sometimes opposite, simple, pinnately-veined leaves; flowers in axillary racemes, panicles or cymes, perfect or polygamous, greenish, calyx-tube campanulate, lined with a disk, 4-5 toothed, petals 4-5, small, short-clawed, notched at the end and hooded or globose, sometimes lacking, disk free from the ovary, stamens 4-5, in front of the petals, short, ovary 3-4 celled, style 3-4 cleft ; fruit a berry-like drupe, oblong or globose, containing 3-4 nutlet-like seeds.

A genus of about 75 species, native of temperate and warm regions. Five of these occur in eastern and six in the western parts of North America. 


\section{Key to the Species}

1. Flower parts in 4's, petals present, large shrub or tree

2. Flower parts in 5's, petals lacking, low shrub

R. cathartica

R. alnifolia

\section{Rhamnus cathartica L in né I753 Buckthorn}

A shrub or small tree $2-6 \mathrm{~m}$. high; bark brown, twigs often ending in stout thorns; leaves alternate or sometimes opposite, ovate or elliptic, rounded or narrowed at the "base, obtuse or acuminate at the apex, minutely serrate, glabrous, $3-6 \mathrm{~cm}$. long, $1.5-3 \mathrm{~cm}$. wide, petioles $1-2 \mathrm{~cm}$. long; flowers clustered in the axils of the leaves, dioecious, greenish, about $4 \mathrm{~mm}$. broad, sepals 4 , spreading or reflex, lanceolate, $2 \mathrm{~mm}$. long, petals 4 , minute, erect, about the same length as the stamens, pedicels $5-8 \mathrm{~mm}$. long, slender; fruit a globose drupe about $8 \mathrm{~mm}$. in diameter, with $3-4$ grooved nutlets: c a th a $\mathrm{tic}$, purgative.

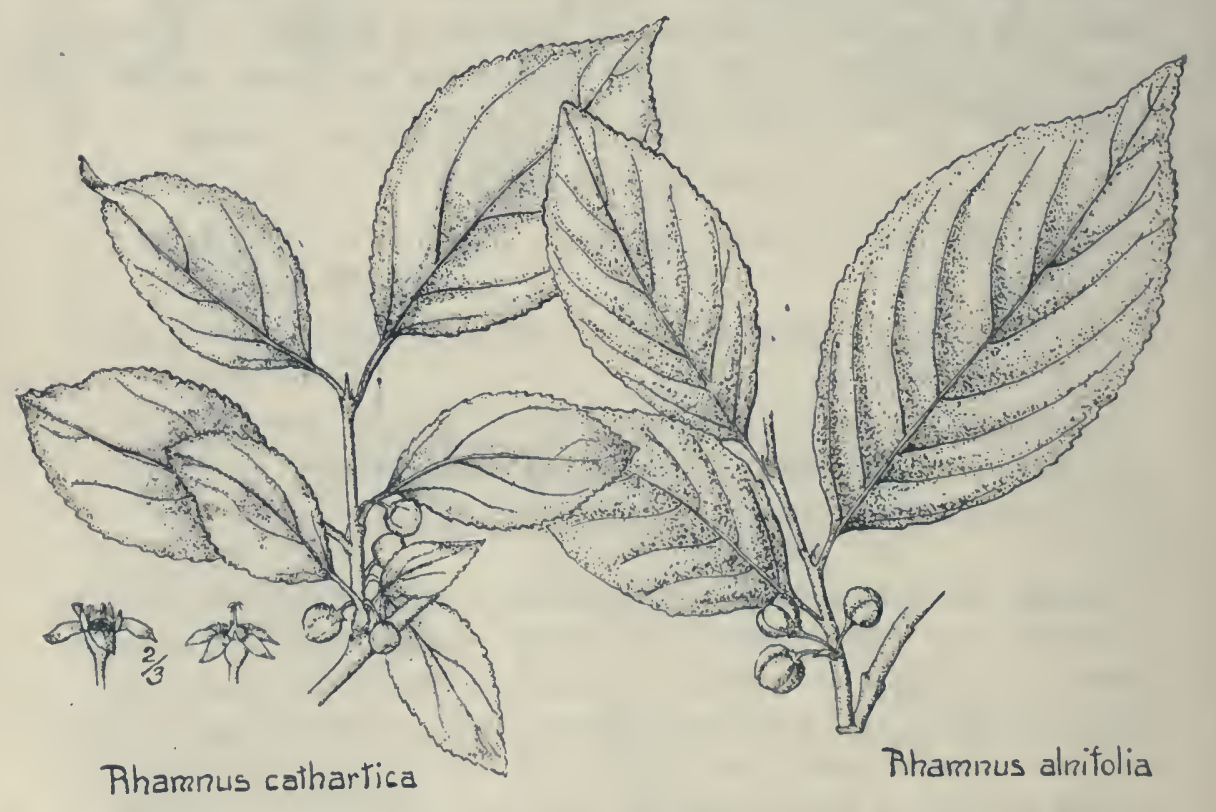

Frequently planted for hedges. Introduced from Europe and native of that continent and Asia. Flowers in May and June, fruits ripe in August and September. The leaves remain green and are retained on the shrubs until very late in the autumn. 


\section{Rhamnus alnifolia L'Heritier I788 Dwarf Alder}

A small shrub 3-6 dm. high, thornless; bark gray or dark on the old branches, young twigs puberulent; leaves alternate, ovate to elliptic, rounded or narrowed at the base, acute or obtuse at the apex, crenate-serrate, glabrous above, puberulent along the veins beneath, 4-10 cm. long, 2$5 \mathrm{~cm}$. wide, veins nearly straight, in 4-6 pairs, petioles $4-10 \mathrm{~mm}$. long; flowers $1-3$ in the axils of the leaves and appearing with them, green, small, 2-3 mm. broad, mostly dioecious, sepals 5, about $1 \mathrm{~mm}$. long, petals lacking, pedicels slender, 4-5 mm. long, fruit a black ovoid or globose drupe, about $6 \mathrm{~mm}$. in diameter, nutlets 3 : a $\mathrm{ln}$ if olia, leaves as in Alnus, the alder.

Mostly in tamarack swamps throughout the northern half of the state and as far south as Minneapolis. Distributed from Newfoundland to British Columbia, south to New Jersey, Pa., Ill., Neb., Wyo., etc. Blossoms in May and June, fruit ripe in July and August.

\section{Ceanothus L in n é 1753}

\section{(Ancient Greek name for some plant)}

Low bushes or shrubs with alternate, simple, petioled leaves; flowers white, blue or yellow, in small umbel-like clusters forming dense panicles or corymbs at the summit of naked flower branches, calyx-tube topshaped, sepals 5, incurved, petals 5 , hooded, spreading with slender claw, longer than the calyx lobes, attached under the disk, stamens 5, filaments elongated, ovary sunk in the disk, 3-celled, styles 3, short; fruit a dry capsule, 3-lobed, splitting lengthwise at maturity into 3 nutlets.

A genus of 35 species, natives of North America and Mexico, only the two following within our range.

\section{Key to the Species}

1. Leaves ovate or ovate-oblong, pubescent

C. americanus

2. Leaves oblong or narrowly oval, or elliptic-

lanceolate, nearly smooth

C. ovatus

\section{Ceanothus americanus L in n é 1753 New Jersey Tea}

Branching shrub, 3-9 dm. high, several branches from a deep reddish root, lower branches dark brown, upper ones densely puberulent or rustycolored ; leaves ovate or ovate-oblong, mostly obtuse or cordate at the base, acute at the apex, finely serrate, pubescent on both sides especially along 


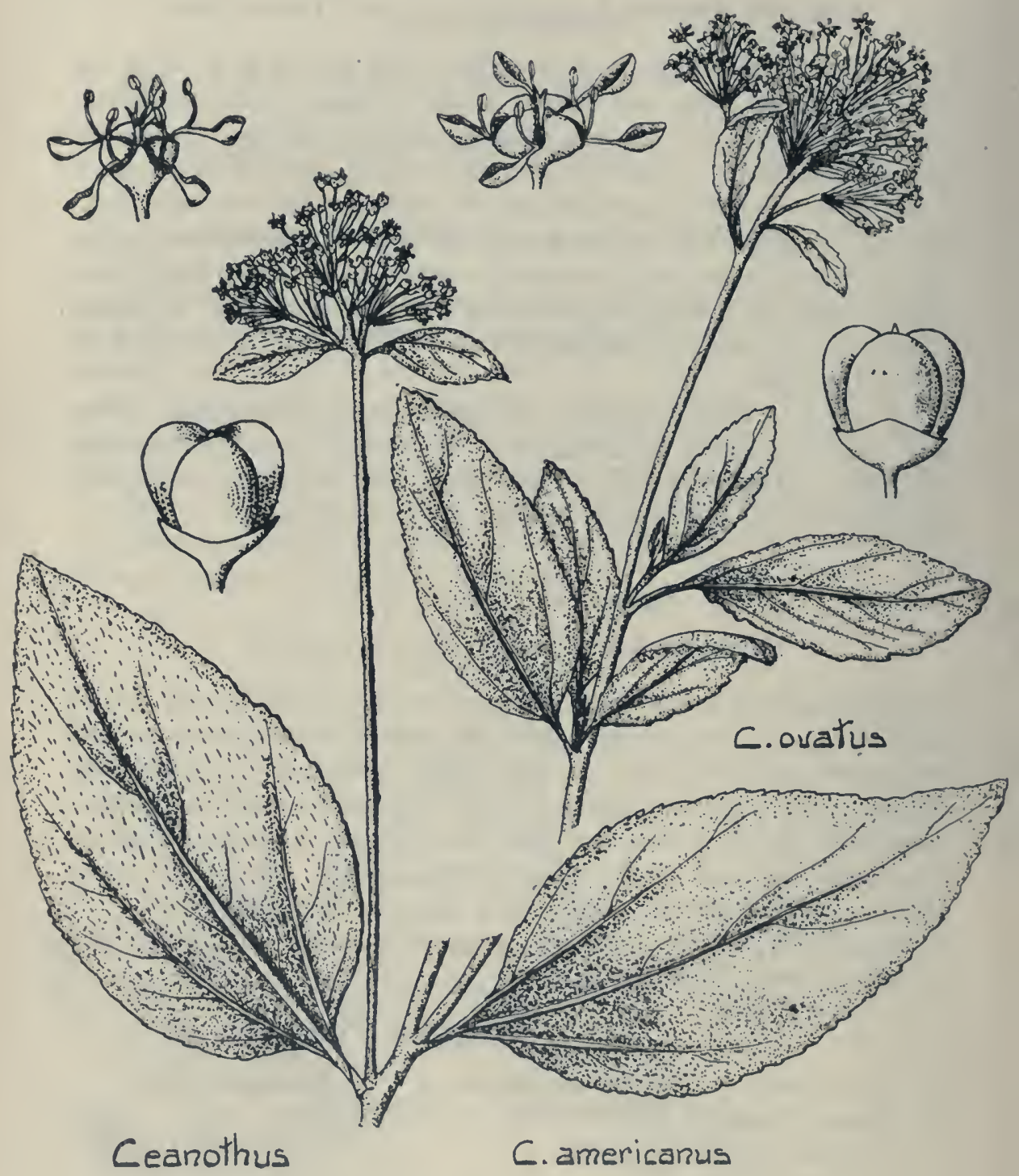

the veins, with three principal nerves, $3-10 \mathrm{~cm}$. long, $2.5-5.5 \mathrm{~cm}$. broad, petioles 6-12 $\mathrm{mm}$. long; peduncles several, axillary and terminal, naked or with one or two leaves just below the flowers, $10-15 \mathrm{~cm}$. long; fiowers very numerous, white, small, about $2 \mathrm{~mm}$. broad, pedicels 7-8 $\mathrm{mm}$. long, petals long and narrow clawed; fruit globose, depressed, faintly 3-lobed, splitting into 3 valves: a merican us, American. 
Common throughout the state, except far northward. Distributed from central Maine to Ontario and Manitoba, south to Florida and Texas. The leaves were used for tea during the American revolution. This small shrub has a thick, gnarled root, often $15-20 \mathrm{~cm}$. in diameter. Flowers in July, fruit ripe in September.

\section{Ceanothus ovatus Desfontaines 1809 Smaller Red-root}

A shrub 3-6 dm. high, much branched, nearly glabrous throughout; leaves narrowly oval or elliptic-lanceolate, narrowed or rounded at the base, obtuse at the apex, finely and sharply glandular-serrate, glabrous or slightly pubescent along the principal veins, $2-5 \mathrm{~cm}$. long, $1-2.5 \mathrm{~cm}$. wide, petioles about $5 \mathrm{~mm}$. long; peduncles short, nearly always terminal; flowers in dense, umbel-like clusters, white, about $5 \mathrm{~mm}$. broad, pedicels 10-15 mm. long; fruit globose, slightly flattened at the top, faintly 3lobed: o v a t u s, egg-shaped.

Probably throughout the state but less common than the preceding. Distributed from Vt. and eastern Mass. to Manitoba, Minn., Ill. and south to Texas. Blossoms in June, fruit ripe in September.

Var. p u be s c e n s Torrey and Gray 1878.

This variety has leaves permanently sordid-tomentose, it occurs in the southern part of the state.

\section{Vitaceae Grape Family}

Climbing or erect shrubs with watery acid juice; leaves alternate, simple, palmately veined or lobed, or compound ; tendrils and flower-clusters opposite the leaves; flowers in panicles, racemes or cymes, small, regular, greenish, perfect or polygamo-dioecious; calyx entire or 4-5 lobed, petals 4-5, separate or coherent, valvate, often falling off when flowers open, stamens 4-5, opposite the petals, filaments short, disk present or sometimes lacking, ovary 2-celled, generally immersed in the disk, ovules $1-2$ in each cavity; fruit a 2 -celled berry, seeds usually 4 , seedcoat bony.

\section{KEY TO THE GENERA}

1. Hypogynous disk present, petals deciduous as they open

Vitis

2. Hypogynous disk lacking, petals not deciduous as they open 
Vitis L i n n é 1753

(The classical Latin name of the Vine)

Climbing or trailing woody vines, rarely shrubby, mostly with tendrils; leaves simple, (in our species), usually palmately lobed or dentate; flowers in a compound thyrse, very fragrant, mostly dioecious or polygamodioecious, calyx very short, usually with a nearly entire border or none at all, petals 5, separating only at the base and falling without expanding, hypogynous disk of 5 nectar-bearing glands, alternate with the stamens; fruit a globose or ovoid berry, few-seeded and pulpy, seeds with a beaklike base.

A genus of about 40 species, natives of warm and temperate regions. In addition to the following some other species occur in the southern and western parts of the United States.

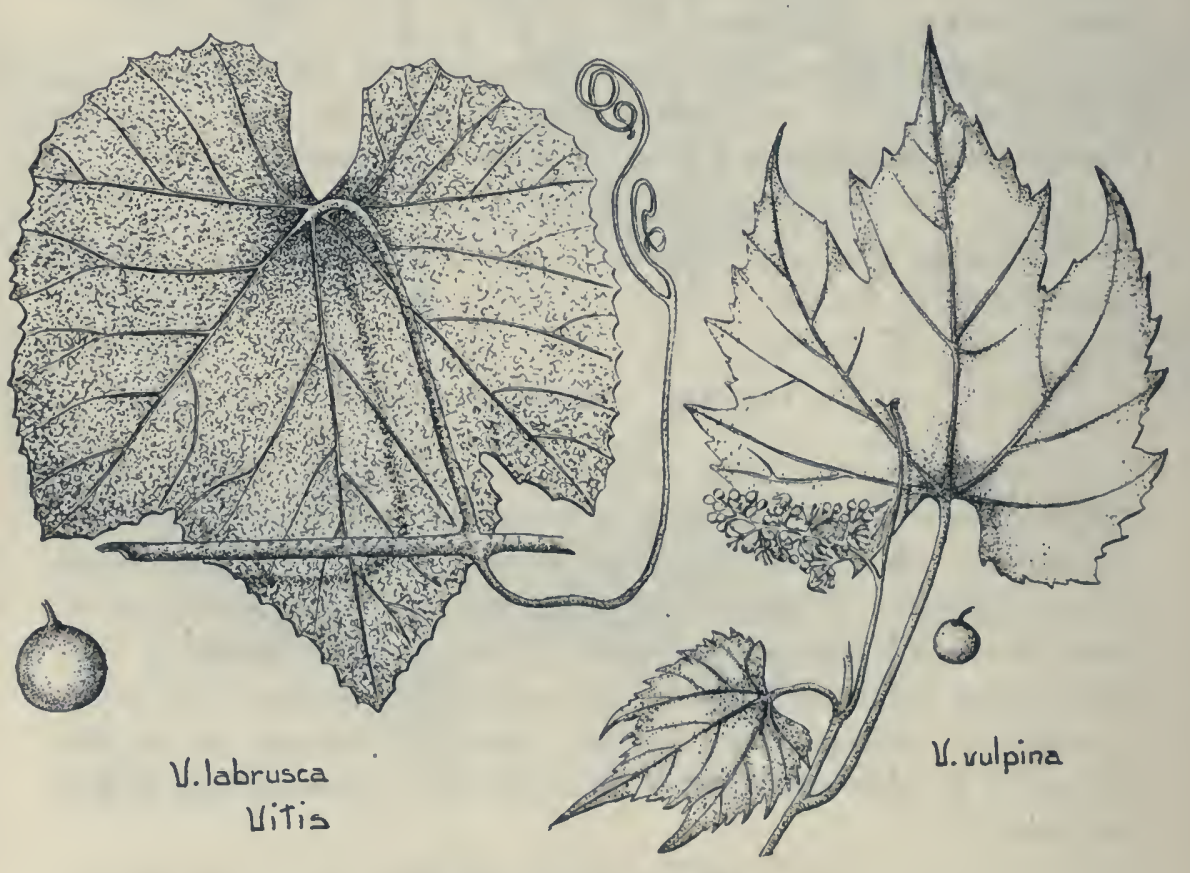

Key to the Species

1. Lower leaf surface velvety or woolly, berries large, cultivated V. Labrusca

2. Lower leaf surface nearly smooth, berries small, $\quad V$. vulpina native. 


\section{Vitis Labrusca L in né I753 Northern Fox-grape}

Climbing or twining vines, often ascending tall trees, stems sometimes becoming 6-12 cm. in diameter, bark loose and separating into strips, twigs rusty-pubescent, especially when young; leaves opposite the tendrils, cordate, dentate or deeply lobed, with rounded sinuses, upper surface glabrous or nearly so when mature, tawny or rusty-pubescent beneath, 4-12 $\mathrm{cm}$. long, 5-14 cm. wide, petioles 5-10 cm. long, rusty-pubescent; fertile flowers in compact panicles, 6-10 cm. long, staminate inflorescence looser, flowers yellowish-green, fragrant; berries black or brownish-purple, with a bloom, 10-15 mm. in diameter, borne in compact bunches, strongly musky: La br u s a, the wild grapevine.

Occurs in moist or dry thickets, from New England to the Allegheny Mountains, south to Georgia, also in northwestern Indiana.

This species has given rise, through cultivation, to the Isabella, Catawba, Concord and other varieties of grapes. Flowers in May or early June, fruit ripe in September.

\section{Vitis vulpina L i n n é 1753 River bank or Frost Grape}

Climbing or trailing vine, ascending high into tall trees, stems $2-10$ $\mathrm{cm}$. in diameter, with loose, fissured bark; leaves alternate, the upper ones opposite tendrils or inflorescences, cordate, mostly 3-7 lobed, with broad sinuses, coarsely toothed, glabrous or with scattered hairs along the veins beneath, $6-20 \mathrm{~cm}$. long, $5-15 \mathrm{~cm}$. broad, petioles $5-10 \mathrm{~cm}$. long; inflorescences paniculate, rather loose, $8-12 \mathrm{~cm}$. long, flowers small, greenish, petals falling as flower opens, very fragrant; fruit a bluish-black berry, with bloom, 6-10 mm. in diameter, very juicy and sour: $\mathrm{v} \mathrm{u} 1 \mathrm{p}$ i n a, pertaining to a fox.

Common throughout the state. Distributed from New Brunswick to W. Va., westward to North Dakota and Kan. The wild grape vine is sometimes grown as a climber on porches, pergolas, etc. The fruit is used in making wine and preserves. Blossoms in May and June, fruit ripens from September to November.

\section{Parthenocissus Pla n chon 1887 Virgin's Bower Woodbine}

$$
\text { (Gr. parthenos, virgin, c is sos, ivy) }
$$

Climbing or trailing woody vines with alternate, digitately compound or simple lobed leaves, tendrils tipped with adhesive expansions or disks, or sometimes only coiling; inflorescence a compound cyme or panicle, 


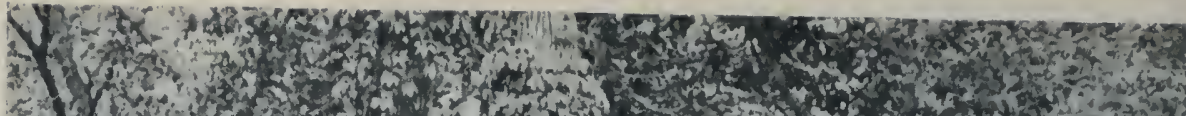
H.

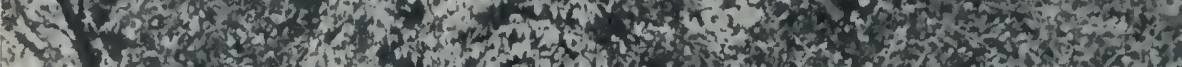

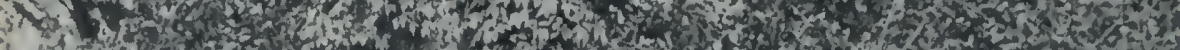

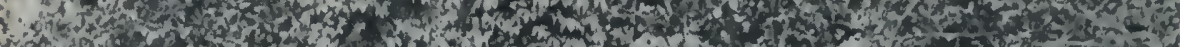

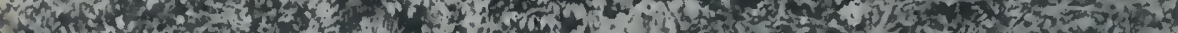

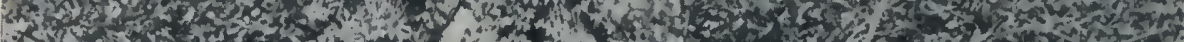

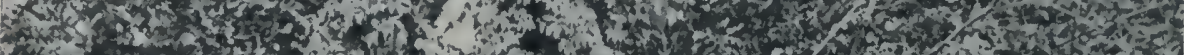

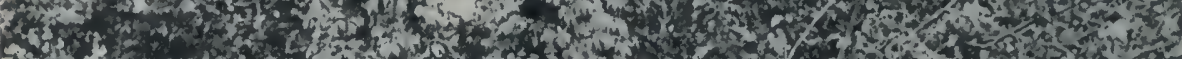

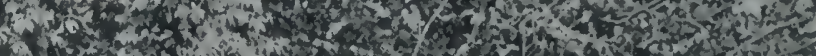

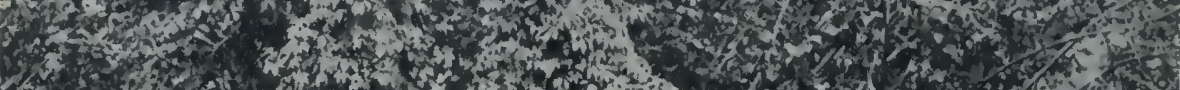

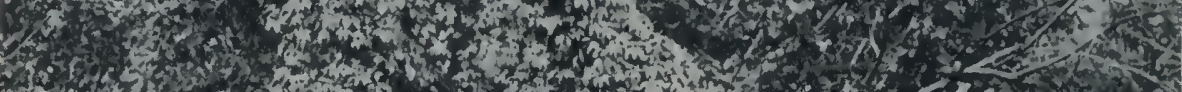

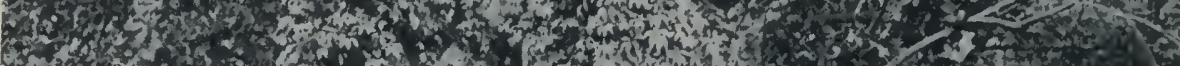

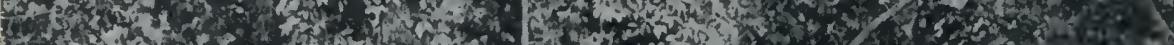

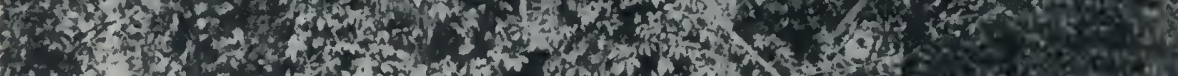

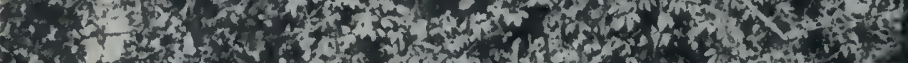

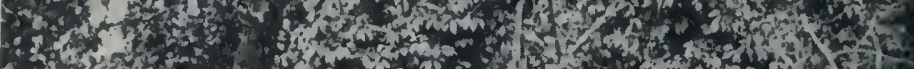

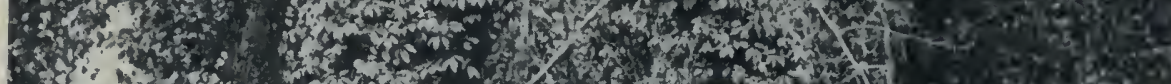

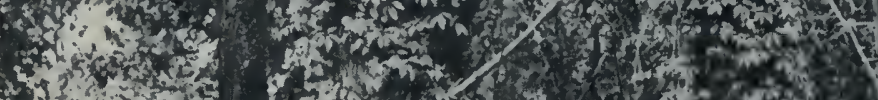
and Axi.t.

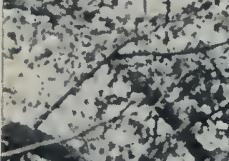

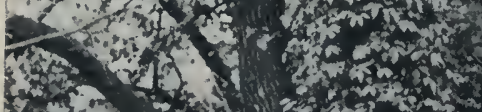
m. a.

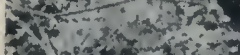
Q . Youstins nothe x.m. (3) 3. axtsing s.t. sit 2. 2. 5.t. (1) 
flowers perfect or polygamo-dioecious, calyx slightly 5-lobed, petals thick and concave, expanding before dropping off, disk obsolete or wanting in our species, stamens 5, ovary 2-celled, ovules 2 in each cavity; fruit a globose, 1-4 seeded berry, flesh thin, inedible.

- A genus of about 10 species natives of eastern North America and Asia.

\section{Key to the Species}

1. Leaves simple and lobed or some 3 -foliate

P. tricuspidata

2. Leaves all palmately compound 5-7-foliate

a. Tendrils with 5-12 branches, mostly with adhesive disks, leaflets much paler beneath

P. quinquefolia

b. Tendrils with 2-5 branches, mostly without adhesive disks, leaflets not much paler beneath.

P. vitacea

Parthenocissus tricuspidata (Siebold \& Zuccarini) Pla n chon I 887 Boston Ivy

A high climbing. vine, when growing on walls very closely appressed, young shoots and foliage pinkish, with scattered granules of wax, tendrils short and much-branched, adhesive disks large and numerous; leaves mostly simple, 3-lobed and palmately veined, more rarely 3 -foliate, very coarsely toothed, the teeth mucronate-tipped and bristly-ciliate, both surfaces with a few scattered short, stiff hairs, the simple leaves cordate at the base, acute at the apex, $5-9 \mathrm{~cm}$. long, $5-8 \mathrm{~cm}$. wide, leaflets of the compound leaves $5-7 \mathrm{~cm}$. long, the two lateral ones oblique at the base, petioles stout, $4-8 \mathrm{~cm}$. long; flowers in short-stalked racemes; fruit a blueblack berry: $t$ ric u s p id a t a, three-toothed.

This species is not entirely hardy in Minnesota and is able to endure our winters without injury only when growing in well protected situations. Very extensively cultivated in the cities of the eastern states. Native of China and Japan.

Parthenocissus quinquefolia (Linne) Pla n ch on 1887 Virginia Creeper Woodbine

Ampelopsis quinquefolia Michaux 1803 Psedera quinquefolia (Linné) Greene 1906

A high climbing or trailing woody vine, stem sometimes $3-6 \mathrm{~cm}$. in diameter, tendrils opposite the leaves, 5-12-branched, mostly ending in adhesive disks; leaves petioled, 5-7-foliate, leaflets stalked, oval-elliptic or 


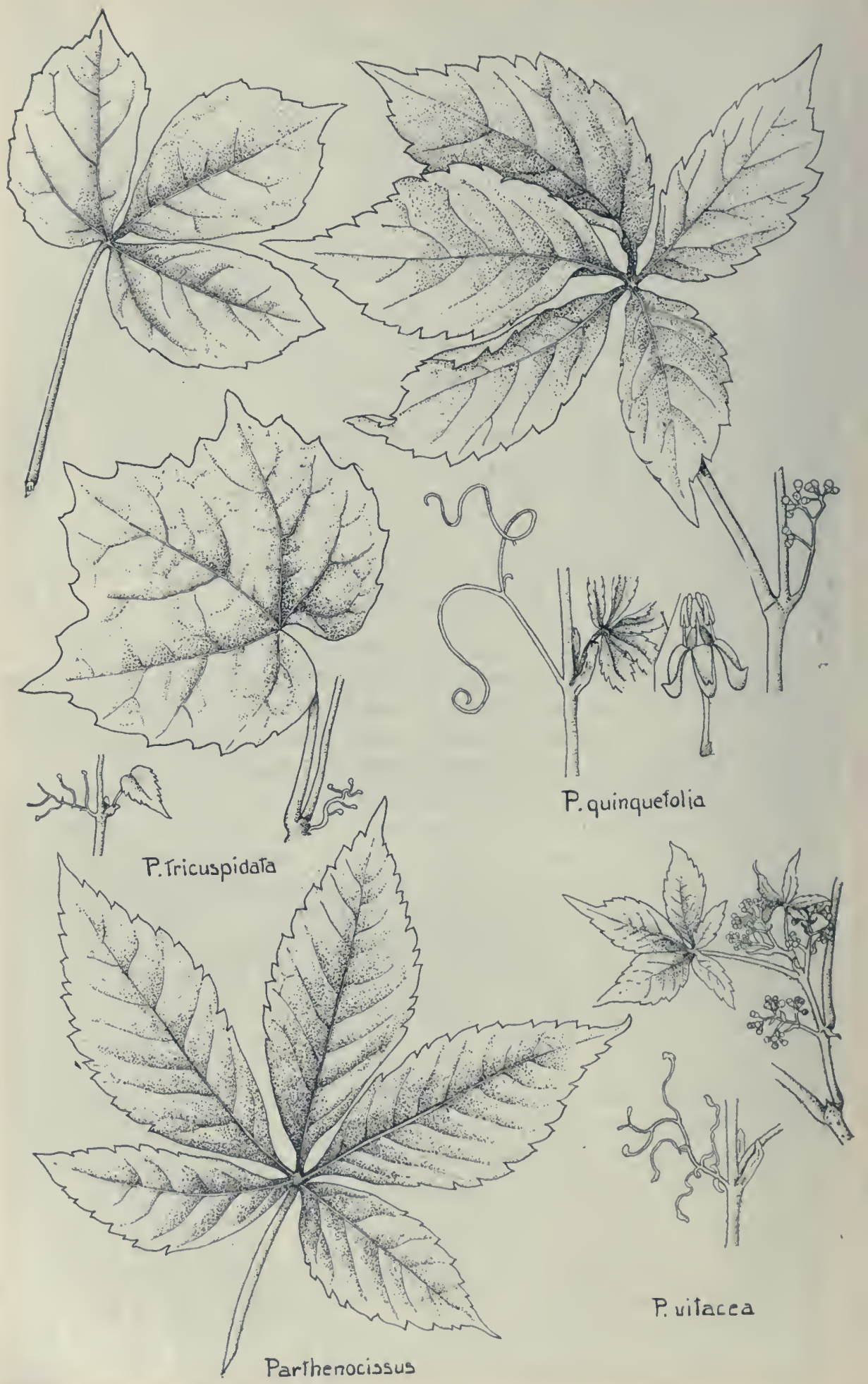


oblong lanceolate, coarsely serrate, dull green above, much paler beneath, glabrous throughout, $4-12 \mathrm{~cm}$. long, $2-6 \mathrm{~cm}$. wide; inflorescence paniculate, $6-12 \mathrm{~cm}$. long, rather loose, its main branches unequal, flowers small, greenish, about $6 \mathrm{~mm}$. broad, calyx forming a shallow cup, petals spreading or reflexed, about $2.5 \mathrm{~mm}$. long, stamens erect, slightly shorter than the petals; fruit a blue-black berry, not very fleshy, 6-7 mm. in diameter: q u in qu e f o 1 i a, five-leaved.

In woods and thickets throughout the state. Distributed from N. H. to Quebec and Manitoba, south to Fla., Tex. and Mexico. Blossoms in June, fruit ripe in September.

Extensively planted as a climber on porches, fences, walls, etc. Called Parthenocissus or Ampelopsis Engelmanni by horticulturists.

\section{Var. Saint Pauli Relh der 1905}

Somewhat pubescent upon the younger leaves and shoots, aerial roots numerous, leaflets cuneate to a sessile or scarcely petiolulate base, cymules somewhat racemosely arranged.

Occurs in the southeastern part of the state and probably as far north as St. Paul. Distributed from IIl. to Iowa and southwestward.

\section{Parthenocissus vitacea $\mathrm{Hit} \mathrm{chcock} 1894$}

A high climbing or trailing vine, tendrils with 2-5 long twining branches, these only very rarely ending in adhesive disks, no aerial rootlets; leaves petioled, digitately compound, leaflets 5-7, ovate to ovate-lanceolate, cuneate or slightly rounded at the base, acute at the apex, coarsely dentate, deep green, thin, somewhat shining above, scarcely paler beneath, glabrous or slightly pubescent, $4-13 \mathrm{~cm}$. long, $2-8 \mathrm{~cm}$. wide, petioles $5-10 \mathrm{~mm}$. long; inflorescences regularly dichotomous, flat-topped, peduncles $4-8 \mathrm{~cm}$. long, the first branches nearly equal, flowers greenish, about $5 \mathrm{~mm}$. in diameter, calyx entire, shallow petals spreading or reflexed; fruit obovoid, bluish black, 6-10 $\mathrm{mm}$. in diameter, somewhat fleshy, at least more so than in the preceding: vit a cea, like the grape-vine.

Common throughout the state. Distributed from Me. to Assiniboia and south to Tex. Planted to some extent, the leaves turn a brilliant scarlet in the fall becoming very showy.

\section{Thymelaeaceae Leatherwood Family}

Shrubs or trees with very tough, acrid inner bark; leaves alternate, simple and entire; flowers in racemes or capitate clusters or borne singly, 
regular and mostly perfect, calyx tubular, colored and corolla-like, petals none (in our genera), stamens usually twice as many as the calyx-lobes or fewer, inserted on the calyx-tube and longer than its lobes, ovary 1celled, ovule 1, style short or elongated; fruit a berry-like drupe.

The family is represented by only one genus within the state.

\section{Dirca L in n é I753 Leatherwood Moosewood}

(Dirca, perhaps from the name of a region in Thebes)

Branching shrubs with tough, fibrous bark, branchlets jointed; leaves alternate, thin, short-petioled; flowers $2-4$ in a cluster, appearing before the leaves, subtended by an involucre of hairy bud scales, calyx corollalike, tubular-funnel-shaped, obscurely 4-lobed, petals lacking, stamens inserted on the calyx-tube about the middle, twice as many as the lobes, the alternate ones longer, filaments very slender, disk lacking, ovary nearly sessile, 1-celled, style filiform, long-exserted; fruit a red, oval-oblong drupe.

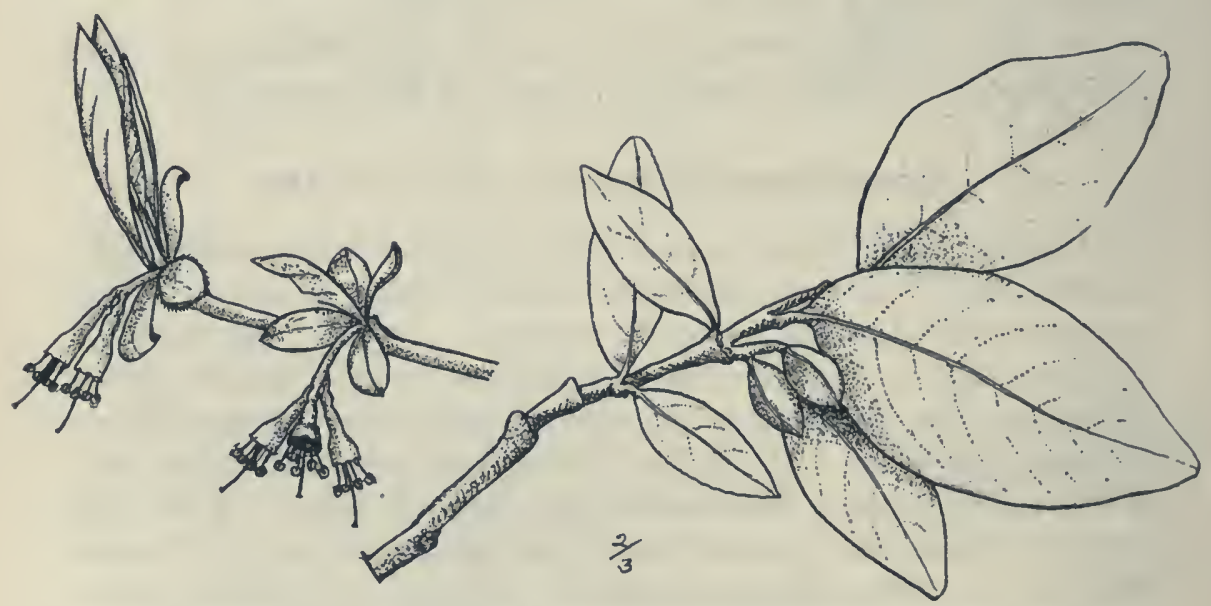

A genus of 2 species, one in the southeastern United States, the other in California.

\section{Dirca palustris L in né I753 Leatherwood}

A branching shrub, 0.5-2 m. high, bark on stem brownish, the twigs yellowish-green, jointed, wood white and brittle, inner bark unusually tough, bud scales hairy, becoming very large when flowers and leaves unfold; leaves alternate, oval or oblong, rounded at the base, blunt at the apex, entire, glabrous in age, pubescent when young, $3-8 \mathrm{~cm}$. long, 1.5-5 
$\mathrm{cm}$. wide, petioles about $2 \mathrm{~mm}$. long; flowers appearing in clusters of 2-5 before the leaves, nearly sessile, the yellowish calyx about $1 \mathrm{~cm}$. long; drupe oval-oblong, red, 10-12 mm. long: palust $\mathrm{r}$ is, marshy.

Common in the northeastern part of the state and westward as far as the White Earth Indian Reservation and Lake of the Woods, infrequent throughout the wooded area southward. Distributed from New Brunswick to Minn., southward to Va. and Mo. Blossoms in April and May, fruit ripe in August. The bark was used by the Indians for making thongs; it produces violent vomiting if taken internally and is an irritant to the skin if applied externally.

\section{Elaeagnaceae Oleaster Family}

Shrubs or trees, mostly silvery scaly or stellate pubescent; leaves entire, opposite or alternate ; flowers in clusters or rarely solitary, in the axils of the leaves or at the nodes of twigs of the preceding season, calyx of the perfect or pistillate flowers urn-shaped, 4-lobed or cleft, upper part deciduous, stamens 4 or 8 , those of the perfect flowers inserted on the throat of the calyx, filaments short, disk round or lobed, ovary 1-celled, ovule 1 , erect, style slender; fruit drupe-like, the lower part of the calyx becoming fleshy and enclosing the achene.

\section{KEY TO THE GENERA}

1. Flowers perfect, stamens 4 , leaves alternate

2. Flowers dioecious, stamens 8 , leaves opposite

Elaeagnus

Shepherdia

\section{Elaeagnus L in n é 1753}

(Gr. e 1 a e a, olive, a g nos, chaste-tree)

Shrubs or trees with silvery-scaly branches and foliage; leaves simple, alternate and petioled; flowers borne singly or in clusters of 2-4 in the axils of the leaves, short-stalked, perfect, or staminate and pistillate, calyx tubular, slightly constricted just above the ovary, campanulate and 4-lobed, deciduous, stamens 4, inserted on the upper part of the calyxtube; fruit drupe-like, fleshy or mealy, inclosing the ellipsoid achene.

A genus of about 20 species, natives of Europe, Asia, North America and Australia.

\section{Key to the Species}

1. Twigs with brown scales, thornless, native shrub

E. argentea

2. Twigs without brown scales, often thorny, cul- 


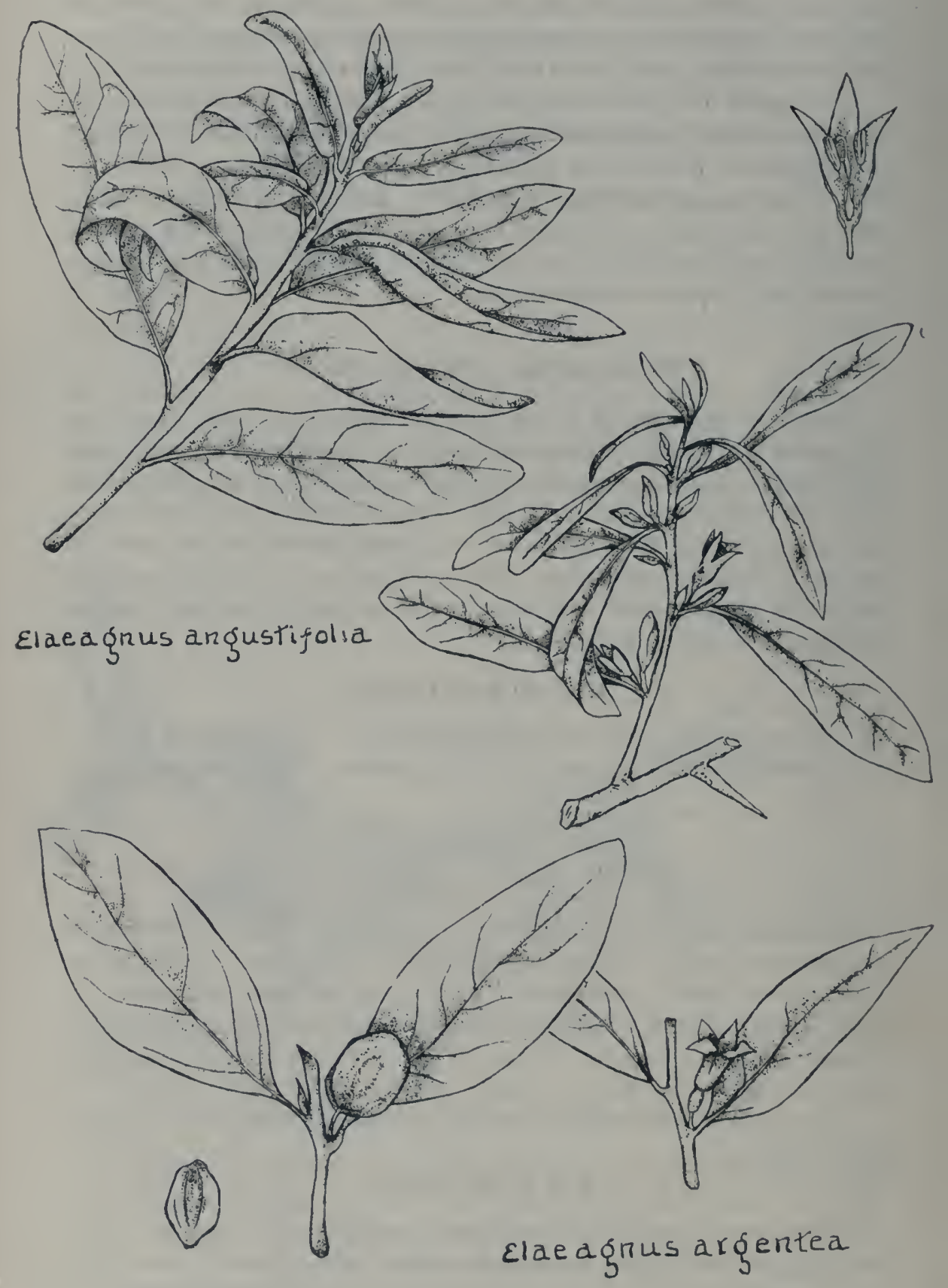




\section{Elaeagnus argentea Pursh I8I4 Silver-berry}

A much branched, unarmed shrub, 1-4 m. high, stoloniferous, branches covered with ferruginous scales, becoming silvery; leaves oblong-ovate or oval-lanceolate, rounded at the base, blunt or acute at the apex, densely silvery-scurfy on both sides, $3-7 \mathrm{~cm}$. long, $1-3.5 \mathrm{~cm}$. wide, petioles $3-5 \mathrm{~mm}$. long; flowers fragrant, silvery on the outside, yellow on the inside, 10-14 $\mathrm{mm}$. long, lobes of the calyx triangular, about $3 \mathrm{~mm}$. long; fruit $1 \mathrm{~cm}$. long, the achene 8-striate: argente a, silvery.

Native in the northwestern part of the state. Distributed from Quebec to Hudson's Bay and British Columbia, south to Minn., South Dakota and Utah. Blossoms from May to July, fruit ripe July to August.

\section{Elaeagnus angustifolia Lin né 1753 Russian Olive}

A tall shrub or more often a small tree, sometimes attaining a height of 10-16 m. (30-50 feet) often spiny, the bark on last year's twigs smooth and olive-colored, young shoots silvery gray and densely covered with stellate hairs; leaves alternate, entire, ovate-lanceolate to lanceolate, slightly narrowed at the base, obtuse or acutish at the apex, grayish-green with scattered peltate-stellate hairs on the upper surface, silvery gray beneath, 2.5-8 cm. long, $1-1.5 \mathrm{~cm}$. wide, petioles about $1 \mathrm{~cm}$. long; flowers axillary, solitary or in groups of $2-3$, calyx tubular-campanulate, about $1 \mathrm{~cm}$. long, 8-9 mm. broad, 4-lobed, silvery gray on the outside, lemon-colored -within, very fragrant, petals lacking, stamens very short, inserted near the throat of the calyx, pedicels 2-3 mm. long; fruit oblong-ovoid: a n g u s t if o 1 i a, narrow-leaved.

Entirely hardy and extensively planted as an ornamental shrub or tree on account of the silvery gray foliage and fragrant flowers. Native of Europe. Blossoms in June, fruit ripe in September.

\section{Shepherdia Nutta 11 I8I8}

\section{(Named for John Shepherd, an English Botanist)}

Shrubs or small trees, twigs brown, or silvery-scurfy or stellate-pubescent ; leaves opposite, petioled; flowers small, dioecious or sometimes polygamous, in fascicles or short spikes, at the nodes of the shoots of the preceding season, or axillary; calyx of pistillate flowers urn-shaped, 4-lobed, inclosing the ovary and becoming berry-like in fruit, disk 8-lobed, calyx of staminate flower 4-parted, valvate in bud, stamens 8 , disk many-lobed, 
style slender, stigma one-sided; fruit berry-like, the fleshy calyx inclosing an achene or nutlet.

A genus of three known species two of which occur within the state, the other western.

\section{Key to the Species}

1. Leaves ovate or oval, green above, silvery beneath, thornless shrub.

S. canadensis

2. Leaves oblong, silvery on both sides, mostly thorny shrub,

\section{S. argentea}

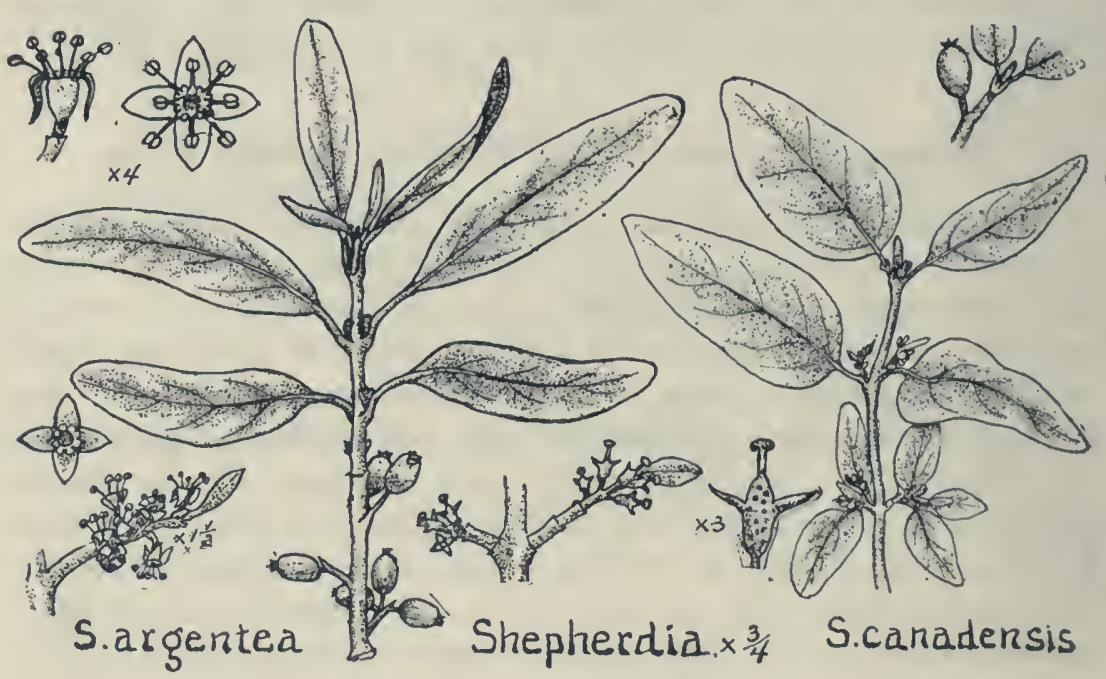

Shepherdia canadensis (Linné) $\mathrm{N} u \mathrm{t}$ t a 11 18r8 Canadian Buffaloberry

\section{Lepargyraea canadensis (Linné) Greene 1890}

A spreading shrub 1-3 m. high, thornless, bark gray, young shoots brown-scurfy; leaves ovate or oval, rounded at the base, blunt at apex, green and nearly smooth above, silvery beneath but with rusty scales, 2-6 $\mathrm{cm}$. long, 1-2.5 cm. wide, petioles 4-6 mm. long; flowers in short spikes at the nodes of the twigs, yellowish, about $5 \mathrm{~mm}$. wide, buds formed in the summer with the leaves, expanding before or with the leaves next spring, brown, about $1.5 \mathrm{~mm}$. in diameter: fruit a yellowish berry, very insipid or nauseous, about 4-6 mm. long: $\mathrm{c}$ a $\mathrm{n}$ a d e $\mathrm{n} \mathrm{s}$ i s, Canadian.

This species occurs around Lake of the Woods and probably eastward along the International Boundary. Distributed from Newfoundland to 
Alaska, south to Nova Scotia, Me., western N. Y.; Mich., Wis. and Minn. Blossoms April-June, fruit ripe July-August.

\section{Shepherdia argentea Nutta11 I818 Buffalo-berry Lepargyraea argentea Greene 1890.}

Shrubs or small trees 1-6 m. high, more or less thorny, with gray bark and brown or silvery-scurfy twigs; leaves opposite, oblong-lanceolate or cuneate-oblong, rounded at the base, obtuse at the apex, densely silveryscurfy on both sides, $2.5 \mathrm{~cm}$. long, 6-15 mm. wide, petioles 5-10 mm. long; flowers in clusters at the nodes of the twigs, yellowish; fruit ovoid, red, acid and edible, 4-6 $\mathrm{mm}$. long: a $\mathrm{r}$ g e $\mathrm{n} \mathrm{t}$ e a, silvery.

Occurs in the western and probably in the extreme northern part of the state. Distributed from Manitoba and Minn. to Kansas and westward. Planted to a considerable extent as an ornamental shrub or small tree. Blossoms in May and June, fruit ripe July to August.

\section{Ilicaceae Holly Family}

Trees or shrubs with watery sap; leaves simple, alternate, petioled, often leathery in texture; flowers in axillary clusters or borne singly, small, regular, white or greenish, mostly polygamo-dioecious; calyx 3-6 parted, generally persistent, petals 4-6 or sometimes more, separate or slightly united at the base, deciduous, stamens hypogynous, as many as the petals or more, anthers cordate, disk lacking, ovary superior, 3-several celled, style short or none, ovules 1-2 in each cavity of the ovary; fruit a small berry-like drupe enclosing several nutlets.

\section{Ilex $\mathrm{L}$ in né 1753}

\section{(Classial Latin name of the holly oak)}

Shrubs or trees; leaves alternate, entire or dentate or spiny-toothed, sometimes leathery, stipules minute; flowers axillary, cymose or solitary, perfect or polygamous, calyx small, 4-6 toothed, petals 4-6, separate or united only at the base, oval or obovate, spreading, stamens as many as the petals and attached to their base; fruit a berry-like drupe containing 4-6 nutlets. 
A genus of about 160 species, mostly natives of America, some in Asia, Africa and Australia. In addition to the following about 12 species occur in the eastern and southeastern parts of the U.S.

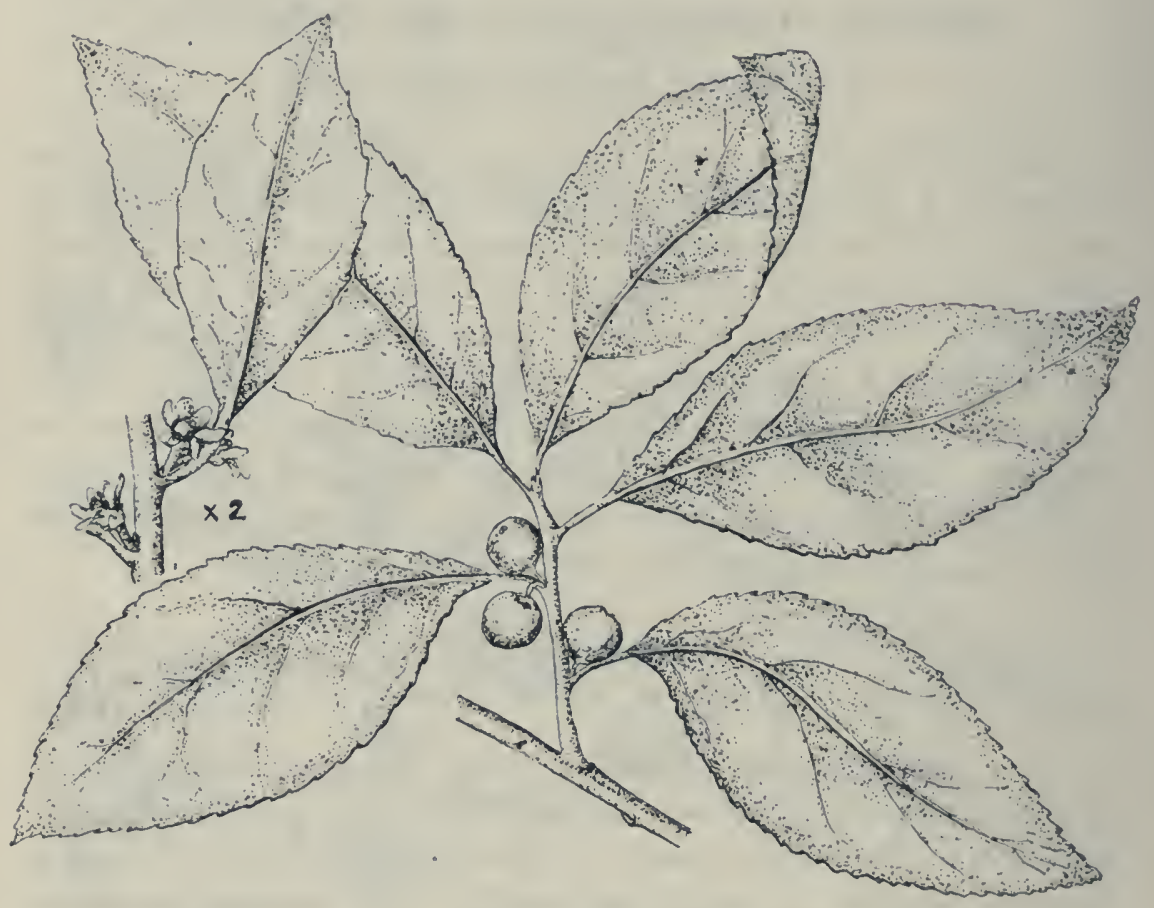

\section{Ilex verticillata (Linné) A. G r a y 1856 Virginia Winter-berry} Black Alder

A shrub .5-6 m. high, with a smooth grayish bark, twigs glabrous or slightly pubescent; leaves oval, obovate, or oblong-lanceolate, acute at the base, acute or acuminate at the apex, serrate, dark green and nearly glabrous above, pubescent at least on the veins beneath, $4-11 \mathrm{~cm}$. long, $1.5-4 \mathrm{~cm}$. wide, petioles $8-12 \mathrm{~mm}$. long; flowers mostly crowded, pedicels about $3 \mathrm{~mm}$. long, sepals ciliate on the margins, petals spreading or rcflexed; fruit a bright red drupe, 6-7 mm. in diameter: verticill a t a, in whorls.

Common in swamps throughout the northern and northeastern parts of the state, and occasionally as far south as Lake Pepin. Distributed from Nova Scotia to Florida, west to western Ontario, Minn. and Mo. Blossoms in June, fruit ripe in September. 


\section{Sapindales Maple Order}

\section{Staphyleaceae Bladder-nut Family}

Shrubs or trees with mostly opposite, odd-pinnate or 3-foliate leaves with stipules; flowers perfect, in terminal or axillary clusters, sepals 5 , petals 5, stamens 5, alternate with the petals, inserted along the edge of the conspicuous disk ; fruit a bladdery capsule (in our species), seeds solitary or few in each cavity of the ovary.

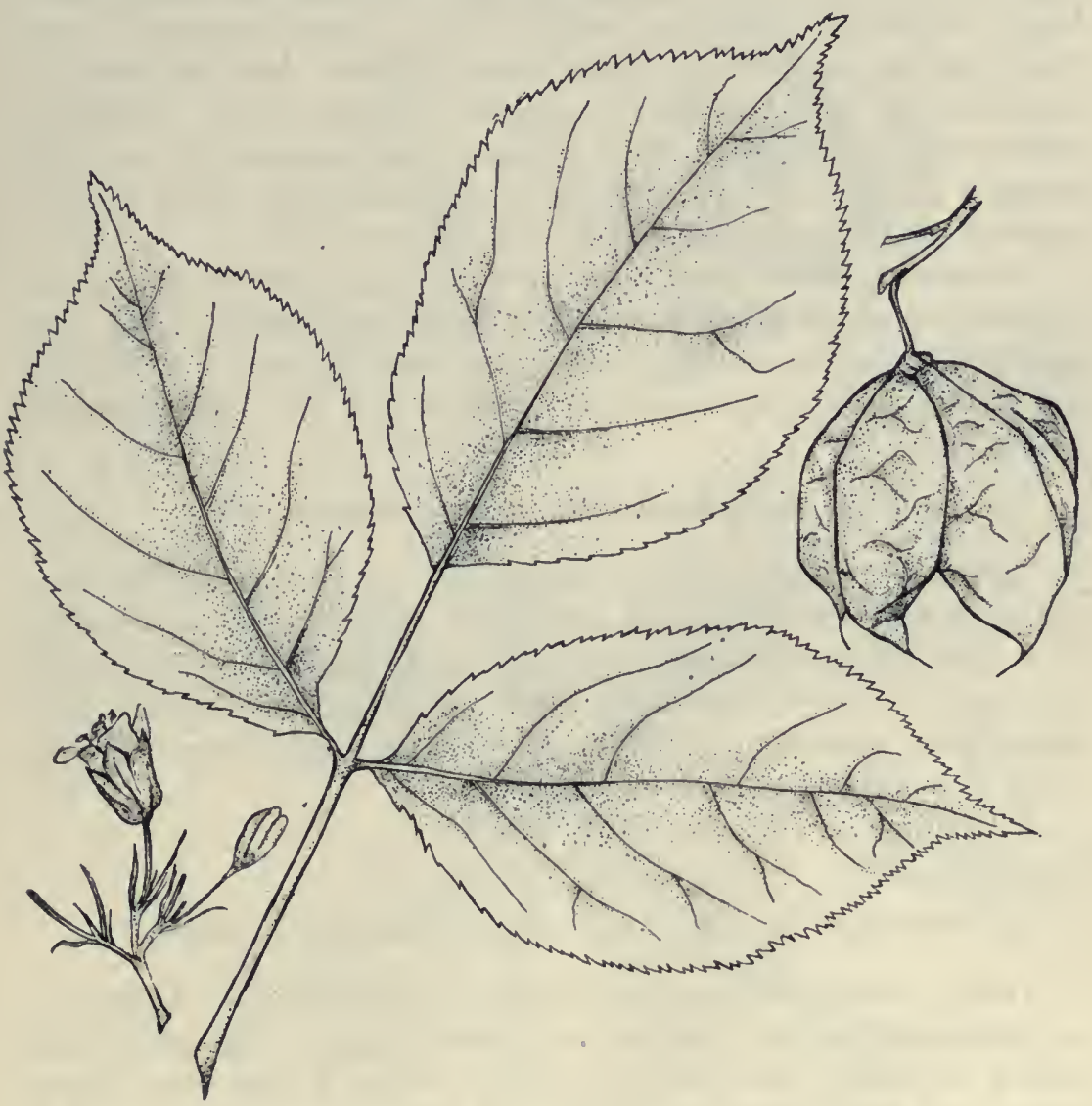

Staphylea L in né I753 Bladdernut

(Gr. st a p h y l e, cluster)

Shrubs with opposite 3-foliate or pinnate leaves; flowers whitish, in drooping terminal racemes or panicles; calyx deeply 5-parted, the lobes 
erect, petals 5, erect, spatulate, pistil consisting of from 3-several carpels, styles slightly cohering; fruit a 3 -lobed, inflated capsule, dehiscent at the summit, seeds hard and globose.

A genus of about six species of the north temperate zone. One other species besides the following occurs in California.

\section{Staphylea trifolia L in n é I753 American Bladdernut}

A shrub 1-3 m. high, with grayish bark, branches greenish and striped; leaves long-petioled, trifoliate, leaflets ovate to obovate, narrowed at the base, acuminate at the apex, finely serrate, smooth above, pubescent at least along the veins beneath, $4-10 \mathrm{~cm}$. long, $2-6 \mathrm{~cm}$. broad, the terminal leaflet slightly larger than the two lateral ones; racemes $3-6 \mathrm{~cm}$. long, flowers 8-10 mm. long; fruit an inflated capsule, $3-6 \mathrm{~cm}$. long, $2-3 \mathrm{~cm}$. in diameter: $\mathrm{t} r$ if o $\mathrm{l}$ i a, three-leaved.

Frequent in moist thickets and ravines in the southern part of the state, as far north as White Bear Lake and west as far as New Ulm. Distributed from western Quebec and western New England, west to Minm. and south to South Carolina and Mo. Blossoms in May, fruit ripe JulyAug.

\section{Sapindaceae Soapberry Family}

Trees or shrubs, rarely herbaceous plants, with watery sap; leaves alternate, or more rarely opposite, pimately or palmately compound, without stipules; flowers polygamo-dioecious, regular or more commonly irregular, calyx-lobes 4-5, imbricated, petals 3-5, disk fleshy, stamens 5-10, rarely more numerous, usually inserted on the disk, ovary 2-4-celled, orules 1 or more in each cavity; fruit various.

A large family of mostly tropical species.

\section{Aesculus Lin né 1753 Horse-chestnut Buckeye}

Trees or shrubs with opposite, digitately compound leaves, leaflets serrate and straight-veined; flowers in a terminal panicle, often polygamous, most of them with imperfect pistils, calyx tubular, 5-lobed often gibbous at the base, petals 4-5, unequal, stamens 8-10, (mostly 7), unequal in length, ovary 3 -celled, style 1 , ovules 2 in each cavity of the ovary, fruit a leathery capsule, 3-valved, 3-seeded, or frequently only 1 -seeded, seeds. very large witl thick shining coat and a large scar, cotyledons veryi thick and fleshy.

A genus of about 15 species natives of America and Asia. 


\section{Key to the Species}

1. Flowers white, spotted with yellow and pur-

ple, leaflets abruptly acuminate

2. Flowers yellow, leaves acuminate, bark fetid

Ac. Hippocastanum

Ae. glabra

\section{Aesculus Hippocastanum L i n né 1753 Horse-chestnut}

A medium-sized to large tree, 10-20 meters (30-65 feet) high, bark brown, fissured into irregular, plate-like scales; leaves long-petioled, leaf-

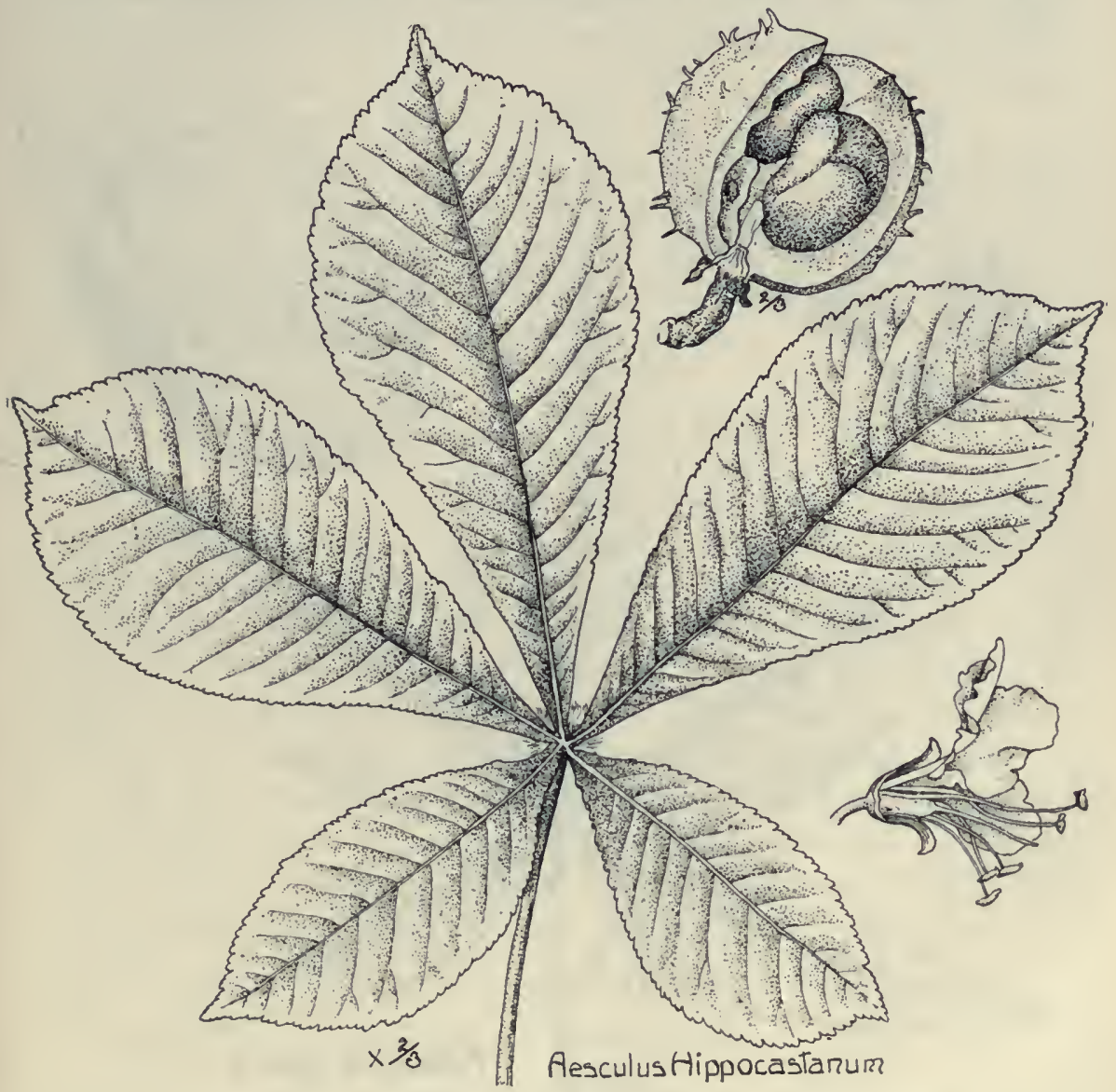

lets 5-7 (sometimes 3), obovate, narrowed towards the base, abruptly acuminate at the apex, irregularly crenate-serrate, pubescent when young, glabrate when mature, $8-20 \mathrm{~cm}$. long, $2.5-6 \mathrm{~cm}$. wide, petioles $10-15 \mathrm{~cm}$. long; flowers numerous in large panicles, white, blotched with yellow, 
showy, 12-15 mm. long, stamens exserted; fruit globose, covered with spines, seeds with a large, conspicuous scar: $\mathrm{H}$ i p p o c a s t a n u m, horsechestnut.

This species is cultivated to a slight extent in parks and yards, especially in the southeastern part of the state. Introduced from Asia via Europe. It is grown very extensively farther south and east and occasionally found escaped from cultivation.

The wood is whitish slightly tinged with yellow, light, soft and very close grained. Blossoms in May and June, fruit ripe in August and September.

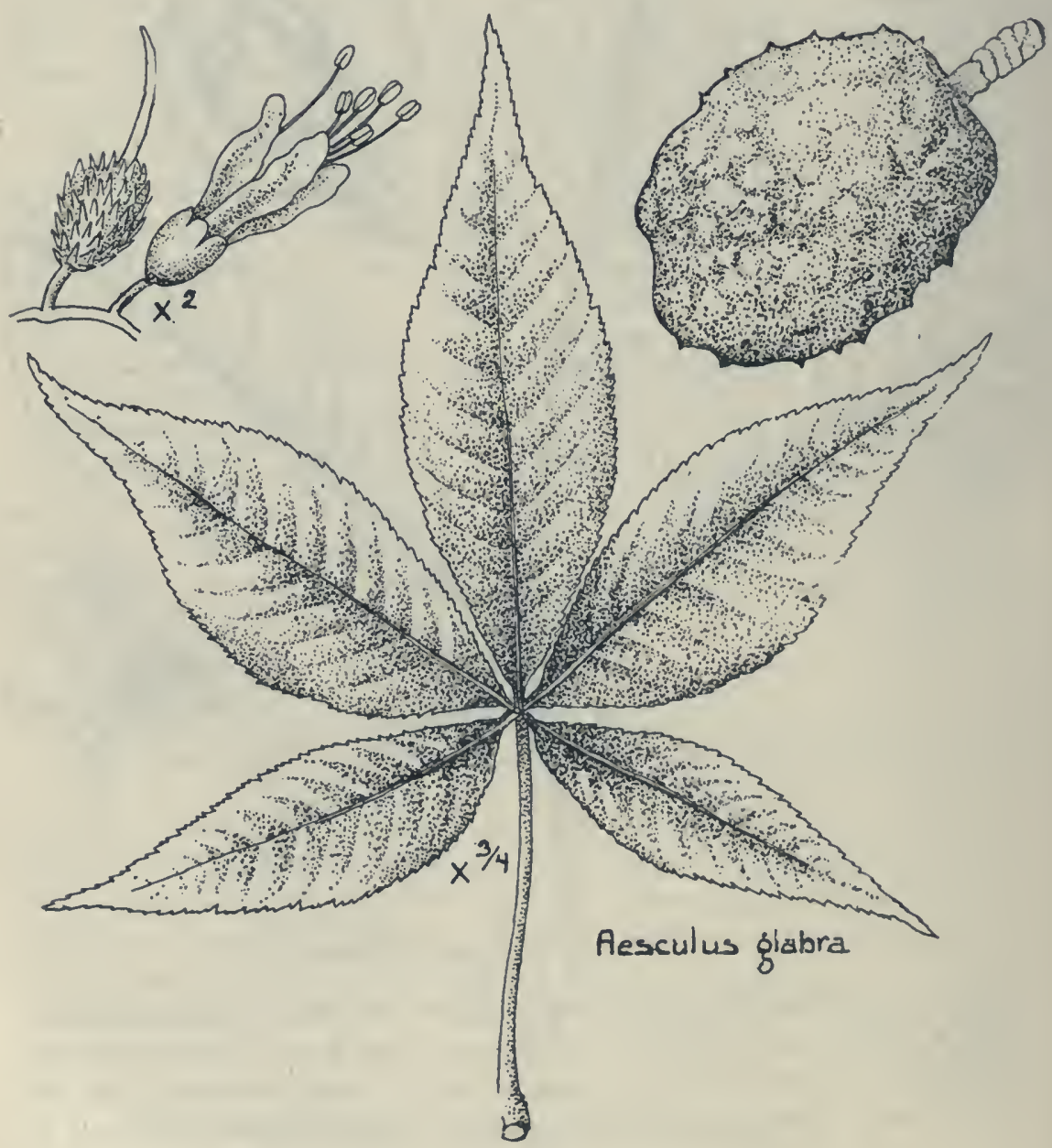




\section{Aesculus glabra Wi $11 \mathrm{~d}$ e now r8o9 Ohio Buckeye Fetid Buckeye}

A tree reaching a maximum height of about $16 \mathrm{~m}$. (50 feet), bark of trunk dark and furrowed, exhaling a fetid odor; leaves opposite, longpetioled, leaflets 5-7, oval, oblong or lanceolate, narrowed at the base, acuminate at the apex, finely and sharply serrate, glabrous above, pubescent in the axils of the veins beneath, $8-15 \mathrm{~cm}$. long, $2.5-6 \mathrm{~cm}$. wide, petioles $7-15 \mathrm{~cm}$. long; inflorescence a terminal panicle, $10-15 \mathrm{~cm}$. long, about $5 \mathrm{~cm}$. in diameter, flowers numerous, pale yellow, about $15 \mathrm{~mm}$. long, calyx campanulate, petals 4, slightly unequal, stamens curved, exserted; fruit $2.5-3.5 \mathrm{~cm}$. in diameter, very prickly when young, becoming smoothish at maturity: $\mathrm{g} l \mathrm{a} b \mathrm{r}$ a, smooth.

Frequently planted. Distributed in woods from the Alleghenies of Pa. to Alabama, west to Mich. and Ind. The wood is soft and white, the sap wood slightly darker, weighing $28 \mathrm{lbs}$. The timber is used for artificial limbs and several kinds of woodenware articles. Blossoms in April and May. Fruit ripe in August and September.

\section{Aceraceae Maple Family}

Trees or shrubs with watery often sugary sap; leaves opposite, simple and palmately lobed or more rarely palmately or pinnately divided; flowers in axillary or terminal cymes, clusters or racemes, polygamous or dioecious, regular, calyx mostly 5-parted, petals 5 or none, disk thick, round or lobed, sometimes wanting, stamens 4-12, mostly 8, ovary 2-celled, 2 lobed, styles 2, from between the lobes; fruit 2 long-winged samaras united at the base, each 1 -seeded, cotyledons rolled up in the seed.

The family consists of two genera, Acer and Dipteronia. The latter differs from Acer in the samara being winged all around. The genus Acer contains a little over one hundred species, natives of the north temperate zone.

\section{Acer Linné 1753 Maple \\ (L. a c e $r$, maple tree)}

\section{Key to the Species}

1. Leaves simple

a. Shrubs, flowers in racemes, or narrow panicles, native 
b. Trees, flowers in panicles, corymbs or umbellike clusters, native and cultivated

(1) Leaves pinnately-veined, irregularly serrate, flowers in terminal panicles

(2) Leaves palmately lobed, lobes coarsely dentate-serrate or cut, or almost entire, flowers in corymbs or umbel-like clusters

(a) Flowers greenish, appearing with the leaves

x. Flowers in erect, flat-topped panicles, wings of fruit long, spreading

y. Flowers in pendant, umbel-like clusters, long-pedicelled, wings of fruit short, not spreading

(x) Leaves with shallow lobing, sinus at the base closed, petioles and veins beneath pubescent

(y) Leaves with deeper lobing, sinus at the base shallow or none, petioles glabrous

A. platanoides

A. tataricum

A. nigrum

A. saccharum

(b) Flowers red or yellowish-red, appearing from separate buds before the leaves

$x$. Flowers yellowish-red, leaves deeply 5-lobed, lobes narrow at the base

A. saccharinum

y. Flowers brilliant red, leaves about 3lobed, lobes not narrow at the base 2. Leaves compound, flowers strictly dioecious

A. rubrum

A. negundo

\section{Acer spicatum La marck 1786 Mountain Maple}

A shrub $2-4 \mathrm{~m}$. high, very rarely a small tree, bark green or greenish ; leaves mostly 3- (rarely 5-) lobed, coarsely serrate, cordate at the base, lobes acute or taper-pointed, glabrate above, pubescent beneath, $6-12 \mathrm{~cm}$. long, 5-10 cm. wide, petioles $3-10 \mathrm{~cm}$. long, inflorescence a raceme or narrow panicle, $7-10 \mathrm{~cm}$. long, flowers greenish-yellow, $6-8 \mathrm{~mm}$. hroad; samaras $2-2.5 \mathrm{~cm}$. long, wings slightly divergent, $7-8 \mathrm{~mm}$. wide: $\mathrm{s}$ p i c a $\mathrm{t} \mathrm{m}$, in spikes.

Moist or damp rocky woods, abundant in the northern and northeastern part of the state, infrequent or local farther southward, collected at 


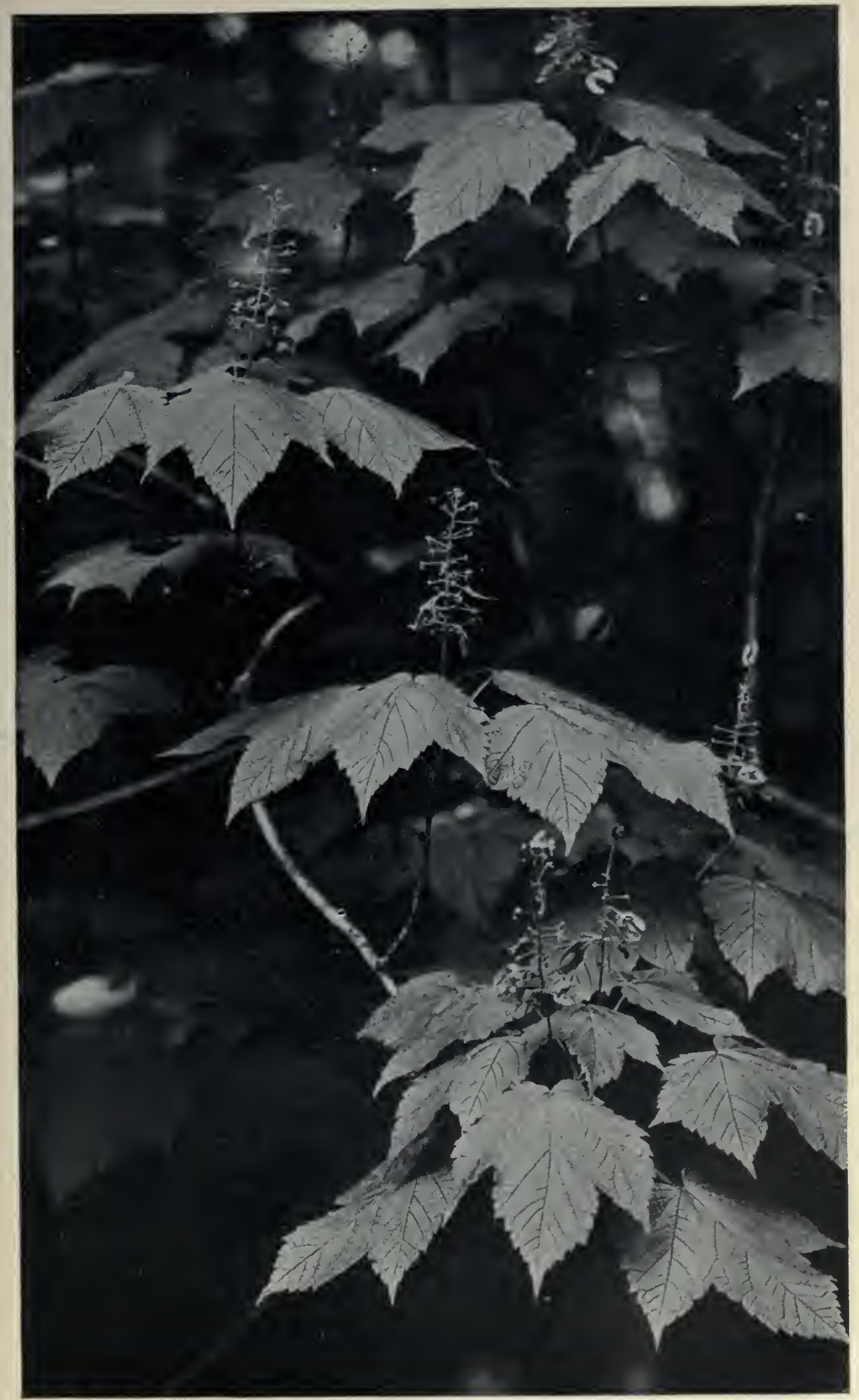

Acer spicatum Mountain Maple. 
Winona, Brownsville, and other scattered localities in the southeastern part of the state. Distributed from Newfoundland and Labrador to Hudson's Bay and Manitoba, south to New England, N. Y. the Great Lakes, northeastern Ia. and the mountains of Georgia. The wood is soft, light reddish-brown and weighs 33 lbs.' Blossoms in May and June, fruit ripe in August and September.

\section{Acer tataricum Lin né I753. Tatarian Maple}

A small tree, 6-8 m. (18-24 faet) high; leaves ovate, slightly cordate at the base, acute or acuminate at the apex, dopbly and irregularly serrate or sometimes obscurely lobed," glabroùs abore, sometimes pubescent along the veins beneath, $5-8 \mathrm{~cm}$. long; $3-5 . \mathrm{cm}$. wide; panicles narrow, erect or ascending, 6-8 cm. long, flowers whitish, $6-7 \mathrm{~mm}$. broad; samaras slightly spreading, $3.5-4.5 \mathrm{~cm}$. long, wings $10-12 \mathrm{~mm}$. wide: t a t a r i c u m, of Tartary.

Frequently cultivated as an ornaiméntal tree and perfectly hardy, native of southeastern. Europe. Blossoms in. May, fruit ripe in August and September.

\section{Acer platanoides Li in né I753 Norway Maple}

A large tree with spreading branches, sometimes attaining a height of $32 \mathrm{~m}$. (100 feet), leaves 5- rarely 7-lobed,-slightly cordate at the base, lobes coarsely toothed and acute-pointed, glabrous above, pubescent in the angles of the veins beneath, $8-20 \mathrm{~cm}$. wide, $7-15 \mathrm{~cm}$. long, petioles $\mathrm{S}-10$ $\mathrm{cm}$. long; inflorescence a corymb; appearing with the leaves, $6-7 \mathrm{~cm}$. broad, glabrous; flowers yellowish-green, 10-12 mm. broad; samaras widely spreading, $3-5 \mathrm{~cm}$. long, wings $8-10 \mathrm{~mm}$. wide; p lat a noides, like the plane tree.

Grown in parks and along boulevards, sometimes escaping from cultivation in the East. Native of middle Europe and Asia Minor. Blossoms in May, fruit ripe in autumn.

Several garden forms are recognized and are frequently planted in this state.

Forma g lo b o s u m. Forming a globose head:

Forma $\mathrm{R}$ e it e $\mathrm{n} \mathrm{b}$ a chi. Greenish-red when unfolding, turning dark blood-red in late summer.

Forma $\mathrm{S} c \mathrm{~h} w$ è d 1 è $\mathrm{r}$ i. Leaves bright red when young, later-turining to dark green. 


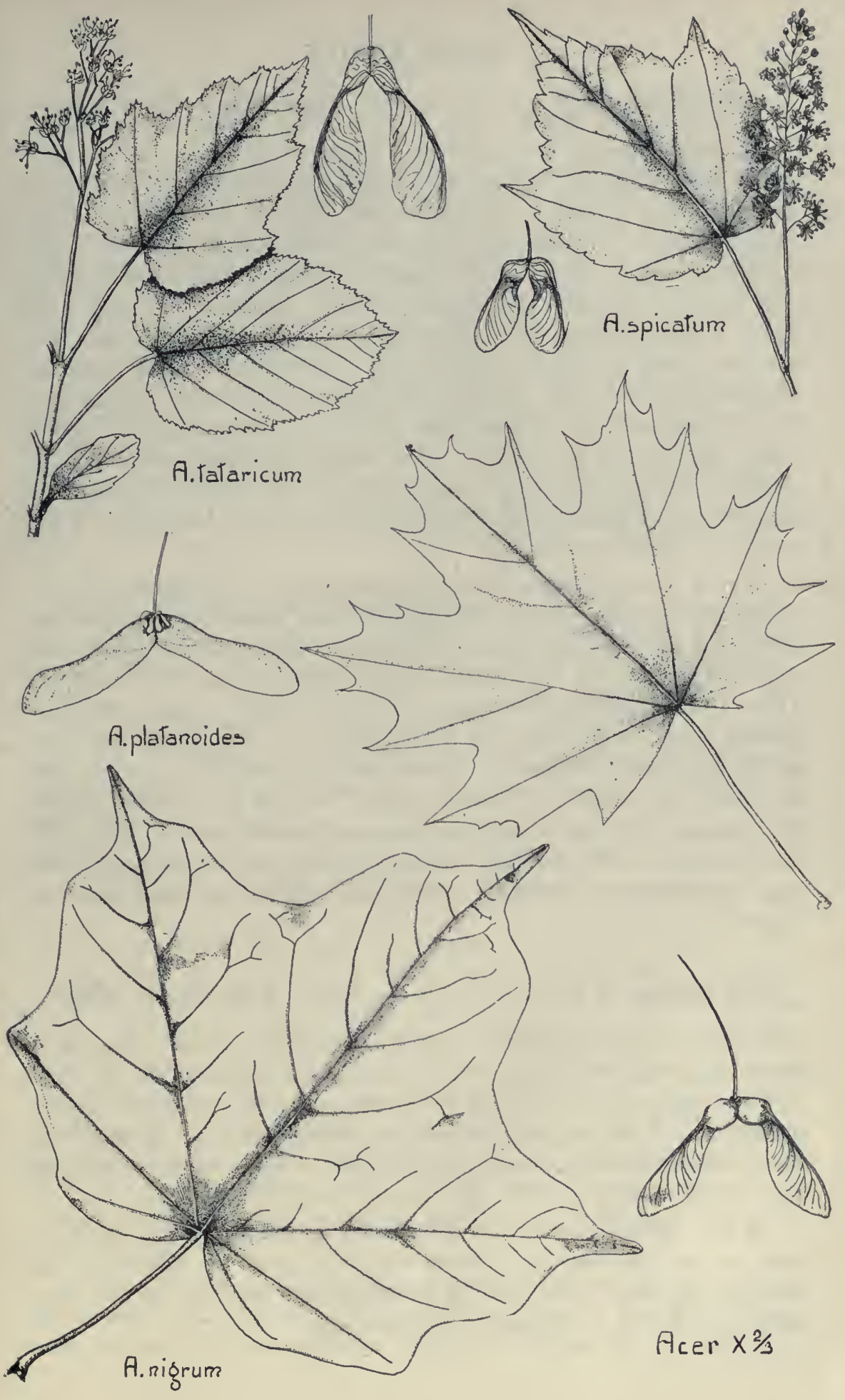




\section{Acer saccharum Marshall I785 Sugar Maple Hard Maple}

A large handsome tree, attaining a height of 30-40 m. (95-120 feet), and a trunk diameter of 6-12 dm., bark of trunk furrowed and rough, grayish-brown, separating into scales, the bark of branches and young trees is smooth and pale gray, sometimes with whitish blotches; leaves 3-5 lobed, cordate, truncate or cuneate at the base, with rounded sinuses and pointed, sparingly sinuate-toothed lobes, glabrous and dark green above, brighter beneath and slightly hairy in the axils of the veins, 5-16 $\mathrm{cm}$. long, $6-20 \mathrm{~cm}$. broad, petioles $4-10 \mathrm{~cm}$. long; flowers in umbellate, drooping clusters, from terminal, leaf-bearing and lateral leafless buds, pedicels long and very slender, hairy, calyx campanulate, greenish-yellow, sepals hairy at the apex, about $4 \mathrm{~mm}$. long, petals none, stamens in the staminate flowers twice as long as the calyx, in the pistillate flower shorter than the calyx; samaras slightly spreading, $2.5-3.5 \mathrm{~cm}$. long, wings $8 \mathrm{~mm}$. wide : $\mathrm{s}$ a $\mathrm{c} \mathrm{c}$ h a r u $\mathrm{m}$, sugar.

In rich woods common and in places abundant throughout the state, except the extreme west. Distributed from southern Newfoundland southward along the mountains to northern Georgia and western Florida, westward to Lake of the Woods, eastern Nebraska, eastern Kansas and Texas. Often planted as a shade tree. The wood is heavy and closegrained, hard, tough, and takes a good polish. It has a high fuel value and is much used as firewood. Forms with the grain curled or contorted are known as "curled" or "birdseye maple" and are much valued in cabinet making. The sap is the main source of "maple sugar." The Chippewa Indians of the northern part of the state still make considerable sugar from the sap. Blossoms in April and May, fruit ripe in July and August.

\section{Acer nigrum Michat x filius I8Io Black Sugar Maple}

A tree nearly as large as the preceding species, bark somewhat darker; leaves green and scarcely paler beneath, usually pubescent on the under side and along the petiole, but not always so, lobes wider and usually shorter than in the preceding species, not toothed, sinus at the base commonly closed, making the leaf appear peltate, stipules often conspicuous, in all other respects like the sugar maple: $\mathrm{n}$ i g $\mathrm{r}$ u m, black.

In rich woods, common in southeastern corner of the state where it seems to be quite distinct. Farther north it seems to grade into the preceding species. The wood is essentially the same as in the sugar maple and the sap is employed in the same way. 


\section{Acer saccharinum Lin né I753 Soft Maple Silver Maple}

A large tree attaining a height of $33 \mathrm{~m}$. (100 feet), and a trunk diameter of 10-14 dm., usually branched into 3-4 secondary stems, bark furrowed, the surface separating into scales, reddish-brown, bark of secondary stems and large branches smooth and gray, leaves deeply 5-lobed with narrow sinuses, lobes remotely and irregularly serrate, truncate or slightly heart-shaped at the base, upper surface green and glabrous, lower surface silvery white and more or less pubescent at least when young, 7-16 $\mathrm{cm}$. long, 6-14 cm. wide, petioles 5-12 cm. long; flowers yellowish-red, in nearly sessile, lateral clusters, appearing many days before the leaves, the staminate and pistillate in separate clusters, sometimes on the same tree. sometimes on different ones, calyx slightly 5-lobed, petals lacking, stamens. 5-7, exceeding the calyx in the staminate flowers; samaras spreading, pubescent when young, about $5 \mathrm{~cm}$. long, wings $12-14 \mathrm{~mm}$. wide: s a cc h a r in $u m$, sugary.

Along streams and riverbanks, common southward and occurring scattered northward to the upper Mississippi, Vermillion Lake, etc. Distributed from New Brunswick to Florida, west to Dakota, Nebraska and Oklahoma. Very extensively planted as a shade and ornamental tree. The wood is light brown in color, close-grained, strong and hard, weighing 33 lbs. It is easily worked and is used for furniture and for floors. Sugar is made to a slight extent from the sap. Blossoms in March and April, fruit ripe in June.

\section{Acer rubrum Lin né I753 Red Maple Swamp Maple}

A medium-sized, slender tree, 6-20 meters (18-65 feet) high and a trunk diameter of 1-4 dm., bark of the stem gray, separating into flaky ridges, twigs dark red and lustrous, leaves sharply 3-5 lobed, cordate or truncate at the base, lobes acuminate, irregularly serrate or toothed, green and glabrous above, paler and tomentose at least along the veins beneath, 5-12 cm. long, 6-12 cm. wide, petioles $3-8 \mathrm{~cm}$. long; flowers monoecious or dioecious, crimson or yellowish, in lateral sessile clusters, appearing long before the leaves, petals present, linear-oblong, stamens 3-7, in the pistillate flowers much reduced; fruits on drooping pedicels, glabrous, samaras slightly spreading, about $3 \mathrm{~cm}$. long, $8-9 \mathrm{~mm}$. wide: r u b r u m, red.

In swamps and moist woods, abundant in the eastern part of the state from the north as far south as Winona, west to the White Earth Indian Reservation and Redwood Falls. The wood is light brown in 


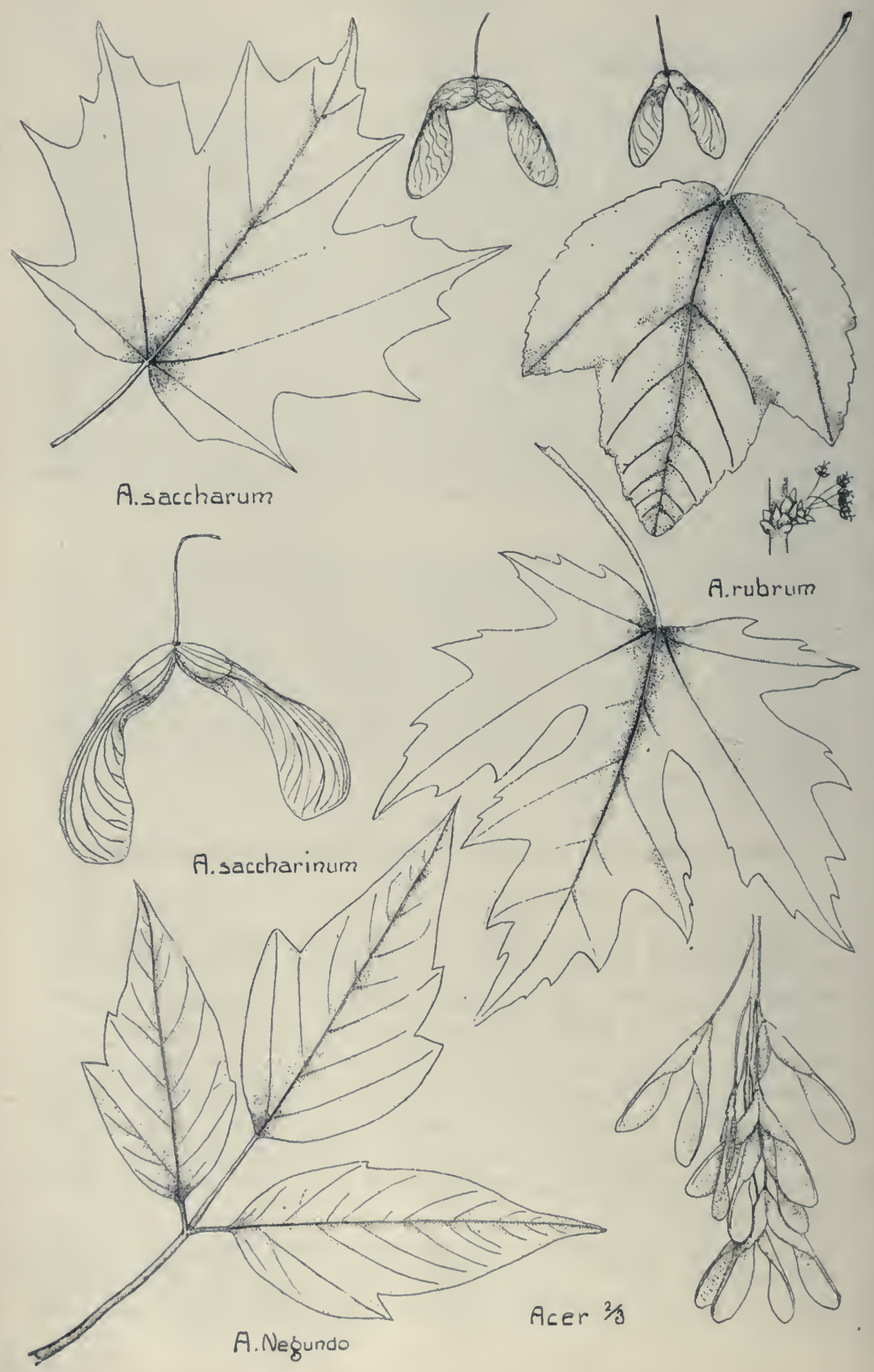


color, close-grained, heavy but not strong, weighing $39 \mathrm{lbs}$. It is used in the manufacture of furniture. The bark is sometimes used in dyeing. Blossoms in March and April, fruit ripe in June.

\section{Acer negundo Linné I753 Box Elder}

A tree $12-20 \mathrm{~m}$. (36-60 feet) high, usually dividing into a number of stout, spreading branches, bark on trunk dark gray or brown, deeply divided into broad, rounded ridges, leaves 3-5 foliate, with slender petioles, leaflets ovate or oval, rounded or wedge-shaped at the base, acute or acuminate at the apex, coarsely and irregularly serrate, sometimes 3-lobed: glabrous or slightly pubescent, bright green above, paler beneath, 4-10 $\mathrm{cm}$. long, $2-7 \mathrm{~cm}$. broad; flowers dioecious, appearing with the leaves, the staminate borne in umbel-like clusters from non-leafy shoots, the pistillate in terminal racemes on leafy shoots, small, greenish, the staminate on long, hairy pedicels ; fruit in racemes, samaras slightly spreading, wings 4-5 cm. long, 10-14 mm. wide, greenish-yellow, falling in autumn or persisting into the winter: $\mathrm{ne} g \mathrm{u} \mathrm{nd}$, of uncertain derivation.

Along banks of streams and lakes and along fences, edges of thickets, etc. Common throughout the state especially southward and westward, less frequent northeast. Distributed from Vt. to Manitoba, south to Fla., Tex., New Mexico and Mexico. Extensively planted as a shade tree and wind break, especially in the prairie regions of the state. Reproduces very easily from seed. The wood is creamy white in color, close-grained, light, soft and not strong, used for fence posts, fire wood, and to a small extent manufactured into furniture. The sap is used in some localities for making maple sugar. Blossoms in April, fruit ripe in autumn.

\section{Anacardiaceae Sumac Family}

Trees or shrubs with acrid, resinous or milky sap; leaves alternate, rarely opposite; flowers small, regular, perfect or polygamous, calyx 3-5 cleft, petals 3-7, imbricated in the bud, sometimes lacking, stamens as many or twice as many as the petals, inserted along the edge of a rounded disc, ovary 1-5 celled, styles 1-3, ovule one in each cavity; fruit mostly a small drupe, seed-coat crustaceous or bony.

\section{Rhus L in né I753 Sumac}

(Gr. rhous, sumac)

Shrubs or trees with alternate, compound or simple leaves, stipules none; flowers in axillary or terminal panicles, greenish-white or yellow, 
small, polygamous, calyx 5-cleft or 5-parted, petals 5, spreading, stamens 5 , inserted between the lobes of the disk, ovary 1 -celled, 1 ovule, styles 3 ; fruit a kind of dry drupe, small, 1-seeded.

A genus of about 120 species, natives of warm and temperate regions. 'The greatest number of species occur in South Africa. In addition to the following about 12 more species occur in the eastern, southern and western parts of the United States.

\section{Key to the Species}

1. Erect shrubs or trees, leaflets more than 3

a. Leaflets serrate, toothed or deeply lobed or cut

(1) Twigs and petioles hairy
(a) Leaflets serrate
R. typhina
(b) Leaflets deeply cut or lobed
R. typhina sar.
laciniata

(2) Twigs and petioles smooth and glaucous
(a) Leaflets serrate
(b) Leaflets deeply cut or lobed

R. glabra

$R$. glabra var.

\section{laciniata}

b. Leaflets entire, fruit white

R. Vermix

2. Vines or low shrubs, leaflets 3

R. toxicodendron

\section{Rhus typhina Li n né i760 Staghorn Sumac \\ Rhus hirta Sudworth I892.}

A shrub or sometimes a small tree reaching a height of $10 \mathrm{~m}$., more commonly 3-4 m., bark smooth and gray, twigs densely velvety-hairy; leaves odd-pinnate, petioles pubescent, $15-30 \mathrm{~cm}$. long, leaflets 11-31, oblong-lanceolate, rounded at the base, acuminate at the apex, sharply and sometimes coarsely serrate, dark green and nearly glabrous above, paler and pubescent beneath, sessile, $4-14 \mathrm{~cm}$. long, $1.5-4.5 \mathrm{~cm}$. broad; panicles terminal, dense-flowered, 9-12 cm. long, flowers yellowish-green, polygamous, 5-6 mm. broad; drupe globose, about $4 \mathrm{~mm}$. in diameter, thickly covered with bright crimson, straight hairs: t y p h in a, smoky.

In dry rocky soil. Occurs in the eastern part of the state from the southern boundary northward to the Canadian border, extending west into the Big Woods and to Martin County. Common in Pine County and westward to Mille Lacs and Cass County. Distributed from eastern Quebec to southern Georgia, west to Minnesota, Mo. and Miss. The wood is soft, greenish-yellow, weighing 27 lbs. The bark is rich in tannin. 


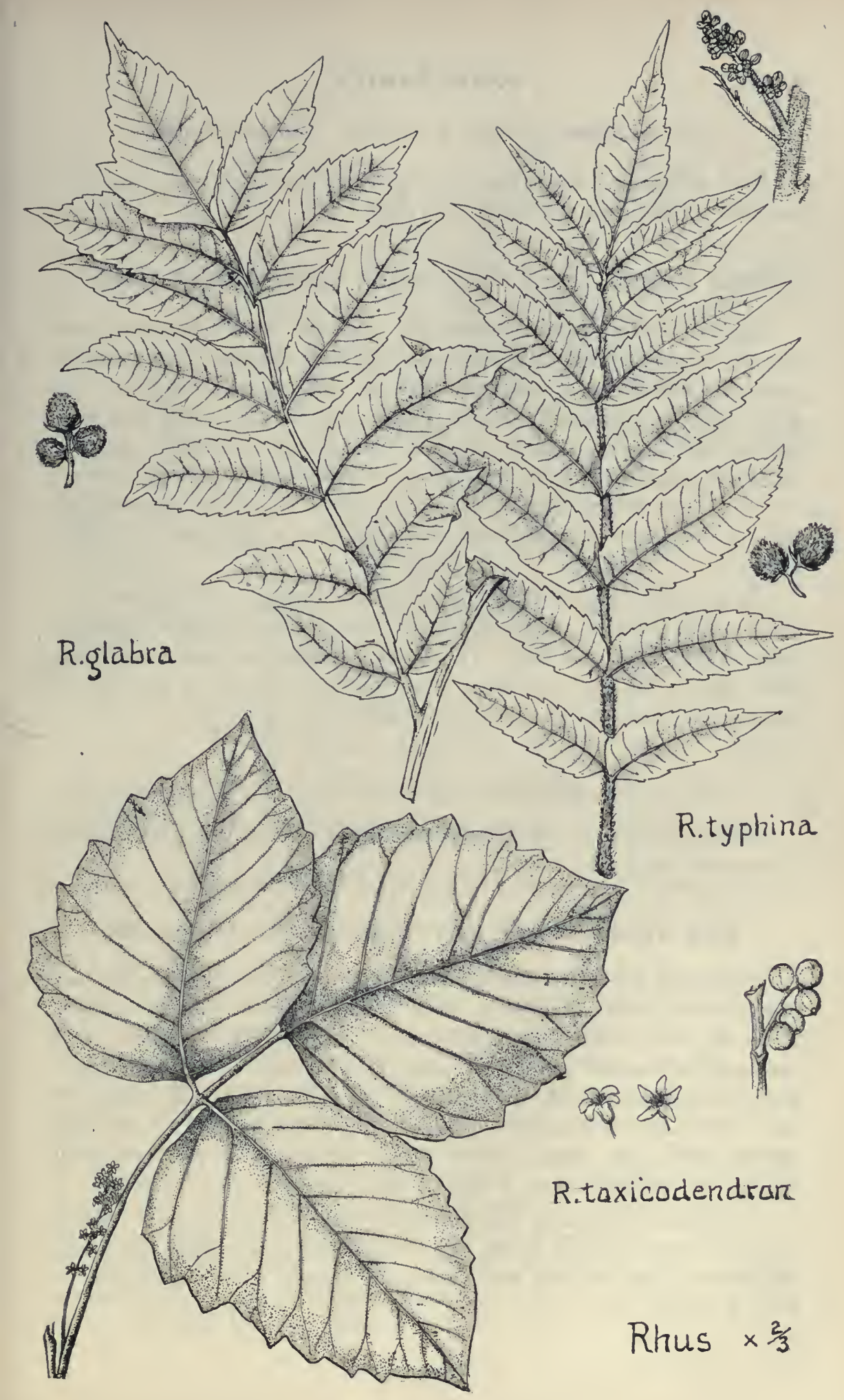




\section{Var. laciniata (Wood) R e h d e r Cut-leaf Sumac}

With leaflets and bracts more or less deeply laciniately cut or toothed, frequently planted as an ornamental shrub.

\section{Rhus glabra Lin né 1753 Scarlet Sumac Upland Sumac}

A shrub or very rarely a small tree, $0.5-6 \mathrm{~m}$. high, bark smooth and grayish, twigs glabrous and somewhat glaucous, petioles of ten purplish, glabrous; leaflets 11-31, oblong-lanceolate, rounded and slightly oblique at the base, acuminate at the apex, sharply serrate, dark green and of ten shining above, paler beneath, glabrous throughout, $4-10 \mathrm{~cm}$. long, 1.5-3 $\mathrm{cm}$. wide; panicles many-flowered, about $8-10 \mathrm{~cm}$. long, puberulent when young, flowers small, greenish, about $5 \mathrm{~mm}$. broad; drupe globose; 3-4 mm. in diameter, covered with short, reddish acid hairs: g l a bra, smooth.

In dry soil, common throughout the state except north of Lake Superior where it is rare. Distributed from central Me. to British Columbia, south to Fla., Miss. and Ariz. The leaves are sometimes used for tanning. This species, like the preceding, often has the whole or a part of the inflorescence changed into clusters of small leaves.

\section{Var. laciniata (Carriere) Robins on}

With leaves that are laciniately bipinnatifid to bipinnate, planted as an ornamental shrub.

\section{Rhus Vernix L in né I753 Poison Sumac Poison Oak}

A shrub or small tree sometimes reaching a height of $8 \mathrm{~m}$., more commonly 2-4 m. high, bark gray, twigs greenish; leaves petioled, pinnate, 15-36 cm. long, leaflets 7-13, obovate or oval, or the lowermost ovate, narrowed or rounded at the base, acute or acuminate at the apex, entire, green on both sides, glabrous or slightly puberulent, 4-14 cm. long, 1.5-6 $\mathrm{cm}$. wide; panicles axillary, numerous, long-peduncled, 10-17 cm. long, flowers green, very small, about $2 \mathrm{~mm}$. broad; fruit yellowish-green, smooth and shining, about $4 \mathrm{~mm}$. in diameter: ve $\mathrm{n}$ ix, varnish.

Infrequent in swamps, reported from Houston and Winona counties, occurs in Hennepin and Anoka counties and along the upper Mississippi. Distributed from western Me. to western Ontario and Minn., south to Fla., Miss. and La. 
The plant is very poisonous to the touch and causes serious inflammation of the skin. The irritation is caused by a non-volatile oil secreted by the leares and bark and found in all parts of the plant. The effect of the oil can be neutralized by applications of sugar of lead dissolved in alcohol. Blossoms in May and June, fruit ripe in autumn.

\section{Rhus toxicodendron var. radicans (Linné) T o r r y}

Distinguished from the preceding by the climbing habit, sometimes ascending high into trees by means of roots that attach themselves to the bark. The stem sometimes attains a diameter of 3-6 cm.

In woods, thickets and along roadsides, in the southeastern part of the state.

\section{Juglandaceae Walnut Family}

Trees with alternate, pinnately-compound leaves, stipules lacking; flowers monoecious, the staminate in catkins, the pistillate solitary, or 2-3 together in a cluster or spike, the staminate flowers consisting of 3-many stamens and an irregular perianth, adnate to the bract, pistillate flower with a 3-5 lobed regular perianth, adherent to the ovary, pistil consisting of 2 carpels, orule 1, basal, styles 2; fruit a kind of drupe with dehiscent or indehiscent exocarp inclosing the bony endocarp (nut sliell), nut incompletely 2-4 celled, 1 seed, 2-4 lobed, cotyledons very much corrugated.

\section{KEY TO THE GENER.}

1. Husk indehiscent, nut rugose, pith of twigs chambered Juglans

2. Husk splitting into segments, nut smooth or angled, pith not chambered

Carya

\section{Juglans Li n n é 1753 \\ (L. Jovis glans, nut of Jupiter)}

Trees with spreading branches, bark fragrant, buds superposed, twigs with dark, chambered pith, leaves compound, odd-pinnate; staminate flowers in drooping, cylindrical catkins, borne on the twigs of the previous year, stamens 12-40, subtended by a bract and a 3-6 parted perianth, pistillate flowers borne singly or in clusters at the ends of the shoots produced in the spring, calyx 4-parted, petals 4 , in the sinuses of the calyx, adnate to the ovary, styles 2, short, stigmas 2, large and fringed; drupe large, globose or ovoid, the exocarp somewhat fleshy, fibrous and indehiscent, 
endocarp bony, rough or rugose, nut indehiscent or separating into two valves in decaying.

A genus of about 8 species, natives of the north temperate zone, one in the Vest Indies and one or two in the Andes of South America.

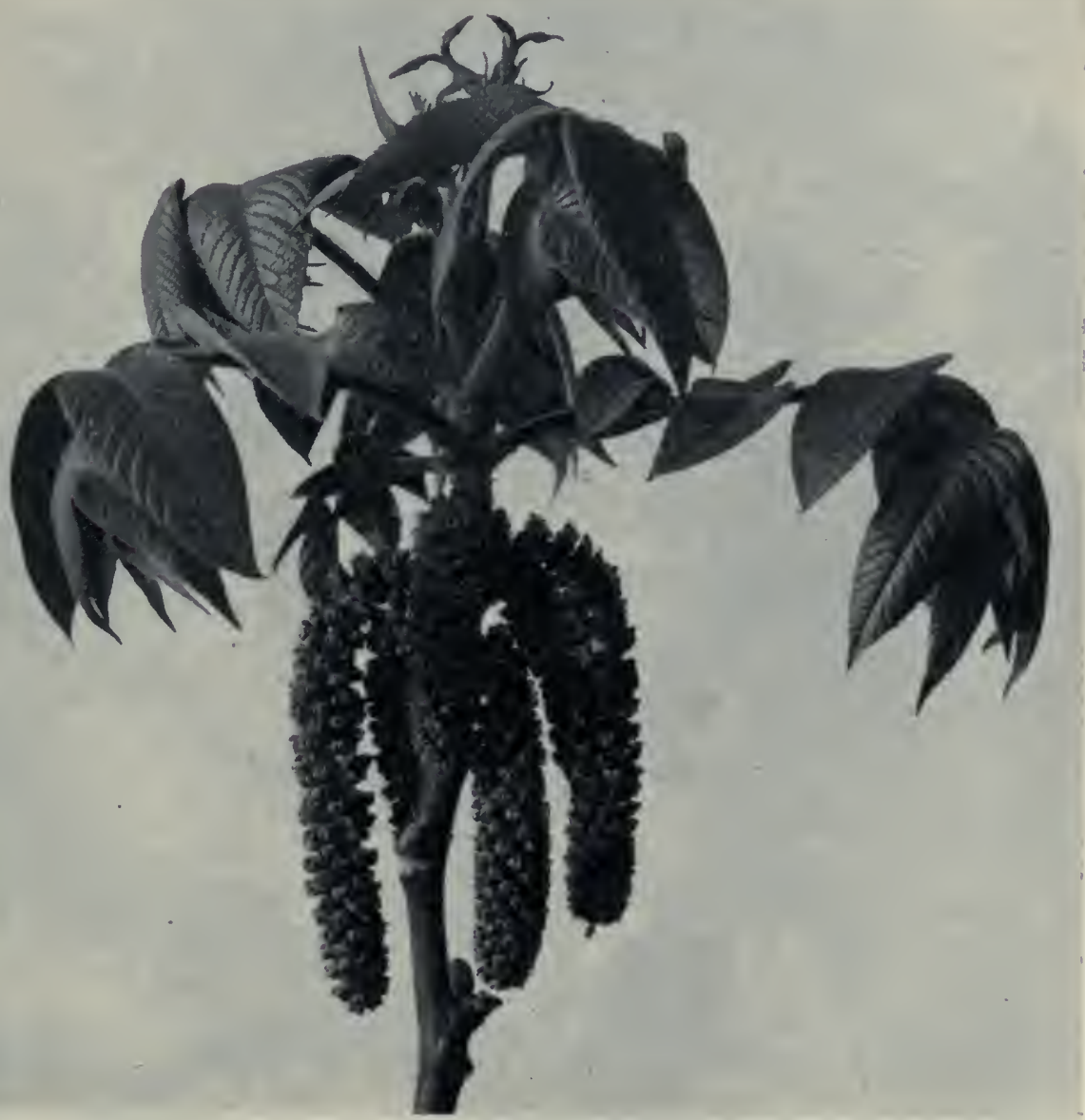

Staminate and pistillate flowers of Juglans cinerea

\section{Key to the Species}

1. Bark gray, fruit oblong, twigs and foliage viscid-hairy

J. cinerea

2. Bark dark brown, fruit globose, twigs and foliage not viscid-hairy 


$$
\text { 3.t. }
$$

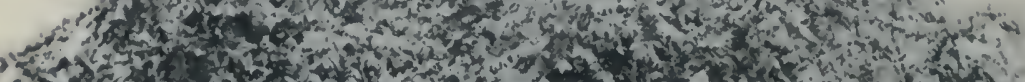

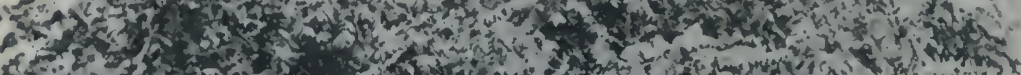

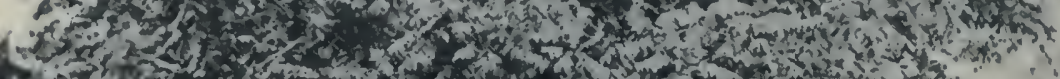

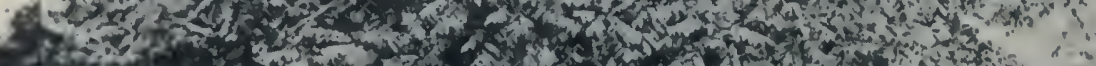

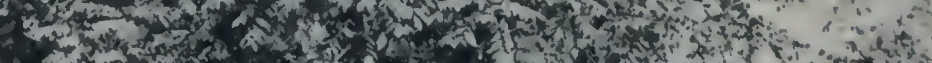

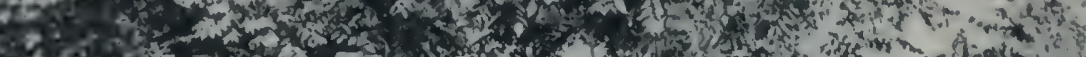

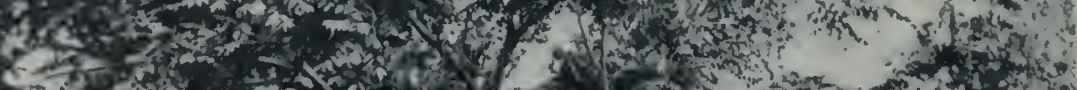

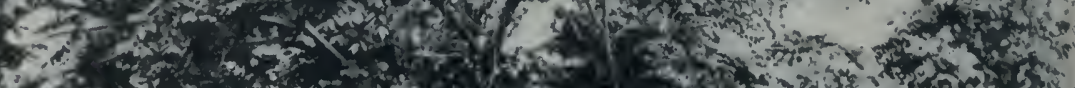

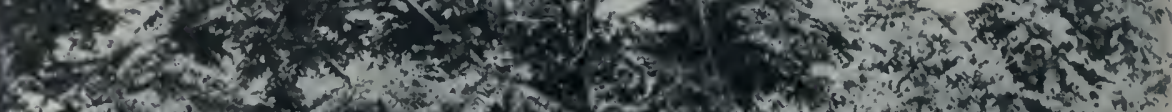

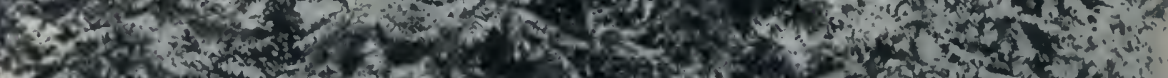

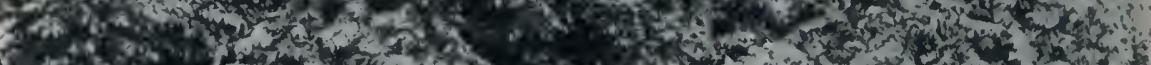

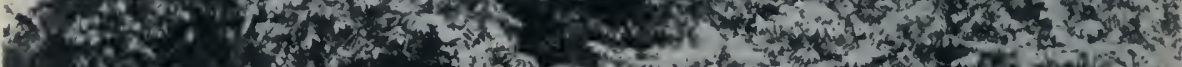
Q6.

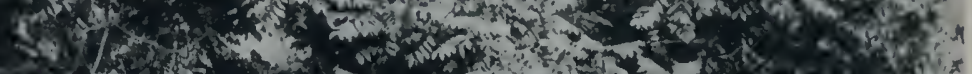

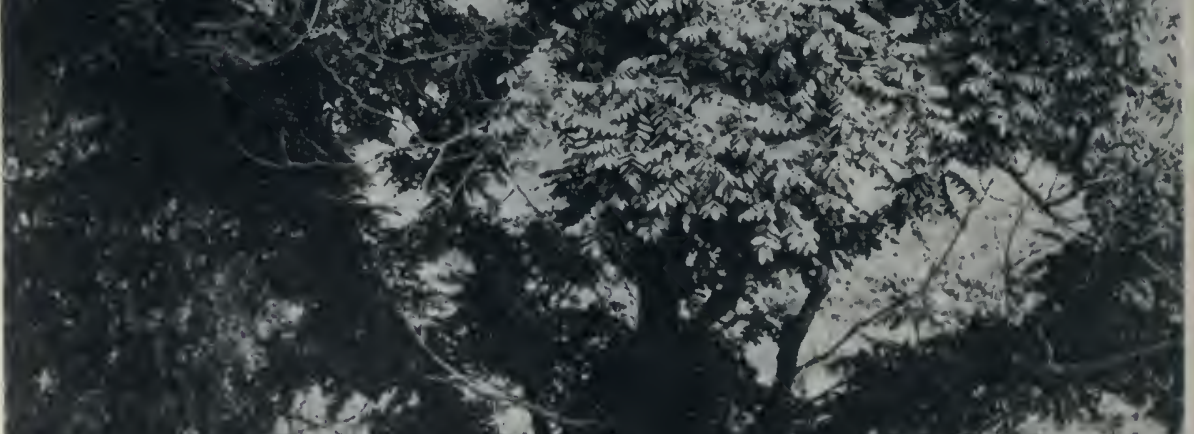

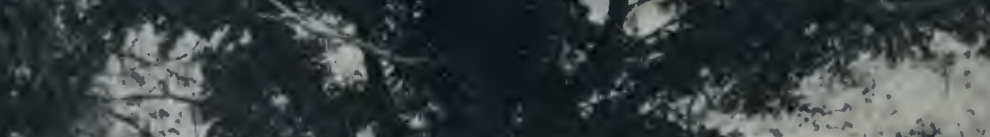

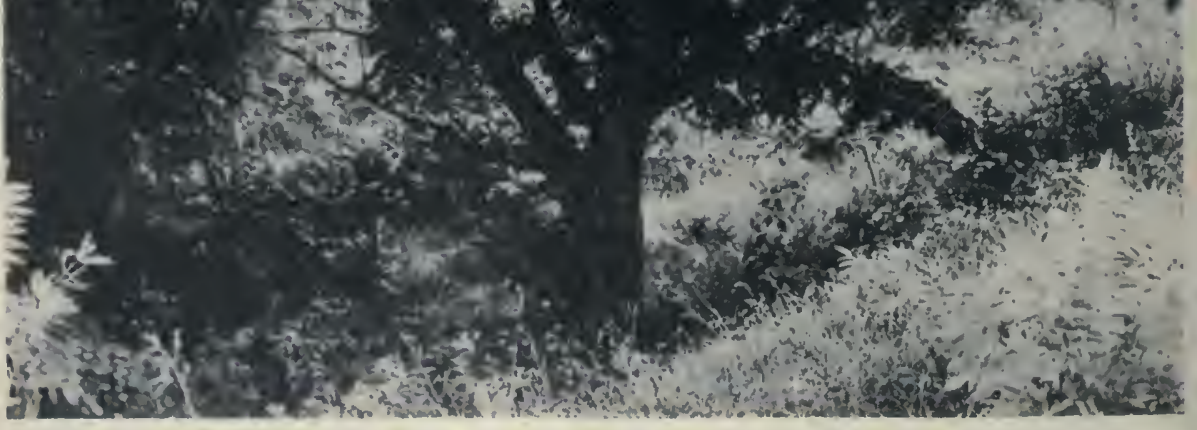

Juglans cinerea Butternut 


\section{Juglans cinerea L in né I753 Butternut, White Walnut}

A tree 15-30 meters (45-90 feet) high, with wide spreading branches, bark of trunk divided into ridges, light brown or gray, young twigs glandular-pubescent, leaves with glandular-pubescent petioles, $20-50 \mathrm{~cm}$. long, leaflets 11-17, oblong-lanceolate, round or cordate at the base, usually unequal, acuminate at the apex, finely serrate except at the base, very pubescent when young, permanently downy-pubescent beneath, $5-12 \mathrm{~cm}$. long, $2-5 \mathrm{~cm}$. wide; staminate flowers in thick catkins, $5-8 \mathrm{~cm}$. long, pistillate in 2-6 flowered spikes, flowers about $1 \mathrm{~cm}$. long, stigma red, large and fringed, 5-7 mm. long; fruit ovate-oblong, clammy, obscurely 2-4 ridged, pointed, 4-6 cm. long; nut deeply sculptured and rough with sharp ridges, 2-celled at the base, seeds very oily and sweet: c in e r e a, ash-colored.

In rich woods and hillsides, common southward and southeastward, not found southwest. Extends northward to the Snake River in Pine and Kanabec Counties and to the north boundary of Aitken County along the Mississippi River. Distributed from New Brunswick to the mountains of Georgia, west to Ontario, eastern Kansas and Arkansas.

The wood is coarse-grained and not strong, light brown becoming darker with exposure. It is used in cabinet making and in interior finishing of houses, weighing $25 \mathrm{lbs}$. Sugar is sometimes made from the sap and the green husks of the fruits are used for dyeing cloth yellow and orange-colored. Blossoms in April and May, fruit ripe in October and November.

\section{Juglans nigra L i n né I753 Black Walnut}

A large, handsome tree, $20-40 \mathrm{~m}$. (60-125 feet) high, and a trunk diameter of 4-8 dm., branches wide spreading, bark rough and dark brown; leaves with pubescent petioles, $25-50 \mathrm{~cm}$. long, leaflets 11-17, ovate-lanceolate, rounded and often unequal at the base, acuminate at the apex, sharply serrate, glabrous above, soft-pubescent at least along the midrib beneath, $4-12 \mathrm{~cm}$. long, $1.5-5 \mathrm{~cm}$. wide; staminate flowers in stout puberulous catkins, 6-12 cm. long, pistillate flowers in 3-5 flowered spikes, flower about $4 \mathrm{~mm}$. long, stigmas yellowish-green, tinged with red, 1-1.5 $\mathrm{cm}$. long; fruit solitary or in pairs, globose, light yellowish-green, slightly roughened, $4-5 \mathrm{~cm}$. in diameter, nut oval or oblong, slightly flattened, 3-4 $\mathrm{cm}$. in diameter, dark brown, irregularly ridged or corrugated, 4-celled at the base, slightly 2-celled at the apex: n ig ra, black.

In rich woods, frequent in the southeastern part of the state, extending north to Nininger, Dakota County, and into southern Scott and Carver 


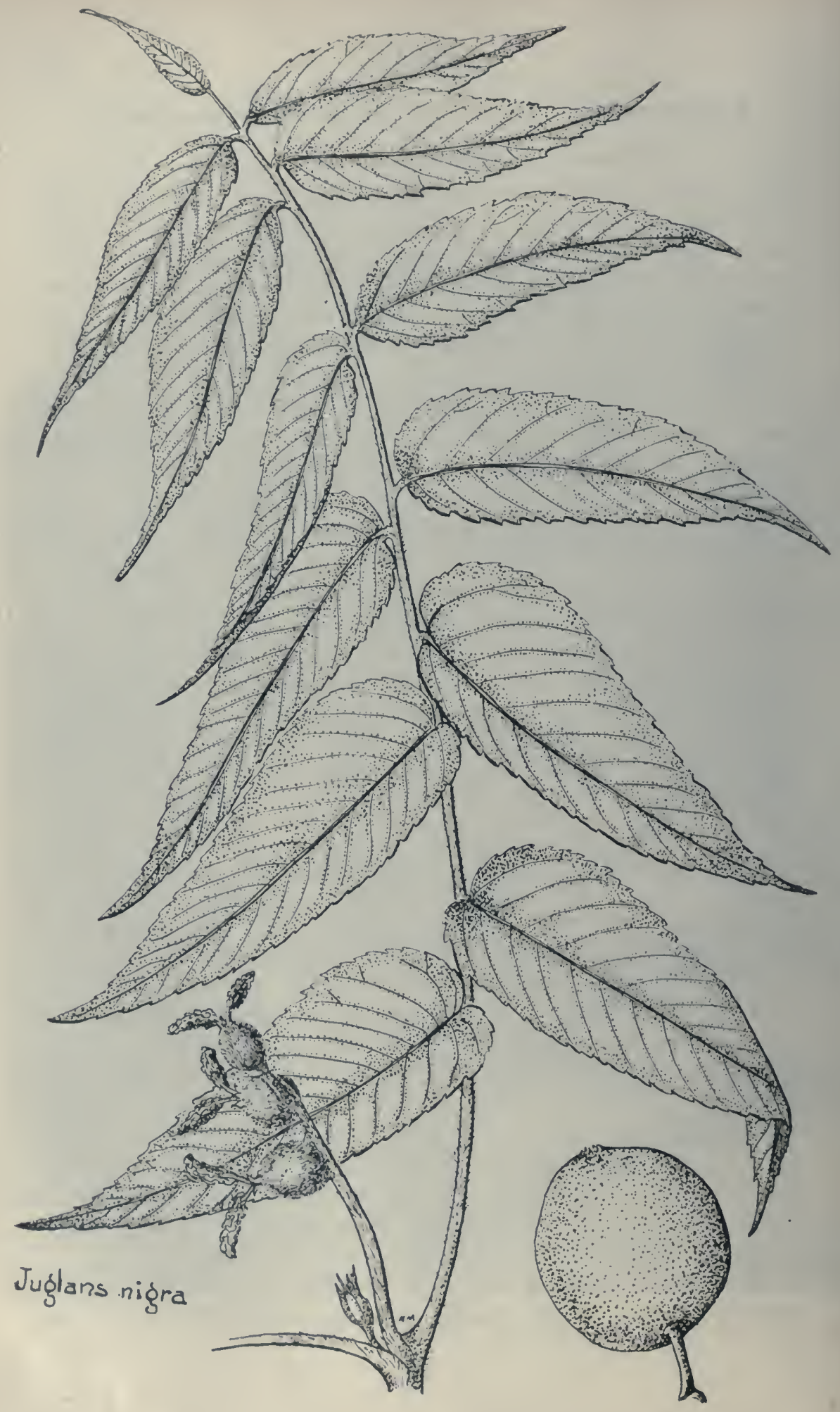




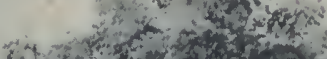

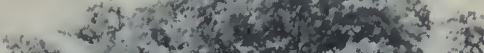

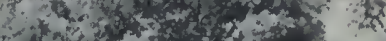

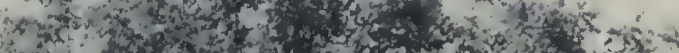

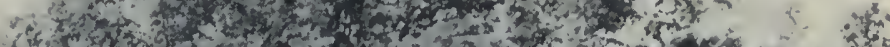

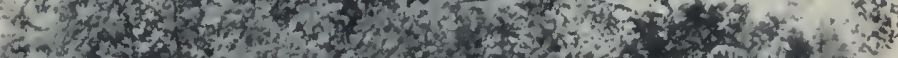

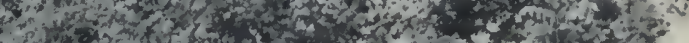

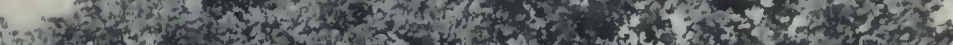

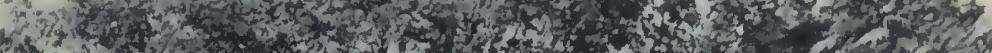

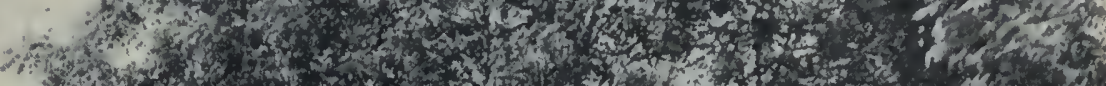

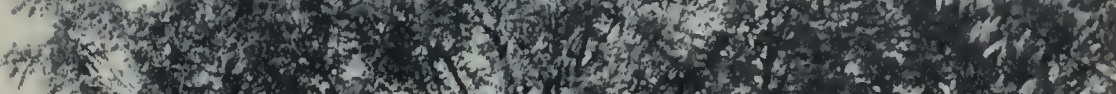

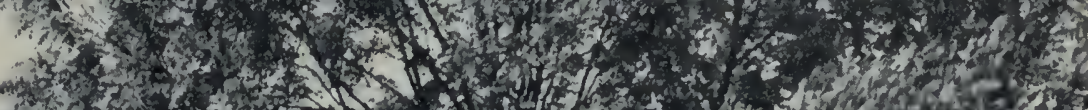

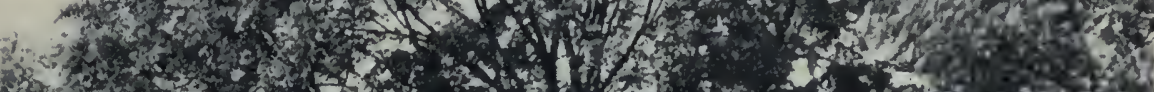

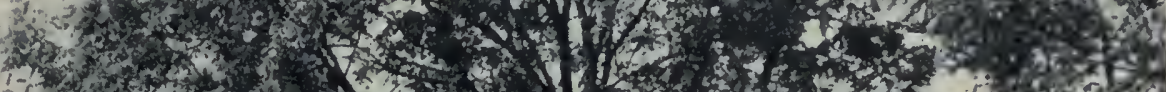

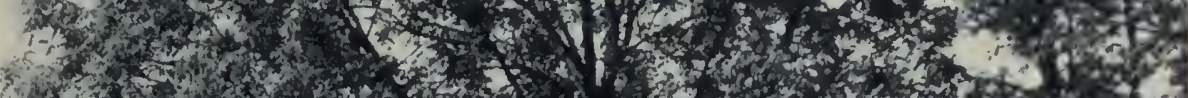

$6 \log ^{2}$

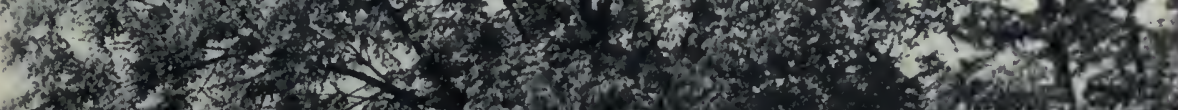

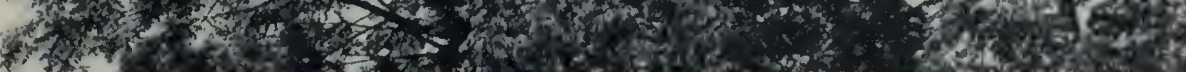
F.

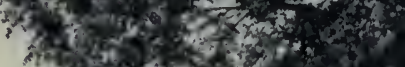

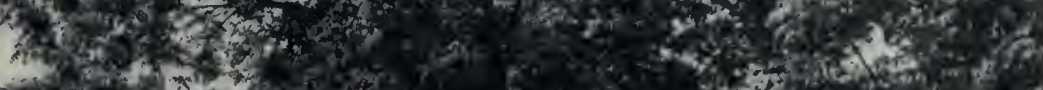

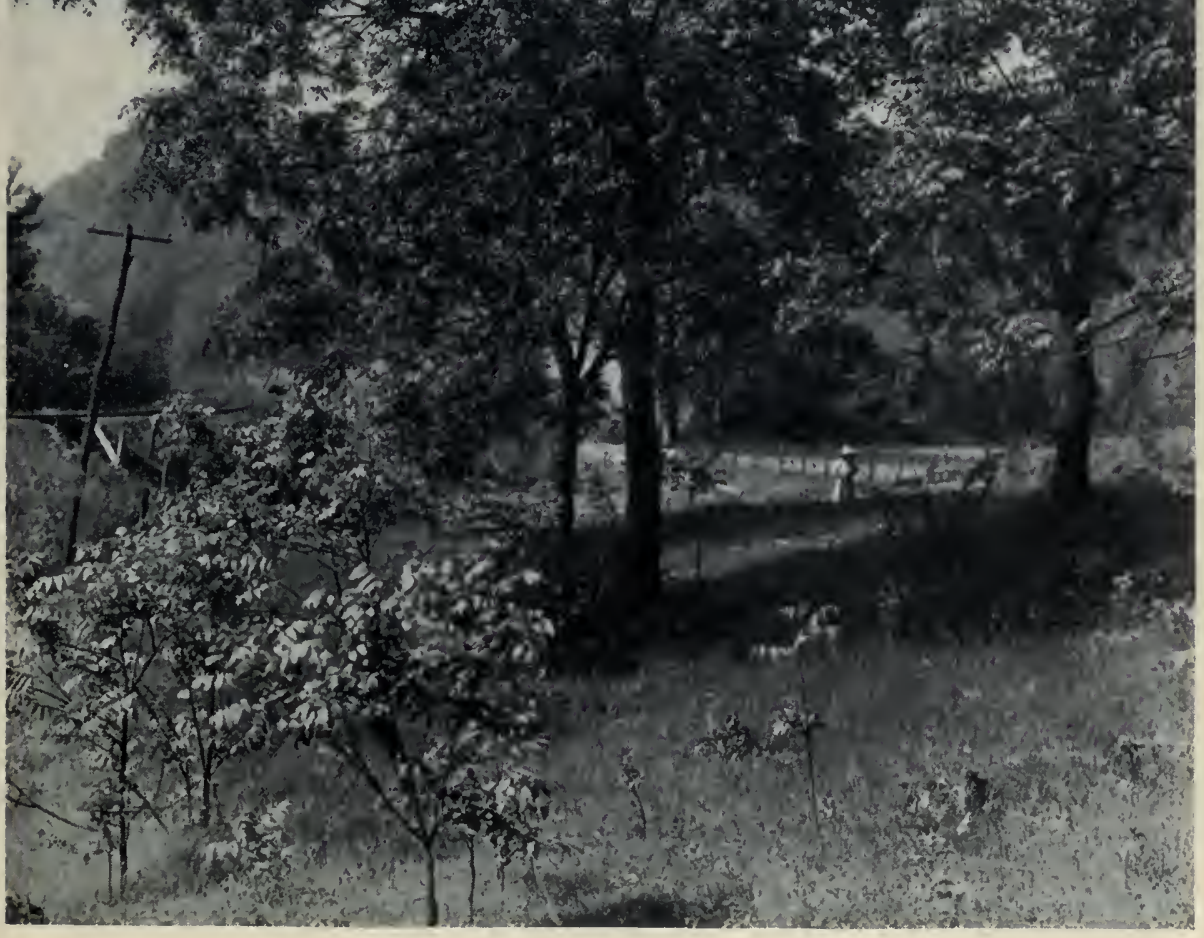


Counties and to Walnut Grove in the south edge of Redwood County, westward as far as Nobles County. Distributed from western Mass. to Fla., west to Ontario, Minn. and Tex.

The wool is heavy, hard, strong, rather coarse-grained, rich, dark brown and very durable, weighing $38 \mathrm{lbs}$. Largely used in furniture and cabinet-making, for interior finishing of houses, for gun stocks, ctc. Flowers in May, fruit ripe in October and November.

\section{Carya $N$ ut t a 11 I8 18 Hickory}

\section{Hicoria Rafinesque 1808}

(Gr. carya, nut, walnut)

Trees with compound, odd-pinnate leaves, bark close and smooth, or shaggy, wood very tough and hard; staminate flowers in slender pendulous catkins, borme in 3's on a common peduncle at the base of the shoots of the season, calyx adnate to the bract, 2-3 cleft, pistillate flowers sessile in 2-6 flowered spikes, with a calyx-like involucre, usually 4-lobed, styles 2 or 4 , short, papillose or fimbriate; fruit subglobose, oblong or obovoid, the husk separating more or less completely into 4 valves, nut bony, smooth or angled, incompletely 2-4 celled, seed sweet and delicious or very bitter and astringent.

A genus of about 10 species, natives of eastern North America. One occurs in Mexico.

\section{Key to the Species}

1. Bark shaggy, leaves white-tufted along the margin

C. ovatit

2. Bark not shaggy, mature leaves almost smooth

C. cordiformis

\section{Carya ovata (Miller) K. Ko ch 1876 Shag-bark Hickory Shell- bark Hickory}

Hicoria ovata (Miller) Brit to 1888

A large tree $16-30 \mathrm{~m}$. (50-90 feet) high, bark of trunk shaggy, separating into narrow plates that are sometimes $25 \mathrm{~cm}$. long, light gray, hard and tough, young twigs puberulent, leaves with petioles $15-30 \mathrm{~cm}$. long, glabrous or pubescent, leaflets 5 , rarely 7 , the three upper obovatelanceolate, the lower pair smaller and oblong-lanceolate, narrowed at the base, acuminate at the apex, serrate, glabrous in age, except the points of the serrations which have tufts of hairs, upper leaflets $12-16 \mathrm{~cm}$. long, $6-8 \mathrm{~cm}$. wide; staminate catkins in $3 ' \mathrm{~s}, 6-8 \mathrm{~cm}$. long, slender; fruits sub- 


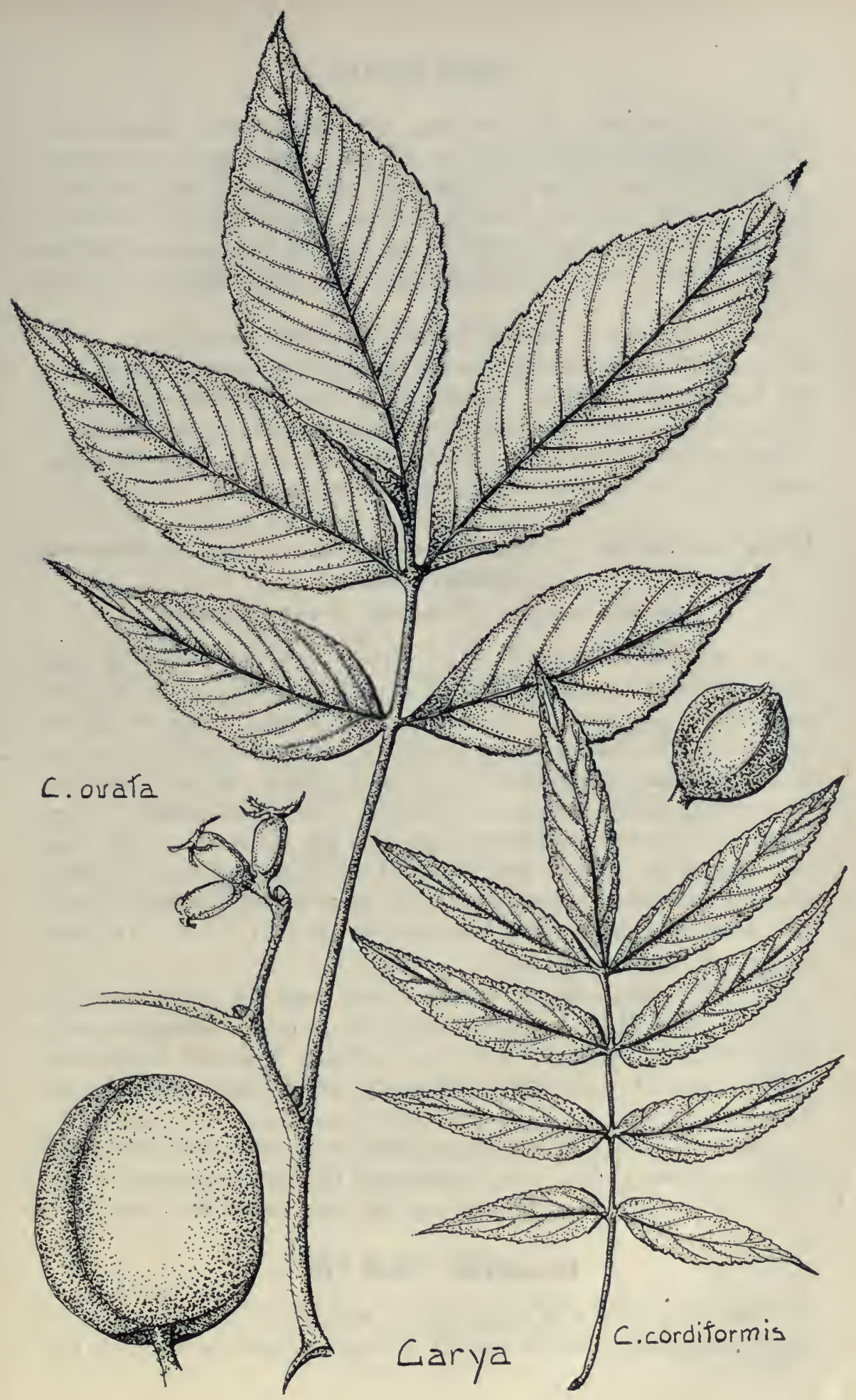


globose or depressed, $4-6 \mathrm{~cm}$. long, nut white, slightly flattened and angled, mucronate-tipped, 4-celled at the base, shell hard: o v a t a, ovate.

In rich woods, common in Houston County, extends north as far as Weaver and Kellogg in Wabasha County, near Chatfield in Olmstead County, and occurs infrequently as far west as Moscow and Freeborn County. Distributed from New England and western Quebec to Minu., Tex, and Fla.

The hickory nut of commerce is obtained mainly from this tree. The wood is light brown in color, heavy, very hard and strong, close-grained and flexible. It is used very extensively in the manufacture of carriages, wagons and agricultural machinery, also for axc-handles, baskets, etc. It is the heaviest and strongest of our native woods, weighing 52 lbs. Blossoms in May, fruit ripe in September and October.

\section{Carya cordiformis (Wangenheim) K. Koch 1876 Bitter-nut Swamp Hickory}

\section{Hicoria minima (Marshall) B rit to $n$ I888.}

A rather slender tree, $12-25 \mathrm{~m}$. (36-75 feet) high, bark of trunk smooth or rough, but not peeling off in such large loose plates as in the preceding species, leaves $12-25 \mathrm{~cm}$. long, with slender, pubescent petioles, leaflets 5-9 lanceolate or oblong-lanceolate, narrowed or slightly rounded at the base, sessile, acuminate at the apex, sharply serrate, puberulent when young, becoming glabrous in age, the three upper leaflets $9-12 \mathrm{~cm}$. long, 2.5-4 cm. wide; staminate catkins in 3 's, slender, $8-12 \mathrm{~cm}$. long; fruit subglobose, narrowly 6-ridged, $2.5-4 \mathrm{~cm}$. long, husk thin, irregularly 4-valved; nuts slightly compressed, short pointed with persistent stigmas, 1.5-2.5 cm. long, thin-shelled, seed very bitter: c ordifor m is, heartshaped, not very appropriate.

In rich woods, common southward and extending through the Big Woods north to Mille Lacs, infrequently to the upper Mississippi and to the tributaries of the St. Louis river. Distributed from New England and western Quebec, to Lake Huron, Minn. and eastern Neb., south to Va. and Texas.

The wood is light brown, close-grained, very liard, heavy, strong and tough, weighing 47 lbs. It is largely used for hoop poles for flour barrels, ox yokes, fuel, etc. Blossoms in May, fruit ripe in Sept. and Oct.

\section{Betulaceae Birch Family}

Trees or shrubs with sweet, watery sap; leaves alternate, petioled, simple and pinnately veined, stipules deciduous; staminate flowers in pen- 
dulous catkins, 1-3 together in the axil of each bract, 2-10 stamens, with or without a perianth, the pistillate in erect, spreading or drooping catkins or in clusters or spikes, pistillate flowers with or without a calyx, adnate to the 1-2-celled ovary, ovules 1-2 in each cavity of the ovary, style 2-cleft or divided; fruit a small, flattened or ovoid samara, mostly 1-celled and 1 -seeded, seed coat membranous, endosperm none.

\section{IEY TO THE GENERA}

1. Pistillate flowers clustered, not in a spike or catkin, fruit an acorn-like nut

\section{Corylus}

2. Pistillate flowers in a spike or catkin, fruit not acorn-like

a. Pistillate catkin small, terminal, loose and

few-flowered, fruit subtended by a 3-cleft

wing or enclosed by a sack

(1) Fruiting bract leaf-like, 3-lobed, bark smooth

(2) Fruiting bract closed, sack-like

Carpinus

Ostrya

b. Pistillate catkin compact, many-flowered

(1) Pistillate bract 3-lobed, 3-flowered, bracts and catkins deciduous

(2) Pistillate bracts 5-lobed, 2-flowered, bracts and catkins persistent

Betula

Alnus

\section{Corylus Li in né 1753}

(Gr. classical name of the hazel, perhaps from Gr. corys, a helmet, in allusion to the involucre)

Shrubs or small trees with alternate, broad, serrate or slightly lobed or incised leaves; staminate catkins 1-3 at the ends of twigs of the previous season, expanding long before the leaves, the flowers solitary in the axil of each bract, stamens 4 , each filament 2-cleft or forked and each branch bearing an anther sack (making apparently 8 stamens), pistillate flowers several, from scaly buds, terminating early leafy shoots, ovary inferior, crowned with a small adherent perianth, stigmas 2, long and slender; nut ovoid or sub-globose, inclosed in a leafy involucre or husk, consisting of two more or less united and enlarged bracts.

\section{Key to the Species}

1. Involucre or husk consisting of 2 broad, fringed bracts $C$. americana

2. Involucre bracts united and prolonged into a tubular bristly beak 


\section{Corylus americana IV a 1 te $\mathrm{r}$ I788 Hazel-nut}

A shrub, 1-2.5 $\mathrm{m}$. high, bark gray and smooth, young twigs and petioles hispid-pubescent or glandular-bristly; leaves ovate or broadly oval, obtuse or cordate at the base, acuminate at the apex, serrate all around,

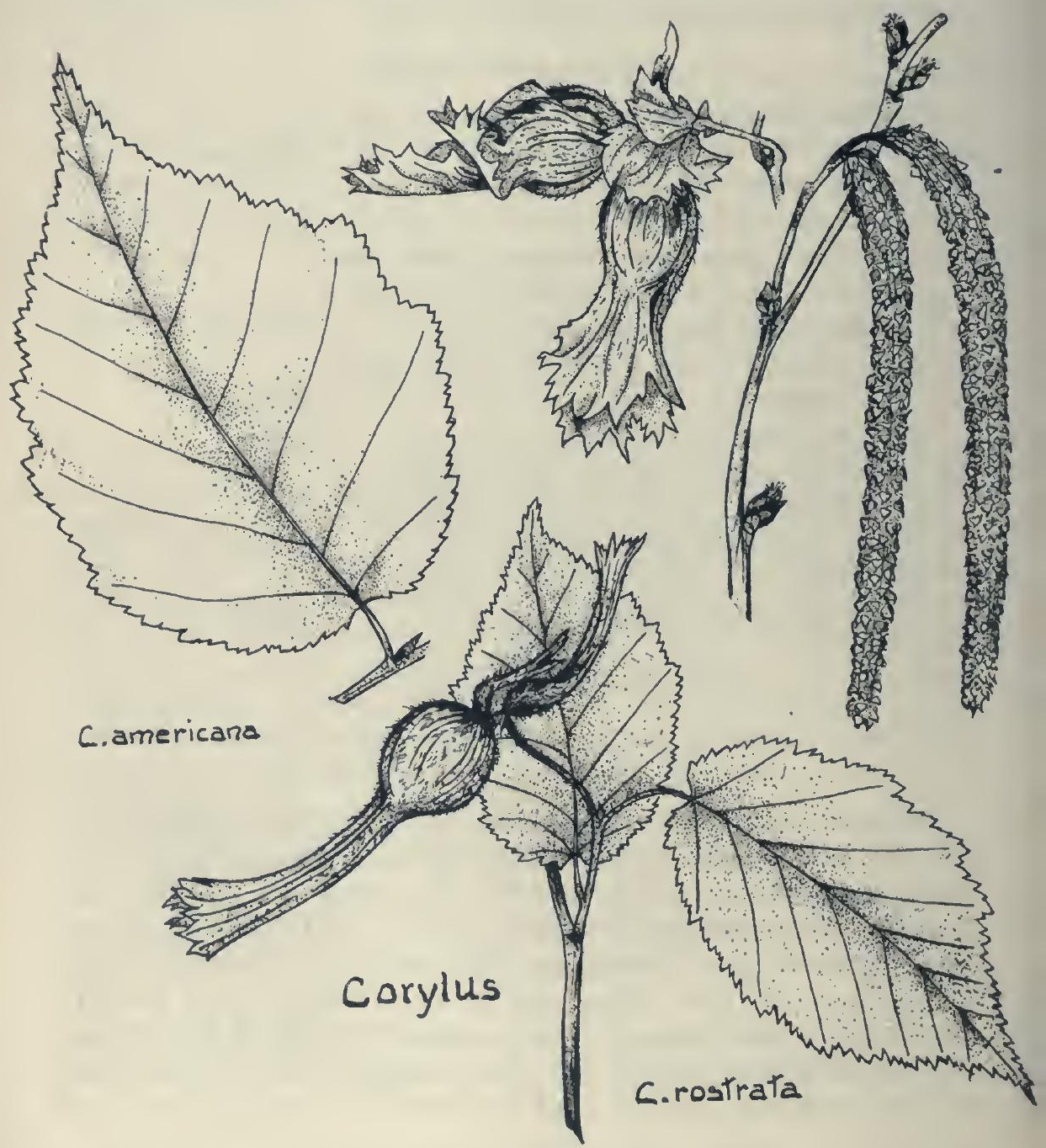

sometimes slightly lobed, glabrous or nearly so above, finely tomentose especially along the veins beneath, 6-16 cm. long, 4-12 cm. wide, petioles $5-20 \mathrm{~mm}$. long; staminate catkins $4-8 \mathrm{~cm}$. long; involucre of the nut composed of 2 leaf-like bracts, free down to the nut, serrate or cut along 
the margins, finely pubescent and with scattered glandular bristles; nut compressed, light brown and mostly striate, $1-1.5 \mathrm{~cm}$. long: a meric a n a, American.

In thickets, on hillsides etc., common and in places abundant throughout the state. Distributed from Maine and Ontario to Manitoba, south to Fla. and Kan. Flowers in March and April, fruit ripe in July and Sept.

\section{Corylus rostrata A it o n I789 Beaked Hazel-nut}

A shrub, 2-4 $\mathrm{m}$. high, stems $2-5 \mathrm{~cm}$. in diameter, bark gray, with scattered lenticels, leaves ovate or oval, cordate or obtuse at the base, acuminate at the apex, sharply and somewhat irregularly serrate, or slightly lobed, glabrous above, or with a few scattered hairs, pubescent at least along the veins beneath, $5-13 \mathrm{~cm}$. long, $3.5-8 \mathrm{~cm}$. wide, occasionally larger, petiole about $1 \mathrm{~cm}$. long; involucral bracts united into a beak, lacerate at the end, $3-4 \mathrm{~cm}$. long beyond the nut, bristly hairy; nut ovoid, slightly compressed and striate, 10-12 mm. long: $\mathrm{r}$ ost $\mathrm{r}$ a $\mathrm{ta}$, furnished with beak like the prow of a vessel.

In woods and thickets, common northward, especially north of Lake Superior, where the bushes reach a height of 4-5 m., rare and local southward, extending southwest to Douglas County, and southeast to Houston County. Distributed from Quebec to British Columbia, south to Del., Ga., Mich., Mo. and westward. Blossoms in April and May, fruit ripe in August and September.

\section{Carpinus L i 11 n é r753 Hornbeam}

(Latin name for the hornbeam)

Trees and shrubs with smooth gray bark, stems ridged; leaves with straight veins, ending in the primary teeth; flowers in catkins, staminate catkins from lateral, short branches, cylindric, about 4-6 cm. long, one staminate flower to each bract, stamens $3-12$; pistillate flowers in short terminal catkins, 2 flowers to each bract, each subtended by a bractlet which is persistent, enlarges and becomes a 3-lobed wing at maturity, stigmas 2, awl-shaped; fruit a nut, ovoid, several-nerved, situated at the base of the bractlet.

A genus of about 12 species, natives of the northern hemisphere, only one species is native to America. 
Carpinus caroliniana $\mathrm{W}$ a 1 te $\mathrm{r}$ I788 American Hornbeam Blue Beech

A small tree, 6-10 m. (18-30 ft.) high, stem ridged, with gray bark, sometimes with lighter blotches; leaves ovate to ovate-lanceolate, rounded at the base, acuminate at the apex, sharply and doubly serrate, reins

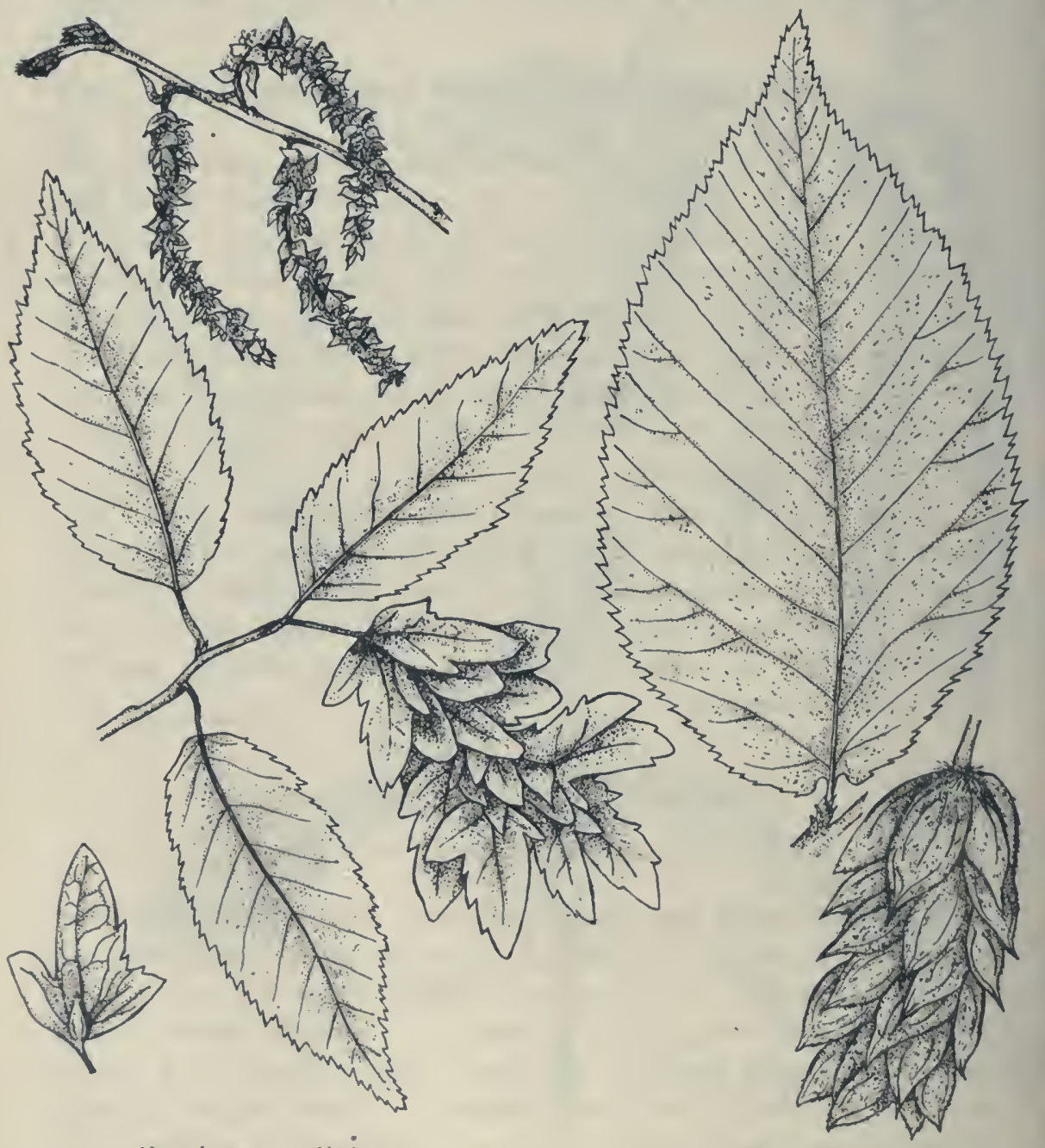

Carpinus caroliniana

Ostrya virginiana

nearly straight and parallel, glabrous above, pubescent in the axils of the veins beneath, $4-8 \mathrm{~cm}$. long, $2-4 \mathrm{~cm}$. wide, petioles slender about $1 \mathrm{~cm}$. long; staminate catkins $3-5 \mathrm{~cm}$. long, scales brown, triangular, reiny and 
pubescent along the margin; anthers hairy at the tips; pistillate catkins terminating leafy shoots, very pubescent, bractlets in fruit 3-lobed, and prominently veined, about $25 \mathrm{~mm}$. long, nutlets ovate, veined, $5 \mathrm{~mm}$. long: c: a r o li n i a na, Carolinian.

In moist woods, especially along streams, common throughout the south half of the state, extending north into Pine County and the White Earth reservation. Nova Scotia to Ontario and Minn., south to Fla. and 'Texas.

Wood light brown, close grained, very hard and durable, weight 45 lbs. Used for wedges, levers and for fuel. Blossoms in April and May, fruit ripe in August.

Ostrya (Micheli) Scopoli i 760

(Gr. ostrya, a tree with hard wood)

Small to medium-sized trees, bark brown and furrowed, foliage resembling that of the birch; leaves with slightly bent veins; staminate catkins 1-3 together, from scaly buds at the tips of the branches of the previous year, flowers solitary in the axil of each bract, stamens 2-10; pistillate catkins solitary, at the ends of short leafy branches of the season, 2 flowers to each bract, each flower subtended by a bractlet which enlarges and becomes sack-like in fruit, pistil incompletely 2-celled, tipped

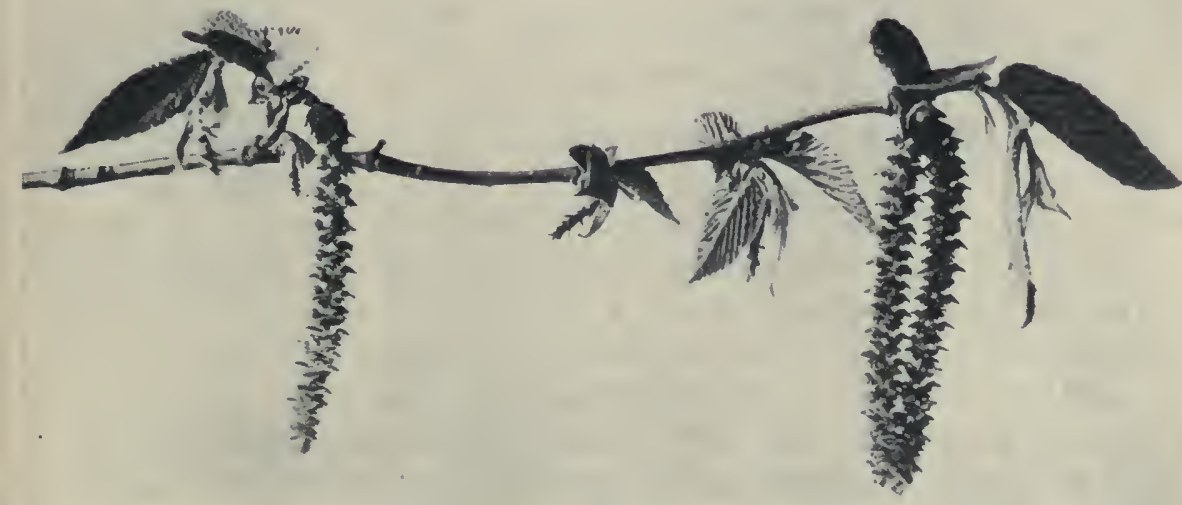

Flowering twigs of Ostrya virginiana 
with 2 long stigmas, ovules 2 ; nut oroid or oblong, smooth and shiny, at the bottom of an inflated sack, the mature pistillate catkin hop-like.

$A$ genus of 4 species. Beside the following another occurs in the southwestern part of the U. S., one in Europe and Asia, and one in Japan.

\section{Ostrya virginiana (Miller) K. K o ch 1876 Hop Hornbeam}

\section{Ironwood}

A tree $7-13 \mathrm{~m}$. (22-42 ft.) high, bark brown, finely furrowed and scaly, twigs of the season pubescent; leaves ovate or oblong-ovate, rounded or slightly cordate at the base, often oblique, acuminate at the apex, sharply and mostly doubly serrate, slightly pubescent especially along the veins, $5-11 \mathrm{~cm}$. long, $2.5-5 \mathrm{~cm}$. broad, petioles $3-10 \mathrm{~mm}$. long pubescent ; staminate catkins $2-3 \mathrm{~cm}$. long, bracts triangular, acute, anthers with a tuft of hairs at the apex, bractlet of each pistillate flower forming a sack in fruit, 12-14 mm. long, veined, bristly-haired at the base, nuts compressed, shining, $5 \mathrm{~mm}$. long, the ripe hop-like catkin erect or spreading: virg in i a $\mathrm{n}$, Virginian.

Mostly in rich woods, throughout the state, in some localities abundant, does not occur close to the shores of Lake of the Woods. Distributed from Nova Scotia to Manitoba, Minn., Neb. and southwestward. Blossoms in April and May, fruit ripe in July and August.

Wood light brown, close grained, hard, durable and heavy. Next to the shell-bark hickory our hardest and heaviest wood, weight $51 \mathrm{lbs}$. Used for wedges, levers, etc., and for fuel.

\section{Betula Linné I753 Birch}

(Latin name of the birch)

Trees and shrubs with mostly aromatic twigs and smooth resinous bark which frequently separates into thin papery plates and peels off transversely, becoming thick, scaly, and deeply furrowed at the base, lenticels elongated transversely; flowers in catkins, appearing before or with the leaves, staminate flowers 3 to each shield-shaped scale of the catkin, subtended by 2 bractlets, flower consisting of 2 2-cleft stamens (each division bearing a half anther) and a perianth of 2 unequal parts; pistillate flowers 3 or 2 to each 3 -lobed scale, perianth lacking, pistil 2celled, stigmas 2, clongated, mostly persistent ; fruit a flattened or lenticular, winged nut or samara, at maturity deciduous together with the scales of the catkin. 
A genus of about 40 species, natives of the arctic and north temperate zone.

\section{Key to the Species}

1. Trees, with white bark

a. Leaves serrate or toothed, not deeply cut

(1) Bark peeling in papery layers, leaves ovate, native

B. papyrifera

(2) Bark peeling slightly above, dark and furrowed at the base, leaves triangular $B$. verrucosa

b. Leaves deeply cut

(1) Leaves with long slender points

B. populifo!iu laciniata

(2) Leaves cut, but not very long-pointed

B. verrucosa lobata

2. Trees or shrubs with gray, yellow, or dark bark

a. Trees

(1) Twigs fragrant, bark very ragged, yellowish gray

B. lutea

(2) Twigs not fragrant, bark reddish brown, trunk scaly

b. Shrubs

(1) Tall shrubs, 4-8 m. high, leaves ovate

(2) Shrubs, 1-2 m. high, leaves obovate to orbicular

B. nigra

B. Sandbergii

B. pumila

\section{Betula papyrifera Marshall r785 Paper Birch Canoe Birch Betula alba var papyrifera (Marshall) Spach}

A large tree, reaching a maximum height of $25 \mathrm{~m}$. (78 ft.), and a trunk diameter of $2-5 \mathrm{dm}$.; bark white (except on young trees where it is brownish red) and peeling off in papery layers, twigs slender with pale lenticels; leaves ovate, obtuse, truncate or sub-cordate at the base, acuminate at the apex, usually doubly and often irregularly serrate, dark green and glabrous above, pubescent abong the veins beneath and glandular or resin-dotted, $5-8 \mathrm{~cm}$. long, $3-5 \mathrm{~cm}$. wide; staminate catkins 5-10 $\mathrm{cm}$. long; pistillate catkins slender, erect, at the ends of short leafy shoots 2-3 cm. long, fruiting catkin drooping, $3-5 \mathrm{~cm}$. long, 7-10 mm. in diameter, fruiting bracts about $4 \mathrm{~mm}$. long puberulent, nut oval : p a p y r i f e r a, paper bearing.

Common and in places very abundant throughout the state except southwestward. Distributed from Newfoundland and Labrador to Hud- 


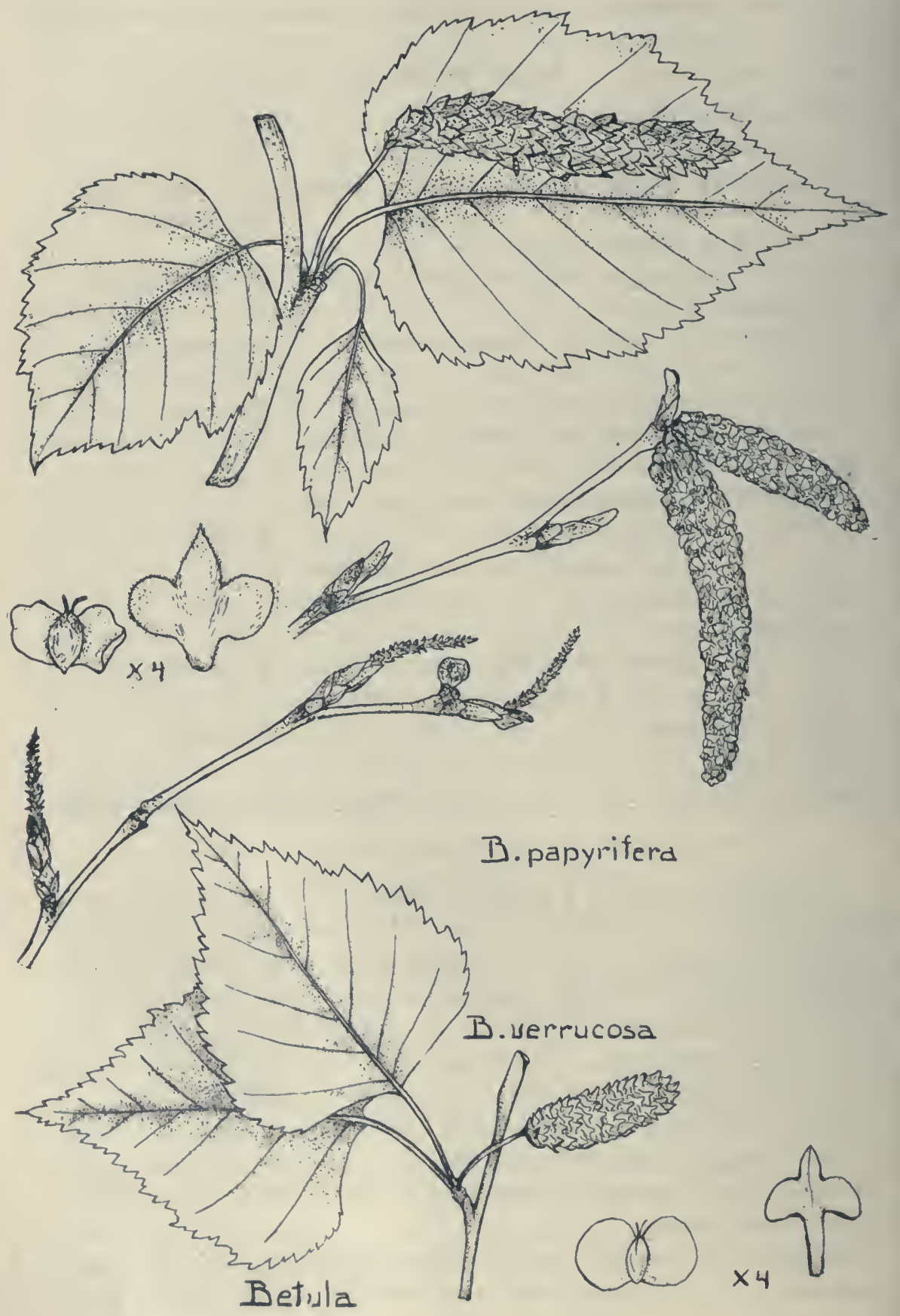


sun Bay and Alaska, south to N. Y., Pa., Ind., northern Iowa, Neb., Wyo. and Wash. Blossoms in April and May, fruits in August and September.

Wood light brown, close-grained, strong and tough, weight $37 \mathrm{lbs}$. It is used for making spools, shoe lasts and pegs, for wood pulp and fuel. The Indians use the wood for making snow-shoe frames, sledges and paddles, the bark in making canoes, receptacles for gathering maple sap, drinking cups, and for covering tepees, the sap sometimes as a drink and boiled down as a syrup.

\section{Betula verrucosa. Eh rhart I79I European White Birch}

\section{Betula alba Linné 1753 in part}

A small to medium-sized tree, 6-13 m. (20-40 ft.) high, bark white, peeling slightly into papery layers except at the base where it is more or less rough and furrowed and dark gray in color, branches slender and more or less drooping, those of the year reddish and glandular-dotted; leaves rhombic-ovate, broadly wedge-shaped or truncate at the base, acuminate at the apex, doubly and usually unequally serrate, bright green and glabrous on both sides, sometimes with glandular dots, ciliate along the margins, $4-7 \mathrm{~cm}$. long, $2.5-4 \mathrm{~cm}$. wide, petiole glabrous, reddish, with few, mostly dark glands, $2-3 \mathrm{~cm}$. long; pistillate catkins on short, lateral bi-foliate shoots, in fruit $2-3 \mathrm{~cm}$. long, $7 \mathrm{~mm}$. in diameter, pointing towards the tip of the branch on which they are borne, peduncles 10-18 $\mathrm{mm}$. long, the 3-parted bracts 5-6 $\mathrm{mm}$. long, lateral lobes recurved, samara 5-6 nm. wide, wings much wider than the nutlet: ve r r u cos a, warted.

Introduced from Europe, frequently planted as a park tree, and passing under the name of $\mathrm{B}$ e $\mathrm{tul}$ a a $\mathrm{lb}$ a Linné. It seems that Linné described two different kinds of trees under the name of $\mathrm{B}$ e $\mathrm{t} \mathrm{u} \mathrm{la}$ a l b a, viz. the preceding and B. pubescens. The two were separated by Ehrhart in 1791, and it seems advisable to retain the nomenclature which he proposed. Blossons in April-May, fruits Aug.-Sept.

There are several cut leaf forms of B. ver rucosa, such as var. lo b a t a and var. in cis a. "Betula elegantissima pendula" or "Betula alba pendula elegans" is a form of Betulaver $\mathrm{rucos}$ a with slender drooping branches, commonly known as Weeping Birch.

\section{Betula populifolia M a rs h a 11 I 785 var. laciniata Cut Leaf Birch}

A small tree, with deeply cut, long-pointed leaves, bark white, peeling slightly on the branches; twigs very slender; leaves ovate, deeply cut and lobed, long-pointed at the apex, broadly wedge-shaped at the base, gla- 
brous or slightly glandular, length $3-4 \mathrm{~cm}$., width $1.5-3 \mathrm{~cm}$., petioles very slender, $2.5-4 \mathrm{~cm}$. long; staminate catkins usually solitary, drooping, 6-8 $\mathrm{cm}$. long; pistillate catkins on slender peduncles, $1-2 \mathrm{~cm}$. long, the fruiting catkins $2-3 \mathrm{~cm}$. long, about $1 \mathrm{~cm}$. wide, fruiting scales with the lateral lobes broad and slightly recurved, nutlet broad winged: p o p u I i f o li a, poplar leaved, la c iniat a, deeply cut.

$\Lambda$ handsome but short-lived tree, often planted in parks and lawns. B. populifolia is native of northeastern U. S.

\section{Betula lutea Micha ux filius I8I2 Yellow Birch}

A large tree, sometimes attaining a height of $25-30 \mathrm{~m}$. (80-90 ft.) and a trunk diameter of $1 \mathrm{~m}$., bark of the trunk gray or yellowish gray. peeling off into thin papery layers, causing a ragged appearance, twigs gray or brownish with light lenticels, aromatic, with the flavor of wintergreen; leaves ovate to oblong-ovate, rounded or sub-cordate and mostly unequal at the base, acute at the apex, sharply and sometimes doubly serrate, dark green and dull above, paler beneath and pubescent along the veins, 5-11 cm. long, 3-7 cm. wide, petioles 1-1.5 cm. long, pubescent, staminate catkins 2-4 together, 4-8 cm. long; pistillate catkins sessile, about $1 \mathrm{~cm}$. long; fruiting catkin oblong-ovate to sub-globose, $15-25 \mathrm{~mm}$. long, $12-16 \mathrm{~mm}$. thick, scales 3-lobed to the middle, 6-8 mm. long, ciliate, lateral lobes ascending, about $3 \mathrm{~mm}$. wide, nutlet wider than its wing; l u te a, yellow.

In rich, moist woods, common throughout the north half of the state, rare southward. Distributed from Newfoundland, Nanitoba, south to Ind., Ill, and Minn. Flowers in May, fruit ripe in Aug. and Sept.

This birch is one of the most valuable timber trees of eastern North America. Wood light brown, close grained, hard and heavy, taking a beautiful polish, weight $40 \mathrm{lbs}$. It is largely used in the manufacture of furniture, inside finish, and for fuel. Most imitation mahogany is made from this wood.

\section{Betula nigra L in n é I753 Red Birch River Birch}

A tall, usually slender tree, sometimes attaining a height of $30 \mathrm{~m}$. (100 ft.), bark at the base of old trunks dark brown, deeply furrowed, higher up on large branches lustrous reddish brown and peeling more or less freely, twigs reddish, young shoots pubescent; leaves triangularovate, broadly wedge-shaped or truncate at the base, apex obtuse or acute, irregularly-serrate or somewhat pinnately-lobed, dark green and glabrous 
above when mature, paler and glabrous or somewhat tomentose beneath, $3.5-8 \mathrm{~cm}$. long, $2.5-6 \mathrm{~cm}$. wide, petioles $8-15 \mathrm{~mm}$. long; staminate catkins 2-3 together, $6-10 \mathrm{~cm}$. long, pistillate catkins oblong-cylindric, $1-1.5 \mathrm{~cm}$. long, about $4 \mathrm{~mm}$. in diameter; fruiting catkins spreading, pedicelled,

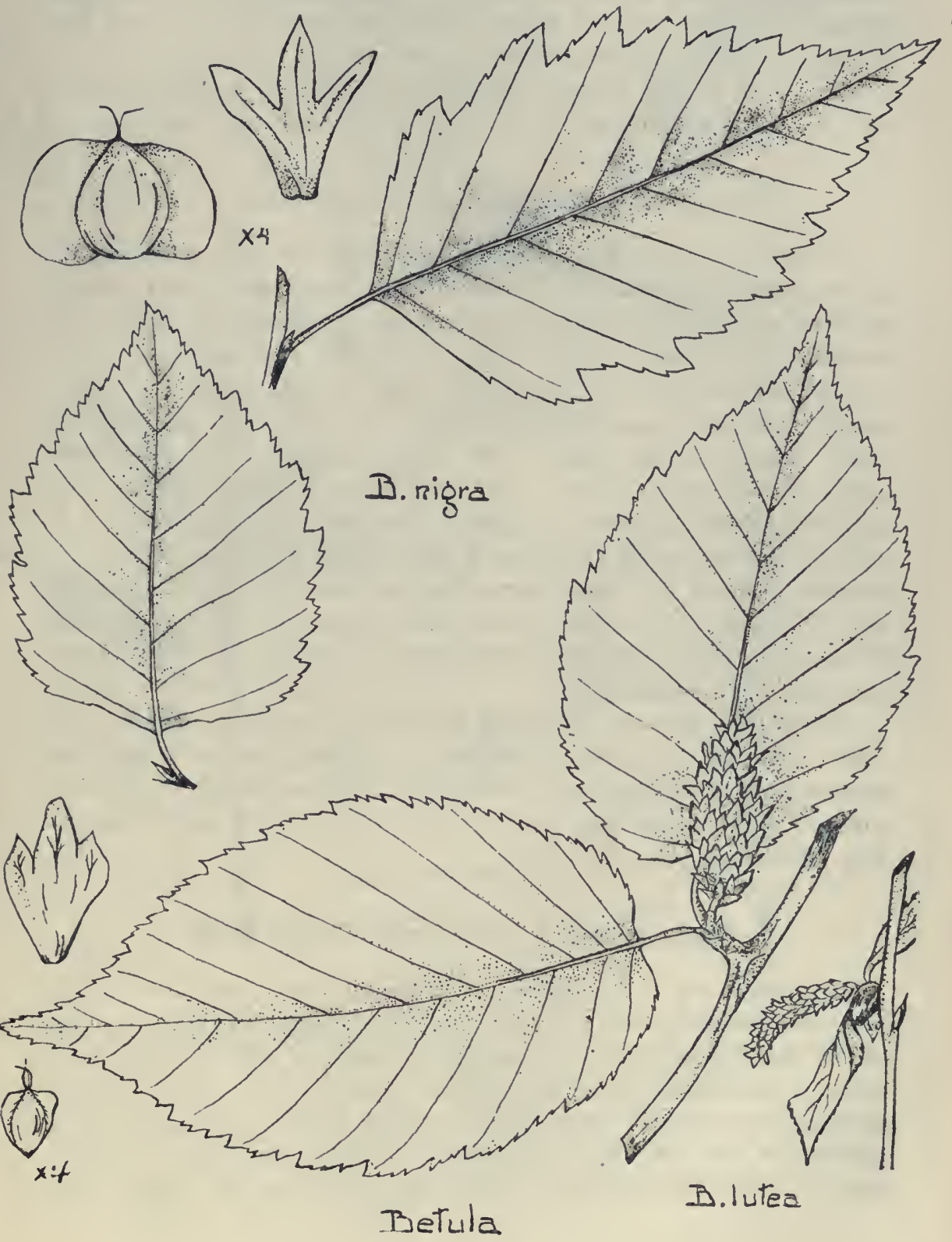


15-25 mm. long, 11-14 mm. in diameter, scales deeply 3-lobed, tomentose, 6-8 mm. long, lateral lobes ascending, samaras $6-7 \mathrm{~mm}$. wide, nutlet twice as wide as the wings: $\mathrm{n} \mathrm{i} g \mathrm{r}$ a, black.

Along the bottom lands of streams and rivers, common along the Mississippi bottoms as far as Wabasha County, also reported from near Mankato. Distributed frem Mass. to Minn, south to Fla., Tex. and Kan. Blossoms in April and May, fruit ripe in autumn.

The wood is light brown, close grained, hard, and strong, weight 36 lbs. It is used in manufacture of furniture, for staves and fuel.

\section{Betula Sandbergii B ritt o n 1904}

A tall shrub, 4-8 m. high, stems several from one root, ascending, 3-7 $\mathrm{cm}$. in diameter, bark dark brown, not peeling, twigs dark gray or brownish, with a few obscure lenticels, leaves ovate to oblong-ovate, rounded or narrowed at the base, acutish at the apex, serrate, glabrous above, pubescent beneath, at least along the veins, length $3-5 \mathrm{~cm}$., width $1.5-3.5 \mathrm{~cm}$, petioles 6-10 $\mathrm{mm}$. long, pubescent; leaves on sterile twigs more broadly ovate, larger, ( $7 \mathrm{~cm}$. long, $5 \mathrm{~cm}$. wide), coarsely serrate and more pubescent; staminate catkins $1-2$, at the ends of branches, $3-4 \mathrm{~cm}$. long; pistillate catkins pedicelled, cylindric, $12-15 \mathrm{~mm}$. long, $1.5-2 \mathrm{~mm}$. in diameter; fruiting catkins ascending or erect, $15-20 \mathrm{~mm}$. long, 6-7 $\mathrm{mm}$. in diameter, pedicels $8-12 \mathrm{~mm}$. long, sometimes bearing a small leaf, scales about 3.5-4 mm. long, margins ciliate, lateral lobes at right angles; samara $3 \mathrm{~mm}$. wide, nutlet ovoid, about the width of the wing: S a nd bergi named for J. H. Sandberg.

In tamarack swamps, Hennepin County. This species has not been collected in any other part of the state but probably occurs in tamarack swamps in the northern part of the state. It is possible that it has been confused with young trees of Betula papyrifera. Flowers in May, fruits in September.

\section{Betula pumila L i n né i 767 Dwarf Birch}

$\Lambda$ shrub, 0.5-4 m. high, erect or ascending, twigs brown with light dots, young shoots mostly soft-pubescent but not glandular, leaves obovate, oval or nearly orbicular, wedge-shaped, narrowed or rounded at the base, obtuse or rounded at the apex, somewhat coarsely serrate, dull green and glabrous above in age, paler beneath, tomentose when young, becoming glabrous in age, prominently reticulate-veined on both sides, $1-3.5 \mathrm{~cm}$. long, 8-20 mm. wide (larger on sterile shoots); staminate catkins borne 


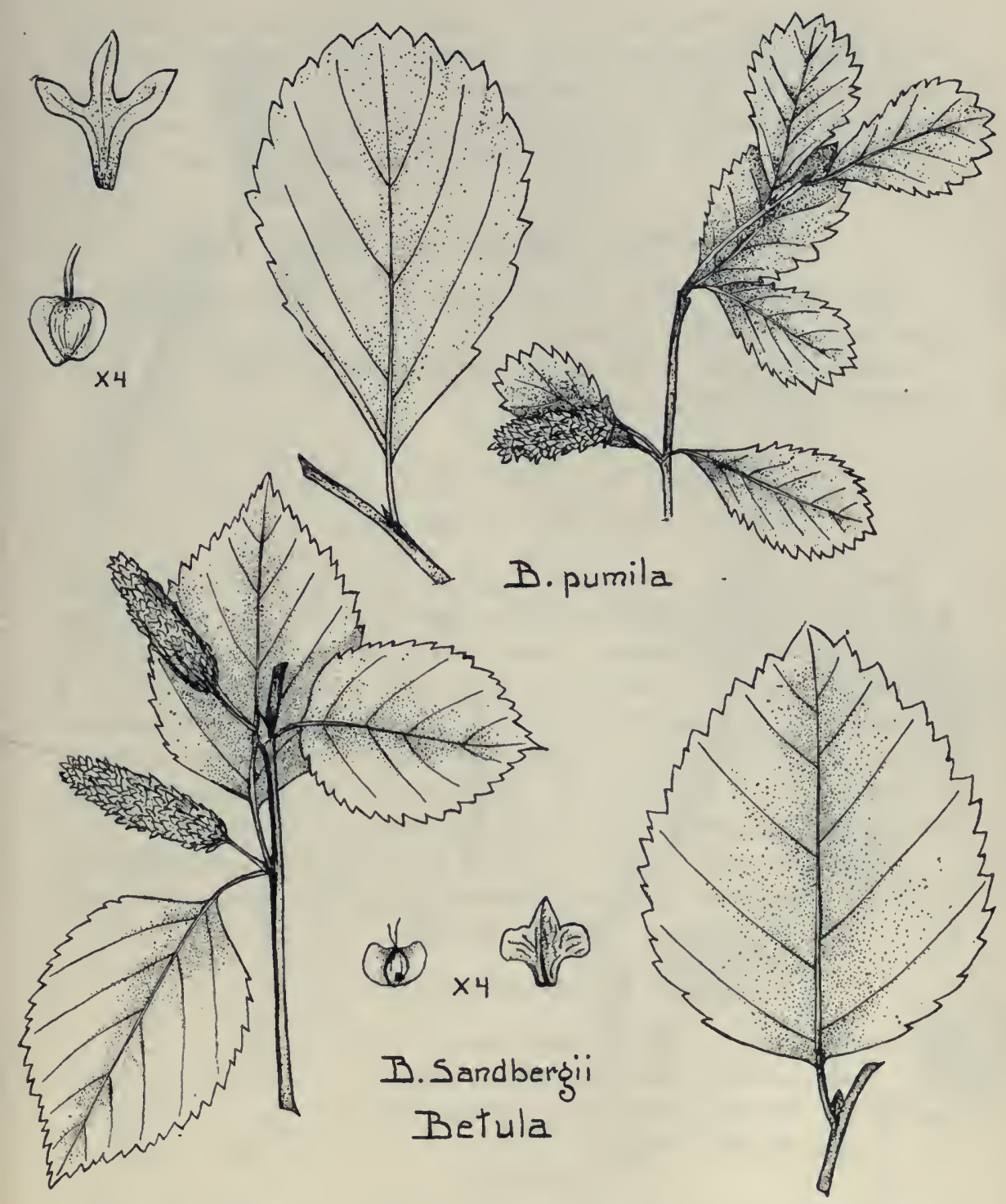

singly, erect, oblong, about $1 \mathrm{~cm}$. long; pistillate catkins ending short leafy shoots, 5-8 mm. long; fruiting catkins oblong-cylindric, erect, pedicelled, $8-25 \mathrm{~mm}$. long, 6-8 $\mathrm{mm}$. in diameter, scales about $4 \mathrm{~mm}$. long: lateral lobes spreading, slightly shorter than the middle one, puberulent or ciliolate; samara cordate, $2.5-3 \mathrm{~mm}$. broad, nutlet slightly broader than its wings: pumila, dwarf. 
In bogs and tamarack swamps, common throughout the north half of the state, and as far south as Minneapolis and St. Paul, rare and local farther south, in Goodhue, Olmstead and Houston counties. Distributed from Newfoundland to western Ontario, south to N. J., Ill., and Minn., also Europe and Asia. Flowers, in May, fruit ripe in July and August.

\section{Betula pumila var. glandulifera R e ge 1 r 865}

Differs from the species in that the young branchlets and leaves are resiniferous or glandular-dotted.

Northwestern part of the state. Distributed from Ontario and Mich. to Minn. and Saskatchewan.

\section{Alnus Gaertner I79I Alder (Latin name of the alder).}

Shrubs or trees with dentate or serrate leaves and few-scaled buds; flowers in catkins, appearing the preceding season and expanding before or with the leaves, staminate flowers 3 or 6 in the axil of each bract, perianth of four parts, stamens 4 , the 2 outer flowers subtended by 1-2 bractlets each, pistillate flowers 2 or 3 in the axil of each bract, perianth lacking, 2 small bractlets subtending each flower, ovary 2-celled, styles 2, in fruit the bracts become woody and 5-toothed or pointed and together form a cone-like structure, nutlet flattened, with or without wings.

A genus of about 14 species, natives of the northern hemisphere and the Andes Mountains of South America. In addition to the following, some 6 or 7 species occur in North America.

\section{Key to the Species}

1. Leaves finely serrate, resinous beneath when young, nutlets with a membranous wing A. crispa

2. Leaves coarsely serrate, not resinous, nutlet acute-margined, wingless

A. incana

Alnus crispa (Aiton) Pursh 18I4 Green or Mountain Alder Alnus alnobetula (Ehrhart) K. Koch 1872

A shrub 0.6-3 m. high, bark gray or brownish, young shoots brownish, more or less pubescent and glutinous; leaves ovate or oval, rounded at the base, obtuse or acute at the apex, finely, sharply and often irregularly serrulate or incised-serrate, dark green and glabrous above, lighter green 

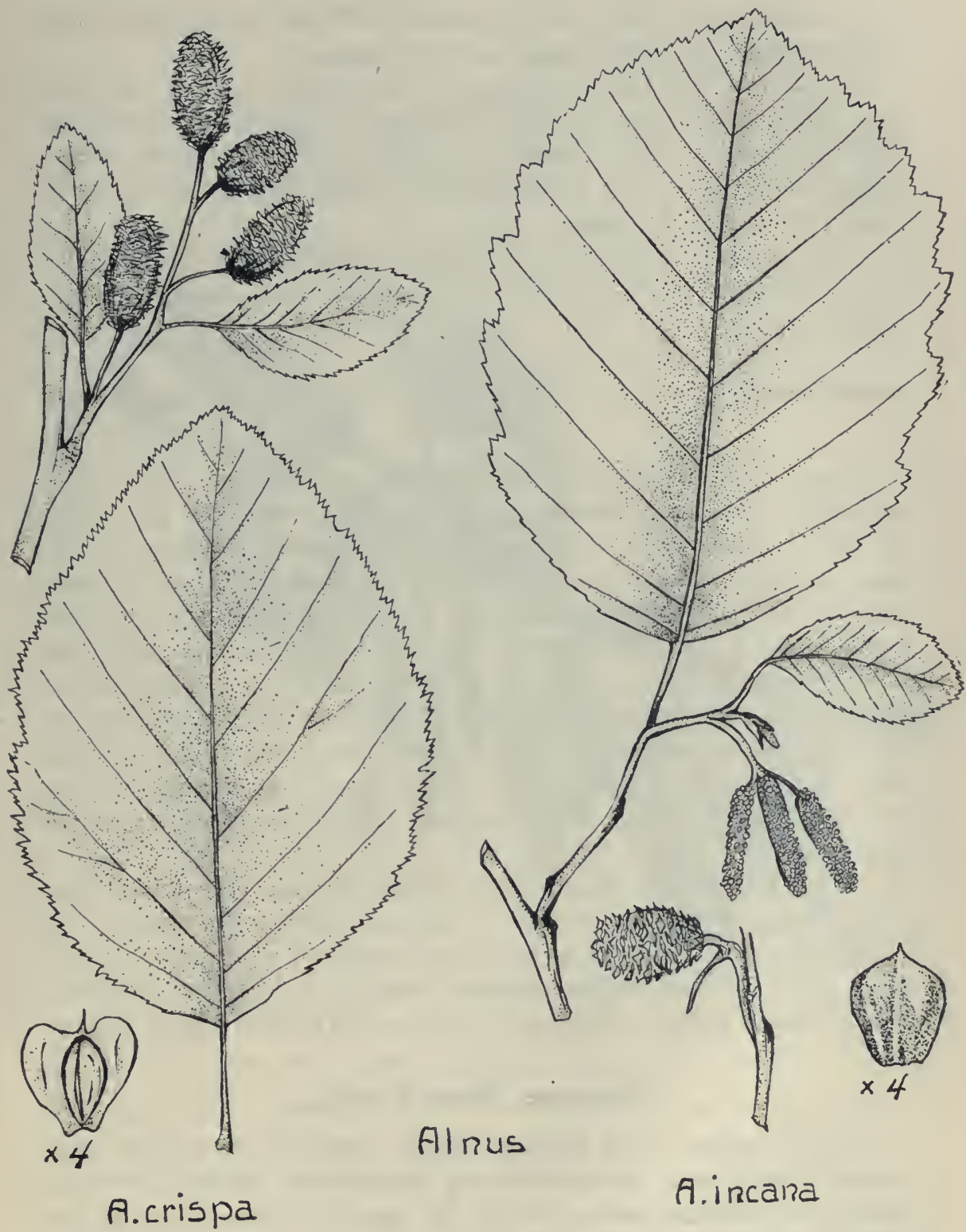

Alnus

A.incana

and usually pubescent beneath along the veins, (young foliage glutinous and more or less pubescent), $4-8 \mathrm{~cm}$. long, $3.5-5 \mathrm{~cm}$. wide, petioles $8-10$ mm. long; catkins expanding with the leaves, the staminate 2-3 together, slender, $6-10 \mathrm{~cm}$. long, the pistillate in a loose raceme, fruiting catkin 15-18 mm. long, 7-9 mm. thick, persistent scales firm and woody, irregu- 
larly 5-lobed, about $4 \mathrm{~mm}$. long, samaras 2-2.5 mm. wide, nutlet ovoid, slightly broader than the wing: $\mathrm{c}$ is $\mathrm{p}$ a, curled.

Cool shores and banks, common in the northern part of the state, especially north of Lake Superior, distributed from Newfoundland and New Brunswick to Alaska, south to Mass., N. Y., Mich., and British Columbia, in the mountains to Virginia and North Carolina. Flowers in June, fruit ripe in September.

This species in Winkler's Monograph of the Betulaceae is given as var. crispa of A. a 1 nobet u 1 a. It seems better to regard it as a distinct species.

\section{Alnus incana ( L i n né) W ill d e now 1805 Speckled or Hoary Alder}

A tall shrub or occasionally a small tree, 2-8 m. high, stems erect or ascending, bark dark brown, young twigs reddish-brown; leaves oval or ovate, rounded or narrowed at the base, obtuse or acuminate at the apex, serrate or dentate, with serrulate teeth, dark green and glabrous above, paler and glaucous beneath and pubescent at least along the veins, $5-9 \mathrm{~cm}$. long, 4-6 cm. wide, petioles $1.5-2 \mathrm{~cm}$. long; staminate catkins 3-4, in short racemes, $6-10 \mathrm{~cm}$. long, in winter purplish-brown; pistillate catkins exposed through the winter, 3-4 together, borne below the staminate, expanding before the leaves, fruiting catkin $1-1.5 \mathrm{~cm}$. long, $6-10 \mathrm{~mm}$. thick, scales woody and 5-toothed, about $4 \mathrm{~mm}$. long; samara orbicular or slightly ovoid, without wings but with thin margins: in c a na, very gray.

In wet soil, usually along shores of lakes or banks of streams, common throughout the northern half of the state and southeastward as far as Minneapolis and St. Paul, infrequent southward to Houston county. From Newfoundland to Saskatchewan, south to N. Y., Pa. and Neb., also in Europe and Asia. Flowers in April and May, fruit ripe in autumn.

\section{Fagaceae Beech Family}

Trees or shrubs, with alternate, simple, often deeply lobed or cleft leaves; flowers small, monoecious; the staminate in pendulous or erect catkins, the pistillate solitary or several together, subtended by an involucre of united bracts, which becomes a lour or cup in fruit ; staminate flowers with 4-7 sepals, stamens 4-20, petals 0, pistillate flowers with 4-8, early disappearing sepals, petals 0, ovary 3-7-celled, inferior, ovules 1-2 in each cavity; fruit a 1 -seeded nut.

Only the following genus occurs in Mimnesota. 


\section{Quercus Lin né I753 Oak}

(L. quercus the oak-tree)

'Trees or sometimes shrubs; leaves deciduous, withering persistent, or, in some species of warm climates, evergreen, alternate, 5-ranked, simple, pinnately veined, variously shaped, often lobed, furnished with small

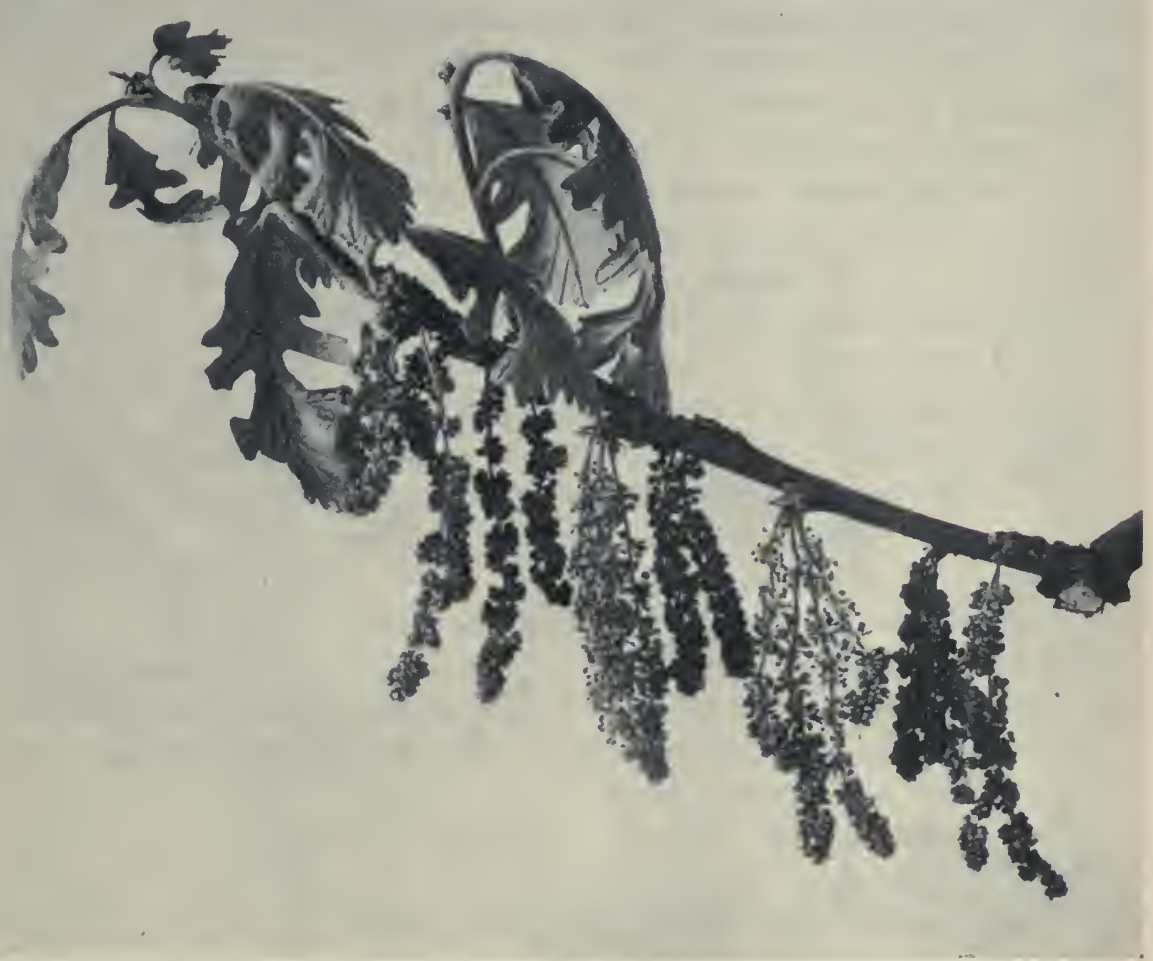

Staminate and pistillate flowers of Quercus macrocarpa

deciduous stipules; buds covered with numerous scales ; flowers monoecious. apetalous, in all our species appearing with the leaves in spring, the staminate in catkins clustered from scaly buds of the past year's growth and also from the lower nodes of the new growth, sepals $4-7$; petals 0 , stamens 4-12, pistil 0 , the pistillate solitary or in small clusters in the axils of the leaves of the new growth, sepals 6 , united, petals 0 , stamens 0 , pistil 3-parted, ovary inferior, nearly 3 -celled, ovules usually 6 , stigmas 3 ; each pistillate flower surrounded by a cup-like involucre of many small concrescent scales, fruit (acorn) a nut surrounded at the base by a cuplike involucre; seed solitary, without endosperm, the large embryo with 
thick elliptical cotyledons which remain within the nut during germination.

A genus of about three hundred species native of the warm parts of the north temperate zone and of the adjacent tropical mountains. About fifty species occur in the United States, twenty-two of which occur in the eastern half of the country. Many oaks are valuable for their hard strong wood, the astringent bark of several species is used in tanning leather and the outer bark of two species from southwestern Europe and northern Africa furnishes the cork of commerce.

In cultivation oaks are raised from seed. After cutting they renew themselves by the growth of shoots from the stumps.

1. Leaves lobed, the lobes acute, bristle pointed, acorn ripening the second autumn-Black Oaks

a. Leaves dull green, their lobes cut about half way to the midrib, acorn cup shallow

Q. rubra

b. Leaves glossy, their lobes separated about three fourths of the way to the midrib, acorn cup about one-half as long as acorn

(1) Scales of cup loose, pubescent

(2) Scales of cup appressed, smooth

Q. velutina

(a) Acorn elongated, autumn foliage brown

(b) Acorn nearly round, autumn foliage scarlet

Q. cllipsoilalis

Q. coccinca

2. Leaves with rounded lobes or crenate or toothed, lobes of teeth not bristle-tipped, acorns ripening the first autumn--White Oaks

a. Leaves deeply round lobed

(1) Leaves dull, smooth, acorn cup not fringed

Q. alba

(2) Leaves glossy above, hairy below, acorn cup fringed

Q. macrocurpa

b. Leaves crenate or dentate, not deeply lobed

(1) Tree, leaves broadly rhombic, acorns long peduncled

(2) Shrub or small tree, leaves more than twice as long as broad, acorn short peduncled

Q. bicolar

Q. prinoides

\section{Quercus rubra L in né 1753 Red Oak}

Large tree, 12-24 m. (40-80 ft.) high, $3 \mathrm{dm} .-1 \mathrm{~m}$. in diameter, (exceptionally in the eastern states, $45 \mathrm{~m}$. high and $2 \mathrm{~m}$. in diameter), trunk 
straight, limbs spreading not gnarled, bark of limbs and small trunks smooth, gray, of large trunks fissured and with broad flat-topped ridges, grayish brown; buds thick, pointed at the top, narrowed at the base, $5 \mathrm{~mm}$. long, $3 \mathrm{~mm}$. wide, smooth except at the top; leaves lobed about half way to the midrib into several broad triangular acute, bristle-pointed lobes, each lobe having usually two or three narrow bristle-tipped teeth near its outer end, leaf widest about the middle, tip acute, bristle pointed, base rounded or broadly wedge-shaped; leaves covered with a light down when

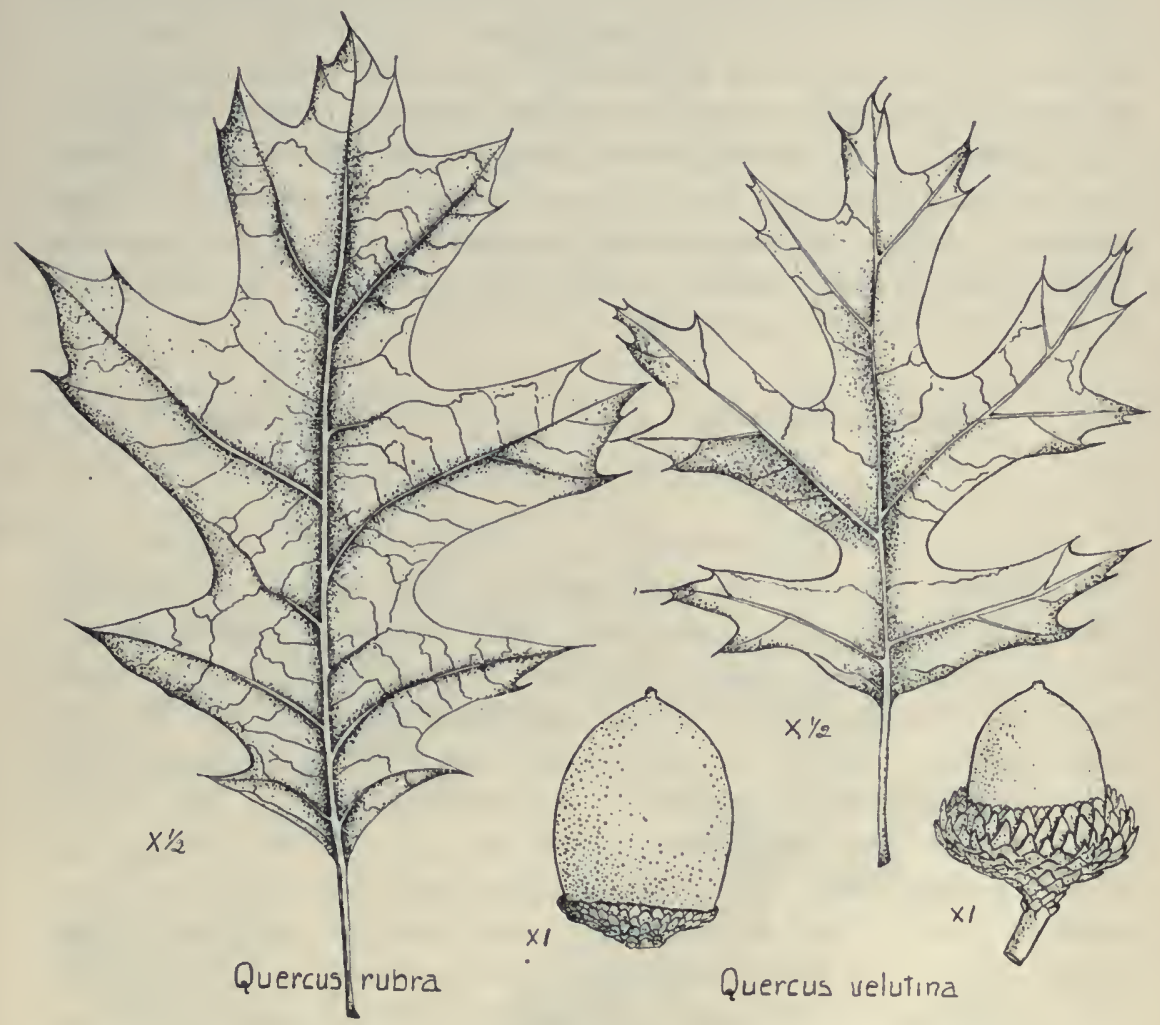

young, smooth at maturity or with small tufts of brownish hairs in the axils of the large veins beneath, dull dark green above, paler beneath, turning red in autumn, $10-18 \mathrm{~cm}$. long, $7-16 \mathrm{~cm}$. wide, petioles $2-4 \mathrm{~cm}$. long; flowers opening when the leaves are about half grown; staminate catkins slender, almost smooth, 4-10 cm. long, flowers scattered, about $3 \mathrm{~mm}$. in diameter; acorns ripening the second year, borne on stalks about $5 \mathrm{~mm}$. long; acorn broad-based, $2-3 \mathrm{~cm}$. long, $1.5-2 \mathrm{~cm}$. wide, dark brown, downy, seed very astringent; acorn cup flat, saucer-shaped, covering 
only the base of the acorn, scales of cup closely appresied and adherent, slightly puberulent: r u b r a, red.

In various well-drained soils, Nova Scotia and Quebec to Minnesota, Nebraska, Tennessee and northern Georgia. In Mimnesota throughout the forest regions even to the extreme northeastern corner of the state, most abundant and largest in the rich soils of the central portion of the state where it occurs with hard maple, white elm and basswood. Flowers in late April and May, acorns ripe a year from the next September.

Wood light reddish brown, hard, strong, coarse, weight 41 lbs., used for construction and finish of houses, cheap furniture and for fuel. On account of its coarse grain and liability to crack in drying the wood of the red and black oaks is much less valuable than that of the white oaks.

Cultivated as an ornamental tree both in this country and Europe. The black and red oaks can be easily transplanted as they have comparatively shallow and fibrous roots. In pastures their shallow roots are often injured by the trampling of cattle which has led to the notion that they do not do well in cultivation.

\section{Quercus velutina $\mathrm{L}$ a marck 1783 Black Oak}

Q. tinctoria Michaux r8or.

Large tree 12-24 m. (40-80 ft.) high, $6 \mathrm{dm}-1.2 \mathrm{~m}$. in diameter (occasionally much larger in the Ohio valley) ; bark dark brown or nearly black, ridged, scaly, inner bark orange; buds rounded or slightly pointed, hairy, in Minnesota specimens 3-5 mm. long, 2-3 mm. wide, in more typical eastern specimens 6-10 mm. long; leaves thick, variable in shape, deeply divided into five or seven lobes, widest about the middle, the lobes again somewhat deeply lobed or merely toothed, all the ultimate divisions very acute and bristle-pointed, tip acute, bristle-pointed, base truncate or very broadly wedge-shaped, leaves dark green and glossy above, paler yellowish or brownish below, crimson when they appear in the spring, silvery and woolly when half grown, smooth, or the lower side more or less hairy when mature, turning brown in the autumn, $8-17 \mathrm{~cm}$. long, $10-15 \mathrm{~cm}$. wide, petiole $3.5-6 \mathrm{~cm}$. long; flowers opening when the leaves are half grown, staminate catkins $8-18 \mathrm{~cm}$. long, hairy, flowers about $+\mathrm{mm}$. in diameter, reddish, pistillate flowers short stalked or nearly sessile; acorns ripening the second season, round, 12-18 mm. long, 11-17 mm. wide, dark lorown, covered with whitish down, cup top-shaped about $2 \mathrm{~cm}$. broad, covering one-third to one-half of the acorn, covered with a fine satiny pubescence, scales loose, thin, their tips free and spreading: velutina, velvety, referring probably to the acorn cups. 
Dry soil, Maine to Minnesota, Nebraska, Mississippi and Florida. In Minnesota very abundant with shell-bark hickory on dry hills in the southeast corner of the State, not known in the vicinity of Minneapolis nor from the central and northern parts of the state.

Wood reddish brown, hard, strong, not tough, coarse, weight 44 lbs.; little used except for fuel. Bark used for tanning, as a yellow dye, and medicinally as an astringent.

\section{Quercus ellipsoidalis E. J. Hill I899 Northern Pin Oak "Black Oak"}

Tree, $10-20 \mathrm{~m}$. (33-65 ft.) high, 3-6 dm. or rarely $1 \mathrm{~m}$. in diameter, or low and almost shrub-like; bark at first smooth, later roughened and divided by shallow fissures into large plates, dark brown or blackish, branches dark gray, inner bark light yellow, buds rounded or pointed, nearly smooth, 1-3 mm. long, .75-1.5 mm. wide; leaves oval in outline;

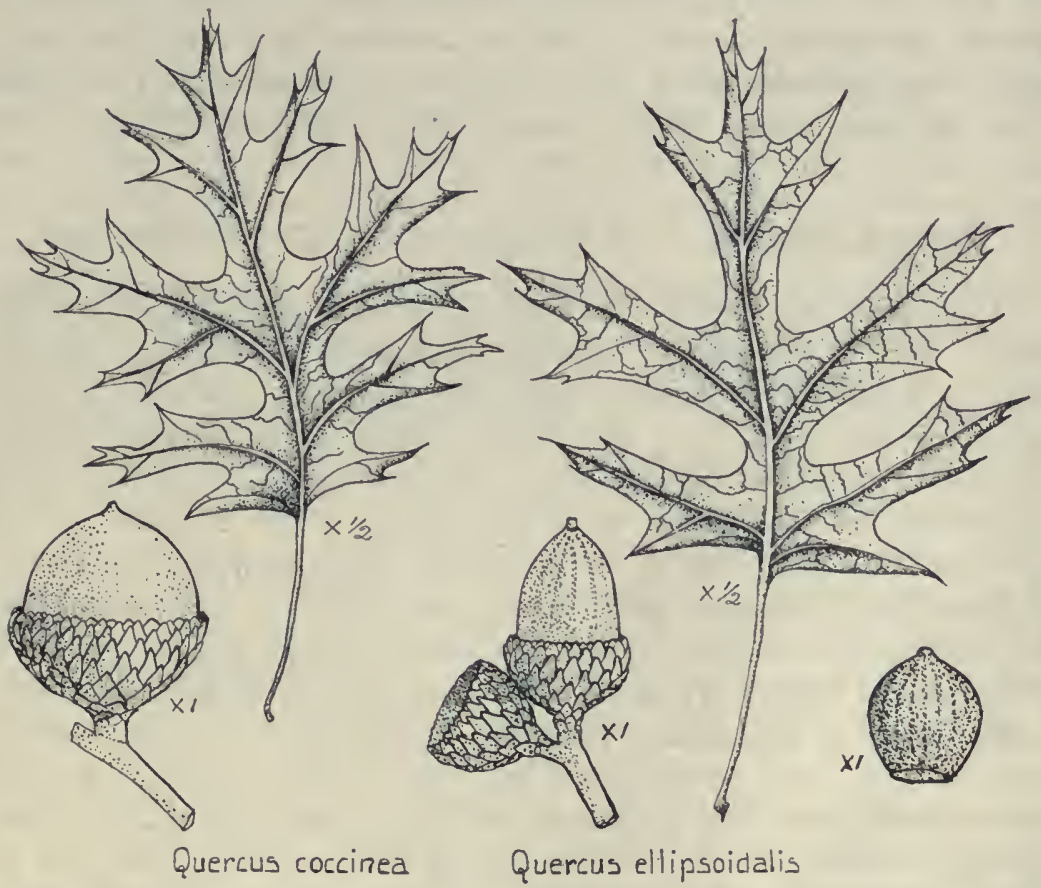

very deeply cut into about five lobes, widest about the middle, the lobes deeply cut or toothed, the ultimate divisions all acute and bristle-tipped, tip of leaf bristle pointed, base broadly wedge-shaped, bright glossy green above, somewhat paler below, downy and reddish when they first appear, 
soon becoming green and smooth except for little tufts of hair in the axils of the larger veins beneath, turning brown in autumn and persisting throughout the winter, 7-14 cm. long, 7-12 cm. wide, petioles $2.5-4 \mathrm{~cm}$. long; flowers appearing with the leaves, opening when they are about half grown; staminate catkins pubescent, 3.5-4.5 cm. long, flowers rather crowded, about $2.5 \mathrm{~mm}$. in diameter, pistillate flowers short peduncled; acorns ripening the second season, solitary or in pairs, borne on peduncles, $1 \mathrm{~cm}$. or less in length; acorn brown, usually striped with darker lines, slightly downy or smooth, 13-20 mm. long, about $10 \mathrm{~mm}$. wide, cup topshaped, narrowed at the base, $13-15 \mathrm{~mm}$. wide, covering one-third to one-half of the acorn, its scales slightly pubescent, closely appressed: e 11 ipsoidalis, ellipsoidal, referring to the shape of the acorns.

Sterile soil, southern Michigan, and Illinois, to Manitoba and Iowa. In Minnesota apparently throughout the whole state except the northeastern corner, but reports have so confused this species with the next that it is difficult to limit its distribution. In the east central part of the state it covers large areas of sterile sandy soil with a copse-like growth. In prairie districts, it appears sometimes as a low shrub 1-3 m. high. The common "black oak" of the region around the Twin Cities.

Wood light brown, strong, coarse, heavy, used only for fuel.

\section{Quercus coccinea M u e $\mathrm{n} \mathrm{h}$ ha u s e $\mathrm{n}$ I770 Scarlet Oak}

Tree 10-20 m. (33-65 ft.) high, 3-6 dm. in diameter, occasionally larger; bark rather smooth, divided by shallow fissures into irregular ridges and plates, dark brown or grayish, inner bark reddish; buds oval, acute, 3-5 mm. long, 1.5-3 $\mathrm{mm}$. wide, slightly hairy towards the top; leaves oval in outline, deeply cut into five or seven lobes, broadest about the middle, the lobes again lobed or toothed, all the ultimate divisions acute and bristle-pointed, tip of leaf acute, bristle-pointed, base truncate or broadly wedge-shaped, bright glossy green above, somewhat paler below, slightly downy when young, but soon becoming smooth except for a few tufts of small hairs in the axils of the large veins beneath, turning bright scarlet in autumn and persisting throughout the winter, $8-12 \mathrm{~cm}$. long, $7-11 \mathrm{~cm}$. wide, petioles $2.5-4 \mathrm{~cm}$. long; flowers appearing with the leaves opening when they are about half grown, staminate catkins slender, smooth or nearly so, about $8 \mathrm{~cm}$. long, flowers scattered, about $2.5 \mathrm{~cm}$. in diameter, pistillate flowers short stalked; acorns ripening the second season, solitary or in pairs, sessile or horne on peduncles $12 \mathrm{~mm}$. long, or less; acorn oval, round, or somewhat elongated, 15-18 mm. long, about $13 \mathrm{~mm}$. wide. light brown, often slightly downy, seed pale yellow, bitter, 
cup top-shaped, narrowed at the base, about $18 \mathrm{~mm}$. wide, covering onethird to one-half the acorn, its scales appressed, slightly puberulent; c o c c in ea, scarlet, referring to the autumn foliage.

Dry sandy soil, Maine to Minnesota, Nebraska, Mllinois and North Carolina. In Minnesota its distribution is uncertain owing to confusion with the previous species, it is known to occur in the southeastern part of the state and in the vicinity of Minneapolis, where however it is not abundant. Flowers in late April and May, fruit ripe a year from the following September.

Easily grown from seed and transplanted. A useful ornamental tree on account of its beautiful autumn foliage.

Wood reddish brown, hard, strong, coarse, weight 42 lbs., used for construction, cheap furniture, etc., little used except for fuel.

\section{Quercus alba Li in né I753 White Oak}

Large tree $15-20 \mathrm{~m}$. (50-65 ft.) high, 1-1.5 $\mathrm{m}$. in diameter, (in the Ohio valley sometimes $30 \mathrm{~m}$. high, and $2-3.5 \mathrm{~m}$. in diameter); bark pale gray, scaly but not deeply cracked; buds ovate, blunt, slightly hairy, about $3 \mathrm{~mm}$. long; leaves crowded towards the ends of the twigs, lobed more than half way to the midrib into about seven nearly regular rounded lobes, tip rounded, base wedge-shaped, when young densely downy, at maturity smooth, upper surface light green, usually dull, lower surface pale, veiny, leaves turning purplish red in autumn, and usually' remaining on the tree all winter, 7-16 cm. long, $3.5-12 \mathrm{~cm}$. wide, petioles $1-2 \mathrm{~cm}$. long; flowers opening when the young leaves are about half grown; staminate catkins $7-8 \mathrm{~cm}$. long, very slender, flowers scattered, about 2.5 $\mathrm{mm}$. in diameter, pistillate flowers in clusters of two or three on a peduncle about $5 \mathrm{~mm}$. long, or nearly sessile; acorns ripening the first season, sessile or on slender peduncles 1-3 cm. long, acorn 22-30 mm. long, 14-20 mm. wide, pale brown, glossy, seed sweet and edible; acorn cup finely downy, one-third to one-fourth as long as the acorn, its scales firm and broad, the lower ones much thickened, the upper thin, not forming a fringe: $\mathrm{l} \mathrm{b}$ a, white, referring to the pale leaves and bark.

Heavy, well-drained, but usually acid soils, Maine to Minnesota, south to Florida and Texas. In Minnesota abundant in the southeastern part and as far north as the Twin Cities, often forming considerable woodlands almost to the exclusion of other trees, northern limit unknown but it appears to be absent from the northern part of the state. Flowers in May, acorns ripe in September.

Grown from seed, the acorns germinate within a few weeks of their 
ripening and produce a long tap-root before, winter. The white oak is very deep-roated and is very difficult to transplant after it reaches any consiclerable size.

Wood light brown, hard, durable, weight $46 \mathrm{lbs}$.; one of our most useful woods for heavy construction, ship building, railway ties, interior finish of houses, furniture, etc., also much used for fuel. The "white oak" lumber of commerce is obtained indiscriminately from this and the two following species; bark astringent, used for tanning and in medicine.

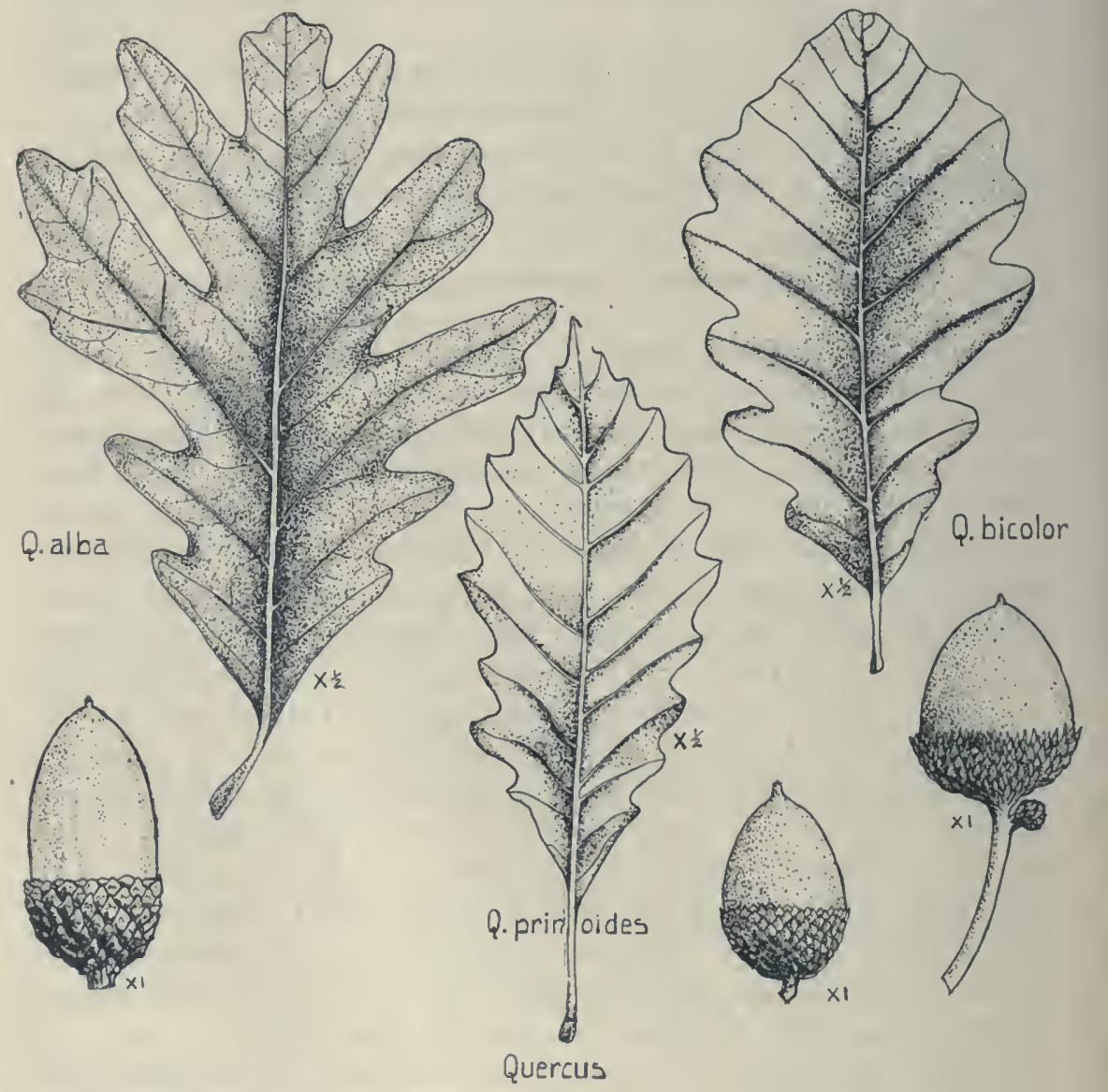

Quercus macrocarpa Mi cha ux I80I Bur Oak

Large tree 10-25 m. (33-82 ft.) high, $3 \mathrm{dm} .-1.5 \mathrm{~m}$. in diameter (in the Ohio valley sometimes twice this size) or under unfavorable situations stunted and sometimes barely $2 \mathrm{~m}$. high, branches very strong and gnarled, 
producing in open grown trees an irregular and widely spreading crown, in dense forest often with a tall straight trunk and short branches; bark dark grayish brown, rough, heavily 'ridged and fissured, the twigs and smaller branches often with prominent corky wings; buds rounded, pubescent, about $2-3 \mathrm{~mm}$. long; leaves crowded at the extremities of the twigs, very variable in shape, irregularly round lobed, usually most deeply lobed about the middle, broadest and much less deeply lobed above the middle, on scme trees very slightly lobed, on others cut almost to the midrib, tip rounded, base wedge-shaped; when young densely woolly, at maturity

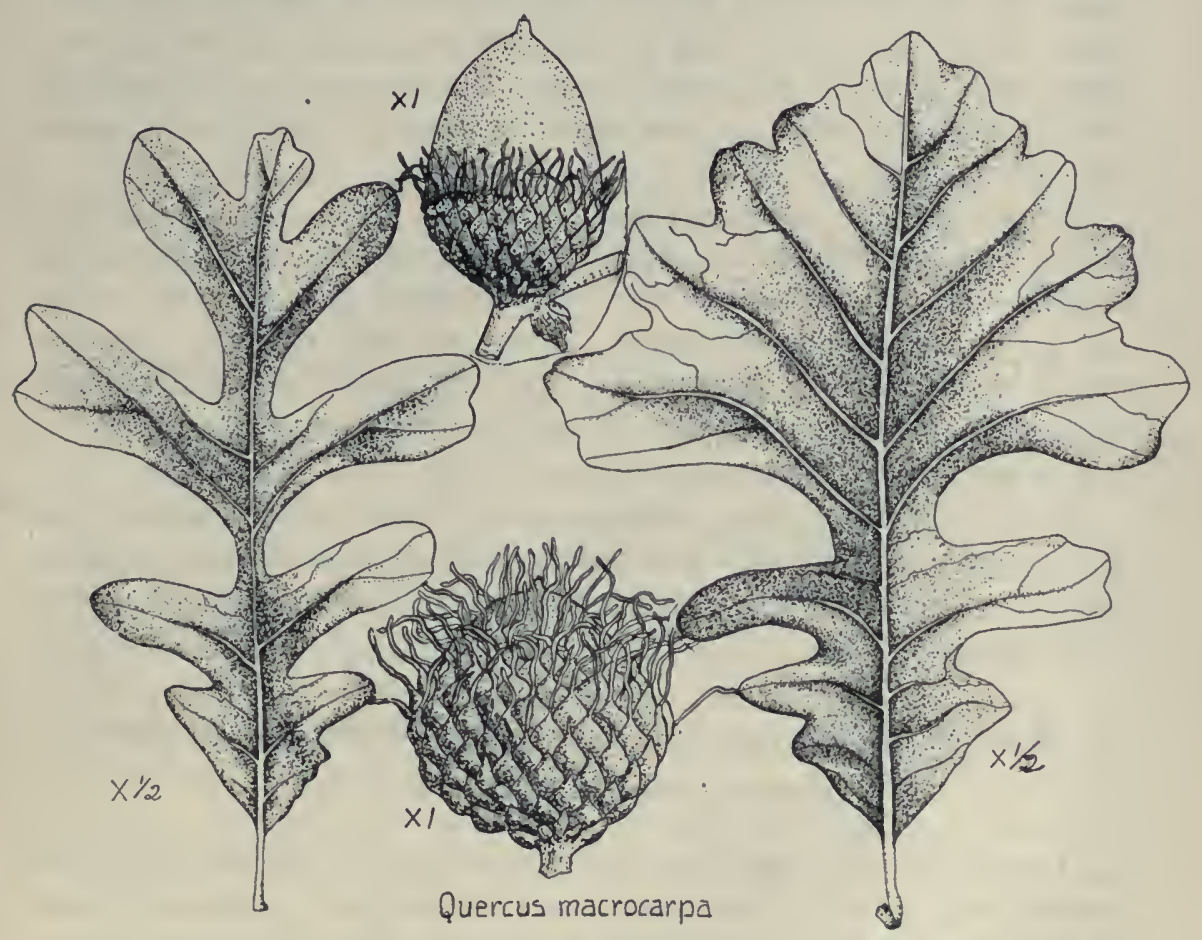

smooth, glossy, dark green above, paler below and pubescent with stellate hairs, turning brown in autumn and promptly deciduous, $7-18 \mathrm{~cm}$. long, 4-12 cm. wide, petioles $5 \mathrm{~mm} .-2 \mathrm{~cm}$. long; flowers appearing with the leaves, opening when the latter are about one-fourth grown, staminate catkins 4-6 cm. long, hairy, flowers about $1.5 \mathrm{~mm}$. in diameter, pistillate flowers usually in pairs, sessile or short peduncled; acorns ripening the first season, sessile or borne on stout peduncles seldom over $1 \mathrm{~cm}$. long in Minnesota specimens, acorn round or oval, 12-25 mm. long, pale brown, slightly downy above, cup deep, sometimes nearly covering the acorn, pubescent, its scales closely appressed, but the upper ones ending in fine 
thread-like ends which form a fringe about the acorn, seed somewhat bitter; a very variable tree both in foliage and in fruit characters, in the southern part of its range occur forms with very large acorns as much as $5 \mathrm{~cm}$. long borne on peduncles over $5 \mathrm{~cm}$. in length: $\mathrm{macrocarpa}$, large fruited, named from some of its forms with very large acorns.

Dry soils, Nova Scotia to Manitoba, south to Tennessee and Texas, west to Montana, western Nebraska and Kansas. Throughout Minnesota except in the extreme northeast corner. In the central part of the state it forms extensive open woodlands on light calcareous soils, it also occurs on the richest and heaviest soils of the state in company with hard maple, white elm, bass wood, and red oak, and much reduced in size; forms small groves in the prairie region. Flowers open in Minnesota in May or late April, about a week earlier than those of white oak, acorns ripe in September.

Grown from the acorns which germinate very freely. Its slow growth during its early years in our climate and the difficulty of transplanting saplings of any considerable size have prevented this tree from being planted to any considerable extent. It was naturally the most abundant tree in the vicinity of Minneapolis, and care should be taken to raise young trees to take the place of the old native specimens when they die, as it is one of our finest ornamental trees.

Wood light brown, hard, very strong and tough, durable, weight 46.5 lbs.; it is somewhat stronger than white oak, has the same uses as the latter and is not distinguished from it commercially. One of our most valuable timber trees.

\section{Quercus bicolor Willdenow I80I Swamp White Oak}

Quercus platinoides Sudworth 1892

Tree 10-20 m. (33-66 ft.) high, $6 \mathrm{dm} .-1 \mathrm{~m}$. in diameter (sometimes considerably larger in New York, Ohio, and other parts of the east) ; bark of trunk grayish brown, ridged and furrowed, bark of twigs ragged, and irregularly peeling; buds rounded, $2 \mathrm{~mm}$. long, nearly smooth; leaves often crowded at the extremities of the twigs, rhombic in outline, broadest a little above the middle, coarsely crenate, dentate, or with shallow somewhat acuie lobes, leaves of exposed branches thick, dark green above. densely white hairy below with short stellate hairs, leaves of lower shaded branches much thinner, pale green on both sides, sparingly pubescent below, leaves turning brown in autumn and deciduous, $7-18 \mathrm{~cm}$. long. $3.5-11.5 \mathrm{~cm}$. wide, petioles $5 \mathrm{~mm} .-1.5 \mathrm{~cm}$. long; flowers opening when the leaves are about one-third grown; staminate catkins about $6 \mathrm{~cm}$. long. 
slender, flowers scattered, about $2.5 \mathrm{~mm}$. in diameter; pistillate flowers in few-flowered long peduncled clusters; acorns ripening the first season, solitary, paired, or in clusters of three, borne on slender peduncles, 3-7 $\mathrm{cm}$. long, acorn 20-30 mm. long, 15-20 mm. wide, light brown, slightly downy above, cup cup-shaped, one-third to one-half as long as the acorn, pubescent, its lower scales thickened, upper ones loose and some of them often with thread-like tips forming a fringe about the acorn, but never so prominently as in bur oak: bic olor, two colored, referring to the dark green and white of the leaves.

Moist soil, Maine to Minnesota, Georgia and Arkansas. In Minnesota it is common in the river bottoms of the extreme southeastern corner of the state and occurs, though rarely, as far north as St. Paul. Reports of this species from north of the Twin Cities are probably erroneous.

Wood light brown, hard, strong and tough, durable, weight 47.5 lbs., with the same uses and properties as white oak and bur oak, this wood is not distinguished from them commercially.

\section{Quercus prinoides Will de now I8J Chinquapin Oak}

Shrub or small tree $2-5 \mathrm{~m}$. (6-16 ft.) high, up to $1 \mathrm{dm}$. in diameter; bark light brown, scaly; buds rounded, slightly hairy, 2-3 mm. long; leaves lanceolate, broadest above the middle, sharply and coarsely toothed; tip acuminate, base wedge-shaped, upper side light green and glossy, with a few scattered stellate hairs, lower side pale, densely hairy, $4-12 \mathrm{~cm}$. long, $2-5 \mathrm{~cm}$. wide, petioles $5 \mathrm{~mm} .-2 \mathrm{~cm}$. long; staminate catkins about $4 \mathrm{~cm}$. long, pistillate flowers sessile or short peduncled; acorns ripening the first season, sessile or borne on peduncles about $1 \mathrm{~cm}$. long, elliptical, 1.5-2 cm. long, $1-1.5 \mathrm{~cm}$. wide, light brown, downy towards the top, cups pubescent, about one-third as long as the acorn, the basal scales thickened and prominent; p rino ides, p r inos, referring to the chestnut leaved oak, Quercus prinos, and id es, like.

Dry limestone ridges, Maine to Nebraska, North Carolina and Texas. In Minnesota it is known to occur only on bluffs in the extreme southeast corner of the state. Specimens in the herbarium of the University have leaves somewhat intermediate in character between this species and Quercus Muhlenbergi i Engelmann (Q. acuminat a Sarge $n t$ ) with 8-10 teeth on each side of the leaf, the lower side of the leaves silvery white, the unripe acorns with peduncles about $1 \mathrm{~cm}$. long. Reports of the presence of Quercus M uhlenbergi in the state appear to be based on this form. More study is needed of the western forms of this species. 
Wood light brown, hard, and heavy, too small to use for anything but fuel.

\section{Myricaceae Bayberry Family}

Shrubs or trees, leaves simple, alternate, generally coriaceous, resindotted and aromatic; flowers monoecious or dioecious, in short scaly catkins, solitary in the axil of the bract, calyx and corolla lacking, staminate flower with 2-16 stamens, filaments short, free or more or less united, anthers 2-celled, pistillate fowers consisting of a solitary 1-celled ovary, subtended by $2-8$ bracts, ovule 1 , style short, stigmas 2, linear; fruit a drupe-like nut.

The family includes the two following genera.

\section{KEX TO THE GENER.}

1. Leaves entire or slightly serrate, without stipules Niyrica

2. Leaves deeply pinnatifid or cut, stipulate Comptonia

\section{Myrica L i n n é 1753}

(Ancient Greek name of a shrub, perlaps from the fragrance.)

Shrubs or small trees, leaves entire, serrate or dentate, mostly resindotted, monoecious or dioecious; staminate catkins oblong or cylindric, stamens 4-8, filaments slightly united below, pistillate catkins ovoid or globular, pistil subtended by 2-4 deciduous or persistent bractlets; fruit small, globular or short-cylindric, dry, coated with resinous granules or wax.

A genus of 34 species of wide geographical distribution, besides the following, 3 occur in the eastern and southern parts of the United States and 2 on the Pacific coast.

\section{Myrica Gale L i n 11 é I753 Sweet Gale}

A branching slırub $0.5-1.5 \mathrm{~m}$. high, branches dark brown, with pale lenticels, young shoots slightly pubescent; leaves oblanceolate, cuneate at the base, obtuse and dentate at the apex, dark green and glabrous above, pale and pubescent or glabrous beneath, mostly resin-dotted on both sides and aromatic, 3-6 cm. long, $8-18 \mathrm{~mm}$. wide, petioles about $2 \mathrm{~mm}$. long; staminate catkins oblong-cylindrical, 10-15 mm. long, loose-bracted, pistillate catkins ovoid-oblong, about $5 \mathrm{~mm}$. long, stigma very prominent; fruiting catkin 7-10 mm. long, drupe resinous-waxy, inclosed by 2 thick, persistent bractlets, $2-3 \mathrm{~mm}$. long: G a le, an aromatic plant.

In swamps and along lakes and streams, along the International 
Boundary and the north shore of Lake Superior, south to Carleton county. Distributed from Labrador to New England and along the Great Lakes to Minn., south in the mountains to Va., also in Europe and Asia. Flowers in May and June, fruit ripe in August.

\section{Comptonia B a n k s rjgr}

\section{(Named for Bishop Compton of Oxford)}

A low branching shrub; leaves narrowed, deeply pinnatifid, with stipules, young foliage pubescent ; flowers in catkins, monoecious or dioecious, staminate catkins cylindric, stamens 4-8 in the axils of the bracts; pistillate catkins oroid or globose, borne below the staminate catkins in

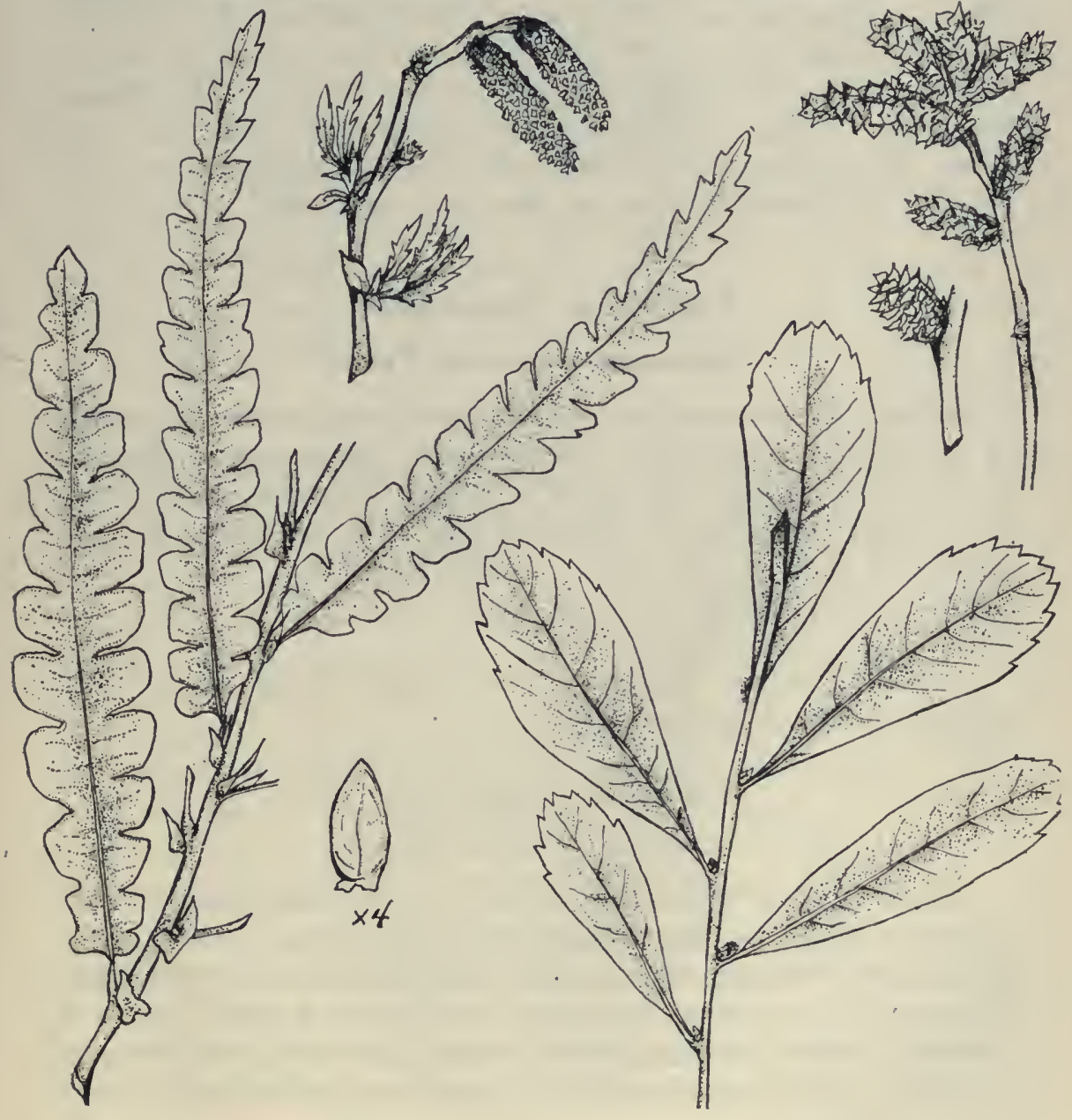

Comptonia peregrina

Myrica Gale 
monoecious plants, pistil subtended by $S$ persistent, narrow bracts which form a bristly involucre in the ripe fruit; fruit a bony oblong nut.

A monotypic genus of eastern North America.

\section{Comptonia peregrina (Linné) C o $u 1$ t e r 1894}

Myrica asplenifolia Linné I753

A shrub 3-6 dm. high; leaves linear-lanceolate, pinnatifid and fernlike, sweet-scented, acute or rounded at the apex, lobes rounded or pointed, entire or acute, sparingly pubescent, 6-12 cm. long, 10-15 mm. wide, petioles about $5 \mathrm{~mm}$. long, stipules half-cordate, usually deciduous; staminate catkins clustered at the ends of branches, $3-4 \mathrm{~cm}$. long; pistillate catkins becoming bur-like in fruit, about $1 \mathrm{~cm}$. in diameter: p e r e g r i $\mathrm{n} \mathrm{a}$, wandering. In dry, sandy soil, frequent northeastward, occuring scattered farther south to Pine county and southwest to Cass Lake. Also reported from near Excelsior, Hennepin County, but it is doubtful if it occurs there. From Nova Scotia to Manitoba, south to North Carolina, Ind. and Mich. Blossoms in April and May, fruits in autumn.

\section{Umbellales Carrot Order}

\section{Cornaceae Dogwood Family}

Shrubs or small trees, rarely herbs; leaves simple, opposite, verticillate or alternate, usually entire; flowers perfect, polygamous or dioecious, in cymes or heads, calyx 4-5 parted or toothed, adnate to the top of the ovary, petals 4-5, valvate or imbricated, inserted at the edge of the disk, stamens as many as the petals, and alternating with them, or more numerous, ovary inferior, 1-2 celled, style 1 , ovule 1 in each cell; fruit a 1-2 celled, 1-2 seeded drupe.

Only two genera of the family occur in North America, one of which is represented in the Mimnesota flora.

\section{Cornus Li n 11 é 1753}

(L. Cornus, cornel, perhaps from c or n u, horn)

Shrubs or trees (occasionally herbs); leaves simple, mostly entire, opposite, verticillate or sometimes alternate; flowers small, white or greenish, in cymes or heads, (when in heads subtended by large, white, petallike bracts in our species), calyx-tube campanulate, 4-toothed, petals 4, spreading, stamens 4, ovary 2-celled, 1 ovule in each cell, stigma truncate or capitate; fruit an ovoid or globular drupe, stone 2-celled and 2 -seeded. 
$\Lambda$ genus of about 25 species, natives of the North Temperate zone, Mexico and Peru. In addition to the following 11 others occur in North America.

\section{Key to the Species}

1. Leaves opposite

a. Fruit light blue, leaves downy pubescent beneath at least when young

(1) Twigs green, leaves broadly ovate or orbicular,

C. circinata

(2) Young twigs silky-downy, leaves ovate or elliptical

C. Amomum

b. Fruit white, leaves glabrous or pubescent

(1) Twigs gray, leaves ovate-lanceolate

(2) Branches bright red, purple or brownish

C. paniculata

(a) Branches brownish, spreading-pubescent leaves spreading-pubescent beneath

(b) Branches bright red-purple, smooth, minute-pubescent on both sides

C. Baileyi

C. stolonifera

2. Leaves alternate, clustered at the ends of the flowering shoots

C. alternifolia

\section{Cornus circinata L'H e ritier I738 Round-leaved Dogwood}

A shrub 1-3 m. high, branches green, warty-dotted; leaves broadly ovate or orbicular, rounded at the base, abruptly pointed at the apex, with scattered pubescence above, paler and woolly-pubescent beneath, $8-14 \mathrm{~cm}$. long, 6-13 cm. wide, petioles $1.5-2 \mathrm{~cm}$. long; flowers in many-flowered cymes, white, 5-7 mm. broad, petals oblong, pedicels pubescent; fruit globose, liglit blue, about $5 \mathrm{~mm}$. in diameter, stone subglobose, slightly ridged: $\mathrm{c}$ i $\mathrm{r}$ c in a $\mathrm{t}$ a, rolled into a coil.

In sandy or rocky soil, in woods and thickets, frequent and occasionally common throughout the state. From Nova Scotia to Manitoba, south to Va., I1l. and Ia. Flowers in June, fruit ripe in August.

\section{Co:nus Amomum Mi11er 1768 Silky Cornel Kinnikinnik}

A shrub 1-3 m. high, twigs brownish or purplish, the younger ones silky-downy; leaves ovate, oval or ovate-lanceolate, narrowed or rounded at the base, acuminate at the apex, glabrous or thinly appressed-pubescent above, finely pubescent, usually with brownish hairs beneath, $4-8 \mathrm{~cm}$. long, 2.5-4.5 cm. wide; flowers in flat, many-flowered cymes, white, $8-9 \mathrm{~mm}$. 

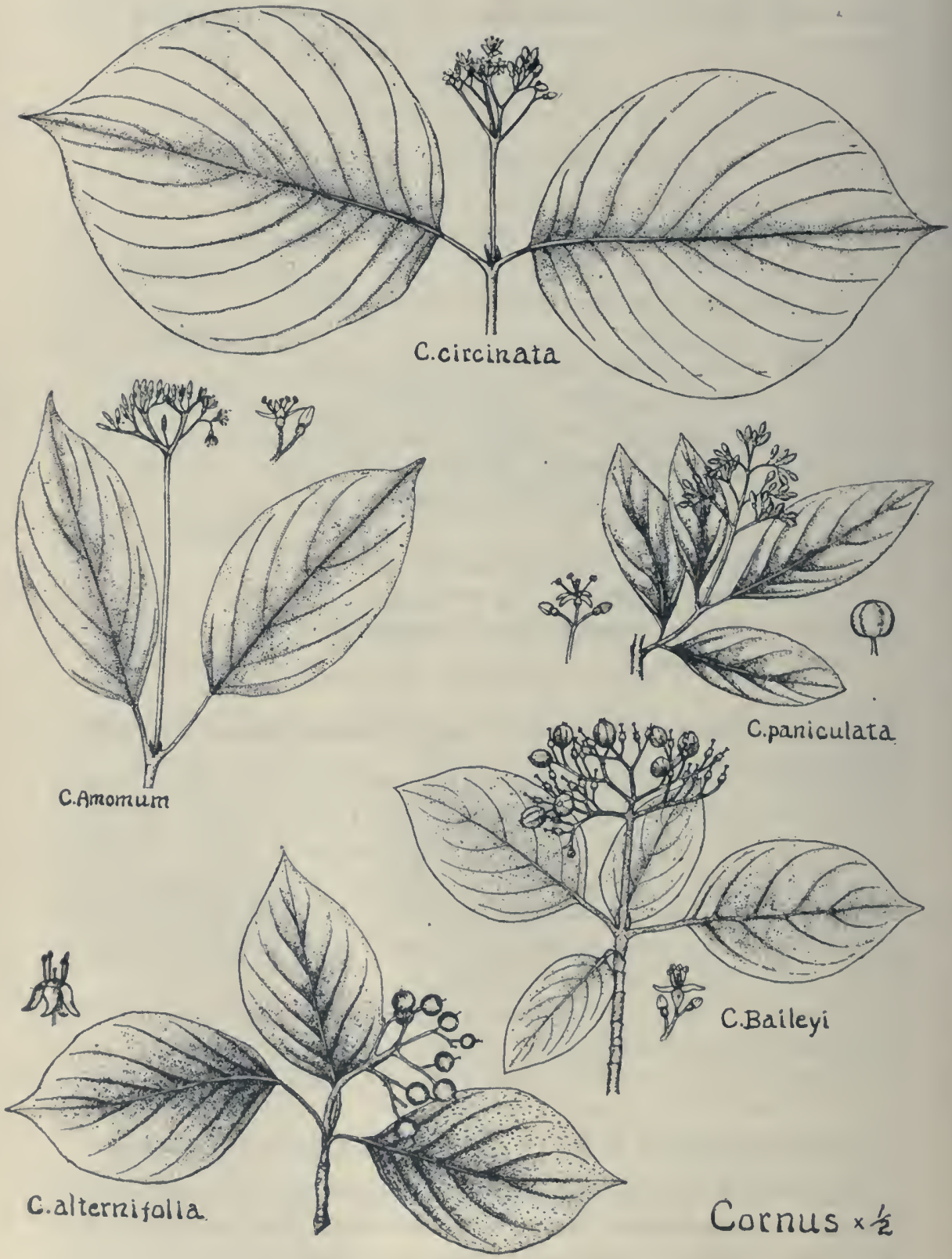
broad, pedicels and ovaries pubescent, styles $2-3 \mathrm{~mm}$. long, stigma capitate or club-shaped; fruit globose, light blue, 6-7 mm. in diameter, stones somewhat irregular or oblique in shape, slightly ridged and narrowed at the base: A momum, an aromatic shrub.

In low rich woods and along streams, frequent throughout the state, except far northward. From Newfoundland to North Dakota, south to Fla. and La. Blossoms in June, fruit ripe in August.

The inner bark is used by the Indians, under the name of Kinnikinnik, to mix with their tobacco for smoking.

\section{Cornus paniculata L'H e ritie r I788 Dogwood}

A shrub 2-5 $\mathrm{m}$. high, bark gray and smooth, young twigs mostly glabrous; leaves lanceolate or ovate-lanceolate, narrowed at the base, long-acuminate at the apex, light green above, much paler beneath, with scattered appressed-pubescence on both sides, $4-10 \mathrm{~cm}$. long, $1.5-4 \mathrm{~cm}$. wide, petioles about $1 \mathrm{~cm}$. long, cymes paniculate, loosely flowered, flowers white, petals lance-oblong, 2-3 mm. long, calyx-tube with appressed white pubescence; fruit white, globose or nearly so, about $6 \mathrm{~mm}$. in diameter, stone subglobose, thicker than long, ridged: $\mathrm{p}$ a n ic u l a t a, panicled.

In rich soil, thickets, woods, etc. Common throughout the south half of the state and in the Valley of the Red River. In the Big Woods it is the most abundant species; not reported from the northeastern part of the state. From Me. to Minn. and Ontario, south to North Carolina and Nebraska. Flowers in June, fruit ripe in August and September.

\section{Cornus Baileyi Coulter and Evans 1890 Bailey's Dogwood}

A shrub 1-4 m. high, branches brown or reddish-brown, covered with spreading pubescence; leaves ovate to ovate-lanceolate, rounded or narrowed at the base, acuminate at the apex, appressed pubescent above, spreading or woolly-pubescent beneath, $3-8 \mathrm{~cm}$. long, $1.5-3.5 \mathrm{~cm}$. wide; cymes rather dense, the branches and pedicels pubescent; flowers white, 6-7 mm. broad, petals lanceolate; fruit white, subglobose, about $6 \mathrm{~mm}$. in diameter, stone flattened and slightly oblique, considerably broader than long: $\mathrm{B}$ a i l e y i, named for L: H. Bailey.

Along the sandy shores of lakes and in moist ground, common in the northern part of the state. Distributed from Pa. to Saskatchewan, south to Wyo. and Neb.

This species resembles the following somewhat closely and has generally been confused with it. It differs in the pubescent twigs and more woolly pubescent leaves. Blossoms in June, fruit ripe in Aug. and Sept. 
Cornus stolonifera $\mathrm{M}$ ich a $\mathrm{ux}_{\mathrm{x}} \mathrm{I} 8 \mathrm{O} 3$ Red-osier Dogwood Kinnikinnik

A shrub 1-4 m. high, generally stoloniferous, branches smooth, bright reddish-purple, young shoots mostly finely appressed-pubescent, leaves oval, ovate, or ovate-lanceolate, rounded or sometimes narrowed at the base, acute or abruptly pointed at the apex, bright green and thinly appressed-pubescent above, whitish and sparingly pubescent beneath or some-

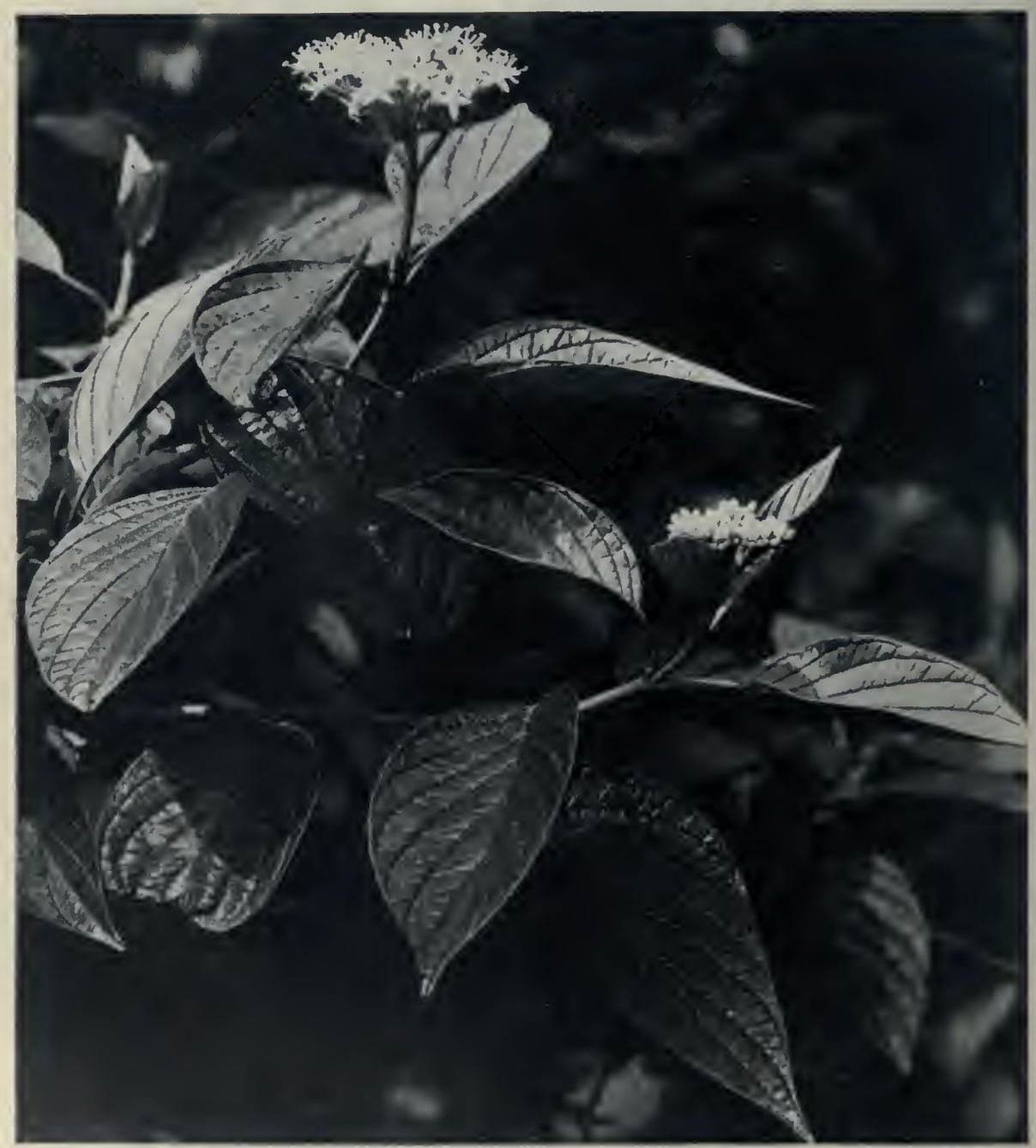

Cornus stolonifera 
times glabrous throughout, 4-10 cm. long, 2.5-5.5 cm. wide, petioles slender, 18-25 mm. long; cymes flat-topped, $3-5 \mathrm{~cm}$. broad, flowers white, 5-6 $\mathrm{mm}$. broad, petals ovate-lanceolate, calyx and pedicels with thin, appressed pubescence, styles about $1.5 \mathrm{~mm}$. long; fruit white or whitish, globose, 6-8 mm. in diameter: st o l o $\mathrm{n}$ if e r a, bearing stolons.

In moist or wet places, abundant throughout the north half of the state and common southward to Winona, Blue Earth, Mower and Houston Counties. Distributed from New Brunswick to British Columbia south to the District of Columbia, the Great Lakes region, Iowa, Neb. and New Mexico. Begins blossoming in June and continues through July and Aug., fruit ripens July-Sept.

\section{Cornus alternifolia Linné fili us I78I Dogwood}

A shrub or small tree, 2-6 m. high, bark smooth, dark or brownish on the main stem, branches greenish, streaked with white, leaves alternate, usually clustered at the ends of branches, oval or ovate, narrowed or sometimes rounded at the base, acuminate or abruptly pointed at the apex, glabrous and with the veins distinctly marked on the upper side, whitish and thinly pubescent beneath, $5-10 \mathrm{~cm}$. long, 3-6 cm. wide, petioles slender, 1-2 cm. long; cymes rather loose-flowered, 4-6 cm. broad, flowers white, petals oblong, reflexed, $3 \mathrm{~mm}$. long, calyx finely appressedpubescent; fruit globose, deep blue, on reddish pedicels, about $8 \mathrm{~mm}$. in diameter, stones slightly flattened and channeled: a I t e r $\mathrm{n}$ if olia, with alternate leaves.

In rich soil, in woods, copses, etc., frequent and occasionally common throughout the state, except far northward. Distributed from eastern Quebec to western Ontario, Minn. and Ia., south to Georgia and Alabama. Blossoms in May and June, fruit ripe in August and September.

\section{Rubiales Madder Order \\ Rubiaceae Madder Family}

Herbs, shrubs or trees, leaves simple, opposite, or verticillate, mostly with stipules; flowers perfect but often dimorphous, regular, calyx-tube adherent to the ovary, its limb variously lobed, corolla sympetalous, campanulate, funnel-shaped or rotate, 4-5-lobed, frequently hairy within, stamens 4-5, borne on the corolla alternate with its lobes, ovary 1-10celled, inferior, ovules 1-several in each cavity of the ovary; style short or elongated; fruit a capsule, a berry or a drupe. 
A very large family of plants, the greater number of species of which are found in tropical regions. Only one genus of woody plants of this family occurs within the state.

\section{Cephalanthus L in né 1753}

(Gr. ke phale, head, a n thos, a flower)

Shrubs or small trees, leaves opposite or verticillate, short-petioled and entire; flowers in axillary or terminal heads, small, white or yellow, subtended by bracts, calyx-tube short, its limb 4-lobed, corolla tubular, with 4 slightly spreading lobes, stamens 4 , inserted on the corolla-tube.

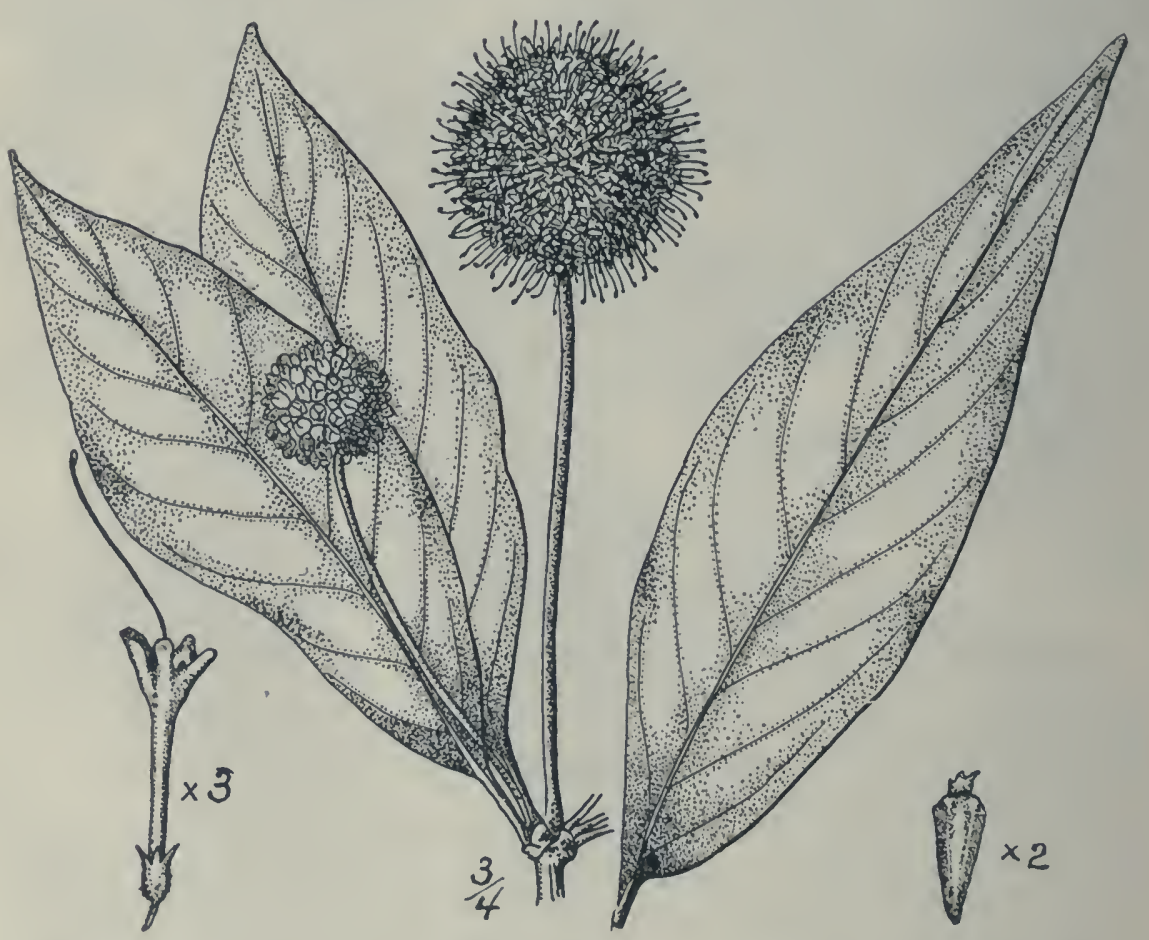

with very short filaments, ovary 2-celled, 1-2 ovules in each cavity, style slender, long-exserted, stigma capitate; fruit splitting into $2-4$ achene-like parts.

A genus of 6 species, natives of North America and Asia. The following species is the only one occurring in the U. S. 


\section{Cephalanthus occidentalis L i n né I753 Buttonbush}

A shrub, 1-3 m. high; branches glabrous; leaves opposite or verticillate, entire, petioled, ovate or oblong-lanceolate, mostly narrowed at the base, acuminate at the apex, glabrous above, glabrous or very sparingly pubescent beneath, $7-14 \mathrm{~cm}$. long, 4- $6 \mathrm{~cm}$. wide; petioles $1-2 \mathrm{~cm}$. long; peduncles axillary and terminal, 6-10 cm. long, heads globose, $2-4 \mathrm{~cm}$. in diameter, flowers white, sessile and closely crowded, 8-12 mm. long: styles slender, about twice as long as the corolla, calyx-tube surmounting the ovary, persistent ; fruit narrowly-obconic, 5-6 mm. long: o c c id e n$\mathrm{t}$ a 1 is, western.

In swamps and low grounds, infrequent in the southeastern part of the state, reported as far north as Taylors Falls. Distributed from New Brunswick to western Ontario and California, south to Fla., Tex. and Ariz. Blossoms in June, fruit ripe in September.

\section{Caprifoliaceae Honeysuckle Family}

Shrubs, trees or vines, or perennial herbs; leaves opposite, simple or pinnately compound f flowers perfect, regular or irregular, cymose, calyxtube adherent to the ovary, 2-5-toothed or lobed at the top, petals united into a sympetalous, tubular, campanulate, or rotate corolla, 5-lobed above, frequently with a sack-like enlargement at the base; stamens 5 (rarely 4), borne on the tube of the corolla and alternating with the lobes, anthers oblong or narrow and elongated, filaments inserted on the corolla, ovary inferior, 2-5-celled, style slender, stigma enlarged or capitate, 2-5-lobed, ovules 1-several in each cell, fruit a 1-several-seeded berry, drupe or capsule, seeds oblong or globose, with small embryo, and fleshy endosperm.

\section{KEY TO THE GENERA}

1. Leaves compound, flowers small, white, in compound cymes

Sambucus

2. Leaves simple

a. Flowers in compound cymes, corolla rotate, small; fruit a 1-seeded drupe

Viburnum

b. Flowers in pairs, or few-flowered racemes or cymes, corolla campanulate or tubular. fruit a berry or a capsule

(1) Fruit a few-seeded berry

(a) Corolla short-campanulate, regular: margin of leaves entire 
(b) Corolla tubular or long-campanulate, more or less irregular

(2) Fruit a 2-celled capsule, leaves serrate

\section{Diervilla}

\section{Sambucus L in né I753 Elder}

(Classical name of the elderberry)

Shrubs, trees or perennial herbs; leaves opposite, pinnately compound, leaflets serrate, or sometimes laciniately cut or dissected; flowers small, white, very numerous in compound cymes, calyx-lobes or teeth 3-5, minute or almost laching, corolla 3-5 lobed, regular, rotate, stamens 5, attached to the base of the corolla, filaments short, ovary 3-5-celled, one ovule in each cavity, style short, 3-lobed; fruit a berry-like drupe, containing 3-5 1 -seeded stones.

$A$ genus of about 20 species, of wide geographical distribution, 3 other species besides the following occur in the western part of North America.

\section{Key to the Species}

1. Stems woody, pith brown, fruit bright red

S. racemosa

2. Stems hardly woody, pith white, fruit black-purple

S. canadensis

\section{Sambucus racemosa Lin n é I753 Red-berried Elder} Sambucus pubens Michaux 1803

A shrub, 1.4 m. high, bark gray and warty, young shoots commonly. pubescent, with large brown pith; leaflets 5-7, ovate to ovate-lanccolate, narrowed and mostly unequal at the base, sessile or short-stalked, longacuminate at the apex, sharply serrate, finely pubescent beneath, $4-13 \mathrm{~cm}$. long, $2-4 \mathrm{~cm}$. wide, occasionally much larger; flowers in a pyramidal cluster of compound cymes, white, turning brown in drying, 3-4 mm. broad, petals reflexed, stamens very short; fruit a bright red drupe, 4-5 $\mathrm{mm}$. in diameter : $\mathrm{r}$ a c e $\mathrm{mos}$ a, with racemes, not particularly appropriate.

On rocky banks, in ravines, woods, etc., common throughout the state. Distributed from New Brunswick to British Columbia, south to Ga., Colo., and Calif. Blossoms in April and May, fruit ripe in June and July.

Var. la c in iat a Koch, a cut-leaved form of this species, is commonly cultivated, and occasionally spontaneous. S a mbucus nigra var. la ciniat a (Miller) DeCandolle, the corresponding form of a similar European species, is occasionally cultivated. 
Sambucus canadensis Li n né 1753 Common Elder

A shrub, 1-3 m. high, stems scarcely woody, young twigs with large white pith; leaflets 5-11, mostly 7 , ovate to ovate-oblong or lanceolate, rounded and slightly unequal at the base, sessile or nearly so, long-

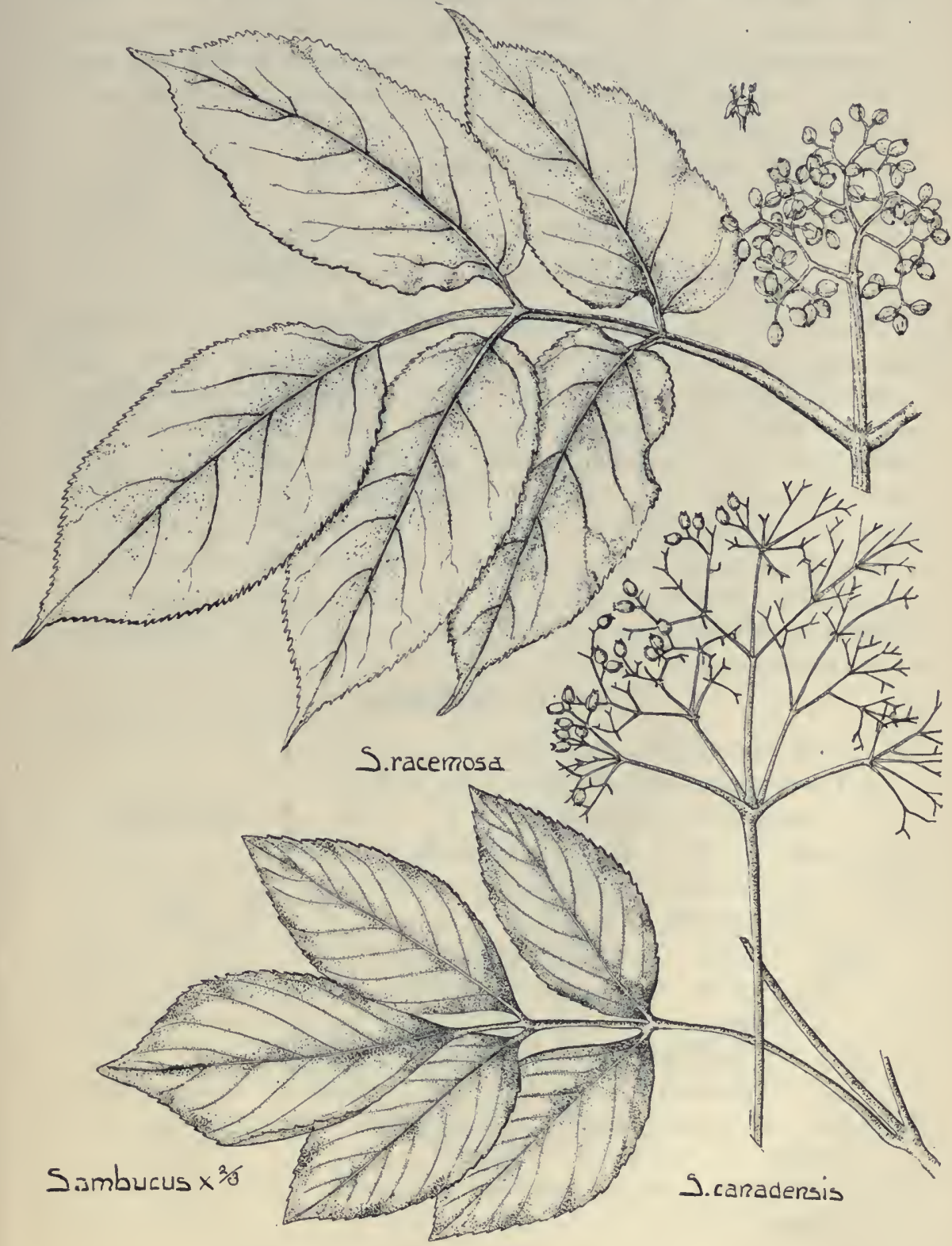


acuminate at the apex, sharply serrate, glabrous above, sometimes slightly pubescent on the veins beneath, 7-15 cm. long, 3-6 cm. wide; inflorescence very ample, 10-20 cm. broad, 6-10 cm. high; flowers white, 5-6 mm. broad; fruit a dark purple to black drupe, 5-6 $\mathrm{mm}$. in diameter, edible, stones roughened: c a n a d e n s is, Canadian.

In moist or rich soil, common throughout the south half of the state, rare northwestward. New Brunswick and Nova Scotia to Manitoba, south to Fla., 'Tex. and Ariz. Blossoms in late June and July, fruit ripe in August and September.

$\Lambda$ cut-leaf form is occasionally cultivated.

\section{Viburnum L in né 1753}

(Classical name of the wayfaring tree)

Shrubs or trees; leaves entire, serrate, dentate, or lobed, stipules sometimes present, leaf buds naked or with a pair of scales; flowers white, or rarely pink, numerous, in flat, compound cymes, sometimes the marginal flowers of the cyme larger and sterile, calyx ovoid or turbinate, 5-toothed, corolla rotate or spreading, regular, 5-lobed, stamens 5, borne on the tube of the corolla, ovary inferior, 1-3-celled, ovule 1 in each cavity of the ovary, style short, 3-lobed or 3-cleft; fruit a 1-celled, 1-seeded, ovoid or globose drupe, stone somewhat flattened and ridged, seed compressed.

A genus of about 100 species, of wide geographical distribution. In addition to the following about 15 other species occur in different parts of North America.

\section{Key to the Species}

1. Leaves 3-lobed, palmately veined

a. I'lowers all perfect and alike, lobes of leaves shallow, not coarsely dentate

V. paticiforum

b. Some or all of the flowers sterile, leaves more deeply 3-lobed, coarsely and irregularly dentate

(1) Marginal flowers large and sterile, central ones perfect, clusters flattopped, native

$V$. americanum

(2) All the flowers sterile, clusters spherical, cultivated

2. Leaves not lobed, pinnately veined, dentate or serrate

a. Leaves finely serrate, veins not very prominent 
(1) Leaves and inflorescence densely pubescent, winter buds naked, cultivated $\quad V$. Lantana

(2) Leaves and inflorescence glabrous, winter buds scaly

V. Lentago

b. Leaves coarsely dentate, veins prominent $\quad V$. pubescens

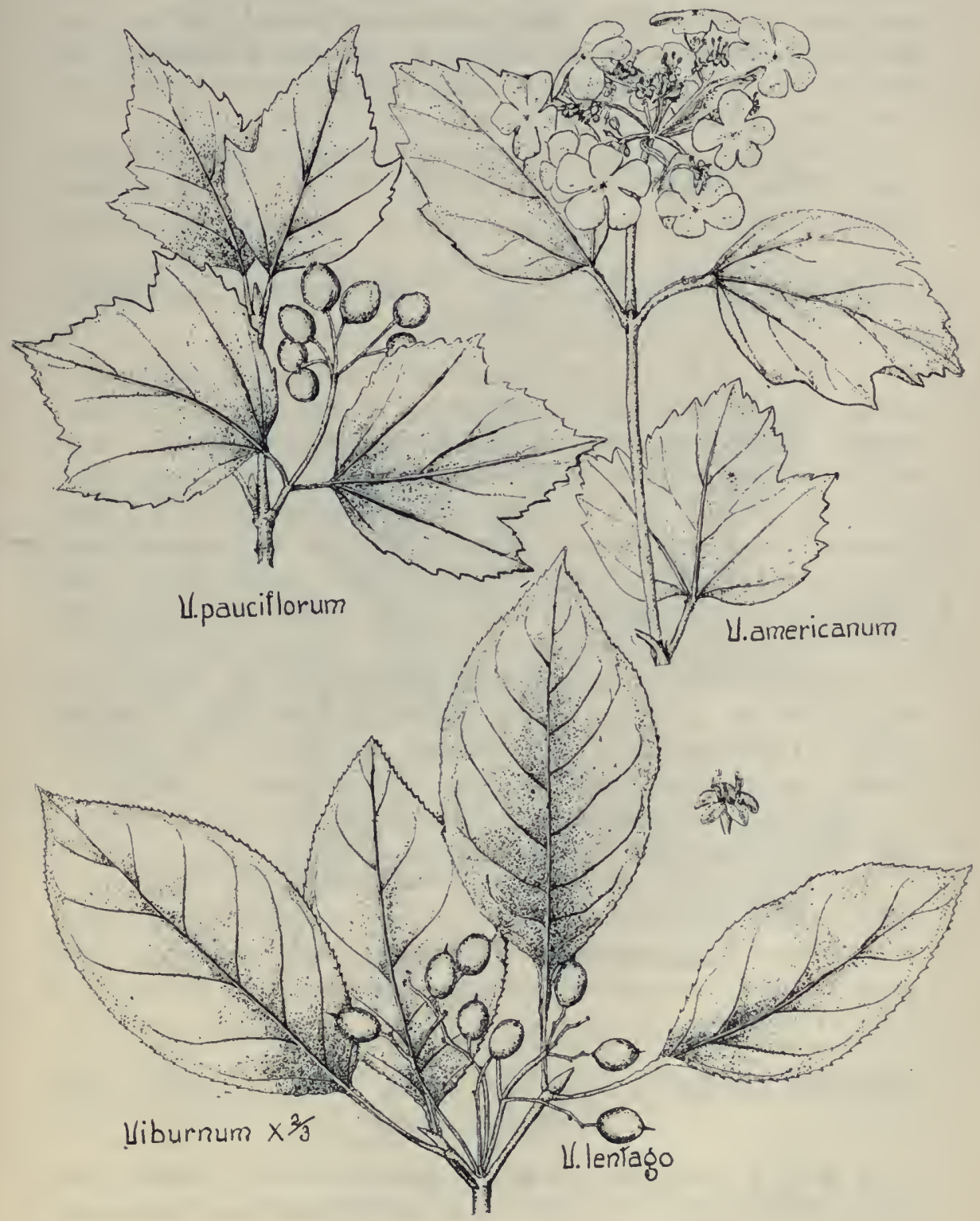




\section{Viburnum pauciflorum $R$ a fin esque 1838 Squashberry}

A low straggling shrub, 0.7-2 m. high, bark grayish, young shoots reddish brown and ridged; leaves broadly oval or obovate, narrowed, truncate or cordate at the base, mostly with three shallow lobes, dentate, glabrous above, more or less pubescent on the veins beneath, $5-9 \mathrm{~cm}$. long, 4.5-9.5 cm. wide, petioles $1-2 \mathrm{~cm}$. long; cymes few flowered, $3-4 \mathrm{~cm}$. long, about $2 \mathrm{~cm}$. broad, flowers all perfect, 5-6 mm. broad, stamens shorter than the corolla; drupe globose to ovoid, light red, acid, 8-10 mm. long, stone ovate, pointed: p a c if 1 o r um, few flowered.

In cold woods north of Lake Superior. Distributed from Newfoundland to Alaska, south to Maine, N. H., Vt., Pa. and in the Rocky mountains to Colorado. Blossoms in June, fruit ripe in August and September.

\section{Viburnum americanum Miller i768 Highbush Cranberry Pembina}

A shrub, 1-3 m. high, branches nearly erect, smooth and grayish; leaves deeply 3-lobed, cuneate or rounded at the base, lobes taper-pointed, coarsely and irregularly dentate or sometimes almost entire, glabrous above, with a few scattered hairs along the veins beneath, 5-13 cm. long, 4.5-12 $\mathrm{cm}$. broad, petioles $1.5-3 \mathrm{~cm}$. long with 1-3 glands below the blade, cymes flat-topped, $5-10 \mathrm{~cm}$. in diameter, the outer flowers large and sterile, 1-2 cm. broad, the fertile ones very small, 2-3. mm. broad; fruit an ovoid drupe, about $1 \mathrm{~cm}$. long, stone round, flattened: a m er i c a n u m, American.

In swamps and low ground, common throughout the northern half of the state and in the Big Woods, less frequent southward to Houston county. Distributed from Newfoundland and Quebec to British Columbia, south to New Jersey, Pa., Mich. and northeastern Iowa.

This species seems sufficiently distinct from the European V. o p u l us with which it has usually been identified.

The fruit is used for making sauce and preserves, "Pembina, borns first by a river, and then given to the town and county is stated by Keating to be from the Chippewa word for this fruit, a n e p e mbin a n, which name has been shortened and corrupted into Pembinz" (Narrative of Long's Expedition).

Viburnum Opulus Linné var. sterilis De Candolle 1830

\section{Guelder Rose}

$\Lambda$ shrub 2-3 m. high, with smooth grayish branches; leaves broadly ovate, 3 -lobed, lobes shorter than in the preceding species, coarsely and 
irregularly serrate, truncate or slightly cordate at the base, with scattered hairs above, pubescent beneath 'when young, $3.5-10 \mathrm{~cm}$. long, 4-11 cm. wide, petioles $2-3 \mathrm{~cm}$. long, with several glands below the blade; flowers all sterile, in dense globose clusters $5-10 \mathrm{~cm}$. in diameter, at first greenish, later becoming white: O p u l u s, Latin name of a tree, ste rilis, sterile.

Extensively planted as an ornamental shrub, perfectly hardy; the leaves are likely to be badly infested with aphis causing them to curl and shrivel very badly. Blossoms in June.

\section{Viburnum Lantana L in n é 1753 Wayfaring Tree}

A shrub or sometimes a small tree, 1-3 m. high, branches brown, young shoots ashy pubescent, winter buds naked; leaves ovate to ovateoblong, mostly cordate at the base, blunt or acutish at the apex, finely and sharply serrate, densely stellate pubescent on both sides, petioles

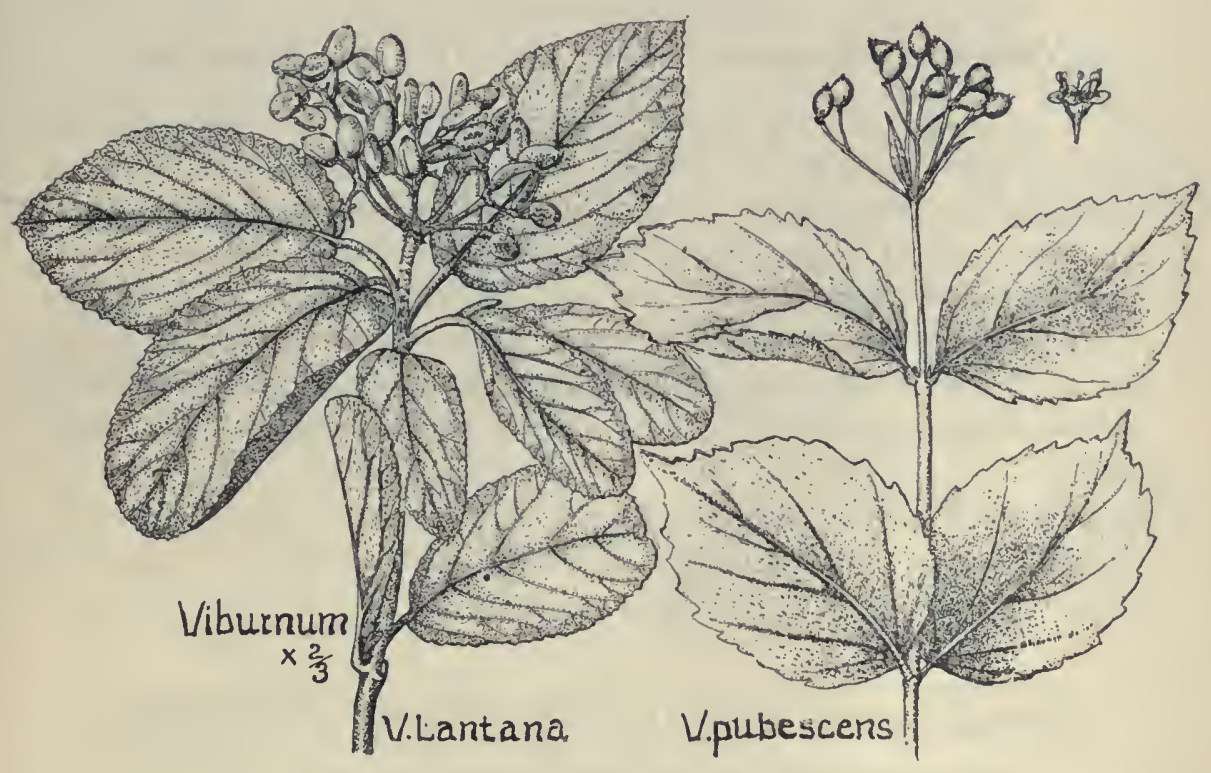

1-2 cm. long pubescent; cymes short-peduncled, the whole cluster about 6-8 $\mathrm{cm}$. broad, flowers all perfect and alike, 7-10 mm. broad, stamens 6-7 $\mathrm{mm}$. long; fruit oblong-ovoid, flattened, about $1 \mathrm{~cm}$. long; L a n t a n a, a genus name of mythological origin.

Frequently cultivated and perfectly hardy. Introduced from Eurasia. Blossoms in May, fruit ripe in August. 


\section{Viburnum Lentago L in n é I753 Black Haw}

A tall shrub or sometimes a small tree, 3-6 m. high, bark smooth and gray or brownish, winter buds scaly, acuminate, young shoots glabrous; leaves oval or ovate, rounded at the base, acuminate at the apex, finely and sharply serrate, glabrous on both sides or sometimes slightly puberulent beneath, 4-11 cm. long, $2.5-5.5 \mathrm{~cm}$. wide, petioles about $2 \mathrm{~cm}$. long. often widened and wavy-margined below the middle; inflorescence consisting of 4-6 sessile cymes, the cluster hemispherical, 6-10 cm. broad; flowers white, 6-7 mm. broad, stamens about $3 \mathrm{~mm}$. long; drupe oval, bluish-black, 10-12 mm. long, slightly flattened, edible, stone oval: L, e n t a go, Latin name of a shrub.

In rich woods, freçuently along banks of streams, common throughout the south half of the state, less frequent northward. I)istributed from Quebec to Manitoba, south to N. J., Ga., Ind. and Mo. Blossoms in May and June, fruit ripe in August.

\section{Viburnum pubescens (Aiton) Pursh I8I4 Arrowwood}

A branching shrub, 6-14 dm. high, bark gray, on young shoots reddish brown; leaves ovate or oblong-ovate, rounded or slightly cordate at the base, acute or acuminate at the apex, coarsely dentate, veins few and very prominent on the upper side, glabrous or with scattered hairs above, soft downy beneath at least when young, $4-7 \mathrm{~cm}$. long, $3-5 \mathrm{~cm}$. wide, petioles $8 \mathrm{~cm}$. or less long, pubescent; cymes peduncled, the cluster $3-4 \mathrm{~cm}$. broad, flowers $4 \mathrm{~mm}$. broad, stamens about $3 \mathrm{~mm}$. long; drupe oval, dark purple, about $8 \mathrm{~mm}$. long; stone 2-grooved, on each face: p ubescens, hairy.

In rocky woods, common throughout the state. Distributed from western Quebec and Vermont to Manitoba, south to Ga., Ill., Iowa and Wyo. Blossoms in May, fruit ripe in August.

\section{Symphoricarpus J us si e u 1789 Snowberry Wolfberry}

(Gr. s y p pora, borne in clusters, carpos, fruit)

Low, upright, branching shrub; leaves opposite and simple; flowers pink or white, small, perfect, in axillary or terminal clusters, calyx-tube short, 5-toothed, regular, corolla campanulate, 4-5-lobed, sometimes hairy on the inside, occasionally gibbous at the base, stamens $4-5$, borne on the corolla-tube, ovary inferior, 4 -celled, 2 of the cells containing abortive 
ovules, the others with a single ovule in each, style slender, stigma capitate or 2-lobed; fruit a 2-seeded berry, seeds bony.

A genus of about 10 species, natives of North America.

\section{Key to the Species}

1. Flowers in dense, axillary and terminal spikes, stamens and styles protruded

S. occidentalis

2. Flowers in few-flowered, interrupted spikes, at the ends of the branches, stamens and styles not protruded

S. raccmosus

\section{Symphozicarpus occidentalis $\mathrm{H}$ oo k e $\mathrm{r} 1833$ Wolfberry}

A low, erect shrub, 0.3-1 m. high, sometimes considerably branched, bark gray and shreddy on the older branches; leaves ovate, rounded, or narrowed at the base, blunt or acute at the apex, entire or undulate-

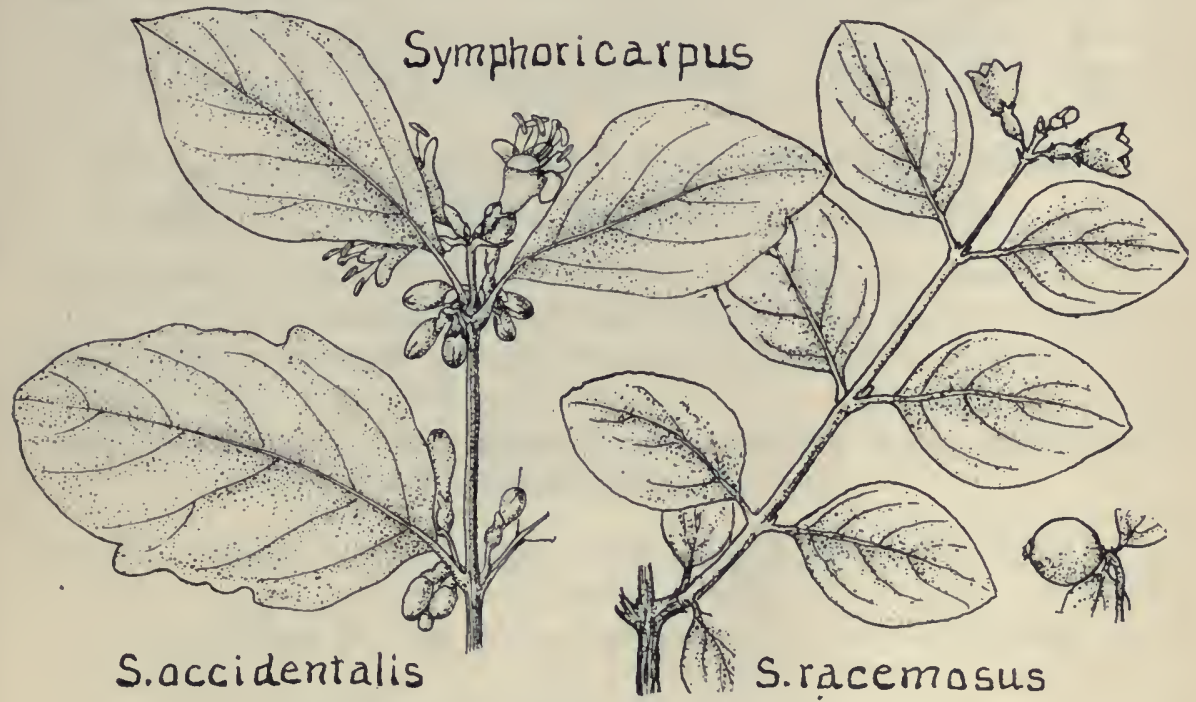

crenate or sometimes lobed, glabrous above, thinly pubescent at least along the reins beneath, $2-7 \mathrm{~cm}$. long, $1.5-4.5 \mathrm{~cm}$. wide, or occasionally much larger, petioles 4-10 mm. long, often pubescent; flowers in dense axillary and terminal spikes, corolla pinkish, short funnel-form, 6-9 $\mathrm{mm}$. long, very hairy within, stamens and style protruding beyond the end of the corolla; fruit a nearly globular berry, white, 7-10 $\mathrm{mm}$. in diameter: o c c ident a lis, western.

In dry or rocky soil, common and often abundant except northeastward. Distributed from northern Mich, and I1l. to Kan. and west to 
the Rocky mountains. Blossoms in June and July, fruit ripe in Septenıber, often persistent throughout the winter.

This species is very variable in the size and form of leaf.

\section{Symphoricarpus racemosus Mic ha $11 \times 1803$ Snowberry}

An erect branching shrub, 0.3-1 m. high, bark on older branches gray and shreddy, young shoots slender, yellowish brown; leaves oval, ellipticoblong or nearly orbicular, narrowed or rounded at the base, obtuse at the apex, glabrous above, pilose beneath, margin entire or crenate, length 2-5 cm., width 1-3 cm., petioles 2-3 mm. long; flowers $1-2$ or several in interrupted spikes, at the ends of the branches, corolla pink or white, campanulate, 4-5 mm. long and about as broad, hairy within, stamens and style not protruded beyond the corolla; fruit a snow-white berry, globose, 5-10 mm. in diameter: $\mathrm{r}$ a c e m o s u s, racemed.

In rocky and dry soil, throughout the state. Distributed from northeastern Quebec to Alaska, south to western Mass., Pa., Mich., Mont. and California. Blossoms in June and July, fruit ripe in Aug. and Sept.

Symphoricarpus racemosus var. pauciflorus $\mathrm{R}$ o b b in s 1867 Symphoricarpus pauciflorus (Robbins) Britton 1894

A dwarf shrub, differing from the species in having uniformly smaller leaves which are much paler beneath and more pubescent.

Common in the northern part of the state, infrequent farther south.

\section{Symphoricarpus racemosus var. levigatus Fernald Cultivated Snowberry}

Erect shrub, 1-1.5 m. high, leaves larger than in the species, glabrous on both sides; flowers often numerous, in interrupted spikes.

Frequently cultivated in gardens and occasionally escaping.

\section{Lcnicera L in 11 é 1753 Honeysuckle (Named for Adam Lonitzer)}

Erect shrubs or woody twining vines; leaves opposite, entire; flowers in terminal heads or spikes, or in pairs on axillary peduncles, calyx adherent to the ovary, its limb usually minute, 5-toothed or nearly entire, petals 5 , united into a more or less irregular corolla, corolla trumpet-, funnel-, or bell-shaped, the tube often gibbous at the base and honey bearing, the limb 5-cleft or 2-lipped, the upper lip consisting of 4 petals, the lower of 1 , stamens 5 , borne on the corolla-tube, alternate with the petals, pistil 
1, compound, 2-3-parted, ovary inferior, 2-3-celled (rarely 1-celled), style 1, stigma 1, capitate or 2-3-lobed; fruit a berry, usually 2-3-celled, few-seeded, in species with flowers in pairs, the two berries sometimes coalescent.

A genus of about 100 species, chiefly of the north temperate zone.

\section{Key to the Species}

1. Flowers terminal, in dense clusters or interrupted spikes, upper leaves of floweringshoots connate-perfoliate, usually vines: sub-genus Caprifolium

a. Flowers long trumpet-shaped, cultivated

b. Flowers with a short tube and spreading 2-

L. sempervirens lipped limb, native

(1) Margin of leaves parchment-like, not ciliate

(a) Leaves nearly or quite glabrous

L. dioica

(b) Leaves pubescent beneath

L. dioica glaucescens

(2) Margin of leaves green, ciliate

L. hirsuta

2. Flowers in pairs, on axillary peduncles, none of the leaves connate-perfoliate, mostly upright shrubs: sub-genus $\mathrm{X}$ y los te $\mathrm{um}$

a. Peduncles long and slender, over $1 \mathrm{~cm}$. long

(1) Leaves pubescent, native shrubs

(a) Leaves thick, woolly, corolla 2-lipped

(b) Leaves thin, bristly, corolla nearly regular

L. o.3longifolia

L. canadensis

(2) Leaves glabrous, corolla not 2-lipped, cultivated

L. tatarica

b. Peduncles mostly under $1 \mathrm{~cm}$. long, leaves thick and veiny

(1) Ovaries united, berry blue-black, native

L. costulca

(2) Ovaries separate, berries red, cultivated

L. Morrowi

\section{Lonicera sempervirens L i n n é I753 Trumpet Honeysuckle}

Tall twining vine, bark pale brown, shredded, twigs glabrous; leaves broad-oval, ovate, or the lower ones lanceolate, the uppermost pair on flowering shoots connate-perfoliate forming usually a broad elliptical disk, upper side dark green, smooth, lower side glaucous, smooth or somewhat 

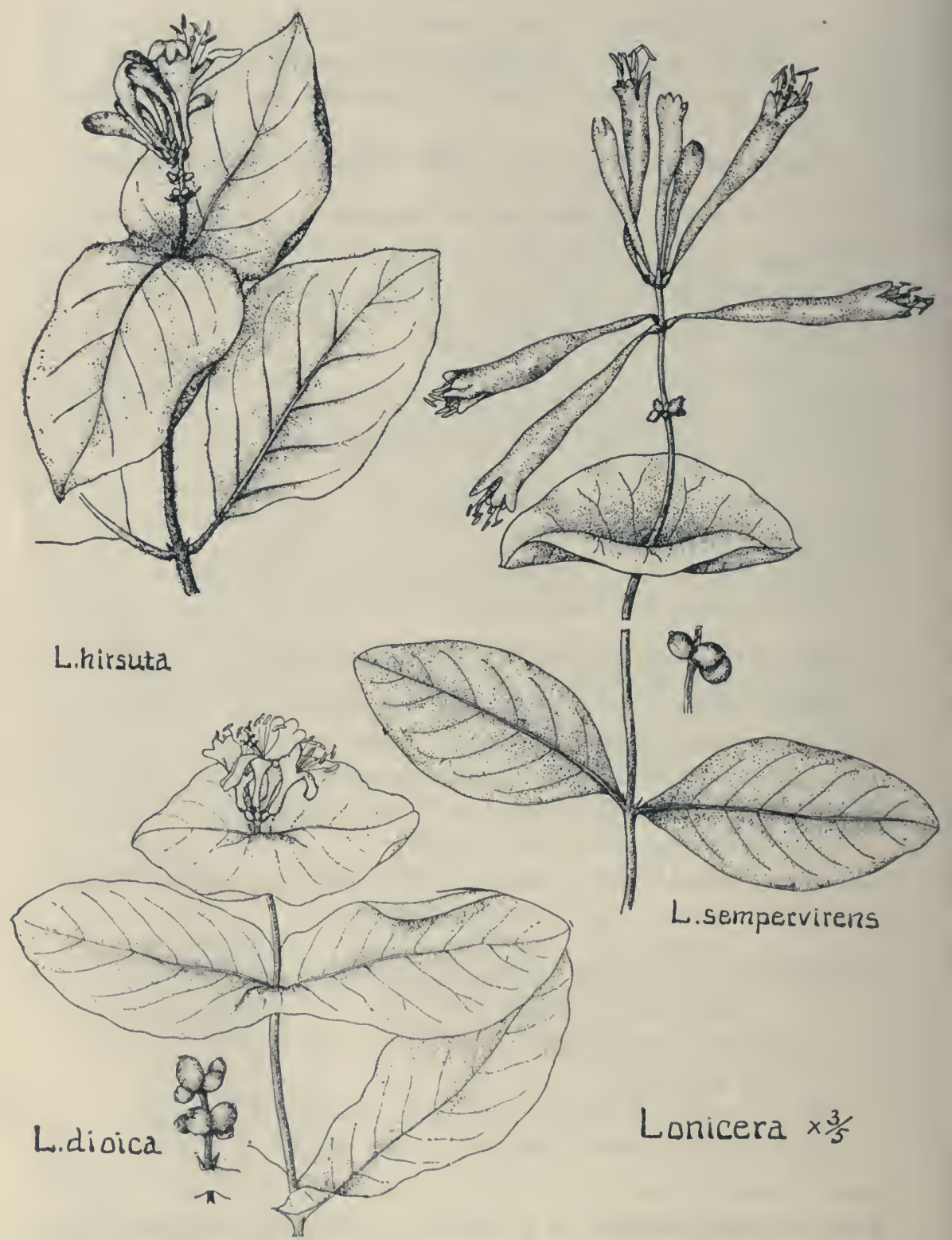

hairy, margin smooth and parchment-like, tip retuse, rounded, or slightly: acute, base of lower leaves narrowed, sessile or short petioled, length +.7 $\mathrm{cm}$., width $1-5.5 \mathrm{~cm}$. ; flower in interrupted, terminal spikes, limb of calyx minute, 5-lobed, corolla scarlet, often with more or less yellow, trumpetshape, nearly regular, its tube $4-5 \mathrm{~cm}$. long, about $6 \mathrm{~mm}$. wide at the 
throat, its limb scarcely spreading, about $5 \mathrm{~mm}$. long; berries scarlet: sempervirens, evergreen, a character which it has in the southern states but not in Minnesota.

Cultivated; native, Maine to Nebraska and southwards. A hardy and handsome climber, often grown upon porches, etc. Its conspicuous scarlet flowers are in bloom for a long period in summer.

\section{Lonicera dioica $\mathrm{L}$ i n $n$ é 1767}

Lonicera glauca Hill i 769

\section{Lonicera parviflora Lamarck 1783}

Twining vine or shrubby, 1-3 m. high; bark grayish, peeling on old stems, twigs glaucous and glabrous; leaves oblong or elliptical, the uppermost 2-4 pairs on flowering stems connate-perfoliate, the uppermost pair forming a rhomboid or elliptic usually obtusely angled disk, upper side of leaves bright green, glabrous, lower side very glaucous, entirely glabrous or with a few scattered hairs, margin parchment-like and without hairs, tip obtuse to rounded, base when not connate, sessile and clasping; flowers in dense terminal clusters, calyx-limb barely $1 \mathrm{~mm}$. long, obscurely 5-toothed, corolla yellowish, or more frequently dull-maroon. with a yellowish tube, its tube 7-10 $\mathrm{mm}$. long, gibbous at the base and expanding to a width of about $3 \mathrm{~mm}$. at the throat, its limb 2-lipped, cleft into 5 , somewhat unequal linear petals, 5-10 mm. long, corolla smooth without, hairy within, stamens exserted, filaments hairy, style hairy, stigma capitate; berries red: $\mathrm{d}$ i o i c a, dioecious which this plant is not.

Maine to Manitoba, south to North Carolina, Ohio and Missouri. In its typical form occurring somewhat rarely in copses and rocky woods in eastern and southern Minnesota. Flowers in May and June.

\section{Lonicera dioica var. glaucescens ( $\mathrm{R}$ y d b e r g)}

\section{Lonicera glaucescens Rydberg 1897}

Leaves ovate to obovate, often only one pair connate-perfoliate, the lower ones narrowed at the base and sometimes short-petioled, glabrous on the upper side and margin but the lower side more or less hairy, of ten densely so ; flowers more frequently pale yellow, tube of corolla hairy on the outside, $10-15 \mathrm{~mm}$. long, somewhat more slender than in the type.

Ontario and Michigan to Saskatchewan, south to Virginia, Nebraska and Wyoming. Rocky woods, copses, bluffs, etc., throughout the wooded part of Minnesota. Much more abundant than the type. 
This form has been described as a distinct species but in Minnesota it intergrades completely with L. dioica. Only two of the Minnesota specimens of that species in the University herbarium are completely glabrous. Several others, agreeing in all other respects with typical L. d io ic a have a few scattered hairs on the lower side of the leaf: the form and number of the perfoliate disks often varies greatly in the same individual, and out of 20 flowering specimens showing the foliage characters of the variety $\mathrm{g} l \mathrm{l}$ u cescen $\mathrm{s}$ five have the floral characters of typical L. dioica. Very pubescent specimens of this variety are sometimes confused with $\mathrm{L}$. h irsut a but can be readily distinguished from that species by their smooth and parchment-like leaf margin.

\section{Lonicera hirsuta Eat on I8I8}

Twining vine, bark grayish and peeling, twigs usually pubescent above; leaves broadly ovate to orbicular, the upper 1-2 pairs on flowering branches connate-perfoliate, the uppermost disk orbicular or rhombic, upper side dark green slightly hairy, lower side whitish and densely hairy, margin ciliate and not at all parchment-like, tip of leaf obtuse or shortacuminate, base, when not connate, rounded, sessile or short-petioled, length $6-11 \mathrm{~cm}$., width $4-7 \mathrm{~cm}$; flowers in dense terminal clusters, often with either sessile or stalked clusters in the axils of the lower perfoliate disk, calyx-limb scarcely $1 \mathrm{~mm}$. long, obscurely 5-lobed, corolla yellow, its tube $10-18 \mathrm{~mm}$. long, gibbous at the base, expanding gradually into the 2-lipped, 5-petaled limb of about the same length, corolla-tube hairy and glandular on the outside, hairy within, stamens and style exserted, the filaments and style somewhat hairy below: hirsuta, hairy, bearded.

Vermont, Ontario and Manitoba, south to Pa., Mich. and Minn. In Minnesota common in the region of coniferous forest in the northern and northeastern parts of the state, not occurring elsewhere. Flowers in June and July.

\section{Lonicera oblongifolia (Goldie) Hooker 1833}

Shrub, 5-15 dm. high, bark grayish, twigs puberulent; leaves ovatelanceolate to oblong, thick, dark green above, pale beneath, finely-woolly pubescent, especially beneath, margin thickened, woolly but not ciliate, tip acute or obtuse, base tapering, length 2.5-10 cm., width 1-3.5 cm., petioles $2 \mathrm{~mm}$. long or wanting; flowers in pairs in the axils of the lower leaves, peduncles slender, $1-3 \mathrm{~cm}$. long, bracts at base of ovaries very minute or deciduous, before the flowers open, ovaries more or less fused, 
limb of the calyx nearly wanting, having 5 minute, triangular teeth, less than $0.5 \mathrm{~mm}$. long, corolla yellow, of ten streaked with purple, the tube about $5 \mathrm{~mm}$. long, gibbous just above the base, more or less hairy within and without, limb 2-lipped, spreading, about $1 \mathrm{~cm}$. across, the upper lip slightly 4-cleft, the lower consisting of a single petal, stamens exserted,
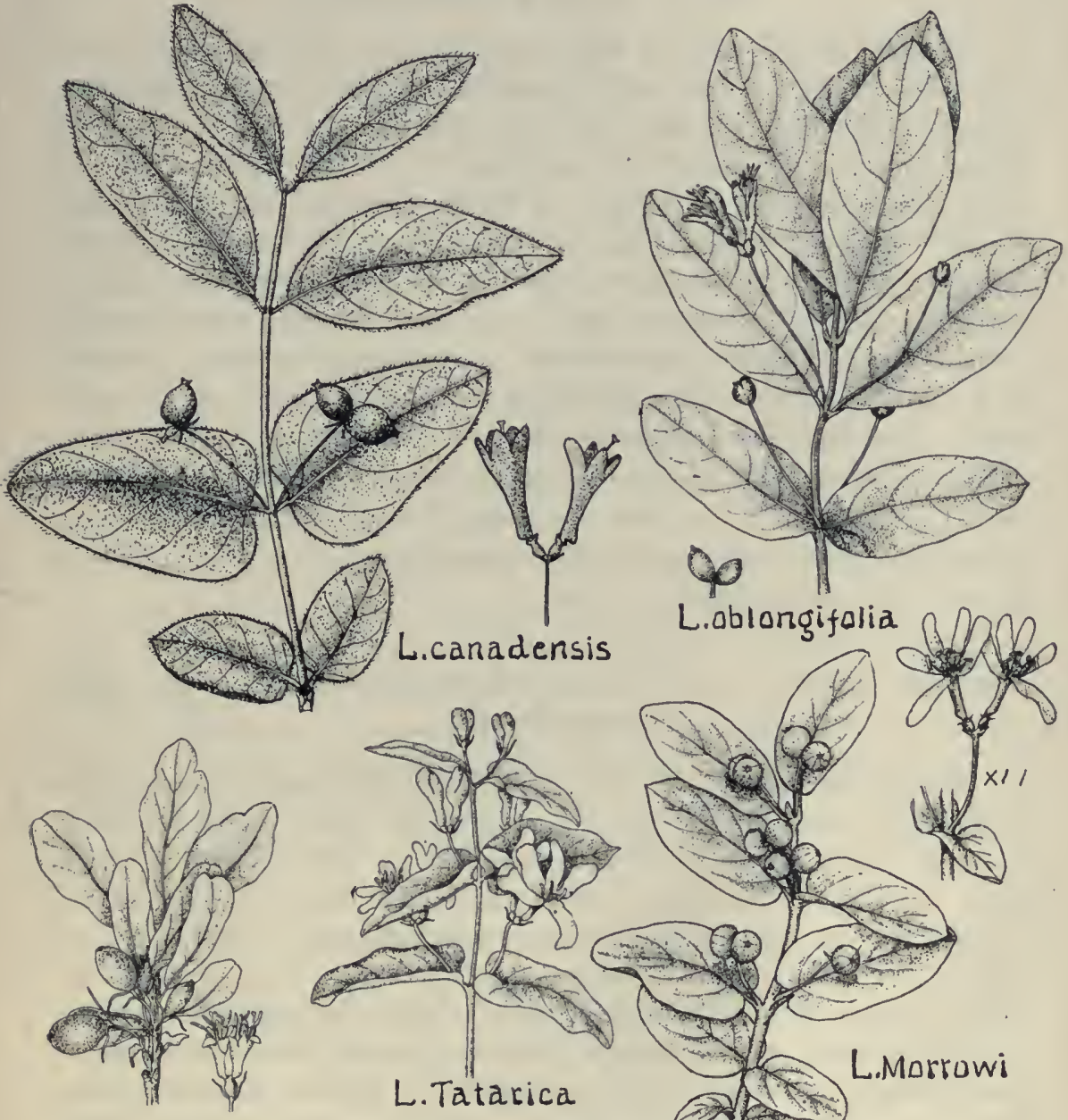

L. coeriulea
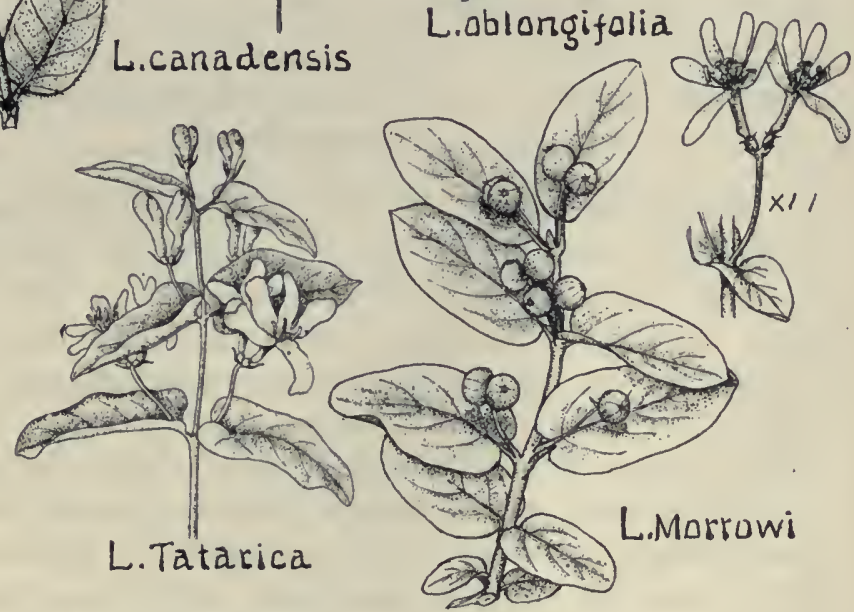

Lonicera $\times \frac{3}{5}$

the filaments hairy; fruit red or purplish, the two berries nearly distinct or more or less completely united: o blong if o li a, oblong-leaved.

Swamps. New Brunswick to Manitoba, south to northern New England, Pa., Mich., and Minn. In Minnesota confined to the region of 
evergreen forest, in the northern and northeastern parts of the state. Flowers in June, fruit ripe in late July.

\section{Lonicera canadensis M a r s h 11 I 785}

\section{Lonicera ciliata Muhlenberg I8I3}

Irregular shrub, 1-1.5 m. high, bark grayish, twigs glabrous; leaves ovate or lance-ovate, thin, bright green, upper side glabrous, lower side slightly hairy, margin ciliate, tip acute or somewhat obtuse, base acute rounded or cordate, length 2-9 cm., width $1.5-4 \mathrm{~cm}$., petioles $5-8 \mathrm{~mm}$. long; flowers in pairs, in the axils of the lower leaves, peduncles slender, about $1 \mathrm{~cm}$. long, bracts at base of ovaries small, the longest lanceolate, about $2 \mathrm{~mm}$. long, the others about $0.5 \mathrm{~mm}$. long, ovaries separate, limb of calyx obscurely lobed, about $1 \mathrm{~mm}$. long, corolla greenish yellow, funnelshaped, the tube gibbous at the base, $1.5 \mathrm{~cm}$. long, expanding gradually into a nearly equally 5 -lobed limb about $5 \mathrm{~mm}$. long, slightly hairy within, stamens included; berries separate, red: c a n a de n s is, Canadian.

Moist woods. Quebec and Nova Scotia to Saskatchewan, south to Pa., Mich., and Minn. In Minn. occurring throughout the region of evergreen forest in the northern and northeastern parts of the state. Flowers in May, fruit ripe in July.

\section{Lonicera tatarica Linné I753 Tartarian Honeysuckle Twin Honeysuckle}

Upright shrub, $1.5-3 \mathrm{~m}$. high, bark light gray, twigs glabrous, green or reddish; leaves ovate, glabrous, rather thin, upper side dark green, lower paler but not glaucous, margin smooth or with a very few sparse hairs, tip acute or sometimes obtuse, base heart-shaped, length $3-7 \mathrm{~cm}$. width 1.7-4 cm., petioles about $5 \mathrm{~mm}$. long; flowers in pairs, from the axils of the upper leaves, peduncles slender, 1-2 cm. long, bracts at the base of ovaries partly awl-shaped, about $5 \mathrm{~mm}$. long, partly ovate, less than $1 \mathrm{~mm}$. long, ovaries distinct, glabrous, limb of calyx with 5 lanceolate sepals, about $1 \mathrm{~mm}$. long, corolla pink or whitish, the tube gibbous at the base, about $5 \mathrm{~mm}$. long, hairy within, the limb irregularly cleft into 5 linear or lanceolate lobes, about $1 \mathrm{~cm}$. long, stamens somewhat exserted, filaments hairy ; berries separate, red : $t$ a $t$ a $r$ i c a, Tartarian, referring to its native land.

Cultivated, native of southeastern Russia to central Asia.

A hardy shrub, much planted, ornamental both in flower and in fruit. 
Besides the typical form with pink flowers there are forms with white flowers and with various shades of pink flowers, some with considerably larger leaves and flowers than the type. Flowers in May.

\section{Lonicera coerulea $\mathrm{L}$ i n n é 1753}

Erect shrub, $3 \mathrm{dm}$. to $1 \mathrm{~m}$. high, bark light brown, much shredded, twigs pubescent; leaves oval, narrow-oblong or obovate, thick, upper side hairy, or smooth, lower side pale, coarsely hairy, margin ciliate, tip round or obtuse, base rounded or narrowed, length $2-4 \mathrm{~cm}$., width $8-20 \mathrm{~mm}$., petioles about $1 \mathrm{~mm}$. long; flowers in pairs from the axils of the lower leaves, peduncle 2-8 $\mathrm{mm}$. long, bracts at base of ovaries awl-shaped, 3-5 $\mathrm{mm}$. long, hirsute, ovaries of the two flowers completely united, glabrous, limb of calyx very minute, scarcely lobed, glabrous, corolla pale yellow, glabrous in Minnesota specimens, the tube slightly gibbous at the base, about $7 \mathrm{~mm}$. long, the lobes nearly equal, about $5 \mathrm{~mm}$. long, stamens exserted; fruit an oval bluish-black berry, bearing the scars of two flowers close together near the summit, edible: co e r u lea, blue, from the color of the fruit.

Wet woods and bogs. Labrador to Alaska, south to Pa., Mich. Yellowstone Park and Oregon, also occurs in Scandinavia and Switzerland. In Minnesota confined to the northeast corner of the state. Flowers in Nay and June, fruit ripe about August 1.

The American specimens of this species are assigned to the variety villosa (Michaux) Torrey \& Gray. Minnesota and Wisconsin specimens, as well as those of the western U. S. have thinner and less veiny leaves than those from Europe and eastern North America.

\section{Lonicera Morrowi A. Gra y 1856}

Spreading shrub, about $2 \mathrm{~m}$. high, bark grayish brown, twigs finely pubescent; leaves oblong, thick and veiny, dark green above, paler beneath, upper side finely and sparsely hairy, lower side hairy, margin ciliate, tip obtuse or rounded, base cordate, length $2.5-5 \mathrm{~cm}$., width $1.5-2.5$ $\mathrm{cm}$., petioles about $3 \mathrm{~mm}$. long; flowers in pairs, axillary, peduncles 7-10 $\mathrm{mm}$. long, bracts small, pubescent and ciliate, the two longest linear, 3-5 $\mathrm{mm}$. long, the others ovate, about $2 \mathrm{~mm}$. long, ovaries separate, limb of calyx with 5 obtuse, triangular, ciliate teeth, corolla white, yellow or fading, pubescent, the tube 7-10 $\mathrm{mm}$. long, the limb with 5 slightly ir- 
regular lobes, 8-12 mm. long, stamens exserted, the filaments hairy; berries separate, bright red: M or row i, named for Dr. James Morrow.

Cultivated. Native of Japan.

$\Lambda$ very handsome and hardy shrub, ornamental both in flower and fruit and covered with foliage from earliest spring until hard freezing in the fall. A very useful plant for untrimmed hedges where there is plenty of space. This plant grows readily from seed: it is distributed extensively by birds and is apt to appear spontaneously in the vicinity of cultivated plants. Flowers in May and June, fruits from August to late autumn.

\section{Diervilla M o e n ch $\mathbf{I} 794$}

\section{(Named for Dr. Dierville)}

Upright shrubs; leaves opposite, serrate; flowers axillary and terminal, cymose or solitary, calyx-tube slender and elongated, narrowed below the 5 persistent sepals, corolla tubular, or funnel-shaped, the tube slightly gibbous at the base, 5-lobed, stamens 5, borne on the tube of the corolla, anthers linear, ovary 2-celled, inferior, ovules numerous in each cavity, style long and slender, stigma capitate; fruit a capsule, oblong, slenderbeaked or pointed, 2-valved.

$\Lambda$ genus of about 8 species, two of eastern North America, the others of eastern Asia.

\section{Key to the Species}

1. Native, flowers less than $2 \mathrm{~cm}$. long, yellow

D. Lonicra

2. Cultivated, flowers more than $2 \mathrm{~cm}$. long, rose-pink or whitish

D. florida

\section{Diervilla Lonicera Mi11 e r I768}

Low upright shrub, $1 \mathrm{~m}$. or less high, bark grayish brown, twigs smooth except for two narrow hispid lines, leaves ovate or ovate-lanceolate, smooth, except a little rough hairy along the veins, margins finely serrate, tip long-acuminate, base wedge-shaped to rounded, $6-13 \mathrm{~cm}$. long, 2-7 cm. wide, petioles $5-10 \mathrm{~mm}$. long; flowers terminal or axillary, in clusters of 2-6, sepals bristle-like, about $5 \mathrm{~mm}$. long, corolla fumnelshaped, about $1.5 \mathrm{~cm}$. long, $1.5 \mathrm{~cm}$. in diameter, the free portion of the petals linear, corolla pale yellow, growing darker: Lon ic era, the generic name of the honeysuckle.

Newfoundland to Manitoba, south to North Carolina, Indiana and Minnesota. In Minnesota throughout the wooded part of the state. Flowers in June. 


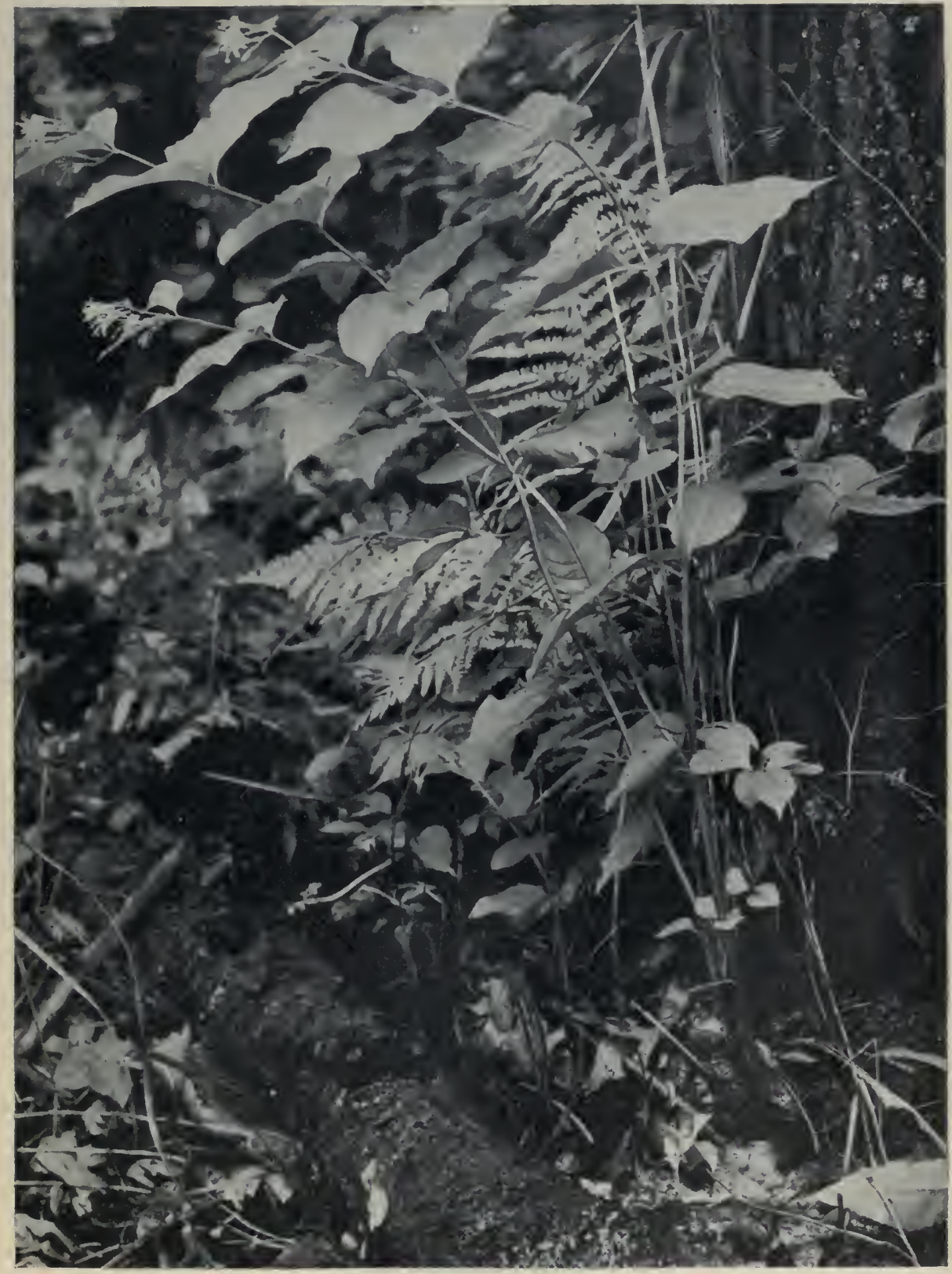

Diervilla Lonicera 


\section{Diervilla florida Sie bold \& Z u c carin i 1835 Weigela Weigela rosea Lindley}

Shrub, 1-2 m. high, bark grayish-brown, twigs hairy in two lines; leaves ovate to obovate, upper side smooth, lower side rough-hairy along the veins, margin finely serrate, tip acuminate, base wedge-shaped or rounded, $4-7 \mathrm{~cm}$. long, 2.5-3.5 cm. wide, petioles about $2 \mathrm{~mm}$. long; flowers axillary or terminal, in clusters of 1-4, sepals narrow-lanceolate, about $1 \mathrm{~cm}$. lcng, united for one-third to one-half of their length, corolla broadfunnel-shaped, nearly regular, about $3 \mathrm{~cm}$. long, $3.5 \mathrm{~cm}$. in diameter, the free part of the petals broadly triangular, rose-pink or whitish in some varieties, stigma 2-lobed: f 1 or id a, flowering.

Cultivated. Native of northern China.

A very ornamental bush, much cultivated under the name of Weigela and apparently quite hardy in the vicinity of Minneapolis where it

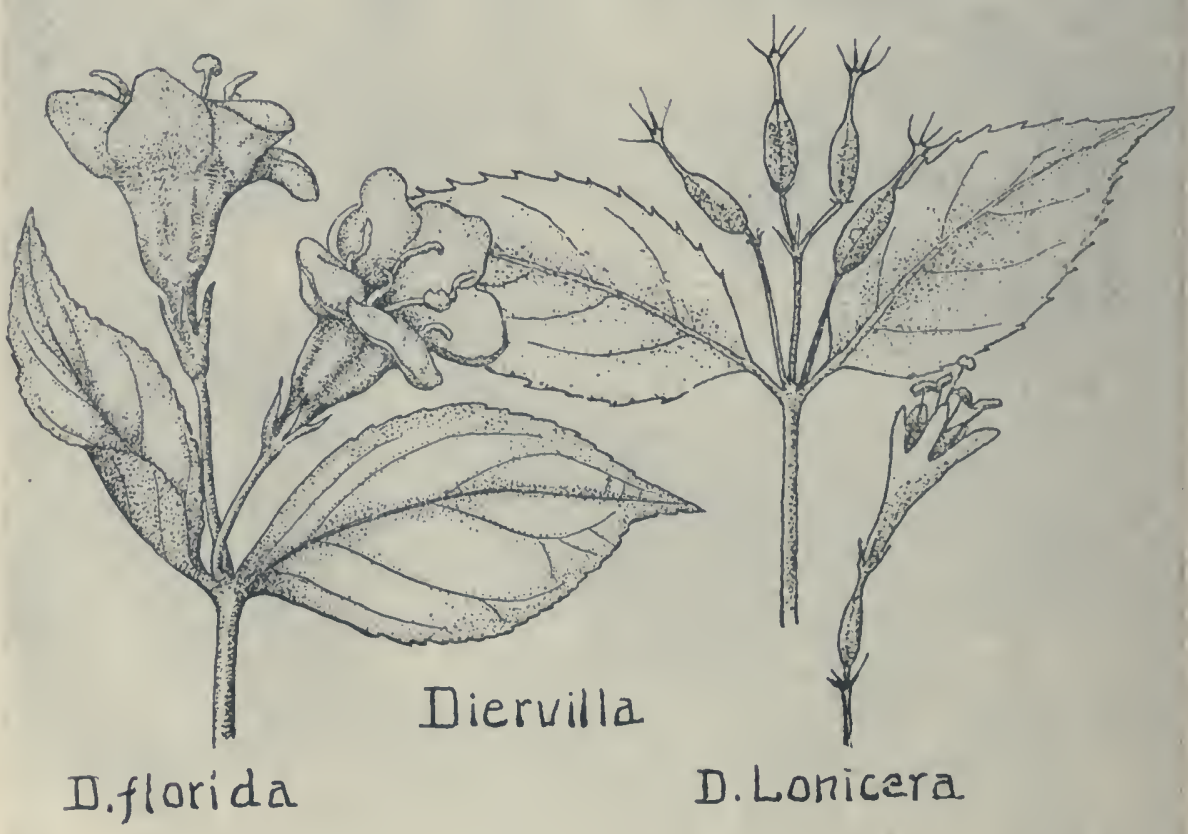

blooms in early June. There are numerous hybrids between this and other related Asiatic species. They appear to be less hardy than D. florida. 


\section{Asterales Aster Order}

\section{Compositae Composite Family}

Herbs, rarely shrubs or trees; flowers in dense heads, surrounded by a calyx-like involucre, the receptacle naked (i. e. bearing only flowers) or bearing scales among the flowers, flowers perfect, monoecious, polygamous or dioecious, calyx adherent to the ovary, the free limb (pappus) variously modified as scales, spines, bristles, plumes, etc., or entirely wanting, petals 5 , rarely 0 , united, corolla either regular, tubular or bell-shaped, or irregular, 2-lipped or flat and ligulate, the marginal flowers of the head often different in form, from the central ones, stamens 5 or 0 , usually united by their anthers, pistil 1, compound, ovary inferior, 1-celled, 1seeded, style 1, 2-cleft above, stigmas 2, fruit an achene.

An immense family, the largest of flowering plants, containing about 12,000 species. Herbaceous species of this family are very abundant in our flora especially in prairie regions, comprising such well known plants as sunflowers, asters, goldenrods, daisies, thistles, dandelions, etc. Woody plants of this family are rare and are largely confined to warmer climates. Our only shrubby genus is the following.

\section{Artemisia L in né I753 Wormwood Sage-Brush}

\section{(Named for Artemisia, wife of Mausolus)}

Herbs or slrubby plants, bitter and aromatic, often canescent or tomentose; leaves alternate; heads few to many-flowered, pendulous or nodding, in panicles, racemes, or spikes, flowers all tubular, greenish or yellowish, involucre ovoid, oblong or hemispherical, its bracts imbricated in several series, the outer ones shorter, receptacle flat or convex, naked or pubescent, not chaffy, central flowers perfect, sometimes sterile, marginal flowers usually pistillate and fertile, their corolla 2-3-toothed, in some species the flowers all perfect and fertile; achenes obovoid or oblong, 2ribbed or striate, with a small rounded summit, and no pappus.

A genus of about 200 species, natives of the northern hemisphere and southern South America. The following species is the only shrubby one within the state.

\section{Artemisia frigida Wi11 de n ow I804 Mountain Sage}

A low tufted perennial, 3-6 dm. high, woody at the base, densely silkycanescent throughout, aromatic; leaves $1-3 \mathrm{~cm}$. long, pinnately parted and 3-5-cleft, the divisions linear, the leaves towards the base of the 
stems with shorter and slightly broader lobes, the upper ones sessile and less divided; heads globose, mostly numerous, in racemes, or sometimes paniculate, short-peduncled, about $5 \mathrm{~mm}$. long and $4 \mathrm{~mm}$. broad, involucre hemispheric, bracts oblong, canescent, receptacle villous-pubescent, central flowers fertile; achenes ovate, about $1 \mathrm{~mm}$. long: f rigid a, frosty.
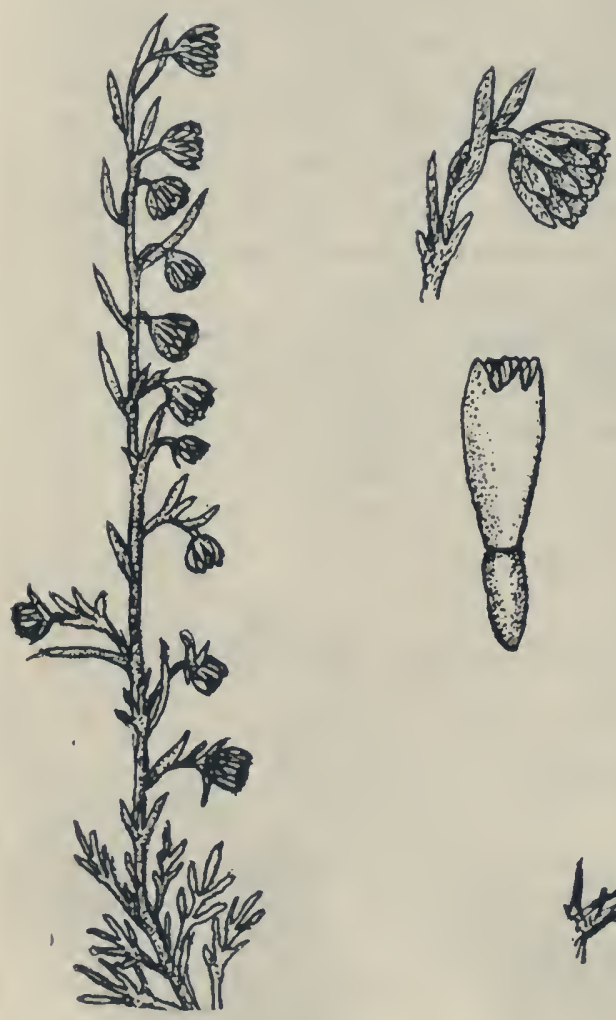

On dry prairies and in dry rocky soil, common in the western and northwestern parts of the state as far southeast as Minneapolis, less frequent and local farther south. Distributed from Minn. to British Columbia, south to Tex., New Mexico and Oregon; Asia. Blossoms in August and September. The leaves appear in early April.

\section{Liliales Lily Order}

\section{Smilacaceae Smilax Family}

Woody or herbaceous vines, usually with prickles, climbing by means of tendrils; leaves alternate, simple, usually entire, netted between the 


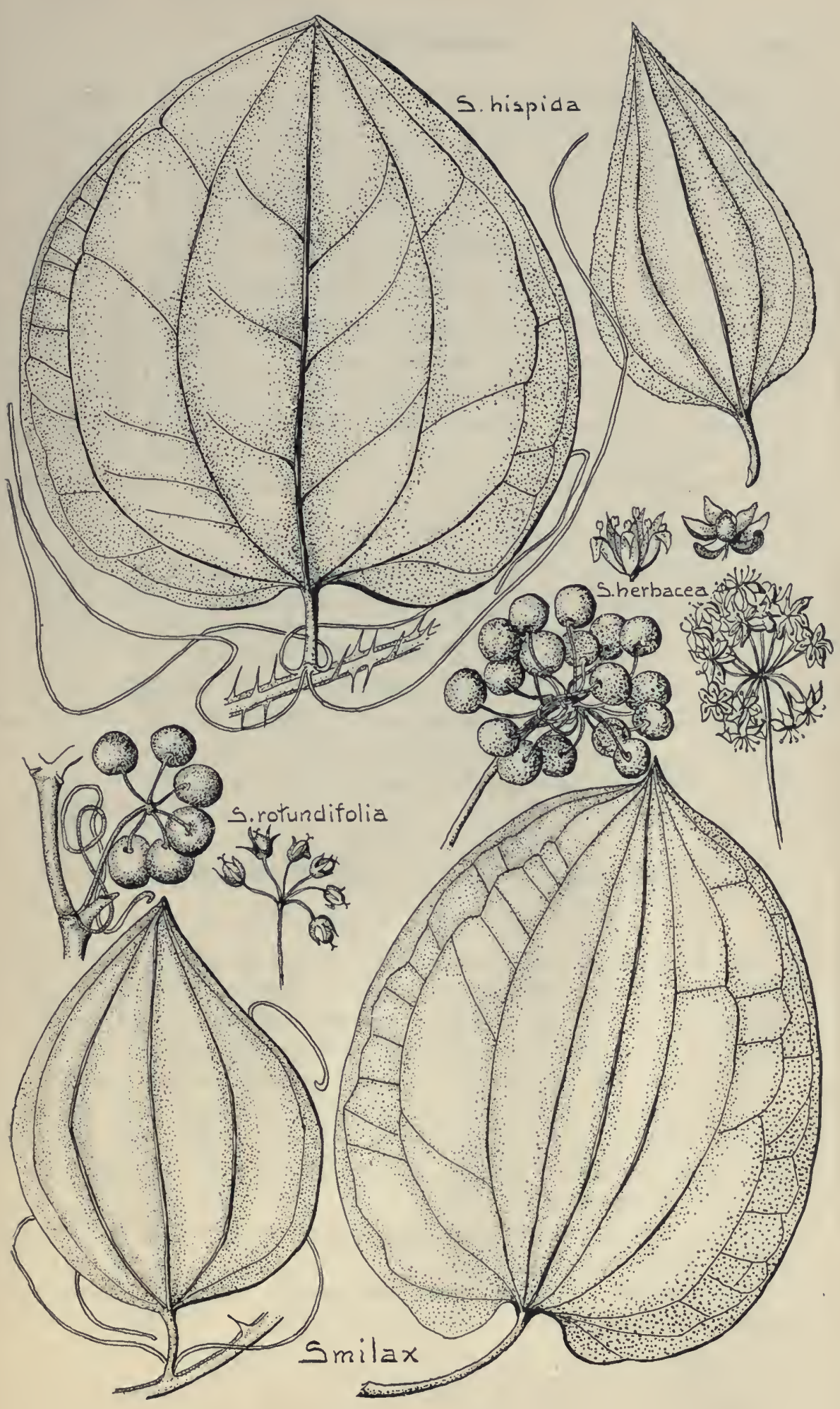


parallel veins; flowers dioecious, in axillary umbels; sepals 3 , petals 3 , separate, stamens 6, stigmas 1-3, ovary 3-celled; fruit a 1-6-seecled globose berry.

A family of 3 genera, found in warm and temperate regions.

\section{Smilax L in n é 1753}

\section{(Greek name of a woody climber)}

Vines, with tendril-like appendages at the base of the petals; leaves alternate, simple, entire, or sometimes lobed, the lower ones reduced to scales, veins 3-7; flowers small, greenish, in axillary 6-80-flowered umbels; sepals and petals similar, separate, 3 each; stamens 6 , on the bases of the sepals and petals, staminate flowers without a pistil, pistillate flowers with 1-6 imperfect stamens, ovary 3-celled; berry globose, black or bluish black.

Propagation by seeds.

A genus of about 195 species, widely distributed, but especially abundant in tropical America and Asia; 16 species occur in the United States.

\section{Key to the Species}

1. Stem not prickly, annual and herbaceous

S. herbacca

2. Stem prickly, perennial and woody,

(a) Stem very prickly, leaves mostly 7 -nerved

(b) Stem with few prickles, leaves mostly 5-nerved

S. hispida

S. rotundifolia

\section{Smilax herbacea L in né I753 Carrion-flower}

\section{S. pulverulenta Michaux I8o3}

Stem 2-8 ft. high, annual but more or less woody, arising from short thick tubers; leaves ovate-oblong to ovate or round, the margin entire or minutely toothed, tip abruptly sharp-pointed, base heart-shaped, smooth and green above, gray-downy or flaky below, thin, veins $5-9,5-15 \mathrm{~cm}$. long, 4-12 cm. wide, petioles $3-8 \mathrm{~cm}$. long, with two or more tendrils at the base; umbels $15-80$-flowered on peduncles $2-20 \mathrm{~cm}$. long, flowers grecnish, ill-smelling, $6-8 \mathrm{~mm}$. wide, on pedicels $1-2 \mathrm{~cm}$. long; berries bluish black, 2-4-seeded, 6-8 mm. diameter; her b a ce a, herb-like, referring to the annual habit.

Frequent throughout the state, especially in woodlands; New Brunswick-Fla-Tex-Nebr-Saskatchewan.

The variety e cir r h a a, which lacks tendrils, is found in the southeastern part of the state. 


\section{Smilax hispida M uhlenberg I843 Prickly Greenbriar}

Stem high-climbing, perennial and woody, thickly armed as a rule with long slender bristles; leaves ovate-lanceolate to ovate or rounded, margin usually fringed with minute teeth, or entire, tip pointed, base rounded or cordate, smooth above and below, thin, veins $7-9,5-15 \mathrm{~cm}$. long, 3-12 cm. wide, petioles $1-2 \mathrm{~cm}$. long; umbels 6-20-flowered on peduncles $3-4 \mathrm{~cm}$. long, flowers greenish, $5 \mathrm{~mm}$. wide, on pedicels $5-10$ $\mathrm{mm}$. long; berries bluish black, 5-6 mm. diam.; h is p id a, prickly, referring to the stem.

Occasional in thickets and the edges of woods in the southern half of the state; Ontario-Va-Tex-Nebr-Minn.

\section{Smilax rotundifolia L i n n é 1753 Greenbriar, Catbriar}

Stem high-climbing, perennial and woody, sparsely armed with stout prickles, arising from somewhat tuberous rootstocks; leaves ovate to nearly round, margin entire or nearly so, tip abruptly short-pointed, base rounded or cordate, smooth and shining above, smooth below, thick, veins 5-7, 4-8 cm. long, 3-8 cm. wide, petioles about $1 \mathrm{~cm}$. long, tendrils usually 2-3; umbels 2-10-flowered, on peduncles $1-2 \mathrm{~cm}$. long, flowers greenish, 4-5 $\mathrm{mm}$. wide, on pedicels $1 \mathrm{~cm}$. long; berries bluish black, 1-3-seeded, 5-6 mm. diam.; r o t u n d if o 1 i a, round-leaved.

In woods along streams throughout the forest district; Ontario-GaTex-Colo-Minn. 



\section{Glossary}

Achene A dry one-seeded fruit

Acrid Sharp, sour, umpleasant to the taste

Acuminate Tapering into a long point

Acute Sharp-pointed

Adherent More or less grown together

Adnate Grown together

Aerial Growing in the air

Aggregate Grouped together

Alternate With a single leaf at each point of attachment

Anatropous Turned back or downward

Annual Lasting only one growing season

Anther The upper part of the stamen containing the pollen

Apetalous Without petals

Apex Tip or upper end

Apocarpous Having or consisting of separate carpels or pistils

Apopetalous Having or consisting of separate petals

Appendaged With an addition or projection

Appressed Lying close to or against another part

Aquatic Growing in the water

Aril The fleshy often bright-colored outer coat of some seeds

Arilled With a fleshy outer coat

Aromatic Spicy, fragrant

Ascending Growing obliquely upward

Astringent Drawing together, hence puckering

Auricle An appendage more or less ear-like in shape

Awl-shaped More or less spine-like

Awn A slender bristle-like structure

Awn-pointed Tipped with an awn

Axil The angle between leaf and stem

Axillary Borne in the axil of a leaf
Axis The part of a stem or branch which bears leaves, flowers, or flower parts

Barbed Curved like a fish-hook

Basal At the base or arising from it

Beak An elongated tapering structure

Beaked Bearing a beak

Bearded With hairs restricted more or less to a definite area

Berry A fleshy fruit with a thin skin or soft rind, the seeds embedded in pulp

Bifoliate Consisting of two leaflets

Bipinnate With two sets of leaflets, primary and secondary

Bipinnatifid Pinnately lobed, with the lobes again divided

Biternate With three divisions, each subdivided into three leaflets

Blade The flat part of a leaf

Boreal Northern

Boss A raised knob or disk

Bract The leaf found below a flower or flower cluster

Bracteole, bractlet A small leaf or scale on the pedicel below the flower

Bulb A short stem with fleshy scales, usually below ground

Bulblet A small bulb, often above ground

Bulbous Like a bulb; bearing bulbs

Calcareous Containing much lime

Calyx The cup- or saucer-shaped outer part of the flower, usually green

Campanulate Bell-shaped

Cane The elongated new shoot of bushes and shrubs

Canescent Gray and hoary

Capitate Head-like

Capsule A dry fruit consisting of two or more carpels or pistils 
Carpel A simple pistil, or the unit part of a compound pistil

Cartilaginous Firm and tough, like cartilage

Catkin A long hanging cluster of flowers

Cell The cavity or chamber of an ovary

Chaffy Applied to a head with scales betwcen the flowers, as in the sunflower liead

Ciliate Margined with hairs

Claw The narrowed lower part of a petal

Cleft Cut about halfway to the middle

Coherent United, or clinging together

Compound Consisting of two or more similar parts united

Compound leaf Consisting of two or more leaflets

Concrescent Grown together

Cone An elongated axis bearing stamens or ovule-bearing scales, as in the pine

Conifer Cone-bearer, as in the pine, spruce and fir

Connate Grown together or united

Constricted Narrowed or pinched

Convolute Rolled up lengthwise

Cordate Heart-shaped

Coriaceous Leathery in texture

Corm A solid bulb-like organ, as in the crocus

Corolla The brightly colored part of most flowers, just within the green calyx

Corymb A flat-topped or convex flower cluster, blooming first at the edge

Corymbose Corymb-like; arranged as in a corymb

Cotyledon A seed leaf

Creeping Growing along the ground

Crenate Scalloped; with rounded shallow teeth

Crenulate Finely crenate

Cuneate Wedge-shaped

Cyme A flower cluster blooming from the apex or middle first, usually somewhat flat

Cymose In a cyme; cyme-like

Cymule A small cyme

Deciduous Falling off, usually at the close of the season

Declined Bent down

Decumbent The lower part of the stem flat on the ground
Decurrent Running down the stem, as the bases of some leaves

Deflexed Bent down

Dehisce To split open

Dehiscent Splitting open, used of pods, etc.

Deltoid Delta-like, triangular

Dentate Toothed

Denticulate With small teeth

Depressed Flattened from above

Dichotomous Two-forked

Digitate Resembling the fingers of a hand

Dilated Broadened

Dimorphous Of two forms

Dioecious Bearing pistils and stamens on different plants

Disk The base of a flower to which the parts are attached; the center of a head

Dissected Cut or divided into numerous parts

Divided Lobed nearly or quite to the base

Drupe A fleshy fruit with a pit or stone such as the plum

Drupelet A small drupe

Elongated Long, drawn out

Emarginate Indented at the tip

Embryo The young plant in a seed

Endocarp The inner wall of a fruit, as the stone of a plum

Endosperm The food supply stored about the plantlet in many seeds

Entire Without teeth, lobes or divisions

Epidermal The outer layer, the skin of plants

Epigynous Applied to a flower with the parts upon the ovary

Even-pinnate With all the leaflets paired

Exfoliated Split off, usually in scales

Exocarp The outer part or wall of a fruit

Exserted Projecting beyond the surrounding parts

Exudation Sap, resin or milk that has oozed out, usually dried

Fascicle A cluster, usually dense

Fascicled Borne in dense clusters

Ferruginous Rusty or rust-colored

Fertile Bearing fruit; bearing pollen

Fertilization The process by which pollen changes the ovule into a seed

Fetid Ill-smelling

Fibrous Consisting of fibers; woven in texture 
Filament The stalk bearing the anther

Filiform Thread-like

Fimbriate Fringed

Flexible Bending readily

Flower An axis bearing. stamens or pistils or both, and usually also sepals and petals

Foliaceous More or less green and leaf-like

Follicle A dry fruit of one carpel, splitting on one side only

Fruit A developing or ripened ovary; often also the axis containing the real fruits

Fungus A colorless plant, such as a mold or mushroom

Gametophyte The structure which produces gametes or sex cells

Genus A group of related species, as the elm genus, the lilac genus

Gibbous Swollen

Glabrate, glabrous Without hairs

Gland A surface or structure which produces nectar, resin, oil, etc,; often a small appendage or projection

Glandular Bearing glands, or glandlike

Glaucescent Somewhat bluish or whitish

Glaucous Covered with a bloom, a bluish or whitish wax coating

Globose Ball-like or nearly so

Globular Ball-like

Glume The small scales at the base of grass or sedge flower

Glutinous Sticky, glue-like

Grafting The artificial union of two twigs of different kinds

Habitat The home of a plant

Hastate Arrow-shaped, but with the basal lobes diverging

Head A dense cluster, of sessile flowers such as that of the aster and sunflower

Herb A non-woody plant, which dies annually, at least down to the ground

Herbaceous Herb-like, soft

Hip The fleshy ripened receptacle of a rose, containing the bony fruits

Hirsute With somewhat coarse stiff hairs

Hispid With stiff bristly hairs

Hybrid A cross between two different but related plants
Hypogynous Applied to a flower with the other parts attached below the ovary

Imbricated Overlapping like the shingles of a roof

Incised Cut

Included Not projecting beyond the other parts

Indehiscent Applied to fruits that do not split to let out the seeds

Inferior Applied to an organ situated below another one, especially to the ovary when below the other flower parts

Inflorescence A flower cluster

Infrastipular Below the stipules at the base of a leaf

Integument A protective layer for coat, as the covering of an ovule or seed

Internode The part of a stem between two joints, often itself called a "joint"

Involucre The group of leaves or scales just below a head of flowers, as in the sunflower, or sometimes below a single flower or cluster

Involucral Pertaining to the involucre

Irregular Applied to a flower in which the petals are unlike

Keel The two fused lower petals of the flower of the pea family

Keeled Ridged, like the keel of a boat

Lacerate Torn

Laciniate Torn or cut into a fringe

Lanceolate Shaped like a lance

Leaflet The division of a compound leaf

Leaf-scar The scar left by the falling of the leaf

Legume A dry fruit of one carpel, splitting on two sides, as in pea and bean pods

Lenticel A corky projection on the bark

Ligule A ribbon-shaped corolla, as in the rays of a sunflower head

Ligulate Strap- or ribbon-shaped

Linear Line-like, long and narrow, with the sides nearly parallel

Lip The upper and lower halves of an irregular corolla or calyx, as in the snap-dragon; the irregular petal of an orchid

Lobe A division of a simple leaf 
Lobed With the margin more or less cut or divided

Loculicidal Applied to a dry fruit which splits between the cross walls

Lustrous Shining

Membranous Membrane-like, papery

Micropyle The opening through which the pollen tube enters the ovule

Monoecious Bearing stamens and pistils in different flowers of the same plant

Monotypic Used of a genus containing a single species

Mucronate With a sharp point

Nerve One of the lines or ridges running through a leaf

Net-veined With veins running in various directions and connecting with each other

Nodding Hanging on a bent pedicel

Node The part of the stem which normally bears a leaf

Nut A dry, one-seeded, indehiscent fruit with a stony shell or covering

Nutlet A diminutive nut

Ob- A prefix meaning reversed or inverted

Obcordate Reverse heart-shaped, the tip of the heart downward

Oblanceolate Reversed lance-shaped, the tip downward

Oblique Slanting, uneven

Oblong About twice as long as broad, the sides nearly parallel

Oblong-lanceolate Broadly lanceshaped

Obovate Reversed egg-shaped, the tip downward

Cbtuse Blunt

Cdd-pinnate With an odd or unpaired leaflet at the tip of a compound leaf

Opposite Of leaves, directly across from each other; of flower parts, in front of

Ovate, ovoid Egg-shaped

Ovule The young unfertilized seed, as found in the flower

Palmate Like the fingers of the hands

Panicle A compound flower cluster, the lower branches longer and blooming first
Paniculate In a panicle

Papilionaceous Butterfly-like, as the flowers of the pea family

Papillose With tiny projections

Pappus The bristles, hairs, awıs, etc., found on the tips of fruits of dandelions, aster, sunflowers, etc.

Parasitic Growing upon and getting its nourishment from some other plant

Parted Deeply cut

Pedicel The stalk of a single flower

Peduncle The stalk of a flower cluster or of a solitary flower

Peltate Shield-like, the stalk attached in the middle below

Pendent Hanging

Pendulous Hanging

Perennial Lasting from year to year

Perfect A flower having both stamens and pistils

Perfoliate Applied to leaves which are united around the stem

Perianth The term applied to the calyx and corolla when they are similar

Pericarp The ripened ovary; the wall of the fruit

Perigynium The sack enclosing the ovary or fruit in the sedges

Perigynous Applied to a flower in which the parts form a cup around the ovary

Persistent Remaining after blooming or fruiting

Petal The term applied to the parts of the corolla.

Petaloid Petal-like, brightly colored

Petiole The stalk of a leaf

Petiolule The stalk of a leaflet

Pinna A division or leaflet of a pinnate leaf

Pinnate With leaflets on botli sides of a common stalk

Pinnatifid Pinnately cleft to the middle or beyond

Pistil The central part of the flower containing the young seeds

Pistillate With pistils but without stamens

Plumose Plume-like or feathery

Pod A dry fruit of one carpel, splitting along two lines

Pollen The dust-like matter found in the anther

Polygamous With both perfect and imperfect, staminate or pistillate, flowers

Polygamo-dioecious The perfect and imperfect flowers on different plants 
Polypetalous With separate petals

Pome A fleshy fruit with a core, as the apple

Prickle A sharp needle-like outgrowth of the bark

Primary Of the first rank

Propagation The process by which new individuals arise or are produced without the use of seed

Puberulent, puberulous Finely hairy

Pubescent Hairy

Pungent Sharp

Pyriform Pear-shaped

Raceme A somewhat elongated axis bearing flowers with about equal pedicels

Racemose In a raceme

Rachis The axis of a spike or of a compound leaf

Radiate Like the spokes of a wheel

Ray One of the ribbon-like flowers of the composites

Receptacle The end of a flower stalk bearing the flower parts, or in the composites bearing the flowers

Recurved Bent back

Reflexed Bend down or back

Regular Having the members of each part alike in size and shape

Reniform Kidney-shaped

Resinous, resiniferous Bearing resin

Reticulate Net-like

Reticulation A net-like marking or roughening

Retrorse Turned downward or backward

Revolute With the margin rolled back

Rhizome An underground root-like stem

Rhomboid More or less diamondshaped

Rootstock An underground stem

Rostrate Beaked

Rotate Flat and circular in outline; wheel-shaped

Rudimentary Imperfect; beginning

Rugose Wrinkled, roughened

Salver-form, salver-shaped With a slender tube, abruptly widened into a flat top

Samara A winged fruit, as in the maple and elm

Scabrate, scabrous Rough

Scale A minute leaf

Scape A leafless flower-bearing stalk arising from the ground

Sclerenchyma Hard stone-like tissue
Scurfy With bran-like scales

Segment A part or division

Segregated Separated from

Semiherbaceous Partly herbaceous

Sepal One of the outer circle of flower parts, usually green, a division of the calyx

Septicidal Splitting through or along the septa or cross partitions of the fruit

Serrate With teeth as in a saw

Serrulate Finely saw-toothed

Serration A tooth

Sessile Not stalked; seated

Sheath The part of a leaf or leaf base which clasps or encloses the stem

Shrub A woody plant, usually less than 20 feet tall

Simple Consisting of one part, not compound

Sinuate With wavy margin

Sinuous Wavy, twisted

Sinus A notch or bay

Spadix A fleshy axis bearing sessile flowers

Spathe A leaf-like structure more or less enclosing a flower cluster

Spatulate Spoon-shaped, shaped like a spatula

Species A group of like individuals, as white pine, bur oak, etc.

Spherical Ball-shaped

Spike An elongated axis bearing sessile flowers

Spikelet A small few-flowered spike, the flower cluster of grasses and sedges

Spine A sharp woody outgrowth of the stem, a reduced leaf

Sporangium A spore-bearing sack or structure

Spray A feathery branch

Spur A hollow projection from a sepal or petal

Stamen The part of the flower which bears the pollen

Staminate With stamens but without pistils

Staminoid A stamen which no longer produces pollen

Standard The large upper petal of the flower of the pea family

Stellate Star-shaped

Sterile Not producing seed; without pollen

Stigma The tip of the pistil which receives the pollen

Stipule A leaf-like part at the base of the stalk of the leaf 
Stipulate With stipules

Strap-shaped Long and narrow in outline

Stratified Used of seeds germinated artificially in layers

Striate Marked with parallel lines

Stoloniferous With runners, or with runner-like branches

Style The pin-like extension of the pistil, bearing the stigma at its tip

Stylopodium A disk-like expansion at the base of the style, as in the carrot family

Subcordate Somewhat heart-shaped

Submerged Under water

Subsessile Nearly sessile

Subtend To stand below on the axis

Sucker A shoot arising from an underground bud

Superior Applied to a part placed above another part

Sympetalous Having or consisting of united petals

Syncarpous With united carpels

Teeth The regular projections along the leaf margin

Tendril A slender coiling holdfast

Ternate Of three leaflets

Terrestrial On the ground, not water-dwelling

Thorn A reduced sharp-pointed branch

Thyrse A dense much-branched flower cluster

Tomentum A dense layer of hairs

Tomentose With a dense mat of hairs

Trailing Crecping along the ground

Tribe A group of genera within the family
Trifoliate With three leaflets

Truncate Cut off squarely

Tuberous With a tuber or with large swollen roots

Tubular Like a tube

Tundra An arctic meadow or marsh

Twice-compound With two sets or ranks of leaflets

Twining Winding spirally about a support

Two-ranked In two rows

Umbel A flower-cluster with all the pedicels arising from the same point Umbellate Borne in umbels

Unarmed Without spines, thorns, or prickles

Valve One of the portions into which some dry fruits split; a trapdoor-like opening in the pollen chambers of some anthers

Verticillate Three or more in a circle

Vestigial Reduced almost to disappearence

Villous With long soft hairs not matted together

Webby With a tuft of slender, curly hairs

Weft A tuft of hair

Whorl A group of three or more similar organs, as leaves, radiating from the place of attachment

Whorled Borne in a whorl

Wing One of the two lateral petals of the Pea family

Zygomorphic Applied to a flower with petals of different form 


\section{Index}

The first number is regularly the page of the description, the second number the page of the illustration. Synonyms are in italics.

Abies, 20, 21

balsamea, 22, 21

concolor, 23

Menziesii var. Parry. ana, 26

Abietineae, 19, 21

Acer, 219, 223, 226

negundo, 227, 226

nigrum, 224, 223

platanoides, 222, 223

rubrum, 225, 226

saccharinum, 225, 226

saccharum, 224, 226

spicatum, 220, 221, 223

tataricum, 222, 223

Aceraceae, 219

Aesculus, 216

glabra, 219, 218

Hippocastanum, 217

Ailanthus, 83 glandulosa, 83, 84

Ailanthus Family, 83

Alder, 254

Alnus, 254, 255

alnobetula, 254

crispa, 254, 255

incana, 256, 255

Almond Willow, 67

Amelanchier, 150, 152

alnifolia, 153

canadensis, 151, 152

oblongifolia, 151, 152

oligocarpa, 153, 152

rotundifolia, 153

spicata, 153, 152

spicata, 151

American Bladdernut, 216

Elm, 76

Hornbeam, 244

Larch, 29

Laurel, 89

Linden, 72

Mountain Ash, 148

Yew, 41

Amorpha, 177, 178

fruticosa, 178 canescens, 179, 178

microphylla, 179

nana, 179,178

Ampelopsis Engelmanii, 207

quinquefolia, 205

Anacardiaceae, 227

Andromedia, 92, 93

glaucophylla, 92

Angiospermae, 44

Apple, 162

Arctostaphylos, 94, 93

Uva-ursi, 94

Arbor vitae, 35

Aronia, 153

nigra, 154, 147

Arrowwood, 284

Artemisia, 297 frigida, 297-298

Aspen, 56

Asterales, 297

Aster Order, 297

Atragene americana, 46

Austrian Brier, 144

Pine, 34

Bailey's Dogwood, 273

Balsam, 22, 59

Balsam Fir, 22

Poplar, 59

Willow, 64

Barberry, 48

Barberry Family, 48

Basilima sorbifolia, 132

Basswood, 70, 72

Bayberry Family, 268

Beak Willow, 70

Beaked Hazel-nut, 243

Bearberry, 94

Bee Tree, 72

Beech Family, 256

Berberidaceae, 48

Berberis, 48

Thunbergii, 50, 49

vulgaris, 49

Betula, 246, 248, 251, 253 alba, 249 var. papyrifera, 247

lutea, 250, 251

nigra, 250, 251

papyrifera, 247,248

pumila, 252, 253

var. glandulifera, 254

populifolia var. la-

ciniata, 249

Sandbergii, 252, 253

verrucosa, 249,248

Betulaceae, 240

Bignonia catalpa, 116

Bignoniaceae, 116

Bilberry, 99

Birch, 246

Birch Family, 240

Bitternut, 240

Bittersweet Family, 194

Bittersweet Order, 194

Black Alder, 214 Ash, 111

Plackberry, 121, 126

Black Chokeberry, 154

Haw, 284

Oak, 260, 261

Raspberry, 123

Spruce, 27

Sugar Maple, 224

Walnut, 235

Willow, 67

Bladdernut, 215

Bladdernut Family, 215

Blue Ash, 110

Blue Beech, 244

Blueberry, 100, 102

Bog Willow, 64

Boston Ivy, 205

Box Elder, 227

Bramble, 121

Bridal Wreath, 129

Bristly Locust, 177

Buckeye, 216

Buckthorn, 197, 198

Buckthorn Family, 197

Buffalo-berry, 213

Buffalo Currant, 192

Burning Bush, 195 
Bur Oak, 264

Buttercup Family, 46

Buttercup Order, 44

Butternut, 235

Buttonbush, 277

Cabbage Rose, 145

Cabinet Cherry, 164

Canada Plum, 166

Canadian Buffalo Berry, 212

Canoe Birch, 247

Caprifoliaceae, 277

Caragana, 179, 180 arborescens, 180 digitata, 181, 180

Carrion-flower, 300

Carrot Order, 270

Carpinus, 243 caroliniana, 244

Carya, 238, 239 cordiformis, 240, 239 ovata, 238, 239

Caryophyllales, 51

Catalpa, 116, 117 bignonioides, 116 catalpa, 116,117 speciosa, 118, 117

Catalpa Family, 116

Catbriar, 301

Ceanothus, 199 americanus, 199, 200 ovatus, 201, 200

Celastraceac, 194

Celastrales, 194

Celastrus, 195 scandens, 196

Celtis, 77 occidentalis, 77,78

Cephalanthus, 276 occidentalis, 277,276

Chamaedaplne, 91 calyculata, 92

Checkerberry, 93

Chimaphila, 86 maculata, 87 umbellata, 86,87

Chinquapin Oak, 267

Chiogenes, 95, 96 hispidula, 95

Chionanthus, 115,114 virginica, 115

Chokeberry, 153

Choke Cherry, 164

Cinnamon Rose, 141

Cinquefoil, 119

Clematis, 46, 48 paniculata, 48,47 verticillaris, 46,45 virginiana, 47
Climbing Bittersweet, 196

Cockspur Thorn, 159

Colorado Blue Spruce, 26

Common Elder, 279 Juniper, 40 Lilac, 112 Locust, 176 Tamarisk, 53

Compositae, 297

Composite Family, 297

Comptonia, 269 peregrina, 270, 269

Coniferales, 19

Cordate Willow, 64

Cork Elm, 74

Cornaceae, 270

Cornus, 270, 272 alternifolia, 275, 272

Amomum, 271, 272

Baileyi, 273, 272

circinata, 271,272

paniculata, 273, 272 stolonifcra, 274

Corylus, 241, 242 . americana, 242 rostrata, 243, 242

Cottonwood, 56

Crataegus, 154, 156, 158 Chapmani var. Plukenetii, 158

Crus-Galli, 159, 156

macracantha, 157,156 var. succulenta, 157 mollis, 155, 156

punctata, 158 rotundifolia, 157, 156 tomentosa, 158

Creeping Snowberry, 95

Crowberry; 105

Crowberry Family, 195

Cultivated Snowberry, 286

Cupressineae, $35,20,36$

Cut Leaf Birch, 249

Sumac, 230

Cucumber Tree, 45

Cydonia, 146 japonica, 146, 147

Cypress Tribe, 35,20

Dasiphora fruticosa, 120

Dewberry, 124

Diervilla, 294, 296

florida, 296

Lonicera, 294, 295, 296

Dirca, 208 palustris, 208

Dogberry, 186

Dogwood, 273, 275

Dogwood Family, 270
Douglas Fir, 23 Spruce, 23

Dwarf Alder, 199 Bilberry, 99 13irch, 252 Plum, 168 Savin, 40 Willow, 68

Elaeagnaceae, 209

Elaeagnus, 209 angustifolia, 211, 210 argentea, 211, 210

Elder, 278

Elm, 73

Elm Fanily, 73

Empetraceae, 105

Empetrum, 105 nigrum, 105

English Elm, 76

Epigaea, 90 repens, 91

Ericaceae, 84

Ericales, 84

Euonymus, 195 atropurpureus, 195, 196

European Barberry, 49 Gooseberry, 186 Linden, 72 White Birch, 249

Fagaceae, 256

False Acacia, 176 Indigo, 178

Fetid Buckeye, 219 Currant, 190

Fir, 20

Fir Tribe, 19

Fivefinger, 119

Flowering Almond, 170 Crab, 160 Plum, 171

Forsythia, 113 suspensa, 113, 114 viridissima, 113, 114

Fragrant False Indigo, 179

Frost Grape, 203

Fraxinus, 107, 109 americana, 108, 109 lanceolata, 110, 109 nigra, 111, 109 pennsilvanica, 108, 109

lanceolata, 110 quadrangulata, 110 , 109

viridis, 110

Fringe Tree, 115 
Garden Roses, 146

Garden Syringa, 183

Gaultheria, 93 procumbens, 93

Gaylussacia, 95, 96 baccata, 96

Gentianales, 107

Gentian Order, 107

Geraniales, 80

Geranium Order, 80

Ginkgo, 44, 43 biloba, 44

Ginkgoaceae, 43

Ginkgoales, 43

Ginkgo Family, 43

Ginkgo Order, 43

Glandular Thorn, 157

Gleditsia, 173 triacanthos, 175,174

Glossy Willow, 63

Golden Currant, 192

Grape Family, 201

Green Alder, 254 Ash, 110

Briar, 301

Guelder Rose, 282

Cymnocladus, 172 dioica, 173

Gymnospermae, 19

Hackberry, 77

Hairy Lilac, 112

Hamamelidaceac, 193

Hamamelis, 193 virginiana, 193, 194

Hardhack, 132

Hard Maple, 224

Hardy Catalpa, 118

Hazelnut, 242

Heath Family, 84

Heath Order, 84

Hemlock, 24

Hickory, 238

II icoria, 238

minima, 240

ovala, 238

Highbush Cranberry, 282

Hoary Alder, 256

Willow, 68

Holly Family, 213

Honey Locust, 175

Honeysuckle, 286

Honeysuckle Family, 277

Hop Hornbeam, 246

Hop-tree, 82

Hornbeam, 243

Horse Chestnut, 216, 217

Huckleberry, 96

Huntingdon Willow, 67
Hydrangea, 183, 184, 185 arborescens, 184 paniculata, 185,184

Ilex, 213 verticillata, 214

Ilicaceae, 213

Indian Bean, 116

Ironwood, 246

Jack Pine, 35

Juglandaceae, 232

Juglans, 232 cinerea, 235, 233, 234

nigra, 235, 236, 237

I une-berry, 150

Juniper, 40

Juniperus, 40, 36 communis, 40, 36, 39

sibirica, 41

nana, 41

sabina var. procum-

bens, 40

virginiana, 38

Kalmia, 89, 88 polifolia, 90

Kentucky Coffee-tree, 173

Kinnikinnik, 271, 274

Labrador tea, 88

Larch, 28, 29

Large Cranberry, 104

Large-flowered Syringa, 182

Large-fruited Thorn, 158

I.arix, 28, 21

americana, 29

decidua, 29

europaea, 29

laricina, 29, 21

Larix, 29

Lead-plant, 179

Leatherwood, 208

Leatherwood Family, 207

Ledum, 87,88 groenlandicum, 88

Leguminosae, 171

Lepargyraea argentea 213 canadensis, 212

Ligustrum, 115, 114 vulgare, 115

Lilac, 111

Liliales, 298

Lily Order, 298

Lime Tree, 72

Linden, 70

Linden Family, 70

Lombardy Poplar, 57

Longleaf Willow, 61
Long-spined Thorn, 157

Lonicera, 286, 288, 291

canadensis, 292, 291

ciliata, 292

coerulea, 293, 291

dioica, 289, 288

glauca, 289

glaucescens, 289

glaucescens, 289

hirsuta, 290, 288

Morrowi, 293, 291

oblongifolia, 290, 291

parviflora, 289

sempervirens, 287,288

tatarica, 292, 291

Lycium, 106

vulgare, 106

Madder Family, 275

Madder Order, 275

Magnolia, 45 acuminata, 45 .

Magnoliaceae, 44

Magnolia Family, 44

Maiden-hair Tree, 44

Mallow Order, 70

Malus, 159, 161 baccata, 160,161 floribunda, 160 ioensis, 162, 161 Malus, 162

silvestris, 162, 161

Soulardi, 162

Malvales, 70

Maple, 219

Maple Family, 219

Maple Order, 215

Matrimony Vine, 106

Meadow Sweet, 130

Menispermaceae, 50

Menispermum, 50 canadense, 51

Menziesia, 89 glabella, 89

Missouri Goosberry, 188

Mock Orange, 181, 183

Moonseed, 50, 51

Moonseed Family, 50

Moosewood, 208

Moraceae, 77

Morello Cherry, 168

Morus, 79, 78 alba, 80,78 rubra, 79, 78

Mountain Alder, 254 Ash, 147

Cranberry, 102

Maple, 220, 221

Pine, 34

Sage, 297 
Mugho Pine, 34

Mulberry, 79

Mulberry Family, 77

Myrica, 268 asplenifolia, 270

Gale, 268, 269

Myricaccae, 268

Narrow-leaf Cottonwood, 57

Newcastle Thorn, 159

New Jersey Tea, 199

Ninebark, 127

Northern Black Currant, 191

Fox-grape, 203

Gooseberry, 188

Pin-oak, 261

Norway Maple, 222

Pine, 33

Spruce, 28

Oak, 257

Ohio Buckeye, 279

Oleaceae, 107

Oleaster Family, 209

Olive Family, 107

Opulaster opulifolius, 127

Osier Willow, 68

Ostrya, 245

virginiana, 246, 244, 245

Oxycoccus macrocarpus, 104

Oxycoccus, 103

palustris, 103

Paper Birch, 247

Parthenocissus, 203, 206

Engelmannii, 207

quinquefolia, 205, 206

Saint Paulii, 207

tricuspidata, 205, 206

vitacea, 207, 206

Pea Family, 171

Pear Haw, 158

Pear-thorn, 158

Pembina, 282

Persian Lilac, 112

Philadelphus, 181,182 coronarius, 183,182 grandiflorus, 182

Phlox Order, 106

Physocarpus, 127 opulifolius, 127,128 intermedius, 128

Picea, 25, 21

Abies, 28

alba, 26

canadensis, 26 excelsa, 28

mariana, 27, 21

nigra, 27

Parryana, 26

pungens, 26

Pin Cherry, 168

Pinaceae, 19

Pine, 30

Pine Family, 19

Pine Order, 19

Pink Order, 51

Pinus, 30, 31

banksiana, 35, 21, 31

divaricata, 35

Laricio, 34 austriaca, 34, 31

montana, 34, 31

Mughus, 34

resinosa, 33, 31

silvestris, 33,31

Strobus, 32, 21, 31

Pipsissewa, 86

Poison Ivy, 231

Oak, 230, 231

Sumac, 230

Polemoniales, 106

Populus, 53, 55, 58

alba, 54, 55

angustifolia, 57,58

balsamifera, 59,58 candicans, 58

deltoides, 56,55 grandidentata, 56,55 nigra italica, 57,58 tremuloides, 56,55

Potato Family, 106

Potentilla, 119 fruticosa, 120

Prairie Rose, 136 Wild Rose, 138

Willow, 70

Irickly Ash, 81

Gooseberry, 186

Greenbriar, 301

Prim, 115

Privet, 115

Prunus, 163, 165, 167, 169,171

americana, 166, 167

Jesseyi, 170, 167

Cerasus, 168, 169

japonica, 170, 171

serotina, 164, 165

nigra, 166,169

pennsylvanica 168 , 169

pumila, 168, 167

triloba, 171

virginiana, 164, 165

Iscdera quinquefolia, 205
Fseudotsuga, 23, 21

Douglasii, 23

mucronata, 23

taxifolia, 23,21

Ptelea, 82 trifoliata, 82

Fulse Family, 171

I'urple Virgin's Bower, 46

Purple Willow, 63

Pussy Willow, 66

Pyrus americana, 148

aucuparia, 150

baccata, 160

ioensis, 162

nigra, 154

floribunda, 160

Malus, 162

sambucifolia, 148

sitchensis, 148

Quaking Asp, 56

Quercus, 257, 264

alba, 263, 264

bicolor, 266, 264

coccinea, 262, 261

ellipsoidalis, 261

macrocarpa, 264, 257,

265

platanoides, 266

prinoides, 267, 264

rubra, 258, 259

linctoria, 260

velutina, 260, 259

Quince, 146

Rambler Rose, 136

Ranales, 44

Ranunculaceae, 46

Kaspberry, 121

Red Ash, 108

Ked-berried Elder, 278

Red Birch, 250

Cedar, 38

Currant, 191

Elm, 74

Red-fruited Thorn, 155

Maple, 225

Mulberry, 79

Oak, 258

Red-osier Dogwood, 274

Pine, 33

Raspberry, 123

Rhamnaceae, 197

Rhamnus, 197 alnifolia, 199, 198 cathartica, 198

Rhus, 227, 229 glabra, 230, 229 laciniata, 230

hirta, 228 
radicans, 231

toxicodendron, 229

radicans, 232

typhina, 228, 229

laciniata, 230

vernix, 230, 231

Ribes, 185, 187, 189

aureum, 192

Cynosbati, 186, 187

floridum, 192, 187

gracile, 188, 187

grossularia, 186, 187

hudsonianum, 191. 189

lacustre, 190, 192

missouriense, 188

oxyacanthoides, 188 , 187

prostratum, 190, 189

rubrum, 190, 191

triste, 190, 189

uva-crispa, 186

vulgare, 191, 189

River-bank Grape, 203

Birch, 250

Robinia, 175

hispida, 177, 176

pseud-acacia, 176

Rock EIm, 74

Rosa, 134

acicularis, 137, 139

arkansana, 138, 137

blanda, 138, 137

centifolia, 145

cinnamomea, 141

eglanteria, 144

Engelmanni, 139

Fendleri, 140

foetida, 144, 143

gallica, 145, 143

multiflora, 136, 143

pratincola, 138

rubiginosa, 142, 143

rugosa, 142, 143

Sayi, 139

setigera, 136, 143

spinosissima, 144, 143

Woodsii, 140, 137

Rosaceae, 118

Rosales, 118

Rose, 134, 145

Rose Acacia, 177

Rose Family, 118

Rose Order, 118

Round-leaved Dogwood, 271

Rowan Tree, 150

Rubiaceae, 275

Rubiales, 275
Rubus, 121, 124, 125

allegheniensis,

124

amabilis, 126

canadensis, 126, 124

canadensis, 124

idaeus, 123

aculeatissimus, 123

nigrobaccus, 126

nutkanus, 122

occidentalis, 123,125

parviflorus, 122

procumbens, 124

strigosus, 123,125

villosus, 124,125

villosus, 126

Rue Family, 80

Russian Mulberry, 80

Rum Cherry, 164

Russian Olive, 211

Rutaceae, 80

Sabina, 38,36

horizontalis, 40,39

prostrata, 40

virginiana, $38,36,37$

Sage-brush, 297

Salicaceae, 53

Salisburia adiantifolia, 44

Salix, 59, 62, 65, 69

alba, 67,69

amygdaloides, 67,65

babylonica, 63, 62

balsamifera, 64,65

bebbiana, 70

candida, 68, 69

cordata, 64, 62

discolor, 66, 65

fluviatilis, 61,62

humilis, 70, 69

longifolia, 61

lucida, 63, 62

myrtilloides, 64, 62

nigra, 67,65

petiolaris, 66,65

purpurea, 63, 62

rostrata, 70, 69

sericea, 66, 65

tristis, 68,69

viminalis, 68,69

Salmon Berry, 122

Sambucus, 278, 279 canadensis, 279

pubens, 278

racemosa, 278, 279

Sandbar Willow, 61

Sand Cherry, 168

Sapindaceae, 216

Sapindales, 215
Savin, 38

Saxifragaceae, 181

Saxifrage Family, 181

Scarlet Oak, 262 Quince, 146

Sumac, 230

Scotch Fir, 33

Pine, 33

Rose, 144

Scrophulariales, 116

Service-berry, 150, 151

Shadbush, 151

Shagbark Hickory, 238

Shellbark Hickory, 238

Shepherdia, 211, 212 argentea, 213, 212 canadensis, 212

Shrubby Bittersweet, 196 Cinquefoil, 120

Trefoil, 82

Shoestrings, 179

Siberian Crab, 160 Lilac, 112

Pea-tree, 180

Silky Cornel, 271 Willow, 66

Silver-berry, 211 leaf, 54

Maple, 225

Simarubaceae, 83

Slender Willow, 66

Slippery Elm, 74

Small Cranberry, 103

Smaller Redroot, 201

Smilacaceae, 298

Smilax, 300, 299 herbacea, 300, 299 hispida, 301, 299 pulverulenta, 300 rotundifolia, 301, 299

Smilax Family, 298

Smooth Gooseberry, 188 Wild Rose, 138

Snapdragon Order, 116

Snowberry, 284, 286

Soapberry Family, 216

Soft Maple, 225

Solanaceae, 106

Sorbaria, 132 sorbifolia, 132, 133

Sorbus, 147 americana, 148, 149 aucuparia, 150, 149 sambucifolia, 148, 149

Soulard's Crab Apple, 162

Sour Cherry, 168

Speckled Alder, 256

Spiraea, 130, 131

arguta, 130, 133

Bumalda, 130, 131 


Anthony Water-
er, 130
opulifolia, 127
salicifolia, 130, 121
sorbifolia, 132
tomentosa, 132, 131
Van Houttei, 129, 131

Spruce, 25

Squash Berry, 282

Staghorn Sumac, 228

Staphylca, 215

trifolia, 216, 215

Staphyleaceae, 215

Stceple Bush, 132

Sugar Maple, 224

Sumac, 227

Sumac Family, 227

Swamp Hickory, 240

Maple, 225

Gooseberry, 190

Laurel, 90,

White Oak, 266

Symphoricarpus, 284, 285

occidentalis, 285

racemosus, 286, 285

levigatus, 286 pauciflorus, 286

Syringa, 111, 181

amurensis, 112

persica, 112

villosa, 112

vulgaris, 112,114

Tamarack, 28, 29

Tamaricaceae, 51

Tamarisk, 52

Tamarisk Family, 51

Tamarix, 52 gallica, 53,52

Tatarian honeysuckle, 292 Maple, 222

Taxaceae, 41

Taxus, 41

baccata var. minor, 41

canadensis, 41, 42

Thimble Berry, 122
Thuja, 35, 36

occidentalis, 35,36

Thymclaeaceae, 207

Tilia, 70 americana, 72,71 europaea, 72,71

Tiliaceae, 70

Toothache Tree, 81

Toothed Aspen, 56

Trailing Arbutus, 91

Tree-of-Ileaven, 83

Trumpet Honeysuckle, 287

Tsuga, 24, 21 canadensis, 24, 21

Twin Honeysuckle, 292

Ulmaceae, 73

Ulmus, 73,75

americana, 76, 75

campestris, 76, 75

fulva, 74,75

racemosa, 74, 75

Umbellales, 270

Upland Sumac, 230

Vaccinium, 97

caespitosum, 99, 98

canadense, 102, 101

macrocarpum, 104

Oxycoccus, 103, 104

pennsylvanicum, 100, 101

nigrum, 102

uliginosum, 99, 98

Vitis-idaea, var. $m i$ nus, 102

Viburnum, 280

americanum, 282, 281

Lantana, 283

Lentago, 284, 281

Opulus var. sterilis, 282

pauciflorum, 282, 281

pubescens, 284, 283

Virginia Creeper, 205

Virgin's Bower, 47

Winter-berry, 214
Virgin's Bower, 46, 203

Vitaceae, 201

Vitis, 202

Labrusca, 203, 202

vulpina, 203, 202

Wahoo, 195

WaInut Family, 232

Water Ash, 111

Wayfaring Tree, 283

Weigela, 296

rosea, 296

Western Mountain Ash, 148

White Ash, 108

Cedar, 35

Elm, 76

Mulberry, 80

Oak, 263

Pine, 32

Poplar, 54

Spruce, 26

Walnut, 235

Willow, 67

IVild Black Cherry, 164

Currant, 192

Crabapple, 162

Hydrangea, 184

Plum, 166

Red Cherry, 168

Raspberry, 123

Willow Family, 53

Wintergreen, 93

Witch-hazel, 193

Witch-hazel Family, 193

Wolfberry, 285

Woodbine, 203, 204, 205

Wormwood, 297

Xanthoxyluin, 80 americanum, 81

Yellow Birch, 250

Yew, 41

Yew Family, 41 




QK

484

M6C 5

cop. 2

BioMed
Clements, Frederic Edward Minnesota trees and shrubs 
Q

1.

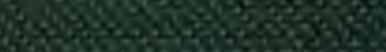

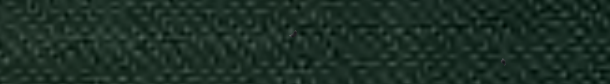

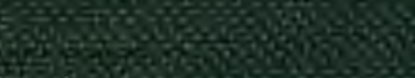

F,

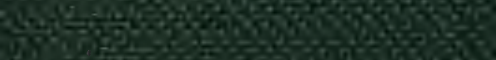

$630.5 \%$

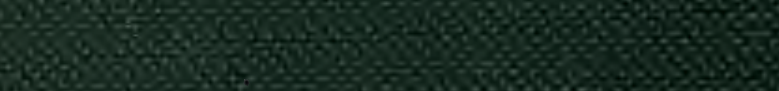

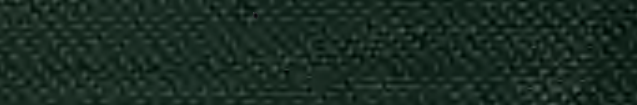

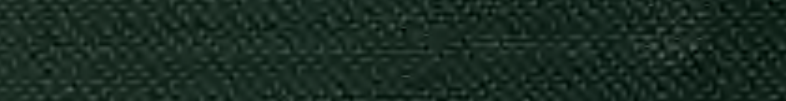

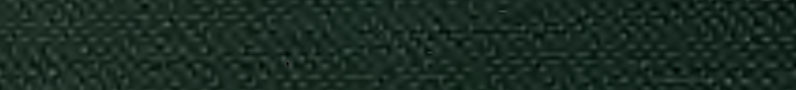

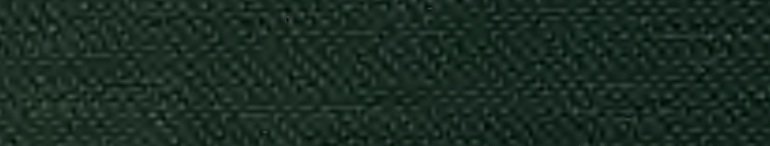

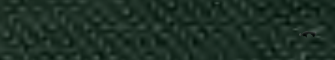

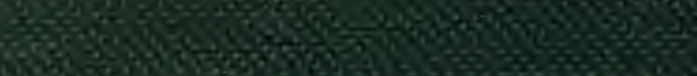

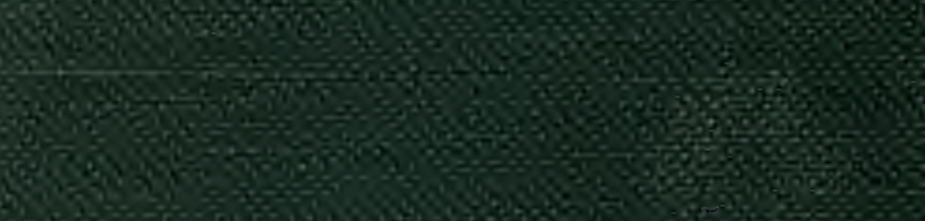

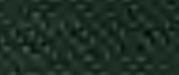

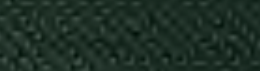

68

38 .

8.5.

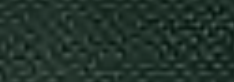

ons

00060 sh

W. 